



\title{
STUDIES IN CONSTITUTIONAL LAW
}

\section{DUE PROCESS OF LAW}

\author{
UNDER THE
}

\section{FEDERAL CONSTITUTION}

BY

\section{LUCIUS POLK MCGEHEE}

PROFESSOR OF LAW IN THE UNIVERSITY OF NORTH CAROLINA; LATELY ASSOCIATE EDITOR OF THE AMERICAN AND ENGLISH ENCYCLOPADIA OF LAW, SECOND EDITION

\section{EDWAKD THOMPSON COMPANY}

NORTHPORT, LONG ISLAND, N. Y. I 906 


\section{Copyright I906}

by

Edwakd Thompson Company

All rights reserved 


\section{PREFACE}

The plan of the series to which this volume belongs offers a happy opportunity to trace the application of certain fundamental ideas throughout the extended field of American law. By isolating "due process of law" and devoting to it a separate "study" the history and elements of the conception, its relation to other constitutional guaranties, and the part it has performed and is still performing in the upbuilding of a system of individual rights should emerge more clearly than is possible in a general treatise on constitutional law. If I have failed to effect in some measure these objects, the fault is wholly my own. No richer or more interesting field could offer itself to the student or practitioner.

The object of this study is to present the views of the subject entertained by the United States Supreme Court, upon which devolves the final decision of questions of due process both in proceedings by the federal authorities and in those by the state. Accordingly, the material of this volume is primarily the decisions of that court. An effort has been made to include all the decisions of the court through 199 U. S. Decisions of other jurisdictions have been used only as far as seemed necessary to round out, to the best of my judgment, the discussions of the questions involved from an historical or logical point of view. 
Due process of law, under the shaping influence of the decisions of the Supreme Court of the United States, is in course of active growth. Not that the conception is receiving new elements, but its application is being delimited by the gradual " process of judicial inclusion and exclusion." And this process demands the consideration of far-reaching principles whose estimation is difficult in proportion to their very comprehensiveness. Contemporary public opinion as reflected with more or less exactness in the minds and opinions of the judges; the views entertained on economic and moral questions, on the functions of the central government in respect of the states, on the duties of all government with regard to its citizens - all these things tend to be .woven into the precedents of our jurisprudence. As yet the decisions on this subject under the National Constitution extend over hardly more than a generation. It will be seen that the task of mapping out the field presented for study is full of difficulty. I have tried constantly to emphasize the general principles involved in the discussion, and as far as possible to state the views of the court in its own language. By this course I hope the reader may have at hand the means of weighing and checking the statements made.

Owing to complications which could not be foreseen or avoided, the printing of this volume has been considerably delayed. In the meantime a decision of far-reaching importance on a subject falling within its scope has been rendered by the Federal Supreme Court, - Haddock $v$. Haddock; 201 U. S. 562.

In the Haddock case, by the decision of a bare iv 
majority of the court, against the dissent of Harlan, Brewer, Brown, and Holmes, JJ., it was finally decided that a decree for divorce rendered in a state other than that of the matrimonial domicil of the parties at the suit of a husband bona fide domiciled in the state of the forum, against the wife who remained a resident of the state of the matrimonial domicil, is not a decree in rem. It is, therefore, not a proceeding in which constructive service by publication, in accordance with the law of the forum, against the nonresident defendant imparts any validity to the decree as against her; and such a decree is not, when brought in question outside the state where it is rendered, within the protection of the full faith and credit clause of the United States Constitution. The interesting correlative question of the effect of such a decree within the state of the forum is not examined. Is it valid there as against both parties? This would contradict the reasoning of Pennoyer $v$. Neff, 95 U. S. 714 . Is it valid as to the plaintiff and not against the defendant? This would explode the prineiple stated by the court in Atherton $v$. Atherton, 181 U. S. 155 , that a wife without a husband or a husband without a wife is " unknown to the law;" and would be as if, the relative position of the objects $A$ and $B$ being the question, the position of $\mathrm{A}$ with respect to $\mathrm{B}$ could be changed withont affecting the position of $B$ with respect to $A$. It has been said that the states are still at liberty, upon principles of international comity, to recognize the divorce decrees of sister states, rendered under the circumstances of the Haddock case, if they choose to do so. But it would seem that such a recognition, while not affected by the full faith and 
credit clause of the Constitution, must involve a determination by the state of the federal question of what amounts to due process of law under the Fourteenth Amendment. In the view of the writer, the opinions of the dissenting justices embody the correct view of the matters decided, and the holding is to be earnestly regretted. It illustrates strikingly the presence of some of the formative influences above mentioned.

Unifersity OF NORTh Carolina,

L. P. McG.

Chapel Hill, N. C.,

July, 1906. 


\title{
TABLE OF CON'TENTS.
}

\author{
CHAPTER I.
}

THE HISTORY AND SCOPE OF THE CONSTITUTIONAL GUAR. ANTY OF DUE PROCESS OF LAW.

PAGE

Introductory $\ldots \ldots \ldots \ldots \ldots \ldots \ldots \ldots \ldots \ldots \ldots \ldots \ldots \ldots \ldots \ldots, 1$

History of the Phrase........................... 3

In English Law Before the Revolution............... 3

In American Constitutions....................... 17

"Due Process" in the Federal Constitution............ 17

In the Fifth Amendment...................... 17

In the Fourteenth Amendment.................... 19

Equivalent Phrases in State Constitutions............ 23

Scope of the Guaranty in English and American Law........ 24

The English Guaranty No Bar on Parliament........... 24

American Guaranty Restrains All Governmental Activity. .. 26

Due Process in the Fourteenth and in the Fifth Amendments

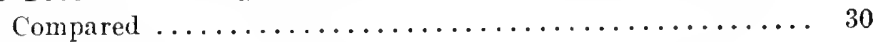

Relation of Federal Government Toward Due Process by the

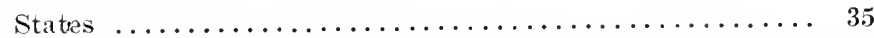

Supervisory Powers of the Supreme Court of the United States 35

Direct Enforcement of Due Process by Congress.......... 42

\section{CHAPTER II. \\ THE ELEMENTS OF DUE PROCESS.}

Definitions Collected and Their Relations Shown............ 49

How the Presence of Due Process Is Tested.............. 53

Historical Test - Positive and Inclusive............. 53

Intrinsic Test - Both Inclusive and Exclusive.......... 56

Some Fundamental Requisites...................... 58

Equality and Generality of the Law $\ldots \ldots \ldots \ldots \ldots \ldots \ldots, 60$

The Requirement Stated and Explained.............. 60

Confiscatory Legislation....................... 64

Confusing Functions of Different Departments of Govern-

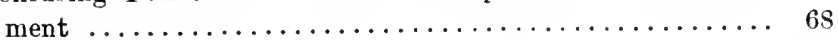

Notice and Hearing............................. 73

The Requirement of Notice and Hearing Generally ...... 73

What It Includes under Our Constitutional Guaranties... 76

Notice and Hearing Must Be Required, Not Matters of

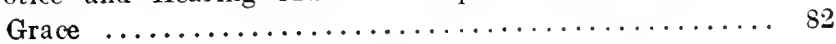




\section{CHAPTER III. \\ JURISDICTION AND DUE PROCESS.}

PAGE

The General Requirement of Jurisdiction............. 85

Judgments in Personam..................... 89

Judgments Against Nonresident Joint Debtors, etc ....... 93

Jurisdiction Over Foreign Corporations............. 100

Extraterritorial Control in Equity Over Property and Rights of Action..............................

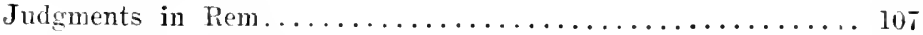

Extension of Conception of Proceedings In Rem ......... II 2

Situs of Personal and Intangible Property as Affecting Juris-

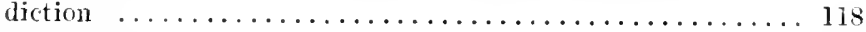

Divorce Decrees......................... 122

Bankrupt and Insolvent Laws................. 130

Jurisdiction as to Crimes and Penalties............ 133

\section{CHAP'TER IV.}

THE RIGHTS PROTECTED BY DUE PROCESS OF LAW.

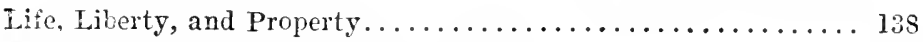

Ve-ted Rights and Due Process of Law.............. 142

Ve-ted Rights and Other Constitutional Guaranties.......... 145

Ex Post Facto Laws and Bills of Attainder ............ 146

Laws Impairing the Obligation of Contracts............. 148

All Law- Impairing Tested Rights Condenned by Due Process. 153

What Rights Are Vested or Otherwise............. 155

Expertancies and Niere Contingencies.............. 157

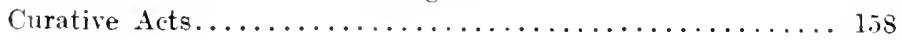

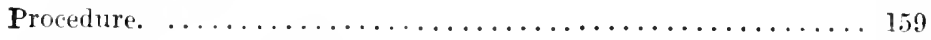

What the Term Covers..................... 159

Tribunal Before Which Trial Is Had.............. 162

rocedure in Criminal Cases.................. 104

Proceedings for Contempt................... 169

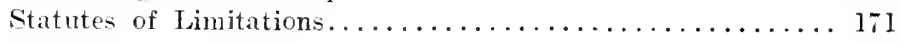

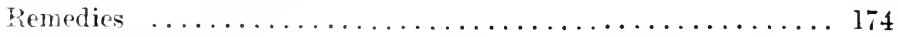

Laws Annexing Conditions or Penalties to Rights of Action or

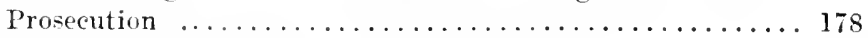

Evidence and the Creation of Presumptions........... 180

\section{CHAPTER V.}

THE PERSONS PROTECTED BY DUE PROCESS.

Corporations ............................ 189

Aliens - Immigration Laws. . . . . . . . . . . . . 190

Inhabitants of Acquired Territory ............... 197 


\section{CHAPTER VI.}

THE PARAMOUNT RIGHTS OF TIIE STATE AND DUE

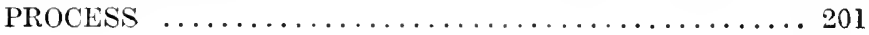

\section{CHAPTER VII. \\ TAXATION.}

The Taxing Power and Its Extent................. 20s

Limitations on the Taxing Power................. 215

Property Taxed Must Be Within Jurisdiction .......... 218

Assessment of Property Lying Partly in Several Jurisdictions. 223

Exemptions from Taxation.................. 226

The Public Purpose of the Tax................. 2.28

Summary Proceedings for Collection.............. 232

Notice and Hearing. ....................... 235

The Hearing Actually Provided............... 242

Local Assessments ...................... 246

\section{CHAPTER VIII. \\ THE EMINENT DOMAIN.}

Its General Nature and Limitations............... 253

The Public Purpose or Use................... 255

Various Public Uses Enumerated................ 256

The Criterion of a Public Use................. 262

The Necessity of Taking or Appropriation ............ 272

Compensation ...........................

Necessity for Compensation................ 278

Property for Which Compensation Must Be Providerl....... 283

Amount of Compensation and Provision for Payment ..... 289

What Amounts to a Taking of Property.............. 291

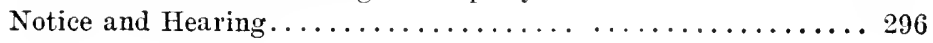

\section{CHAPTER IX. \\ THE POLICE POWER.}

Characteristics and Limitations................. 300

Its Exercise Must Be Reasonable................ 306

Police Power or Eminent Domain as Dependent on Reason-

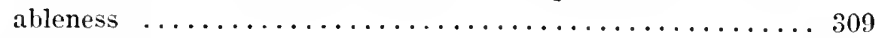

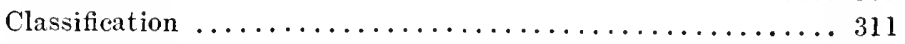

Business Affected with a Public Interest ............. 314

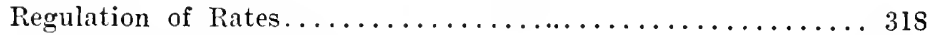

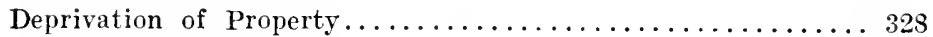

Private Rights Must Be Involved............... 328 
PAGE

Professions and Offices as Property ............... 333

Limiting the Enjorment of Property .............. 356

Confiscation of Property.................... 337

Conscquential Damage from Police Regulation.......... 338

Imposition of Expense Connected with Police Pegulation . . . . 339

Creation of Liabilities Connected with Enjoyment of Property

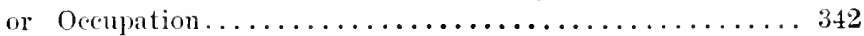

Deprivation of Liberty. . . . . . . . . . . . . . . . . . 343

Freedom of Contract and Business................... 345

Regrulater for Public Morals, Health, or Safety . . . . . . . 345

Business Affected with Public Interest.............. 349

Regulation in the Interest of Certain Classes - to Prevent

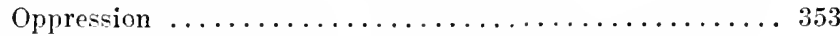

Regulation in the Interest of Economic Prosperity and General Welfare........................ 357

Exaction of Licenses...................... 363

Committing Legislative or Judicial Functions to Executive... 365

Notice and Hearing. ........................... 370

Due Process Does Not Require Jury, and May Be Executive... 37l Right to Destroy Before Hearing Limited by Necessity...... 372 


\title{
DUE PROCESS OF LAW.
}

\author{
CHAPTER I.
}

THE HISTORY AND SCOPE OF THE CONSTITU-

TIONAL GUARANTY OF DUE PROCESS

OF LAW.

INTRODUCTORY.

$\mathrm{D}^{\mathrm{s}}$

UE PRoCESs OF LAW, as the meaning of the Chapter words has been developed in American decisions, implies the administration of equal

laws according to established rules, not violative of the fundamental principles of private right, by a competent tribunal having jurisdiction of the case and proceeding upon notice and hearing. ${ }^{1}$ The phrase is and has long been exactly equivalent to and convertible with the older expression "the law of the land." 2

1 In effect, this description agrees with that given by the court in Chicago, etc., R. Co. v. Chicago, 166 U. S. 226.

2 See infra, p. 16.

We shall see that "due process of law" appears in English law at least as early as 1354, when we find it used in an Act of Parliament, 28 Edw. III, c. 3, and in a petition to Parliament by the Earl of Arundell for the removal of the attaint on his father, 2 Rot. Parl. 256, 257. See infra, pp. 9, 65.

It is perhaps worth noticing that the writ of novel disseisin, in use since about A. D. 1166, charged the tenant with having disseised the demandant " unjustly and without a judgment," injuste et sine judicio. Glanville, lib. xiii, c. 33. "As to the words sine judicio, which are equivalent to the absque ordine judiciario of the canonists, we may translate them by 'without process of law.'" 2 Poll. and M. Hist. 52. For earlier uses of these phrases in English and canon law, see 2 Poll. and M. Hist. 47, note 4. Among other instances is 
Chapter

I.

In various legal sys. tems.
The basis of due process, orderly proceedings and an opportunity to defend, must be inherent in every body of law or custom as soon as it advances beyond the stage of uncontrolled vengeance. Indeed, the emphasis placed on a literal adherence to customary rules of procedure is one of the most marked features of primitive law, and, with the advance of civilization and the application of reflection to old collections of custom, the principle of notice and an opportunity to defend would take its place as a part of the jus gentium, to become later the law of nature, ${ }^{3}$ or the law of God. ${ }^{+}$The idea was familiar to the Jewish law, ${ }^{5}$ and in the Roman law may be discovered underlying the conception of "justice," as "the steadfast and continued disposition to render to every man his rights," ${ }^{6}$ while two lines from Seneca,

"Qui statuit aliquid, parte inaudita altera, Aequum licet statuerit, haud aequum fuerit," 7

have become, through Lord Coke, ${ }^{5}$ a maxim of Engciter Leges Menrici. 74, 1 (about A. D. 1115), where, in connection with homicide, occurs qui injuste vel sine judicio occisi.

3 Y. B. 9 Edw. IV, 14, pl. 9.

4 Rex $r$. Cambridge University, 1 Stra. 558, 567.

5 "Doth our law judge any man before it hear him and know what he doeth?" John vi. 51 .

6 The opening words of the Institutes are: Justitia est constans et perpetua voluntas jus suum cuique tribuere. "Due process of law." says Mr. Justice Matthews, "in spite of the absolutism of Continental governments, is not alien to that code which survived the Roman Empire as the foundation of modern civilization in Europe, and which has given us that fundamental maxim of distributive justice, sum mique tribuere." Hurtado $r$. California, 110 U. S. 516.

7 Seneca, Medea, 199, 200. The lines may be rendered:

Who hath adjudged of aught, one side unheard,

Just though the judgment, were himself uninst.

8 Bagg's Case, 11 Coke $99 a$. 
lish law, ${ }^{9}$ the aphoristic expression of the soul of Chapter due process.

But whatever may be the case in other systems, due process is fundamental in American law, and under the Constitution of the United States, as under the constitutions of the individual States, no person can be deprived of life, liberty, or property without due process of law, or except by the law of the land.

This book is confined to an investigation of the requirements of due process in the Constitution of the United States, and the treatment of similar clauses in State constitutions will be incidental merely.

As we shall see, several of the elements of this general characterization have been developed by the courts, in seeking the real content of due process of law as the phrase was adopted in our constitutions from the English law. But there the same exigency for determining the latent meaning of the words did not exist. It was used as equivalent to the law of the land, and imported every due and regular proceeding in a cause in accordance with statute or common law, implying notice and hearing.

\section{HISTORY OF THE PHRASE.}

In English Law Before the Revolution.

The 39th chapter of the Magna Carta of King Magna John ${ }^{1}$ provides that "No freeman shall be taken,

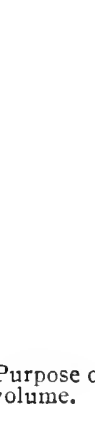




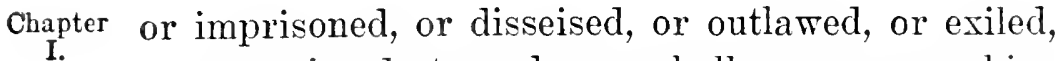
I. or any wise destroyed; nor shall we go upon him, nor send upon him, but by the lawful judgment of

The confusion running through many modern commentators and writers as to the form and numbering of this provision of Magna Carta justifies a few words of explanation. The substance of the provision forms chapter 29 of the Articles of the Barons, which was a memorandun of the heads of the agreement between John and the Barons, from which the Great Charter was afterwards reduced to formal shape. In this instrument the chapter stood: "Ne corpus liberi hominis capiatur, nec imprisonetur, nec dissaisietur, nec utlagetur, nec exuletur, nec aliquo modo destruatur, nec rex eat vel mittat super eum vi, nisi per juditium parium suorum vel per legem terrae." The same provision forms in the reissues of the Great Charter by Henry III, c. 32 in the first reissue, 1 Hen. III, 1216 ; c. 35 in the second reissue, $2 \mathrm{Hen}$. III, 1217 ; c. 29 in the third reissue, 9 Hen. III, 1225. The Charter was originally issued without division into chapters or paragraphs, though the Articles of the Barons was divided into separate paragraphs unnumbered. The division into numbered paragraphs was introduced in the statute books for convenience of reference. Thompson, Magna Carta, 159, 445.

To a comparatively recent period, the only copy of the Charter printed in the statutes was that of 9 Henry III, and this was the copy printed and commented on in the Seeond Institute by Lord Coke. Consequently, it is easy to understand how this provision of Magna Carta was usually referred to as chapter 29. In more modern times, and especially since the beautiful edition of the Great Charter in all its various forms prepared by Blackstone from a careful collation of the manuscripts available to him and issued by the Clarendon Press in 1759 , the practice of referring to the original Charter has become usual.

The amount of confusion on these matters in quarters where it would least be expected is surprising. See Cooley's Const. Limit., 6 th ed., 429, and the address of Chief Judge Parker, of the New York Court of Appeals, before the Bar Association of Georgia, reprinted in the American Law Review for 1903. 37 Am. Law Rev. 643.

It may be added that the clause " nulli vendemus, nulli negabimus, ant differamus, rectun aut justicium," which immediately follows in the Great Charter, is numbered as a separate chapter in the earlier issues (c. $40,17 \mathrm{John}$; c. 33,1 Hen. III; c. 36,2 Hen. III), and its equivalent in the words "ne jus vendatur vel differatur vel velitum sit" is chapter 30 of the Articles of the Barons. In the third reissue of Henry III, this provision forms a part of chapter 29. 
his peers or by the law of the land." This provi- Chapter sion appears in the reissues of the Great Charter, with the insertion in the second ( 2 Hen. III, A. D. 1217) and third (9 Hen. III, A. D. 1225) charters of Henry III of the words, "of his freehold or liberties, or free customs," so that the clause in its final form is: "No freeman shall be taken or imprisoned or disseised of his freehold, or liberties, or free customs, or outlawed, or exiled," etc. ${ }^{2}$

The once prevalent view of this chapter was that it was intended to be a guaranty of trial by jury and due process of law. We now know that historically this view was incorrect, that the guaranty of "the lawful judgment of peers" referred only to a feudal right, to which trial by jury was utterly hostile; ${ }^{3}$ that the requirement of conformity to the "law

2 Chapter 29 stands then in the original text of 9 Hen. III: "Nullus liber homo capiatur vel imprisonetur aut disseisietur de libero tenemento suo vel libertatibus, vel liberis consuetudinibus suis, aut utlagetur, aut exuletur, ant aliquo modo destruatur, nec super eum ibimus, nec super eum mittemus, nisi per legale judicium parium suorum, vel per legem terrae." The words added in the second and third charters of Henry III are italicized.

3 For judicium parium, see 1 Stubbs' Const. Hist. 578, and note 1; 1 Poll. \& M. Hist., 2d ed., 173 and note, 594; Pike, Const. Hist. House of Lords, 169; McKeclunie, Magna Carta, 158, 438, et seq. "For a legal instrument to call the verdict of recognitors a judgment would have been as gross a blunder in 1215 as it would be at the present time." 1 Poll. \& M. Hist., 173, note.

For the identification of judicium parium with jury trial, see Bagg's Case as reported 1 Rolle's Rep. 225 (where it is said: " En cest case, Bagg nest disfranchise et ouste de son liberties per pares, hoc est, per jurie, nec per legem terrae"); 3 How. St. Tr. 152 (quoted below, p. 15); 4 Blackst. Com. 349, etc. This old view, so universally repudiated by modern scholars, is reiterated in the opinions of the Supreme Court of the United States by Harlan, J., in Thompson $v$. Utah, 170 U. S. 349, and in Maxwell $v$. Dow, 176 U. S. 609. The true view was given long before by Matthews, J., in Hurtado $v$. California, 110 U. S. 529. Real judicium parium survived as 
Chapter of the land" was intended as a guaranty against
I. certain arbitrary proceedings on the part of the king, the enforcement of execution without any judgment, or after a mere pretext of judgment; and that the most that was guaranteed was judgment by some of the known contemporary methods of trial, ordeal, battle, or compurgation. ${ }^{4}$ But Magna Carta came in after ages to be regarded with almost superstitious reverence. It was practically taken out of the category of statutes, in which class its place was technically fixed by the confirmatio cartarum of 1297 , and became "a sacred text, the nearest approach to a 'fundamental statute' that England has ever had." 5 Such a document, looked to by each succeeding generation as a living guaranty of rights, is naturally interpreted in each age according to the needs of the time. The broad construction which was given to the 39 th chapter by the statesmen and lawyers of the seventeenth century during the constitutional struggles with the Stuarts, became fixed in the commentaries of Coke and subsequent writers,

a privilege of the peers alone. 2 Coke's Inst. 48 . At an earlier time it included all classes, except villains, even Jews and burgesses. 1 Poll \& M. Hist., 2d ed., 173, note; McKechnie, Mag. Carta, 438, 448.

4 For per legem terrac, see Thaser, Prelim. Tr. on Evi., 199, 201; McKechnie, Magna Carta, 442; Pike, Const. Hist. House Lords, 170. Bigelow, Hist. Proc., 155, note, says: "As to the expression per legem terrae, which has caused so much discussion in the law books, and generally been interpreted by the courts to mean that defendants in criminal courts must be tried by jury upon presentment or indictment, it may be observed that jury trial in criminal cases hat not come into use at this time, except as a matter of special grace on the part of the king. . . . The expression per legem torrae simply required judicial proceedings. according to the natme of the case, the duel, ordeal, or compuration in criminal cases, the ducl, witnesses, charters, or recomition in property cases."

51 Poll. \& M. Ilist., 2d el.. 173. 
and in the period of our Revolutionary War was Chapter woven into the very texture of American constituI. tional law.

The materials on which the seventeenth century lawyers seized for their interpretation of the Charter take us back to the thirteenth century contests between the King's Council and Parliament.

For a long period after 1215, the English Constitution was still in a fluid state, while govermmental powers and machinery were slowly evolving toward Struggles between Parliament the familiar type of later times. By the fourteenth century, the King's Council, whose functions were chiefly executive and judicial, had become separated from Parliament. But the powers of each were illdefined, and the Parliament throughout that century was continually petitioning against the vague and indefinite jurisdiction of the Council. With the accession of the House of Lancaster at the end of the fourteenth century, both Parliament and the Council passed largely under the control of the leading. nobles, and such protests became less common. Finally, with the coming of the Tudors, the loose jurisdiction of the Council was in a measure defined and vested in a sort of committee, which became known as the Court of Star Chamber. ${ }^{6}$ The later history of the Council does not concern us, but the petitions of the fourteenth century Parliaments, which sometimes received the King's assent and so became laws, were seized on by the serenteenth century lawyers as interpretations of "lawr of the land," and "due process of law." 7

6 See 1 Steph. Hist. Crim. Law, c. vi, p. 166; 1 Holdsworth, Hist. Eng. Law, c. vi, p. 264.

$\tau$ This series of statutes and petitions is quite fully given in the 
With the lapse of a century after its passage, the 39th chapter of Magna Carta had lost the meaning it had for its contemporaries. The King's courts, administering the royal justice, had become the repositories and guardians of the "common law;" their methods of procedure were standards, definite and fixed; and the people saw in the Charter a guaranty of those very metlods which the barous had intended to curtail. It was natural then that in the complaints against the Council, the guaranty in this Charter of the "law of the land" should be continually inroked.

Fourteenth century

These complaints were founded on arbitrary imstatutes. prisonments, deprivations of property, or interference with the ordinary administration of justice. ${ }^{8}$ In 1331, there is an enactment (Stat. $5 \mathrm{Edw}$. III, c. 9) that "No man from henceforth shall be attached by any accusation nor forejudged of life or limb, nor his lands, tenements, goods, nor chattels seized into the King's hands, against the form of the Great Charterand the law of the land." Again, in 1350, the

speech of Sir Edward Littleton before the House of Lords in the debates which followed the case of the Five Knights. See 3 How. St. Tr. 86-89, 122, 123. See, also, 2 Stubbs' Const. Hist. 637-639; 1 Holdsworth's Hist. Eng. Law, 267-269; 1 Steph. Hist. Crim. Law, 169 et seq.

8 The petition of 1368 recites: "that many of your commons are hurt and destroyed by false accusers, who make their accusations more for their revenge and particular gain than for the profit of the King, or of his people; and those that are aecused by them, somo are taken and others are made to come before the King's Council by writ or other commandment of the King, upon grievous pains, contrary to the law." 3 How St. Tr. 89,122 . In 1363, a statute, 37 Edw. III, c. 18, declared that divers people make false suggestions to the King himself, as well for malice as otherwise, whereat the King is often grieved and divers of the realm put in damage, against the form of the Great Charter. 3 How. St. Tr. 88. 
Commons petition that "No freeman be put to answer for his freehold, nor for anything which touches life and member, fine or ransom by information before the Council of our lord the King, nor before any of his ministers save by process of law used in that behalf in times past." The King grants the petition and promises that proceedings shall be "by process of law;" but adds that in any matter which touches life or limb, contempt or excess, things shall be as has been customary. ${ }^{9}$ Statute 25 Edw. III, c. $t$ (A. D. 1351), recites the prorisions of "the Great Charter of the franchises of England that no freeman shall be imprisoned, nor put out of his freehold, nor free custom, unless it be by the law of the land," and enacts that "From henceforth none shall be taken by petition or suggestion made to our lord the King or his Council, unless it be by presentment or indictment of his good and lawful people of the same neighborhood, where such deeds be done, in due manner, or by process made by writ original at the common law, nor that none be ousted of his franchises, nor of his freehold, unless he be duly brought in to answer and forejudged of the same by the course of the law." 1 Three years later, it is enacted (Stat. $28 \mathrm{Edw}$. III, c. 3), "That no man, of what state or condition soever he be, shall be put out of his lands, or tenements, nor taken, nor imprisoned, nor indicted, nor put to death, without he be brought in to answer by due process of law." In 1362, in a petition, the Commons recited the existing guaranties as fol-

92 Rot. Parl. 228. See also 1 Steph. Hist. Cr. Law, 169; 1 Holds. Hist. Eng. Law, 268; 3 Reeves' Hist. Eng. Law (Am. ed. $1880), 159$.

1 Rot. Parl. 36 Edw. III. See 3 How. St. Tr. 88, 122. 

Chapter lows: "Whereas it is contained in the Great Char-
I. ter and other statutes that no man be taken or imprisoned by special command without indictment and other process to be made by the law," etc.; ${ }^{2}$ but the King only answered that he is pleased "if any man find himself grieved, that he come and make his complaint, and right shall be done unto him.' A statute of the next year (Stat. $37 \mathrm{Edw}$. III, c. 18) recites the charter thus: "Though it be contained in the Great Charter that no man be taken or imprisoned, or put out of his freehold without process of law.', 3 In 1368 the House of Commons prayed that no man be put to answer without presentment before justices, or a matter of record, or by due process and original writ according to the ancient law of the land. The King granted the petition "because this article is an article of the Great Charter.",

Thus, in the statutes and petitions of the Parliaments of Edward III the phrases "process of law" or "dne process of law" have come to be used as equivalent to "law of the land" in the Great Charter, or perhaps for the whole phrase per legale judicium parium suorum vel per legem terrae. ${ }^{4}$ In

2 See 3 Reeres. Hist. Eng. Law (Am. ed. 1880), 159. Of this statute Sir Edward Coke said: "For the true sense and exposition of these worls [by the law of the land] see the statute $37 \mathrm{Edw}$. III. c. 8 [18]. where the words "by the law of the land' are rendered "withont hue process of law."," 2 Inst. 50.

32 Rot. Parl. 205, 42 Edw. III; Stat. 42 Edw. III, c. 13. See 3 How. St. Tr. 89, 122.

4 This is in agreement with the suggestion that the plirases of Magna Carta expres one single idea and not two district ones. "In medieral tatin. rel will often tand for and. . . The wording of the clauce leaves open the question whether a man can ever be imprisoned or disciced hy the baw of the land without having had the juldement of his prers." I poll \& M. Itist.. 2d ed.. 173. note. 
the earliest instances it is used in contradistinction to information, or includes both common-law process Chapter and indictment or presentment. Its wider meaning is apparent in the later instances.

With Edward's reign did not cease the acts of King and Council against which Parliament had struggled. ${ }^{5}$ The parliamentary protests which conKing's pre-
rogative Imprisonment with. out cause. tinued into the fifteenth century throw no further immediate light on "due process of law," but they are of interest in their bearing on the seventeenth century constitutional contests which finally settled the meaning of that phrase. In 1389 we find the King, in answer to a remonstrance of the Commons against writs quibusdam certis de causis, asserting his prerogative, "as his progenitors had done before him," to imprison subjects by force of his special mandate merely. ${ }^{6}$ Ten years later, a petition setting forth that cases are removed before the Council to be tried before enemies of the parties and praying that the practice may cease, receives the royal acquiescence with the saving clause "unless one party is rich and the other poor so that justice can not otherwise be done." " In those rude days when "the good old rule, the simple plan" prevailed, the rights of the poor and weak against the rich and powerful needed greater powers for their enforcement than the ordinary courts had at their disposal, and after the troubles of the wars between the Houses of Lancas-

51 Holdsworth, Hist. Eng. Law, 269: 2 Stubbs' Const. Hist. 638.

- 1 Holdsworth, Hist. Eng. Law, 269.

71 Steph. Hist. Crim. Law, 170. See also the petition of the Commons and the answer of the King, through his council. in 2 Rich. II, in Miss Schofield's Court of Star Chamber, xrvii (Tniversity of Chicago). 
Chapter ter and York, this branch of the Council's jurisdic-

I. tion was exercised by Henry VII's new Court of Star Chamber without protest. Nor did the prerogative of the King, exercised through his council, to imprison on special mandate only, bring forth any general protest, as it was used by the wise and masterful Tudor sovereigns, who knew well the point beyond which the people would not bear interference with their rights.

The

Stuarts and Parlia. ment "Due process" finally interpreted.

With the breach between the Stuart kings and the Parliament in the early seventeenth century, the Crown's prerogative to imprison by special mandate became of vital importance, and was challenged as not in accordance with the law of the land or due process of law. Charles I, unable to obtain from Parliament the supplies needed for the prosecution of his disastrons Continental wars, resorted to the expedient of a forced loan. Some gentlemen, the historic "five knights," who refused payment of this illegal exaction, were by the King's command, without further canse named in the writ, thrown into prison. The judges, upon habeas corpus brought to secmre their release, refused to interfere, ${ }^{\mathrm{s}}$ basing their action particularly on a precedent of Elizabeth's reign, when such an imprisonment had been held not to be illegal. ${ }^{2}$ The attitude of the country, however, was very different when this prerogative was asserted in an isolated case by a strong and respected sovereign, and when it was employed as a means of enforcing a system of irresponsible government by a discredited king. These events

8. 3 How. St. Tr, 151-159.

- Resolution of Judges, Anderson 297. 
produced prolonged debates in Parliament "on the liberty of the subject," in which the whole matter was thoroughly threshed over with a wealth of learning. ${ }^{1}$ The formation of the Petition of Right in the Commons under the leadership of Sir Edward Coke was the result, and that great constitutional document became a statute of the realm by the grudging assent of the King. ${ }^{2}$ This instrument recites various guaranties of the rights of the subject and acts of the King declared to be in violation thereof, which show the meaning given to the guaranties. Chapter 29 of the Magna Carta of 9 Hen. III, and Stat. $28 \mathrm{Edw}$. III, c. 3 (where the words "due process of law" are used) are recited and declared to be violated by imprisonment of subjects "without any cause showed," "but that they were detained by your Majesty's special command, signified by the lords of your Privy Council;" Stat. 25 Edr. III, c. 4, is given, and declared to be infringed by commissions authorizing trial by martial law. ${ }^{3}$

\section{See 3 How. St. Tr. 1-234.}

The question of the personal rights of Englishmen was elaborately argued in conference with the House of Lords by a comimittee of the Commons composed of most eminent lawyers. The committee consisted of the ex-chief justice of the King's Bench, Sir Edward Coke; John Selden, the celebrated antiquary and profound lawrer; Edward Littleton afterwards Sir Edward, Chief Justice of the Common Pleas and Lord Keeper; and Sir Dudley Digges. The committee divided the argument among themselves, and the speeches of Littleton and Selden are particularly valuable for an historical review of the statutes and cases. 3 How. St. Tr. 86-126.

2 Stat. 3 Car. I, c. 1; 5 Stat. Realm 23.

3 Judge Cooley, Const. Limit., 6 th ed., 429 , note, gives as a textual quotation from the body of the petition a sentence wherein the phrase "due process of law" is used. This is not found in the petition as printed in the Statutes of the Realm. Mr. Guthrie follows him. Guthrie, Fourteenth Amendment, 69. 

Chapter The construction thus put upon these acts is confirmed for the future by the King's assent to the prayer "that no freeman, in any such manner as is before mentioned, be imprisoned or detained, ${ }^{+}$ . . . and that the aforesaid commissions, for proceeding by martial law, may be revoked and annulled; and that hereafter no commissions of like nature may issue forth to any person or persons whatsoever to be executed as aforesaid, lest by colour of them any of your Majesty's subjects be destroyed or put to death contrary to the laws and franchises of the realm."

Interpretation embodied in Coke's

Second Institute.
The reasoning of the English statesmen of the seventeenth century about the use of the term "due process of law," is contained in the hearing on habeas corpus of the Case of the Five Knights, and in the debates on the Petition of Right. In all the

4 "And whereas also by authority of Parliament in the five-andtwentieth year of King Edward III, it is declared and enaeted, that no man shall be forejudged of life or limb against the form of the Great Charter and the law of the land; and by the said Great Charter and other the laws and statutes of this your realm, no man ought to be adjudged to death but by the laws established in this your realm, either by the customs of the said realm or by Acts of Parliament; and whereas no offender of what kind soever is exempted from the proceedings to be used and punishments to be inflicted by the laws and statutes of this your realm; nevertheless of late divers commissions under your Majesty's Great Seal have issued forth, by whieh certain persons have been assigned and appointed commissioners with power and authority to proceed within the land, according to the justice of martial law, against such soldiers and mariners, or other dissolute persons joining with them, as should commit any murder, robbery, felony, mutiny, or other outrage or misdemeanour whatsoever. and by such summary course and order as is agreeable to martial law, and is used in armies in time of war, to proceed to the trial and condemnation of sueh offenders, and them to eause to be executed and put to death aceording to the law martial." Petition of light, 7. Sce MeKechnie, Magna Carta, 442: The Story of Habeas Corpus, by Edward Jenks, 18 L. Quart. Rev. 75. 

proceeding to curb the irresponsible doings of Chapter

Charles, Sir Edward Coke took a leading part, and the often-quoted passage of his Second Institute, subsequently published, commenting on per legem terrae, is but an abstract of the views expressed by himself and his associates during that struggle and reflected in the Petition of Right. Coke says that by "the law of the land" is meant "the common law, statute law, or custom of England,", 5 and in another place he adopts the words of the statutes of 1362 and 1350: "For the true sense and exposition of these words [per legem terrae], see the statute 37 Edw. III, c. 8 [18], where the words 'by the law of the land' are rendered 'without due process of law,' for there it is said, though it be contained in the Great Charter, that no man be taken, imprisoned, or put out of his freehold without process of law; that is [and he takes the explanation from Stat. $25 \mathrm{Edw}$. III, c. 4] by indictment or presentment of good and lawful men where such deeds be done, or by writ original of the common law." ${ }^{6}$ In the debate in Parliament on the Petition of Right, to an argument of the attorney general "that per legem terrae in Magna Carta (which is the foundation of this question) can not be understood for process of law and original writs; for that in all criminal proceedings no original writs are used at all," and that "the statute cited by the Commons makes process of law and writ original all one," the Managers for the Commons reply "that they do not intend original writs only by law of the land, but all other legal 
Chapter process, which comprehends the whole proceedings of law upon cause, other than trial by jury, judicium parium, unto which it is opposed." Then follows an examination of the old statutes, and the conclusion is that the expressions in all of them "import any due and regular proceedings of law upon a cause, other than the trial by jury." 7

The equivalence of the two phrases "law of the land" and "due process of law," assumed by Coke and his associates from the old statutes of the fourteenth century, has been universally stated upon his authority by American courts, and has become an established rule of interpretation. ${ }^{\mathrm{s}}$

Other conceptions gravitate to "due process."
While the constitutional conception of "law of the land" and "due process" was thus being built up, it was to a greater or less extent assimilating certain other fundamental ideas whose origin was widely different. Prominent among them was that of notice and hearing before condemnation, which was said by the medirval chancellors to be required by "the law of nature," and has frequently since been based on the equivalent conceptions of the law of God or natural justice or reason. ${ }^{9}$ As early as the fourteentl century the idea was adranced, though only by the victims, that a bill of attainder without any opportunity for hearing granted to the person attainted was not in accordance with the law

73 How. St. Tr. 152.

8 Murras $v$. Hoboken Land, etc., Co., 18 How. (U. S.) 272; Davidson $x$. New Orleans, 96 U. S. 97; Greene $v$. Briggs. 1 Curt. (U. S.) 311 ; Normal Sehool Dist. $v$. Blodgett, 155 Ill. 441. See the numerous additional citations in $10 \mathrm{Am}$. and Eng. Encyc. of Law (2d ed.) 290.

9 See infra, p. 73 . 
of the land or due process of law. ${ }^{1}$ And in 1616, it Chapter was held that proceedings on the part of a municipality which deprived a freeman of the freedom of the city without hearing was open to this objection. ${ }^{2}$ In all these instances the wider generalization is gradually emerging that all purely arbitrary proceedings whereby one is deprived of personal rights are contrary to the law of the land or due process.

At this stage of its growth the conception was adopted during the formative period of our history Adoption can consti. into the Constitution of the United States and into the constitutions of the several States, where it has had a vigorous development, and the courts have from time to time added essential characteristics which they have held to be implied in the conception itself.

\section{"Due Process" in the Federal Constitution.}

In the Fifth Amendment.

In the Federal Constitution the words "due process of law" occur in but two places. The first is in Guaranties of Fifth Amend. the Fifth Amendment to the Constitution, one clause of which provides that no person shall "be deprived of life, liberty or property without due process of law." The other provisions of this amendment guarantee trial by jury in cases of capital or infamous crime, and forbid double jeopardy, compelling a person to be a witness against himself, or the taking of private property for public use without just compensation.

The first ten amendments to the Federal Constitu-

1 See infra, p. 65.

2 Bagg's Case, 11 Coke 99a. See infra, p. 74. 
Chapter tion were a concession to the fears of a generation

I.

Adoption of first ten amendments.
Scope of first ten amend. ments.

which had taken part in the Revolution. The struggle with England for rights, held to be the sacred inheritance of all free English subjects, had left the States and the people of the country keenly alive to the value of liberty and profoundly jealous and distrustful of centralized power. The feeling was widespread that under the Constitution as proposed the States were weakened and a place left for encroachments which might in time end in their absorption into the Federal Government. Under these circumstances ratification of the Constitution by the requisite number of States was secured only by an understanding that amendments would be adopted declaring the rights of the people and restricting the powers of the general government. In pursuance of this understanding a proposition to amend the Constitution was brought forward by Mr. Madison in the First Congress, and the first ten amendments were framed, and ratified by the requisite number of States in December, $1791 .^{3}$

These amendments do not affect the powers of the States in respect to their orn people, but limit the porrers of the general govermment alone." "The Constitution," said Chief Justice Marshall in 1833, "was ordained and established by the people of the United States for themselves, for their own govern-

3 See, for a sketch of the events leading to the adoption of the first ten amendments, Jackson $r$. Wood, 2 Cow. (N. Y.) 819, note; O'Neil $r$. Vermont, 144 U. S. 323, per Field, J., dissenting, at p. 361.

4 Spies $r$. Illinois, 123 U. S. 131, 166 (18ST). Perhaps the earliest adjudieation to this effect was in 1824 in a nisi prius decision of the New Fork Supreme Court by .Judge Walworth, afterwards the Chancellor of the State. Jackson $v$. Wood, 2 Cow. (N. Y.) 819, note. 
ment, and not for the government of the individual States. Each State established a constitution for itself, and in that constitution provided such limitations and restrictions on the powers of its particular government as its judgment dictated. The people of the United States framed such a government for the Cnited States as they supposed best adapted to their situation and best calculated to promote their interests. The porrers they conferred upon this government were to be exercised by itself; and the limitations on power, if expressed in general terms, are naturally, and, we think, necessarily applicable to the government created by this instrument. They are limitations of power granted in the instrument itself; not of distinct governments framed by different persons and for different purposes." ${ }_{5}$

This construction governs, of course, the application of the Fifth Amendment, and the provision for "due process", which it contains. ${ }^{6}$

\section{In the Fourteenth Amendment.}

In very different circumstances of our national life, was adopted as a part of the Federal Constitution the Fourteenth Amendment, in which the phrase Place of Fourteenth Amendment in Constitu"due process of law" occurs again. This amendment belongs to the group, the Thirteenth, Fourteenth, and Fifteenth Amendments, by which the results of the struggle of the Civil War were secured and rendered permanent. $\mathrm{By}$ the Thirteenth Amendment, which declares that "neither slavery

5 Barron $v$. Baltimore, 7 Pet. (U. S.) 243, 247.

- Munn $v$. Illinois, 94 U. S. 123; Kelly $v$. Pittsburgh, 104 U. S. 78; Hallinger $v$. Davis, 146 U. S. 319; Fallbrook Irrigation Dist. $v$. Bradley, 164 U. S. 112. 
Chapter nor involuntary servitude, except as a punishment
I.

I. for crime where the party shall have been duly convicted, shall exist within the United States, or in any place within its jurisdiction," the freedom of the negro race was assured, but their rights were still at the mercy of State legislation. Some of the former slave States passed laws especially directed against the negro race, and imposing various disabilities on former slaves. In some instances they were denied the right to appear in the towns, except in the capacity of menial servants. They were denied the right to purchase land. They were not permitted to testify in cases where a white man was a party. ${ }^{7}$ It was felt that national protection was necessary for the freedmen, and the Fourteenth Amendment was proposed to the States, and declared ratified in July, 1868. Its first section is as follows: "All persons born or naturalized in the United States, and subject to the jurisdiction thereof, are citizens of the United States and the State wherein they reside. No State shall make or enforce any law which shall abridge the privileges or immunities of citizens of the United States; nor shall any State deprive any person of life, liberty or property without due process of law; nor deny to any person within its jurisdiction the equal protection of the laws.',

Thus it will be seen that the Fourteenth Amendment was broader in its scope than the wrongs by which it was occasioned. "Tt had its origin in a purpose to secure the newly made citizens in the full

7 Slanghter-House Cases, 16 Wall. (U. S.) 36, the court by Miller, J. See also Wilson. Hist. Am. People, vol 5, p. 18 et scq.; Rhodes, Hist. U. S. from Compromise of 1850 , rol. 5, p. 18. 
enjoyment of their freedom," said Mr. Justice Field, "but it is in no respect limited in its operation to them. It is universal in its application, extending its protective force over all men, of every race and color, within the jurisdiction of the States, throughout the broad domain of the Republic."s "All history," continued the learned justice, "shows that a particular grievance suffered by an individual or a class, from an oppressive or defective law, or the absence of any law touching the matter, is often the occasion of and cause for enactménts, constitutional or legislative, general in their character, designed to cover cases not merely of the same, but all cases of a similar nature. The wrongs which were supposed to be inflicted upon or threatened to citizens of the enfranchised race, by special legislation directed against them, moved the framers of the amendment to place in the fundamental law of the nation provisions not merely for the security of those eitizens, but to insure to all men at all times and in all places due process of law and the equal protection of the laws. Oppression of the person and spoliation of property by any State were thus forbidden, and equality before the law was secured to all."

That "due process of law" under this amendment is a right of all classes of persons is now the veriest commonplace, but in the Slanghter-House Cases, in 1872, the first instance in which this amendment came before the Supreme Court, the majority of the court seemed inclined to give it a much nar-

8 Santa Clara County $v$. Southern Pac. R. Co., 18 Fed. Rep. 385, 399 (1883). 
Chapter rower operation. In that ease, Mr. Justice Miller,

I. for the court, after alluding to the origin of the amendment, observed: "We doubt very much whether any action of a State not directed by way of discrimination against the negroes as a class or on account of their race, will ever be held to come within the purriew of this provision. It is so clearly a provision for that race and that emergency that a strong case rould be necessary for its application to any other." 9 The course of events has contradicted this forecast, and the same court could say in 1898 that the majority of cases which had arisen under this amendment turned not upon a denial to the colored race of rights therein secured to them but upon alleged discriminations in matters entirely outside of the political relations of the parties ag. grieved. ${ }^{1}$

Transactions before July,

The provision for due process of law in the Fourteenth Amendment applies to all deprivations of life, liberty, or property since its passage, and it has been

9 Slaughter-House Cases, 16 Wall. (U. S.) $36,81$.

In Maxwell $r$. Dow. 176 U. S. 581, 591, the court, speaking by Mr. Justice Peckham, adverted to this expression as an imlividual dictum, and said: "The opinion upon the matters actually involved in the case has never been doubted or overruled by any judgment of this court. It remains one of the leading cases upon the subject of that portion of the Fourteenth Amendment of which it treats."

1 Holden $x$. IIarly, I69 U. S. 366, 382.

The journal of the committee which framed the amendment: the full argument of Senator Roscoe Conkling, who was a member of the conmittee, in San Mateo County $r$. Sonthern Pae. R. Co., argued Dec. 19, 1882, before the Supreme Court, but in riew of a settlement never deciled by that tribunal (see 116 (T. S. 13S) : and the debates in Congress upon the amendment, show conelusirely that, as the words of the clause indieate, its benefits were never intentel, ly its framers at least, to be limited to the negro race. See Guthrie, Fourteenth Amendment, 22, 25, and the quotations there given. 
held to prohibit a taking of property without due process by proceedings under a statute enacted before the passage of the amendment.' In the case so holding, a dam and embankment had been erected before the date of the amendment, which were claimed to injure the riparian rights of an adjoining landowner. It was held that the maintenance of the dam might be viewed as a continuous trespass, but, if not, that building a new dam which raised the head of water after the amendment, gave the riparian owner a right to claim the protection of due process. $^{2}$

\section{Equivalent Phrases in State Constitutions.}

The provisions of the Fourteenth Amendment in restraint of deprivation by the States of due process of law form simply an additional guaranty in the name of the national government of rights already guaranteed by the several States. ${ }^{3}$ The constitution of nearly every State in the Union ${ }^{4}$ contains an

2 Kaukauna Water Power Co. v. Green Bay, etc., Canal Co., 142 U. S. 254.

3 siee infra, p. 35.

4 The Ordinance of 1787 for the government of the Northwest Territory provides the protection of the law of the land for "liberty and property" only. Sec. 14, Art. 2. The constitution of Vermont extends the same protection only to "liberty." New Jersey merely declares that the privilege of "possessing and protecting property" shall be inalienable, but this clause has been understood as securing to property the law of the land. Maxwell $v$. Goetschius, 40 N. J. L. $391,39 \mathrm{Am}$. Rep. 242. In view of other provisions of various constitutions, such as the guaranty of certain remedies for wrong and injustice, either without delay, or by due course of law, it by no means follows, even when the article providing due process is incomplete or is omitted altogether, that protection for life, liberty, and property is wanting. See Durkee $v$. Janesville, $28 \mathrm{Wis}, 464,9 \mathrm{Am}$. Rep. 500. 

Chapter equivalent provision. The form of the provision is
I. sometimes a translation in substance of the famous clause of Magna Carta, and guarantees the "law of the land;" sometimes, as in the Federal Constitution, "due process of law" is secured; and some States use the expression, "due course of law." But all these phrases are, in substance, identical. ${ }^{5}$

SCOPE OF THE GUARANTY IN ENGLISH AND AMERICAN

The

English guaranty no bar on Parliament.

\section{LAW.}

All the great English guaranties of private rights were called forth in resistance to the tyranny and oppression of the Crown. ${ }^{6}$ In theory at least, the subject's person and property were under the protection of the law of the land and judicium parium, as against the acts of the King himself or others exercising authority from him, as by his letters patent. The right to the judgment of peers as originally

5 Mason $r$. Messenger. 17 Towa 261; Gilchrist Schmidling, 12 Kan. 263: Durkee $v$. Janesville, 28 Wis. 464.

6 In later times the curtailment of royal powers is associated with the maxim that the king ean do no wrong. Chief Justice Markham is said to have told Edward IV/ that he could not arrest a man upon suspicion of felony, as any of his subjects might, because if he should wrong a man by such arrest the injured person rould have no remedy. 3 How. St. Tr. 15. See Pollock, Essays in Jurisprudence. 214. Of the proceedings on the deposition of Edward II, Mr. L. O. Pike says - as might well be said in other early cases: "In those rude times men had, of course, not arrived at that refinement of doctrine acenrding to which only the sovereign's advisers are responsible for the misgovernment of the sovereign." 1 Hist. Cr. in Eng. 226.

T King Ienry VI granted to the corporation of dyers in London power to search, and if they found any eloth dyed with logwood, that the cloth should he forfeit; and it was adjudged that this charter concerning the forfeiture was against the law of the land; for no forfeiture can grow by letters patent. 2 Inst. $4 \bar{i}$, stated in London's Case, 8 Coke 125\%. 
understood was retained by the lords alone, and, even in the case of a lord, a trial by his peer's could be demanded only when the suit was at the instance of the King, as by an indictment, and an appeal (the old private suit for murder or felony) was to be tried as in the case of any common person. ${ }^{8}$ With regard to the guaranty of the law of the land, its protection was held to be effective also against unjust and arbitrary action on the part of municipal corporations, which, says Lord Coke, "derive their authority from the King." ' 9 Thus, in Bagg's Case ${ }^{\mathbf{1}}$ it was lield that no freeman of any city or borough can be disfranchised from the corporation if it has not authority so to do either by express words of charter or prescription, and in the absence of such authority, he ought, according to Magna Carta, to be convicted by course of law before removal. Lord Coke also illustrates per legem terrae by a case wherein a custom in a city was adjudged void because "against the law of the land."' 2 But under the English system of parliamentary sovereignty ${ }^{3}$ these

8 Y. B. 10 Edw. IV, fol. 6, pl. 17; 2 Inst. 48 ; Hurtado v. California, 110 U. S. 516.

See as to judicium parium, supra, p. 5. For appeal in the old technical sense of a formal accusation of treason or felony, brought by one subject against another and usually ending in trial by combat, see $4 \mathrm{Bl}$. Com. 312; McKechnie, Magna Carta, 418; and the curious case of Ashford $v$. Thornton, 1 B. \& Ald. 405, the last appearance in English history of this survival of a primitive state of society. The abolition of appeals followed immediately in 1819 by Stat. 59 Geo. III., c. 46.

- Bagg's Case, 11 Coke 100.

111 Coke $99 a$.

22 Inst. 46. So Coke, referring to Y. B. 43 Edw. III, Mich., fol. 32, pl. 30 , which, however, says merely that because the custom was alleged in this city only and not elsewhere it was adjudged void.

3 Coke, 4 Inst. 36; 1 Bl. Com. 160; Dicey, Law of Const. 39. 
Chapter guaranties could impose no restraint on Parlia-
I.

American guaranty restrains all govern. mental activity.

ment, ${ }^{4}$ and consequently bills of attainder and other acts for punishment without trial are within the legal competence of the law-making porrer.

We are thus brought face to face with a fundamental distinction between the English guaranty of the law of the land and the clauses of a similar purport in American constitutions. While the English provision exists solely against executiveaction, under our system of paramount written constitutions, to which all departments of the government are equally subject, the provision extends alike to the executive, judicial, and legislative activities of the States and the nation. ${ }^{5}$ With regard to the States, the question is placed beyond doubt by the words of the Fourteenth Amendment: "Nor shall any State deprive any person of life, liberty or property without due process of law; nor deny to any person within its jurisdiction the equal protection of the laws." The Supreme Court of the United States, in a case in

4 In Bonham's Case, 8 Coke 118a, Coke has these words: "And it appears in our books, that in many cases, the common law will control acts of Parliament and sometimes adjudge them to be utterly void; for when an act of Parliament is against common right and reason. or repugnant or imposible to be performed, the common law will control it and adjulge such act to be void." See also Day c. Savalge. Hob. 87. Prof. Thayer (1 Cas. Const. Law, 48, note), after a thorough examination of the passage in Coke, conchudes that he only intended to amounce the rule of construction that Acts of Parliament are to be construed according to common law and natural right, to the extent of giving a forced construction, if necessary. At any rate, such a statement as Coke's. if it bears the interpretation commonly given to it (1 Bl. Com. 91; 1 Kent Com. 448), is but a closet speculation, never put in practice. Dices, Law of Const. 58 et seq.

5 Chicago, etc., R. Co. $v$. Chicago, 166 U. S. 226, 233-240. And see Murray $r$. Hoboken Land, etc., Co., is How. (U. S.) 272-276. 
which the enjoyment of the equal protection of the Chapter laws was the direct issue, used the following reasonI. ing equally applicable to due process: "They [the words quoted] have reference to the actions of the political body denominated a State, by whatever instruments or in whatever modes that action may be taken. A State acts by its legislative, its executive or its judicial authorities. It can act in no other way. The constitutional provision, therefore, must mean that no agency of the State, or of the officers or agents by whom its powers are exerted, shall deny to any person within its jurisdiction the equal protection of the laws. Whoever, by virtue of public positions under a State government, deprives another of property, life or liberty without due process of law, or denies or takes away the equal protection of the laws, violates the constitutional inhibition; and as he acts in the name of and for the State, and is clothed with the State's power, his act is that of the State. This must be so or the constitutional inhibition has no meaning. Then the State has clothed one of its agents with power to annul or to evade

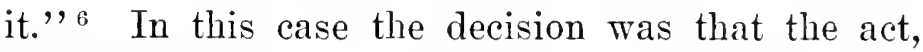
whether judicial or ministerial, of a judge in his official capacity was within the prohibition of the amendment.

The Fourteenth Amendment has been held likewise to render void the judgment of a probate court Embrace judicial determining that a person absent for seven years was dead and granting letters of administration on his estate, when in fact he was alive, although the

${ }^{6}$ Ex $p$. Virginia, 100 U. S. 339 . See also Hovey v. Elliott, 167 U. S. 409 . 
Chapter judgment had been confirmed by the highest court of

the State; ${ }^{7}$ and, as was observed in a later case, a State's "judicial authorities may keep within the letter of the statute prescribing forms of procedure in the courts, and give the parties interested the fullest opportunity to be heard, and yet it might be that its final action would be inconsistent with that amendment." s

A municipal ordinance so enforced by the authorities charged with its administration as to rork a substantial deprivation of rights to a particular class of residents is also void within this prohibition. ${ }^{9}$ In a case so holding, the court said: "Though the law itself be fair on its face and impartial in appearance, set, if it is applied and administered by public authority with an evil eye and an unequal hand, so as practically to make unjust and illegal discriminations between persons in similar circumstances, material to their rights, the denial of equal justice is still within the prohibition of the Constitution."

The legis.

lative

power re.

But the class of State acts most commonly held strained. void as denying due process of law are enactments of the legislature. Considering this class of cases, the United States Supreme Court in Hurtaro v. California." said: "The concessions of Magna Carta were wrung from the king as guaranties against the oppressions and usurpations of his prerogative. It did not enter into the minds of the barons to provide security against their own body or in favor of the

7 Scott $r$. MeNeal, 154 U. S. 34.

8 Chicago, etc., R. Co. $v$. Chicago, 166 U. S. 226.

- Yick Wo $v$. Hopkins, 118 U. S. 373.

1110 U. S. 516. 
commons by limiting the power of parliament; so that bills of attainder, ex post facto laws, laws declaring forfeitures of estates, and other arbitrary acts of legislation, which occur so frequently in English history, were never regarded as inconsistent with the law of the land, for notwithstanding what was attributed to Lord Coke in Bonham's Case, ${ }^{2}$ the omnipotence of parliament over the common law was absolute even against common right and reason. The actual and practical security for English liberty against legislative tyranny was the power of a free public opinion represented by the commons. In this country written constitutions were deemed essential to protect the rights and liberties of the people against the encroachments of power delegated to their governments, and the provisions of Magna Carta were incorporated into bills of rights. They were limitations upon all the power's of government, legislative as well as executive and judicial. It necessarily happened, therefore, that as these broad and general maxims of liberty and justice held in our system a different place and performed a different function from their position and office in English constitutional history and law, they would receive and justify a corresponding and more comprehensive interpretation. Applied in England only as guards against executive usurpation and tyranny, here they liave become bulwarks also against arbitrary legislation." ${ }_{3}$ Applying the principle of due process to legislative acts, as this reasoning requires, the statement is frequently made that the terms

3 See also Davidson $r$. New Orleans, 96 U. S. 97. 
Chapter "law of the land" and "due process of law" demand something more than a mere statute; for a State can not make anything due process of law which by its, own legislation it chooses to declare such." "If life, liberty and property could be taken away by the direct operation of a statute, the enjoyment of these rights rould depend upon the will and caprice of the legislature, and the [Constitutional] provision would be a mere nullity.",

The arguments which extend the national guaranties to all departments of government undoubtedly apply to the provisions of State constitutions, and it has been so held. ${ }^{6}$

DUE PROCESS IN THE FOURTEENTH AND IN THE FIFTH AMENDMENTS COMPARED.

Relation of the Fourteenth to the first eight amendments.

The first eight amendments to the Constitution of the United States, which form the so-called Federal Bill of Rights, enumerate a number of rights with the enjorment of which by the people there may be no interference on the part of the national government. The Fourteenth Amendment contains a much less extensive and specific recital of rights protected against the State. As due process of law has been defined only in the most general terms and is in its nature not susceptible of exhaustive characterization, it was inevitable that sooner or later the question should arise whether under that phrase, in the

4 Argument of Daniel Webster in Dartmouth College $v$. Woodward. 4 Wheat. (U. S.) 581 ; Davidson $v$. New Orleans, 96 U. S. 97 ; Chicagro, ete. R. Co. $v$. Chicago, 166 U. S. 226 ; Hoke $v$. Henderson, 4 Der. L. (15 N. Car.) 1.

5 Dorman $r$. State, 34 Ala. 216.

6 Mulligan $v$. Smith, 59 Cal. 206. 
Fourteenth Amendment, security from the violation of certain of the rights specifically guaranteed by the first eight amendments conld be enforced.

There is at least a prima facie presumption that the other rights enmmerated in the Fifth Amendment were not considered as included in "dne process of law" which is contained in the same list with them. One of these rights is indictment by a grand jury for capital or infamous crimes. In Hurtado $v$. California, ${ }^{7}$ when the legality of a conviction of murder upon an information filed by the district attorney according to the constitution and laws of California was questioned upon the ground that the person convicted had been deprived of the due process of law to which he was entitled under the Fourteenth Amendment, the Supreme Court of the United States decided against this contention. "We are to construe this phrase in the Fourteenth Amendment," said the court, "by the usus loquendi of the Constitution itself. The same words are contained in the Fiftl Amendment. That article makes specific and express provision for perpetuating the institution of the grand jury so far as relates to prosecutions for the more aggravated crimes, under the laws of the United States. . . . According to a recognized canon of interpretation, especially applicable to formal and solemn instruments of constitutional law, we are forbidden to assume, without clear reason to the contrars, that any part of this most important amendment is superfluous. The natural and obvious inference is, that in the sense of the Constitution, 'due process of law' was not meant

7110 U. S. 516. 
Chapter or intended to include, ex vi termini, the institution and procedure of a grand jury in any case. The conclusion is equally irresistible that when the same phrase was employed in the Fourteenth Amendment to restrain the action of the States, it was used in the same sense and with no greater extent; and that if in the adoption of that amendment it had been part of its purpose to perpetuate the institution of the grand jury in all the States, it would have embodied, as did the Fifth Amendment, express declarations to that effect."

Is "due, process" identical in the Fifth and Fourteenth Amendments?
The identity of the meaning of the phrase in the two amendments is here asserted for reasons which would seem to exclude equally its extension to any of the rights enumerated in the Fifth Amendment. ${ }^{8}$ This view of the effect of the Fourteenth Amendment is developed in a later case, when the court, after referring to Inurtado $v$. California as having pointed out that "due process" was used in the same sense in both amendments and with no greater extent of meaning in the Fourteenth, proceeded: "As due process of law in the Fiftl Amendment referred to that law of the land which derives its authority from the legislative powers conferred on Congress, by the Constitution of the Uniter States, exercised within the limits therein prescribed, and interpreted according to the principles of the common law, so in the Fourteenth Amendment, the same words refer to that law of the land in each State which derives its authority from the inherent and reserved powers of the State exerted

8 See disonting oninions of Tarlan, .J., in Hurtado $v$. California, 110 U. S. 538 ; and in Maxwel] $r$. Dow. 176 C. S. 5 S1. 
within the limits of those fundamental principles of liberty and justice which lie at the base of all our civil and political institutions." 's But in Chicago etc., R. Co. v. Chicago, ${ }^{1}$ decided in 1897 , it was determined by the same court that due process of law does not permit a State to appropriate private property for a public use without just compensation, although the Fifth Amendment specifically provides for compensation in such cases.

The conclusion in this case (in which the opinion was rendered by Mr. Justice Harlan, who dissented in Hurtado v. California) seems to be opposed to the reasoning quoted above, and in order to harmonize the cases we are led to infer that the nature of the right denied, ${ }^{2}$ whether or not that right is guaranteed by the Fifth or any other of the earlier amendments restraining federal action, determines whether due process is present as required by the Fourteenth Amendment. This inference is entirely in harmony with all that is said in Chicago, etc., R. Co.v. Chi-

Content of the Four. teenth Amend. ment does not depend on prior enumera. tion.

9 In re Kemmler, 136 U. S. 436.

1166 U. S. 226, followed in Norwood $v$. Baker, 172 U. S. 269, 277 ; San Diego Land, etc., Co. v. National City, 174 U. S. 754.

In Fallbrook Irrigation Dist. $v$. Bradley: $164 \mathrm{U}$. S. 112 , there is a dictum by Mr. Justice Peckham, who delivered the opinion of the court, which indicates that he considered the absence of compensation could not be relied on as against the taking of private property by the State if the taking was for a public purpose.

2 In Dreyer $v$. Illinois, $187 \mathrm{U}$. S. 85, the question whether double jeopardy (which is forbidden by the Fifth Amendment) is prohibited by the due process clause of the Fourteenth Amendment, is raised but not determined. That the infliction of cruel and nnusual punishment, forbidden to the United States by the Eighth Amendment, is not forbidden to the States by this clause of the Fourteenth Amendment, provided equality of punishment is preserved, is inferable from In re Kemmler, 136 U. S. 436. 
Chapter cago, where the reasoning is as to the fundamental character of the right to compensation.

That the specific mention of riglits in the first eight amendments has no necessary connection with their inclusion in or exclusion from the first section of the Fourteenth Amendment appears also from a consideration of the course of decision with regard to the privileges and immunities of citizens of the United States, secured by the Fourteenth Amendment against abridgment by the States. The argument has frequently been advanced that the rights protected by the first eight amendments are such privileges and immunities; ${ }^{3}$ but though the view has had distinguished adrocates, ${ }^{4}$ the court has held otherwise and has asserted the true criterion to be the fundamental character of the right for which protection is claimed, ${ }^{5}$ so that some of the rights enumerated in the early amendments may be privileges and immunities of citizenship, while other's are not. ${ }^{6}$

3 Notably in Preser $v$. Illinois, 116 U. S. 252; and in Spies $v$. Illinois, 123 L. S. 131, by Mr. John Pandolpl Tucker. In both these cases the decision pasied off on other points.

4 It is implier though not distinetly announeed in Mr. Justice Harlan's discenting opinion in Hurtado $r$. California, $110 \mathrm{U}$. S. 516, and is arlopted by the dissenting justices in O'Neil $v$. Vermont, 144 U. S. 323. See the opinion of Field, J.. at pp. 361, 363; of Iarlan, J., at p. 3\%0. It is strongly adroeated by Mr. Guthrie in his book on the Fourteenth Ameniment, which appeared before the decision in Maxwell $r$. Dow, 176 [. S. 581. Mr. Guthrie lays much stress on the opinions expressed in lebate by the advocates of the amendment in Congress, an aroument fully met in the atse last cited.

5 Maxwell $r$. Dow, 176 U. S. 581, Harlan, J., dissenting at length on the ground inter alia indicated in the last note. The view stated in the text is necessarily inrolved also, as is pointed out in Maxwell $v$. Dow, in the holding in Hurtado $v$. California, 110 U. S. 516, and the line of cases which follow it.

6 In Arlams $r$. New York, 192 I. S. 594, the question is raised, but its determination was not found necessary, whether the right 
In 1901, the court, having occasion to consider the meaning of due process in the Fifth and Fourteenth Amendments, said: "While the language of those amendments is the same, yet as they were enIdentity of meaning grafted upon the Constitution at different times and in widely different cireumstances of our national life, it may be that questions may arise in which different constructions and applications of their provisions may be proper." But in the decision of the case before it, the court proceeded "on the assumption that the legal import of the phrase, "due process of law,' is the same in both amendments.", 7

RELATION OF FEDERAL GOVERNMENT TOWARD DUE PROCESS

BY THE STATES.

Supervisory Powers of the Supreme Court of the United States.

Before the passage of the Fourteenth Amendment the security of the citizens of the several States for due process of law in proceedings by the State lay in its institutions alone. Even if due process was deDue proc.
ess by States before and after the Fourteenth nied, the federal government had no right to inter-

Amend.

to be free from unreasonable searches and seizures (Const. U. S., Amend. IV) and from being compelled to testify against one's self (Const., Amend. V) are such privileges and immunities. See also In re Kemmler, 136 U. S. 436, that immunity from cruel and unusual punishment is not an immunity of citizenship in the United States as against the States.

7 French $v$. Barber Asphalt Paving Co., 181 U. S. 324.

"The Fourteenth Amendment," it has been held, "legitimately operates to extend to the citizens and residents of the States the same protection against arbitrary State legislation affecting life, liberty and property as is offered by the Fifth Amendment against similar legislation by Congress." Hibben $v$. Smith, 191 U. S. $310,325$. 
Chapter fere. The Fourteenth Amendment changed this con1. dition of affairs. It made it a matter of national concern that the State should not deny due process to its citizens and to others. It gave to the United States the right to supervise the performance of this duty, and transferred from the State to the Federal Supreme Court the ultimate decision on the question of the presence of due process in all proceedings affecting life, liberty, and property. But under the amendment the authority of the federal court is merely to determine whether the State by some offcial action has provided due process or has failed in that duty; and if a denial of due process appears, it can only pronounce the proceedings void. The power of the federal government ordinarily ends with that act. Thus the primary duty of providing for the protection of life, liberty, and property by due process of law rests still with the States, and the Fourteenth Amendment operates merely as a guaranty additional to the State constitutions against encroachments on the part of the States upon fundamental rights, which their governments were created to secure. It did not radically change the whole theory of the relations of the State and federal governments to each other and of both governments to the people. ${ }^{8}$ It has not had the effect of converting the national Supreme Court into a general court of appeal, where decisions of the State courts, involving merely questions of general justice and equitable

8 U. S. $v$. Cruikshank, 92 U. S. 542; Slaughter-House Cases, 16 Wall. (U. S.) 36 ; In re Kemmler, 136 U. S. 436 ; Orr $v$. Gilman, 183 U. S. 278,286 ; U. S. $v$. Moore, 129 Fed. Rep. 630 ; Ex p. Riggins, 134 Fed. Rep. 404. 
considerations in the taking of life or property, may be reviewed. ${ }^{9}$

In exerting its supervisory jurisdiction, the sole question before the court is whether the State's act has infringed the provision of the Fourteenth Amendment or some valid act of Congress made in pursuance thereof. ${ }^{1}$ Upon all questions involving merely the conformity of the act with the constitution of the State, the decision of the highest State court is final and conclusive, however unjust, oppressive, or harsh an act may have been upheld by it. ${ }^{2}$ But when the State's decision is against the validity of a right claimed under the federal Constitution or laws, the denial of due process under the national Constitution becomes a question. ${ }^{3}$

Within these principles, the presence of the essential features of due process is always a federal question, which the United States Supreme Court will decide for itself; / but due process, so far as mere procedure not affecting fundamental rights is concerned, is process due according to the law of the State, ${ }^{4}$ and the determination of the State is con-

9 Davidson $v$. New Orleans, 96 U. S. 97, 104; Missouri Pac. R. Co. $v$. Humes, 115 U. S. 512, 520; New York, etc., R. Co. v. Bristol, 151 U. S. 556 ; Fallbrook Irrigation Dist. $v$. Bradley, 164 U. S. 112.

1 Fallbrook Irrigation Dist. v. Bradley, 164 U. S. 112.

2 Kirtland $v$. Hotchkiss, 100 U. S. 491 ; Missouri Pac. R. Co. $v$. Humes, 115 U. S. 512, 520; Fallbrook Irrigation Dist. v. Bradley, 164 U. S. 112; French v. Barber Asphalt Paving Co., 181 U. S. 324; Hibben $v$. Smith, 191 U. S. 310 ; Olsen $v$. Smith, 195 U.S. 332 ; National Cotton Oil Co. v. Texas, 197 U. S. 130, 131.

When the interpretation in a particular way of a State law by the State court was unnecessary to the determination of the case, the Federal Supreme Court need not pass on the validity of the State's interpretation. King $v$. Mullins, 171 U. S. 404.

3 Green Bay, etc., Canal Co. v. Patten Paper Co., 172 U. S. 58.

4 Walker $v$. Sauvinet, 92 U. S. 90. 
Chapter clusive as to what the State law requires, ${ }^{5}$ however

much the requirements may differ among the several States. While the cardinal principles of justice are immutable, the methods by which justice is administered are subject to constant change in conformity to the wishes of the citizens of the different States, and the course of legislation has already produced great divergencies in respect to form. On one side of a State line there may be a right to trial by jury and on the other side no such right may exist; but the orderly procedure laid down in each State is due process of law; for the Fourteenth Amendment does not profess to secure to all persons in the United States the benefit of the same laws and the same remedies. ${ }^{6}$ In a case which involved the presence of due process in a proceeding for the collection of taxes, the Supreme Court observed: "The vice which underlies the entire argument of the plaintiff in error arises from a failure to distinguish between the essentials of due process of law under the Fourteenth Amendment and matters which may or may not be essential under the terms of a State assessing or taxing law. The two are neither correlative nor coterminous. The first, due process of law, must be found in the State statute and can not be departed

"Law in its regular administration through courts of justice is due process, and, when secured by the law of the State, the constitutional requisition is satisfied." Caldwell $v$. Texas. 137 U. S. 692. 5 Caldwell $x$. Texas, 137 U. S. 692; Iowa Cent. R. Co. $v$. Iowa. 160 U. S. 389; In re Krug, 79 Fed. Rep. 308.

When the construction of a statute by the State cout is such that due process of law exists in the statute as construed, the construction is conclusive. Baltimore Traction Co. $v$. Belt R. Co.. 151 U. S. 138.

6 Missourj $v$. Lewis, 101 U. S. 22, 31; Holden $v$. Hardy, 169 U. S. 366. 
from without violating the Constitution of the United States. The other depends on the law-making power Chapter of the State, and, as it is solely the result of such authority, may vary or change as the legislative will of the State may see fit to ordain. It follows that to determine the existence of one (due process of law) is the final province of this court, while the ascertainment of the other (that is, what is merely essential under the State statute) is a State question within the final jurisdiction of the courts of last resort of the several States. When, then, a State court decides that a particular formality was or was not essential under the State statute, such decision presents no federal question, providing always the statute, as thus construed, does not violate the Constitution of the United States by depriving of property without due process of law. This paramount requirement being fulfilled, as to other matters, the State's interpretation of its own laws is controlling and decisive." 7

Always must the court look beyond the form of the question presented, to its substance to detersubstance. mine whether an essential of due process is involved. Thus the question of the reasonableness of the notice required under a State statute involves a vital element of due process, and the decision of the State court on this question is not binding on the Federal Supreme Court. ${ }^{9}$ On the other hand, methods of

7 Castillo $v$. McConnico, 168 U. S. 674; French $v$. Taylor, 199 U. S. 274 . See also Iowa Cent. R. Co. $v$. Iowa, 160 U. S. 389 ; Allen $v$. Georgia, 166 U. S. 138.

8 Simon $r$. Craft, 182 U. S. 436 ; Louisville, etc., R. Co. $v$. Schmidt, 177 U. S. 230.

9 Scott $v$. McNeal, 154 U. S. 34,35 ; Roller $v$. Holly, 176 U. S. 398. 
Chapter procedure popularly regarded as most fundamental

and necessary safeguards to the rights of the citizen, such as indictment by a grand jury or trial by jury, are within the power of the State and may be granted or taken away, without infringing the Fourteenth Amendment. ${ }^{1}$

Irregulariv ties and errors in State

As it is preëminently and exclusively the duty of the State courts to construe the statutes of the State, irregularities in proceedings or errors in construction of statutes on the part of State conrts acting within their jurisdiction will not constitute a denial of due process so long as the fundamental requisites thereof are present. ${ }^{3}$ In a case where an infant contended that he ras deprived of due process of law by his guardian's sale of his real property under an order of court, but without giring bond as required by statute, the court said: "The statute inder" which the court acted would, if followed, have given Arrowsmith all the protection which had been guaranteed to him by the Constitntion of the United States. The bond in question was a matter of procedure only, and if it ought to have been required the court erred in ordering a sale without having first caused it to be filed and approved. At most, this was an error of judgment

1 See Holden $v$. Hardr, 169 U. S. 366.

3 In re Converse, 137 U. S. 631: Bergemann $v$. Backer, 157 U. S. 655 ; Central Land Co. r. Laidley, 159 U. S. 103; Iowa Cent. R. Co. $v$. Iowa, 160 U. S. 389 ; National Cotton Oil Co. v. Texas, 197 U. S. $115,130,131$.

As has been seen, supra, p. 27, judicial action is as much within the Fourteenth Amendment as legislative action. and therefore if a State judgment in terms or by its necessary operation deprives a party of due process, it is reviewable. See Lehigh Water Co. $v$. Easton, 121 U. S. 388, 392. 
in the court. The constitutional provision is, "Nor Chapter shall any State deprive any person of life, liberty or property without due process of law.' Certainly a State can not be deemed guilty of a violation of this constitutional obligation simply because one of its courts, while acting within its jurisdiction, has made an er'roneous decision. The legislature of a State performs its whole duty under the Constitution in this particular, when it provides a law for the government of its courts, while exercising their respective jurisdictions, which, if followed, will furnish the parties the necessary constitutional protection. All after that pertains to the courts, and the parties are left to their appropriate remedies for the correction of errors in judicial proceedings." 4 Nor can the denial of the right of trial by jury, though it is clearly erroneous to construe the laws of the State as justifying the refusal, rork a deprivation of due process. ${ }^{5}$ But the principle that erroneous decisions of State courts do not work a denial of due process is to be limited to questions involving conformity with the State constitution and laws, matters upon which the decision of the State courts is final, and even in such a case the decision must not deprive a person of those fundamental rights guaranteed by the Constitution, which may be infringed by the conduct of the court in its administration of the law as well as by the law itself under which the court is proceeding.

4 Arrowsmith $v$. Harmoning, 118 U. S. 194.

5 Iowa Cent. R. Co. v. Iowa, 160 U. S. 389. 
Chapter

\section{Direct Enforcement of Due Process by Congress.}

So far the function of the national government under the Fourteenth Amendment has been considered only in its supervisory and, so to say, negative aspect. May Congress in addition by direct legislation provide for the enjoyment of due process by citizens of the several States? Congress, first, has such porter to legislate in protection of rights as is given it by direct grant in the Constitution, and second, the power to protect and enforce every right created by, arising under, or dependent upon the Constitution of the United States. The second or implied power may be based on the duty of the government to protect its citizens in the enjoyment of the rights conferred on them, which is correlative to the grant of such rights; or it may be found in the general poter ' "to make all laws which shall be necessary and proper for carrying into execution the foregoing powers, and all other powers vested by this Constitution in the government of the United States, or in any department or officer thereof.", s Each of the Thirteenth, Fourteenth, and Fifteenth Amendments contains the specific declaration that "Congress shall have power to enforce this provision by appropriate legislation." By this declaration, "some legislation," said the Supreme Court. "is contemplated to make the amendments fully effective. Whatever legislation is appropriate, that is, adapted to carry out the objects the amendments have in view, whatever tends to enforce submission

i Const. U. S.. Art. I, \$ S. ๆ 1 S.

8 L. S. v. Cruikshank, 1 Foods (U. S.) 308; Logan $v$. L. S., 144 U. S. 263. 
to the prohibitions they contain, and to secure to all Chapter persons the enjoyment of the perfect equality of I. civil rights and the equal protection of the laws against State denial or invasion, if not prohibited, is brought within the domain of Congressional power." 9

The object of the Fourteenth Amendment, as has been declared in repeated decisions, is not to confer the rights enumerated in its first section directly on any one, but to guarantee all citizens or persons against being deprived of those rights by State action. The enumerated rights are recognized as preëxisting and fundamental, not created by nor dependent on the Constitution, and the only right conferred by that instrument is the right of exemption from the prohibited denial by the States or their agencies. " "It [the Fourteenth Amendment]," said Mr. Justice Bradley, in the United States Circuit Court in a case affirmed by the Supreme Court," "is a guaranty of protection against the acts of the State government itself. It is a guaranty against the exertion of arbitrary and tyrannical power on the part of the government and legislature of the State, not a guaranty against the commission of individual offenses; and the porrer of Congress, whether express or implied, to legislate for the enforcement of such a guaranty does not extend to the passage of laws for the suppression of crime within

${ }^{2}$ Ex $p$. Virginia, 100 U. S. 339.

1 U. S. $r$. Cruikshank, 92 C. S. 542, affirming 1 Woods (U. S.) 308 ; Virginia $r$. Rives, 100 U. S. 313; Ex p. Virginia, 100 U.S. 339 ; U. S. v. Harris, 106 U. S. 629; Civil Rights Cases, 109 U. S. 3; Ex $p$. Yarbrough, 110 U. S. 65I; Logan $v$. U. S.. 144 U. S. 263; James $v$. Bowman, $190 \mathrm{U}$. S. 127.

2 U. S. $v$. Cruikshank, 1 Woods (U. S.) 308 , affirmed 92 U. S. 542.

No direct grant to enforce due process; 
Chapter the States. The enforcement of the guaranty does
I. not require or authorize Congress to perform 'the duty that the guaranty itself supposes it to be the duty of the State to perform, and which it requires the State to perform." "' 3 Evidently, therefore, this grant of power confers on Congress no authority to legislate with respect to these rights except as to their denial by the States, and it can not, solely by virtue of the clause conferring power to enforce by appropriate legislation, pass acts to secure, as against individuals, the affirmative enforcement of the rights specified. So far as this provision goes, the duty of legislation with regard to the individual enjorment of due process rests still with the State. ${ }^{+}$

There being no direct grant, we turn to the im- nor im. plied porrer of Congress. But this extends only to power. protect rights arising under or dependent ou the Federal Constitution; and not due process of law, but only the exemption from its denial by the state, is inchuded in that category. Therefore, it rould seem plain that Congress has no power to legislate directly to zrotect the citizen in the enjorment of this right as against the acts of individuals depriving or tending to deprive him thereof. Nor has it attempted to do so by providing ${ }^{5}$ that "if two or

3 Quoted and approved in U. S. v. Harris, 106 U. S. 629. See also Civil Fights Cases, 109 U. S. 3.

4 See cases cited in the last three notes.

5 Rev. Stat. U. S., \$5.50s: 1 Fed. Stat. Annot. 802.

This statute is constitutional, but applies only to rights secured by the Constitution and laws of the United States. For instance, the right to be protected from violence while in the custody of a United States marshal awaiting trial under indictment in a federal court, is a right, the enforcement of which devolves on the national government under its Constitution and laws. If a person in this 
more persons conspire to injure, oppress, threaten or intimidate any citizen in the free exercise or enChapter joyment of any right or privilege secured to him by the Constitution or laws of the United States, or because of his having so exercised the same," they shall be severely punished; for dne process of law is not included among these rights and privileges.

These propositions would seem to be clearly deducible from the decisions of the Supreme Court as Authority to the contrary. to the general scope of the Fourteentl Amendment and as to the clause therein guaranteeing the equal protection of the laws, which is entirely parallel with that securing due process of law. But recently the Circuit Court of the United States in Alabama has reached very different conclusions. ${ }^{6}$ A negro who was under indictment for murder in the courts of Alabama was forcibly taken from the State authorities and murdered by a mob. Individuals accused of taking part in the murder were arrested and indicted under sections 5508 and 5509 of the Revised Statutes of the United States for conspiring to deprive a citizen of rights and privileges secured by the Constitution and laws of the United States. The indictment alleged the right and privilege to be tried by due process of law. The court upon habeas corpus brought by one of the prisoners held the indictment to be good and refused to discharge the petitioner. The court distinguished the nature of the right arising under the due process clause of the Fourteenth Amendment from that arising under the

situation is lynched, the perpetrators of the crime may be indicted and punished under this section. Logan $v$. U. S., 144 U. S. 263.

${ }^{6}$ Ex p. Riggins, 134 Fed. Rep. 404. 
Chapter equal protection of the laws clause of the same
I. amendment, and this distinction was necessary because the Supreme Court had declared unconstitutional an Act of Congress to punish a conspiracy to deprive any person of the equal protection of the laws. ${ }^{7} \quad$ The equal protection of the laws is secured, it is said, by legislation establishing proper laws, and "no act of a private citizen can defeat the enjoyment of this status;', she due process clause, on the other hand, makes it the duty of the State to render to every person accused of crime due process of law, which includes not only proper legislation but the orderly and undisturbed working of the machinery of justice. "Until it has done its perfect rork, the administration of due process, which in a case like this can not be enjoyed except by the regular and orderly morking of judicial procedure, is not afforded by the State.", "The very words of the Fourteenth Amendment inevitably utter a command that the State shall afford due process to the citizen," and the right or privilege so guaranteed "necessarily carries with it and includes in it the right, privilege or immunity to enjoy freedom, exemption from lawless assault, which supervenes between the State and the performance of its duty, and by such violent interference prevents the citizen having, when the State is endeavoring to afford it, due process at the

7 U. S. $v$. Harris, 106 U. S. 629, holding Rev. Stat. U. S., \$5519, not warranted by the Constitution. See 1 Fed. Stat. Annot. S05.

8 A modern "gunpowder plot" to prevent the passage of a law enforcing equal rights wonld seem not to have oecurred to the court.

จ Ex p. Riggins, 134 Fed. Rep. 416-419. 
hands of the State."' Two stages of the State's Chapter duty are distinguished: the first involves only the I. passing of proper laws and the appointment of proper officer's to execute them, and is owing to the whole public; the second stage "includes the obligation, in many instances, to administer judicial procedure in the individual case, and is due to a particular person." The performance by the State of the duty implied in the second stage can only be prevented when, some proceeding has been begun creating the duty toward a particular person. When that stage is reached, as it was in the case under discussion, it is "resistance to the efforts of the State's officers to perform their duty, preventing them from doing the things which the law requires them to do, which defeats the State's discharge of the duty of rendering due process of law, and thereby assaults the enjoyment of the privilege or immunity of the citizen to have due process at the hands of the State.", 2

The cardinal fallacy, if there be a fallacy, in this reasoning, is finding in the Fourteenth Amendment any positive duty on the part of the State to render due process to any one. The words of the amendment are guarded and negative: "Nor shall any State deprive any person of life," etc., "without due process of law." After thus finding the

1134 Fed. Rep. 412, 413.

2134 Fed. Rep. 413, 414. An appeal from this decision was taken to the United States Supreme Court, but that court, holding simply that habeas corpus was not the correct way under the circumstances to test the sufficiency of the indictment, remanded the case with directions to quash the writ. Riggins $v$. U. S., 199 U. S. 547 . 
48

Chapter guaranty of the performance of a positive duty, in I. place of a merely negative one, on the part of the State, the other steps taken by the court are comparatively easy. 


\section{CHAPTER II.}

THE ELEMENTS OF DUE PROCESS.

DEFINITIONS COLLECTED AND THEIR RELATIONS SHOWN.

A $\mathrm{T}$ the beginning of this book, due process of Chapter

A law or law of the land was said to imply the administration of equal laws according to established rules, not violative of the fundamental Formation of concep. principles of private right, by a competent tribu * tion grad. nal having jurisdiction of the case and proceeding upon notice and hearing. The several distinct elements whose presence is necessary to constitute due process as thus characterized have grouped themselves around that phrase at various times and under the exigency of various circumstances. Most of them had a distinct legal history before they were associated in one of their aspects as constituting due process. As one or another of the principles involved in due process has been prominent in the minds of judges and jurists, definitions of tie "law of the land" and "due process of law" have been framed wherein specific aspects of the conception have occupied the centre of the mental picture. Each embodies a true but partial view of due process. Some of the best known of these are given here.

One of the most famous and perhaps the most oft quoted definition is that of Daniel Webster in his speech in the Dartmouth College Case. His argu- 
Chapter ment was addressed to the point that the act of a State legislature which took away rights and franchises acquired by the college in virtue of a prior charter, was violative of the provision of the New Hampshire constitution which declares that no one shall be deprived of "property, privileges or immunities but by the judgment of his peers or the law of the land." He had in mind, then, a legislative act, partaking of the character of a judgment in that it operated on rights already acquired, and was directed against a single corporation, but which was passed without legal opportunity to defend. The definition emphasized, therefore, the necessity of generality or equality in the law and notice and hearing. He said: "By the law of the land is most clearly intended the general law; a law which hears before it condemns; which proceeds upon inquiry, and renders judgment only after trial. The meaning is that every citizen shall hold his life, liberty, property and immunities under the protection of the general rules which govern society. Everything which may pass under the form of an enactment is not therefore to be considered the law of the land. If this rele so, acts of attainder, bills of pains and penalties, acts of confiscation, acts reversing judgments, and acts directly transferring one man's estate to another, legislative judgments, decrees, and forfeitures, in all possible forms, would be the law of the land. Such a strange construction would render constitutional provisions of the highest importance completely inoperative and roid. It would tend directly to establish the union of all porrers in the legislature. There would be no general permanent 
law for courts to administer or men to live under." ${ }_{1}$ Chapter The same conception of general law combined with II. established modes of procedure appear's in the characterization of due process in a case contemporary with the last, where the court said: ${ }^{2}$ "As to the words from Magna Carta incorporated into the ConDefinition by Johnstitution of Maryland, after volumes spoken and written with a view to their exposition, the good sense of mankind has at length settled down to this, - that they were intended to secure the individual from the arbitrary exercise of the power's of government, unrestrained by the established principles of private rights and distributive justice." ${ }_{3}$

When the point at issue was whether in the enforcement of general or equal laws, methods of procedure which protected fundamental rights were observed, descriptions which laid stress on methods in settled use were framed. Such are: "By due process of law is meant one [process] which, following the forms of law, is appropriate to the case and just to the parties to be affected;" " "due process of

1 Dartmouth College $v$. Woodward, 4 Theat. (U. S.) 518. The first sentence of this extract is quoted in Ex p. Wall, 107 U. S. 289; Hovey $v$. Elliott, 167 U. S. 409.

2 Columbia Bank $v$. Okely, 4 Wheat. (U. S.) 235, per Johnson, J., quoted in U. S. $v$. Cruikshank, 92 U. S. 554; Scott $v$. McNeal, 154 U. S. 45 .

3 "Distributive justice" is one of the divisions of justice discussed by the old writers on the law of nature. Pufendorf defines it in effect as that species of justice which is exercised by one who gives to each meuber of society the rights due under the social contract, i. e., his " perfect rights." Law of Nature and Nations, lib. 1, c. 7, § 9. The idea is evidently derived from the definition of justice with which the Institutes of Justinian opens: Justitia est constans et perpetua voluntas jus suum cuique tribuere. Mr. Justice Matthews, in Hurtado $v$. California, 110 U. S. 516 , refers to "that fundamental maxim of distributive justice, suum cuique tribuere."

4 Hagar v. Reclamation Dist. No. 108, 111 U. S. 701.

Definitions emphasizing orderly procedure. 
Chapter law means law in its regular course of administra-

II.

Emphasis on presence of jurisdiction.

Judicial process not usually essential.

tion through courts of justice." 5 When the facts require no more, it is defined as a trial according to the "course, mode and usages of the common law." " As applied to judicial proceedings, the words "due process of law" have been held to mean "a course of legal proceedings according to those rules and principles which have been established in our systems of jurisprudence for the protection and enforcement of private rights. To give such proceedings any validity, there must be a tribunal competent by its constitution-that is, by the law of its creation-to pass upon the subject-matter of the suit." 7

But neither proceedings according to common law, nor judicial proceedings in a formal court for the trial of actions, are essential to due process. "Though it generally implies and includes actor, reus, judex, regular allegations, opportunity to answer, and a trial according to some settled course of judicial proceedings, yet this is not universally true."'s Summary administrative process has from time immemorial been sanctioned in the collection of taxes and in other cases; ${ }^{9}$ although when life and

52 Kent Com. 13, quoted in Caldwell v. Texas, 137 U. S. 692.

6 Hoke $v$. Henderson, 4 Dev. L. (15 N. Car.) 1.

7 Pennoyer $v$. Neff, 95 U. S. 714, per Field, J., quoted in Scott $v$. MeNeal, 154 U. S. 46.

8 Murray $v$. Hoboken Land, etc., Co., is How. (U. S.) 272, per Curtis, J. "It is a mistaken idea that due process of law requires a plenary suit and a trial by jury in all cases where pronerty or personal rights are involved." Ex $p$. Wall, 107 U. S. 265, 283. "Due process is not necessarily judicial process." Reetz $r$. Michigan, 188 U. S. 505, 507 .

9 Murray v. Hoboken Land, etc., Co., 18 How. (U. S.) 272; Weimer $v$. Bunbury, 30 Mich. 201. 
liberty or the title or possession of property are involved, due process has been said to require that Chapter there be a regular course of judicial proceedings, ${ }^{1}$ though not trial by jury. ${ }^{2}$

HOW THE PRESENCE OF DUE PROCESS IS TESTED.

Historical Test - Positive and Inclusive.

When a particular law or procedure is drawn in question on the ground that it is wanting in due process of law, upon what principle is its validity to be tested? The first inquiry must be, of course, whether it conflicts with any provision of the Constitution itself. If it is not found to do so, we must examine the connotation of the phrase at the time of its adoption into the Constitution of the United States. For this purpose we must determine "those settled usages and modes of proceeding existing in the common and statute law of England, before the emigration of our ancestors, and which are shown not to have been unsuited to their civil and political condition by having been acted on by them after the settlement of this country." ${ }_{3}$ In a later case, this test was somewhat enlarged, the court saying that that was due process of law which was "in substantial accord with the law and usage in England before the Declaration of Independence,

1 Hagar $v$. Reclamation Dist. No. 108, 111 U. S. 701. This statement requires limitation. See infra, p. 80 .

2 Ex p. Wall, 107 U. S. 288, the court saying: "The important right of personal liberty is generally determined by a single judge, on a writ of habeas corpus, using affidavits and depositions for proofs, when facts are to be established."

3 Murray v. Hoboken Land, etc., Co., 18 How. (U. S.) 272. 
Chapter and in this country since it became a nation, in similar cases." 4

If a particular procedure is found to have been sanctioned by English practice and adopted as suited to the conditions in this country, it measures up to the requisites of due process; but if the inquiry has only negative results, we must not immediately conclude that due process is wanting.

Failure of historical test.

For the test proposed, though sufficient for the purposes of the cases in which it was announced, is only positive and inclusive, not negative and exclusive. To hold every procedure not fulfilling these requirements to be a deprivation of due process, "would be to deny every quality of the law but its age, and to render it incapable of progress or improvement. It would be to stamp upon our jurisprudence the unchangeableness attributed to the Progres.
sive nature sive nature
of law. Court "has not failed to recognize the fact that the law is, to a certain extent, a progressive science; that in some of the States, methods of procedure which, at the time the Constitution was adopted, were deemed essential to the protection and safety of the people, or to the liberty of the citizen, have been found to be no longer necessary. Even before the adoption of the Constitution, much had been done toward mitigating the severity of the common

4 Lowe $v$. Kansas, 163 U. S. 81. For other cases wherein proceedings sanctioned by inmemorial usage have been held to be "due process of law," see Ex p. Wall, 107 U. S. 265; Eilenbecker $r$. Distriet Ct., 134 U. S. 31. Where a United States court is proceeding in impaneling a jury by a method different from that prescribed by the State statute, the procedure "must not conflict with or abriclge the right as it exists at common law." Lewis $v$. U. S., 146 U. S. 377.

5 Hurtado $v$. California, 110 U. S. 516. 
law, particularly in the administration of its crimi- Chapter nal branch. The number of capital erimes, in this II. country at least, had been largely deereased. Trial by ordeal and by battle had never existed here, and had fallen into disuse in England. The earlier practice of the common law, which denied the benefit of witnesses to a person accused of felony, had been abolished by statute, though so far as it deprived him of the assistance of counsel and compulsory process for the attendance of his witnesses, it had not been changed in England. But to the credit of her American colonies, let it be said that so oppressive a doctrine had never obtained a foothold there. The present century has originated legal reforms of no less importance. The whole fabric of special pleading once thought to be necessary to the elimination of the real issue between the parties has crumbled to pieces. The ancient tenures of real estate have been largely swept away, and land is now transferred almost as easily and cheaply as personal property. Married women have been emancipated from the control of their husbands, and placed upon a practical equality with them, with respect to the acquisition, possession and transmission of property. Imprisonment for debt has been abolished. Exemptions from execution have been largely added to, and in most of the States homesteads are rendered incapable of seizure and sale upon forced process. Witnesses are no longer incompetent by reason of interest, even though they be parties to the litigation. Indictments have been simplified, and an indictment for the most serious of erimes is now the simplest of all. In several of 

Ehapter the States grand juries, formerly the only safeguard
II. against a malicious prosecution, have been largely abolished; and in others the rule of unanimity, so far as applied to civil cases, has given way to verdicts by a three-fourths majority." 6

\section{Intrinsic Test - Both Inclusive and Exclusive.}

In view of all these instances, say the courts, the probability of further changes to adapt the law to new conditions of society must be recognized. It is, then, of the utmost importance that the adoption of such future changes as experience shall commend should not be hampered by a narrow interpretation of due process. Lest these results should follow, a definition of due process which should be complete both in what it includes and in what it excludes has never been attempted, and the court has preferred the wiser and more conservative course of ascertaining the intent and application of the phrase "by the gradual process of judicial inclusion and exclusion, as the cases presented for decision shall require, with the reasoning on which such decisions may be founded." 7 But the reasoning of the cases must recognize some test, however vague. and this test is declared to lie in the fact that the provision questioned does not involve an infringement of "certain fundamental rights, which that system of jurisprudence, of which ours is a derivative, has always recognized;"s or it must observe "those

e Holden $v$. Hardy, 169 U. S. 366.

7 Daridson $v$. New Orleans, 96 U. S. 97 ; Holden $v$. Hardy, 169 U. S. 366 ; Orient Ins. Co. v. Daggs, 172 U. S. 563.

8 Brown $v$. Levee Comrs., 50 Miss. 468, quoted in Hurtado $v$. California, 110 U. S. 536. 
general rules established in our system of jurisprudence for the security of private rights;" ${ }^{9}$ or the Chapter II. act must not overstep "the inherent and reserved powers of the State exerted within the limits of those fundamental principles of liberty and justice which lie at the base of all our civil and political institutions." 1

The pursuit of the "fundamental principles of liberty and justice"' would seem to throw us hope- law. lessly into the fields of speculation cultivated by writers on the law of nature and the nebulous natural rights of man. But in the recognition of "fundamental principles' apart from constitutional provisions, the courts, true to the method which has built up the common law, base their decisions less on deductive reasoning from a priori assumptions, than on the recognition of rights which have been asserted at a definite time and place against particular acts of tyranny and have become embedded in our law. This tendency toward cautious conservatism is well illustrated by the remarks of a New Jersey judge, Mr. Justice Van Syckel, discussing an analogous point. He recognizes but two classes of rights "for which immunity against the encroachments of the lawmaker can be claimed." The first includes those for which constitutional protection is especially provided; the other class, not shielded by such express provision, "is, I think, limited to two or three instances." They are, the right to private property, to notice and a hearing before judgment, and the principle that a man shall not be made a

- Hagar v. Reclamation Dist. No. 108, 111 U. S. 701, 709.

1 Hurtado $v$. California, 110 U. S. 535. 
Chapter judge in his own case. ${ }^{2}$ As regards the last point, II. the United States Supreme Court has held, while distinguishing the case from that of a judge of a court acting in a matter in which he was personally interested, that the qualification or disqualification for interest of the members of the board of assessors for a municipal tax was a question of local law for the decision of the State courts, not involving due process under the Fourteenth Amendment. ${ }^{3}$

Some fundamenta!

Among matters held fundamental and essential requisites. is the presence of notice and hearing which is of the rery essence of due process. ${ }^{4}$ The possession of jurisdiction by the tribunal passing upon rights of life, liberty, or property, the necessity of compensation when property is taken for a public pur. pose ${ }^{6}$ have each been recognized as fundamental in due process under the Fourteenth Amendment; while the right of a person accused of felony to be present in the trial court during the trial is essen. tial at least to due process under the Fifth Amendment. ${ }^{\top}$ But whether exemption from double jeopardy, or the right not to be compelled to give evidence against one's self, ${ }^{\mathrm{s}}$ is included in this category

2 Noore $r$. State, 43 N. J. L. 203, 243, 244. These remarks are found in a discenting opinion.

2 Lent $v$. Tillson, 140 C. S. 316 : Hibben $v$. Smith, 191 U.S. 310.

Making an interested parts julge was taken as the extreme instance of an act contrary to natural right in old cases. "Even an Act of Parliament made against natural equity, as to make a man judge in his own ease, is void in itself." Day $\tau$. Saradge. Hob. 87. See also Bonham's Case, S Coke 118a; Smith $v$. Hancock, Sț̣le 138.

4 See infra, p. 73.

5 See infra. p. 85.

see infra, p. 278.

7 See infra. ]. 16.5.

8 Adams $v$. New York, 192 U. S. 585. 
is not determined. And the granting or withhold- Chapter ing of rights once considered peculiarly fundamental has been held to be wholly within the domain of the States. ${ }^{9}$

Finally the subject-matter of the case and the nature of the proceeding in which due process of control. law is involved must almays be considered in determining whether the taking is warranted by constitutional provision. ${ }^{1}$ The requirement of due process as affecting judicial proceedings has been declared to be well settled, however undetermined the meaning may be in other connections. ${ }^{2}$

Where it is sought to justify the taking as an exercise of the sovereignty of the State, especially Paramount state aumay the requirements of due process be modified. "In judging what is 'due process of law," " said Mr. Justice Bradley," "respect must be had to the cause and object of the taking, whether under the taxing power, the power of eminent domain, or the power of assessment for local improvements, or none of these; and, if found to be suitable or admissible in the special case, it will be adjudged to be 'due process of law;' but, if found to be arbitrary, oppressive, and unjust, it may be declared to be not 'due process of law.' "' In a later case, the same judge, speaking for the court, said: "The process of taxation does not require the same kind of notice as is required in a suit at law, or even in

9 Such are the right to accusation by a grand jurs, Hurtado $v$. California, 110 U. S. 575; and the right to trial by jury itself, Maxwell $v$. Dow, 176 U. S. 581.

1 Ex p. Wall, 107 U. S. 288.

2 Pennoyer $v$. Neff, 95 U. S. 714.

3 Concurring opinion in Davidson $v$. New Orleans, 96 U. S. 97. 

Chapter proceedings for taking private property under the
II. power of eminent domain. It involves no violation of due process of law, when it is executed according to customary forms and established usages, or in subordination to the principles which underlie them." 4 The general principle is that when the state is acting in its sovereign capacity, its acts are for the good of the whole community, and private rights and interests must rield to this paramount object. But to this matter we shall return at a later stage of the discussion.

It is necessary now to examine in detail some of the leading elements of due process. The requirement, first, of general and equal lams; second, of notice and hearing; and, third, of the presence of jurisdiction, will be taken up.

Equality and Generality of the Law.

The re.

quirements stated and explained.

The conception of law is opposed to all merely arbitrary or capricions action on the part of the state depriving individuals of life, liberty, or property. Early in English history an appeal was made to this conception in petitioning Parliament for a reversal of a bill of attainder, but, according to the British Constitution, the authority of Parliament is absolute, and the idea of the intrinsic necessity of equality or generality could not be developed as applied to acts of Parliament, although in substance it was employed to restrain the quasi-legislative activity of municipal bodies.

Under the American theory of constitutional government, in which constitutions are a restraint

4 Bell's Gap R. Co. v. Pennsylvania, 134 U. S. 232. 
even on the legislature, the idea has had a more fruit- Chapter ful development. Purely arbitrary decrees or enactments of the legislature directed against individuals or classes are held not to be "the law of the land," or to conform to "due process of law." The conception comes clearly to the front in Mr. Webster's definition of "law of the land," which has been already quoted, and it has been frequently repeated by the courts. "Due process of law within the meaning of the [Fourteenth] Amendment," said the Federal Supreme Court, "is secured if the laws operate on all alike, and do not subject the individual to an arbitrary exercise of the powers of government." " "By the law of the land," said the Michigan court, "we understand lams that are general in their operation, and that affect the rights of all alike, and not a special act of the legislature, passed to affect the rights of an individual against his will and in a way in which the same rights of other persons are not affected by existing laws. Such an act, unless expressly authorized by the Constitution, or clearly coming within the general scope of legislative power, would be in conflict with this part of the Constitution, and for that reason, if no other, be void." 7 "The clause 'law of the land,'," said Mr. Justice Catron, when a member of the Supreme Court of Tennessee, "means a general and public law, equally binding upon every member of

6 Giozza $v$. Turnan, 148 U. S. 657. 662. See also Yick Wo $v$. Hopkins, 118 U. S. 356 ; Dent $v$. West Virginia,129 U.S. 114; Leeper $v$. Texas, 139 U. S. 462; Yesler $v$. Washington Harbor Line Com'rs, 146 U. S. 646 ; Duncan $r$. Missouri, 152 U. S. $37 \tau$; Orr $v$. Gilman, 183 U. S. 278, 287.

7 Sears $r$. Cottrell, 5 Mich. 251. See also Millett $v$. People, 117 IIl. 294, 57 Am. Rep. 869 . 


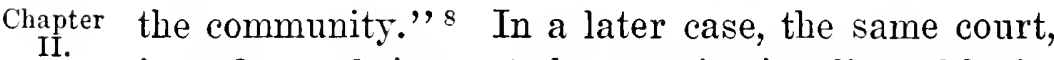
in order to bring out the constitutionality of legislative classification, preferred to define the phrase as meaning a law "which embraces all persons who are or may come into like situation and circumstances." 9

"Equality But the necessity of emphasis on this aspect of due process is less necessary because the Fourteenth Amendment of the Constitution of the United States, and many State constitutions as well, contain clauses especially directed against legislation lacking the character of generality. The Federal Constitution provides specifically for the equal protection of the laws, and many State constitutions carefully limit the power of the legislature to pass local or special laws. ${ }^{1} \quad$ Restraints on arbitrary legislation may result from the clauses in some constitutions prohibiting "exclusive or separate emoluments" and "perpetuities and monopolies.",

Classification per. mitted.

The requirement does not, in the absence of some specific constitutional provision, prevent the legislature from passing a law which is confined in its operation to a particular locality, ${ }^{3}$ or which embraces

8 Vanzant $r$. Waddel, 2 Yerg. (Tenn.) 260.

9 Stratton $r$. Morris, 89 Tenn. 497, citing many earlier cases from the same court. This is the same test adopted by the federal Supreme Court for conformity with the "equal protection of the laws" clause of the Fourteenth Amendment; viz., that the statute be general, embracing all persons under substantially like circumstances, and not an arbitrary exercise of power. Jones $v$. Brim, $165 \mathrm{U}$. S. 180 ; Lowe $v$. Kansas, 163 U. S. 81; Duncan $v$. Missouri, 152 U. S. 377 ; Hayes $r$. Missouri, 120 U. S. 68.

1 See, for instance. Waite $r$. Santa Cruz, 184 U. S. 302 , construing the constitution of California.

2 State $r$. Moore, 104 N. Car. 714.

3 State $v$. Moore, 104 N. Car. 714. 
the whole of a class, howerer few the individuals Chapter who compose it may be, provided the classification II. of persons upon which the law rests is natural and not founded on arbitrary caprice, ${ }^{4}$ or, in more accurate language perhaps, provided the ostensible purpose of the law is not seen to be a mere cover for carrring out purposes having no relation to the classification adopted. ${ }^{5}$ Thus it is no objection to the validity of a law providing for the taxation of railroads, that the method of assessing railroads differ's from the method provided for all other property, in that railroads are assessed by a State board while all other property in the State is assessed by county officials. ${ }^{6}$ Nor is a statute regulating railroad rates wanting in due process of law because it classifies the rates which the railroads may charge on some natural basis. "Thether the classification shall be according to the amount of passengers and freight carried, or of gross or net earnings, during a previous year, or according to the simpler or more constant test of the length of the line of the railroad, is a matter within the discretion of the legislature." 7 That the regulation adopted shall operate uniformly on each class is all that the constrtution requires. ${ }^{s}$ Nor does a law providing that the possession of poliey slips "by any person other than a public officer" shall be prima facie evidence

4 Budd $v$. State, 3 Humph. (Tenn.) 483, 39 Am. Dec. 189; Stratton $v$. Morris, 89 Tenn. 497,521 .

5 Lochner $v$. New York, 198 U. S. 45.

B State Railroad Tax Cases, 92 U. S. 575; Kentucky Railroad Tax Cases, 115 U. S. 321; Pittsburgh, etc., R. Co. v. Backus, 154 U. S. 421 .

7 Dow $r$. Beidelman, 125 U. S. $680,691$.

s Chicago, etc., R. Co. v. Iowa, 94 U. S. 155. 
Chapter that the possessor has them knowingly, become in-
II.

II. valid by reason of the exception of public officers, since the exception clearly applies to those public officers only who have possession in the performance of their public duties. ${ }^{9}$

\section{Confiscatory Legislation.}

Extreme instances of laws lacking in generality are acts which forfeit or confiscate the life, liberty, or property of a private citizen, or citizens, by the mere edict of the legislature. "In these cases," said the United States Supreme Court, "the legislative body, in addition to its legitimate functions, exercises the powers and office of judge; it assumes, in the language of the text-books, judicial magistracy; it pronounces upon the guilt of the party, without any of the forms or safeguards of trial; it determines the sufficiency of the proofs produced, whether conformable to the rules of eridence or otherwise; and it fixes the degree of punishment in accordance with its own notions of the enormity of the offense." 1

Bills of attainder,

Acts of attainder, bills of pains and penalties, tory. which are a species of acts of attainder inflicting punishment less than death, ${ }^{2}$ acts of confiscation, and the like, all fall within this prohibition. The feeling that such proceedings were contrary to the law of the land, although in a technical sense legal, may be traced to the fourteenth century when the

9 Adams $v$. New York. 192 U. S. 585. affirming 176 N. Y. 351.

1 Cummings $v$. Missouri, 4 Wall. (U. S.) $277,323$.

2 Cummings $v$. Missouri, 4 Wall. (U. S.) 277, 323; Doe $v$. Buford,

1 Dana (Ky.) 510. 
conception of "law of the land" was taking its Chapter modern meaning. In the reign of Edward II, the exile and disinheritance of the Despencers passed by an assembly of magnates hostile to the Crown and not properly summoned as a Parliament, was reversed in a later Parliament on the ground that the "said award was made without calling them [the Despencers] to answer, and without the assent of the prelates, which are peers of the realm in Parliament, and against the Great Charter of the franchises of England, which says no freeman shall be banished or other way destroyed, but by lawful judgment of his peers or the law of the land, and for that they were not called in court to make answer, and for these errors and for that the causes in the said award were not duly proved." ${ }_{3}$ On similar grounds were placed the act annulling the sentence against the Earl of Arundel in $1330 ;{ }^{4}$ and the supplementary statute of 1354 , enacted on a petition which states that there is no record or evidence of any just cause wherefore the Earl of Arundel ought to have been destroyed or put to death "without judgment and due process of law (sanz juggement et due process de lei)." ${ }_{5}$ In the same year the attainder of Roger. Earl of Mortimer, was reversed upon the petition of his heir, who alleged that the record of his attainder was "erroneous and defective at all points, especially in so far as the

3 Proceedings against the Despencers, 1 How. St. Tr. 33.

4 The Earl's son petitions that it may please our lord the King to consider how Esmon. his father, Earl of Arundel. was taken, imprisoned, and put to death, and his lands and chattels forfeited "against the law and custom of the country." 2 Rot. Parl. 55, 4 Edw. III, A. D. 1330.

52 Rot. Parl. 256, 257. 28 Edw. III, A. D. 1354. 
Chapter said earl mas put to death and disinherited without II. any accusation and without being put to judgment or to answer (sanz estre mesne en juggement ou en respons)." " These were, however, only instances of attainder's reversed when the opposite party came into power. Bills of attainder passed with apparent or real regularity were common enough in the middle ages, ${ }^{7}$ and were sometimes passed even after the death of the person attainted. ${ }^{8}$

Against persons ready to stand trial.

Henry VIII is said to have been the first sovereign to introduce the practice of bills of attainder without citation or opportunity to defend against persons who were ready to answer in a regular court of justice. The judges who were consulted on the legality of such an act, answered at first that it was a dangerous question, that Parliament ought to give an example of justice to inferior courts, that no inferior courts could act in that arbitrary way, and they thought no Parliament ever would. But, on further pressure, they answered that if a bill of attainder were so passed, its validity could not be brought in question at law. Accordingly proceedings were had in this manner against the Countess of Salisbury and others less distinguished. ${ }^{9}$ But

6 2 Rot. Parl. 256, 28 Edw. III, A. D. 1354.

7 Attainders of treason in the fourteenth century were an ordinary device of the dominant faction to secure the forfeiture of estates. 1 Pike, Hist. Cr. in Eng. 228.

8 See the eases of the Duke of Gloucester in 1397, 1 How. St. Tr. 130, and of Cromwell and other regicides after the Restoration. 1 Pike, Hist. Cr. in Eng. 406. "The most remarkable instance of a medixval punishment reappearing almost within living memory is the Act of Attainder passed [by the Irish Parliament] in 1798 against Lord Edward Fitzgerald and others after death." 2 Pike, Hist. Cr. in Eng. 380.

9 lieeves, 1Iist. Eng. Law (Am. ed., 18s0) 555, 556. See also 
opposition to the injustice of acts of attainder Chapter was beginning to affect public opinion, and there II. were protests and much hesitation in the House of Commons upon the passage of the bill against the Lord Admiral Seymour in 1549. ${ }^{1}$ A century and a half later, in the case of Sir John Fenwick, the act of attainder was passed by a majority of only six in the Lords and thirty-three in the House, and against very spirited opposition in both bodies. ${ }^{2}$ Such judicial legislation continued to be resorted to whenever the occasion seemed to require a departure from the usual and orderly forms of administering justice through the courts. ${ }^{3}$ Sentences of this character are, however, utterly opposed to the modern spirit of justice and gradually ceased to be resorted to. "The bill [of pains and penalties] against Queen Caroline," says Sir J. F. Stephen, "will probably long continue to be referred to as the last instance of such legislation." 4

Legislation of this character, as well as ex post facto laws generally, is by special constitutional Special
constitu tional proprovision placed beyond the competency of both the hibitions.

1 How. St. Tr. 481, extract from Burnet's Hist. Reformation. The illegality of these bills was argured again on the act of attainder against Sir John Fenwick in 1696. 13 How. St. Tr. 633.

11 How St. Tr. 494, and 2 Burnet's Reform, 99, quoted in note.

213 How. St. Tr. 538, A. D. 1696. This method of procedur6 was resorted to because one of the two witnesses, necessary to conrict of treason, having disappeared, escape was inevitable on an ordinary prosecution. 2 Pike, Hist. Cr. in Eng. 325.

31 Steph. Hist. Cr. Law, 161; Pike, Hist. Cr. in Eng., passim; 4 Reeves Hist. Eng. Law (Am. ed., 1880) 554; Cummings $v$. Missouri, 4 Wall. (U. S.) 277, quoting Story on the Constitution, § 1344. A notable instance of a bill of pains and penalties was the act against Bishop Atterbury in 1723. 16 How. St. Tr. 323. The bill is at p. 644 .

41 Steph. Hist. Cr. Law, 161. 
Chapter national ${ }^{5}$ and State legislatures, ${ }^{6}$ by clauses in the II.

Confiscatory civil legislation. Federal Constitution; and State constitutions limit the power of the legislatures by like provisions. ${ }^{i}$

Confiscatory legislation of a civil character is as much opposed to due process of law as judgments of the legislature imposing penalties for crime. "A statute which declared in terms and without more that the full and exclusive title of a described piece of land, which is now in $A$, shall be and is hereby rested in B. rould, if effectual, deprive $A$ of his property without due process of law within the meaning of the constitutional provision."'s For "where rights of property are admitted to exist, the legislature can not say they shall exist no longer." 9

The prohibition equally extends to a taling by the State for a public purpose, unless just compensation is made to the orner. ${ }^{1}$

\section{Confusing Functions of Different Departments of Government.}

One of the objections niged against arbitrarr and confiscatory legislation is, as has been seen,

" (onct. T. S.. Art. I. \$ ?, 3: \& Fod. Stat. Innot. 695.

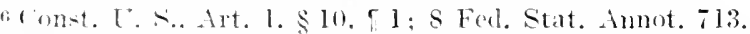

i Sep 12 Am. \& Eng. Enere. Law (2d ed.) 527 , and note 6.

8 Davidon $r$. New Orleans, 96 L. S. 97. 102; Missouri Pac. R. Co. r. Nebraka, 164 L. S. 403, 417 ; Chicago, ete., I. Co. r. Chicago, 166 ['. S. 220, 296: Zeigler $r$. South, etc.. Alabama R. Co.. 58 Ala. 594: Davis 1 . State. tis Ala. 59. 63. 44 Am. Rep. 128: Wrnehamer $r$. People. 13 X. Y. 37s; Taylor r. Porter, \& 11 ill (N. I. 145: Hoke $r$. Henderonn, 4 Des. (IS X. Car.) 15: Norman r. Heist. 5 W. \& S. (Pa.) 17l: Pogers r. Com. 76 Va. 989.

9 Wynehamer $r$. Penple. 13 X. Y. 378. 393, per Comstoek, J.

1 Davidson $r$. New Orleans, 96 U. S. 97. per liralley. J.. concurring; Chieago, ete., R. Co. $r$. Chicago, 166 U. S. 226, 236. And sec infra, p. $27 \mathrm{~s}$. 
that it obliterates those lines of separation between the different departments of government whose exChapter II. istence is firmly embedded in the substance of our institutions, ${ }^{2}$ and forms, according to publicists and judges, so important a safeguard to the rights of the citizen. ${ }^{3}$

The constitutions of the Federal Union and of nearly all the separate States declare that the powDepart-
ments of governers of the government shall be distributed among three branches; the legislative, the executive, and the judicial. ${ }^{4}$ The legislative department makes, the executive executes, and the judiciary construes the law. ${ }^{5}$ But though the idea which lies at the basis of the division is clear, and the importance of preserving broad lines of separation is admitted by the courts, the application of the principle in detail is difficult. ${ }^{6}$

The functions of government are necessarily Difficulty of decomplex, and its activities may assume a doubtful markation. aspect and partake to such an extent of the duties of more than one department as to render proper classification, in the absence of distinct constitu-

2 The American constitutions are supposed to have derived the principle from Montesquieu. Crane $v$. Meginnis, 1 Gill \& J. (Md.) 476, $19 \mathrm{Am}$. Dec. 237. See Montesquieu, Spirit of Laws, 1. 11, c. 6.

3 Some recent writers regard the theory of the separation of powers as discredited. See Goodnow, Comparative Administrative Law, 20. But it would not seem to affect the practical value of the principle that lines of demarkation between the different branches of government do not admit of being drawn with mathematical exactness, or that the separation as actually provided in various constitutions must have more or less of an arbitrary nature about it.

4 See Bondy, The Separation of Governmental Pouers (Columbia University Studies) 17 .

5 Wayman $v$. Southard, 10 Wheat. (U. S.) 1, 46.

6 See Kilbourn $v$. Thompson, 103 U. S. 16S; Story on Const., 5th ed., 393, 395; Bondy, Sep. Gov. Powers, 69. 
Chapter tional provisions, largely a matter of the point of

II. view from which the particular activity exercised is observed. As has been well said, "While it is true that the executive, legislative and supreme judicial powers of the government ought to be forever separate and distinct, it is also true that the science of government is a practical one; therefore, while each [department] should firmly maintain the powers belonging to it, it can not be forgotten that the three coördinate parts constitute one brotherhood, whose common trust requires a mutual toleration of the occupancy of what seems to be a 'common because of vicinage,' bordering the domains of each." 7

Attitude of courts toward problem.

In the presence of such a state of things the courts are reluctant to pronounce acts of the legislative department void, because it may have assumed, in their opinion, powers belonging to another branch, or have confused the functions of the executive and the judiciary. ${ }^{8}$ Yet in some cases statutes conferring on one department of government powers which belong to another have been pronounced void as denying due process of law. ${ }^{\text {* }}$ Thus where a statute declared that it should be the duty of every landowner to clean out streams flowing through his land, and that in case of failure to do so, the tax assessor should note the fact and the county clerk should, thereupon, add a specified drainage tax to the assessment of such landowner, it was held that the statute ras void as conferring judicial powers on ministerial officers and amount-

7 Brown $r$. Turner, $70 \mathrm{~N}$. Car. 102.

8 Wayman $x$. Southard. 10 Wheat. (U. S.) '1, 46.

s* See infra, pp. 16.t. 365 et scq. 
ing to a taxing of property without due process of law. ${ }^{9}$ A New York court has held that a statute Chapter in which the legislature assumed judicial powers and took from the judges discretion in certain cases amounted to a denial of due process. ${ }^{1}$

While the several States started with the same Generally a matter theory of the division of powers, constitutional pro- $\begin{gathered}\text { of State } \\ \text { decision. }\end{gathered}$ visions and the natural growth in a living body of law have led to differences in the practical distribution of duties among the departments of the government. In each State the location of lines of demarkation between the three powers must depend upon its own constitution and laws as interpreted by its highest court.2 The Federal Supreme Court has, therefore, held the separation of powers to be in general a matter of local law not cognizable under the due process clause of the Fourteenth Amendment. "Whether the legislative, executive, and judicial powers [of a State]," said the Supreme Court, "shall be kept altogether distinct and separate, or whether persons or collectious of persons belonging to one department may in respect to some matters exert powers which, strictly speaking, pertain to another department of government, is for the determination of the State. And its determination one way or the other cannot be an element in the inquiry, whether the due process of law prescribed by the Fourteenth Amendment has been re-

$\diamond$ Cleveland, etc., R. Co. $v$. People, 212 III. 638. This holding, which is undoubtedly correct, would perhaps have been better put on the ground that the statute provided no hearing for the landowner.

1 Riglander $v$. Star Co., 98 N. Y. App. Div. 101.

2 See People $v$. Hurlbut, 24 Mich. 63. 
Chapter spected by the State or its representatives, when

II. dealing with matters involving life or liberty.", 3

Judicial

function.

of execu.

tive off

The functions committed to executive officers by cers.

Prestumption as to discharge of duties. the laws may involve decisions of questions of fact which concer'n the private rights of individuals and which might, if the legislature so directed, be made the subject of actions in formal courts. Questions of this character are administrative in so far that it is competent for the legislature to commit their decision to administrative officials, ${ }^{4}$ but are judicial or quasi-judicial in so far that the power to decide arbitrarily does not exist. and notice and a hearing are necessary to constitute due process of law. The decision of administrative offeials may in the absence of constitutional restriction be made final by the legislature, or it may be reviewable in the courts; but, if notice and an opportunity to be heard are present, in neither case is the constitutional guaranty intiringed. 5

In this way the legislature has intrusted general or local administrative officials with judicial functions in respect to the assessment or collection of taxes, the power of eminent domain, and the police power, using the last phrase in its widest extent." When the authority to decide questions involving private riglits and to hear complaints is conferred on administrative bodies, "their duties are judicial

3 Dreyer $v$. Illinois, 187 U. S. 71, 84. See also Ohin $v$. Dollison, 194 U. S. 445, where, in a liquor law, the absence of due process was claimed because the legislature failed to define "wholesale" and "retail" and left the amount of fine or penalty to the court.

4 Murray v. Hohoken Land, ete., Co., 18 How. (U. S.) 272.

s Hibben v. Smith, 191 U. S. 310.

p. These matters are treated in subsequent chapters. See pp. 159, $189,208,253$. 
in their nature and they are bound in morals and in law to exercise an honest judgment as to all matters Chapter submitted for their official determination. It is not to be presumed that they will act otherwise than according to this rule,' and there is no deprivation of due process of law. In such a case if the administrative board refuse to hear the person entitled to be heard, he may compel a hearing by mandamus or injunction, but he can not waive his remedy and then assert the denial of a hearing as a defense to an action to enforce the board's decision.s

Notice and Hearing.

Justice requires that a hearing and an oppor- Referred tunity to present defenses must precede condemnaof nature. tion. Around this ideal of justice has grown up the constitutional conception of "the law of the land" or "due process of law," but the ideal was not confined to one system of jurisprudence, and was common to thoughtful men everywhere. ${ }^{9}$ Such a principle would obriously, when the conception of a law of nature had emerged, be referred to that head, and thus it is classed in an early reference by the English Court of Chancery. A Year Book of Edward IV records that, "In Chancery it was obserred by the chancellor that a man shall not be prejudiced by mispleader or for default of form but according to the truth of his matter, and we

7 Spring Valley Water Works $v$. Schottler, 110 U. S. 347, 354; Hibben $v$. Smith, 191 U. S. 322; Lieberman $v$. Van De Carr, 199 U. S. 552, affirming 175 N. Y. 440 .

8 Reetz $v$. Michigan, 188 U. S. 505, 509 ; Shank $v$. Smith 157 Ind. 401 , cited in Hibben $v$. Smith, 191 U. S. 321.

9 See supra, p. 3. 
Chapter have to judge secundum conscientiam et non secun-
II.

dum allegata, for if a man by bill suggests that one has done wrong to him, and the defendant says nothing and we have knowledge that he has not done wrong to the plaintiff, he shall recover nothing. And there are two kinds of powers and processes, namely, potentia ordinata et potentia absoluta: ordinata is where a certain order is observed, as in positive law, but the law of nature non habet certum ordinem, but by whatever means the truth may be known, etc., ideo dicitur processus absolutus. In the law of nature it is required that the parties should be present, or that they should be absent through contumacy, that is to say, that they are summoned and make default, et examinatio veritatis." 1

Imolied in

"law of ,

Early in the seventeenth century, this requirement of the law of nature is said by the Court of King's Bench to be implied in "the law of the land" as used in Magna Carta. In Bagg's Case, ${ }^{2}$ it was determined that an alderman of a city could not be deplived of the freedom of the city contrary to the due course of law as required by the Great Charter, and in illustration of the proposition it is said that, though lawful cause of his removal exists, yet if " it appears by the return that they [the municipal authorities] have proceeded against him without hearing his answer to what was objected, or that he was not reasonably warned, such removing of him is void, and shall not bind the party, quia, quicunque aliquid statuerit, parte inaudita altera, aequum licet statuerit, haud aequus fuerit, ${ }^{3}$ and such remoring is

1 Y. B. 9 Filw. IV, 14, pl. ?.

211 Coke aga (1. D. 16ilo).

3 As to these veres. see suma, p. 2. 
against justice and right." Other cases afterwards decided dwell on the necessity for hearing in similar circumstances, ${ }^{4}$ and in Dr. Bently's Case, Fortescue, J., quaintly remarks: "The laws of God and man both give the party an opportunity to make his defense, if he has any. I remember to have heard it observed by a very learned man upon such an occasion, that even God himself did not pass sentence upon Adam, before he was called upon to make his defense. Adam (says God) where art thou? Hast thou not eaten of the tree, whereof I commanded thee that thou shouldest not eat? And the same question was put to Eve also.', s

This doctrine was adopted into American jurisprudence to the fullest extent, and was referred to Based on justice, common the principles either of natural justice, ${ }^{6}$ of international law, or of the common law. " "It is a rule," said Mr. Justice Story, "founded in the first principies of natural justice, that a party shall have an opportunity to be heard in his defense before his property is condemned." And of a foreign judgment which violated this rule, he proceeded: "Upon

4 Rex $r$. Mayor of Oxford, Palmer 453; Protector $r$. Colchester, Style 447; Le Roy $v$. Campion, 1 Sid. 14. 2 Sid. 97 ; Capel $r$. Child, 2 Cromp. \& J. 558 ; Bonaker $v$. Evans, 16 Q. B. 162,71 E. C. L. 162.

In the case from Style, in 1655, Rolle, C. J., said: "He ought to be heard what he could say for himself, else how could it be known whether there were just cause to remore him or no, and it is very hard to deprive one of his freehold without hearing him. - . You ought to have convented him before vou put him out." And Glyn, C. J.. said: "You ought not to proceed against him and never hear him, though the crime objected against him be true."

5 Rex $v$. Cambridge University, 1 Stra. 55s, 567.

6 Lafayette Ins. Co. r. French, 18 How. (U. S.) 404.

7 D'Arey $v$. Ketchum, 11 How. (U. S.) 165.

8 Picquet $r$. Swan, 5 Mason (U. S.) 35, per Stors, J. 
Chapter the eternal principles of justice it ought to have

II.

no binding obligation upon the rights or property of the subjects of other nations, for it tramples under foot all the doctrines of international law.", 9 "It is a rule as old as the law," the Supreme Court has said, "and never more to be respected than now, that no one shall be personally bound until he has had his day in court; by which is meant, until he has been duly cited to appear, and has been afforded an opportunity to be heard. Judgment without such citation and opportunity wants all the attributes of a judicial determination. It is judicial usurpation and oppression, and never can be upheld where justice is justly administered.',

\section{What It Includes under Our Constitutional Guaranties.}

Notice and hearing Tequisite uniler con. stitutions.

The clauses in our constitutions guaranteeing "the law of the land" and "due process of law," have always been held to include the opportunity to present any defenses which might affect the decision of the court or tribunal. The opportunity to defend implies notice of an official inquiry into the facts, and "notice and learing", are necessary to due process of law; are, indeed, "the essential elements", thereof.2 The notice and hearing requisite are present generally when the person whose life, liberty, or property is to be taken has, upon reasonable

9 Bradstreet $r$. Neptune Ins. Co., 3 Sumn. (U. S.) 600. And see Windsor $r$. MeVeigh, 93 U. S. 274.

${ }^{1}$ Galpin $v$. Page, 18 Wall. (U. S.) 350 ; Hovey $v$. Elliott, 167 U. S. 40 ?.

2 Simon v. Craft, 182 U. S. 436 ; Hooker v. Los Angeles, 188 U. S. 314,318 . 
notice, at some stage of the proceedings, an opportunity to present objections to the proposed action Chapter II. before a tribunal authorized to give effect to the objections, if it regards them as valid. ${ }^{3}$ Thus, after judgment in a suit, a rule against a per'son not a party thereto to show cause why he should not be compelled to pay the amount of the judgment has been held to be sufficient notice and, if followed by a hearing wherein opportunity to defend was allowed, to constitute due process of law. ${ }^{4}$

An opportunity to defend does not in all cases inrolve the presence of the party during the trial. ${ }^{5}$ Presence not essen. Thus, in a trial of the issue of lunacy in a State court, it was held not essential that the alleged lunatic be personally present, when notice of the inquisition was personally served on her, and her interests were represented at the hearing by a guardian $a d$. litem, the sheriff having returned as required by statute that it was not consistent with her health or safety to be present in person, and the statute warranting her absence in such a case. ${ }^{6}$

The notice of a proposed course of action which will result in a taking of life, liberty or property must, in order to be due process. be reasonable in time, so as to give a real opportunity to present defenses. The authority to prescribe the time of notice resides in the legislature, and the courts will require a very clear case before interfering on this ground. In a case wherein a railroad company con-

3 Wilson $v$. Standefer, 184 U. S. $399,415$.

4 Louisville, etc., R. Co. $v$. Schmidt, 177 U. S. 230.

5 As to the necessity of presence of the accused during the trial of grave criminal charges, see infra, p. 165.

${ }_{6}^{6}$ Simon $r$. Craft, 192 U. S. 436. 

Chapter tended that a reassessment against its property for
II. the cost of a local improvement was a deprivation without due process because the notice of the reassessment mas insufficient, it appeared that the law under which the reassessment was had prescribed three successive publications in a newspaper stating a time when the council would consider the reassessment, and that the owner of property reassessed was given ten days from the last publication to file objections. This virtually amounted to ten days' notice after the last publication. The Supreme Court, in holding that the notice could not be pronounced insufficient, said: "It may be that the authority of the legislature to prescribe the length of notice is not absolute and beyond review, but it is certain that only in a clear case will a notice authorized by the legislature be set aside as wholly ineffectual on account of the shortness of the time. The purpose of notice is to secure to the owner the opportunity to protect his property from the lien of the proposed tax or some part thereof. In order to be effectual it should be so full and clear as to disclose to persons of ordinary intelligence in a general way what is proposed. If service is made only by publication, that publication must be of such a character as to create a reasonable presumption that the owner, if present and taking ordinary care of his property, will receive the information of what is proposed and when and where he may be heard. And the time and place must be such that with reasonable effort he will be enabled to attend and present his objections. . . . The fact that the owner after being notified is required to appear and file his 
objections within ten days, is thus the sole ground of complaint. But how many days can the courts Chapter II. fix as a minimum? How much time can be adjudged necessary as matter of law for preparing and filing objections? How many and intricate and difficult are the questions involved? Regard must always be had to the probable necessities of ordinary cases. No hardship to a particular individual can invalidate a general rule." "

A clear case presenting the question of the suffiSufficiency of notice. ciency of notice arose in Roller v. Holly, wherein, as to nonresidents, a statute of Texas requiring appearance on five days' notice was held not to be due process of law. "For aught that appears here," said the court, "parties may be called from the uttermost parts of the earth to come to Texas and defend suits against them within five days from the day the notice is served upon them." Under the Texas statutes, judgment by default could only be entered on the fifth day of the term, but a nonresident could not be required to know this and was entitled to construe the notice as it read on its face. "Very probably, too," continued the court, "the court which rendered the judgment would have set the same aside, and permitted him to come in and defend; but that would be a matter of discretion, a contingency which he was not bound to contemplate. The right of a citizen to due process of law must rest upon a basis more substantial than favor or discretion."

Since the constitutional requirement regards the

7 Bellingham Bay, etc., R. Co. $v$. New Whatcom, 172 U. S. 318. 8176 U. S. 398. 
Chapter reason of the thing and looks to substance rather
II.

Depend on nature of the case.

Dispensed with in some cascs. than to form, notice and hearing depend on the nature of the case and must be adapted to the class to which it belongs. ${ }^{9} \quad$ Thus due process does not ex $\imath \cdot i$ termini require proceedings in a court of justice. ${ }^{1}$ In many cases a hearing before an executive or administrative board has been held sufficient to legalize the taking of the property of the citizen, ${ }^{2}$ but it has been said that he may be deprived of life or liberty only after a regular trial in due form in a court of justice. ${ }^{3}$ This, however, was but a dictum, and in view of later decisions is to be received with caution. ${ }^{*}$

In some special cases neither notice nor a trial is requisite to constitute due process of law. In cases of direct contempt committed in its presence, the court in the exercise of a power which is inherent and necessary to the existence of its authority to protect the rights of the eitizen may punish the offender directly, and it is within its discretion to do so without notice to him or giving him an opportunity to purge himself of the contempt. ${ }^{5}$ Again. when the defendant on trial for felons voluntarily pleads guilty, the necessity of a trial is dispensed with and

a Davirlonn $r$. New Orleans, 96 [. S. 97, 107: Palmer $r$. Me.

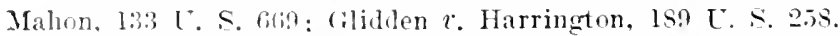

lyckillen $r$. Anderson. 95 U. S. 41; Public Clearing House $v$. Copne. 194 ['. S. 497. 508.

z Soe supra, p. 72.

3 Hagar $r$. Reclamation Dist. No. 108, 111 L. S. 701.

4 See Caldwell r. Texas, 137 U. S. 692: In re Converse, 137 U. S. 624; Leeper $v$. Texas, 139 U. S. 462; Reetz $v$. Michigan. 188 U. S. 507. The first three cases show how reluetant the Supreme Court of the United States is to interfere with State courts acting in accordance with general laws in their own jurisdiction: the last. the wide freelom which the legislature has in conferring jurisdiction upon bodies other than established courts.

5 Ex p. Terrs, 12S U. s. 2s9. See further infra. 1. 169. 
the court may pronounce even the sentence of death upon him without depriving him of due process of Chapter II. law. ${ }^{6}$

Provided the essentials of a fair hearing on notice are present, due process of law does not demand Appeal or review not that machinery to review the result of the hearing or to correct errors therein be provided. "One hearing," the Supreme Court has said, "if ample, before judgment satisfies the demand of the Constitution in this respect," and "if a single hearing is not due process doubling it will not make it so." 7 This rule of course holds as to all questions of mere fact involved. ${ }^{\mathrm{S}}$ When the decision of any subordinate court, tribunal, or officer is made final on points of law upon which the jurisdiction may depend, the distribution of the powers of the government under the Constitution may be involved. ${ }^{9} \quad$ The Federal Supreme Court generally regards such questions, when arising on error to the State courts, as matter of local law. ${ }^{1}$ It has gone far in upholding the validity of Acts of Congress vesting in merely administrative tribunals the final determination of questions involving their own jurisdiction. ${ }^{2}$

6 Hallinger $v$. Davis, 146 U. S. 314.

7 Pittsburg, etc., R. Co. $v$. Backus, $15 \frac{1}{2}$ C. S. 426. 427. See also Mckane $v$. Durston, 153 U. S. 684. 68T; Reetz $r$. Michigan, 188 U. S. 508; Hibben $v$. Smith, 191 U. S. 322. And see infra, p. 159. 8 Long Island Tater Supply Co. $v$. Brooklyn, 166 U. S. 655, 695. a See supra, Confusion of Different Departments of Government, p. 68 .

1 See supra, p. 71.

2 See infra, The Persons Protected - Aliens, p. 190, and the sections on Totice and Hearing under Eminent Domain and Police Poucer, pp. 296, 370. 
Chapter

II. hearing $e x$ gratia required.
Notice provided by implication.

\section{Notice and Hearing Must Be Required, Not Matters of Grace.}

If notice and hearing are essential, they must be required by law. In a leading Ner York case it is observed: "It is not enough that the omners may by chance have notice, or that they may as a matter of favor have a hearing. The law must require notice to them and give them the right to a hearing and an opportunity to be heard. It matters not upon the question of the constitutionality of such a law, that the assessment has in fact been fairly apportioned. The constitutional validity of law is to be tested not by what has been done under it, but by what may by its authority be done.", 3 But a statute is to be construed as one law with the Constitution, and, therefore, where notice and a hearing were actually had, and due process was required, not only by the federal but by the State constitution, it was not open to the defendant to object that the hearing was merely ex gratia. ${ }^{4}$

Similarly the powers granted by a municipal charter must be exereised subject to all the restrictions imposed by constitutional provisions, and a clanse therein granting local taxing porrer to a city need not expressly require notice. But an ordinance which attempts to exercise the power by providing for a special assessment must require notice either expressly or by implication. In a case coming to the Supreme Court from Oregon a local as-

3 Stuart $v$. Palmer. 44 N. Y. 183, 185, by Earl, J.. for the court. See also Rees $r$. Watertown, 19 Wall. (U. S.) 107 ; Louisville, etc., R. Co. $r$. Schmidt, 177 U. S. 230 .

4 Kentucky Railroad Tax Cases. 115 U. S. 334. 
sessment, levied for the cost of a sewer, was contested on the ground that no notice was provided for either in the city charter or in the ordinance requiring the construction of the sewer. The ordinance did, in fact, in accordance with the charter name "three disinterested persons" as viewers and direct that "said viewers shall hold stated meetings" in a specified place, "and all persons interested may appear before said viewers and be heard in the matter of making said estimate." The viewers, immediately upon their appointment, gave notice of their first meeting. In the State court, Strahan, J., had said: "I think it would be a reasonable construction of this ordinance to hold that the right to be heard implies that notice shall be given, and, if this be so, the ordinance does provide for notice by necessary implication. That which is implied in a statute is as much a part of it as what is expressed." 5 The Supreme Court approved this ruling, saring it was not a strained construction that the ordinance provided for notice. ${ }^{6}$

It appears that a public sitting after due notice implies the opportunity to be heard. In State Railroad Tax Cases, which involved the validity of a law Public sit-
ting after notice im-
plies hearing. of Illinois for assessing railroads, the statute provided that railroad property should be assessed by the State board of equalization sitting at a time and place designated, and fixing the assessment with a schedule of the railroad's property, made by its own officers, before it. The method of assessment was held not to be open to objection. The court, by Mr.

5 Paulson v. Portland, 16 Oregon 450, 464.

6 Paulsen $v$. Portland, 149 U. S. 30, 40. 
Chapter Justice Miller, said: "This board has its time of
II. sitting fixed by law. Its sessions are not secret. No obstruction exists to the appearance of any one before it to assert a right, or redress a wrong; and, in the business of assessing taxes, this is all that can be reasonably asked." ' In a later case involving the validity of a similar law in Kentucky, the court, after quoting Mr. Justice Miller's remark abore, said: "In the proceedings questioned in these cases, there was in fact and in law notice and a hearing." It laid stress on the return of the corporation through its officers, which constituted a statement of its own case and formed the matter on which the board was to act. ${ }^{8} \mathrm{~A} \cdot$ like holding has been made with respect to a hearing before a State medical board for license to practice medicine. The statute made no special provision for notice, or hearing, or authority to summon witnesses or compel them to testifs, but it provided for meetings at specified times and a specified place. "When a statute," said the court, "fixes the time and place of meeting of any board or tribunal, no speciai notice to parties interested is required. The statute is itself sufficient notice. If the plaintiff in error had applied at any meeting for a hearing, the board would have been compelled to grant it, and if on such hearing his offer of or demand for testimony had heen refused, the question might have been fairly presented to the State courts, to what extent the action of the board had deprived him of his rights." ${ }^{9}$

T State Railroad Tax Cases. 92 C. S. 610.

\& Kentucky Railroad Tax Cases. 115 U. S. 332.

- Rectz $v$. Michican, 188 C. S. 505, 50?. 


\section{CHAPTER III.}

\section{JURISDICTION AND DUE PROCESS.}

\section{THE GENERAL REQUIREMENT OF JURISDICTION.}

\section{TOTAL want of jurisdiction over the person or thing to be affected by a judgment renders the judgment void, and the proceedings in Chapter III. A which it was obtained are obnoxious to the consti- notice.

tutional guaranty of due process of law. ${ }^{1}$ This principle was deduced from the natural right to notice and a hearing. The acquisition of jurisdiction depends on bringing home notice in some form to the person whose life, liberty or property is to be affected by the judgment, and jurisdiction, though acquired, is subject to the limitation that it must be lawfully pursued and validates judgment only after hearing or an opportunity to defend." "What is

1 Pennoyer $v$. Neff, 95 U. S. 733.

2 Windsor $v$. MeVeigh, 93 U. S. 274; Hassell $v$. Wilcox, 130 U.S. 493 ; Hovey $v$. Elliott, 167 U. S. 409; Bradstreet $v$. Neptune Ins. Co., 3 Sumn. (U. S.) 600 ; China Mut. Ins. Co. v. Force, 142 N. Y. 95 ; Woodruff $v$. Taylor, 20 Vt. 65; Boggs v. Com., 76 Va. 989.

The principle of the common law which forbade judgment against any one until he had appeared, 2 Poll. \& M. Hist. 592, since it existed in very primitive times, could not have been founded consciously on theories of justice and the law of nature. There was a time when the blood-feud was the only redress for a person injured. The blood-feud was replaced by a voluntary reference to an arbitrator, who awarded damages to the person injured. Jenks, Law and Politics in the Middle Ages, 100 et seq.; Maine, Ancient Law (3d Am. ed.) 364 ; Holmes, Com. Law, 3 . The roluntary nature of this proceeding was a most marked feature, and impressed its character 80 deeply that traces survive in the procedure of courts long after the 
Chapter absolutely indispensable [to jurisdiction] is," said the United States Circuit Court for New York, "unless he [the person whose life, liberty or property is involved] lias consented to the act of deprivation, that he shall have notice of the proceeding, either actual or, in proper cases, constructive, by publication, or by seizure of the thing itself; and that he shall have an opportunity to be heard in defense of his right or title. If the proceeding is wanting in these essentials, then by the principles of the common law, whatever force and effect the judgment may otherwise have, it can not bind him; he is not and can not be treated as a party to the judgment without a violation of what is regarded as a fundamental rule of natural justice. This rule of the common law is obviously intimately connected with the constitutional prohibition upon the States and the general government, forbidding them to deprive any person of his property without 'due process of law.',", 3

Sister-state judgments.

The clause of the Constitution guaranteeing full faith and credit to the judgments of sister States, has no application to judgments rendered without jurisdiction. The fact of jurisdiction is always open to inquiry, and the record of a judgment rendered state had undertaken the administration of justice in regular tribunals. The defendant must consent to the jurisdiction. and his appearance in private actions is consent. The state exhausts itself in efforts in civil cases to make him appear, by the issuance of process leading at last to outlawry, $3 \mathrm{Bl}$. Com., ch. xix; in eriminal cases, to make him sulmit to the jurisdiction and plead, by the peine forte et dure, 4 Bl. Com. 341; Carter, Outlines Eng. Leg. Hist. 180. But it was ages before the last traces of the primitive eoneeption were outgrown, and the obstinacy of the defendant was simply ignored.

3 Lavin $v$. Emigrant Industrial Sav. Bank, is Blatehf. (U. S.) 1, per Choate, D. J. 
in another State may be contradicted as to the existence of the jurisdictional facts recited in it." Chapter III. "Judgments recovered in one State of the Union," says Mr. Justice Gray, "when proved in the courts of another, differ from judgments recovered in a foreign country in no other respect than that of not being re-examinable upon the merits, nor impeachable for fraud in obtaining them, if rendered by a court having jurisdiction of the cause and of the parties." ${ }_{5}$

Speaking generally, jurisdiction extends to all persons and things lying within the territory of the State, and to neither persons nor things lying beTerritorial jurisdic. tion of persons and things. yond those limits. ${ }^{6}$ The jurisdiction of a State, then, is based on the presence either of the person or of the res within its limits; it is either jurisdiction of the person or jurisdiction of the subject-matter. When a person is within the State, he is subject to the process of its courts, and is personally bound by a judgment against him after the service of such process. When he is not within the State, jurisdiction can be acquired without his consent only through, and to the extent of, property within the State belonging to him, by a proceeding in which that property, the res, is brought within the grasp of the court. ${ }^{7}$

If a fact or proceeding is jurisdictional in its

4 Thompson $v$. Whitman, 18 Wall. (U. S.) 457 (the leading case on this proposition); Cole $v$. Cunningham, $133 \mathrm{U} . \mathrm{S} .107$; Thormann $v$. Frame, 176 U. S. 350 ; National Exch. Bank v. Wiley, 195 U. S. 257.

5 Hanley $v$. Donoghue, 116 U. S. 4.

6 Story, Confl. Laws, 539. Galpin v. Page, 18 Wall. (U. S.) 350.

7 Boswell v. Otis, 9 How. (U. S.) 336; Cooper $v$. Reynolds, 10 Wall. (U. S.) 316,317 ; Picquet $v$. Swan, 5 Mason (U. S.) 35. 
Chapter nature, that is, if it must exist or be performed as
III.

Presence of juris. dictional facts.

a condition to jurisdiction attaching or continuing, a judgment rendered without the presence of such fact is necessarily void and subject to collateral attack. ${ }^{\mathrm{s}}$ Upon this ground the issuance of letters of administration upon the estate of a person whose continued absence has raised the presumption that he is dead, is, if he is subsequently proved to have been alive at the date of issuance, absolutely void, as are all proceedings thereunder. The jurisdiction to grant such letters is dependent upon the very fact of death, and any notice required to be given is likewise based on the same fact, and is not addressed to or intended to warn him upon whose estate letters are issued. ${ }^{9} \quad$ But a statute authorizing administration on the estates of persons who have disappeared for a period of seven years or more and who consequently are presumed dead, may be ralid, if it is based on the priuciple that mere absence for the period mentioned gives jurisdiction to grant letters of administration, provided that reasonable provision for notice is made in the event that the absentee may be alive, and that property rights are adequately safeguarded. ${ }^{1}$

8 Instances and illustrations are found in Wise $v$. Withers, 3 Cranch (I'. S.) 331; Rose $r$. Himely, 4 Cranch (U. S.) 241; Wisconsin 1 . Peliean 1ns. Co., 127 C. S. 205; Andrews $v$. Andrews, 188 U.S. 14; and other cases cited in the prior notes to this chapter.

D Seott $v$. Mcieal, 154 U. S. 34; Lavin $v$. Emigrant 1ndustrial Sar. Bank, 18 Blatehf. (U. S.) 1, a full and able consideration of the question by Choate, D. J. Contra is Roderigas $r$. East River Sav. Inst., $63 \mathrm{~N}$. Y. 460 , which is somewhat shaken in Roderigas $v$. East River Sav. Inst., 76 Y. Y. 316.

1 Cunnius $v$. Reading School Dist., 198 U. S. 458, affirming 206 Pa. St. 469 .

Upon the latter point the Pennsylvania statute uphold provided 
When jurisdiction has once attached, errors upon Chapter questions of mere procedure, or in the rulings of the court or tribunal, will not have the effect of ousting the jurisdiction, or render a judgment or decree pronounced after such error subject to collateral attack; the proper and only way to correct errors not affecting the jurisdiction is by writ of error or by appeal. ${ }^{2}$

\section{JUDGMENTS IN PERSONAM.}

When a proceeding is strictly in personam, $\begin{gathered}\text { Personal } \\ \text { service or }\end{gathered}$ brought to determine the personal rights and obli- appearance gations of the parties, personal service within the State or a voluntary appearance in the cause is essential to the acquisition of jurisdiction. ${ }^{3}$ The same rule obtains in a proceeding quasi in rem as to the validity of a personal judgment attempting to determine the obligations of the defendant except as to the disposition of the res. ${ }^{4}$ The invalidity of judg-

that, if the absentee is proved to be alive, all powers conferred by the letters cease, the administrator must account to date, but all receipts or disbursements remain valid, provided that no title to property received as heir, next of kin, etc., is valid, but such property may be recocered. No property is to be paid to any one by the administrator unless the person receiving it gives security to return it in the event of the supposed decedent returning.

2 Grignon $v$. Astor, 2 How. (U. S.) 319 ; MeNitt $v$. Turner, 16 Wall. (U. S.) 366 ; Mohr $v$. Manierre, 101 U. S. 417 ; Thaw $v$. Fitchie, 136 U. S. 519 ; Simmons $v$. Saul, 138 U. S. 439 ; Reinach $v$. Atlantic, etc., R. Co., 58 Fed. Rep. 43.

3 D'Arcy $v$. Ketchum, 11 How. (U. S.) 174; Webster $v$. Reid, 11 How. (U. S.) 437; Cooper v. Reynolds, 10 Wall. (U. S.) 316; Pennoyer $v$. Neff, 95 U. S. 714 ; St. Clair $v$. Cox, 106 U. S. 353; Pana $v$. Bowler, 107 U. S. 529; Hart $v$. Hansom, 110 U. S. 15l; Grover, etc., Sewing Mach. Co. $v$. Radeliffe, 137 U. S. 294 ; Wilson $v$. Seligman, 144 U. S. 41.

4 Picquet $v$. Swan, 5 Mason (U. S.) 35 ; Boswell $v$. Otis, 9 How. (U. S.) 348 ; Freeman $v$. Alderson, 119 U. S. 185. 
Chapter ments without service results as well from the prinIII. ciples of international law as from those of due process of law. The rule that the jurisdiction of a State is confined to persons and things within its territorial limits belongs to intermational law, and the principle of the law of nature or natural justice, which requires notice and a hearing or opportunity to be heard before condemnation, is as essential in international law as in due process. ${ }^{5}$

Personal judgments in sister States.
Before the passage of the Fourteenth Amendment, the Supreme Court pronounced roid personal judgments of any State obtained on constructive service only against a nonresident, whenever called in question beyond the limits of the State of the forum. In so holding the general doctrines of international law were applied; for the members of the Union, save as restricted by the Constitution, possess and exercise the authority of independent states. ${ }^{6}$ Nor is the application of this principle affected by Article IV, Section 1, of the Federal Constitution, which provides that "full faith and credit shall be given in each State to the public acts, records, and judicial proceedings of every other State," or by the Acts of Congress passed in pursuance thereof. "The Act of May 26, 1790" (1 Statutes at Large, 122)," said the court, "gives to a judgment rendered in any State such faith and credit as it had in the courts of the State where it was recovered. But this provision, though general in its terms, does not extend to judgments rendered against persons not amenable to the jurisdiction rendering the judg-

5 Pennoyer $r$. Neff, 95 U. S. 715.

- Pennoyer $v$. Neff, 9.5 U. S. 715.

6* Rev. Stat. U. S., see. $905 ; 3$ Fed. Stat. Annot. 37. 
ments. . . The doctrine of this court as well Chapter as of the courts of many of the States is, that this III. Act of Congress was not designed to displace that principle of natural justice which requires a person to have notice of a suit before he can be conclusively bound by its result; nor those rules of public law which protect persons and property within one State from the exercise of jurisdiction over them by another." s

As the Constitution then stood, the federal government had no concern with the presence of due Status of in State process of law in, and the consequent validity of, judgments rendered in a State against persons or property within its own limits; and, although such judgments rendered contrary to the first principles of justice ought to have been held void by the State courts, yet the Federal Supreme Court frequently limited its holding to the point of their extraterritorial invalidity. Such language, it was observed in Pennoyer v. Neff," "can be justified only on the ground that there was no mode of directly reviewing such judgment or impeaching its validity within the State where rendered; and that, therefore, it could be called in question only when its enforcement was elsewhere attempted." But the conditions were changed by the enactment of the Fourteenth Amendment, and the presence of due process of law, as construed by the Federal Supreme Court, was made an essential to the validity of a judgment in a State court even against its own citizens. ${ }^{1}$ Since, in de-

7 Citing D'Arcy v. Ketchum, 11 How. (U. S.) 165.

8 Lafayette Ins. Co. v. French, 18 How. (U. S.) 404.

995 U. S. 732.

1 Pennoyer $v$. Neff, 95 U. S. 715. 
Chapter termining the validity of judgments, the doctrines
III. of international law and of due process of law are the same, the necessity of such cautious limitation of the point adjudicated would seem to have disappeared, but expressions of this kind are still employed by the court. Thus in Grover, etc., Sewing Mach. Co. v. Radcliffe," it is said: "The distinction between the validity of a judgment rendered in one State under its local laws upon the subject and its validity in another State is recognized by the highest tribunals of each of these States." And the court observed that even if the judgment could have been entered against a nonresident on constructive service in accordance with local law, "he could not be held liable upon such judgment in any other State, contrary to the laws and policy of such State." As was said by a State court in a recent case, observations such as these were not to be taken as superseding the principle establislied in Pennoyer $v$. Neff, or as casting any doubt upon it. ${ }^{3}$

Extraterritorial personal service.

To secure personal jurisdiction orer nonresidents, a personal service beyond the limits of the State is equally ineffective as is constructive service by publication. The process of a court runs legally only within the limits of its jurisdiction, and it is only by service made within those limits that a right to pronounce a personal judgment against a nonresident without his consent is acquired. ${ }^{4}$

A general appearance entered by a person merely

2137 U. S. 295. For similar remarks, see Hart $v$. Sansom, 110 U. S. 156; Goldey $r$. Morning News, 150 U. S. 518.

3 Kemper-Thomas Paper Co. r. Shyer, 108 Tenn. 464.

4 Sugg $v$. Thornton. 192 U. S. 524; De La Montanya $v$. De La Montanya, 112 Cal. 115; Atherton $v$. Atherton, 181 U. S. 155. 
constructively served, waives all questions as to the sufficiency of the service, and gives the court jurisdiction to render a valid personal judgment. ${ }^{5}$ A Chapter III.

General and special special appearance may usually be entered to chal- apce. lenge the jurisdiction without waiving the illegality of service or submitting to the jurisdiction of the court. ${ }^{6}$ But a State statute which declares that a special appearance constitutes a general submission to the jurisdiction does not work a denial of due process of law. It does not interfere with the substance of the defendant's rights, since he may choose not to appear at all, and then he will be free to question the judgment rendered against him; but it merely puts a certain construction on a step in the case, a thing which the State has a right to do. ${ }^{7}$

Judgments Against Nonresident Joint Debtors, Etc.

Suppose a nonresident enters into a partnership or an association within a State, and the laws of the State and his own agreement contain a provision that Consent to certain service by nonresithe State courts shall have jurisdiction to render judgments binding on him in litigation arising out of the business of the association or partnership, upon the serrice of process in a specified manner, as upon service on his resident partner or manager, constituted for this purpose his agent to receive service.

5 Goldey $v$. Morning News, 156 U. S. 521.

6 Harkness $r$. Hyde, 98 U. S. 476.

7 York $v$. Texas, 137 U. S. 15; Kauffman $v$. Wooters, 138 U..S. 285.

Such a statute is not binding on the federal courts sitting in such States, under the Act of Congress requiring conformity "as near as may be" to procedure in the State courts. Southern Pac. R. Co. $v$. Denton, 146 U. S. 202 ; Mexican Cent. R. Co. $v$. Pinkney, 149 U. S. 194. 

Chapter Is jurisdiction so obtained valid? A line of Eng-
III. lish cases express the general doctrine of intering to international law. national law and hold that such an agreement in respect to jurisdiction entered into by a citizen of one independent sovereignty forming business relations in another sovereignty is valid and gives the latter sovereignty jurisdiction in accordance therewith, when the agreement is in conformity to the laws of the latter sovereignty." "It is not contrary to natural justice," said the Court of Exchequer, "that a man who has agreed to receive a particular mode of notification of legal proceedings should be bound by a judgment in which that particular mode of notification has been followed, even though he may not have had actual notice of them." 9

Modified by liederal Constitution.

Latrs of this character enforce a wise domestic policy, in that they prevent the need of the citizen having recourse to foreign tribunals for remedies on the contracts made by aliens doing business in the sovereignty. But how far this principle of international law is applicable between the States under our dual system of gorernment depends on the relation between the States established by the Constitution. This relation is that of independent sovereignties except as modified by constitutional

s Rnusillon $r$. Rousillon, 14 Ch. D. 370; Copin $v$. Adamson, L. R. 9 Exch. 345, affimed 1 Ex. D. 17; Bank of Australasia r. Harding, 9 C. B. 661 ; Vallée $v$. Dumergue, 4 Exch. 290; Dices, Confl. Laws 37 . See also Pennoyer $r$. Neff. 95 U. S. 735; Ouseley $v$. Lehigh Valley Trust, etc., Co., 84 Fed. Rep. 602.

9 Vallee $r$. Dumergue, 4 Exch. 290.

Whether the mere fact that the laws of the foreign sovereignty where the judgment is rendered provide that the eitizen shall be bound by a designated form of notice is sufhicient of it-elf to imply a conclusive assent seems unsettled. See Copin $x$, Adamson, L. R. 9 Exch. 345, 1 Ex. D. 17. 
provisions," one of which is that "the citizens of Chapter each State shall be entitled to all privileges and immunities of citizens in the several States." 2

The right to resort to the federal courts in controversies arising with eitizens of other States may Right to resort to federal be considered a privilege of citizenship; and, at any rate, the jurisdiction being fixed in the federal courts by Act of Congress under the Constitution, ${ }^{3}$ neither an act of the State legislature ${ }^{4}$ nor a private agreement made in advance and operating generally as to all controversies ${ }^{5}$ may abridge the right. The citizen "can not bind himself in advance," it has been said, "by an agreement which may be specifically enforced thus to forfeit his rights at all times and on all occasions, whenever the case may be presented." ${ }_{6}$

No action on the part of the State or of individuals, then, can have the effect of preventing a Consent to diction. removal from the State courts to the federal courts, if the right of removal has been claimed in apt time. ${ }^{7}$ But it seems that a voluntary agreement entered into by a nonresident consenting to a State's jurisdiction in suits to enforce liabilities arising from a particular transaction, may be effective, so far at least as to create an estoppel to deny the validity

1 Pennoyer $v$. Neff, 95 U. S. 715.

2 Const. L. S., Art. IV, sec. 2 ; 9 Fed. Stat. Annot. 158.

3 Acts March 3, 1887, e. 373, 1 (24 Stat. L. 552) ; Aug. 13, 18s8, c. $866 . \S 1$ ( 25 Stat. L. 434$) ; 4$ Fed. Stat. Annot. 265 et seq.

${ }^{4}$ Cowles $r$. Mercer County, 7 Wall. (U. S.) 118 ; Goldey $v$. Morning News, 156 U. S. 518 ; Barrow Steamship Co. $v$. Kane, 170 U. S. 100, 111; Blake $v$. McClung, 172 U. S. 239.

5 Home Ins. Co. $v$. Morse, 20 Wall. (U. S.) 445.

6 Home Ins. Co. $v$. Morse, 20 Wall. (U. S.) 445.

7 Martin $v$. Baltimore, etc., R. Co., 151 U. S. 686; Powers v. Chesapeake, etc., R. Co., 169 U. S. 98. 

Chapter of a State judgment rendered in accordance with the
III. agreement. Thus an authority in a judgment note to an attorney to confess judgment has been held by a State court to validate the judgment confessed, although no notice had been served on the nonresi-

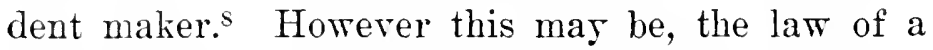
state giving its courts jurisdiction, without personal service within the State, over a nonresident partner or party to a joint contract, upon personal service on the resident partner or party, or on a resident agent, is, at least so far as the extraterritorial ope-

8 Kingman $v$. Paulson, 126 Ind. 507.

Grover, ete., Sewing-Maeh, Co. $\tau$. Radeliffe, 137 U. S. 287, affirming $66 \mathrm{Md}$. $5 \mathrm{ll}$, is only to the point that when judgment is not confessed in accordance with the authority given, it is void, and personal jurisdiction must be acquired by service of process on the defendant.

National Exch. Bank $v$. Wiley, 195 C. S. $25 \%$, is to the point that a judgment so confessed is open to attack in another State on the grownd that juricdictional facts were wanting.

becoming surety on a bond under a law which authorizes judg. ment aguinst the surety when judgment is recovered against the principal, is a consent which binds the surety by a judgment so rendered. Beall $r$. New Mexico, 16 Wall. (U. S.) 535; Moore $r$. Huntington, 17 Wall. (U. S.) 417 ; Johnson $v$. Chicago, ete., Elevator Co, 11 ! L. S. 888 : llopkins $v$. Orr, 124 L. S. 510. In the first case cited the rourt sail: "A party who enters his name as surety on an apjeal bonl does it with a full knowledge of the responsibilities incurred. In view of the law relating to the subject, it is equivalent to a consent that judgment shall be entered up against him, if the aprellant fails to sustain his appeal. If judgment may thus be entered on a recognizance and against stipulators in admiralty. We see no reason in the nature of things, or in the provisions of the Constitution, why this effect should not be given to appeal bonds in other actions, if the legislature deems it expedient. No fundamental constitutional principle is involved; no fact is to be aseertained for the purpose of rendering the sureties liable which is not apparent in the reend itself: no object (exerpt mere delay) ean be subserved by compelling the appellees to bring a separate action on the appeal bond." 
ration of the judgment so obtained is concerned, a mere nullity.

Considering the cases holding this doctrine in the light of the principle of international law announced above, they establish that in the absence Chapter III. of the nonresident's personal assent to the jurisdiction, a State can not by its laws annex conditions to the individual's right to make lawful investments or engage in lawful business within the State. ${ }^{1}$ When, however, conditions can be exacted constitutionally, the general doctrine of international law applies. It is so in the case of corporations - artificial beings whom the State may exclude entirely or receive on such terms as it will. ${ }^{2}$ And the principle has been applied to the case of individual stockholders in corporations. A statute of Missouri declared that upon judgment recovered against a corporation and execution thereon returned unsatisfied, execution might issue against any stockholder individually "upon motion in open court after suffi-

${ }^{\circ}$ Goldey $v$. Morning News, 156 U. S. 519, and citations there given; Brooks $v$. Dun, 51 Fed. Rep. 138; Moredock $v$. Kirby, 118 Fed. Rep. 182.

The New York joint-debtor act provided that when joint debtors are sued and one is brought into court on process, though the other is never served, judgment may be rendered against both, by virtue of the process. Suit was brought in New York on a joint and several obligation of $G$. and A. G. appeared, but A., who was a citizen of Louisiana, was not served and did not appear. Judgment was given against both. It was held, on principles of general jurisprudence, that A. was not, outside the State of New York, bound by the judgment and that the full faith and credit clause of the Constitution had no bearing on the case. D'Arey $r$. Ketchum, 11 How. (U. S.) 165 ; Board of Public Works $v$. Columbia College, 17 Wall. (U. S.) 521. See also Hanley $v$. Donoghue, 116 U. S. 1; Renaud v. Abbott, 116 U. S. 277 .

1 See Moredock $v$. Kirby, 118 Fed. Rep. 180.

2 See infra, p. 189. 
Chapter cient notice in writing", to the stockholder. An exe-
III. cution so issued against a nonresident, without personal service within the State, was held, on familiar grounds, to have no validity either in the State of issuance or elsewhere, ${ }^{3}$ but, in the course of its opinion, the court suggested that a State statute such as is frequently enacted with regard to corporations, to the effect that each nomresident stockholder should appoint an agent within the jurisdiction to receive service for him; that, in default of appointment, service may be made on a designated public official, and that judgment rendered against the corporation after such service should bind the stockholders whether within or without the State, might be valid on stockholder's without the State on the ground that the stockholders must be taken to have consented to the sufficiency of the service. ${ }^{4}$

Corry i'.

The principle of this suggestion is applied in a late case in the Supreme Court of the United States. A statute of Maryland imposed on stockholders in Marrland corporations a personal tax because of their ownership in the stock, without regard to their place of residence. The payment of the tax by the corporation on behalf of the shareholders was provided for, and the corporation was, thereupon, given a lien upon the stock for the amount of the taxes paid, which it was entitled to enforce by a personal action. The statute made no provision for notice to shareholders individually, but provided a sufficient notice with respect to the corporation.

3 Wilson $v$. Seligman, 144 U. S. 41. See also Howell v. Manglesdorf, 33 Kan. 194; Dodd v. St. Louis, ete., R. Co., 108 Mo. 581.

4 Wilson $v$. Seligman, 144 U. S. 45, per Gray, J. 
The validity of the tax was disputed by a nonresident stockholder on the ground that the State had Chapter III. no jurisdiction to levy a personal tax upon nouresidents, at least, without giving them personal notice. The court adopted the view of the Maryland Court of Appeals that "a notice to each shareholder is unnecessary because the corporation represents the shareholders," 5 and said that by that construction the statutory provisions in question were "in legal effect constituting the corporation the agent of the stockholders to receive notice and to represent them in proceedings for the correction of an assessment," and that this condition attached by the law to the acquisition of stock in a domestic corporation was not in the opinion of the court arbitrary or unreasonable, nor a deprivation of due process of law. ${ }^{6}$

Another phase of the decisions denying the right of the State to secure jurisdiction over nonresidents entering into partnership or joint contracts within the State, is presented by laws making constructive service on the nonresident party or debtor by personal service on the resident partner or debtor, binding on the partnership property within the State. Expressions are found by the United States Supreme Court indicating that such laws are valid within the State, though invalid in other States. ${ }^{7}$ The reasoning in Pennoyer $v$. Neff would seem to establish that laws of this character, since the Fourteenth Amendment, give no validity to judgments against the joint property of joint debtors either

5 James Clark Distilling Co. v. Cumberland, 95 Md. 474; Corry v. Baltimore, $96 \mathrm{Md} .321$.

6 Corry $v$. Baltimore, 196 U. S. 466.

7 Hall v. Lanning, 91 U. S. 160. 

Chapter within or without the State, ${ }^{8}$ and the same result
III. would seem to follow as to partnerships where the common-lar conception of a partnership is unaltered. But as to partnerships, laws of this character have been held to recognize the partnership as a legal entity distinct from the members who compose the firm, and have been held valid within the State of the forum. ${ }^{9}$

\section{Jurisdiction Over Foreign Corporations.}

Statutes giving the jurisdiction.
In Pennoyer v. Neff, ${ }^{1}$ it is said that that case is not meant to assert that a State may not require of nonresident corporations doing business therein an assent to be bound by a particular kind of notice,

8 See supra, p. 93.

Even within the jurisdiction and as to the joint property of the defendants, the validity of "joint debtor acts" has been denied on the ground that they assume the status on which the jurisdiction is asserted - " that the defendants are joint debtors, and that may be, to the defendant who is not served, the rital point of the controversy." Tay $x$. Hawley, 39 Cal. 96.

Such statutes, since they infringe on the right to notice and a hearing, can not be referred to the category of procedure.

9 Sugg $r$. Thornton. 132 U. S. 524. This case arose on the Texas statute, and the only question was the validity of the judgment in Texas. Even this question was considered in the opinion in a supplementary argument, after disposing of the ease on anotler point.

The validity of the judgment in the Texas case involves the proposition that a State may annex conditions to entering into a partnership within its limits, without regard to the intention of the nonresident partners. The condition becomes a quality impressed on the partienlar capital invented. which places it on a different plane from other property belonging to the nonresident. Investments in corporations appear to be differentiated by the fact that the ineorporators by their voluntary act, in return for certain advantages, surrender rertain privileges.

The validity of the Iowa statute to a like effect is assumed by the Circuit Court in Ralya Market Co. $v$. Armour, 102 Fed. Rep. 530.

195 U. S. 735. 
or to deny that this assent may render a judgment Chapter obtained in conformity therewith binding upon the III. nonresident corporation. ${ }^{2}$ The disclaimer was inserted because the conit had previously recognized the ralidity of certain State laws which designate a method of bringing suit against a foreign corporation doing business within a State by service of process on its officer's or agents resident in the State; ${ }^{3}$ or (as since established) which require the corporation to name an agent to receive service, and in default of such designation validate service on some public officer of the State. ${ }^{4}$ These types of statute were rendered necessary by the once prevalent doctrine that a foreign corporation could not be sued for the recovery of a personal demand outside the State where it was chartered, and had its legal domicil. ${ }^{5}$

The constitutionality of these statutes follows from the principles that a corporation is not a citiThe stat-
utes constitutional. zen within the privilege and immunity clauses of the Federal Constitution; ${ }^{6}$ that its right to do business in States other than that of its origin depends on interstate comity only ${ }^{7}$ that the State has the power to attach reasonable conditions to the right, ${ }^{8}$ which power is certainly as extensive as its power

2 See Dicey, Confl. Laws, 369, 377, and supra, p. 94.

3 Lafapette Ins. Co. $v$. French, 18 How. (U. S.) 404.

4 Cady $v$. Associated Colonies, 119 Fed. Rep. 420.

5 Middlebrooks $v$. Springfield F. Ins. Co., 14 Conn. 301; 6 Thomp. Corp., $\$ 7989$.

6 Paul $v$. Virginia, 8 Wall. (U. S.) 168; Blake $v$. McClung, 172 U. S. 239 ; Orient Ins. Co. $v$. Daggs, 172 U. S. 557.

7 Augusta Bank $v$. Earle, 13 Pet. (U. S.) 519.

8 Augusta Bank $v$. Earle, 13 Pet. (U. S.) 519; Hooper v. California, 155 U. S. 648 . 
Chapter over domestic corporations. ${ }^{9}$ The authority to at-

III. tach conditions includes the authority to demand an assent to the jurisdiction of the State permitting the corporation to do business within its limits, ${ }^{1}$ but does not include the right to attach as a condition precedent to doing business within the State, an agreement abridging or impairing the right to resort to the United States courts in pursuance of a privilege secured by the Federal Constitution. ${ }^{2}$ Nor does it extend to corporations employed in the business of the general government or engaged in commerce under the authority or with the permission of Congress. ${ }^{3}$

The stat-

The conditions imposed upon foreign corporations, including the provisions for serrice on their resident agents, must not violate the settled doctrines of public law. They must also be reasonable and conform to that rule of natural justice which requires notice of a suit to a party before he can be bound by its result, ${ }^{4}$ in other words, to the principle of due process of law. To give validity, then, to a personal judgment against a foreign corporation under such a law, it must appear that the corporation is actually doing business within the State, since without this as a condition precedent no juris-

9 Orient Ins. Co. $v$. Dagess. 172 C. S. 566.

I Lafayette Ins. Co. r. French, 18 How. (C. S.) 407; Battimore, etc., R. Co. $r$. Harris, 12 Wall. (T. S.) $65 ;$ Ex $r$. Schollenberger, 96 U. S. 37 .

2Barrow Steamship Co. $v$. Kane. I70 L. S. 111: Blake $\tau$. McClung. 172 I. S. 25.5.

3 Pemhina Comsol. Silver Min., ete. Co. $v$. Pennsylvania. 125 U. S. 185. 186.

4 Lafapette In Co. r. French, 18 How. (U. S.) 406; St. Clair ข. Cox, 106 U. S. 356 . 
diction can attach. ${ }^{5}$ The fact, therefore, that an officer of the corporation who resides or is temporarily within the State is served with process therein, gives no jurisdiction unless the corporation is engaged in business within its limits." Further, unless the corporation has under the law designated some person to receive service of process, or has by failure to do so acquiesced in a statutory designation, the person served must stand in a representative capacity to the corporation at the time of the service. ${ }^{\top}$

In Connecticut Mut. L. Ins. Co.v. Spratley, the question who is an agent upon whom service may Who is agent for service of be made is much discussed. The language of Mr. Justice Field in an earlier case was quoted, that it is requisite that his duties be not limited to those of a subordinate employee, or to a particular transaction, and that his agency had not ceased when the matter in suit arose. ${ }^{9}$ Another early case was said to establish that an agent with power to contract was clothed with power to receive notice for the company. ${ }^{1}$ It was declared not a requisite that the agent be specially empowered by the company to receive service of process. "In the absence of express authority," it was said, "the question depends

5 St. Clair $v$. Cox, 106 U. S. 359 ; Wabash Western R. Co. $v$. Brow, 164 U. S. 27]; Conley $v$. Mathieson Alkali Works, 190 U. S. 406; Cady $v$. Associated Colonies, 119 Fed. Rep. 420.

${ }^{6}$ Fitzgerald, etc., Constr. Co. $v$. Fitzgerald, 137 U. S. 9s; Goldey v. Morning News, 156 U. S. 518; Conley $v$. Mathieson Alkali Works, 190 U. S. 406 ; Geer $v$. Mathieson Alkali Works, 190 U. S. 428.

? St. Clair $v$. Cox. 106 U. S. 350 ; Mexican Cent. R. Co. v. Pinkney, 149 U. S. 194 ; In re Hohorst, 150 U. S. 663.

8172 U. S. 602.

9 St. Clair r. Cox, 106 U. S. 359, 360.

1 Lafayette Ins. Co. $v$. French, 18 How. (U. S.) 404. 
Chapter upon a review of the surrounding facts and upon

III. the inferences which the court might properly draw from them. If it appear that there is a law of the State in respect to the service of process on foreign corporations and that the character of the agency is such as to render it fair, reasonable, and just to imply an authority on the part of the agent to receive service, the law will and ought to draw such an inference and to imply such authority, and service under such circumstances and upon an agent of that character would be sufficient.', 2 In this case an insurance company had ceased to do further business in Temnessee and had withdrawn its agent from that State, but it still had policies ontstanding therein, the premiums on which were paid to an agent in Kentucky. Upon the death of a policy-holder in Tennessee, the compans sent an agent whose contract of emplorment described him as employed "for" special service in any matters which may be referred to you," to investigate the case, with anthority to compromise the claim. Service mon this agent was held to be valid and to constitute due process of law.

Statutes warranting service not essential.

While laws providing for the service of process on foreign corporations exist in perhaps all the States, by the better and more modern doctrine such laws are not essential. It is considered that when a corporation avails itself of the comity of a sister State, enters there, makes contracts, and does business, it by such action submits to the jurisdiction of that State and a service upon its principal agent

2172 U. S. 617. See also Strain v. Chicago Portrait Co., 126 Fed. Rep. 831. 
therein is sufficient to bind it by a personal judgment Chapter rendered by the courts of that State. ${ }^{3}$ "The liabilIII. ity," says the United States Supreme Court, "of a foreign corporation to be sued in a particular jurisdiction need not be distinctly expressed in the statutes of that jurisdiction, but may be implied from a grant of anthority in those statutes to carry on its business there." $\neq$ The same principles apply to give jurisdiction to the United States courts sitting in a State and give them jurisdiction against foreign corporations in conformity with local statutes providing for service of process, ${ }^{5}$ or, upon the more reasonable views just explained, in the absence of such statute. ${ }^{6}$ But it should be noticed that some States hold to the doctrine that a personal judgment against a nonresident corporation is invalid in the absence of an express law authorizing service, and decline to take jurisdiction of such suits except as far as it has been expressly conferred by statute.

\section{Extraterritorial Control in Equity Over Property and Rights of Action.}

Property and causes of action beyond the limits of a State may, where those who own the property or are entitled to maintain the action are within

3 Baltimore, etc., R. Co. $v$. Harris, 12 Tall. (U. S.) 65, explained and applied in Barrow Steamship Co. $v$. Kane, 170 U. S. 108, 109 ; Wilson Packing Co. $v$. Huntern, 8 Biss. (U. S.) 429 ; Hayden $v$. Androscoggin Mills, 1 Fed. Rep. 93 - March $v$. Eastern R. Co., 40 N. H. 577 et seq.

4 Barrow Steamship Co. $v$. Kane, 170 U. S. 108.

5 Ex p. Schollenberger, 96 U. S. 369 ; New England Mut. L. Ins. Co. v. Woodworth, 111 U. S. 146.

- Barrow Steamship Co. $v$. Kane, 170 U. S. 100.

7 See cases cited in Barrow Steamship Co. $v$. Kane, 170 U. S. 110. 
Chapter the jurisdiction of the State, be controlled to a limIII. ited extent by the decree of a court of equity, operating in personam and enforced by process in personam. Whenever, by reason of the existence of a trust or of fraud or of any matter of equitable cognizance, a court of chancery has jurisdiction and the necessary parties are before the court, it may by a decree in personam according to the equities between the parties compel a conveyance of the title to real property with the formalities necessary according to the lex loci rei sitae, and the exercise of this jurisdiction does not interfere with the supreme control over property of the State where it is situated. $^{\mathrm{S}}$ Upon the same principle, equity exercises control over personal property and contract rights lying beyond the territorial jurisdiction of the court. ${ }^{9}$ The doctrine is applied by the courts of the parties' domicil to restrain in other States the prosecution of suits which would result in defeating the operation of the laws of the domicil to the injury of its citizens. ${ }^{1}$ Thus the courts of the domicil may enjoin suits in other States instituted to evade the exemption laws of the domicil, ${ }^{2}$ or foreign suits by the resident creditors of the insolvent, the effect of

8 Penn $v$. Baltimore, 1 Ves. 444, 2 Thite \& T. Lead. Cas. (4th Am. ed.) 1806; Nlassie $v$. Watts, 6 Cranch (U. S.) 148; Northern Indiana P. Co. $r$. Michigan Cent. R. Co., 15 How. (U. S.) 233: Pennoyer $r$. Nefi, 95 C. S. 714. 723; Phelps $v$. MeDonald, 99 U. S. 298.

9 Phelps $v$. MrDonnld, 9n [T. S. 308: Cole $v$. Cunningham, 133 U. S. 107: Mitehell $r$. Bunch. 2 Paige (N. Y.) 606.

1 Cole $r$. Cunningham, 133 U. S. 107.

2 Wilson $r$. Joseph, 107 Ind. 490; Zimmerman $v$. Franke, 34 Kan. 650; Keyser $r$. lice. 47 Md. 203: Snook $r$. Snetzer. 25 Ohio St. 516; $12 \mathrm{Am}$. \& Eng. Encyc. Law (2d ed.) 256, $16 \mathrm{id} .422$. 
which would be to give such creditors a preference not allowed by the domestic insolvency laws. ${ }^{3}$

JUDGMENTS IN REM.

In a well-known case the Federal Supreme Court laid down the conditions of jurisdiction in rem as Presence
and seiz. ure of res follows: "Jurisdiction of the res is obtained by a seizure under process of the court, whereby it is held to abide such order as the court may make concerning it. The power to render the decree or judgment which the court may undertake to make in the particular cause depends upon the nature and extent of the authority vested in it by law in regard to the subject-matter of the cause. . . . While the general rule in regard to jurisdiction in rem requires the actual seizure and possession of the res by the officer of the court, such jurisdiction may be acquired by acts which are of equivalent import and which stand for and represent the dominion of the court over the thing, and in effect subject it to the control of the court. Among this latter class is the levy of a writ of attachment or seizure of real estate, which being incapable of removal, and lying within the territorial jurisdiction of the court, is for all practical purposes brought under the jurisdiction of the court by the officer's levy of the writ and return of that fact to the court. So the writ of garnishment or attachment or other form of service on a party holding a fund which becomes the subject of litigation, brings that fund under the jurisdic-

3 Cole $v$. Cunningham, 133 U. S. 107 (affrming Cunningham $v$. Butler, 142 Mass. 47, $56 \mathrm{Am}$. Rep. 657): Dehon $i$. Foster, 4 Allen (Mass.) 545; $16 \mathrm{Am}$. \& Eng. Encyc. Law ( $2 \mathrm{~d}$ ed.) 422. 
Chapter tion of the court, though the money may remain in III. the actual custody of one not an officer of the court." 4

Proceedings in rem and quasi in rem.

Proceedings in rem are either strictly in rem or quasi in rem. The first of these classes includes "proceedings against property alone, treated as responsible for the claims asserted by the libelants or plaintiffs. The property itself is in such actions the defendant, and, except in eases arising during war for its hostile character, its forfeiture or sale is sought for the wrong, in the commission of which it has been the instrument, or for debts or obligations for which by operation of law it is liable. The court acquires jurisdiction over the property in such cases by its seizure, and of the subsequent proceedings by public citation to the world, of which the orner is at liberty to avail himself by appearing as a claimant in the case.", 5 Proceedings quasi in rem are brought against persons in order to subject specific property to the discharge of the claims asserted. They differ from actions strictly in rem principally "in that the interest of the defendant is alone sought to be affected, that citation to him is required, and that judgment therein is only conclusive betreen the parties." ${ }_{6}$ As to what proceedings are quasi and what strictly in rem, it is said in a leading case: "In a strict sense, a proceeding in rem is one taken directly against property, and has for its object the disposition of the property, without reference to the titles of individual

4 Cooper $r$. Resnolds, 10 Wall. (U. S.) 308, per Miller, J.

- Freeman $t$. Alderson, 119 U. S. 185, per Field, J.

- Freeman $t$. Alderson, 119 U. S. 185. 
claimants; but in a larger and more general sense, the terms are applied to actions between parties Chapter III. where the direct object is to reach and dispose of property owned by them, or of some interest therein. Such are cases commenced by attachment against the property of debtors, or instituted to partition real estate, foreclose a mortgage, or enforce a lien. As far as they affect property in the State, they are substantially proceedings in rem in the broader sense which we have mentioned." i

The typical case of a proceeding strictly in rem is a libel in admiralty to enforce a maritime lien or forfeiture, and such a proceeding binds the res as Acquired by seizure and valid only on against the whole world, in the absence of any personal notice to the parties interested. ${ }^{s}$ The seizure brings the property within the custody of the court, and operates to impart notice of the fact to the owners and others interested in the property. In such a case, the rule that seizure is notice is necessary, because the only process is served on the thing itself ; and it is reasonable, "because," in the language of Chief Justice Marshall, "it is the part of common prudence for all those who have any interest in it to guard that interest by persons who are in a situation to protect it." 9 Some discussion has, however, arisen as to whether mere seizure is enough to give jurisdiction. In Windsor $v$. $M c$ $V e i g h$, in a passage frequently quoted, Mrr. Justice Field says: "The jurisdiction acquired by the seizure is not to pass upon the question of forfeiture

7 Pennoyer $v$. Neff, 95 U. S. 734, per Field, J.

8 Castrique $v$. Imrie, L. R. 4 H. L. 414; The Globe, 2 Blatchf. (U. S.) $42 T$.

9 The Mary, 9 Cranch (U. S.) 144. 
Chapter absolutely, but to pass upon that question after op-
III. III. portunity has been afforded to its owner and parties interested to appear and be heard upon the charges. To this end, some notification of the proceedings, beyond that arising from the seizure, prescribing the time within which the appearance must be made, is essential. Such notification is usually given by monition, public proclamation, or publication in some other form. The manner of the notification is immaterial.', 1 The case in which this passage occurs was one which involved the validity of confiscation proceedings under an Act of Congress authorizing" confiscation "of the property of rebels." There was a seizure of land in controversy and publication of monition. In response, the owner of the land appeared and filed an answer, but this was stricken out by the court on the ground that it appeared from the answer that the owner was "within the Confederate lines and a rebel." The lands were, therefore, adjudged forfeited and sold. It was held that the sale was void and passed no title. The statement of the facts shows that no question of want of notice was involved, and the sole question was whether the court's action deprived the defendant of his constitutional right to be heard. Want of a hearing after notice, not want of notice, was fatal, in accordance with the principle happily stated elsewhere in the opinion that "jurisdiction is the right to hear and determine; not to determine without hearing.", 2 The two cases seem to present

193 U. S. 279.

2 In a later case, Mr. Tustice Field said: "The law assumes that property is always in possession of its owner, in person or by agent, and it proceeds upon the theory that its seizure will inform 
no practical conflict. If the mere seizure gives juris- Chapter diction, the jurisdiction may yet be forfeited by III. failure to proceed according to the principles of natural justice, namely, on notice and hearing. Usually in a strict proceeding in rem no person can complain of want of hearing, because every person haring any interest may make himself a party and appeal from the sentence. ${ }^{3}$

In attachment and garnishment proceedings the $\underset{\text { Attach. }}{\text { ments. }}$ effect of a judgment depends on the course adopted by the defendant. "If the defendant appear's, the canse becomes mainly a suit in personam, with the added incident, that the property attached remains liable, under the control of the court, to answer any demand which may be established against the defendant by the final judgment of the court. But if there is no appearance of the defendant, and no service of process on him, the case becomes, in its essential nature, a proceeding in rem, the only effect of which is to subject the property attached to the payment of the demand which the court may find to be due to the plaintiff." 4

In no case of proceedings in rem or quasi in rem does the court by seizure and constructive service Personal
judgments unwar. gain authority to pronounce a judgment binding the

him, not only that it is taken into the custody of the court, but that he must look to any proceedings authorized by law upon such seizure for its condemnation and sale." Pennoyer $v$. Neff, 95 U. S. i15.

3 The Mary, 9 Cranch (U. S.) 144, per Marshall, C. J.; Bradstreet $v$. Neptune Ins. Co., 3 Sumn. (U. S.) 609, per Story, J.; The Ann, 5 Hughes (U. S.) 292, 8 Fed. Rep. 923; Leigh v. Green, 193 U. S. 79.

4 Cooper $v$. Reynolds, 10 Wall. (U. S.) 318, per Miller, J.; Story Confl. Laws 549. 
Chapter orner of the res personally; it can control only the III. disposition of the property seized. ${ }^{5}$ Even though the proceeding is one, as in a suit begun by attachment, where the judgment is personal in form, it is without effect as to nonresidents not personally served, except to dispose of the property attached. No personal execution can issue against the nouresident, nor can any personal liability for costs attach on such a judgment. ${ }^{6}$

Extension of Conception of Proceedings In Rem.

With the principle so frequently announced that all proceedings are either in personam or in rem, and that as against nomresidents without personal service, only in proceedings in rem was jurisdiction acquired and due process of law present, ${ }^{7}$ it became necessary to force every proceeding in which constructive serrice of process was held valid into the class of proceedings in rem.

Scizure not the criterion.

The have seen the conception extended from a proceeding begun by seizure under process directed against the res as the actual defendant and binding

5 Boswell $r$. Otis. 9 IIow. (C. S.) 348: Cooper $v$. Reynolds, 10 Wall. (L. S.) 31s; Pennorer $r$. Neff. 95 L. S. 723; Freeman $r$. Alderson, 119 [T. S. 1S.): Johnson $r$. Powers, 139 U. S. 159; Dewey r. Des Moines, 173 C. S. 193.

- Cooper $r$. liegnolds, 10 Wall. (U. S.) 31S; Freeman $r$. Alderson. 119 L. S. 185.

T Yet in Cooper $r$. Rernolds. 10 Wall. (U. S.) 30s, the court by Miller. I.. said: "We do not deny that there are cases, which not partaking of the nature of proceedings in rem, when the judgment is to have an effect on personal rights, as in dirorce suits. or in proceedings to compel conveyance, or other personal acts, in which the legislature has properly made the jurisdiction to depend on publication of notice, or on lringing the suit to the notice of the party in some other mode, when he is not within the territorial jurisdiction." 
on all the world, ${ }^{s}$ to a proceeding against persons, Chapter begun by an act "of equivalent import" to seizure, and conclusive only between the parties. An action to try the title to land and for a partition thereof was subsequently held a quasi proceeding in rem, although it is not apparent in what sense it could be considered as begun by a constructive seizure of the property. ${ }^{9}$ The same construction was put upon a proceeding to condemn land for a railroad, where the owner of the property was a nonresident, who was served constructively only. The court held the notice under the circumstances due process of law and the proceeding not open to collateral attack. The reasoning is not technical, but is placed on broad grounds of public policy; that the owner of

8 In the first lecture of "The Common Law," Mr. Justice Holmes outlines the history of penalties inflicted on animals and inanimate things, and finds their source in the savage's ascription of personality to non-human objects, animate and inanimate. From this he derives the form of the admiralty procedure in rem, the reason of course being changed to suit advancing enlightenment. If this be true, and every analogy points that way, it would seem a mere matter of historical accident that the res is the defendant and the process served on it, and we shall not be inclined to give too much weight to a procedure with such an origin, when the problem is whether a particular proceeding shall affect nonresidents and those not summoned personally. In an opinion pronounced when Chief Justice of Massachusetts, Mr. Justice Holmes said: "It is true as an historical fact, that these symbols [personification of the res as defendant] are used in admiralty proceedings. . . . But a ship is not a person. It can not do a wrong or make a contract. To say that a ship has committed a tort is [from a modern standpoint] mercly a short-hand way of saying that you have decided to deal with it as if it had committed one, because some man has committed one in fact. There is no a priori reason why any other claim should not be enforced in the same way. . . . The fact that it is not so enforced under existing practice affords no test of the powers of the legisla. ture." Tyler $v$. Judges, 175 Mass. 71.

9 Freeman $v$. Alderson, 119 U. S. 185. 
Chapter real property can not evade the duties and obliga-
III. tions which the law attaches to his property by absence from the State, and that otherwise the burdens of taxation and eminent domain would be a name only. ${ }^{1}$ In Arndt v. Griggs, ${ }^{2}$ a suit under the Nebraska statutes to remove a cloud on and quiet the title to certain lands, brought by one in actual possession under a tax deed, was held to be due process of law as to nonresidents, although there was only constructive serrice upon them. There is inherent in every sovereign state, it was said, the power to secure and quiet the title to real property within its limits, and since the duty which is correlative to this porrer devolves on the States and not on the national government, "no proceeding which it [the State] provicles can be declared invalid, unless in conflict with some special inhibition of the Constitution or against natural justice.' The validity of the jurgment rests then on the State's power to settle titles within its jurisdiction and the exercise of that power by giving a greater effect to a judgment to quiet title than was given to such a decree in equity." Throughout the opinion the action is treated as in rem, though not begun by seizure.

Proceed. ings to es cheat land and fore. close liens.
The principle of this decision is reaffirmed and emphasized in Hamilton $v$. Brown, ${ }^{4}$ wherein it was held that a proceeding to escheat land in conformity with the Texas statute which provided for construc-

1 Huling $r$. Kaw Valley R., etc., Co., 130 U. S. 559.

2134 U. S. 316.

3 See Hart $r$. Sansom, 110 U. S. 15l, and the remarks on this ease in Arndt $r$. Griggs, 134 U. S. 316, and Roller $v$. Holly, 176 U. S. 398.

161 U. S. 256. 
tive or substituted service on nonresidents, was, as to them, due process of law and conclusive. The court said: "As to personal property, indeed, a judgment in rem after notice by publication only might not bind persons who had no actual notice of the proceedings, unless the thing had been first seized into the custody of the court. But it was within the power of the legislature of Texas to provide for determining and quieting the title to real estate within the limits of the State and within the jurisdiction of the court, after actual notice to all known claimants, and notice by publication to all other persons." In Roller v. Holly, ${ }^{5}$ a suit to enforce an equitable lien for purchase money against a nomresident on constructive service was pronounced valid, and the court said: "If the plaintiff be in possession, or have a lien upon land within a certain State, he may institute proceedings against nonresidents to foreclose such lien or to remove a cloud from his title to the land," calling in nonresidents by constructive service in accordance with local legislation. "In suits for the foreclosure of a mortgage or other [pre-existing] lien upon such property, no preliminary seizure is necessary to give the court jurisdiction. The cases in which it has been held that a seizure or its equivalent" is necessary, "are those where a general creditor seeks to establish and foreclose a lien thereby acquired." This generalization will evidently not include Hamilton $v$. Brown, which was not mentioned by the court, but it shows that the court has consciously

5176 U. S. 398. See also Kemper-Thomas Paper Co. v. Shyer, 108 Tenn. 450. 
Chapter abandoned the conception of proceedings in rem, III. using that term broadly as determining jurisdiction, as begun by seizure.

Character of proceed. ings controlled by political necessity.

Indeed it seems fair to say that the old criterion has shifted, and that now a quality which was an incident of proceedings strictly in rem - the validity of constructive service or notice - has, under pressure from constitutional provisions, become the test of proceedings in rem in the broad sense; that this quality may arise from considerations of political necessity and expediency without reference to the manner of beginning the action and equally without reference to the conclusive effect of the judgment. In the nature of things, in the shifting of criteria, the State courts must lead the way, and principles may be established in the State courts for many years before receiving the approval or disapproval of the Federal Supreme Court. In order to force all cases of valid service by substitution or construction within the classification of proceedings in rem, the conception of res has been widened to take in intangible things. We shall see the status of parties treated as a res, ${ }^{6}$ though in such cases seizure is of course impossible. Seizure is dispensed with also in cases where to talk of a pre-existing lien would seem a mere straining of language. Thus proceedings for the probate of a will have been held in rem as binding upon constructive service. "The decree of the court admitting the will to probate," it has been said. "is in the nature of a judgment in rem which establishes the will against all the world."

6 Sec infra, p. 122.

7 Bonnemort $r$. Fill. 16i Mass. 33s. See also Matter of Young, 123 N. Car. 358, and 22 Am. and Eng. Enerce. of Law (2d ed.) 112. 
A recent case in the United States Supreme Court, where a grant of letters of administration was treatChapter III. ed in effect as a proceeding in rem, illustrates the same tendency.s

In short, it would seem that any proceeding is in rem for the purpose of jurisdiction, which the po- fected, the litical exigencies of the State, that is public policy, require should be effective upon service by publication or constructive service. In upholding the provision of the Massachusetts "Torrens Act," which made the registration of title conclusive as against every one, without personal service of citation, Chief Justice Holmes, in a passage which represents his own views only, said: "If, on the other hand, the object is to bar indifferently all who might be minded to make an objection of any sort against the right sought to be established, and if any one in the world has a right to be heard on the strength of alleging facts, which, if true, show an inconsistent interest, the proceeding is in rem. 2 Freeman Judgm. (4th ed.) 606. All proceedings, like all rights, are really against persons. Whether they are proceedings or rights in rem depends on the number of persons affected." ${ }^{9}$ This is surely

8 Cunnius $v$. Reading School Dist., 198 U. S. 458. See supra, p. 88.

9 Tyler $v$. Judges, 175 Mass. 71. This case went to the United States Supreme Court, but the interesting question involved was not determined, the case being dismissed on the technical ground that the appellant was not a party and the point a mere moot point. The validity of the act would seem to follow from the Supreme Court cases cited above. Acts of this character have been upheld also in Minnesota, Dewey $v$. Kimball, 89 Minn. 454; aud in Illinois, People $v$. Simon, 176 Ill. 165. In Ohio such an act was held not to afford due process of law. State $v$. Guilbert, 56 Ohio St. 575. See Torrens Acts, 28 Am. and Eng. Encyc. of Law (2d ed.) 25l; Leigh $v$. Green, 193 U. S. 79, 92. 
Chapter sound sense and seems to be warranted by the trend
III.

III. of the modern cases. But it is not alone in cases where the judgment is conclusive against the world that the conception of proceedings in rem needs extension. In the recent case of Cunnius $v$. Reading School Dist., 1 the power of a State to acquire jurisdiction over the estates of absentees by constructive service is upheld. The court does not classify the proceeding as in rem or in personam, but it proceeds on the broad ground that the property dealt with is subject to the burdens and obligations of property generally in the State, and that a statute authorizing the procedure is within the police powers of the State and necessary for the well-being of society.

Situs of Personal and Intangible Property as

Affecting Jurisdiction.

Mobilia scquntur personam.

Tangible personal property.

When a proceeding in rem is brought to subject to particular claims personal property and intangible things, an antecedent difficulty arises in determining whether the res is within the limits of the State. Personal property has in general no locality, and the law of the orner's domicil governs the validity of transfers and alienations thereof, according to the maxim. mobitia sequuntur personam, unless, says Mr. Justice Story, " there is some positive or customary law of the country where it is found to the contrary.',

The exception is a large one and removes a number of proceedings from the operation of the rule.

1198 U. S. 458.

2 Black $v$. Zacharie, 3 How. (U. S.) 514. 
According as personal property is a tangible thing, or a mere chose in action, different views as to its

situs may be entertained. Where personalty consists of tangible objects, the laws of the State where it is actually found determine the validity of a seizure and sale under attachment or garnishment rather than the law of the State of the owner's domicil. ${ }^{3}$ The law of the State of the actual situs of tangible personal property governs likewise its liability to taxation, for the power of a State to separate personal property from its owner and give it a situs for taxation is indisputable. ${ }^{4}$

When personal property is intangible, a mere chose in action, the question of its situs is still more obscure. Here the legal fiction mobilia sequuntur Intangible
personalty - the maxim applied.

personam seems the only possible guiding principle, and accordingly in a famous case, State Tax on Foreign Held Bonds, ${ }^{5}$ it was, in the opinion pronounced for the majority of the court, raised as regards the right of taxation to the position of a principle of law. The case actually determined only that a State law imposing a tax on the bonds of a domestic corporation, secured by a mortgage on real property belonging to the corporation in the State, and authorizing the corporation to deduct the amount of the tax from the interest due on the bonds, was as to nonresidents a law impairing the

3 Green $v$. Van Buskirk, 5 Wall. (U. S.) 307 .

4 Tappan $v$. Merchants' Nat. Bank, 19 Wall. (U. S.) 490; Pullman's Car Co. $v$. Pennsylvania, 141 U. S. 22: New Orleans $v$. Stampel, 175 U. S. 319 ; Blackstone $v$. Miller, 188 U. S. 204; Carstairs $r$. Cochran, 193 U. S. 10; Old Dominion Steamship Co. $v$. Virginia, 198 U. S. 305; Union Refrigerator Transit Co. $v$. Kentucky, 199 U. S. 194.

515 Wall. (U. S.) 300. See further infra, p. 208. 

Chapter obligation of contracts. But the principle that debts
III.

generally could have no situs apart from the residence of the creditor was broadly announced, and seems to have been understood as the basis of the decision.

Principle of the

The principle, hotrever, could not be maintained maxim in its entirety. It was soon held that shares of stock in corporations might be separated from the person of the owner, given a situs where the corporation was, and taxed against nonresidents. ${ }^{6}$ The later cases lay stress on the fictitious character of the rule that the domicil of the owner is the situs of intangible personalty, and declare that the rule must give way whenever it conflicts with logic and the policy of the State. Thile the decision in State Tax on Foreign Held Bonds is followed when a tax on foreign held bonds is in question, s. it has "been cut down to its precise point by later cases.", 9 Bonds, the subject-matter of the case, have been distinguished as more than mere evidences of debt; for the debt upon such instruments is held to be inseparable from the paper which declares and constitutes it, and which, therefore, gives a physical situs to the property represented. ${ }^{1}$

- Tappan r. Merchants' Nat. Bank, 19 Wall. (U. S.) 490 ; State Railroad Tax Cases, 92 U. S. 607; Pullman's Palace Car Co. $v$. Pennsylvania, 141 C. S. 18; Corry r. Paltimore, I96 C. S. 460.

T State Railroad Tax Cases, 92 U. S. 607; Pullman's Palace Car Co. r. Pennylyania, 141 L. S. 22; New Orleans $r$. Stempel, 175 C. S. 320: Blackstone $r$. Miller, 189 L. S. 206 ; Assessors $v$. Comptoir Natirnal d'Escompte, 191 U. S. 388.

8 Murray $r$. Charleston, 96 C. S. 432.

9 Plackstone r. Miller, 18s L. S. 206.

1 Blackstone $r$. Miller, 1 s C. S. 206. See also Bacon v. Hooker, 17\% Mass. 335: 2 Ames Cas. Bille \& Notes, si2 rt srq.

In New Orleans $r$. Stempel, 175 U. S. 320, the ease of State 
With respect to matters other than taxation, the situs of debts may be fixed at the residence of the debtor, and the State where the debtor is domiciled may, in the interest of the home creditors, control Chapter III. the legal fiction that the situs of the debt is the domicil of the creditor, since it rests on comity merely." Thus for the purpose of succession and distribution, all simple contract debts have their situs and are assets at the domicil of the debtor; ${ }^{3}$ and a debt evidenced by a negotiable security is in this respect a simple contract debt, without regard to the place where the instrument is found. ${ }^{4}$ But the situs of debts by record or specialty is ascertained for purposes of administration by the physical situs of the writing which evidences them. ${ }^{5}$ Again, under garnishment statutes, the State wherein the debtor resides may be made the situs of the debt, so that a garnishment there is due process of law, and it would seem hard to imagine any other rule which would not render such statutes a mere nullity as to nonresident creditors. ${ }^{6}$

Franchises granted by a State have their situs $\begin{gathered}\text { Fran. } \\ \text { chises. }\end{gathered}$ for purposes of taxation within the State which grants them, and the act of another State in taxing

Tax on Foreign Held Bonds is said to establish only that the fiction of law, declaring the situs of bonds and mortgages to be that of the domicil of the owner, can not be disturbed by the legislature "when in fact they are in his possession."

2 Wilkins $v$. Ellett, 9 Wall. (U. S.) 740; Chicago, etc., R. Co.

v. Sturm, 174 U. S. 710.

3 Wilkins $v$. Ellett, 9 Wall. (U. S.) 740, 108 U. S. 256; Wyman

v. Halstead, 109 U. S. 656.

4 Wyman $v$. Halstead, 109 U. S. 656.

5 Beers $v$. Shannon, 73 N. Y. 292.

6 Chicago, etc., R. Co. $v$. Sturm, 174 U. S. 710; King $v$. Cross, 175 U. S. 396. 

Chapter such franchises deprives their owners of property
III. without due process of law. ${ }^{7}$

\section{DIVORCE DECREES.}

State may determine citizens' domicil.

Jurisdic. tion de. riends on domicil.
There is a class of cases which are neither strictly in personam nor in rem. Such are suits for divorce, that is, suits to determine the status toward one another of the parties to a marriage. The jurisdiction in these cases depends upon the domicil of one or both parties, for it is said to be an inalienable right of the State in the exercise of its sovereign power to determine the status of its own domiciled subjects and citizens. ${ }^{\mathrm{s}}$

When neither party has acquired a bona fide domicil in the State wherein the decree of divorce is pronounced (a question which is not to be decided only by the local laws of that State), the decree is not binding in any other State, nor is it within the full faith and credit clause of the United States Constitution. ${ }^{9}$ And when a divorce has been granted in one State on a merely colorable domicil, obtained for the special purpose of a divorce, in fraud of the laws of the State of the real domicil, it is granted withont jurisiliction and may be impeached collaterally in the State of the real domicil or in any other State. ${ }^{1}$ When the State granting the divorce is, however, the domicil of both parties, the decree

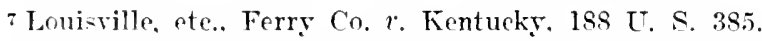

8 Dition $r$. Ditson. 4 R. I. 106, quoted in Atlerton $r$. Atherton, 181 U. S. 166. See also Pennoyer $v$. Neff, 95 U. S. 722. 734.

9 Bell $v$. Bell, 181 U. S. 175; Streitwolf $v$. Streitwolf. 181 U. S. 179 ; Winston $v$. Winston. 189 L. S. 507; Manning $r$. Spurek. 199 IIl. 450 .

1 Andrews 1. Andrews, 189 U. S. 14. See also Barher $r$. Barber, 21 How. (U. S.) 588; Wallace $x$. Wallace, 62 N. J. Eq. 509. 

made after due service of process is valid every- Chapter where, being within the protection of the full faith and credit clause of the Constitution, 2 and the same rule obtains where one of the parties, though not personally served with process within the State, has voluntarily appeared. ${ }^{3}$

But great difficulty and much difference of opinSeparate of parties.

ion exist where the real or apparent domicils of the husband and wife are in different States, and a decree of divorce has been rendered after constructive service only, without an appearance by the nonresident. A wife acquires a domicil apart from her husband through his wrong doing, as where she is forced to leave their common matrimonial domicil by his conduct, ${ }^{4}$ or when he deserts her, leaving her in the common matrimonial domicil ; ${ }^{5}$ but a wife living apart from her husband without sufficient cause retains the domicil of the husband and can acquire no new domicil. ${ }^{6}$

The question of the ralidity of a decree of divorce under such circumstances involves the nature of the suit as partaking of the qualities of a proceeding in rem or in personam. Marriage possesses at once the qualities of a civil contract and a status. It has its foundation and origin in contract, but the contract results in a status which is beyond the

2 Atherton $v$. Atherton, 181 U. S. 155.

3 Cheever $v$. Wilson, 9 Wall. (U. S.) 108: Lỵde $v$. Lynde, 181 U. S. 183.

4 Hunt $v$. Hunt, 72 N. Y. 218 ; Cheever $v$. Wilson, 9 Wall. (U. S.) $123,124$.

5 Barber $v$. Barber, 21 How. (U. S.) 582.

${ }^{6}$ Cheely $v$. Clayton, 110 U. S. 705 ; Atherton $v$. Atherton, $18 \mathrm{l}$ U. S. 164 . 
potrer of the parties.' Some courts, looking en-

tirely at the contract elements of marriage and ignoring or losing sight of its other elements, proceed on the theory that a decree of divorce pronounced in the State of the domicil of one of the parties is essentially a decree in personam and that, while valid within the State where pronounced, it is not valid outside that State in the absence of personal service or voluntary appearance on the part of the defendant. As a consequence, $A$, the resident of the decreeing State, is free from the matrimonial tie, while $B$, the nonresident, is still bound by it. ${ }^{9}$

111 results.

The objection to treating decrees of divorce as of no further effect than judgments in personam is that this treatment creates a state of confusion in the relations of the parties, which is opposed to public policy. The results are well shown in a recent New Jersey case: "The matrimonial relation of the husband and wife is terminated in the State in which [the decree] is rendered. Within the boundaries of that State a marriage afterward contracted by either of the parties with a third person is entirely valid. So, too, sexual relations between the former husband and wife within that jurisdiction subsequent to the entry of the decree are illicit, unless sanctioned by a new marriage. But if the decree is without extraterritorial force, the entire

7 Maynard $v$. Hill, 125 C. S. 210; Andrews $v$. Andrews, 188 U. S. 30; Ditson r. Ditson, 4 R. I. 101 .

o People r. Baker, 76 X. Y. 78, 32 Am. Rep. 274; Jones r. Jones, 108 N. Y. 415, 2 Am. St. Rep. 447; Harris $v$. Harris, 115 N. Car. 587, $44 \mathrm{Am}$. St. Rep. 471; MeCreery $v$. Davis, $44 \mathrm{~S}$. Car. 195.

1 Felt $r$. Felt. 59 N. J. Eq. 607, $83 \mathrm{Am}$. St. Rep. 612, affirming 57 N. J. Eq. 101. See also Dunlam $v$. Dunham, 162 1ll. 604, 607. 
status of both parties is reversed as soon as they pass beyond the limits of that State. A subsequent marriage to a third person within that State then becomes roid, and the relations of the parties to it become adulterous, while sexual relations between the parties to the decree, which are meretricious if indulged in within that State, become matrimonial again when indulged in without its borders. A condition of the law which makes the intercourse of a man and woman either legitimate or adulterous as they happen to be within the limits of one State or another, is not to be tolerated any further than is plainly required by public policy." A husband without a wife or a wife without a husband is, says the Federal Supreme Court, a state of things "unknown to the law." 2

Other courts regard the status of the parties as the actual subject-matter or res in dispute, and the Divorce decrees treated as suit for divorce as essentially a proceeding in rem or quasi in rem. ${ }^{3}$ This view flows from the necessity of recognizing the extraterritoriality of divorce decrees, on some ground harmonizing with general principles. But the extraterritoriality of such de-

2 Atherton $v$. Atherton, 181 U. S. 162.

${ }^{3}$ Dunham $r$. Dunham, 162 111. 605, 610; 2 Bishop Marriage, Div. \& Sep. 23 ; Freeman on Judgments, § 606 ; Black on Judgments, § \$22.

"To this familiar class of subjects [proceedings in rem] has, by a rather' artificial process of reasoning. been added the 'marriage state.' This has been done upon the idea that it constitutes a distinct 'matter,' and it is accorded a situs as an incident to the domicil of one or both of the spouses within the territorial jurisdiction. Its foundation is a domicil with residence. This result has been reached with much difficulty and not without strong protest." Wallace $r$. Wallace, 62 X. J. Eq. 514. per Pitner. T. C. See also Coddington $v$. Coddington. 20 N. J. Eq. 263; Ditson $v$. Ditson, 4 R. I. 87 . 

Chapter crees can extend only to the dissolution of the mar-
III.

riage status and can not annex to the judgment the incidents of a judgment in personam, such as the payment of alimony, unless indeed alimony is decreed after a voluntary appearance by the nonresident party.j

Tecisions in Federal surreme

Surprisingly few cases dealing with this quesCourt. tion have been before the United States Supreme Court. In Barber $x$. Barber, the decree enforced was rendered when the parties were both residents of New York. In Cheever v. Wilson, the defendant while not a resident of Indiana, where the wife seeured the divorce, made a voluntary appearance. In Cheely 2 . Chuyton, a divorce was held null because the court had never obtained jurisdiction in accordance with the local laws, but it was declared that "the courts of the State of the domicil of the parties doubtless have jurisdiction to decree a divorce, in accordance with its laws. for ans cause allowed by those laws, without regard to the place of the marriage, or to that of the commission of the offense for which the divorce is granted; and a divorce so obtained is ralid everywhere." This was in accord with the dictum in Pennoyer $v$. Neff, when after explaining the rules as to the validity of sister; State judgments in personam and in rem, the court said: "To prevent any misapplication of the views expressed in this opinion, it is proper to observe that we do not mean to assert, by anything that we have

4 Felt $r$. Felt. 57 N. J. Eq. 105; Rigney $v$. Rigney, 127 N. Y. 408.

: Jỵnde $r$. Lynde. 181 C. S. 183.

. 21 How. (I'. S.) 582 .

79 Wall. (L. S.) 108.

.110 L. S. 701. 
said, that a State may not authorize proceedings to determine the status of one of its citizens toward a nonresident, which would be binding within the State, though made without serrice of process or personal notice to the nonresident. . . . One of the parties guilty of acts for which, by the law of the State, a dissolution [of the marriage relations] may be granted, may have removed to a State where no dissolution is permitted. The complaining party would, therefore, fail if a divorce were sought in the State of the defendant; and if application could not be made to the tribunals of the complainant's domicil in such case, and proceedings be there instituted without personal service of process, or personal notice to the offending party, the injured citizen mould be without redress.", 9

We have not yet reached a decision that a decree granted on constructive notice without the State is valid as a decree in rem. ${ }^{9 *}$ That question seemed to Decree ing on con structive be presented in Atherton $v$. Atherton, decided in 1901. ${ }^{1}$ Here a woman resident in New York married a resident of Kentucky and the pair acquired a matrimonial domicil at the husband's home in Kentucky. Thereafter the wife left her husband and returned to New York, and after the lapse of a sufficient time, according to the laws of Kentucky, he brought suit for a divorce upon the ground of desertion. The statutes of Kentucky provide that in such cases the plaintiff is required to file an affidavit stating the place of the defendant's residence and his or her post office, whereupon the clerk en-

$9 *$ See reference to Haddock $v$. Haddock in the preface. 

Chapter ters an order marning the defendant to defend the
III. action within sixty days and at the same time appoints an attorney for such defendant "whose duty it shall be to make diligent efforts to inform the defendant by mail concerning the pendency and nature of the action"' and report the results to the court. Constructive notice is presumed on the thirtieth day after the entry of the order and the appointment of the attorney. All formalities having been duly observed, a decree of divorce was entered for the husband. Cpon a subsequent action by the wife for a divorce in New York on the ground of cruelty, the courts of that State held the Kentucky decree not binding in New York and granted a dirorce to the wife, holding that she had acquired a separate domicil in New York by reason of her husband's cruelty, so that the courts of New York had jurisdiction. ${ }^{2}$ This judgment was reversed by the United States Supreme Court, which held that the Kentucky court, by the constructive service, acquired jurisdiction of the case, and that the jurgment was within the protection of the full faith and credit clause of the Constitution and valid in all the States. But the court carefully limited the decision to the vers point inrolved. It was said: "This case does not involve the validity of a dirorce granted on constructive service, by the court of a state in which only one of the parties ever had a domicil; nor the question to what extent the good faith of the domicil may be afterwards inquired into. In this case, the divorce in Kentucky was hy the court of the State which had alwars been the undoubted domicil of the hus- 
band and which was the only matrimonial domicil of the husband and wife. The single question to Chapter III. be decided is the validity of that divorce, granted after such notice had been given as was required by the statutes of Kentucky." 3 Of the validity of the constructive notice required by the laws of Kentucky, it is said:" "We are of opinion that the undisputed facts show that such efforts were required by the statutes of Kentucky and were actually made, to give the wife actual notice of the suit in Kentucky, as to make the decree of the court there granting a divorce upon the ground that she had abandoned her husband, as binding on her as if she had been served with notice in Kentucky, or had voluntarily appeared in the suit. Binding her to that full extent, it established, beyond contradiction, that she had abandoned her husband, and precludes her from asserting that she left him on account of his crue! treatment"- a fact which she asserted by her suit in New York. The constructive service to the nonresident appears to arail notliing as bringing the defendant into court, the statutory provision being merely notice prescribed in the interests of fairness and to rebut the idea that the proceedings were arbitrary; in a word, it brings the res into court and not the defendant. ${ }^{5}$

These points are necessarily settled in Atherton $v$. Atherton: that the nature of a divorce proceedPoints ing is such that it must bind both parties equally, "a husband without a wife or a wife without a hus-

3181 U. S. 171.

4181 U. S. 172.

5 De La Montanya $r$. De La Montanya, 112 Cal. 115,53 Am. St. Rep. 173; Doughty $v$. Doughty, 28 N. J. Eq. 586. See supra, p. 92. 
Chapter band" being unthinkable; that jurisdiction to pro-

III. nounce such decrees depends on the domicil of the parties; that jurisdiction certainly exists in the State where the matrimonial domicil was, unless one party has bona fide acquired a new domicil for cause; that a decree thus pronounced by a State having jurisdiction is within the full faith and credit clause of the Federal Constitution and valid in every State; that jurisdiction does not require personal service in the State or a voluntary appearance; that constructive serrice without the State in conformity with its laws, when these provide for such steps as may be presumed to give the absent party actual notice of the suit, is due process of law. Further than this the Supreme Court has not yet gone.

\section{BANKRUPT AND INSOLVENT LATS.}

Double character of decrees in bank. ruptcy.
Proceedings under bankrupt and insolvent laws likewise exhibit a double nature. They are proceedings in rem so far as concerns the status of the debtor, the title to his property within the State, and the legal incidents necessary to the adjudication of status, ${ }^{6}$ but so far as the operation of the adjudication as a discharge is concerned, its validity, according to the view which may be looked upon as settled in the United States, is dependent on the principles governing judgments in personam. ${ }^{7}$

; Freeman on Judgments, 4th ed. 607; Hanover Nat. Bank $v$. Moyses, 180 U. S. 181, 192.

i Balkwin r. Hale, 1 Wall. (U. S.) 232; Hawley $v$. Hunt, 27 Iowa 307 ; Main $r$. Messner, 17 Oregon 78.

It has been strongly contended that in effeeting a discharge the adjudication operates on the status of the bankrupt, that such status is a res within the jurisdiction of the State of the debtor's domicil, and that the determination of the courts there should be binding 
An adjudication of bankruptcy together with the public formalities of notice required by the act ${ }^{8}$ determines conclusively the status of the debtor as a bankrupt and the facts upon which that status is based, for instance, that he has been guilty of a particular act of bankruptey, ${ }^{9}$ and it operates on the property of the debtor within the State to bring it under the control of the court or to transfer title to the assignee, subject of course to existing priorities. ${ }^{1}$ But a bankrupt or insolvent law has of itself no extraterritorial force, and it is only upon the principle of comity that such an adjudication can be held operative on persons or property not within the State rendering the judgment or decree. The principle of comity has not in the United States been extended to validate the title of an assignee in invitum under a foreign bankrupt law, except when the claim of such assignee was not opposed to the claims of resident citizens or creditors pursuing their remedies by attachment or otherwise. ${ }^{2}$ Nor

on courts everywhere. See Discharge in Insolvency and Its Effect on Non-Residents, by Hollis R. Bailey, 6 Harv. L. Rev. 349.

8 Shawhan $v$. Wherritt, 7 How. (U. S.) 643; Hanover Nat. Bank v. Moyses, 186 U. S. 181, 192.

9 Brown v. Smart, 69 Md. 331, affirmed 145 U. S. 454.

1 Crapo v. Kelly, 16 Wall. (U. S.) 610; Geilinger v. Philippi, 133 U. S. 246.

2 Security Trust Co. v. Dodd, 173 U. S. 629 ; Receiver of State Bank $v$. Plainfield First Nat. Bank, 34 N. J. Eq. 450; Matter of Waite, 99 N. Y. 433. See also Crapo v. Kelly, 16 Wall. (U. S.) 622 .

A voluntary assignment for the benefit of creditors receives in this particular a more liberal construction, and "if valid where made, onght generally to be valid everywhere, being the exercise of the personal right of the owner to dispose of his own." Cole $v$. Cunningham, 133 U. S. 129; Security Trust Co. $v$. Dodd, 173 U. S. 628 . 
Chapter has it been recognized so as to give validity to a discharge under the laws of one State as against the debt of a nonresident creditor, and it makes no difference that the debt was contracted or to be performed in the State granting the discharge, ${ }^{3}$ or that suit is brought, if the plaintiff is a nonresident creditor, in the courts of that State. ${ }^{4}$ In other words, so far as the adjudication operates as a discharge, jurisdiction depends on the citizenship of the parties and not on the place where the contract was made or where it is to be performed. ${ }^{5}$

Summary

The effect of bankrupt or insolvent laws passed preme Court. by the several States has been stated by the Federal Supreme Court as follows: "State legislatures may pass insolvent laws, provided there be no Act of Congress establishing a uniform system of bankruptey conflicting with their provisions, and provided that the law itself be so framed that it does not impair the obligation of contracts. Certificates of discharge, however, granted under such a law can

3 Baldwin $v$. Hale, 1 Wall. (U. S.) 223, disapproving Scribner ๘. Fisher, 2 Gray (Mass.) 43.

4 In Main $v$. Messner, 17 Oregon 78 , it is held on principles which seem to follow irresistibly from Baldwin $v$. Hale, 1 Wall. (L. S.) 2:32, and other decisions of the Federal Supreme Court, that a discharge under a domestic bankrupt law is no defense even in the courts of the State granting the discharge against the claim of a non-resident and non-assenting ereditor.

5 Hawley $x$. Hunt, 27 Iowa 303, an admirable opinion by Chief Justice Dillon.

The English rule is otherwise. In Potter v. Brown. 5 East 124, Lord Ellenborongh said: "The rule was well laid down by Lord Mansfiekl in Ballantine $r$. Colding [Cook, Bankrupt Law, 8th ed. 487] that what is a discharge of a debt in the country where it was contracted is a discharge of it everswhere." This principle has been followed consistently in later eases. Ellis $v$. MHenrr. L. R. 6 C. P. 234; Gibbs r. La Société Industrielle, etc., 25 Q. B. D. 399 ; Dicey, Confl. Laws 449. 
not be pleaded in bar of an action brought by a citi. Chapter zen of another State in the courts of the United III. States, or of any other State than that where the discharge was obtained unless it appear that the plaintiff proved his debt against the defendant's estate in insolvency, or in some manner became a party to the proceedings. Insolvent laws of one State can not discharge the contracts of citizens of other States; because such laws have no extraterritorial operation, and consequently the tribunal sitting under them, unless in cases where a citizen of such other State voluntarily becomes a party to the proceedings, has no jurisdiction of the case." ${ }_{6}$

\section{JURISDICTION AS TO CRIMES AND PENALTIES.}

The common law considers crimes as altogether Crime is local, and cognizable and punishable exclusively in the country where they are committed. ${ }^{7}$ This principle may be considered from two points of view: first, no state, as a general rule, extends the obligations and penalties of its own criminal laws to acts committed besond its territorial limits; and, second, the courts of no state execute the criminal or penal laws of another.

6 Gilman $v$. Lockwood, 4 Wall. (U. S.) 409. See also Sturges $\boldsymbol{v}$. Crowninshield, 4 Wheat. (U. S.) 187; Ogden $v$. Saunders, 12 Wheat. (U. S.) 213; Cook $v$. Moffat, 5 How. (U. S.) 310 ; Denny v. Bennett, 128 U. S. 497 ; Cole $v$. Cunningham, 133 U. S. 114 ; Brown $v$. Smart, 145 U. S. 454.

"An assignment under the laws of another State of the Union stands upon the same ground as one made under the laws of a foreign country; for the States are in this respect independent of one another, and subject to no common control so long as there is no national bankrupt law." Taylor $v$. Columbian Ins. Co., 14 Allen (Mass.) 353 .

i Story, Confl. Laws 620. 
The first branch of this rule requires qualificaIII. tion and explanation. In England it seems not $\underset{\text { Exceptions }}{\text { piracy. }}$ to be recognized as to English subjects, and Chief Justice Cockburn laid down that British subjects in all parts of the world are subject to the criminal laws of England. ${ }^{8}$ In the United States, its recognition is subject to exceptions growing out of the doctrines of international law, and to modifications under our system of government and our common and statute law. An exception founded on the principles of international law exists with respect to piracy on the high seas. This offense, without regard to the nationality of the vessels which are the object of the outrage, is regarded as a crime against the law of nations, and the courts of all civilized countries will inflict punishment on the guilty persons, whether they be citizens or foreigners. ${ }^{9}$

Federal jurisdic tion within Statcs.

The dual nature of our government may make acts committed within the territorial limits of a State cognizable and punishable in the federal courts either exclusively or concurrently with the State courts. Exclusive jurisdiction may arise either beeause the crime was committed at a place where the United States has exclusive jurisdiction, as on lands acquired from the States for forts or arsenals, ${ }^{1}$ or because the crime is one exclusively against the United States. But the same act may offend against both the United States and the State. "While of-

8 In re Tirnan, 5 B. \& S. 679. 117 E. C. L. 679.

$\because$ U. S. $r$. Klintock, 5 Whent. (U. S.) 144: I'. S. $v$. Smith. 5 Wheat. ([..S.) 353: L. S. $v$. Furlong, 5 Wheat. (L. S.) $1 S 4$.

$1 \mathrm{Y}$. S. $r$. Ward, Woolw. (C. S.) 17, holding also that an Indian reservition is not within the sole and exclusive jurisdiction of the Cnitel states, unless by express proviso. 

fenses exclusively against the States are exclusively Chapter cognizable in the State courts, and offenses exclusively against the United States are exclusively cognizable in the federal courts, it is also settled that the same act or series of acts may constitute an offense equally against the United States and the State, subjecting the guilty party to punishment under the laws of each government.", ${ }_{2}$ Exclusive jurisdiction over acts done by the officers of the United States in the performance of their official duties has been held to lie in the federal courts. ${ }^{3}$

Seeming exceptions arise also at common law and under statutes from the nature and effects of crime. The power to declare that certain acts are Exceptions giving. tion to criminal, to define crime, resides in the State, and though a criminal act may be committed in one State, yet its consequences may reach into another, and by common law or statute may be punishable in the State where its effects are felt, without regard to the position of the criminal. ${ }^{4}$ Or, when committed elsewhere, its criminal character may be rested upon the ground that it is an offense against the sovereignty of the State or the rights of its citizens. $^{5}$ The dignity and sovereignty of the State are

2 Pettibone $v$. U. S., 148 U. S. 197 , eiting Cross $v$. North Carolina, 132 U. S. 131.

A change in the phraseology of the United States statutes dealing with the criminal jurisdiction of the federal courts is discussed and its effects considered in Sexton $v$. California, 189 U. S. 319.

3 Neagle, Petitioner, 135 U. S. 1.

4 As by death there from a wound given elsewhere. Com. $v$. Macloon, 101 Mass. 1, 100 Am. Dec. 89: Tyler $v$. People, 8 Mich. 320; State $v$. Caldwell, $115 \mathrm{~N}$. Car. 79t. See Simpson $v$. State, 92 Ga. 41, 44 Am. St. Rep. 75 : State $v$. Morrow, 40 S. Car. 221.

5 As forgery in another State of titles to land within the State of the forum. Hanks $v$. State, 13 Tex. App. 289. See Extraterri- 

Chapter directly involved when residents therein leave the
III. State for the express purpose of avoiding its criminal laws as to some act affecting their continued status, commit the act elsewhere, and return within the State. In such a case, they may be punished as though the forbidden act had been committed within the State. ${ }^{6}$ Again, a complete criminal act may consist of several distinct and separable acts or elements, and the laws of a State may recognize the commission of certain of the constituent acts within the State as constituting the commission of the crime therein so as to give its courts jurisdiction. ${ }^{7}$ In the absence of elements such as these, the porrer of a State to enact statutes punishing extraterritorial crime does not exist, ${ }^{\mathrm{s}}$ and in a State whose constitution guarantees a trial by a jury of the vicinage, the attempt to inflict punishment for acts committed elsewhere has been held to be a denial of due process of law. ${ }^{3}$

Foreign penal laws not enforced.
Interstate extradi. tion.
The second branch of the rule, that no State mill execute the criminal or penal laws of another, while universal in its application by American courts, inrolves not a question of constitutional law but of international comity. ${ }^{1}$

torinl Crime, by Dr. Francis Wharton, 4 Southern Law Rev. N. S. 690.

${ }^{6}$ Ex $p$. Kinney, 3 Hughes (U. S.) 9. See also State $v$. Cutshall, 110 N. Car. 552.

7 People $r$. Burke, 11 Wend. (N. Y.) 129; State $v$. Caldwell, 115 N. Car. $794 ;$ Ex $p$. McNeeley, 36 W. Va. 84.

\& See People r. Merrill, (Supm. Ct. Gen. T.) 2 Park, Crim. (N. Y.) 590 , recersed on other grounds 14 N. Y. 74.

9 State $r$. Cutshall, $110 \mathrm{~N}$. Car. 545.

1 Wisconsin $r$. Peliean Ins. Co., 127 U. S. 268; Huntington $v$. Attrill, 146 U. S. 657 . 
The provision in the United States Constitution Chapter for the extradition of fugitives from the justice of one III. State who take refuge in another State practically involves considerations of interstate comity alone. Though the duty imposed on the executive of the State where the criminal has taken refuge is merely a ministerial one, the United States has no authority under the Constitution or Acts of Congress to compel compliance by an executive who refuses surrender. ${ }^{2}$ When the presence of a fugitive from justice in a sister State has been secured by violence, there is no constitutional provision to which the accused can appeal to prevent his trial on the criminal charge in the State to which he has been abducted. ${ }^{3}$ Nor when he has been rightfully brought within a State on one charge is there anything to prevent his trial on other criminal charges withont first giving him an opportunity to return to the State from which he was extradited. ${ }^{*}$

2 Kentucky $v$. Dennison, 24 How. (ए. S.) 66.

3 Ker $v$. Illinois, 119 U. S. 436 ; Mahon $v$. Justice, 127 U. S. 700.

4 Lascelles $v$. Georgia, 148 U. S. 537. 


\title{
CHAPTER IV. \\ THE RIGHTS PROTECTED BY DUE PROCESS OF LAW.
}

\author{
LIFE, LIBERTY, AND PROPERTY.
}

Chapter

IV.

So-called "inalienable rights."

THE United States Constitution in both clauses where "due process of law" is mentioned, provides that the protection of due process shall embrace "life, liberty, and property." ${ }_{1}$ In the Declaration of Independence it is declared as selfevident truth that all men "are endowed by their Creator with certain inalienable rights, and that among these are life, liberty, and the pursuit of happiness." Mr. Justice Field has remarked that the "Fourteenth Amendment was intended to give practical effect to the Declaration of 1776 of inalienable rights, rights which are the gift of the Creator, which the law does not confer, but only recognizes," ${ }^{2}$ and

1 This trinity of rights ean not be connected with the famous enumeration of the Great Charters of 2 and 9 Henry III, de libero tenemento suo, vel libertatibus, vel liberis consuetudinibus. These words in the charter referred to property rights alone, while life and liberty were the object of other provisions in the same chapter. Even as an enumeration of property rights, and though disseisictur be taken in its early general and not in its late technical sense (Pollock and Wright on Possession, 47-49) any list framed in 1217 must have been thoroughly archaie. As to the meaning of the phrase in Magna Carta, see McKechnie, Magna Carta, 445, and the traditional interpretation of Lord Coke, 2 Inst. 47.

2 Dissenting opinion in Slaughter-House Cases, 16 Wall. (U. S.) 36. See the remarks of the same judge. coneurring, in Butcher's Union, etc., Co. $v$. Crescent City Live Stock Landing, ete., Co., 111 U. S. 746 . 
this remark would seem to be equally applicable to Chapter the same words in the Fifth Amendment.

The conservative, practical temper of judges nurtured in the reverence for precedent of the common law, has saved our jurisprudence from decisions formed on speculative or deductive reasoning from this enumeration of "inalienable rights." 3 "Life, liberty, and property" have, indeed, been considered to embrace these inalienable rights in their entirety, and to comprehend every right to which a member of the body politic is entitled under the law; for, as it has been said, the enumeration in the constitutional clause is representative merely. ${ }^{4}$ But in practice this principle of representative interpretation has not been necessary, and because of the wide meaning given to the component members of the phrase, the courts have felt at liberty to deal with each case as it arose on its merits, with reference to applicable precedents. "By the term 'life,' as here used," said Mr. Justice Field, "something Life. more is meant than mere animal existence. The inhibition against its deprivation extends to all those limbs and faculties by which life is enjoyed. The provision equally prohibits the mutilation of the body by the amputation of an arm or leg, or the putting out of an eye, or the destruction of any other organ of the body through which the soul communicates with the outer world. The deprivation not only of life, but of whatever God has given to every one with life, for its growth and enjoyment, is prohibited by

3 See supra, p. 56.

4 State $v$. Julow, 129 Mo. 163. See also Cummings $v$. Missouri, 4 Tall. (U. S.) 277, a case decided, however, before the passage of the Fourteenth Amendment. 
Chapter the provision in question, if its efficacy be not frittered away by judicial decision." "s "The "liberty'

Liberty. mentioned in the Fourteenth Amendment," the Supreme Court has said, "means not only the right of the citizen to be free from the mere physical restraint of his person, as by incarceration, but the term is deemed to embrace the right of the citizen to be free in the enjorment of all his faculties; to be free to use them in all lawful ways; to live and work where he will; to earn his livelihood by any lawful calling; to pursue any livelihood or avocation; and for that purpose to enter into all contracts which may be proper, necessary, and essential to his carrying out to a successful conclusion the purposes above mentioned." " "Liberty," as here interpreted, protects a number of the rights embraced within the guar-

5 Mumn $r$. Illinois, 94 U. S. 113, dissenting opinion. Life within the constitutional guaranty "includes the right of the individual to his bodr in its completeness and without dismemberment." Bertholf $r$. O'Reille, 74 N. Y. 509, 523.

6 Allgever $r$. Louisiana, 165 U. S. 578. See also Matter of Jacobs, 95 N. Y. 99; People $r$. Marx, 99 N. Y. 377, and the dissenting opinion of Field, J., in Powell $v$. Pennsylvania, $127 \mathrm{U}$. S. 678.

Liberty may lawfully be curtailed to the point of endangering life itself. "He [a person or citizen] may be compelled," said the court in Jacohon r. Massachusetts, 197 U. S. 29, "by force if need be, against his will and without regard to his personal wishes or his pecuniary interests, or even his religious or political convictions, to take his place in the ranks of the army of his country and risk the chance of being shot down in its defense."

Historical arguments to show that the term "liberty" was used ly English lawyers and statesmen to refer mercly to personal liberty, and must therefore be understood in the Constitution in that sense, are given in an article on The Meaning of the Tcrm "Libcrty" in Fcderal and State Constitutions, by Mr. C. E. Shattuck, 4 IIarv. L. Rev. 365. quoted in 1 Thay. Cas. Const. Law, 644, note. The matter is settled, and happily settled, in favor of a wider construction. 
anty of "property," in the same provision. The Chapter latter term includes not the physical subject-matter" IV. of ownership, but the right of possession, dominion, and disposition over the subject-matter." "The right of property,' said the Supreme Court of Illi- Property. nois, "preserved by the Constitution, is the right not only to possess and enjoy it, but also to acquire it in any lawful mode, or by following any lawful industrial pursuit which the citizen, in the exercise of the liberty guaranteed, may choose to adopt. Labor is the primary foundation of all wealth. The property which each one has in his own labor is the common heritage. And, as an incident to the right to acquire other property, the liberty to enter into contracts by which labor may be employed in such way as the laborer shall deem most beneficial, and of others to employ such labor, is necessarily included in the constitutional guaranty.', s

The enjoyment by the individual even of life, liberty, and property is always subject to the sorSubject to paramount authority ereign needs of the state, acting for the common

7 "In a strict legal sense, land is not 'properț,' but the subject of property. The term 'property,' although in common parlance frequently applied to a tract of land or a chattel, in its legal signification 'means only the rights of the owner in relation to it.' 'It denotes a right . . . over a determinate thing.' 'Property is the right of any person to possess, use, enjoy, and dispose of a thing.' Seldon, J., in Wynehaner $v$. People, 13 N. Y. 37s-433; 1 Blackst. Com. 138; 2 Austin Jurisp., 3d ed., 817, 818." Eaton $v$. Boston, etc., R. Co., 51 N. H. 504.

8 Braceville Coal Co. v. People, 147 Ill. 66.

Mr. Justice Swayne, dissenting in Slaughter-House Cases, 16 Wall. (U. S.) 36, said: "Property is everything which has an exchangeable value, and the right of property includes the power to dispose of it according to the will of the owner. Labor is property, and as such merits protection. The right to make it available is next in importance to the rights of life and liberty." 
Chapter good of the whole people, and the state in the exertion of its sovereignty, through the police power, the power of eminent domain, and the taxing power, may "take" the rights of the citizen even in their most perfect forms. ${ }^{9} \quad$ They are not, therefore, in a strict sense "inalienable," nor was this constitutional clause intended to render them exempt from the control of the state acting in a legal manner, that is, according to "due process of law.", 1 The purpose of the provisions was to secure the life, liberty and property of the individual from the action of purely personal and arbitrary power, and to place them under the protection of "a government of laws and not of men.', 2

\section{VESTED RIGHTS AND DUE PROCESS OF LAW.}

Two definitions.

The rights which are thus within the protection of due process of law have been called "vested rights," and a vested right has been defined as a right vested in a citizen "to do certain actions or to

a See infra, p. 201.

In the Legal Tender Cases, 12 Wall. (U. S.) 547-551, the court said: "In a state of civil society, property of a citizen or subject is ownerslip, subject to the lawful demands of the sovereign."

1 "If it [the proposition that the legislature ought not to deprive parties of their vested rights] means that there are no cases in which the rights of parties are not to yield to questions of expediency, the proposition is manifestly false, and confliets with the practice of every legislature on earth. In every case, for example, in which a road or canal is run by authority of Parliament through the lands of private persons, the rights, or vested rights, of the private owners are practically abolished by the legislature. They are compelled to yield up a portion of their rights of exelusion, and to receive compensation agreeably to the provisions of the Act." 2 Austin's Jurisprudence, 5 th ed., 857 .

2 Yick Wo r. Hopkins, 118 U. S. 356, 370, quoting the last phrase from the Massachusetts Bill of Rights. 
possess certain things according to the law of the land." 3 Approached from another point of view,

a rested right is one which is complete and consummated, so that nothing remains to be done to fix the right of the individual to enjoy it." This conception is derived from real property law, as is shown by the use of definitions of vested estates to charactertize rested rights. Thus, in Pearsall v. Great Northern R. Co., the Supreme Court of the United States said: "A 'vested right' is defined by Fearne in his work upon Contingent Remainders, as ' an immediate, fixed right of present or future enjoyment;' ${ }^{6}$ and by Chancellor Kent as 'an immediate right of present enjoyment, or a present fixed right of future enjoyment." 7 It is said by Mr. Justice Cooley that "rights are vested, in contradistinction to being expectant or contingent. They are vested when the right to enjoyment, present or prospective, has become the property of some particular person or persons, as a present interest. They are expectant when they depend upon the continued existence

3 Calder $v$. Bull, 3 Dall. (U. S.) 386 , per Chase, J.

This definition has been repeated by Harrington, J., in Bailey v. Philadelphia, etc., R. Co., 4 Harr. (Del.) 389, 400, 444 Am. Dec. 593,602 , and by Duncan, J., in Eakin $v$. Raub, $12 \mathrm{~S}$. \& R. (Pa.) 330, 360. See also Martindale $v$. Moore, 3 Blackf. (Ind.) 282.

In Grinder $v$. Nelson, 9 Gill (Md.) 299, 309, 52 Am. Dec. 694, 701, vested rights are defined as rights to which a person may adhere and upon which he may insist without violating any principle of sound morality. As stated, this definition could never characterize any legal rights, but the idea seems to be the same as that given above.

4 Moore v. State, 43 N. J. L. 203, 243, 244, per Van Syckel, J., dissenting.

5161 U. S. 673.

6 Fearne, Cont. Rems. 1.

74 Kent Com. 202. 
Chapter of the present condition of things until the happenIV. ing of some future event. They are contingent when they are only to come into existence on an event or condition which may not happen or be performed until some other event may prevent their vesting.', 's

The definition of vested rights as those protected by the law of the land is merely an identical proposition and fails to give their characteristics. ${ }^{9}$ The other definitions give their vital characteristic, indeed, but seem to be either too wide, as including rights not protected by the Constitution ${ }^{1}$ or too narrow as confined to vested rights in property. ${ }^{2}$ Accepting the words, in accordance with convenience and settled usage, as synonymous with rights protected by the law of the land or due process of law, the essential qualities of a vested right are that it must be a fundamental right, which is concerned with substance as contrasted with mere form, ${ }^{3}$ and

8 Cooley, Const. Law, 332.

9 "When it is said that the legislature ought not to deprive persons of the 'rested rights,' all that is meant is this: that the rights styled 'vested' are sacred or inviolable, or are such as the parties ought not to be deprived of by the legislature. Like a thousand other propositions, which sonnd speciously to the ear, it is either purely identical and tells us nothing, or begs the question in issue." 2 Austin's Jurisp., 5th ed., 856-857. But, though th proposition may tell nothing, the term is useful as a counter of thought; and it tells us nothing, only if we are unable from investigation to find out the essential qualities of those rights with which the legislature ought not to interfere.

1 See Noore $v$. State, 43 N. J. L. 243.

2 It has been said that there is no such thing as a rested immunity or exemption, and that the term "rested rights" is confined to rights of property. Weed $v$. Binghamton, (Supu. Ct. Spee. T.) 26 Mise. (N. Y.) 208, 212. But a personal right, if suflieiently fundamental, as the right to a hearing, may surely be called rested.

3 See supra, p. 56. 
it must exist complete and perfect ${ }^{4}$ in a definite person, either over particular things (vested right Chapter IV. of property) ${ }^{5}$ or enforceable in favor of definite persons whenever in the future conditions already determined shall arise (vested personal rights).

Vested rights of whatever nature are open to attack and impairment through retrospective legisRetrospec-
tive laws. lation, if unrestrained. ${ }^{6}$ The term retrospective legislation is indeed but a description of legislation affecting vested rights, contingencies, and expectancies.

\section{VESTED RIGHTS AND OTHER CONSTITUTIONAL GUAR-}

ANTIES.

In order to obtain a just estimate of the protection afforded to vested rights by the due process clause in the Constitution, we must examine the relations of that clause to other specific constitutional provisions having for their object the security of individual rights against arbitrary action.

4 "Perfect right" is sometimes used in the sense of a right not dependent on the will of any other person. In this sense it is about equivalent to vested right in its wider meaning explained above. It is sometimes used as meaning a right to whose vindication the state lends its aid and assistance. Vattel, Law of Nations, Prelim., 17. This is true of every legal right, every right which properly comes within the field of law as distinguished from ethics and religion. Holland, Jurisp., p. 56.

5 In speaking of rested rights of property, Mr. Justice Chase, in Calder $v$. Bull, 3 Dall. (U. S.) 386, says: "If any one has a right to property, such a right is perfect and exclusive right; but no one can have such right, before lie has acquired a better right to the property than any other person in the world."

6 "Upon principle, every statute which takes away or impairs rested rights acquired under existing laws, or creates a new obligation. imposes a new duty. or attaches a new disability in respect to transactions or considerations already past, must be deemed 
Chapter

IY.

Constiun tional provisions.

Bills of at. tainder.

II'hat laws are $c x$ post fucto.

\section{Ex Post Facto Laws and Bills of Attainder.}

The Federal Constitution prohibits Congress from passing any bill of attainder or ex post facto law,,$\overline{\text { and }}$ the same prohibition with the additional inhibition of laws impairing the obligation of contracts exists with respect to State action. ${ }^{\mathrm{s}}$

The nature and history of bills of attainder have already been considered. ${ }^{9}$ They are legislative adjudications directed against the past acts of individuals, and are subject to all the objections to which $e x$ post facto laws are liable. In addition ther confuse the functions of the different departments of the government, and are wanting in the quality of generality which is essential to the conception of due process of law.

Ex post facto laws have been the subject of much discussion in the courts, and the meaning of the words as determined in the early case of Calder $v$. Bull ${ }^{1}$ has never been shaken. Ex post facto laws must be retrospective laws which concern criminal and penal matters and not civil rights; and every law is ex post facto which either imposes a punishment for an act which was not punishable at the time it was committed; or imposes a different or additional punishment to that then prescribed; or changes the rules of eridence so that less or other

retrospective: and this doctrine seems fully supported by authorities. Calder r. Pull, 3 Dall. (U.S.) 386 ; Dash $r$. Van Kleeck, 7 Joluns. (N. Y.) 477." Storr, J., in Socicty, etc., v. Wheeler, 2 Gall. (U. S.) 105.

7 Const. U. S., Art. I. $\$ 9, \Upsilon 3 ; 8$ Fed. Stat. Annot. 695.

8 const. U. S.. Art. I, $\S 10$, I 1; 8 Fed. Stat. Ammot. 713 .

'See supra, p. 64.

13 Dall. (U. S.) 386. 
testimony is required to convict than was then required; or in relation to the offense or its consequences alters the situation of the party to his disadvantage. ${ }^{2}$ If the effect of a law is to mitigate the crime or the punishment, it is not within the prohibition. ${ }^{3}$ The legislature may, therefore, remit a separable portion of the punishment prescribed by an existing law, ${ }^{4}$ and it has been said that if the new punishment differs in kind the law prescribing it is not ex post facto, if the change be of that nature which no sane person could by any possibility regard in any other light than that of mitigation. ${ }^{5}$ It is frequently said that laws preseribing different modes of procedure are not ex post facto, but this is so only when fundamental rights are not taken array by the change in procedure, and when the substantial protection with which the existing laws surround persons accused of crime are left intact after the change. ${ }^{6}$ In order to escape unconstitutionality,

a Calder $v$. Bull, 3 Dall. (U. S.) 3S6; Cummings $v$. Missouri, 4 Wall. (U. S.) 277 ; Ex p. Garland, 4 Wall. (U. S.) 333 ; Kring $v$. Missouri, 107 U. S. 221 ; Hopt $v$. Utah, 110 U. S. 574; Medley, Petitioner, 134 U. S. 160; Duncan $v$. Missouri, 152 U. S. 377; Thompson $v$. Utah, 170 U. S. 343 ; Thompson $v$. Missouri, 171 U. S. 380 ; Mallett $v$. North Carolina, 181 U. S. 589 ; U. S. v. Hall, 2 Wash. (U. S.) 366, 26 Fed. Cas. No. 15,285.

In Fletcher $v$. Peck, 6 Cranch (U. S.) 87, Chief Justice Marshall defines an ex post facto law as "one which renders an act punishable in a manner in which it was not punishable when it was committed." But the change may be in the way of mitigation.

${ }^{3}$ Calder $v$. Bull, 3 Dall. (U. S.) 386 ; Com. $v$. Wyman, 12 Cush. (Mass.) 237; People $v$. Hayes, 140 N. Y. 484.

4 Hartung $v$. People, 22 N. Y. 95.

5 People $v$. Hayes, 140 N. Y. 484. And see Com. $v$. Wyman, 12 Cush. (Mass.) 237, when the substitution of life imprisonment for the death penalty was held to be a mitigation.

6 Kring $v$. Missouri, 107 U. S. 221; Thompson $v$. Utah, 170 U. S. 343 ; Thompson $v$. Missouri, 171 U. S. 380. 
Chapter they must relate to modes of procedure only, in which no one can be said to have a vested right. ${ }^{7}$

The inhibition on ex post facto laws has to deal with laws in the field of vested rights, but being confined to criminal and penal enactments, the rights within its sphere are principally those of life or liberty, and it concerns rights of property only as far as a forfeiture thereof may be annexed as a punishment to some criminal act.

\section{Laws Impairing the Obligation of Contracts.}

History of clause.

Vested rights of property are the direct and only object of protection under the associated clause in restraint of State action, forbidding the impairment of the obligation of contracts. The immediate source of this famous clause ${ }^{8}$ appears in the Ordinance for the government of the Northwestern Territory, which was passed about two months before the Constitution received its final shape. The Ordinance contained the provision "that no law ought ever to be made or have force in the said territory that shall in any manner whatever interfere with or affect private contracts or engagements bona fide and without fraud previously formed." 9 In the Federal Constitutional Convention the subject of such a restraint on the States is first mentioned in Madison's Debates, when Rufus King proposed to add to the prohibition on ex post facto laws and bills of

7 Hopt $r$ Utah, 110 U. S. 574.

8 The conditions which led to the adoption of the clause and its effects are ontlined in Edwards $x$. Kearzer, 96 U. S. 595.

9 This clause was dained be both Dane and Lee, with probabilities perhaps in favor of the latter. Meigs, Growth Const., p. 183; 8 Fed. Stat. Annot. 179. 
attainder " in the words used in the Ordinance of Congress establishing new States, a prohibition on Chapter IV. the States to interfere in private contracts." 1 This proposition was objected to by some members as too radical, and by others as providing for matters already secured by the proposed provision against ex post facto laws, which were treated by all as exactly equiralent to retrospective laws. ${ }^{2}$ The next day, Aug. 29, 1787, Mr. Dickinson informed the convention that he had examined Blackstone's Commentaries and he found that ex post facto related to criminal cases only. ${ }^{3}$ Two weeks later, on Sept. 1tth, the clause was reported in substantially its present form and adopted.

The phrase "obligation of contract" savors somewhat of the Roman and civil law, ${ }^{4}$ and it has "Obligation of contract." been plausibly suggested that the words are due to Judge James Wilson, whose training as a Scotch lawyer might suggest the phraseology to him. ${ }^{5}$ But the Federal Supreme Court worked out the meaning of the words deductively from the phrase itself. "What," said Chief Justice Marshall, "is the

1 Madison's Debates, Aug. 28, 1787.

2 Madison's Debates, Aug. 28, 1787. This is, it is contended, the original meaning of the phrase. See Mr. Justice Johnson dissenting in Satterlee $v$. Matthewson, 2 Pet. (U. S.) 380, and note 2 Pet. (U. S.) 681, by the same judge; 1 Hammond's Blackst. 132.

3 Blackstone, it has been noted, does not define the term, but merely illustrates it from the criminal law. Moore $v$. State, 43 N. J. L. 203; 1 Hammond's Blackst. 132.

4 Obligatio is defined as juris vinculum quo necessitate adstringimur alicujus solvendae rei, secundum nostrae civitatis jura. Inst. III. 13, pr. Omnis enim obligatio vel ex contractu nascitur, vel ex delictu. Gaius, Inst. III, 88. Aut enim [obligationes] ex contractu sunt, aut quasi ex contractu, aut ex maleficio, aut quasi ex malificio. Inst. III, 14, 3 .

5 Am. L. Rev. 197. 

Chapter obligation of a contract? and what will impair it?
IV.

It would seem difficult to substitute words which are more intelligible or less liable to misconstruction, than those which are to be explained. A contract is an agreement in which a party undertakes to do, or not to do, a particular thing. The law binds him to perform his undertaking, and this is, of course, the obligation of his contract." ${ }^{6}$ In a later case it was said: "The obligation of a contract consists in its binding force upon the party who makes it. This depends on the laws in existence when it is made; these are necessarily referred to in all contracts and forming [form] a part of them as the measure of the obligation to perform them by the one party, and the right acquired by the other. There can be no other standard by which to ascertain the extent of either, than that which the terms of the contract indicate, according to their settled legal meaning; when it becomes consummated the law defines the duty and the right, compels one party to perform the thing contracted for, and gives the other a right to enforce the performance by the remedies then in force." 7

Construc. tion of

To the obligation of a contract it is necessary clause. that there be a meeting of the minds of the parties. Nutual assent to its terms is of the very essence of the obligation. Consequently a quasi-contractual obligation raised by the law, without any reference to the will of the parties, is not within this clause. ${ }^{8}$

e Sturges $v$. Crowninshield, 4 Wheat. (U. S.) 122.

7 MeCracken $r$. Hayward, 2 How. (U. S.) 608, per Baldwin, J., for the court.

8 Louisiana $r$. New Orleans, 109 U. S. 285; Freeland $v$. Williams, 131 U. S. 405; Morley $v$. Lake Shore, etc., R. Co., 146 U. S. 162. 
The term applies to executed as well as to executory contracts, ${ }^{9}$ and to the contracts of the State itself, ${ }^{1}$ such as the grant of valuable rights or franchises to a private corporation. ${ }^{2}$ But the charter of a corporation is always subject to the police powers of the State. It is, therefore, an implied if not an express term of such contracts that the rights granted are subject to the condition that they shall not be abused or so employed as to defeat the ends of the grant, and that, when so abused or misemployed, they may be withdrawn or reclaimed by the State, in such way and by such modes of procedure as are consistent with law; and further that the corporation shall be subject to such reasonable regulations as the legislature may from time to time prescribe, which do not materially interfere with or obstruct the substantial enjoyment of the privileges the State has granted, but serve only to secure the ends for which the corporation was formed. ${ }^{3}$

The clause extends only to vested rights which arise out of and have their origin in contract, and, under it, a State statute can not be adjudged unconstitutional on the ground merely that it divests a right previously vested. ${ }^{4}$

It has been said that the provision was designed to protect "contracts by which perfect rights, cer-

9 Fletcher $v$. Peck, 6 Cranch (U. S.) 87.

1 Fletcher $v$. Peck, 6 Cranch (U. S.) 87 ; New Jersey $v$. Wilson, 7 Cranch (U. S.) 164; Davis v. Gray, 16 Wall. (U. S.) 203.

2 Dartmouth College $v$. Toodward, 4 Wheat. (U. S.) 518.

3 Chicago L. Ins. Co. $v$. Needles, 113 U. S. 574. See also Richmond, ete., R. Co. $v$. Riclımond, 96 U. S. 521 .

4 Satterlee $v$. Matthewson, 2 Pet. (C. S.) 380 ; Watson $v$. Mercer, 8 Pet. (U. S.) 110; Charles River Bridge $v$. Tarren Bridge, 11 Pet. (U. S.) 420 ; Peerce $v$. Kitzmiller, $19 \mathrm{~W}$. Va. 564, 573. 
Chapter tain definite, fixed private rights of property, are IV.

Existing laws a part of contract.

Relation to "due proc. ess" clause.

\section{vested.', 5}

Laws existing at the time that a contract is made become a part of the contract, as much as if they were explicitly incorporated in it, ${ }^{6}$ and the obligation of the contract is not impaired or due process of law denied by the enforcement of obligations whieh have attached to the subject of the contract in accordance with such laws, althongh the value of the contract may be diminished or destroyed."

The relations between this clause and the "due process of law" clauses in the Constitution are particularly clear because, previous to the Fourteenth Amendment, the States were not forbidden to pass latrs depriving private persons of due process of law, but were prohibited from impairing the obligation of contracts; while the federal government has always been restrained by the due process clause, but never by a guaranty of the sacredness of contract rights. We have seen that the States, under the Constitution as it stood hefore the addition of the Fourteenth Amendment, were not prohibited in general from retrospective legislation ${ }^{8}$ affecting vested rights; and, on the other hand, as a result of the due process clause, the United States can pass no law affecting

- Butler $v$. Pennsplvania, 10 How. (U. S.) 402.

6 Von IIoffman $r$ Quiney, 4 Wall. (U. S.) 535.

7 Provident Sav. Inst. $\dot{v}$. Jersey City, 113 U. S. 506; Lehigh Water Co. $v$. Easton, 121 U. S. 388.

8 In a concurring opinion in Satterlee $v$. Matthewson, 2 Pet. (U. S.) 380 , Mr. Justice Johnson laments "that unhappy idea, that the phrase, ex post facto, in the Constitution of the United States was confined to criminal cases exclusively; a decision which leaves a large class of arbitrary legislative acts without the prohibitions of the Constitution." 
vested rights, save as the power to do so results Chapter from powers conferred either expressly or by impliIV. cation in other clauses of the Constitution. In the Sinking Fund Cases the court declared: "The United States can not, any more than a State, interfere with private rights except for legitimate governmental purposes." "They are not included," it was said, "within the constitutional prohibition which prerents States from passing laws impairing the obligation of contracts, but equally with the States they are prohibited from depriving persons or corporations of property without due process of law." 9

\section{ALL LAWS IMPAIRING VESTED RIGHTS CONDEMNED}

BY DUE PROCESS.

The principles which condemn legislation divesting fundamental rights of life and liberty and rights arising from contract apply equally to all classes of vested rights in property. And this is in accord Retrospec
tive laws impairing rights other than of con. with the spirit of all enlightened jurisprudence. The sweeping maxims of the Roman jurists in condemnation of all retroactive laws ${ }^{1}$ were adopted by

9 Sinking Fund Cases, 99 U. S. 718 . The dissenting opinions of Justices Strong, Bradley and Field were even more emphatic on this point. These views are reiterated in U. S. v. Union Pac. R. Co., I 60 U. S. 1, quoting from the Sinking Fund Cases.

Then the effect of the exercise of powers conferred on Congress either directly or indirectly is to impair contract obligations, that effect does not render the exercise void. Legal Tender Cases, 12 Wall. (U. S.) 457 ; Mitchell $v$. Clark, 110 U. S. 633.

The doctrine here stated has been held to warrant a retroactive application of the United States bankruptcy laws with regard to homestead exemptions. In re Wyllie, 2 Hughes (U. S.) 449. And see $15 \mathrm{Am}$. and Eng. Encyc. of Law (2d ed.) 613.

1 Nemo potest mutare consilium suum in alterius injuriam, is a maxim of Papinian, Dig. 50, 17, 75. Leges et constitutiones futuris certum est dare formam negotiis, non ad faeta praeterita revocari, 

Chapter Bracton in the thirteenth century and have been
IV.

repeated by Coke and Bacon, ${ }^{2}$ and applied by the English courts in the only way possible under an omnipotent parliament; namely, as a rule of construction to the effect that a statute mill never be held to direst vested rights if it is capable of any other meaning. ${ }^{3}$ From Roman, English, and Continental jurists, the same doctrines have become a. part of American constitutional law. Thus, Chancellor Kent, when chief justice of the Supreme Court of New York, declared that "laws impairing previously acquired civil rights are equally within the reason of that prohibition [on ex post facto laws in the Federal Constitution] and equally to be condemned." 4 Elsewhere it has been said: "A retroactive statute partakes in its character of the mischiefs of an ex post facto law, and when applied to contracts or property would be equally unjust and unsound in principle as ex post facto laws when applied to crimes and penalties."'s And we have seen that the phrase ex post facto laws in the Constitution of the United States was treated at first in the convention as equiralent to retrospective lars. But the protection of vested rights so far as they do not fall within the scope of one or the other of nisi nominatim; et de praeterito tempore et adhuc prudentibus negotiis eautum sit. Code 1, 14. 17. See Pufendorf. Law of Nature and Nations, lib. 1, c. 6, $\$ 6$; Domat, Civ. Law, Prelim., Title I, sec. 1, XIII.

2 Tracton. lib. 4, f. 228 (nova constitutio futuris formam imponere debet et non practeritis); Coke, 2 Inst. 292; Bacon, De Aug. Sci., lib. 8, c. 3, aph. 4i-51.

3 Gimore $r$. Shuter, 1 Vent. 330, 2 Show. 16, 2 Ler. 227, T. Jones 108, 2 Mod. 310: Couch $r$. Jeffries, 4 Burr. 2460.

4 Dash $r$. Van Kleerk, 7 .Jolns. (N. Y.) $47 \%$.

o Warren Mfg. Co. v. Etna Ins. Co., 2 Paine (U. S.) 501. 
the constitutional clauses just discussed rests solely Chapter on the provision for "due process of law."

IV.

To bring an enactment within this clause and render it obnoxious to due process of law, it is not

sufficient that the law changes previously existing rules, that is, that it is retroactive or retrospective in the widest sense. Before the passage of the Fourteenth Amendment, as has been seen, the power of the States to enact retroactive laws not ex post facto nor impairing the obligation of contracts was well settled, ${ }^{7}$ even though such laws might divest antecedent vested rights of property. ${ }^{\mathrm{s}}$ But one effect of the amendment, although it does not prohibit retroactive laws as such and therefore such laws are still permissible, ${ }^{9}$ was to prohibit all merely arbitrary interference with fundamental rights, and among those rights are vested rights of property, without regard to the source, contractual or otherwise, by which they became vested. ${ }^{1}$

\section{WHAT RIGHTS ARE VESTED OR OTHERWISE.}

Whether rights are in their nature so fundamental as to be within the due process clanses of the ConDeter: mined as cases arise. stitution can be determined only, as has been point ed out already, by the gradual process of judicial exclusion and inclusion. Instances of personal rights which have been held to be secured by this

7 Baltimore, etc., R. Co. v. Nesbit, 10 How. (U. S.) 395, 401.

8 Watson $v$. Mercer, 8 Pet. (U. S.) 110.

9 League $v$. Texas, 184 U. S. 156, $16 \mathrm{i}$.

$1 \mathrm{~A}$ law which divests a right vested under a contract and so impairs the obligation of the contract is a deprivation of a right of property and therefore inconsistent with the due process clause of the Fourteenth Amendment. Bradley v. Lightcap, 195 U. S. 1, 24. 
Chapter clause are treated later in connection with the subject of procedure. When a denial of rights of liberty and property is the subject of complaint, the attempt to justify interference always takes the form of a plea of the State's sovereignty in the exercise of its porrers of taxation, eminent domain, or the police power, taking the last in its widest sense. Rights of liberty and property will naturally claim discussion in connection with the sovereign powers mentioned.

There are certain more or less definite classes of rights, howerer, which fall below the standard of rested rights. The first of these classes consists of expectancies, possibilities, or mere contingencies, which are not in an exact sense rights at all $;^{3}$ the second, of those technical legal titles, whose assertion depends on the insistence on the requirement of some mere matter of form which the legislature might have dispensed with in the first instance, and may dispense with by curative legislation, in favor of rights already equitably vested, even though technical legal rights are destroyed $;^{4}$ the third, of those

3 " When we oppose a vested or present to a future or contingent right, we are not. I apprehend, opposing a right of one class to a right of another class, but we are rather opposing a right to a chance or posibility of a right." 2 Austin's Jurisp., 5th ed., 856.

"A vested right is property which the law protects, while a mere expectancy is not property and therefore is not protected." Hoeft $r$. Supreme Lodge, etc., 113 Cal. 91, 96.

4 "Laws curing defects which would otherwise operate to frustrate what must he presumed to be the desire of the party affected, can not be considered as taking away rested rights. Courts do not regard rights as vested contrary to the justice and equity of tho case." State $r$. Newark, 27 N. J. L. 197.

Where the notes of unincorporated banking associations were by statute made void. the repeal of the statute was held to have a retroactive effect, and to warrant actions on notes issued by such 
mere matters of procedure, of the hou a given demand may be asserted or resisted, which, being enChapter IV. tirely separable from the substance of the demand, may be changed by the legislature at its will, and the new rule made applicable to existing causes of action. The first two classes concern vested rights of property only, the last includes as well rights of life and liberty as of property.

Under the head of expectancies, possibilities, and contingencies which do not rise to the rank of vested Expectancies and mere conrights, and which, therefore, may be controlled by statutes passed after they have, so far as their nature permits, accrued to particular individuals, may be mentioned the expectation of a person that $h$ will succeed as heir to the fee simple estates of a living ancestor ${ }^{5}$ or to his estates in fee tail; ${ }^{6}$ the possibility of reverter upon the dissolution of a corporation; ${ }^{7}$ a joint tenant's claim to take by sur-

associations before the repeal. Hess $v$. Werts, 4 S. \& R. (Pa.) 361. "The object of the [repealed] act," said the court, "was not to vest a riglit in any unlawful banking association, but directly the reverse. The motive was not to create a privilege or shield them from the payment of their just debts, but to restrain them from violating the law by destroying the credit of their paper."

"There is no vested right in a mode of procedure, Each succeeding legislature may establish a different one, providing only that in each are preserved the essential elements of protection." Backus $v$. Ft. Street Union Depot Co., 169 U. S. 55i, 570; League $v$. Texas, 184 U. S. 156, 158.

5 Randall $v$. Kreiger, 23 Wall. (U. S.) 137, where Swayne, J., for the court, said: "Until that event [the death of the ancestor] occurs the law of descent and distribution may be moulded according to the will of the legislature."

6 Consequently legislation declaring existing estates tail changed to fee simple estates is valid. De Mill $v$. Lockwood, 3 Blatchf. (U. S.) 63. And see Croxall $r$. Shererd, 5 Wail. (U. S.) 268.

7 Bass $v$. Roanoke Nav., etc., Co., 111 N. Car. 439. 
Chapter vivorship property held in joint tenancy; ${ }^{s}$ and a IV. wife's expectation of dower in her husband's lands so long as the husband is alive. ${ }^{9}$

Curative acts.

Wherever any proceeding might have been authorized in advance by the legislature, that proceeding may be ralidated by a retrospective act, curing the irregularities in the original proceeding. ${ }^{1}$ The claim of a party to such original proceeding, because of its irregularity, to insist on titles which, but for that irregularity, would have passed to others, is not a rested right which the Constitution protects, and is inferior to the equitable rights acquired under the proceeding validated. ${ }^{2}$ But the rights of third persons, which depend on the invalidity of the original proceeding and were acquired bona fide before the passage of the curative statnte, are vested, and as to them the statute is inoperative."

8 Holbrook $r$. Finner, 4 Mass. 56s; Miller $v$. Miller, 16 Mass. 59 ; Miller r. Dennett, o N. II. 109 (where the cont said: "Neither [joint tenant] ha! any rested interest in the moiety of the other. The arquisition of the whole estate by survivorship would have been in either nothing more than a hope or expectation, like the expectation of a chili to inherit the estate of a parent"); Bambangh $v$. Bambaugh, 11 S. \& F. (Pa.) 191. But compare Greer $r$. Blanchar, 40 Cal. 1!4: Den $r$. Van Riper, 16 N. J. L. 7 , in which cases a diflerent conclusion was reached.

9 Randall $r$. Kreiger, 23 Wall. (U. S.) 148.

1 Thomson $v$. Lee County, 3 Wall. (U. S.) 327 ; St. Joseph Tp. $v$. Rogers, 16 Wall. (L. S.) 644; Thompson $v$. Perrine, 103 U. S. 806. And see McFadlin $r$. Evans-Snider-Buel Co., 185 U. S. 505.

2 Raverts $v$. Frilge, 3 MeLean (U. S.) 230: Barton $v$. Morris, 15 Ohio 40s; Chestnut $v$. Shane, 16 Ohio 599. See also New Orleans v. Clark, 95 U. S. 644 .

The ralidity of curative acts validating defective acknowledgments luas been said to be sustainable only on the ground that not the contract, but the mode of its proof, is affected. Journeay $r$. Gibson, 56 Pa. St. 57 .

3 Brinton $v$. Seevers, 12 Iowa 359 ; Barrett $v$. Barrett, 120 N. Car. 127. 
PROCEDURE.

\section{What the Term Covers.}

Procedure, frequently called "adjective law," is a word of wide scope, admitted as a technical legal Includes evidence, term only within recent cears. In 1883, the Supreme Court of the United States declared that, as a law term, the word "procedure" was not well understood. The court, however, said further: "Fortunately a distinguished writer on criminal law in America has adopted it as the title to a work of two volumes - Bishop on Criminal Procedure. In his first chapter he undertakes to define what is meant by procedure. He says (sec. 2): 'The term procedure is so broad in its signification that it is seldom employed in our books as a term of art. It includes in its meaning whatever is embraced by the three technical terms - pleading, evidence, and practice.' And in defining 'practice' in this sense, he sars: 'The nord means those legal rules which direct the course of proceeding to bring parties into the court and the course of the court after they are brought in;' and 'evidence,' he sars, as a part of procedure, 'signifies those rules of law whereby we determine what testimony is to be admitted and what rejected in each case, and what is the weight to be given to the testimony admitted." " 4 Since this discussion of the meaning. of "procedure" was written, the term has come into general use, and it can no longer be said that it is not well understood.

4 Kring $v$. Missouri, 107 U. S. 231, per Miller, J. 
Chapter

IV.

Generally subject to state only.

Administration presumed constitu. tional.
The whole subject of procedure is in the control of the legislature and of the courts acting in conformity with the laws. ${ }^{5}$ Such expressions are frequent as that "there is no vested right in a mode of procedure;" "no party has a vested right to a particular remedy;" 7 "a right to have one's controversies determined by existing rules of evidence is not a vested right." \& But every announcement so broad as these must be taken subject to limitations, and the limitation to legislative and judicial control is that the regulation of procedure must not affect fundamental rights. In a recent case, the Federal Supreme Court declared that "the State has full control over the procedure in its courts, both in civil and in criminal cases, subject only to the qualification that such procedure must not work a denial of fundamental rights, or conflict with specific and applicable provisions of the Federal Constitution." 9

A denial of fundamental rights will not, of course, be presumed, and when the record shows no denial, it will not be assumed that the court of its officers abused the powers confided to them, ${ }^{1}$ nor

5 The State has full power over remedies and procedure in its own courts. York $v$. Texas, 137 U. S. 20; Hooker $v$. Los Angeles, 188 U. S. 314.

6) League $r$. Texas, 184 U. S. 156, 158; Backus $v$. Fort St. Union Depot Co., 169 U. S. 557, 570: Hopt $r$. Utah, 110 U. S. 574. See also Louisville, ete, R. Co. $v$. Schmidt, 177 U. S. 230.

7 Com. $r$. 1lighway Com'rs, 6 Pick. (Mass.) 508, per Parker, C. J. ; $6 \mathrm{Am}$. and Eng. Eneyc. of Law (2d ed.) $947 ; 26$ id. 949.

8 Kent $r$. Gray, 53 N. H. 576, citing Cooles, Const. Lim. 367; Tabor $v$. Ward, 83 X. Car. 291 . See $6 \mathrm{Am}$. and Eng. Encye of Law, (2d ed.) $950 ; 26$ id. 749.

9 Brown $x$. New Jerees, 175 L $^{*}$. S. 175; West $v$. Louisiana, 194 U. S. 263.

1 Lowe $v$. Kansas, 163 C. S. 81; Simon $v$. Craft, 182 U. S. 436. 
can denial of due process of law be founded on the claim that a person was denied the right to present defenses which he never in fact asserted, when every defense actually presented was considered by the court; 9 nor by a decision on a question of general law, as that libellous statements in pleadings are absolutely privileged; ${ }^{3}$ nor by the admission of the deposition of an absent witness against the defendant in a criminal trial, although by the common law the evidence may be inadmissible; ${ }^{4}$ nor by the action of the court in denying a motion to set aside a submission of the case ${ }^{5}$ nor by the refusal of the court to permit amendments to the pleadings or the filing of supplementary pleadings. ${ }^{6}$

A State statute providing that a special administrator, appointed pending a contest over the will or the right to act as representative, shall settle with the executor or administrator with the will annexed, without giving notice to distributees, and that such settlement shall be conclusive in the absence of fraud does not work a deprivation of property without due process. In the settlement with the special administrator, the regular representative represents all interests, and upon his final settlement all interested parties are entitled to notice. This satisfies the constitutional provision. ${ }^{7}$

Where a remedy is universally recognized, its application retrospectively by virtue of a subse-

2 Louisville, etc., R. Co. $v$. Schmidt, I77 U. S. 230.

3 Abbott $r$. Tacoma Bank of Commerce, 175 U. S. 409.

4 West $v$. Louisiana, 194 U. S. 258.

5 Thorington $v$. Montgomery, 147 U. S. 490.

6 Sterens $v$. Nichols, 157 U. S. 370; Sawyer $v$. Piper, 189 U.

S. 154 .

7 Robards $v$. Lamb, 127 U. S. 58. 


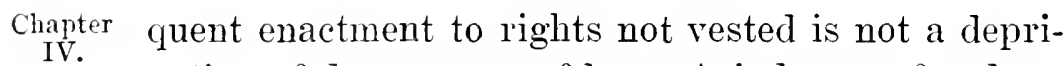
vation of due process of law. A judgment for damages in tort for an act committed under military authority during the civil war between the States was held to rest no rights in the plaintiff, and, when the constitution of the State where the judgment was recovered declared that no one should be liable civilly or criminally for sucl acts, an injunction against execution on a judgment previously recovered for this cause was held to be due process. ${ }^{8}$ The provision in the State constitution, said the court, "remedies the defects of the proceeding by bill in chancery; it creates no new process of law; it makes that which has always been due process of law efficient by removing obstacles and obstructions to its operation. It simply declares that a judgment for a wrong or tort, which in itself was erroneous, is a voidable judgment, and may be avoided if it can be brought within the due processes of law already existing.", 9

\section{Tribunal Before Which Trial Is Had.}

Tribunal generally matter of local law.
The character of the tribunal before which the trial of a question involving life, liberty, or property is to be had, may, in the absence of specific constitutional provisions, be regarded as a question of procedure, depending on the lex fori. Thus the right to and the mode of jury trial in both civil ${ }^{1}$

8 Freeland $v$. Williams, 131 U. S. 405.

${ }^{2}$ Freeland $v$. Williams, 131 U. S. 419, 420. See also Peerce $v$. Kitzmiller, 19 W. Va. 564.

1 Murray $v$. Hoboken Land, etc., Co., 18 How. (U. S.) 280; Walker $v$. Sauvinet, 92 U. S. 90 : Church $v$. Kelsey, 121 U. S. 282; Marvin $v$. Trout, 199 U. S. 212 ; Wilson $v$. North Carolina, 169 U. S. 
and criminal cases, ${ }^{2}$ and the right to indictment by a grand jury in criminal cases, ${ }^{3}$ are, as has been Chapter IV. repeatedly determined, questions to be decided by the States under their own constitutions and laws, though specific clauses of the Federal Constitution guarantee jury trial and grand juries in the United States courts. ${ }^{4}$

Duties judicial or quasi-judicial may be devolved by law on boards or officers of an administrative or Adminisbunal. executive character, and their decisions of the questions submitted to them made final. In a case inrolving the finality of the determination of a State medical board the United States Supreme Court said: "We know of no provision in the Federal Constitution which forbids a State from granting to a tribunal, whether called a court or a board of registration, the final determination of a legal question. Indeed, it not infrequently happens that a full discharge of their duties compels boards or officers of a purely ministerial character to consider and determine questions of a legal nature. Due process is not necessarily judicial process." 5 / Thus the issue of the sanity of the accused after verdict may be determined by administrative or quasi-

586, holding a proceeding by quo uarranto without jury to remove a public officer to be due process.

2 Hallinger $v$. Davis, 146 U. S. 314; Brown $v$. New Jersey, 175 U. S. 175 ; Maxwell $v$. Dow, 176 U. S. 581.

3 Hurtado $v$. California, 110 U. S. 538; Caldwell $v$. Texas, 137 U. S. 692; McNulty $v$. California, 149 U. S. 648 ; Talton $v$. Mayes, 163 U. S. 376, 382; Hodgson $v$. Vermont, 168 U. S. 272 ; Bolln $v$. Nebraska, 176 U. S. 86 ; Maxwell v. Dow, 176 U. S. 581 ; Davis $v$. Burke, 179 U. S. 404.

4 Amendm. V, VI, VII; 9 Fed. Stat. Annot. 256 et seq.; Amer. Pub. Co. $v$. Fisher, 166 U. S. 464 ; Thompson $v$. Utah, 170 U. S. 343.

5 Reetz $v$. Michigan, 188 U. S. 507. 

Chapter administrative process, and need not be tried "by
IV.

a jury in a judicial proceeding surrounded by all the safeguards and requirements of a common-law jury trial;", it is purely a matter of legislative regulation within the control of the State. ${ }^{6}$

Whether jurisdiction orer particular classes of cases is vested in one tribunal or another is thus seen to be a question of local law, and there is no provision of the Federal Constitution prohibiting the State legislature from distributing jurisdiction as it sees fit among courts and other tribunals. ${ }^{*}$ Yet it should be observed that a state statute creating "a court of visitation" empowered to make rates for telegraph and railroad companies and to entertain judicial proceedings to determine the reasonableness of the rates was held by a federal circuit court to be unconstitutional as denying due process of law. It was considered that no hearing before such a body could fulfil the constitutional requirement, because of the mingling of executive and judicial functions in the powers of the "court." 7

\section{Procedure in Criminal Cases.}

In criminal trials certain matters pertaining to procedure have been declared to involve fundamental rights, of which the person accused of crime

6 Nobles $r$. Georgia, 168 U. S. 405.

$6^{*}$ See Church $r$. Kelsey, 121 U. S. 282; Duncan $v$. Missouri, 152 U. S. 377 ; Dreyer $v$. Illinois, 187 U. S. 84 ; Rogers $v$. Peck, 199 U. S. 425 .

7 Western Union Tel. Co. $v$. Mratt, 98 Fed. Rep. 335. The court in this instance relied largely on decisions of the supreme court of the State whose legislation was under consideration. See In re Sims, 54 Kan. 1; Auditor $v$. Railroad Co., 6 Kan. 500. 
may not be deprived without the denial of due process of law, while others are matter's of form only. Chapter IV. Generally, whatever matter's are jurisdictional are essential and protected by the Constitution; matters which do not affect the competency of the court are not jurisdictional and are not protected.

Under the provision of due process of law in the Fifth Amendment to the United States Constitution Entering tial. it has been held that due process requires the defendant to plead or have a plea entered for him. Upon this point the Federal Supreme Court has said: "Due process of law requires that the accused plead, or be ordered to plead, or, in a proper case, that a plea of not guilty be filed for him, before his trial can rightfully proceed; and the record of his conviction should show distinctly, and not by inference merely, that every step involved in due process of law, and essential to a valid trial, was taken in the trial court; otherwise the judgment will be erroneous." $7^{*}$

So, also, under the same provision, the right of a person accused of felony to be present during the Presence during whole of the trial in the trial court, is a substantive right of which he can not be deprived without due process of law, even with his consent. ${ }^{s}$ In a case wherein it was determined that the presence of the accused during the trial of challenges of proposed jurors was essential under the statutes of the Territory of Utah, the court said: "His [the prison-

$7^{*}$ Crain $v$. U. S., 162 U. S. 625.

8 Lewis $v$. U. S., 146 U. S. 372 . But see Trono $v$. U. S., 199 U. S. 521, which perhaps weakens the direct authority against the right to waive the privilege, where presence is not made compulsory by statute. 

Chapter er's] life or liberty may depend upon the aid which, by his personal presence, he may give to counsel and the court and triers in the selection of jurors. The necessities of the defense may not be met by the presence of his counsel only. For every purpose, therefore, involved in the requirement that the defendant shall be personally present at the trial, where the indictment is for a felony, the trial commences at least from the time when the work of impaneling the jury begins." After showing that the accused may not waive this privilege, because the public, as well as himself, has an interest in the legality of his conviction, the court proceeded: "That which the law makes essential in proceedings involving the deprivation of life or liberty can not be dispensed with, or affected by the consent of the accused, much less by his mere failure, when on trial and in custodr, to object to unauthorized methods. . . The legislature has deemed it essential to the protection of one whose life or liberty is involved in a prosecution for felony that he shall be personally present at the trial; that is, at every stage of the trial when his substantial rights may be affected by the proceedings against him. If he be deprived of his life or liberty without being so present, such deprivation would be without that due process of law required by the Constitution." s* The right to be present during trial is confined to presence in the trial court and does not extend, either in courts of the United States or in those of the States, to presence in an appellate court; and so, when, upon affirming the judgment helow. the date of execution 
is settled, in accordance with the law, by the appellate tribunal, the accused can not complain that such Chapter IV. date was fixed in his absence. ${ }^{9}$

These principles, as to the positive rights which are within due process of law, were established in cases which involved the meaning of that term in Presence during tin Fourteenth Anent? the Fifth Amendment to the United States Constitution, and we have no direct adjudication as to whether the right of pleading or the right of the accused to be present at the trial is guaranteed, as against the States, by the due process clause of the Fourteenth Amendment. The Federal Supreme Court has again and again declared that when the highest court of a State has acted within its jurisdiction and in accordance with its construction of the State constitution and laws, very exceptional circumstances will be necessary in order that the Federal Supreme Court may feel justified in saying that there has been a failure of due process of law. "We might ourselves have pursued a different course, but that is not the test. The plaintiff in error must have been deprived of one of those fundamental rights, the observance of which is indispensable to the liberty of the citizen, to justify our interference." ${ }^{1}$ For especially in cases involving procedure, is it true that "due process of law means law in its regular course of administration through courts of justice." 2

๑ Schwab $v$. Berggren, 143 U. S. 442 ; Fielden $v$. Illinois, $143 \mathrm{U}$. S. 452 .

1 Allen $v$. Georgia, 166 U. S. 138, quoted with approval in Wilson $v$. North Carolina, 169 U. S. 586.

2 Caldwell $v$. Texas, 137 U. S. 692. In Miller $v$. Texas, $153 \mathrm{U}$. S. 535, the court said: "As the proceedings were conducted under 
Chapter

$1 \mathrm{~V}$.

Instances

of matters

held not to

involve

"due proc-

ess."

These principles are illustrated in many decisions. Due process of law under the Fourteenth Amendment has been held not to be involved in a decision by a State court that certain acts constituted an offense indictable at the common law. ${ }^{3}$ So the sufficiency of the indictment to charge a specific offense, ${ }^{4}$ or the existence of defects in the indictment and their waiver by the defendant, ${ }^{5}$ are matter's for the determination of the State court and involve no federal question. Nor is there any deprivation of due process of law by a trial and conviction before a judge de facto of a court de jure, the sentence pronounced being valid; ${ }^{\circ}$ nor by a trial by a jury one member of which was an alien, objection not having been taken in proper time under the statutes of the State; ${ }^{\top}$ nor by the entry of a nolle prosequi as to those counts in an indictment of several counts upon which the jury were unable to reach an agreement; ${ }^{\mathrm{s}}$ nor by the action of a State court in dismissing the defendant's appeal, because of his escape from jail and failure to surrender himself according to the order of the court within a certain time; ${ }^{9}$ nor by the action of a State appellate court in dismissing a writ of habeas corpus, when the committing court

the ordinary forms of criminal prosecutions, there certainly was no denial of due process of law." See supra, p. 52 .

3 Howard $\%$. Fleming, 191 U. S. 126.

4 Caldwell $v$. Texas, 137 U. S. 692; Leeper $v$. Texas, 139 U. S. 462 ; Davis $r$. Texas, 139 U. S. 651 ; In re Robertson, 156 U. S. 1S3; Bergeman $v$. Backer, 157 U. S. 655 ; Kohl $v$. Lehlback, 160 U. S. 297; Howard $r$. Fleming, 191 U. S. 126.

5 O'Neil $v$. Vermont, 144 U. S. 323.

6 In re Manning, 139 U. S. 506.

7 Kohl $v$. Lehlback, 160 U. S. 297.

8 Cross $v$. North Carolina, 132 U. S. 131.

- Allen v. Georgia, 166 U. S. 138. 
had jurisdiction and the commitment was not void. Chapter Habeas corpus cannot be availed of as a writ of IV. er'ror or appeal. ${ }^{1}$

Questions which concern the authority by which Execution of senand the manner in which sentences shall be carried tence. into execution are questions of local law and their decision is, in ordinary course, for the State courts alone..$^{2}$

The right to appeal from a judgment of convic- $\begin{gathered}\text { Right of } \\ \text { appeal. }\end{gathered}$ tion for crime is not a necessary element of due process of law." "It is therefore clear that the right of appeal may be accorded by the State to the accused, upon such terms as in its wisdom may be deemed proper," and this is a matter which each State must determine for itself. ${ }^{3}$

\section{Proceedings for Contempt.}

The power to punish summarily for contempt is inherent in superior courts. When the contempt is $\begin{gathered}\text { punish for } \\ \text { contempt. }\end{gathered}$ directly in the presence of the court, the court may inflict punishment and may do so without hearing or trial. ${ }^{4}$ Even in cases of indirect or of civil contempts, no particular method of procedure is

1 Tinsley $v$. Anderson, 171 U. S. 101.

2 In re Kemmler, 136 U. S. 436 (law for execution by electricity); Holden v. Minnesota, 137 U. S. 495 (time of execution to be fixed by the governor); Lambert $v$. Barrett, 157 U. S. 697,159 U. S. 660 (legality of governor's sentence after reprieve); Craemer $v$. Washington, 168 U. S. 124 : Rogers $v$. Peck, 199 U. S. 425.

3 McKane $v$. Durston, 153 U. S. 6S4; Andrews $v$. Swartz, $156 \mathrm{U}$. S. 272; Kohl $v$. Lehlback, 160 U. S. 297; Murphy $v$. Massachusetts, 177 U. S. 155 . And see Dunean $v$. Missouri, 152 U. S. 377.

${ }^{4}$ Ex $p$. Terry, 128 U. S. 289. The court may issue citation to show cause why punishment should not be inflicted for contempt, but no service of interrogatories is necessary. Savin, Petitioner, 131 U. S. 267 . 

Chapter required in the absence of statute.
IV. The court may

Hearing in cases of civil con. tempt. proceed summarily by motion to show cause and a hearing on affidavits to punish by fine and imprisonment. If the right to notice and hearing is substantially protected, "such proceeding is due process of law, and always has been due process of law, and is the process or proceeding by which courts have from time immemorial enforced the execution of their orders and decrees, and can not be said to deprive the parties of their liberty or property without due process of law." 6

But the right to notice and hearing in such cases must be preserved, nor can the contemnor's property be arbitrarily given to another as a punishment for his contempt. In a case wherein the trial court to punish the defendant for a contempt in refusing to obey an order of the court, ordered his answer to be stricken from the files and a decree to be entered against him pro confesso, it was held that the decree was roid. Though jurisdiction had been obtained by service of summons, striking out the defendant's answer and rendering judgment against him was a denial of his right to a hearing before condemnation which is fundamental in the very conception of a court of justice. The judgment, moreover, in effect transferred property of the defendant to the plaintiff arbitrarily and without due process of law.

5 When the court does not have personal knowledge of the contempt, the usual process is by order to show cause. Sarin. Petitioner, 131 L. S. 275: Cudly Petitioner, 131 U. S. 280.

6 Miller, . ., for the court in Eilenbecker $r$. District Ct.. 134 I. S. 31. To the same effect, see Interstate Commerce Commission $v$. Primson. 154 U. S. 447; In re Debs, 158 U. S. 564; Tinsley $v$. An. derson, 171 L. S. 101. 
The exercise of the power arbitrarily assumed was Chapter held to be without jurisdiction and the judgment IV. subject to collateral attack. ${ }^{\text {? }}$

Closely analogous to the power of the court to punish for contempt is its power summarily to disbar or suspend an attorney entitled to practice before it for gross misconduct affecting his professional character. Such a summary proceeding has been held by the Federal Supreme Court civil in nature and not criminal. It is a regular and lawful method of proceeding within the jurisdiction of the court practiced from time immemorial and constitutes due process of law. ${ }^{8}$

\section{Statutes of Limitations.}

Statutes of limitation are usually treated as laws of procedure affecting the remedy only and not the Right to future limitation not right. ${ }^{2}$ A statute of limitations affecting existing causes of action is not unconstitutional either as impairing contracts or denying due process of law, provided a time reasonable, taking into consideration the nature and circumstances of the case, is allowed for bringing action after the passage of the statute and before the bar takes effect. ${ }^{1}$.With the

7 Hovey $v$. Elliott, 167 U. S. 409.

8 Ex $p$. Wall, 107 U. S. 265. And see $E x p$. Burr, 9 Wheat. (U. S.) 529,2 Cranch (C. C.) 379 ; Ex p. Secombe, 19 How. (U. S.) 9 ; Ex $p$. Bradles, 7 Wall. (U. S.) 364; Randall $v$. Brigham, 7 Wall. (U. S.) 523 ; Bradley $v$. Fisher, 13 Wall. (U. S.) 335 ; Ex $p$. Cole, 1 McCrary (U. S.) 405.

9 Townsend $v$. Jemison, 9 How. (U. S.) 407; Barrett $v$. Holmes, 102 U. S. 651 ; Michigan Ins. Co. $v$. Eldred, 130 U. S. 693 ; Davis $v$. Mills, 194 U. S. 451. Consequently they are governed by the les fori and are within the control of the legislature of the State. Great Western Tel. Co. $v$. Purdy, 162 U. S. 329. But this rule is subject to certain exceptions. Davis $r$. Mills, 194 U. S. 451.

1 Terry $v$. Anderson, 95 U. S. 62S; Koshkonong v. Burton, 104 

Chapter limitation specified, the legislature may establish,
IV. lengthen, or shorten the period of limitation for existing' causes of action." "It is difficult to see," said Chief Justice Waite in a leading case, "why, if the legislature may prescribe a limitation where none existed before, it may not change one which has already been established. The parties to a contract have no more a rested interest in a particular limitation which has been fixed, than they have in an umrestricted right to sue. They have no more a rested interest in the time for the commencement of an action than they have in the form of the action to be commenced; and as to the forms of action or modes of remedy, it is well settled that the legislature may change them at its discretion provided adequate means of enforcing the right remain. In all such cases the question is one of reasonableness, and we have, therefore, only to consider whether the time allowed in this statute is, under all the circumstances, reasonable. Of that the legislature is primarily the judge; and we can not overrule the decision of that department of the govermment, unless a palpable error has been committed. In judging of that, we must place ourselves in the position of the legislators, and must measure the time of limitation in the midst of the circumstances which surrounded them, as nearly as possible; for what is

U. S. 668; Vance $v$. Vance, 108 U. S. 514; McGahey v. Virginia, 135 U. S. 662; Wheeler $r$. Jackson, 137 U. S. 245; Camphell $r$. Haverhill, 155 U. S. 610 ; Turner $r$. New York, 168 U. S. 90 : Wilson $r$. Iseminger, 1S5 [. S. 55: Davis $v$. Mills, 194 U. S. 451: Schauble $v$. Schulz, (C. C. A.) 137 Fed. Rep. 389.

2 Vance $r$. Vance, 32 La. Ann. 186, affirmed 108 U. S. 514; Willard $v$. Harvey, 24 N. H. 344. 
reasonable in a particular case depends upon its Chapter particular facts.", 3

The question whether the right to be free from an action becomes, by the expiration of the comWhen stat. waros ber hasat: pleted statutory period, a rested right, demands an examination of the operation of the statute. A distinction has been taken as to the effect of the statute when it is based on the possession of real or personal property, and when it marks a mere prescriptive period for the assertion of a right of action. ${ }^{4}$ When it is founded on possession it ripens into a title, because, though the statute itself may be a mere bar, yet adverse possession for the prescribed period under the statute gives a title as complete and perfect as a grant.5 'This title is a vested right. But when a statute is only a legislative bar to a right of action, as for debt, the case is different. The debt is not paid by the lapse of time, nor in equity is there any vested right not to pay the debt, although the statute has run. ${ }^{6}$ This distinction has been recognized by the Supreme Court of the United States as applied to retrospective laws. In the one case, the right is vested and the legislature may not interfere with it; in the other it is completely within legislative control, even though the statutory period may have barred the right of action. In Campbell v. Holt, ${ }^{7}$ in holding that the bar

8 Terry $v$. Anderson, 95 U. S. 628.

4 Townsend $r$. Jemison, 9 How. (U. S.) 407.

5 Sharon $v$. Tucker, 144 U. S. 533; Toltec Ranch Co. $v$. Cook, 191 U. S. 532; Davis $r$. Mills, 194 U. S. 456; Northern Pac. R. Co. $v$. Ely, 197 U. S. 1.

6 See Dunn $v$. Beaman, $126 \mathrm{~N}$. Car. 766, where, however, the validity of the distinction is left undetermined.

7115 U. S. 620. Bradley and Harlan, JJ., dissented vigorously. 
Chapter of the statute which had already attached as to a IV. debt, was not a vested right, and might be removed by the legislature, Mr. Justice Miller, for the court, said: "It may, therefore, very well be held that in an action to recover real or personal property, where the question is as to the removal of the bar of the statute of limitations by a legislative act passed after the bar has become perfect, such act deprives the party of his property without due process of law. The reason is that, by the law in existence before the repealing act the property had become the defendant's. Both the legal title and the real ownership had become vested in him. . . . But we are of opinion that to remove the bar which the statute of limitations enables a debtor to interpose to prevent the payment of his debt stands on very different ground." It should be remarked, however, that in many jurisdictions the distinction is not observed and all rights perfected by the statute of limitations are regarded as vested. ${ }^{8}$

\section{Remedies.}

Does the statute weaken the remedy?
A remedy as such is no part of the contract and may be changed at the will of the legislature. But when the effect of legislation under the guise of changing remedies is to take away the party's right to enforce his contract, or materially to lessen the effectiveness of his available remedies, his vested rights are interfered with, and a statute having such

The doctrine of the majority is followed in a number of States. See McEldowney $v$. Tyatt, 44 W. Va. 711 ; 19 Am. and Eng. Encyc. of Law ( $2 \mathrm{~d}$ ed.) 171.

8 See $19 \mathrm{Am}$. and Eng. Encyc. of Law (2d ed.) 171. 
an effect is void. "Modes of procedure in the Chapter courts of a State are so far within its control that a IV. particular remedy existing at the time of the making of a contract may be abrogated altogether, without impairing the obligation of the contract, if another and equally adequate remedy for the enforcement of that obligation remains, or is substituted for the one

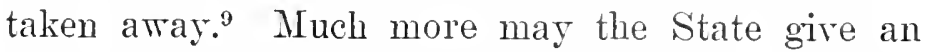
additional and more efficacious remedy for the enforcement of contracts in the performance of which the public health and the public safety are inrolved, provided, always, that the new remedy is consistent with the nature of the obligation to be enforced, and does not impair any substantial right given by the contract." 1 Under this head were held to fall provisions in a revised city charter authorizing additional means of securing the payment of water rents by providing a penalty to be imposed by the board of public works in case of non-payment and a heavy rate of interest on rents continuing in arrear. "We look upon these provisions," said the court, "as merely intended to enforce prompt payment,

9 Citing Bronson $v$. Kinzie, 1 How. (U. S.) 311, 315; Von Hoffman $v$. Quincy, 4 Wall. (U. S.) 552 ; Connecticut Mut. L. Ins. Co. $v$. Cushman, 108 U. S. 64, 2 U. S. Sup. Ct. Rep. 236; McGahey v. Virginia, 135 U. S. 693, 10 U. S. Sup. Ct. Rep. 972.

1 New Orleans City, etc., R. Co. $v$. Louisiana, 157 U. S. 219.

Thus the writs of attachment or mandamus may be taken away, if a legal remedy still remains. Tennessee $v$. Sneed, 96 U. S. 69 ; Antoni $v$. Greenhow, 107 U. S. 769.

Where a mortgage is subject to an existing mechanics' lien, a statute which merely alters and enlarges the means of enforcing the lien cannot be said to impair the mortgagee's contract, which, being subject to the lien, was subject to such changes as the legislature might make in the remedy to foreclose it. Red River Valley Nat. Bank v. Craig, 181 U. S. 548. 
Chapter and as incidental regulations, appropriate to the

IV.

Instances held prohibited.

Capias; exemptions. subject.', 2

So far as they affect debts contracted before the passage of the statutes, State insolvency laws, ${ }^{3}$ laws extending the period of redemption from execution sales, ${ }^{4}$ laws limiting the right to sell under execution unless the property brings a certain proportion of its value, ${ }^{5}$ laws allowing the jury, in a suit for breach of contract, to disregard the express stipulations of the contract, ${ }^{6}$ are among instances of laws nominally effecting remedies which have been held to affect fundamental rights and therefore to be unconstitutional. Stay laws, which suspend for a time the right to issue execution and final process on judgments recovered, have been held to belong to the same class. ${ }^{7}$

Under this head fall laws taking away the right to issue execution against the body of the debtor, or creating in favor of the debtor exemptions from execution against property or modifying such rights of exemption, provided the rights and interests of the creditor are not materially impaired. In Bronson $v$. Kinzie," it was said: "It [the State] mar, if it thinks proper, direct that the necessary implements of agriculture, or the tools of the mechanic, or articles of necessity in household furniture. shall,

2 Provident Sav. Inst. $v$. Jersey City, 113 U. S. 506.

3 Ogden $v$. Saunders, 12 Wheat. (U. S.) 213.

4 Barnitz $v$. Beverly, 163 U. S. 118.

- MeCracken $v$. Hayward, 2 How. (U. S.) 608.

- Effinger $\tau$. Kennes, 115 U. S. 566.

7 Edwards 2 . Kearzey, 96 U. S. 595.

8 Sturges $v$. Crowninshield, 4 Wheat. (U. S.) 122; Edwards $v$. Kearzey, 96 U. S. 595 .

o 1 How. (U. S.) 311. 
like wearing apparel, not be liable to execution on judgments. Regulations of this description have Chapter IV. always been considered, in every civilized community, as properly belonging to the remedy, to be exercised or not by every sovereignty, according to its own views of policy and humanity. It must reside in every State to enable it to secure its citizens from unjust and harassing litigation, and to protect them in those pursuits which are necessary to the existence and well-being of every community. And although a new remedy may be deemed less convenient than the old one, and may in some degree render the recovery of debts more tardy and difficult, yet it will not follow that the law is unconstitutional. Whatever belongs merely to the remedy may be altered according to the will of the State, provided the alteration does not impair the obligation of the contract." In Edwards v. Kear$z e y,{ }^{1}$ this passage was quoted and the last sentence was said to show that the court had in mind only small and unimportant changes and the maxim de minimis non curat lex. It was held that the means of enforcement of a contract is "the breath of its vital existence," and inseparable from the right. Accordingly a retrospective law materially increasing the homestead exemption was held unconstitutional and void. ${ }^{2}$

Laws reducing the debtor's right of homestead have been held constitutional in State courts; ${ }^{3}$ but, Laws reducing homestead. if the reduction is material, it is hard to see how

196 U. S. 595.

2 To the same effect is Gunn $v$. Barry, 15 Tall. (U. S.) 622.

3 See, for instance, Harris $v$. Glenn, $56 \mathrm{Ga} .94$; Leak $v$. Gay, 107 N. Car. 468. 

Chapter such a holding can be reconciled with the doctrine
IV. of the United States Supreme Court. If existing laws as to the enforcement of a contract become a part of its obligation for the creditor, surely the debtor may claim the same right. ${ }^{4}$ The reasoning upon which these cases are supported is that the obligation of the debtor on a contract is merely to pay the debt, and he can have no vested right in an exemption granted ex gratia by the legislature. ${ }^{5}$

\section{Laws Annexing Conditions or Penalties to Rights of Action or Prosecution.}

Requiring security before action.
A statute which recognizes a right of action as existing but regulates its assertion by requiring the plaintiff to give security before being allowed to prosecute it is not a deprivation of due process of law. Thus when the granting of an injunction to stay the collection of taxes was made dependent upon the applicant giving security, the court said: "It can hardly be necessary to answer an argument which excludes from the definition of due process of law all that numerous class of remedies in which, by the rules of court or by legislative provisions, a party invoking the powers of a court of justice is required to give that security which is necessary to prevent its process from being used to work gross injustice."

4 See Galligher $r$. Smiley, 28 Neb. 189.

s Davies Henderson Lumber Co. v. Gottschalk, 81 Cal. 641. And cases cited supra, this paragraph.

The principle that a remedy may be made more effective seems to beg the question, which is whether we are dealing with a remedy or a substantive right.

- McMillan $v$. Anderson, 95 U. S. 42. 
A statute which annexes to the right to prosecute a criminal action the penalty of costs and the liability to imprisonment until payment, if the prosecution shall appear to the court or jury to have been malicious and without probable cause, does not deny due process of law, at least when there is given to the prosecutor upon the trial the right to be heard upon the questions of malice and probable cause. ${ }^{7}$ The court reasoned that the creation of an absolute liability to costs upon the failure of the prosecution would be indisputably valid. The condition annexed to the liability threw the burden on the defendant of establishing malice and want of probable cause on the part of the prosecutor. But the prosecutor, "being the actor, had no right to complain of being obliged, if unsuccessful, to pay the costs upon the conditions previously prescribed by the legislature. Whether the question of probable cause for the prosecution, as affecting the question of costs, should be tried and determined by the court or the jury, and with or after the main question of the guilt of the defendant, is matter of convenient practice, not of constitutional right." There was nothing in the statute, or in the record, to show that the prosecutor had been denied the right to introduce evidence bearing on his good faith, or the right to a hearing on that question, and, therefore, a judgment for costs mas due process of law. ${ }^{8}$

7 Lowe $\imath$. Kansas, 163 U. S. 81.

$8 \mathrm{Mr}$. Justice Brown dissented, saying: "It is a fatal objection to the statute that it undertakes to settle in one trial the rights of two parties to a criminal cause whose interests are adrerse, and to try two distinct and disconnected issues, viz., the guilt of the principal defendant and the innocence of the prosecutor, upon testi- 
Chapter

IV.

Legislative power over rules of evidence.
Creating prima facic presumptions.

\section{Evidence and the Creation of Presumptions.}

It is within the acknowledged power of every legislature to prescribe the evidence which shall be received in the courts of the State and to determine the effect of that evidence. ${ }^{9}$ Statutes regulating evidence may even be given a retrospective effect, since rules of evidence do not form part of the contracts entered into while they are in force, and since there can be no vested right in a mere rule of evidence. ${ }^{1}$

A State may prescribe the evidence which makes a prima facie case, or determine upon whom rests

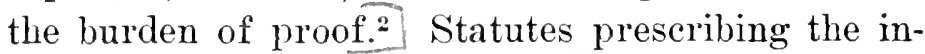
ferences to be drawn prima facie from deeds or from their registration, ${ }^{3}$ or, in a criminal prosecution, from the possession by the defendant of certain articles, implements, or papers, ${ }^{4}$ are unobjectionable from a constitutional point of view;

mony applicable to but one of such issues." In the view of the court, however, testimony on both issues must have been received. Lowe $\tau$. Kansas, 163 U. S. 81.

9 Fong Yue Ting $r$. U. S., 149 L. S. 729 ; Holmes $v$. Hunt, 122 Mass. 505.

1 Marx $v$. Hanthorn, 148 U. S. 172, citing Kendall $v$. Kingston, 5 Mass. 524; Com. v. Williams, 6 Gray (Mass.) 1; Goshen $v$. Richmond, 4 Allen (Mass.) 458; Rich $v$. Flanders, 39 N. H. 304 ; Cooley, Const. Lim. (ed. 1878) 457 .

2 Hugler $r$. Kansas, 123 U. S. 623, 674; Adams $v$. New York, 192 U. S. 585.

3 Pillow $v$. Roberts, 13 IIow. (U. S.) 472; Webb $v$. Den, 17 How. (U. S.) 576; Callanan $v$. Hurley, 93 U. S. 387; Gage $v$. Kaufman, I33 U. S. 47I; Marx $v$. Hanthorn, 148 U. S. 172; Turpin $r$. Lemon, 187 U. S. 59. These are cases of tax deeds, made by statute prima facie evidence of the regularity of the tax title or the like.

4 Adams $v$. New York, 192 U. S. 585. 
provided, it has been held, that the facts upon which the statute raises the presumption have some fair relation to, or natural connection with, the fact presumed; that the inference authorized is not wholly arbitrary, umreasonable or unnatural; and that the person against whom the presumption is drawn has in every case a fair opportumity to make his defense, and, in criminal cases in jurisdictions where trial by jury is guaranteed, to submit the whole question of guilt or innocence to the decision of the jury, after it has weighed all the evidence and given such weight to the presumption as it shall deem proper.5.

The right of a legislature to make the inference from particular states of facts conclusive and ir'e-

Conclusive presump. tions generally.

5 Excise Con'rs $v$. Merchant, 103 N. Y. 143, 57 Am. Rep. 705 ; People $v$. Cannon, 139 N. Y. 32.

Such presumptions are frequently created by the legislature in the exercise of the police power, with reference to offences against liquor laws. Mugler $v$. Kansas, 123 U. S. 623, 674; State $v$. Thomas, 47 Conn. 546, 36 Am. Rep. 98; Com. $v$. Williams, 6 Gray (Mass.) 1; Excise Com'rs $v$. Merchant, 103 N. X. 143, 57 Am. Rep. 705 ; State $v$. Higgins, 13 R. I. 330 (compare State $v$. Beswick, 13 R. I. 211, $43 \mathrm{Am}$. Rep. 26; State $v$. Kartz, 13 R. I. 528, wherein a rebuttable inference from the general reputation of a place as selling liquor illegally was held to deny due process and exceed the powers of the legislature). The game laws: $E x$ p. Maier, 103 Cal. 47, $42 \mathrm{Am}$. St. Rep. 129; Dickhaut $v$. State, 85 Md. 451, 60 Am. St. Rep. 332; and see generally Geer $v$. Connecticut, 161 U. S. 519. Laws to suppress gambling: Adams $v$. New York, 192 U. S. 585, affirming 176 N. Y. 351 ; Voght $v$. State, 124 Ind. 358.

Such statutes, within the limitation stated, do not change the burden of proof, in the sense that a particular quantum of evidence shall be necessary for conviction, but only regulate a formal matter of procedure, the duty of going forward with the evidence. Com. $v$. Williams, 6 Gray (Mass.) 4; People $v$. Cannon, 139 N. Y. 43, 44. 36 Am. St. Rep. 668. Nor do they take away the presumption of innocence. See Thayer, Prelim. Treatise on Evid. 380, 384; Davis $v$. U. S., 160 U. S. 485. 
Chapter buttable, has been vigorously challenged. ${ }^{6}$ The conIV. stitutionality of such statutes depends, however, not on the creation of a conclusive presumption, but upon the character of the matter conchuded. Upon an issue on which a person is entitled to a hearing, an issue the determination of which involves a judicial or quasi-judicial inquiry, the legislature has evidently no power to enact arbitrarily that certain evidence shall be conclusive, any more than it can enact that a court may determine a question without giving the parties an opportunity to be heard. ${ }^{7}$ The legislature can not, therefore, deprive one of his property by making conclusive of its own validity his adversary's claim to title irrespective of what that claim may be; and so it can not make a tax deed conclusive evidence of the vendee's title, ${ }^{8}$ unless before it is made conclusive a reasonable time is allowed for the assertion of adverse rights. ${ }^{9}$ But it may make such a deed conclusive of compliance with all the requirements of law which are merely directory and might have been dispensed with by the legislature in the first place without affecting the validity of the proceedings." The legislature, in

- Wantlan $v$. White, 19 Ind. 470; Voght $v$. State, 124 Ind. 358; Missouri, ete., R. Co. v. Simonson, 64 Kan. 802.

${ }^{7}$ Chicago, ete., R. Co. $v$. Minnesota, 134 U. S. 418; Felix $v$. Wallace County, 62 Kan. 832; Howard $v$. Moot. 64 N. Y. 268.

$8 \operatorname{Marx} v$. Hanthorn, 148 U. S. 182; Turpin $v$. Lemon, $187 \mathrm{U}$. S. 59.

- Such an act is in effect a statute of limitations. Turner $v$ New York, 165 U.S. 90 (affirming 145 N. Y. 451, and approving People $v$. Turner, 117 N. Y. 227) ; Saranac Land, ete., Co. $v$. Comptroller, 177 U.S. 318 . Sce supra, p. 171.

1 Allen $v$. Armstrong, 16 Iowa 513; Larson $v$. Dickey. 39 Neb. 463, 42 Am. St. Rep. 595; Strode $v$. Washer, 17 Oregon 53. See also Marx $v$. Hanthorn, 148 U. S. 172, 30 Fed. Rep. 585. 
a word, cannot by its fiats create presumptions which are conclusive of matters upon which the existence of jurisdiction depends, and among these is the right to a hearing before condemnation.

But it has been said that the prohibition does not extend to the adoption as conclusive of evidence Conclusive presumpwhich, according to the ordinary lules of human exvalid. perience, reasonably tends to prove a fact. ${ }^{3}$ The rule thus announced has been adopted by the Supreme Court of the United States in a case involving the right of a State legislature to enact that conviction of felony shall be an absolute disqualification to practice medicine. The court sustained the statute upon the theory that even as applied to a physician who had been convicted before its passage, it was not a punishment for crime, but established a rule of evidence as to character. It said: "If a State may require good character as a condition of the practice of medicine, it may rightfully determine what shall be the evidences of that character. We do not mean to say that it has an arbitrary power in the matter, or that it can make a conclusive test of that which has no relation to character, but it may take whatever, according to the experience of mankind, reasonably tends to prove the fact and make it a test.* Whatever is ordinarily connected with bad character, or indicative of it, may be prescribed by the legislature as conclusive evidence thereof. It is not the province of the courts to say that other tests would be more satisfactory, or that

s County Seat of Linn County, 15 Kan. 528, per Brewer, J., since of the U. S. Supreme Court.

4 Citing County Seat of Linn County, 15 Kan. 500, 528. 
Chapter the naming of other qualifications would be more
IV.

conducive to the desired result. These are questions for the legislature to determine." 5

Conclusive presumptions in matters of contract.

The legislature may, it appears, create conclusive presumptions upon the principles of estoppel from the signing of a contract; and it may, in the exercise of a power analogous to that exerted in the passage of curative or validating acts, provide that a deed shall be conclusive as to all nou-essential matters. Thus on the principle of estoppel, a law providing that a fire-insurance policy should be conclusive of the value of the property when the policy was issued, was held to be constitutional. Its effect was said to be merely to change open policies to valued ones. "It makes," said the court, "no contract for the parties. In this it permits absolute freedom. It leaves them to fix the valuation of the property upon such prudence and inquiry as they choose. It only ascribes estoppel after this is done - estoppel, it must be observed, to the acts of the parties, and only to their acts in open and honest dealing. Its presumptions can not be urged against fraud." The court further observed that the cases holding that the legislature can not create conclusive presumptions do not apply. Those cases "were not of contract nor gave effect to contracts. It is one thing to attribute effect to the convention of parties entered into under the admonition of the law, and another thing to give to circumstances, maybe accidental, conclusive presumption and proof to establish and force a result against property or lib-

s Hawker $v$. New York, 170 U. S. 189, 195, opinion of the court by Brewer, J. 
erty." ${ }^{6}$ Decisions in State courts holding unconstitutional as against a party to a contract an estopChapter IV. pel which the legislature makes conclusive from its execution, for instance, a statute making bills of lading issued by railroad companies conclusive as to the amount of grain, etc., shipped, ${ }^{\top}$ appear upon the principle just stated to be unwarranted.

Statntes have in some State courts been construed as creating only a prima facie presumption on the ground that to hold the presumption created as absolute would render the statutes contrary to reason and void as depriving a person of property without a hearing. An instance is a statute in one interpretation rendering railroads absolutely liable for "damages to persons and property done or caused by the running of trains.", 8 But the ground of such a ruling in this case would appear indefensible, and the validity of such statutes has been upheld as a proper exercise of the police power of the State in the regulation of thc use of appliances peculiarly dangerous. In a case holding valid the Missouri statute declaring railroads liable abso-

6 Orient Ins. Co. $v$. Daggs, 172 U. S. 557. The holding in this case has been followed in New York L. Ins. Co. $v$. Cravens, $178 \mathrm{U}$. S. 399 ; John Hancock Mut. L. Ins. Co. $v$. Warren, 181 U. S. 76 ; Fidelity Mut. L. Assoc. $v$. Mettler, 185 U. S. 326 . But it will be noted that all these cases concerned foreign corporations doing business in a State, and the decisions were put on the ground also of the State's right to control such corporations.

7 Missouri, etc., R. Co. $v$. Simonson, 64 Kan. 802, 91 Am. St. Rep. 248, Doster, C. J., dissenting. It has been held beyond the power of Congress to make the oath of an infant on his enlistment in the United States army that he is of age conclusive of the fact. Wantlan $v$. White, 19 Ind. 470. Compare Matter of Cline, 1 Ben. (U. S.) 338 .

8 Little Rock, etc., R. Co. v. Payne, 33 Ark. 816, 34 Am. Rep. 55 ; and see Zeigler $v$. South, etc., Alabama R. Co., 58 Ala. 594. 
Chapter lutely for fires produced by their engines, the United IV. States Supreme Court said: "The right of the citizen not to have his property burned without compensation is no less to be regarded than the right of the corporation to set it on fire. To require the utmost care and diligence of the railroad corporations in taking precautions against the escape of fire from their engines might not afford sufficient protection to the owners of property in the neighborhood of railroads. When both parties are equally faultless, the legislature may properly consider it to be just that the duty of insuring private property against loss or injury caused by the use of dangerous instruments should rest upon the railroad company, which employs the instruments and creates the peril for its own profit, rather than upon the owner of the propertr, who has no control over or interest in those instruments." 9

Other

absolute liabilities under police power.
The exercise of the police power in its widest sense, the power of the State to regulate the economic relations of its citizens and persons within its jurisdiction, has been held to justify the creation of presumptions as to various matters based on doctrines of natural equity and common advantage. A statute of Utalı enacted that persons driving stock along highways should be responsible for damage done by the animals in destroying the banks of, or rolling rocks into, the highway. The objection that the statute denied due process of law, the Supreme Court held to be untenable. The act was declared to be a valid exercise of police power. "In effect," said the court, after referring to the case last mentioned,

? St. Louis, etc., R. Co. $v$. Matthews, 165 U. S. 1. 
"the legislature declared that the passage of droves or herds of animals over a hillside highway was so likely, if great precautions were not observed, to result in damage to the road, that where this damage followed such driving, there ought to be no controversy over the existence or non-existence of negligence, but that there should be an absolute legal presumption to that effect resulting from the fact of having driven the herd. - . . It was obviously the province of the State legislature to provide the nature and extent of the legal presumption to be deduced from a given state of facts, and the creation by law of such presumptions is, after all, but an illustration of the power to classify. When the statute is properly understood, therefore, the argument of the plaintiff in error amounts to an assertion that the whole subject of the probative force to arise by operation of law, from any specified state of facts, is, in every sense, by the effect of the Fourteenth Amendment, removed from the jurisdiction of the local authorities. . . As the statute clearly specifies the condition under which the presumption of negligence arises and provides for the ascertainment of liability by judicial proceedings, there is no foundation for the assertion that the enforcement of such ascertained liability constitutes a taking of property without due process of law." 1

Evidence is not rendered inadmissible because it was obtained in an unfair or illegal manner; it illegally may be still pertinent to the issue, although he who obtained it may be liable to civil suit or even to

1 Jones $v$. Brim, 165 U. S. 180. 
Chapter criminal prosecution. ${ }^{2}$ This principle must be careIV. fully distinguished from the ruling that evidence is inadmissible, the use of which compels the defendant in a criminal case, contrary to a constitutional guaranty, to give evidence against himself; or which, in violation of the constitutional provision against unreasonable searches and seizures, was obtained in a search the object of which was to seize private papers of the defendant of such a character that their use would make him a witness against himself. ${ }^{3}$ The use of evidence obtained under duress upon an examination of the defendant in a criminal case by a physician acting pursuant to a direction from the prosecuting attorney, has been held a violation of the defendant's right under the State constitution to be free from unreasonable searches and seizures, and also to be an infringement of the guaranty of due process of law. ${ }^{4}$

2 Adams $v$. New York, 192 U. S. 585, affirming 176 N. Y. 351 ; Com. $v$. Dana, 2 Met. (Mass.) 329; Com. $v$. Tibbetts, 157 Mass. 519. 3 Boyd $v$. U. S., 116 U. S. 616.

This case has been frequently distinguished. See Adams $v$. New York, 192 U. S. 585; State v. Griswold, 67 Conn. 290; Gindrah v. People, 138 Ill. 103: State v. O’Connor, 3 Kan. App. 594.

4 State $v$. Height, 117 Iowa 650. 


\section{CHAPTER V.}

\section{THE PERSONS PROTECTED BY DUE PROCESS.}

$\mathrm{B}^{\mathrm{o}}$ OTH the Fifth and Fourteenth Amendments to the United States Constitution use in connecChapter V. tion with the guaranty of due process of law the word "person," which includes every one within the territory of the United States, without regard to differences of race, color, or nationality. ${ }^{1}$

\section{CORPORATIONS.}

Within the class of persons thus protected are corporations, ${ }^{2}$ including foreign corporations doing business within the State, when and only when such corporations have complied with the reasonable and lawful conditions imposed upon them by the laws of the State ${ }^{3}$ and in accordance with the terms of those conditions, which must give a right to hearing before condemnation. ${ }^{4}$ But due process of law does not demand that an absolute equality between

1 Yick Wo $v$. Hopkins, 118 U. S. 369 (Fourteenth Amendment) ; Wong Wing $r$ U. S., 163 U. S. 236, 237 (Fifth Amendment).

2 Santa Clara County $v$. Sonthern Pae. R. Co., 118 U. S. 394; Covington, etc., Turnpike Road Co. $v$. Sandford, 164 U. S. 57S, 592; Smyth $v$. Ames, 169 U. S. 522; Lake Shore, etc., R. Co. $v$. Smith, 173 U. S. $684,690$.

Corporation charters are contracts within the clause forbidding the impaiment of contracts. See supra, p. 151.

3 Philadelphia F. Assoc. v. New York, 119 U. S. 110; Pembina Consol. Silver Min., ete., Co. $v$. Pennsylvania, 125 U. S. 181.

4 St. Clair $v$. Cox, 106 U. S. 356; Barrow Steamship Co. $v$, Kane, 170 U. S. 100. See supra, p. 102. 
Chapter foreign corporations and domestic corporations
. shall be established. The State may, in certain directions, discriminate against foreign corporations, since corporations are not citizens within the privilege and immunity clauses of the Constitution. ${ }^{5}$

\section{ALIENS - IMMIGRATION LAWS.}

Aliens are entitled to due process of law, but the position of resident and nonresident aliens is different. ${ }^{6}$

Power of administrative officials to exclude aliens.
Every sovereign state has, as inherent in its sovereignty, the right to forbid the entrance of foreigners within its dominions, or to admit them only in such cases and upon such conditions as it may see fit to prescribe. ${ }^{7}$ The exercise of this power belongs to the political department of the government. Congress may, therefore, make laws providing for the exclusion of aliens, prescribing the terms and conditions on which they may be admitted, and establishing regulations for the deportation of aliens who have entered in riolation of law, and may commit the enforcement of such laws to executive offcers. ${ }^{8}$ Further, although Congress may, if it sees fit, authorize the courts to investigate and ascertain the facts upon which the alien's right to land was made by the statutes to depend, yet it may intrust the final determination of those facts to an

5 Blake $r$. McClung, 172 U. S. 259, 260; Sully $v$. American Nat. Bank, 178 U. S. 289. See Wise, Citizenship, 167 et seq.

e U. S. $v$. Williams, 194 U. S. 279 ; U. S. $v$. Ju Toy, 198 U. S. 263.

7 Chae Chan Ping $v$. U. S. (Chinese Exclusion Case), 130 U. S. 581 ; Nishimura Ekiu $v$. U. S., 142 U. S. 659; U. S. $v$. Ju Toy, 198 U. S. 253.

8. Japanese Immigrant Case, 189 U. S. 86 ; U. S. $v$. Williams, 194 U. S. 279. 
executive or administrative officer, and, if it does Chapter so, his order is due process of law, and no other tribunal, unless expressly authorized by law, is at liberty to examine the evidence on which he acted or to controvert its sufficiency. ${ }^{9}$ It seems to follow that the order of an administrative officer excluding aliens made in pursuance of statutory authority is, of necessity, due process. A later case shows that something more is required. In the Japanese Immigrant Case," it was said: "This court has never held, nor must we now be understood as holding, that administrative officers, when executing the provisions of a statute involving the liberty of persons, may disregard the fundamental principles that inhere in 'due process of law' as understood at the time of the adoption of the Constitution. One of these principles is that no person shall be deprived of his liberty without opportunity at some time to be heard before such officers in respect of the matters upon which that liberty depends - not necessarily an opportunity upon a regular, set occasion, and according to the forms of judicial procedure, but one that will secure the prompt vigorous action contemplated by Congress, and at the same time be appropriate to the nature of the case upon which such officers are required to act." 2

While, however, Congress may lawfully exclude,

9 Nishimura Ekiu $v$. U. S., 142 U. S. 651; Fong Yue Ting $v$. U. S., 149 U. S. 711.

1189 U. S. 100.

2 The reading of the opinion of the court in U. S. $v$. Ju Toy, 198 U. S. 253, and the dissenting opinions of Brewer, J. (concurred in by Peckham, J.), in that case and in U. S. $v$. Sing Tuck, 194 U. S. 161, where the real hearing allowed aliens under the Inmigration Laws is set forth, is interesting in the light of the above passage. 
Chapter or regulate the admission of, aliens, an alien who
.

Aliens

rightfully

in country

protected

as citizens

are.

Clandes. tine entry. according to law is rightfully within the country, is entitled to the benefit of the guaranties of life, liberty, and property secured by the Constitution to all persons within the jurisdiction of the United States, and is as fully protected as if he were a native or naturalized citizen of the country. ${ }^{3}$ Among other rights, such an alien is entitled, where his life and liberty are involved, to the same regular course of judicial proceedings as is afforded to citizens, and he can not be summarily deprived of either upon a mere executive hearing." Accordingly it has been held, that the exclusion laws must be confined in their operation to aliens, and can not be applied to citizens of the United States, ${ }^{5}$ nor to any person who is not in strictness an alien, although he may not be entitled to the status of a citizen. ${ }^{6}$

But an equality of right with citizens is not acquired by a clandestine entry into the country and residence here for a period too brief to make the alien in any real sense a part of our population; and the Act of Congress giving, for the

3 Lem Moon Sing $v$. U. S., 158 U. S. 538.

4 Thongh this proposition has not in so many words been announced, it follows necessarily from the principle stated in Hagar $v$. Reclamation Dist. No. 108, 111 U. S. 711, considered with reference to Yick Wo $v$. Hopkins, 118 U. S. 356 ; Wong Wing $v$. U. S., 163 U. S. $22 S$; U. S. $v$. Wong Kim Ark, 169 U. S. 649.

5 U. S. $v$. Wong Kim Ark. 169 U. S. 649.

6 Gonzales $v$. Williams, 192 U. S. 1, where the Acts were held not applicalle to a citizen of Porto Rico since the Act of April 12. 1900 (5 Ferl. Stat. Annot. 762 ), creating a civil government for Porto Rico, etc. pursuant to the cession of the island by Spain. but the court did not pass upon the question whether the people of Porto lico are citizens of the United States. 
period of one year after the landing of such aliens, ${ }^{-}$Chapter the right to deport them upon the order of the V. proper executive officer, whose action in the premises is conclusive, is valid. ${ }^{7}$ Congress has, however, no power to declare that the offense of unlawful residence by an alien within this country is an infamous crime punishable upon a summary hearing by imprisonment at hard labor or by confiscation of property. Detention or temporary confinement as a means of giving effect to the exclusion acts is valid, but an infamous punishment can not be inflicted unless provision is made for a judicial trial to establish the guilt of the accused. ${ }^{\mathrm{s}}$

The equality of right acquired by a resident alien, except as affects his property remaining in this country, is lost by departure from the United Effect of
leaving couning tempora. States even for a temporary purpose; and when, after a temporary absence, he attempts to return, he is subject to the jurisdiction of the executive officers of the government, as would be an alien presenting himself for the first time at our ports. "He ean not," said the court, in a case presenting this issue, "by reason merely of his domicil in the United States for purposes of business demand that his claim to re-enter this country by virtue of some statute or treaty shall be determined ultimately, if not in the first instance, by the courts of the United States, rather than exclusively and finally, in every instance, by executive officers charged by

7 Japanese Immigrant Case, 189 U. S. 86, approving U. S. $v$. Yamasaka, (C. C. A.) 100 Fed. Rep. 404; U. S. v. Ju Toy, 198 U. S. 253.

8 Wong Wing $v$. U. S., 163 U. S. 228 ; U. S. $v$. Williams, 194 U. S. 280 . 

Chapter an Act of Congress with the duty of executing the
V. will of the political department of the government in respect of a matter wholly political in its character." 9

Determining status oi person entering

Whether a person seeking to enter the United States is a citizen and so entitled to have his rights adjudicated by a regular course of judicial procedure, or is an alien whose rights may be finally determined by an executive officer of the government, is a question which presents difficulties. It has been set at rest by a progressive series of decisions, ending in the somewhat anomalous holding that the decision of the executive officer upon the question of citizenship is final, thus lifting an immigration official above all regular courts by allowing him to determine finally the existence of his own jurisdiction. ${ }^{1}$ In 1895 it was held, in the case of an admitted alien, that, under the Act of Congress of August 18, 1894, the decision of the immigration commissioner was final of the aliens' right to enter "by virtue of some law or treaty."' 2 In 1898 the decision of an administrative official excluding a

9 Lem Moon Sing $v$. U. S., 158 U. S. 538, 548, distinguishing Lau Ow Bew $v$. U. S., 144 U. S. 47, and Gee Fook Sing $v$. U. S., 7 U. S. App. 27, 49 Fed. Rep. 147, as having been decided before the statute making executive decision final.

1 U. S. $v$. Ju Toy, 198 U. S. 253.

2 Lem Moon Sing $v$. U. S., 158 U. S. 538.

This decision has been virtually reaffirmed in cases of admitted aliens which involved an alien's right to travel through the United States from one of its ports to a foreign country. The alien has been stopped at the port of his entry into the United States and ordered deported to his own country, because he has failed to satisfy the collector of customs that he intended in good faith to continue his journey to such foreign country, and this proceeding has been adjudged to be valid. Fok Yung Yo $v$. U. S., 185 U. S. 296 ; Lee Gon Yung $v$. U. S., 185 U. S. 306. 
per'son as an alien was reversed on habeas corpus, where there was an admission on behalf of the government of facts which made the person excluded a citizen of the United States. ${ }^{3}$ This decision led to many claims of citizenship on the part of excluded aliens, upon the theory that such a claim ousted the jurisdiction of the immigration officer. But in 1902 when the point was presented to the Supreme Court, ${ }^{4}$ it was held that the mere claim of citizenship did not affect the official's jurisdiction; that "the facts on which such a claim is rested must be made to appear.", The court observed: "It is impossible for us to hold that it is not competent for Congress to empower a United States commissioner to determine the various facts on which citizenship depends."

It might be inferred from these expressions that when the facts were made to appear, a decision Administrative decision not against the claim of citizenship would be reviewed by the courts, and that the jurisdiction of the immigration officer was to decide this question in the first instance only. In 1904 the court held that the person whose claim to citizenship was decided adversely by an immigration inspector had no right of immediate recourse to the courts; an appeal must first be taken, in accordance with the procedure marked

\section{U. S. v. Wong Kim Ark, 169 U. S. 649.}

This case confirmed a series of decisions of the courts of the Ninth Circuit, beginning in 1884 with In re Look Tin Sing, 10 Sawy. (U. S.) 353, 21 Fed. Rep. 905, wherein the opinion was rendered by Mr. Justice Field, as circuit justice. See In re Wong Kim Ark, 71 Fed. Rep. 382.

4 Chin Bak Kan $v$. U. S., 186 U. S. 193.

As to what evidence of citizenship is necessary, see Ark Foo $v$. U. S., (C. C. A.) 128 Fed. Rep. 697. 

Chapter out by the statute, to the secretary of the treasury,
V. and withont such appeal the courts will not entertain the question on habeas corpus. The decision was further based on the ground that the granting of habeas corpus depends on making a prima facie case, which the petitioner had not done. ${ }^{5}$ A case in 1905 went further. A person, claiming citizenship, was denied the right to enter the United States by the collector of the port of San Francisco. He appealed to the secretary of commerce and labor, to whom, since the creation of that department, the appeal lay, and upon confirmation of the ruling, applied to the District Court of the United States for a habeas corpus, and the District Court decided, "seemingly on new evidence," that the petitioner was a native born citizen of the United States. The Supreme Court held that the action of the District Court was error; that it should have determined the writ without a hearing on new and further evidence as to citizenship in the absence of any showing of an abuse of discretion on the part of the executive officer; because in the absence of such showing the decision of the secretary of commerce and labor was conclusive, even upon the question of citi-

5 U. S. $\varkappa$. Sing Tuck, 194 U. S. 161 , reversing (C. C. A.) 128 Fed. Rep. 592.

The court seems to have been influcnced in this case by the consideration, which is surely not a judicial one, that a contrary decision would result in overwhelming the courts with a flood of litigation. "We are of opinion," it was said. "that the attempt to disregard and override the provisions of the statutes and the rules of the department and to swamp the courts by a resort to them in the first instance must fail." It is to be noted that in $\mathrm{U}$. S. $v$. Wong Kim Ark, 169 U. S. 649, the habeas corpus seems to have been granted immediatcly after the decision of the collector of the port of San Francisco. 
zenship, on the nonexistence of which jurisdiction Chapter
depends. ${ }^{6}$

INHABITANTS OF ACQUIRED TERRITORY.

When territory is "incorporated into the United States," it becomes subject to the Constitution of the United States, and its inhabitants are entitled "Effect of ration into the United to the benefit of the guaranties of life, liberty, and property contained in the first eight amendments to that instrument. ${ }^{7}$ Territory may become incor-

6 U. S. v. Ju Toy, 198 U. S. 253.

In U. S. $v$. Sing Tuck, 194 U. S. 161,170 , the court, in the state of the record, declined to pass upon the question which was presented later in U. S. $v$. Ju Toy, 198 U. S. 253. In Ju Toy's case the court proceeded on the ground, inter alia, that the question was virtually settled by precedent, including Sing Tuck's Case.

7 Dorr $v$. U. S., 195 U. S. 138; Rassmussen $v$. U. S., 197 U. S. 516.

The question of the status of the inhabitants of the territories ceded by Spain by the Treaty of Paris as a result of the SpanishAmerican War came prominently before the court in the so-called “Insular Cases," namely, De Lima $v$. Bidwell, 182 U. S. 1; Goetze $v$. U. S., 182 U. S. 221 ; Dooley $v$. U. S., 182 U. S. 222; Armstrong $v$. U. S., 182 U. S. 243; Downes v. Bidwell, 182 U. S. 244.

The specific matter involved was the authority of Congress to regulate tariff relations between the United States and Porto Rico, but the whole subject of the status of acquired territory and the powers of Congress with respect thereto was exhaustively discussed, especially in Downes $v$. Bidwell. Unfortunately the nembers of the court could come to no agreement as to the reasoning upon which the decision should stand, and four justices dissented from the ultimate disposition of the case. What may be called the plurality opinion was rendered by White, J., speaking also for Shiras and McKenna, J.J.; Gray, J., who agreed in substance with the plurality, delivered a concurring opinion; while Brown, J., delivered the opinion of the court, speaking, except as to the disposition of the case, for himself alone.

The plurality opinion stated the doctrine of "incorporation" as laid down in the text above, and this doctrine is formally restated in Rassmussen $v$. U. S., 197 U. S. 516, in the opinion of the court by White, J.; Harlan and Brown, J.J., in concurring opinions eriticised the incorporation theory. Mr. Justice Harlan has throughout all cases presenting the question taken the view that the Con- 
Chapter porated into the United States, as a result of the $\mathrm{V}$.

terms of the treaty of cession by which the United States as a sovereign nation acquires the territory from the sovereignty ceding it, and by legislation on the part of Congress with reference to the territory after its acquisition. ${ }^{8}$ Until it is incorporated by action on the part of Congress, "the territory is to be governed under the power existing in Congress to make laws for such territories, and subject to such constitutional restrictions upon the powers of that body as are applicable to the situation." 9

Status of territory annexed but not "incorporated."
The bare annexation of territory then does not ipso facto extend over it the provisions of the Constitution, and there may be a period of longer or shorter duration during which the enactments of Congress relative to the territory acquired are the supreme law, subject, however, to certain "fundamental limitations in favor of personal rights," 1

stitution with all its guaranties applies to all the territory acquired by the United States. Mr. Justice Brown, referring for a full exposition of his views to Downes $v$. Bidwell, $182 \mathrm{U}$. S. 244, says: "My position . . . js simply that the Constitution does not apply to territories acquired by treaty until Congress has so deelared. and that in the meantime, under its power to regulate the territories, it may deal with them regardless of the Constitution, exeept so far as concerns the natural rights of their inhabitants to life, liherty and property. . . My own view is, and has been, that Congress in dealing with newly aequired territory is unfettered by the Constitution, unless it formally or by implication extends the Constitution to it." Rassmussen $r$. U. S., 197 U. S. 531, 532.

8 Rassmussen $x$. U. S., 197 U. S. 516. And see the preceding note.

9 Hawaii $r$. Mankichi, 190 U. S. 197 ; Dorr $r$ U. S. 195 U. S. 143.

1 Church of Jesns Christ $r$. U. S.. 136 U. S. 1. 44: Downes v. Ridwell, 182 U. S. 244. 277. per Brown, J., aud at p. 29.5, per White. Shiras. and MeKenna, J.J.; Dorr $v$. U. S., 195 U. S. 135. See also Murphy 1 . Ramsey, 114 U. S. 15, 44.

These limitatinns in such a case "would exist rather by inference and the general spirit of the Constitution from which Con- 
which are found in the spirit of the Constitution. Chapter How long the period before incorporation shall last is a question for the political departments of the government, and what those rights are which in the meanwhile limit the uncontrolled exercise of legislative discretion, "must be decided as questions arise." 2 A distinction, however, has been made between those provisions of the Constitution which prohibit the exercise of certain powers under any and all circumstances, such as Art. I, sec. 9, cl. 3, prohibiting absolutely bills of attainder and ex post facto laws, and those contained in the National Bill of Rights guaranteeing certain rights and privileges. ${ }^{3} \quad$ The right of jury trial or of indictment by a grand jury as provided for in the Fifth and Sixth Amendments has been held not to be included among the rights to which the inhabitants of territory acquired but not incorporated can lay claim. ${ }^{4}$ Whether among these fundamental rights is due process of law is a question which has not arisen, but there can be no doubt that when it does arise it will be decided in the affirmative.

Territory "incorporated into the United States" the inhabitants of which are entitled to the rights

The territory entitled to all guaranties.

gress derives all its powers, than by any express and direct application of its provisions." Church of Jesus Christ $v$. U. S., 136 U. S. 1.

2 Dorr $v$. U. S., 195 U. S. 149.

3 Downes $v$. Bidwell, 182 U. S. 277, per Brown, J. See also Dred Scott $v$. Sandford, 19 How. (U. S.) 614, per Curtis, J.; Dorr v. U. S., 195 U. S. 138.

In the passage cited from Downes $v$. Bidwell, it is said: " We do not wish, however, to be understood as expressing an opinion how far the bill of rights contained in the first eight amendments is of general and how far of local application."

4 Hawaii v. Mankichi, 190 U. S. 197 ; Dorr v. U. S., 195 U. S. 138. 
Chapter guaranteed by the first eight amendments, includes the Territories in a strict and technical sense, being those which lie within the United States, between the Atlantic and Pacific oceans, ${ }^{5}$ and the Territories of Alaska and Hawaii. ${ }^{6}$ The power of Congress in legislating for the District of Columbia and all places acquired by the United States within the several States for forts, arsenals, etc., ${ }^{7}$ is subject to the like restrictions. ${ }^{8}$

5 That the Federal Bill of Rights extends to the territories within the limits of the United States previous to the purchase of Alaska in 1867 , seems after some besitation in earlier cases (Chureh of Jesus Christ $v$. U. S., 136 U. S. 1) settled by adjulication beyond controrersy. American Pub. Co. $v$. Fisher, 166 U. S. 464; Springville $v$. Thomas, 166 U. S. 707 ; Thompson $v$. Utah, 170 U. S. 343 ; Black $v$. Jackson, 177 U. S. 349 ; Rassmussen $r$. U. S., 197 U. S. 516.

6 Alaska is within the Federal Bill of Rights. Steamer Coquit$\operatorname{lam} v$. U. S., 163 U. S. 346 ; Binns $v$. U. S., 194 U. S. 486 ; Rassmussen $r$. U. S., 197 U. S. 516.

ITawaii is technically a territory of the United States since the Act of Congress of April 30, 1900, 31 U. S. Stat. at L. 141, c. 339; 3 Fed. Stat. Annot. 186. Hawaii v. Mankiehi, 190 U. S. 197.

i Const. U. S., Art. I, sec. 8, cl. 17; S Fed. Stat. Annot. 663.

8 "There is nothing in the history of the Constitution or of the original amendments to justify the assertion that the people of this District [of Columbia] may be lawfully deprived of the benefit of any of the constitutional guaranties of life, liberty, and property." Callan $v$. Wilson, 127 U. S. 540, 550. See Loughborough $v$. Blake, 5 Wheat. (U. S.) 317 , commented on in Downes $r$. Bidwell, 182 U. S. 244, 259, 262; Capital Traction Co. $v$. Hof, 174 U. S. 1. 


\section{CHAPTER VI.}

THE PARAMOUNT RIGHTS OF THE STATE AND DUE PROCESS.

$T^{1}$

HE guaranties of life, liberty and property contained in the Federal and State Constitutions are not absolute; for all private rights, however fundamental, are enjoyed by individuals as members of organized society, and subject to the paramount right of the state, the embodiment of society, to appropriate or modify them when actual necessity or the public welfare requires such a course. ${ }^{1}$ This paramount right of the state is susceptible of classification, in ordinary cases, under three heads, the police power, the power of eminent domain, and the power of taxation. ${ }^{2}$ Each of these powers is incident to the sovereignty of the state, and all of them reside in and are exercised by the legislative department of government.

The exercise of all these powers proceeds on the theory that the public welfare requires the sacrifice Taxation; eminent of private rights. In eminent domain, the sacrifice

Chapter VI.

Private rights general welfare.

1 Crowley $v$. Christensen, 137 U. S. 86; California Reduction Co. v. Sanitary Reduction Works, 199 U. S. 306.

2 Though "the police power" is used by the Supreme Court of the United States and by the courts generally to include the state's legislative power when exerted in making regulations, not only for the safety, morals, and health of the people, but for the economic welfare of the community, it is doubtful whether this usage does not produce confusion. The general legislative power differs in fundamental particulars from the power to provide for public safety, health, and morals. See infra, p. 300 . 
Chapter of his strict property rights is made up to the owner VI. by direct payment of the value of the property taken. $^{3}$ In taxation, the theory is that the value of the taxes exacted is returned indirectly in the benefits derived by the tax-payer from the government, to the support of which his payments contribute; and that the benefits thus indirectly conferred are in exact proportion to the amount of his contribution. ${ }^{4}$ Upon these considerations a distinction between the taxing power and the power of eminent domain is founded. "In case of taxation," it has been said, "the citizen pays his quota of the common burden. When his land is sequestered for the public use he contributes more than such quota, and this is the distinction between the effect of the exercise of the taxing power and that of eminent domain. When, then, the overplus beyond benefits from these local improvements is laid upon a few landowners, such citizens with respect to such overplus are required to defray more than their share of the public outlay, and the coercive act is not within the proper scope of the power to tax."'s But the practical result of this distinction is reduced to a minimum, because of

3 " When private property is taken for public use, the owner receives full compensation. The taking differs from a sale by him only in that the transfer of title may be compelled, and the amount of compensation be determined by a jury or officers of the government appointed for that purpose." Mobile County $v$. Kimball, 102 U. S. 691. See also Union Refrigerator Transit Co. v. Kentueky, 199 U. S. 194.

4 Mobile County $x$. Kimball, 102 U. S. 691; Illinois Cent. R. Co. $v$. Decatur, 147 C. S. 190; Rolph $v$. Fargo, 7 N. Dak. 640; Webster $v$. Fargo, 9 N. Dak. 208.

5 State $r$. Newark, 37 N. J. L. 415, quoted in Norwood $r$. Baker, 172 U. S. $269,2 S 4$. 
the large discretion vested in the legislature in Chapter equating benefits to burdens. ${ }^{6}$

The police power is different in its operation. It regulates the enjoyment of personal or property rights on the principle that they must be so exercised VI. as to permit an equal enjoyment in others, as expressed in the maxim, sic utere tuo ut alienum non laedas. ${ }^{7}$ Or, it may destroy property on the ground that destruction is necessary to the self-protection of the community, for salus populi est suprema lex. Unlike eminent domain, however, it always proceeds without actual compensation; and frequently, unlike taxation, there is not even in theory any return in benefits for property confiscated or liberty curtailed. It is true that in a number of trpical instances an equivalent return in the common benefits conferred on the community may be postulated. This is the case when loss results to a person or class from the prohibition of particular uses of property or the exercise in certain respects of personal liberty, or from the forced expenditure of money in guarding against apprehended ills. Here it is usual to say that the person or persons who suffer an undoubted loss are compensated for it by sharing in the general benefits which the regulations from which the loss results are intended and calculated to secure. ${ }^{8}$. No compensation is, however, necessary, for such regu-

6 See infra, p. 253.

7 Richmond, etc., R. Co. $v$. Richmond, 96 U. S. 521, upholding the prohibition of steam locomotives on eity streets.

81 Dill. Munic. Corp., 4th ed., \$ 141: Ex p. Lacey. 108 Cal. 326; State $v$. Campbell, 64 N. H. 402 ; Health Dept. $v$. Trinity Church, 145 N. Y. 32; Thorpe $v$. Rutland, ete., R. Co., 27 Vt. $140,62 \mathrm{Am}$. Dec. 625. 
Chapter lation is not an appropriation of private property
vi. rights to a public use; there is merely the restraint or regulation of its private use by the owner. ${ }^{9}$

Penal con sequences no taking.

Again, regulation may require the establishment of laws for the use of property or rights, the infraction of which is attended with penal consequences, which may include the loss of the property or rights misused. ${ }^{1}$ In such a case, there has been no appropriation of private rights to public use, but the loss of the particular property or rights is in the nature of a punishment for violation of law; the theory upon which compensation is given does not apply, and none is required.2

\section{The police power may also act in cases where}

9 Com. $v$. Alger, 7 Cush. (Mass.) 53; State $r$. Griffin, 69 N. H. 1; Health Dept. $x$. Trinity Church, 145 N. Y. 32.

"A prohibition simply upon the use of property for purposes that are declared, by valid legislation, to be injurious to the health, morals, or safety of the community, cannot, in any just sense, be deemed a taking or an appropriation of property for the public benefit. Such legilation does not disturb the owner in the control or use of his property for lawful purposes, nor restriet his right to dispose of it, but is only a declaration by the State that its use by any one, for certain forbidden purposes, is prejudicial to the public interests." Mugler $v$. Kansas, 123 U. S. 623.

1 In Fisher $r$. McGirr, 1 Gray (Mass.) $1,61 \mathrm{Am}$. Dec. 381, Chief Justice Shaw said that "the property of which injurious or dangerous use is made shall be seized and confiscated, because either it is so unlawfully used by the owner or person having the power of disposal or by some person with whom he has placed and intrusted it, or at least that he has so carelessly and negligently used his power and control over it that by his default it has fallen into the hands of those who have made and intend to make the injurious or dangerous use of it, of which the public have a right to complain, and from which they have a right to be relieved. Therefore, as well to abate the nuisance as to punish the offending or careless owner the property may be justly declared forfeited, and either sold for the public benefit or destroyed, as the circumstances of the case may require and the wisdom of the legislature direet."

2 Fisher $v$. McGirr, 1 Gray (Mass.) 1, 61 Am. Dec. 381, 400. 
there is no question of violation of law, as in the destruction of houses, to prevent spread of fire, or of diseased animals, infected clothes, or the like. In cases of this character the destruction is an applicaChapter
VI. no taking. tion of the maxim, salus populi est suprema lex, and the principle, firmly established in the absence of statute, that the owner is entitled to no compensation, rests on the ground of damage without legal injury. The loss is attributed to the overruling necessity whence the destruction resulted rather than to the intervention of man by which it was accomplished. ${ }^{3}$

When, however, public purposes require for the effective exercise of the police power an actual appropriation of the property of citizens chargeable Both police
power and power and domain in. with no wrong, the eminent domain as well as the police power is involved and compensation must be made to the owners. ${ }^{4}$ Such a case has been held to exist where, in order to remore a nuisance resulting from the undrained condition of a tract of low lands within a city, the legislature passed an act providing for the condemnation of the lands, and the transfer of a fee simple title to the city, upon the payment of compensation, and for the filling in of the lands by the city so as to remove the nuisance. The purpose of this legislation was a ralid police purpose, the removal of a nuisance which consti-

3 Maleverer $v$. Spinke, 1 Dyer $36 b$; Prerogative of the King, 12 Coke 13; Mouse's Case, 12 Coke 63; British Cast Plate Manufacturers $v$. Meredith, 4 T. R. 794, 797, per Buller, J.; Bowditch $v$. Boston, 101 U. S. 16 ; Ralli $v$. Troop, 157 U. S., 405; Russell $v$. New York, 2 Den. (N. Y.) 461; Respublica $v$. Sparhawk, 1 Dall. (Pa.) 357.

4 Sweet $v$. Rechel, 159 U. S. 380 . 
Chapter tuted a menace to public health. In the accomplishment of this purpose the legislature, in the exercise of its discretion, found it necessary to take title to the property for a public purpose; that is, to exercise the power of eminent domain. The property owner could not object that his property was decreed forfeited to the city under the police power without giving him a hearing as to its condition, for there was no confiscation, but an appropriation under the power of eminent domain with full compensation. Nor could he object that the taking was unnecessary for the mere destruction of the nuisance, for the city was put to great expense in filling in, and the legislature was justified in its discretion in resorting under the circumstances to the power of eminent domain. ${ }^{5}$

Whether in any particular instance the police power only is exerted, or whether the power of eminent domain is also involved so that compensation is required, may depend, it has been held, on the value of the rights affected and the extent of the State's interference therewith. But this question will be examined in another connection. ${ }^{\circ}$

If the rights of the individual are limited by the ess. powers which represent the common organized action of society, the exercise of the latter in their turn is guarded by constitutional safeguards, either specified guaranties or those fundamental principles of justice connoted by the phrase "due process of law." This implies generality of laws, the right to a hear-

B Sweet $v$. Rechel, 159 U. S. 380; Dingley $v$. Boston, 100 Mass. 544.

6 Sce infra, p. 375. 
ing before condemnation, and forbids action merely Chapter arbitrary. But the application of these principles VI. may vary with the subject-matter of the case, the end to be accomplished, and the power of the State which is exerted. 


\title{
CHAPTER VII.
}

\author{
TAXATION. \\ THE TAXING POWER AND ITS EXTENT.
}

Chapter $\mathrm{N}$ the great case of McCulloch v. Maryland, ${ }^{1}$ Chief
VII.

VII. I Justice Marshall stated the basis of the taxing How guares against. power and the security against its abuse as follows: "The power of taxing the people and their property is essential to the very existence of government, and may be legitimately exercised on the objects to which it is applicable to the utmost extent to which the government may choose to carry it. The only security against the abuse of this power is found in the structure of the government itself. In imposing a tax the legislature acts upon its constituents. This is in general a sufficient security against erroneous and oppressive taxation. The people of a State, therefore, give to their government a right of taxing themselves and their property, and as the exigencies of government can not be limited they prescribe no limits to the exercise of this right, resting confidently on the interest of the legislator and on the influence of the constituents over their representative to guard them against its abuse." The

14 Wheat. (U. S.) 316. In this case the chief justice used the famous expression, so often quoted, "the power to tax involves the power to destroy ; " an effect of the power of which Congress availed itself in taxing State banks. Veazie Bank $v$. Fenno, 8 Wall. (U. S.) 533; Merchants' Nat. Bank v. U. S., 101 U. S. 1. See also Knowlton v. Moore, 178 U. S. 41 ; McCray $r$. U. S., 195 U. S. 27. 
power to tax extends to persons, property, and occupations; it touches property in every shape, in its Chapter VII. natural condition, in its manufactured state, and in its various transmutations; it may reach business in the almost infinite forms in which it is conducted, in professions, in commerce, in manufactures, and in transportation. ${ }^{2}$ It includes also of necessity as an inseparable incident the power of apportionment. "The power of taxing and the power of apportioning taxation," it has been said, "are identical and inseparable. Taxes can not be laid without apportionment; and the power of apportionment is therefore unlimited, unless it be restrained as a part of the power of taxation." 3

To the legislative branch of the government it belongs exclusively to impose taxes and to provide Is Iegisla. tive, not for their levy and collection. This principle is among those which are inherited from the constitution of England, and applies alike to the national and State governments. ${ }^{4}$ In Meriwether v. Garrett, ${ }^{5}$ Mr. Justice Field said: "The levying of taxes is not a judicial act. It has no elements of one. It is a high act of sovereignty, to be performed only by the legislature upon considerations of policy, necessity, and the public welfare. In the distribution of

2 State Tax on Foreign-Held Bonds, 15 Tall. (U. S.) 319 ; Hagar $v$. Reclamation Dist. No. 168, 111 U. S. 701.

3 People $v$. Brooklyn, 4 N. Y. 419.

4 Heine $v$. Levee Com'rs, 19 Wall. (U. S.) 655, 660; State Railroad Tax Cases, 92 U. S. 575, 615; Palmer $v$. McMahon, 133 U. S. 660,669 .

5102 U. S. 472 . The quotation is from a concurring opinion written for himself and Miller and Bradlev, J.J., because "the judgment is not accompanied by a statement of the reasons on which it is founded." 
Chapter the powers of government in this country into three departments, the power of taxation falls to the legislative. It belongs to that department to determine what measures shall be taken for the public welfare and to provide the revenues for the support and due administration of the govermment throughout the State and in all its subdivisions. Having the sole power to authorize the tax, it must equally possess the sole power to prescribe the means by which the tax shall be collected, and to designate the officers through whom its will shall be enforced."

Right of classifica* tion and exemption.

The legislature may in its discretion classify the subjects of taxation and may provide different methods of assessment and collection for the different classes, the only limitation being that all persons or property within a given class shall be treated alike." The State "may, if it chooses, exempt certain classes of property from any taxation at all, such as churches, libraries, and the property of charitable institutions. It may impose different specific taxes upon different trades and professions, and may vary the rates of excise upon various products; it may tax real estate and personal property in a different manner; it may tax visible property only, and not tax securities for payment of money; it may allow deductions for indebtedness, or not allow them. All such regulations, and those of like character, so long as they proceed within reasonable limits and general usage, are within the discretion

6 State Railroad Tax Cases, 92 U. S. 575; Kentucky Railroad Tax Cases, 115 U. S. 321 ; Home Ins. Co. v. New York, 134 U. S. 594; Giozza v. Tiernan, 148 U. S. 657 ; Florida Cent., etc., R. Co. v. Reynolds, 183 U. S. 471 . And see supra, p. 60. 
of the State legislature, or the people of the State in framing their constitution. But clear and hostile discriminations against particular persons and classes, especially such as are of an unusual character, unknown to the practice of our governments, might be obnoxious to the constitutional prohibition. It would, however, be impracticable and unwise to attempt to lay down any general rule or definition on the subject, that would include all cases. They must be decided as they arise. Te think that we are safe in saying that the Fourteenth Amendment was not intended to compel the State to adopt an iron rule of equal taxation. If that were its proper construction, it would not only supersede all those constitutional provisions and laws of some of the States, whose object is to secure equality of taxation, and which are usually accompanied with qualifications deemed material; but it would render nugatory those discriminations which the best interests of society require; which are necessary for the encouragement of needed and useful industries, and the discouragement of intemperance and vice; and which every State, in one form or another, deems it expedient to adopt." " Thus the owners of property falling within one class may be entitled to a review of the assessment proceedings, while for those in another class no opportunity for rehearing may be provided, and yet this does not deprive the latter of due process of law. ${ }^{8}$ And so due process of law is not denied by a statute which taxes surface street railways, while exempting

7 Bell's Gap R. Co. v. Pennsylvania, 134 U. S. 232.

8 Pittsburgh, etc., R. Co. $v$. Backus, 154 U. S. 427; Winona, etc., Land Co. $v$. Minnesota, 159 U. S. 526; Weyerhaueser $v$. Minnesota, 17 U. S. 550. 
Chapter underground street railways ${ }^{9}$ or while taxing ordiVII. nary railroads in the streets at a different rate. ${ }^{1}$ Such differences are sufficient to justify a diversity in the mode and extent of taxation.

Power delegated to munici. palities.

While the power of taxation belongs exclusively to the legislature and can not be delegated by it to other departments of government or to private corporations, ${ }^{2}$ it may be delegated to municipal corporations, which are merely instrumentalities of the State for the better administration of the government in matters of local concern, and when such a corporation is created the power of taxation is vested in it as an essential attribute, for all the purposes of its existence, unless its exercise be in express terms prohibited." As the legislature may grant the taxing power to municipalities, it may at its pleasure take it away, and although such a proceeding may delay the creditors of the municipality in the collection of their debts, it does not deprive them of property without due process of law, however much the repeal of the taxing power may conflict with the provision of the Constitution against the impairment of contracts. ${ }^{4}$

Taxation includes special as. sessments.

Upon the taxing power depends the validity not only of laws providing for revenne for general or local purposes, but also of acts providing for local or special assessments, in which the cost of public improvements is levied in part or wholly on the par-

9 Metropolitan St. R. Co. v. Tax Com'rs, 199 [T. S. 1, 47.

1 Savannah, ete., R. Co. v. Savannah, 198 U. S. 392.

2 Rees $v$. Watertown, 19 Wall. (U. S.) 107 ; Meriwether $v$. Garrett, 102 U. S. 472; Allentown r. Henry, 73 Pa. St. 404.

3 U. S. $v$. New Orleans, 98 U. S. 381.

4 Louisiana $r$. New Orleans, 109 U. S. 289. 
ticular property benefited, upon the theory that he who receives the benefit should bear the burden, and which therefore are not within special constitutional requirements for uniformity. ${ }^{5}$

When a local tax is in question, the right to determine the limits of the taxing district is involved in the taxing power:" So in the levy of a special assessment the legislature may, if it see fit, determine the lands from which it is to be collected, and this determination, being in the lawful exereise of the taxing power, does not deprive the owner of a hearing on the question of the benefit to his land in a sense to work a deprivation of due process of law. ${ }^{7}$ Speaking generally, the question of the division of a State into political units through which taxes are assessed and collected is not one with which the fedelal courts have any concern. "It is for the State to determine," it has been said, "its political subdivisions, the number and size of its municipal corporations, and their territorial extent.s These are matters of a local nature, in which the nation as a whole is not interested, and in which, by the very nature of things, the determination of the State authorities should be accepted as authoritative and controlling. We do not mean to hold that in the creation or change of municipal boundaries there may not be action taken by the State which involves a tres-

5 Hagar $v$. Reclamation Dist. No. 108, 111 U. S. 701; Spencer $v$. Merchant, 125 U.S. 345 ; Fallbrook Irrigation Dist. $v$. Bradley, 164 U. S. 112 ; Norwood $v$. Baker, 172 U. S. 269 ; Dorgan $v$. Boston, 12 Allen (Mass.) 223; State $v$. Newark, 37 N. J. I. 415 ; People $v$. Brooklyn, 4 N. Y. 419 ; Raleigh v. Pearce, 110 N. Car. 32.

6 Williams $v$. Eggleston, 170 U. S. 304, 311.

T See infra, p. 246.

8 See Atty.-Gen. $v$. Lowrey, 199 U. S. 233. 
Chapter VII.

pass upon rights secured by the Federal Constitution, or that in proceedings looking to such change no questions can arise which are of a federal nature, and in respect to which the judgment of the courts of the nation must be controlling. ${ }^{9}$ All that we mean to decide is that the matter of the territorial boundaries of a municipal corporation is local in its nature, and as a rule to be finally and absolutely determined by the authorities of the State." 1 These observations were made in a case wherein the owner of property which had been annexed to a city and upon which an assessment had been made for city taxes, sought to restrain their collection in the federal courts, after the annexation had been declared valid by the highest State court. The United States Supreme Court, acting on the ground indicated, refused to interfere.

9 See also Henderson Bridge Co. $v$. Henderson, 173 U. S. 592 . In this case municipal taxes were levied upon a bridge, and the bridge company elaimed that parts of their property were so far beyond the reach of municipal protection as to reccive no benefit whatever from the municipal government, so that the lery of the taxes amounted to taking private property for public purposes without compensation and constituted a deprivation of due process of law. But the court held otherwise in the absence of evidence showing "so clearly and palpably an illegal encroachment upon private rights as to leave no doubt that such taxation, by its necessary operation, is really spoliation under the guise of exerting the power to tax." Every doubt was to be resolved in favor of the validity of the tax. The State court had ruled adversely to the claim presented, and the Federal Supreme Court could not adjudge that decision so clearly erroneous "as to entitle the defendants to invoke the principle that private property cannot be taken for public use without just cons. pensation."

1 Forsyth $v$. Hammond, 166 U. S. 519, citing Kelly $v$. Pittsburgh, 104 U. S. 78. 


\section{LIMITATIONS ON THE TAXING POWER.}

Chapter

VII.

As extensive as is the power to tax, its exercise is subject to well-established limitations. Special reGeneral limitations. straints in the Constitution upon the taxing power must, of course, be observed; but besides these there are other and more general limitations arising from the nature of onr government and from fundamental principles of justice, embodied in tle conception of "due process of law." So long as the legislature acts within these limitations on its powers, its discretion in determining the subjects and modes of taxation is unlimited, and however oppressive or unjust the exercise of the taxing power may prove, the courts, under the theory of the separation of governmental powers upon which all our constitutions rest, can not interfere. Each branch of the government is responsible ultimately to the people for the abuse of the powers committed to it, and it would serve no good purpose to substitute for the fallible judgment of that department to which the duty of devising and laying taxes is intrusted, the equally fallible judgment of the judiciary, to whom taxation does not belong. ${ }^{2}$

It has been argued that there is a limitation to the power of the legislature to select the subjects of taxation, and upon the extent of the tax imposed, implied in the due process clauses of the Fifth and Selection of subjects taxed; dis. crimination; freedom of contract. Fourteenth Amendments; that when the operation of the tax upon a given subject selected is to create an

2 See State Railroad Tax Cases, 92 U. S. 612; Kirtland $v$. Hotchkiss, 100 U. S. 491 ; Mobile County $v$. Kimball, 102 U. S. 691 ; Kentucky Railroad Tax Cases, 115 U. S. 335. 

Chapter arbitrary discrimination between the subject so taxed
VII. and the subjects not taxed or taxed at a different rate, there is a failure of the generality of the law implied in due process; and that when the operation and effect of taxation at the rate prescribed is necessarily to destroy the manufacture of, or traffic in, the article taxed, or to suppress the business selected for taxation, such manufacture, traffic, or business being harmless or beneficial to the public, the freedom of every man to contract and to engage in lawful pursuits is taken away and he is deprived of property without due process of law. In either of these cases, it is said, the legislative act is not a valid exercise of the taxing power, but a deprivation of fundamental rights which even the taxing power must respect. But it has been held that when, as in the case of the national govermment, the power to tax within the sphere committed to it is limited only by specific provisions of the Constitution, if the tax is one which Congress has power to lay, the right to select the subjects of taxation is unlimited, and that the selection is due process of law and not open to the objection of unjust discrimination. A State's power to tax, so far as the selection of the subjects taxed is concerned, is limited, from the point of view of the Federal Constitution, only by the effect which may be had on the powers of the national government by the tax, and to this extent only is the operation of the selection a proper subject of judicial inquiry. If it be conceded that the State must respect in all laws the right of property and the liberty to contract, the tax is not unconstitutional by reason of its extent, unless its imposition reaches the point of 
the abuse of a legislative power and constitutes the exercise of an authority of which the legislature is Chapter VII. not possessed. This never happens where the business taxed is one which the State in the exercise of its police or legislative power has the right to restrict or prohibit."

Among the limitations arising from our dual system of government is the principle that neither the federal nor the State govermment may tax the agencies, operations, or property of the other, ${ }^{4}$ and that, the regulation of interstate commerce being rested solely in the federal government, the exercise of that power can not be interfered with by a State by the imposition of a tax upon the privilege of transacting such commerce, though the instrumentalities of interstate commerce, if within a State, may be the subject of taxation. ${ }^{5} \quad$ Supported by the fundamental principles of justice and of due process of law, as applicable under our complex system of government are the restrictions that the State can tax only those persons or things which lie within its jurisdiction; that the power to tax can be exercised only for a public purpose, and not in order to enrich one per-

3 McCray $v$. U. S., 195 U. S. 27.

4 M'Culloch $v$. Marpland, 4 Wheat. (U. S.) 316 ; Weston $v$. Charleston, 2 Pet. (U. S.) 466; Collector v. Day, 11 Wall. (U. S.) 113 ; Ward $v$. Maryland, 12 Wall. (U. S.) 418; U. S. $v$. Baltimore, etc., R. Co., 17 Wall. (U. S.) 322 ; Van Brocklin $v$. Tennessee, 117 U. S. $15 \mathrm{l}$; Wisconsin Cent. R. Co. v. Price County, 133 U. S. 496 ; -Pollock r. Farmers' Loan, etc., Co., 157 U. S. 429 ; U. S. v. Rickert, 183 U. S. $438,439$.

5 Leloup $v$. Port of Mobile, 127 U. S. 640, 648; Pullman's Palace Car Co. $v$. Pennsylvania, 141 U. S. 18; Adams Express Co. $v$. Ohio State Auditor, 165 U. S. 194, 166 U. S. 185; Atlantic, etc., Tel. Co. $v$. Philadelphia, 190 U. S. 160 ; Allen $v$. Pullman's Palace Car Co., 191 U. S. 171; Kehrer $v$. Stewart, 197 U. S. 60. 
Chapter son or class of persons at the expense of another; VII.

and generally that the processes of the assessment and collection of taxes can proceed validly only upon notice and hearing or an opportunity to be heard.

\section{Property Taxed Must Be Within Jurisdiction.}

The principles of public law limit the power of a State in imposing taxes, whatever be the form which the tax may assume, to persons, property, and business within the jurisdiction of the State; and a disregard of this rule is a denial of due process of law to the owners of property on which a tax is levied and which is not within the jurisdiction. ${ }^{6}$

When actual situs

When a tax is levied on real property or on tangoverns. gible personal property, the actual situs determines its taxability without regard to the owner's domicil. ' Incorporeal rights issuing out of lands in one State are taxable therein and not in any other State. Thus, when a ferry was operated across the Ohio River between points one of which was in Indiana

${ }^{6}$ Dewey $r$. Des Moines, 173 U. S. 193; Louisville, ete., Ferry Co. $v$. Kentuckr, 188 U. S. 385; Delaware, etc., R. Co. $r$. Pennsylvania, 198 U. S. 341 ; Union Refrigerator Transit Co. $v$. Kentucky, 199 U. S. 194.

i See supra, p. 118. An exception to the rule that tangible personal property is taxable at its actual situs, exists in the ease of shipe or ressels registered under the laws of the United States at a particular port and engaged in interstate eommerce upon waters which are a common highway. Such ressels are not taxable in another State, although they mas touch at ports therein to deliver and receive passengers or freight. "But this is beeanse they are not, in any proper sense, abiding within its limits, and have no continuous presence or actual situs within its jurisdietion, and, therefore, ran be taxed only at their legal situs - their home port and the domicil of their owners." Pullnan's Palace Car Co. $v$. Pennerlvania. 141 U. S. 18. And see Glouester Ferry Co. $r$. Penmsylvania, 114 U. S. 196. 
and the other in Kentucky, under separate franchises from the legislatures of two States, it was held that a tax imposed by the State of Kentucky and levied on a valuation which included the Indiana franchise was a deprivation of property without due process of law. ${ }^{8}$ The two franchises were separate and distinct, and, said the court, "each franchise is property entitled to the protection of the law. . . . While the mode, form, and extent of taxation are, speaking generally, limited only by the wisdom of the legislature, that power is limited by a principle inhering in the very nature of constitutional government, namely, that the taxation imposed must have relation to a subject within the jurisdiction of the taxing government. . . . No difficulty can exist in applying the general rule in this case; for beyond all question the ferry franchise derived from Indiana is an incorporeal hereditament derived from and having its legal situs in that State. It is not within the jurisdiction of Kentucks." The attempted taxation by Kentucky of the company's Indiana franchise was, therefore, a violation of the due process clause of the Fourteenth Amendment; "as much so as if the State taxed the real estate owned by that company in Indiana.", 9

Real estate under mortgage may be taxed by tlıe State at its full value. The State "may do this Land mortgage. either by taxing the whole to the mortgagor, or by

8 Louisville, etc., Ferry Co. $v$. Kentuckr, lss U. S. 3S5.

9 Louisville, etc., Ferry Co. $v$. Kentucky, 188 U. S. 396, 398. See also Henderson Bridge Co. $r$. Kentucky, $166 \mathrm{U}$. S. 150, holding that a franchise to build a bridge over a river flowing between two States was a proper subject of taxation by the State which granted the franchise. 

Chapter taxing to the mortgagee the interest therein repre-
VII. sented by the mortgage, and to the mortgagor the remaining interest in the land." When the interest of the mortgagee is taxed separately there is no deprivation of property without due process of law, although the mortgagee may be a nomresident of the State. A mortgage is an interest in land, dependent for protection on local laws and liable to taxation within the State. ${ }^{1}$

Movement of tangible personalty.

Tangible personal property within a State and subject to its jurisdiction remains liable to State taxation until it passes out of the jurisdiction of the State and becomes subject to federal regulation as an export or as having actually entered into commerce between the States. "Goods," said the United States Supreme Court, "do not cease to be part of the general mass of property in the State, subject as such to its jurisdiction and to taxation in the usual way, ${ }^{2}$ until they have been shipped, or entered with a common carrier for tramsportation to another State, or have been started upon such transportation in a continuous route or journey.', 3 When property thus shipped reaches its destination in another State, it at once becomes intermingled with the general mass of property there and subject to taxation. ${ }^{4}$ Nor, while in transit, can it be taxed by the States through which it passes.

1 Savings, etc., Soc. $r$. Multnomah County, 169 U. S. 421.

2 See Brown $r$. Maryland, 12 Wheat. (U. S.) 419 ; Welton $v$. Missouri, 91 [T. S. 275.

3 Coe r. Errol. 116 U. S. 517.

4 Brown $v$. Houston, 114 U. S. 622: Pittsburg, ete. Coal Co. $v$. Bates, 156 C. S. $57 \%$. See American Refrigerator Transit Co. $r$. Hall, 174 U. S. 70. 
As ras said in a recent case, "while the property is Chapter at rest for an indefinite time awaiting transportaVII. tion, or awaiting a sale at its place of destination, or at an intermediate point, it is subject to taxation. But if it be actually in transit to another State, it becomes the subject of interstate commerce, and is exempt from local assessment."'s Applying these principles, it has been held that an attempt on the part of the State of the origin of chattels to tax their producer on a valuation which includes the value of chattels already shipped beyond the State is void as a deprivation of property without due process of law. ${ }^{6}$

The general principles regulating the situs of Situs of intangible personal property have already been stated, and we personalty. have seen that situs for purposes of taxation is, when the tax is levied on intangible personal property, largely a question for the determination of the State, acting through its legislature and, in the exercise of the discretion with which the legislative department is vested, determining the policy and wisdom of particular taxes. ${ }^{7}$ A debt evidenced by note or bond, and secured by a mortgage on lands, may be taxed at the domicil of the creditor, without regard to the fact that the lands mortgaged as security lie in another State. ${ }^{8}$ Debts may even acquire a situs for purposes of taxation by the presence of

5 Kelley $v$. Rhoads, 188 U. S. 1, 7 ; Diamond Match Co. $v$. Ontonagon. 188 U. S. 82, 95, 96.

e Delaware, etc., R. Co. $v$. Pennsylvania, 198 U. S. 341.

i See supra, p. 118.

8 Kirtland $r$. Hotchkiss, 100 U. S. 491. 

Chapter the evidences thereof in a State in the possession of
vII. an agent for the real owner. ${ }^{9}$

In the case of succession, inheritance, and legacy taxes, the thing taxed is not the property constituting the estate, but its transfer or passage by will, descent, or succession from the dead to the living. ${ }^{1}$ According to the fiction, mobilia sequuntur personam, private international law recognizes the transmission of personal property as taking place at the domicil of the deceased owner, though the property may in fact be elsewhere. ${ }^{2}$ But this is a rule of comity only, and no principle of constitutional law is infringed by the taxation in one State of debts due by its citizens to the estate of a nonresident decedent. "Power over the person of the debtor confers jurisdiction." 3 "The right to take property by devise or descent is the creature of the law, and not a natural right - a privilege - and therefore the authority which confers it may impose conditions upon it. From these principles it is deduced that the States may tax the privilege, discriminate between relatives, and between these and strangers, and grant exemptions, and are not precluded from this power by the provisions of the respective State constitutions requiring uniformity and equality of taxation." 4

a New Orleans $v$. Stempel, 175 U. S. 309 ; Bristol $v$. Washington County, 177 L. S. 133; Assessors $v$. Comptoir National d'Escompte, 191 U. S. 385.

I U. S. $r$. Perkins, 163 U. S. 625; Magoun v. Illinois Trust, etc., Bank, 170 U. S. 283; Knowlton v. Moore, 178 U. S. 41; Orr v. Gilman, 183 C. S. 278.

2 Eidman r. Martinez, 184 U. S. 578.

3 Plackstone $r$. Niller, 188 U. S. 189.

4 Magoun $v$. Illinois Trust, ete., Bank, 170 U. S. 283. 
The power of one State or the nation to tax property within its limits is not affected by the fact that the same property is the subject of taxation by an- Double other sovereignty. "Under our constitutional system, both the national and the State govermments, moving in their respective orbits, have a common authority to tax many and diverse objects, but this does not cause the exercise of its lawful attributes by one to be a curtailment of the power's of government of the other; for, if it did, there would practically be an end of the dual system of government which the Constitution established." ${ }_{5}$ "No doubt this power on the part of two States to tax on different and more or less inconsistent principles leads to some hardship. It may be regretted, also, that one and the same State should be seen taxing on the one hand according to the fact of power, and on the other, at the same time, according to the fiction that . . mobilia sequuntur personam. . . But these inconsistencies infringe no rule of constitutional law." 6

Assessment of Property Lying Partly in Several Jurisdictions. When a corporation has property in more than corporate one State, and each State may tax a portion, the rule of valuation applied must exclude the property lying beyond the State. In taxing corporations there are

s Knowlton v. Moore, 178 U. S. 41. And see South Carolina $v$. U. S., 199 U. S. 437.

6 Blackstone $v$. Miller, 188 U. S. 189, 204, citing Coe $v$. Errol, 116 J. S. 517 ; Knowlton $v$. Moore, 178 U. S. 41. And see Kidd $v$. Alabama, 188 U. S. 730, 732 . 
Chapter VII.

Rule applied must not include property without State.

at least four elements of taxable value: ${ }^{7}$ franchises; capital stock in the hands of the corporation; corporate property; and shares of the capital stock in the hands of the individual stockholders. So far as the property is within its own borders, the State may assess taxes upon these various elements in such a way as to subject the corporation or the stockholders to double taxation, without violating the Federal Constitution. A tax on the capital stock or total assets of a corporation is a tax on the property in which the capital is invested, and therefore when the property is in several States, such a tax may infringe the principle under consideration. ${ }^{8}$

When the method of assessing such a tax provides an equitable means of determining the proportion of the property within the State and therefore subject to taxation, to that without the State, the tax is valid. In the case of a railroad, an assessment which values the property to be taxed (tangible property, capital stock and franchises), in proportion to the ratio which the mileage within the State bears to the total mileage, has been held equitable. ${ }^{9}$ The same method has been sustained of assessing the taxable value of the property of telegraph companies, ${ }^{1}$ the rolling stock of railroads, and the assets of

7 Tennessee $v$. Whitworth, 117 U. S. 129, 136; New Orleans $v$. Houston, 119 U. S. 265.

8 Western Union Tel. Co. $v$. Atty.-Gen., 125 U. S. 530 ; Pullman's Palace Car Co. $v$. Pennsylvania, 141 U. S. 18; Fargo $v$. Hart, 193 U. S. 490 ; Delaware, ete., R. Co. $v$. Pennsylvania, 198 T. S. 341.

${ }^{9}$ Delaware Railroal Tax, 18 Wall. (U. S.) 206 ; Erie R. Co. $v$. Pennsylvania, 21 Wall. (U. S.) 492; State Railroad Tax Cases, 92 U. S. 575; Pittsurnh, ete., R. Co. $v$. Backus, 154 U. S. 421 ; Cleveland, etc., T. Co. $r$. laackus, 154 U. S. 439.

1 Trestern Union Tel, Co. $r$. Attr.-Gen., 125 U. S. 530: Massachusetts $x$. Western Union Tel. Co., 141 U. S. 40 ; Western Union Tel. 
sleeping car companies ${ }^{2}$ and express companies, although the property in some of these cases is intanChapter VII. gible. $^{3}$ When, however, it appear's that the mileage rule will not give a just result, as when in the case of a railroad the company owns terminals in one State whose value more than equals all the line in another State, or when, in the case of an express company, a State undertakes to add to the value of the capital stock for division according to mileage large sums of personalty in another State on the theory that the accumulation imparts credit in the taxing State, the rule is not applicable. Such a case would amount to taxing property without the State on a pretext. ${ }^{4}$

When specific articles of personal property within a State belonging to a corporation, for instance the refrigerator ears used by a company engaged

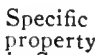
in State constantly in transporting perishable things, are constantly changing, the tax upon such property may be fixed by an appraisement and raluation of the average amount of the property thus habitually used and employed. ${ }^{5}$

Co. $v$. Taggart, 163 U. S. 1; Western Union Tel. Co. v. Missouri, 190 U. S. 412.

2 Marye $v$. Baltimore, etc., R. Co., 127 U. S. 117; Pullman's Palace Car Co. $r$. Pennsylvania, 141 L. S. 18.

3 Adams Express Co. $v$. Ohio State Auditor. 165 U. S. 194. 166 U. S. 185; American Express Co. $r$. Indiana, 165 U. S. 255; Adams Express Co. $v$. Kentucky, 166 U. S. 171.

4 Pittsburgh, etc., R. Co. $v$. Backus, 154 U. S. 421, 431; Western Union Tel. Co. $v$. Taggart, 163 C. S. 1, 23; Fargo $v$. Hart, 193 U. S. 490,500 .

5 American Refrigerator Transit Co. $v$. Hall, 174 U. S. 70, 82. 
Chapter VII.

Exemptions strictly construed.

\section{Exemptions from Taxation.}

The subjects upon which taxes may be levied may also be limited by the action of the State itself by granting an exemption from taxation under such circumstances as to bring the exemption within the protection from impairing the obligation of contracts. But exemptions from taxation, being in derogation of the sovereign power of the State, are never to be presumed, and when they exist, are to be construed most strictly." "The payment of taxes on account of property otherwise liable to taxation can only be aroided by clear proof of a valid contract of exemption from such payment, and the validity of such contract presupposes a good consideration therefor. If the property be in its nature taxable, the contract exempting it from taxation must, as we have said, be clearly proved. It will not be inferred from facts which do not lead irresistibly and necessarily to the existence of the contract. The facts proved must show either a contract expressed in terms, or else it must be implied from facts which leave no room for doubt that such was the intention of the parties and that a valid consideration existed for the contract. If there be any doubt on these matters the contract has not been proven and the exemption does not exist." 7

6 Providence Bank $v$. Billings. 4 Pct. (U. S.) 514, the leading case on this topic; Philadelphia, etc. R. Co. r. Maryland, 10 How. (U. S.) 376 ; Piqua Rranch of State Bank $r$. Knoop, 16 How. (U. S.) 369; Farrington $r$. Tennessee, 95 U. S. 679; Vicksburg, etc.. R. Co. $v$. Dennis, 116 U. S. 665 ; New Orleans City, etc., R. Co. $v$. New Orleans, 143 U. S. 192.

7 Wells $v$. Savannah, 181 U. S. 531, 539.

The decisions of State courts, while not of paramount authority, 
This rule has been applied to the State's right to tax the franchises of public service corporations, whch were operating street railways and which had already either paid for the privilege of occupying Chapter VII. the streets a lump sum, or were paying annually therefor specific amounts or a fixed percentage of receipts. A subsequent tax by the State on the franchises of these corporations, although the taxing statute made provision for the deduction from the tax levied of the sums being paid by the corporations for the use of the streets, was attacked as impairing the obligation of contracts and as a denial of due process of law. The Federal Supreme Court sustained the validity of the tax, holding that, under the recognized rule for the construction of exemptions, the sums which were being paid for the use of the streets by the corporations were not to be considered as releasing or exempting the corporations from payment of taxes. Such a sum, whether paid once for all or in the form of annual exaction, was only the consideration for the grant itself of the franchise, and had no effect in exempting from taxation the intangible property granted. ${ }^{8}$ To the specific contention that there was discrimination amounting to a denial of due process of law against those corporations which had paid a lump sum once for all for the use of the streets, in that the law made no provision in their favor, while providing

are entitled to special respect upon the construction of such grants. Wilson $v$. Standefer, 184 U. S. 399 ; Chicago Theological Seminary v. Illinois, 188 U. S. 662 .

8 Metropolitan St. R. Co. v. Tax Com'rs, 199 U. S. 1; Brooklyn City R. Co. v. Tax Com'rs, 199 U. S. 48; Twenty-third St. R. Co. v. Tax Com'rs, 199 U. S. 53. 
Chapter for a deduction from the tax levied to the amount of VII.

the anmual payments of other corporations, the court said: "The lump sum is so obviously a payment for the franchise that it can not be considered in any just sense as possessing the nature of a tax. It is not even rental. It is like money paid for a tract of land - part of the purchase price." ${ }_{9}$

\section{The Public Purpose of the Tax.}

It is fundamental in the nature of constitutional government that its powers must be exerted solely for the public use and service. Only to this extent are the rights of individuals subordinate to the state, and when the state oversteps this limitation and without regard to benefits to the public levies a contribution, under the form of a tax, upon the property of one person for the use of another person or class, it commits an act of confiscation and deprives the individual upon whom the contribution is levied of his property without due process of law. ${ }^{1}$

Public purpose in taxation and in eminent domain.
Every lawful tax must, then, be imposed for a public purpose. ${ }^{2}$ In determining the public character of the tax, a distinction has been drawn between a public purpose within the power of eminent domain and a public purpose within the taxing power. The Supreme Court of Michigan, speaking through $\mathrm{Mr}$. Justice Cooley, after stating that all governmental

9 Metropolitan St. Ry. Co. $v$. Tax Com'rs, 199 U. S. 16.

1 Lowell $r$. Boston, 111 Mass. 454, $15 \mathrm{Am}$. Rep. 39. See also Fallbrook 1rrigation Dist. $v$. Bradley, 164 U. S. 112, 161.

2 Citizens' Sav., ete., Assoc. v. Topeka, 20 Wall. (U. S.) 655, is the leading ase in the United States Suprene Court on this thoroughly settled proposition. See also Kelly $r$. Pittsburgh, 104 U. S. 78; Cole $r$. La Grange, 113 U. S. 1, and 27 Am. and Eng. Eneyc. of Law (2d ed.) 624 . 
powers exist for public purposes, but are not neces- Chapter sarily to be exercised under the same conditions of Vil. public interest, called attention to the aspects of public interest which must control in eminent domain and in the taxing power. "The most important consideration in the case of eminent domain is the necessity of accomplishing some public good which is otherwise impracticable; and we shall also find that the law does not so much regard the means as the need. The power is much nearer akin to that of the public police than to that of taxation." With regard to taxation, on the other hand, the criterion is not the urgeney of the public need, but "public purpose" is used to distinguish the objects for mhich, according to settled usage, the government is to provide from those which, by like usage, are left to private interest or enterprise. ${ }^{3}$ Courts have usually assumed or declared, however, that the same conditions which make a public purpose in the exercise of one of these sovereign powers will make the purpose public for the other. ${ }^{4}$

The power to decide what is and what is not such a public use as will justify the emplorment of the power of taxation rests primarily with the legislaPublic
purpose a question for legislature priture, and the courts should interfere only when the legislature has plainly overstepped its power. "It is undoubtedly the duty of the legislature," said the Federal Supreme Court, "which imposes or authorizes municipalities to impose a tax to see that it is not

3 People $r$. Salem, 20 Mich. 452.

4 Lowell $r$. Boston, 111 Mass. 454. And see Fallbrook Irrigation Dist. $v$. Bradley, 164 U. S. 112.

5 See infra, p. 255, the discussion of the analogous point in respect to eminent domain. 
Chapter to be used for purposes of private interest instead
VII. vil. of a public use, and the courts ean only be justified in interposing when a violation of this principle is clear and the reason for interference cogent. And in deciding whether, in the given case, the object for which the taxes are assessed falls upon the one side or the other of this line, they must be governed mainly by the course and usage of the government, the objects for which taxes have been customarily and by long course of legislation levied, what objects or purposes have been considered necessary to the support and for the proper use of the government, whether State or municipal. Whatever lawfully pertains to this, and is sanctioned by time and the acquiescence of the people, may well be held to belong to the public use and proper for the maintenance of good government, though this may not be the only criterion of rightful taxation." ${ }_{6}$

Federal courts not bound by State de. cisions.

Legisla. ture may impose general or local taxa. tion;
What is or what is not a public use is a question of general jurisprudence which the federal courts will determine for themselves. ${ }^{7}$

Provided the object is a public one, it rests in the discretion of the legislature to defray the expenses either by general or local taxation. ${ }^{8}$ When, under an act of the legislature for an improvement in one county, which was of benefit to the whole State, the legislature directed the expense to be met

- Citizens' Sav, ete., Assoc. v. Topeka, 20 Wall. (U. S.) 655. See Perry $r$. Keene, 56 N. H. 514: State $r$. Nelson County, l N. Dak. 88.

7 Fallbrook Irrigation Dist. $\iota$. Bradley. 164 U. S. 112.

8 Assessments for a portion of the costs and expenses incident to the location and maintenane of a park in the Distriet of Columbia, dedieated to "the benefit and enjoyment of the people of the United States," may br levied upon the owners of neighboring lands. Wilson $v$. Lambert, 168 U. S. 611. 
by that county by an issue of bonds, the act was held an exercise of the power of taxation and the Chapter VII. court said: "When any public work is authorized, it rests with the legislature, unless restrained by constitutional provisions, to determine in what manner the means to defray its cost shall be raised. It may apportion the burden ratably among all the counties, or other particular subdivisions of the State, or lay the greater share or the whole upon that county or portion of the State specially and immediately benefited by the expenditure."' 9

If, however, the purpose for which taxes are levied is a purpose purely local, the taxes may not be levied on another community or other property in —provided tax is, as to taxpayer, purpose. no way benefited by the improvement. Such an exaction would be a purely arbitrary exercise of despotic power, a denial of due process of law and not a tax in a constitutional sense. "Conceding," said the Supreme Court of Iowa, "to the General Assembly a wide range of discretion as to the objects of taxation, the kind of property to be made liable, and the extent of territory within which the local tax may operate, . . . there must be some limit to this legislative discretion; which, in the absence of any other criterion, is held to consist in the discrimination to be made between what may reasonably be deemed a just tax, for which a just compensation is provided in the objects to which it is to be devoted, and that which is palpably not a tax, but which, under the form of a tax, is the taking of private property for public use, without just comnensation, If there be such a flagrant and palpable departure from

- Mobile County $v$. Kimball, 102 U. S. 691. 
Chapter equality in the burden imposed; if it be imposed for VII. the benefit of others, and for purposes in which those objecting have no interest, and are, therefore, not bound to contribute, it is no matter in what form the power is exercised - whether in the unequal levr of the tax, or in the regulation of the boundaries of the local government, which results in subjecting the party unjustly to local taxes, it must be regarded as coming within the prohibition of the Constitution designed to protect private rights against aggression, however made, and whether under the color of recognized power or not." ' But every presumption is to be made in favor of the validity of legislative action, and unless the purpose is palpably of no benefit to the community or property taxed, unless there is a clear abuse of the legislative discretion, the tax will be sustainer..2

\section{SUMMART PROCEEDINGS FOR COLLECTION.}

Necessity fur summary collection.
The parment of taxes must frequently be enforced against a reluctant and adverse sentiment, which would gladly avail itself of every opportunity to postpone collection, while the necessities of the gorermment for revenue may not admit of the delays incillent to the formal proceedings of a suit in court. From time inmemorial these conditions have been recognized, and the most summary methods of seizure and sale for the satisfaction of taxes and public dnes have been anthorized and, being recognized universally in England and in this comntry, they

1 Morford $r$, Tnger, S Iowa 82.

2 Bonth $r$. Woodhury, 32 Conn. 128. And see Wilson $r$. Lambert, 168 U. S. 6ill; IIenderson Bridge Co. $r$. Henderson, 173 U. S. 592, supra, p. 214, note 9. 
have been held to constitute due process of law. ${ }^{3}$ The earliest case in the Federal Supreme Court on Chapter VII. this point, Murray v. Hoboken Land, etc., Co., ${ }^{+}$arose in 1855 and was likewise the first case in which the meaning" of "due process of law" was fully considered. An Act of Congress provided that, when an account against an officer who held public money had been adjusted by the auditor of the treasury, and the officer found indebted to the government, and he neglected and refused to pay, the solicitor of the treasury should thereupon issue a distress warrant to the marshal of the proper district, who was authorized to seize and sell property of the debtor or his sureties in satisfaction of the debt. The issue of the warrant and the seizure and sale of the debtor's property thereunder were held to constitute due process of law. By a historical review, it was shomn that similar summary process for the collection of taxes and debts due the govermment was sustained by usage both in England and in the United States, and it ras held that the act of the auditor in passing on the accounts submitted to him, although made conclusive until reviewed by the courts, was not a judicial act in such a sense that Congress could not under the circumstances submit the ascertainment of the balance to an administrative officer.

In a later case holding the summary seizure and sale of property for taxes to a State due process of lar, the court said: "The mode of assessing taxes Summary process must not trary. in the States by the federal government, and by all

3 Springer $v$. U. S., 102 U. S. 586; Kelly $r$. Pittsburgh, 104 U. S. 78; Leigh $v$. Green, 193 U. S. 79, Ss; Scottish Union, ete., Ins. Co. $r$. Bowland. 196 U. S. 611 . See supra. p. 53.

418 How. (U. S.) 272. See also King $v$. Mullins, 171 U. S. 429. 
Chapter governments, is necessarily summary, that it may be speedy and effectual. By summary is not meant arbitrary or unequal or illegal. It must under our Constitution be lawfully done. But that does not mean nor does the phrase 'due process of law' mean by a judicial proceeding. The nation from whom we inherit the phrase 'due process of law' has never relied upon the courts of justice for the collection of her taxes, though she passed through a successful revolution in resistance to unlawful taxation. ${ }_{5}$

Retroactive statute imposing penalty for nonpayment.

Forfeiture for nonpay. ment of tax.
Interest and costs in a proceeding to collect delinquent taxes may be imposed by the State, and the statute made applicable to existing cases of delinquency without riolating any right guaranteed by the Federal Constitution. ${ }^{6}$

It has been held in some States in accordance with what appear to be just principles on the subject, that the State camnot declare the forfeiture of lands as a penalty for non-payment of taxes without provision for some proceeding in which the owner may be entitled mpon notice to present objections and defenses to the proposed forfeiture. ${ }^{7}$ Other States have declared an absolute forfeiture to be valid and constitutional. ${ }^{8}$ A case which arose in Test Virginia, where such proceedings were held to be valid, came before the Federal Supreme Court, and that tribunal found it possible to dispose of the points in-

s MeMillen r. Anderson, 95 U. S. 37.

e League $r$. Texas. 184 U. S. 156.

7 Mar-hall $r$. MeDaniel, 12 Bush (Ky.) 37s: Griffin $v$. Mixon, 38 Miss. 424: Parish r. East Coast Celar Co., 133 N. Car. 478.

s Wild $r$. Serpell. 10 riratt. (Va.) 40.5; Levasser $v$. Washburn. 11 Gratt. (Ta.) 5.2; Me(Jure r. Maitland, 24 W. Va. 561: Holly River Coal Co. $v$. Howell, 36 Wr. Va. 459. 
volved without committing itself to either theory. The statutes of West Virginia provided that lands

so forfeited should be sold for the benefit of the school fund, that for this purpose the commissioner of the school fund should institute a proceeding in the Circuit Court, and that in this proceeding the owner might intervene upon due notice and secure a redemption of his lands by payment of the taxes and charges. These provisions were held to constitute due process of law and to remove all constitutional objections to the statute. ${ }^{9}$

A charge in the nature of a tax on a preseribed Occupation

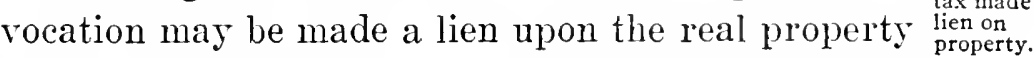
whereon the vocation is conducted, if to the owner of the property is given a reasonable notice and oppor tunity to present objections before the lien attaches. ${ }^{1}$

\section{NOTICE AND HEARING.}

While the legislature's power to impose and apportion taxes is in many respects unlimited, the legislature must generally in providing for their No right of hearing when legislature acts assessment and collection afford a hearing or an opportunity to be heard to the taxpayer. The right to notice and a hearing does not exist as to any matter which the legislature rightfully determines in providing for the tax. We have seen that the right to select the subjects and the method of taxation is inherent in and inseparable from the taxing power. The selection of the subjects of taxation, especially where the tax is a local one or a special assessment in return for benefits, may involve an adjudication

9 King $r$. Mullins, 171 U. S. 429.

1 Hodge $r$. Muscatine County, 196 U. S. 276. 
Chapter that particular property is liable to the tax, ${ }^{2}$ and the
vII. selection of a particular method of taxation, for instance, a specific instead of an ad valorem tax, may involve an adjudication as to the amount due from the individual taxpayer. ${ }^{3}$ The choice of a specific tax by the legislatmre does not, however, deprive the individual taxpayer of due process of law, for so far as the determination of a question of fact is incidentally involved in the course adopted, that determination is a necessary consequence of the exercise of the taxing power. But the legislature may adopt a different course, learing such questions for determination by the officials charged with the execution of the taxing laws, who act in a judicial or quasijudicial capacity and must proceed on notice and hearing. This is necessarily the case, when, instead of a specific, an ad ralorem tax is selected. Then before an individual liability for the tax can arise, it is essential that there be an assessment of the property to be taxed, and an apportiomment of the tax in accordance with the raluation determined by assessment and the rate of taxation. ${ }^{4}$ Thus the field of individual right to notice and hearing may be widened or narrowed with the action of the legislature.

a see infra, p. 246.

3 Hodire $r$. Muscatine County, 196 U. S. 276. 280.

4 The distinction here noticed between specific and ad ralorem taxes was pointed out by Mr. Justice Field in Ilagar $v$. Reelamation Dist. No. 108, 111 ['. S. 709 . "Of the different kinds of taxes which the State may impose," it is there said, "there is a vast number of which, from their nature, no notiee ean be given to the taxpayer. nor would notice he of any possible advantage to him, such as polltaxes. license taxes (not dependent upon the extent of his business), and grenerally specifie taxes on things or persons or oceupations. In such cases the legislature in anthorizing the tax fixcs its amount, 
Ordinarily the process of assessment is committed to executive officers, who in the performance of their quasi-judicial functions must give the property owner notice and an opportunity to present objections, wherever the action of the legislature has left open any question upon which a hearing may possibly change official action. But at least where the property taxed is certain in value, as is money, the interest on bonds, the face value of securities, etc., no assessment is essential other than the statute fixing the rate of taxation. ${ }^{5}$ And the statute imposing the tax may of itself constitute due process of law by providing a time and place for the meeting of the assessing board, and giving an opportunity for a hearing. ${ }^{6}$

and that is the end of the matter. If the tax be not paid. the property of the delinquent may be sold and he be thus deprived of his property. Set there can be no question that the proceeding is due process of law, as there is no inquiry into the weight of eridence, or other element of a judicial nature, and nothing conld be changed by hearing the taxpayer. No right of his is therefore invaded." After instancing particular taxes which fall under this class, the learned judge proceeded: "But where a tax is levied on property not specifically, but according to its value, to be ascertained by assessors appointed for that purpose, upon such evidence as they may obtain, a different principle comes in. The officers in estimating the value act judicially, and in most of the States provision is made for the correction of errors committed by them, through boards of revision or equalization sitting at designated periods provided by law, to hear complaints respecting the justice of the assessments. The law, in prescribing the time when such complaints will be heard, gives all the notice required, and the proceeding by which the valuation is determined, though it may be followed if the tax be not paid, by a sale of the delinquent s property, is due process of law."

5 Dollar Sar. Bank v. U. S., 19 Wall. (U. S.) 240; U. S. $v$. Erie R. Co., 107 U. S. 1; U. S. $r$. Philadelphia, ete., R. Co., 123 U. S. 113; Bell's Gap R. Co. $v$. Pennsylvania, 134 U. S. 232.

6 Palmer $r$. McMahon, 133 U. S. 669 ; Pittsburgh. etc., R. Co. $v$. Backus, 154 U. S. 421; Merchants', etc., Bank $v$. Pennsylvania, 167 
Chapter

III.

General taxes.

Statutes imposing general taxes usually provide for an anmul levy and fix the time within which the assessment shall be made, a specific time and place for the equalization of the assessment and the levy of the tax, a time within which the amount of the tax shall be placed in the tax books, a specific time for the tax books to be delivered to the collector or treasurer, and a specific time for the tax to become a lien on the property taxed, and this is enough to constitute due process of law.7 The Federal Supreme Court in a case decided in 1902 remarked that while the exact requirements of due process in the assessment and collection of general taxes had never been determined by the court, yet proceedings in such cases are to be construed "with the ntmost liberality, sometimes even to the extent of holding that no notice whatever is necessary."'s In the same case the court declared that it was well settled in that court that to constitute due process of law in proceedings "for the imposition of special taxes for local improvements, notice to the owner at some stage of the proceedings, as well as an opportunity to defend, is essential.",

Notice varies with subject. matter.

It has been stated, in discussing the essentials of due process and the general requirements of notice, that the notice required to render a proceeding valid,

U. S. 461, 466. See Kentucky Railroad Tax Cases, 115 U. S. 331, and supra, p. 83.

$\tau$ Winona, etc., Land Co. $v$. Minnesota, 159 U. S. 526 ; Gilmore $v$. Hentig, 33 Kan. 156, 169, 170.

8 Turpin $v$. Lemon, 187 U. S. 57, 58. And see Glidden $v$. Harrington, 189 U. S. $255,258$.

- Turpin $v$. Lemon. 187 U. S. 58, citing Hagar $v$. Reclamation Dist. No. 108, 111 U. S. 701; Paulsen v. Portland, 149 U. S. 30 . See also supra, p. 76 . 
when tested by the due process of law clause of the Constitution, varies with the circumstances of the case and "the cause and objects of the taking," "and that the notice required for the lawful exercise of eminent domain or the police power is not the same as that required in proceedings for taxation. ${ }^{2}$ Since proceedings for the assessment and collection of taxes were in constant use long before the adoption of the Constitution and have been necessarily employed by the federal government and the various States ever since their formation, the rule that whaterer proceedings are in accord witl settled usage in England and in this country constitute due process, ${ }^{3}$ is peculiarly applicable to test the sufficiency of the notice and hearing required in such cases. In conformity with this principle, it has been held that the process of taxation "involves no violation of due process of law when it is executed according to customary forms and established usages, or in subordination to the principles which underlie them." 4

A proceeding for the assessment and collection of taxes may so far partake of the nature of a proceeding in rem that notice by publication is sufficient to give jurisdiction. ${ }^{\mathbf{5}}$ Thus a proceeding strictly against property to enforce by sale a lien for unpaid

1 See supra, p. 80.

2 Bell's Gap R. Co. v. Pennsylvania, 134 U. S. 232.

3 See supra, p. 53.

4 Bell's Gap R. Co. $v$. Pennsylvania, 134 U. S. 232, 239. See also Turpin $v$. Lemon, 187 U. S. $51,57,59$.

5 Lent $v$. Tillson, 140 U. S. 316 ; Paulsen $v$. Portland, 149 U. S. 30 ; Pittsburgh, etc., R. Co. $v$. Backus, 154 U. S. 421 ; Merchants', etc., Bank $v$. Pennsylvania, 167 U. S. 461 ; Bellingham Bay, etc., R. Co. $v$. New Whatcom, 172 U. S. 318. And see the quotations from Dillon $v$. Heller, 39 Kan. 599, in Arndt $v$. Griggs, 134 U. S. 316. 
Chapter taxes does not require personal notice, ${ }^{6}$ but no per-
VII. sonal judgment against a nonresident owner is valid in such a case unless he has been personally served with notice within the jurisdiction, or has voluntarily appeared. ${ }^{7}$ In a case holding notice by publication sufficient for the assessment of "the ordinary annual tax upon personal property," it was declared: "It can only be said that such notices shall be given as are suitable in a given case, and it is only where the proceedings are arbitrary, oppressive, or unjust that they are declared to be not due process of law." s

In the celebrated case of Davidson $v$. New Orrule of leans, ${ }^{9}$ which involved the legality of a special assessment for draining swamp-lands, the court laid down the often quoted principle "that whenever, by the laws of a State, or by State anthority, a tax, assessment, servitude, or other burden is imposed upon property for the public use, whether it be for the whole State or some more limited portion of the community, and those laws provide for a mode of confirming or contesting the charge thus imposed, in the ordinary courts of justice, with such notice to the person, or such proceeding in regard to the property, as is appropriate to the nature of the case, the judgment in such proceedings can not be said to deprive the owner of his property without due process

6 Leigh $v$. Green, 193 U. S. 79 ; French $v$. Taylor, 199 U. S. 274.

7 Dewey $r$. Des Moines, 173 U. S. 193.

8 Glidden $r$. Harrington, 189 U. S. 255, 258. See the concurring opinion of Bradley, J., in Davidson $v$. New Orleans, 96 U. S. 97, whence this statement is in effect taken.

996 U. S. 97. 
of law, however obnoxious it may be to other objections." ${ }_{1}$

In harmony with this rule, the property owner

Chapter

VII.

Applica.

tions.

need not be present when his property is assessed, and it is sufficient that at some stage of the proceedings, as, for instance, before a board of equalization, ${ }^{3}$ or in the courts by a proceeding to review the assessment, he may be heard on the question of the amount of his tax. ${ }^{4}$ It is only necessary that an opportunity to test the validity and fairness of the tax be given before it has become a fixed and permanent charge on the property owner. ${ }^{5}$ Thus when a statute provides that those whose property is to be taken for a local improvement shall be heard as to its necessity and makes no provision for notice to those who may be assessed therefor, the latter cannot complain if a hearing is given to them on the amount of their assessments. ${ }^{6}$ The opportunity may exist before the assessing board, and when this is the case, no further hearing nor right of review need be provided. ${ }^{7}$

1 Quoted in Fagar $v$. Reclamation Dist. No. 108, 111 U. S. 701 ; Kentucky Railroad Tax Cases, 115 U. S. 321; Lent v. Tillson, 140 U. S. 316 ; Leigh $v$. Green, 193 U. S. 88.

2 McMillen $v$. Anderson. 95 U. S. 37.

3 Palmer $v$. McMahon, 133 U. S. 669.

4 Spencer $v$. Merchant, 125 U. S. 345 ; Paulsen $v$. Portland, 149 U. S. 30 ; Winona, etc. Land Co. v. Minmesota, 159 U. S. 536 ; Pittsburgh, ete., R. Co. $v$. Board of Public Works, 172 U. S. 45.

5 Winona, etc., Land Co. $r$. Minnesota, 159 U. S. 537 ; Weyerhaueser $v$. Minnesota, 176 U. S. 550 ; Gallup $v$. Schmidt, $183 \mathrm{U}$. S. 300, 307; Hodge $v$. Muscatine County, 196 U. S. 276. 291; Gilmore r. Hentig, 33 Kan. 169, 170.

6 Voigt $v$. Detroit, 184 U. S. 115; Goodrich $v$. Detroit, 184 U. S. 432 .

7 Spring Valley Water Works $v$. Schottler, 110 U. S. 347; Fall- 
Chapter

VII.

Appraisement of imported goods.
Statute providing for "hear. ing."

The ascertainment and collection of duties on imported merchandise is subject to the same principles. By statute the value fixed by the appraisers is made conclusive, subject to impeachment when they have proceeded fraudulently, on a wrong principle, contrary to law, or have transcended the power's conferred by statute. ${ }^{8}$ The appraisers are vested with quasi-judicial powers, and their determination by value, though summary, is due process of law. It was not the intention of Congress nor is it necessary to the rights of importers that the appraisement should be conducted as is the trial of an issue in a suit in a judicial tribunal. Consequently, the importer can not complain that he is not allowed to be present throughout the proceedings, that he is not allowed to confront the witnesses summoned, or to cross-examine them. ${ }^{1}$

\section{The Hearing Actually Provided.}

The extent of the hearing actually provided for in a given case must depend upon the statute laying or authorizing the tax.

When a statute provides for "a hearing" in connection with the question whether a proposed public improvement shall be undertaken the natural construction is that the hearing extends to eversthing which is essential to the validity of the undertaking.

brook Irrigation Dist. $v$. Bradley, 164 U. S. 112; Mibben $v$. Smith, 191 C. S. 310.

8 Passavant $v$. U. S., 148 U. S. 214 ; Origet $v$. Hedden, 155 U. S. 228.

9 Hilton $v$. Merritt, 110 U. S. 97 ; Earnshaw $v$. U. S., 146 U. S. 60 ; Passavant $r$. U. S., 148 U. S. 214.

1 Auffmordt $v$. Hedden, 137 U. S. 310. 
A California statute for the formation of irrigation districts provided that a petition for the formation of the district, signed by a majority of the property owners in the territory to be included, must be presented to the board of county supervisors at a regular meeting, after publication of the petition for two weeks with notice of the time of the meeting when it was to be presented, and that the "board shall hear the same," and establish the boundaries of the district, subject to the proviso that it had no power to exclude lands included in the petition, if susceptible of irrigation as petitioned for", nor to include lands "which will not in the judgment of the board be benefited" by such irrigation. The statute further provided that when the district had been thus defined, an election should be held therein upon the question whether it should be organized and for the designation of director's; that if the district was organized, the directors elected should organize as a board, one of whose duties should be at a duly advertised meeting at a time specified to examine the assessment of the property for the district made by the proper officer and "hear and determine such objections to the valuation and assessment as may come before them, and the board may change the valuation as may be just." The United States Circuit Court for the Sonthern District of California held the statute void under the Fourteenth Amendment, for the reason, inter alia, that property owners were given no hearing on the sufficiency of the petition which lay at the foundation of the whole proceeding. ${ }^{2}$ The United States Supreme Court re-

2 Bradley $v$. Fallbrook Irrigation Dist., (C. C. A.) 68 Fed. Rep. 948. 
Chapter versed this decision, declaring that the statute pro-
vII. vided for notice and hearing on every essential point. In holding that a hearing as to the sufficiency of the petition and the validity of the preliminary steps in organization, as well as the fact of benefit to the land included, was afforded, Mr. Justice Peckham, for the court, said: "When the act speaks of a hearing of the petition, what is meant by it? Certainly it must extend to a hearing of the facts stated in the petition, and whether those who sign it are sufficient in number and are among the class of persons mentioned in the act, as alone having the right to sign the same. The obvious purpose of the publication of the notice of the intended presentation of the petition is to give those who are in any way interested in the proceeding an opportunity to appear before the board and be heard upon all the questions of fact, including the question of benefits to lands described in the petition. . . . It can not be doubted that, by the true construction of the act, the board of supervisors is not only entitled, but it is its duty, to entertain a contest by a landowner in respect to the question whether the signers of the petition fulfil the requirements described in the first section of the act, and if the board find in favor of the contestant upon that issue, it is the duty of the board, under the provisions of the statute, to deny the petition and dismiss the proceedings. Otherwise, what is the hearing for? And if upon a hearing of the question of benefits to any land described in the petition it appears to the board that such lands will not be henefited. it is the duty of the board to so decide, and to exclude the lands from the district. 
The inclusion of any lands is therefore, in and of itself, a determination (after an opportunity for a Chapter VII. hearing) that they will be benefited by the proposed irrigation." 3

When a statute provides that a tax can be enforced only by suit in a regular court of justice, in the absence of special provisions of the local law limiting the defenses which may be made to such a suit, the Federal Supreme Court declares that "as a principle of general jurisprudence, it is safe to say, that any defense is admissible which establishes the illegality of the proceeding resulting in the alleged assessment, whether because it is in violation of the local law which is relied on as conferring the authority upon which it is based, or because it constitutes a denial of a right secured to the party complaining by the Constitution of the United States." 4

Though no hearing is provided on the question of fixing a taxing district or on the aggregate amount to be assessed on the district, when both these matHearing after assessment involves its legality. ters are delegated to local authorities, yet if a hearing is given to the property owner to test the legality of the charge upon him, there is provision for due process of law. "In the legality of that charge is necessarily involved the legality of all which precedes it and of which it is the consequence."

The necessity of provision for a hearing implies that the act of assessment can not be arbitrarily per- $\begin{gathered}\text { cise honest. } \\ \text { judgment. }\end{gathered}$ formed but demands the honest judgment of the assessors, and the statute need not prescribe the rule

3 Fallbrook Irrigation Dist. v. Bradley, 164 U. S. 171, 173.

4 Kentucky Railroad Tax Cases, 115 U. S. 336.

5 Voigt $v$. Detroit, 184 U. S. 115 ; Goodrich $v$. Detroit, 184 U. S. 432. And see Weyerhaueser $v$. Minnesota, 176 U. S. 550. 
Chapter for arriving at the valuation of the property, but
VII. may leave to taxing officers the power to adopt a suitable rule. ${ }^{6}$ When it was objected to the valuation of property by a board of tax assessors, that the law furnished no rule for ascertaining the value of a special franchise included in the assessment along with tangible property, and that, as the board followed no principle in arriving at the total value, it must have indulged in mere guesswork, which amounted to a deprivation of due process of law, the Supreme Court supported the assessment. After pointing out that hearing was amply provided for, it said: "It will not do to say that the valuation of a piece of property is mere guesswork. True, it is often largely a matter of opinion, and mathematical exactness is not always possible. Various elements enter into and affect an opinion respecting the value of a given piece of property, and all that can be required is that the assessing board exercise an honest judgment based upon the information it possesses or is able to acquire. That valuation is of the property as a totality, and it is unnecessary in making an assessment to disintegrate the various elements which enter into it and ascribe to each its separate fraction of value. Oftentimes the combination itself is no inconsiderable factor in creating the value." 7

\section{LOCAL ASSESSMENTS.}

Legislative functions in laying local as. sessments.
The making of a public improvement, such as opening or grading a street, laying sewer-pipes, or

- Western Union Tel. Co. $v$. Missouri, 190 U. S. 412, 425. Seo also supra, p. 68.

7 Brooklyn City R. Co. v. Tax Com'rs, 199 U. S. 48. 
draining or irrigating lands, involves the determination of various matters of fact. The necessity or propriety of the improvement itself, the method by which its expenses shall be defrayed, and, if a local assessment is determined on, the extent of the area upon which it is to be laid and the manner of apportioning it upon the several parcels of property lying within the limits fixed upon, must all be decided. Every question belonging to the raising of funds to meet the costs of such an improvement, from the creation of a taxing district or the determination of the lands benefited thereby, to the apportionment and collection of the assessment laid, belongs to the legislature. There can be no doubt that "the legislature in the exercise of the right of taxation has the authority to direct the whole or such part as it may prescribe, of the expense of a public improvement, such as the establishing, the widening, the grading or the repair of a street, to be assessed upon the owners of lands benefited thereby. . . . The rule of apportionment among the parcels of land benefited also rests within the discretion of the legislature, and [the burdens to be borne by them] may be directed to be in proportion to the position, the frontage, the area, or the market value of the lands, or in proportion to the benefits as estimated by commissioners." $\mathrm{s}$

8 Bauman $v$. Ross, 167 U. S. 548. And see Mattingly $v$. District of Columbia, 97 U. S. 687, 692. For instances of valid assessments based on frontage, see French $v$. Barber Asphalt Paving Co., 181 U. S. 324; Chadwick $v$. Kelles, 187 U. S. 540; Seattle $v$. Kelleher, 195 U. S. 351 ; on value. Fallbrook Irrigation Dist. $v$. Bradley, 164 U. S. 112 ; on area, Walston $v$. Nevin, 128 U. S. 57 s; Louisville, ete., R. Co. $v$. Barber Asphalt Paring Co., 197 U. S. 430; on benefits, King $v$. Portland, 184 U. S. 61. 
Chapter

VII.

Delegation of legisla. tive func. tions.

In exercising its power, the legislature may either act directly, determining the area benefited and the rate of apportionment absolutely; or it may delegate to local authorities the power to decide as to the necessity of the improvement, the area which will be benefited, and the rule of apportionment, and this delegation may corer all or any of these points. The Federal Supreme Court holds that the legislature acting directly may determine the district benefited by a publie improvement and lay down an absolute rule as to the apportionment of the expense among the parcels of land included. When this course is adopted the act of the legisiature must be deemed conclusive alike of the question of the necessity of the rork, and of the benefits as against abutting property, and to open such questions to review by the courts upon the petition of any and every property holder would create endless confusion. But when the legislature delegates to municipal or local anthorities the determination of the property benefited or the rule of apportionment, or the propriety of making the improvement, or some or all of these questions, they become in their nature judicial in such a sense that the property owner is entitled to a hearing or to notice and an opportunity to be heard. ${ }^{9}$

In some State courts it has been held, however, that the legislature exceeds its powers in enacting a

9 Speneer $v$. Merchant, 125 U. S. 345 ; Walston $v$. Nevin, 128 U.S. 578; Panlsen $v$. Portland, 149 U. S. 30; Fallbrook Irrigation Dist. $v$. Pralley, 164 U. S. 112 ; Bauman $r$. Ross, 167 U. S. 548 ; Parsons $r$. District of Columbia. 170 U. S. 45; French $v$. Barber Asphalt Paving Co., 181 U. S. 324; Jouisville, etc., R. Co. $r$. Barber Asphalt Paving Co., 197 U. S. 430. 
statute which absolutely fixes the proportion of expense to be borne by abutting owners, ${ }^{1}$ or which makes no provision for the indennification of the orrner of the land subjected to the operation of the law, in case the expense of improvements shall exceed the benefits which shall be conferred." These cases proceed upon the ground that no rule of apportiomment can be adopted by the legislature which does not provide for the equating of benefits to burdens in the individnal case; because if the area benefited or the method of apportionment is fixed absolutely by the legislature, in individual cases the burden may exceed the benefit, and the moment this happens property is taken withont compensation for a public purpose, and there is no longer a rightful exercise of the taxing power but a wrongful exercise of the porver of eminent domain. Statutes under which such results may ensue are without the taxing power and unconstitutional.

In Norwood v. Baker, ${ }^{3}$ the United States Supreme Court, in holding a particular assessment void as Position Supreme being a deprivation of property without due process Court. of law, indulged in reasoning which seemed to go to the whole length of denying the power of the legislature to lay down an absolute rule of apportionment without providing for a hearing. The case came up from the United States Circuit Court for the Southern District of Ohio. ${ }^{4}$ The village of Norwood opened a street to the north and south lines of a

I State $v$. Newark, 37 N. J. L. 415 . See Provident Sav. Inst. v. Jersey City, 113 U. S. 506.

2 Tide Water Co. v. Coster, 18 N. J. Eq. 518.

3172 U. S. 269.

4 Baker $v$. Norwood, (C. C. A.) 74 Fed. Rep. 997. 
Chapter tract of land owned by Mrs. Baker. In pursuance of authority conferred on villages by the Ohio statutes, the village determined to connect the two parts of the street by a continuation through Mrs. Baker's land for a distance of three hundred feet. The constitution of Ohio provided that the compensation for private property taken for a public use "shall be assessed by a jury, without deduction for benefits to any property of the owuer." The damages were assessed at $\$ 2,000$. The village council then passed an ordinance assessing the damages and expenses of the condemnation proceedings back upon the property according to frontage, which was one of the methods provided by the Ohio statutes. The amount so assessed against the property was $\$ 2,218.58$, and this was carried to the tax lists of the county to be collected by suit, by sale of the land, or by distraint of sufficient goods and chattels. The whole proceeding, which amounted to charging Mrs. Baker with the sum of $\$ 218.58$ for the privilege of having her land used by the village for a street, was held to be a mere confiscation of property and therefore void. Mr. Justice Harlan, who spoke for the court, said: "In our judgment the exaction from the owner of private property of the cost of a public improvement in substantial excess of the special benefits accruing to him is, to the extent of such excess, a taking under the guise of taxation of private property for public use without compensation. . . . As the pleadings show, the village proceeded upon the theory, justified by the words of the statute, that the entire cost incurred in opening the street, including the value of the property appropriated, could. 
when the assessment was by the front foot, be put Chapter upon the abutting property, irrespective of special benefits. The assessment was by the front foot and for a specific sum representing such cost, and that sum could not have been reduced under the ordinance of the village, even if proof had been made that the costs and expenses assessed upon the abutting property exceeded the special benefits. The assessment was in itself an illegal one because it rested upon a basis that excluded any consideration of benefits."

This decision was widely understood as establishing that special assessments must be limited by the benefits conferred and could not exceed that limit and also as condemning the front foot rule when applied absolutely without providing for a preliminary hearing upon benefits conferred. ${ }^{5}$ In truth the decision was not intended to establish either of these propositions, whatever may be laid down therein in dicta, as is shown in a series of cases which came before the Supreme Court in $1901 .^{6}$ The case was said to have presented "considerations of peculiar and extraordinary hardship," amounting "to actual confiscation of private property to public use,

ธ See, for instance, Adams $v$. Shelbyville, 154 Ind. 473, and cases cited at pp. $476,477$.

6 French $v$. Barber Asphalt Paving Co., 181 U. S. 324, affirming 158 Mo. 534; Wight $v$. Davidson, 181 U. S. 371, reversing 16 App. Cas. (D. C.) 371 ; Tonawanda $v$. Lyon, 181 U. S. 389 , affirming 98 Fed. Rep. 361 ; Webster $v$. Fargo, 181 U. S. 394, affirming 9 N. Dak. 208 ; Cass Farm Co. v. Detroit, 181 U. S. 396, affirming 124 Mich. 433 ; Detroit $v$. Parker, 181 U. S. 399, reversing 103 Fed. Rep. 357; Wormley $v$. District of Columbia, 181 U. S. 402, affirming 15 App. Cas. (D. C.) 58 ; Shumate $v$. Heman, 181 U. S. 402. affirming 159 Mo. 534; Farrell $v$. West Chicago Park Com'rs, 181 U. S. 404, affirming 182 Ill. 250. 

Chapter and bringing the case fairly within the reach of the
Vil.

Fourteenth Amendment." " In one of these cases, Norwood $v$. Baker ras also said to present the question of "the validity of a village ordinance, which imposed the entire cost and expenses of opening a street, irrespective of the question whether the property was benefited by the opening of the street. The legislature of the State had not defined or designated the abutting property as benefited by the improvement, nor had the village authorities made any incuiry into the question of benefits. There having been no legislative determination as to what lands were benefited, no inquiry instituted by the village councils, and no opportunity afforded to the abutting owner to be heard on that subject, this court held that the exaction from the orner of private property of the cost of a public improvement in substantial excess of the special benefits accruing to him is, to the extent of such excess, a taking under the guise of taxation of private property for public use without compensation.",s

Petitioner for act cannot dispute its validity.

The right to challenge an assessment as a denial of due process of law does not exist in one at whose instance the assessment was made, when the proceedings had were in strict compliance with the provisions of the act passed at his petition. ${ }^{9}$

7 Tonawanda $v$. I, con, 181 U. S. 392; French $v$. Barber Asplialt Paving Co., 181 U. S. 344; Wight $v$. Davidson, 181 U. S. 383 ; Cass Farm Co. $r$. Detroit, 181 U. S. 398.

8 Wight $r$. Davidson, 181 L. S. 384. Sce also Scott $r$. Toledo, 36 Fed Rep. 385, decided by Mr. Justice Jackson when eircuit judge of the sixth circuit.

* Shepard $v$. Larron, 194 U. S. 553. 


\title{
CHAPTER VIII.
}

\author{
THE EMINENT DOMAIN.
}

ITS GENERAL NATURE AND LIMITATIONS.

$E^{1}$ MINENT DOMAIN is the name used since Chapter the time of Grotius ${ }^{1}$ to express the power VIII.

under which the state may appropriate private property for public purposes, upon making, according to the principles of natural equity, compensation to the owner. The power is the offspring of political necessity, and is inseparable from sovereignty, unless denied to it by its fundamental law. ${ }^{2}$

Our dual system of government recognizes its existence in both the United States and the States, as inherent in each within its separate and independent Eminent domain in both na. State govsphere. ${ }^{3}$ But, while inherent in both sovereignties, the eminent domain of the national government is paramount, when its exercise is necessary to effectuate powers granted to it by the Constitution. "If," it has been said, "it is necessary that the United States government should have an eminent domain still higher than that of the [individual] State in order that it may fully carry out the objects

11 Thayer Cas. Const. Law, 945. 947; Grotius, De Jure Belli et Pacis. lib. iii, c. 20, 7 ; Gardner $v$. Newburgh, 2 Johns. Ch. (N. Y.) 162.

2 Kohl v. U. S., 91 U. S. 367 ; Searl $v$. School Dist. No. 2, 133 U. S. 553.

3 Kohl $v$. U. S., 91 U. S. 367. 

Chapter and purposes of the Constitution, then it has it.
VIII.

Whatever may be the necessities or conclusions of theoretical law as to eminent domain or anything else, it must be received as a postulate of the Constitution that the government of the United States is invested with full and complete power to execute and carry out its purposes." 4

Exercis.

able by

The eminent domain resides in the state and is

legislature. exercisable by the legislative branch of the government. The legislature may, in its discretion, exercise the power either directly or through agents, authorizing individuals or corporations to expropriate private property when the public interests require such a course. ${ }^{5}$

Grant

Nor can its grant of the power to one person or estoppel. set of persons estop the state from again exercising the right of condemnation whenever and as often as the necessity may arise. " "The only true rule of policy as well as of law is that a grant for one public purpose must yield to another more urgent and important, and this can be effected without any infringement of the constitutional rights of the subject. If in such cases suitable and adequate provision is made by the legislature for the compensation of those whose property or franchise is injured or

4 Stockton $r$. Baltimore, etc., R. Co., 32 Fed. Rep. 19. per Bradley, J., quoted in Cherokee Nation $v$. Southern Kansas R. Co., 135 U. S. 661.

5 Secombe $r$. Milwaukee, etc., R. Co., 23 Wall. (U. S.) 108; Lom. bard $r$. West Chicago Park Com'rs, 181 U. S. 33, 42; Moran $r$. Ross, 79 Cal. 159; Day v. Stetson, 8 Me. 365 ; Beekman $v$. Saratoga, etc., R. Co., 3 Paige Ch. (N. Y.) 45, 22 Am. Dee. 679.

6 West River Bridge Co. v. Dix, 6 How. (U. S.) 507; Hyde Park v. Oakwoods Cemetery Assoc., 119 Ill. 141; Beekman v. Saratoga: etc., R. Co., 3 Paige (N. Y.) 45, 22 Am. Dec. 679. 
taken away, there is no violation of public faith or private right." ?

Constitutional limitations on the exercise of this Chapter Vill.

Limita tions. right demand that the purpose for which the appropriation is made must be a public purpose; that the appropriation be accompanied with just compensation to the owner of the property; and in general, the presence of notice and a hearing is necessary on judicial questions involved.

THE PUBLIC PURPOSE OR USE.

To take property for other than a public purpose; to take, for instance, the property of one citizen and Necessity of public transfer it to another, would be a deprivation thereof without due process of law; and such a proceeding is equally unconstitutional when the appropriation is accompanied by full compensation, as when it is legislative confiscation without compensation. ${ }^{8}$ For, under our Constitution, the State is incapable of itself interfering or of conferring any right to interfere with private property unless it is needed for public objects. ${ }^{9}$

The determination of what is a public use justifying appropriation under public authority belongs

Determination rests legislature. primarily to the la $\pi$-making branch of the government; but, since the Constitution is a restraint on the legislature itself, it devolves upon the courts to declare ultimately whether or not the appropriation

7 Central Bridge Corp. $v$. Lowell, 4 Gray (Mass.) 482, per Bigelow, J.

8 Missouri Pac. R. Co. $v$. Nebraska, 164 U. S. 403; Matter of Tuthill, 163 N. Y. 133, 138 ; Fallsburg Power, etc., Co. v. Alexander, 101 Va. 98.

9 Natter of Tuthill, 163 N. Y. 133, 138; In re Rhode Island Suburban R. Co., 22 R. I. 455. 
Chapter is for a public purpose. According as the one or VIII. the other aspect of the matter is uppermost, this question has been spoken of sometimes as a judicial, sometimes as a legislative one. ${ }^{1}$ In truth, the mat-

Supervis: ory power of courts. ter is purely legislative, and the courts merely exercise a supervisory power, that of keeping the legislature within constitutional bounds. The legislative declaration that a use is public must prevail, unless it appears that such declaration is so manifestly wrong as not to admit of a doubt that the use is not public.2

\section{Various Public Uses Enumerated.}

The courts have not attempted an exact definition of a public use which will justify a taking by eminent domain, but there are certain purposes universally conceded to be within the rightful exercise of this power. Private property may be expropriated

1 In some States (Colorado, Missouri, Washington) there is a constitutional provision that the question is a judicial one to be determined "without regard to any legislative assertion that the use is public." Sarannah v. Haneock, 91 Mo. 54; Healy Lumber Co. $q$. Morris, 33 Wash. 490.

2 U. S. $v$. Gettysburg Electrie R. Co., 160 U. S. 668, 680; Tuttle $v$. Moore, 3 Indian Ter. 712, 729; Hazen $v$. Essex County, 12 Cush. (Mlass.) 477; Vamer $r$. Martin, 21 W. Va. 534; Chicago, ete., R. Co. $r$. Morehonse, 112 Wis. 1.

"In such cnses [the exercise by the legislature of the taxing power, eminent domain, or the police power] it is always to be remembered that the judicial question is a secondary one. The legislature, in determining what shall be done, what it is reasonable to do, dnes not divide its duty with the judges, nor must it conform to their conception of what is prudent or reasonable legislation. The judieial function is merely that of fixing the ontside border of reason. able legislative action, the bomdary beyond which the taxing power. the power of eminent domain, police power, and legislative power in general eannot go without violating the prohibitions of the Constitution, or erossing the line of its grants." Prof. James 13. Thayer, American Doctrine of Constitutional Lax, 7 Harv. L. Rev. 148. 
when its acquisition is necessary to the acknowledged activities of the government, whether exerted by the State itself, by a department thereof, or by the local govermments of counties or municipalities. WithChapter VIII. in this class falls condemnation of property for forts, armories, arsenals, navy yards, light houses, custom houses, court houses, post offices, ${ }^{3}$ the establishment of public alms-houses, ${ }^{4}$ public schools, ${ }^{5}$ and similar enterprises. The construction and improvement of public highways and means of intercommunication are public purposes ${ }^{6}$ and the power of eminent domain may be exerted for public highways, ${ }^{7}$ turnpikes, ${ }^{8}$ railways, ${ }^{9}$ canals, ${ }^{1}$ and for telegraphs and telephones, ${ }^{2}$ as well as for bridges and

3 Kohl $v$. U. S., 91 U. S. 367 ; Ft. Leavenworth R. Co. v. Lowe, 114 U. S. 525 ; Chappell $v$. U. S., 160 U. S. 499, 509, 510. 486.

4 Heyward $v$. New York, 7 N. Y. 314, affirming 8 Barb. (N. Y.)

5 Long $v$. Fuller, 68 Pa. St. 170; Williams $v$. School Dist. No. 6, $33 \mathrm{Vt} .271$.

6 "In every form of government the duty of providing public ways is acknowledged to be a public duty." Matter of Niagara Falls, etc., R. Co., 108 N. Y. 375, 385.

7 Lewis on Em. Dom. 166.

"The public necessity and convenience have always indicated highways as one of the objects for which the state might take privatc property." Dronberger $v$. Reed, 11 Ind. 420, 422.

8 State $v$. Maine, 27 Conn. 641.

9 Secombe $v$. Milwaukee, etc, R. Co., 23 Wall. (U. S.) 108; Cherokee Nation $v$. Southern Kansas R. Co., 135 U. S. 641, 657; Bonaparte $v$. Camden, etc., R. Co., Baldw. (U. S.) 205; People $v$. Township Board, 20 Mich. 452, 477, 4 Am. Rep. 400; Beekman $v$. Saratoga, etc., R. Co., 3 Paige (N. Y.) 45, 73, 74, 22 Am. Dec. 679.

1 Chesapeake, etc., Canal Co. $v$. Key, 3 Cranch (C. C.) 599 ; Willyard $v$. Hamilton, 7 Ohio (pt. ri) 111, $30 \mathrm{Am}$. Dec. 195.

2 Lewis, Em. Dom. 172; Trenton, ete., Turnpike Co. v. American, etc., News Co., 43 N. J. L. 381; State $v$. Central New Jersey Telephone Co., 53 N. J. L. 341.

The right of eminent domain was not granted to telegraph com. 

Chapter ferries, ${ }^{3}$ wharves and landings, ${ }^{4}$ booms for floating
VIII.

Matters logs on streams, ${ }^{5}$ and structures necessary in connection with improved highways, such as depots, ${ }^{6}$ repair shops, ${ }^{7}$ stock yards, ${ }^{8}$ etc.

of police.

Another class of cases includes measures of police control, especially those designed to promote the

panies by the Act of Congress, which allowed them to construet lines through the public clomain and over the military and post roads of the Unitel States. Pev. Stat. L'. S. \$ 5203 et seq.: 7 Fed. Stat. Annot. 205. Western Union Tel. Co. $r$. Pennsylvania R. Co., 195 U. S. $5+0$.

3 Lewis, Em. Dom. I6s; Arnold $r$. Covington, ete.. Bridge Co.. 1 Duval ( $\mathrm{Kr}$ ) 372: Day $r$ Stetson, 8 Me. 365 (ferry): Southern Illinois, etc., Bridge Co. $r$. Stone, I74 Mo. I (toll bridge).

4 Kingsland $v$. New York, 110 N. Y. 56!): Matter of New York, 135 N. Y. 253; Pittsburgh v. Scott, I Pa. St. 302.

5 Lawler $v$. Baring Boom Co., 56 Me. 443; Cotton $v$. Mississippi, ete. Boom Co., 22 Minn. 372; Henly Lumber Co. $v$. Morris, 33 Wash. 490. 503, distinguishing boom companies organized to do a carrying business for the publie, from private logging companies. Compare Brewster $\imath$. J. \&. J. Rogers Co., I69 N. Y. 73.

6 "If lands are required for any of the purposes of the incorporation, or for the purpose of operating and rumning the road, that is, in the proper enjoyment and exercise of the franchise conferred and in the performance of the service to the public assumed hy it, they may be taken in invitum. The only limit to the power is the reasonable necessity of the corporation in the diseharge of its duty to the publie. The right to take lands upon which to erect a manufactory of cars or dwellings for operatives, is not ineluded in the grant. Such purposes are not legitimately and necessarily connected with the management, the running and operating of the railroad. . . But passenger depots, convenient and proper places for the storing and keeping cars and locomotives when not in use. proper, secure, and convenient places having reference to the public interests to be subserved, for the receipt and delivery of freight. and for the safe and secure keeping of property between the time of its receipt and despateh, or after its arrival and discharge and before its removal by the owner or consignee, are among the acknowledged neeessities for the running and operating the railroad, to the proper prosecution of the business in the interests of the public." New Tork, etc., R. Co, r. Kip, 46 N. Y. 546, 552.

7 Chicago, ete., R. Co. $r$. Wilson, 17 Ill. 123.

8 Covington Stock-Yards Co. $v$. Keith, 139 U. S. 128. 
public health. Such are statutes employing the eminent domain to secure the drainage of cities, ${ }^{9}$ or of Chapter VIII. swampy districts, ${ }^{1}$ the procuring of a pure water supply for cities, ${ }^{2}$ the establishment of public cemeteries, ${ }^{3}$ the abating of great public nuisances, ${ }^{*}$ the establishment of public markets, ${ }^{5}$ and the like.

Still other cases arise when great public interests, as irrigation in arid districts ${ }^{6}$ and the construction of dikes and levees in areas subject to overflow, ${ }^{7} \mathrm{or}^{\circ}$ public convenience, such as supply of gas to municipalities, ${ }^{8}$ have been held to warrant the expropriation

๑ Leeds $r$. Richmond, 102 Ind. 372, 376; Kingman, Petitioner, 153 Mass. 566; Stoudinger $v$. Newark, 2s N. J. Eq. 18 7 , and note by reporter. The power in cities to construct sewers may be put on the city's right to maintain streets.

1 Manigault $v$. Springs, 199 U. S. 473; Elmore $v$. Drainage Com'rs, 135 Ill. 269, 25 Am. St. Rep. 363; Anderson $v$. Kerns Draining Co., 14 Ind. 199, 77 Am. Dec. 63; Matter of Ryers, 72 N. Y. I, 28 Am. Rep. 8s; State $r$. Stewart, 74 Wis. 620. These cases place the right only on the ground of public health. See also Heffner $v$. Cass County, 193 Ill. 439; State $v$. Polk County, 87 Minn. 325; Mound City Land, etc., Co. $v$. Miller, 170 Mo. 240.

2 U. S. v. Great Falls Mfg. Co., 112 U. S. 645; Long Island Water Supply Co. $v$. Brooklyn, I66 U. S. 685 ; Burden $v$. Stein, 27 Ala. 104, $62 \mathrm{Am}$. Dec. 758; Lynch $v$. Forbes, 161 Mass. 302, $42 \mathrm{Am}$. St. Rep. 402 ; Gardner $v$. Newburgh, 2 Johns. Ch. (N. Y.) 162, 7 Am. Dec. 528; Stearns $v$. Barre, 73 Vt. 281.

3 Edwards $v$. Stonington Cemetery Assoc., 20 Conn. 466; Balch $v$. Essex County, 103 Mass. 106; Edgecumbe $v$. Burlington, $46 \mathrm{Vt}$. 218.

"The safety of the living requires the burial of the dead in proper time and place." Evergreen Cemetery Assoc. $v$. Beecher, 53 Conn. 551. But see infra, p. 264.

4 Sweet $v$. Rechel, 159 U. S. 380; Dingley $v$. Boston, 100 Mass. 544.

5 Henkel $v$. Detroit, 49 Mich. 249.

6 Fallbrook Irrigation Dist. $v$. Bradler, 164 U. S. 112.

7 Columbia Bottom Levee Co. $v$. Meier, 39 Mo. 53, 57; Coster $v$. Tide Water Co., 18 N. J. Eq. 54, 518.

8 Brunswick Gas Light Co. v. United Gas, etc., Co., $85 \mathrm{Me} .532$, $35 \mathrm{Am}$. St. Rep. 385 ; Stockton $v$. Central R. Co., 50 N. J. Eq. 52; Bloomfield, etc., Natural Gas Light Co. $v$. Richardson, 63 Barb. (N. Y.) 437 . 
Chapter of private property. The construction of parks for

viII. the use of the public for rest and exercise in the open air is a public purpose authorizing the employment of eminent domain. ${ }^{9}$ The preservation of the site of the battle of Gettysburg and the marking out of the positions of the various commands upon the battlefield has been held such a public purpose as warrants the condemnation of lands for these ends. "Any Act of Congress which plainly and directly tends to enhance the respect and love of the citizen for the institutions of his country, and to quicken and strengthen his motives to defend them, and which is germane to, and intimately connected with and appropriate to, the exercise of some one or all of the powers granted by Congress, must be valid. This proposed use comes within such description. - . . Such a use seems necessarily not only a public use, but one so closely connected with the welfare of the republic itself as to be within the powers granted Congress by the Constitution for the purpose of protecting and preserving the whole country. . . No narrow view of the character of this proposed use should be taken. Its national character and importance, we think, are plain. The power to condemn for this purpose need not be plainly and unmistakably deduced from any one of the particularly specified powers. Any number of those powers may be grouped together and an inference from them all may be drawn that the power claimed has been conferred. It is needless to enlarge upon the subject, and the determination is arrived at without

9 Shoemaker $v$. U. S., 147 U. S. 282 ; Wilson $v$. Lambert, 168 U. S. 611 . 
hesitation, that the use intended, as set forth in the petition in this proceeding, is of that public nature which comes within the constitutional power of Congress to provide for by the condemnation of land." 1

Purposes purely asthetic have been held to war- $\begin{gathered}\text { Esthetic } \\ \text { purposes. }\end{gathered}$ rant condemnation under the power of eminent domain. In a recent M[assachusetts case, an act of the legislature forbidding the erection of any house around a park or square in the eity of Boston, known as Copley Square, to a height greater than ninety feet, and providing compensation for all persons damaged by the limitation prescribed for the height of buildings, was sustained as a valid exercise of the power of eminent domain, "for the benefit of the public who use Copley Square." "The uses which should be deemed public in reference to the right of the legislature to compel an individual to part with his property for a compensation and to authorize or direct taxation to pay for it," said the court, "are being enlarged and extended with the progress of the people in education and refinement." Public parks are beautified "by such touches of art as help to produce pleasing and satisfactory effects on the emotional and spiritual side of our nature. . . It hardly mould be contended that the same reasons which justify the taking of land for a public park do not also justify the expenditure of money to make the park attractive and educational to those whose tastes are being formed and whose love of beauty is being cultivated." The statute was passed for the benefit of the public, by "seeking to promote the beauty and attractiveness of a public park in the

1 U. S. v. Gettysburg Electric R. Co., 160 U. S. 668. 
Chapter capital of the commonwealth, and to prevent unrea-

VIII. sonable encroachments upon the light and air which it had previously received," and the court could "not say that this was not a matter of such public interest as to call for an expenditure of public money and to justify the taking of private property.", 2

\section{The Criterion of a Public Use.}

Divergent views

Most of the various cases enumerated are alike in stated. certain particulars. Either the State has a direct property in the improvement (custom houses, court houses, and the like); or the title, when in private persons, is impressed with a trust in faror either of the whole public, entitling every citizen to use the property on the same terms for the same facilities (railroads, canals, highways), or entitling to its use every citizen within the range and objects of the improvement (municipal waterworks, irrigation districts, etc.). These characteristics are, according to one and perhaps the most common view, considered necessary to constitute a public use, to be the criteria by which its existence is tried. The State, when the public use is not a governmental use directly administered, must have a roice in the manner in which the public may avail itself thereof; the undertaking must be under public control and independent of the will of the person or corporation in whom the title by condemnation will be rested, so that the public interest can not be defeated or the entire enterprise abandoned at the will or caprice of the proprietors. ${ }^{3}$ But some courts give to the

2 Atty-Gen. $r$. Williams, 174 Mass. 476, affirmed sub. nom. Williams r. Parker, 1ss L.S. 491.

3 Board of Health $v$. Van Hoesen, 87 Mich. 533; Bloodgood $v$. 
term "public use" a wider meaning and hold that Chapter no use which is clearly for the benefit of the public and which the legislature has declared to be a public use can by the courts be declared not a public use, although the title to the property taken is vested in individuals as strictly private property. ${ }^{4}$ On the one hand it is said that "public use", is equivalent to "public benefit," and when a marked public benefit arises to the community, it is not within the judicial competence to declare that benefit beyond the help of the State's power of eminent domain; on the other hand it is declared that "public use" and "public benefit", are not synonymous and that incidental benefit to the public, however great, is not the criterion. 5

Mohawk, etc., R. Co., 18 Wend (N. Y.) 9, 31 Am. Dec. 313; Matter of Tuthill, 163 N. Y. 133 ; Matter of Deansville Cemetery Assoc., 66 N. Y. 569; Fallsburg Power, etc., Co. v. Alexander, 101 Va. 98; Healy Lumber Co. $v$. Morris, 33 Wash. 490.

4 Olmstead $v$. Camp, 33 Conn. 532, 89 Am. Dec. 221; Talbot $v$. Hudson, 16 Gray (Mass.) 417; Dayton Gold, etc., Min. Co. $v$. Seawell, 11 Ner. 394 ; Chicago, etc., R. Co. v. Morehouse, 112 Wis. 1, 56 L. R. A. 240 .

This view has been beld to authorize the appropriation of unimproved lands by the national government to be sold in town lots in accordance with a general town lot scheme. Tuttle $v$. Moore, 3 Indian Ter. 712 .

5 When the question is reduced to its ultimate elements, it appears that the former view is theoretically correct. See supra, p. 256 , note 2 .

The view that possession or control by the government is essential was adopted by the courts because it made easier the performance of a difficult duty (see Bloodgood $r$. Mohawk, etc., R. Co., 18 Wend. (N. Y.) 9, 31 Am. Dec. 313), and in accordance with the tendeney of judges to establish rules which are definite (Dicey. Law and Opinion, 364). But the difficulty of a judicial duty is no reason for avoiding it, and the reason for preferring a definite rule, which may be changed by legislation if it works hardships, fails where the rule involves a limitation on the power of the legislature.

It has been argued with force that the rule which makes "public use" synonymous witl "public benefit" is less liable to abuse than 
Chapter VIII.

Instances - mill acts, etc.

This difference of view is manifested in a number of cases. Typical are the so-called general mill acts, statutes authorizing lands to be taken or flowed in invitum for the erection and maintenance of mills, and statutes authorizing the taking of property for private manufacturing purposes. Such statutes have been sustained or declared unconstitutional as the eminent domain was held exercisable for any object of public benefit, ${ }^{6}$ or limited to purposes within the State control. ${ }^{7}$ Or, the right of condemmation has been sustained only for mills required to grind for all persons for a toll fixed by law. ${ }^{8}$ Upon the same principles, the power to condemn lands for private roads has been denied ${ }^{9}$ or recognized, ${ }^{1}$ and laws authorizing the formation of cemetery associations and the condemmation of lands for cemeteries, the title to the lands to be in the association with a

that which demands State ownership and control. See the remarks of Hawley, C. J., in Dayton Gold, ete., Min. Co. $v$. Seawell, 11 Nev. 394,410 .

${ }^{6}$ Head $r$. Amoskeag Mfg. Co., 113 U. S. 9; Olmstead $v$. Camp, 33 Conn. 532, 89 Am. Dec. 221; Seudder $v$. Trenton Delaware Falls Co., 1 N. J. Eq. 694, 23 Am. Dec. 756.

7 Gaylord $\imath$. Sanitary Dist., 204 Ill. 576; Ryerson $v$. Brown, 35 Mich. 333; Avery $v$. Termont Electric Co., 75 Vt. 235; Fallsburg Power, ete. Co. $v$. Alexander, 101 Va. 9s; Varner $v$. Martin, 21 IV. Va. 534: Healy Lumber Co. v. Morris, 33 Wash. 490.

8 Bottoms $v$. Brewer, 54 Ala. 2ss; Tyler $v$. Beacher, $44 \mathrm{Vt} .648$, $8 \mathrm{Am}$. Rep. 398; Tarner 2 . Martin, $21 \mathrm{~W}$. Va. 534, 559.

${ }^{9}$ Logan $r$. Stngsdale, 123 Ind. 372; Underwond $v$. Bailer, 59 N. H. 480; Taylor $x$. Porter. 4 Hill (N. Y.) 140; Varmer $v$. Martin, 21 IV. Va. 534; Healy Lumber Co. v. Morris, 33 Wash. 490.

1 Brewer $v$. Bowman, 9 Ga. 37, 40; Harvey $r$. Thomas, 10 Watts (Pa.) 63; In re Road in Plumereek Tp., 110 Pa. St. 544.

In cases where the owner of land is excluded from any public highway, the road giving him an outlet and enabling him to perform his publie duties is a highway and of public utility. Johnson v. Clayton County, 61 Inwa 89. And see Nelson, Cl. J., dissenting, in Taylor $v$. Porter, 4 Hill (N. Y.) 140, 148. 
right on the part of eitizens to purchase burial lots at prices fixed by the association, have been held constitutional in some States, ${ }^{2}$ unconstitutional in others. $^{3}$

Acts permitting the drainage of large, swampy areas and the condemnation of land therefor, have Drainage acts. been miversally sustained when the drainage is for the promotion of public lealth, ${ }^{4}$ but their constitutionality has been denied when the adrantage accrues merely to the property owners by rendering their land more productive. ${ }^{5}$ Drainage acts have been held to be constitutional, howerer, as within the general legislative poter, independently of any effect upon the public health, or of any reference to either the eminent domain or the taxing porer, "as a just and constitutional exercise of the power of the legislature to establish regulations by which adjoining lands, held by various owner's in severalty, and in the improvement of which all have a common interest, but which, by reason of the peculiar natural condition of the whole tract, can not be improved br enjoyed by any of them without the con-

2 Evergreen Cemetery Assoc. $v$. Beecher, 53 Conn. 551.

3 Board of Health $r$. Van Hoesen, 87 Mich. 533 ; Matter of Deansville Cemetery Assoc., 66 N. Y. 569.

* See supra, p. 259.

5 Matter of Ryers, 72 N. Y. 1, 6, 28 Am. Rep. 88, citing Gilbert $r$. Foote, (N. Y. Ct. App.) unreported; Matter of Tuthill, 163 N. Y. 133.

6 Wurts $r$. Hoagland, 114 U. S. 606, 614. See Mound City Land, etc., Co. $v$. Miller, 170 Mo. 240.

This view had its origin in Massachusetts, where it is fully stated and developed in Lowell $r$. Boston, 111 Mass. 454, 15 Am. Rep. 39. It was adopted in the United States Supreme Court in the opinions in the case above cited, and Head $r$. Amo-keag MIf. Co., 113 U. S. 9, both of which were written by Mr. Justice Gray, previously chief justice of Massachusetts. 
Chapter currence of all, may be reclaimed and made useful

VIII. to all at their joint expense;" 7 "making equitable compensation to any whose control of or interest in the property is thereby modified." 8 So far as the necessity of compensation is recognized, these acts would seem to be a true exercise of eminent domain for a public purpose, though the taxing power is also involved in the assessment on the owners.

Irrigation. The same principle has been invoked to sustain the decision that irrigation was a public use. ${ }^{9}$

Federal Supreme Court considers peculiar conditions of State.

In determining what is a public use, the United States Supreme Court has recognized that much depends upon condition of the State, whose eminent domain is sought to be employed, the facts surrounding the subject, matters of climate and soil, and the condition of population. Thus, in the arid climate of Utah, a statute allowing a landowner to condemn a right of way over another's land for a ditch to irrigate his private property has been sustained on the ground that the condemnation was, under the circumstances, for a public use. The court said: "Whether a statute of a State permitting condemnation by an individual for the purpose of obtaining water for his land or for mining should be held to be a condemnation for a public use, and, therefore, a valid enactment, may depend upon a number of considerations relating to the situation of the State and its possibilities for land cultivation, or the successful prosecution of its mining or other industries. Where the nse is asserted to be public, and the right

7 Wurts $r$. Loagland. 114 [. S. 606, 614.

8 Hearl $r$. Amoskeag Mfe. Co.. 113 U. S. 9, 21, 22.

${ }^{9}$ Fallhrook Irrigation Dit. $r$. Rralley. 164 U. S. 112, 163. See also Turlock Irrigation Dist. $v$. Williams, 76 Cal. 360. 
of the individual to condemn land for the purpose of exercising such use is founded upon or is the reChapter VIII. sult of some peculiar condition of the soil or climate, or other peculiarity of the State, where the right of condemnation is asserted under a State statute, we are always, where it can fairly be done, strongly inclined to hold with the State courts, when they uphold a State statute providing for such condemnation. The validity of such statutes may sometimes depend upon many different facts, the existence of which would make a public use, even by an individual, where, in the absence of such facts, the use would clearly be private. Those facts must be general, notorious, and acknowledged in the State, and the State courts may be assumed to be exceptionally familiar with them. They are not the subject of judicial investigation as to their existence, but the local courts know and appreciate them. They understand the situation which led to the demand for the enactment of the statute, and they also appreciate the results upon the growth and prosperity of the State which, in all probability, would flow from a denial of its validity. These are matters which might properly be held to have a material bearing upon the question whether the individual use proposed might not in fact be a public one. It is not alone the fact that the land is arid and that it will bear crops if irrigated, or that the water is necessary for the purpose of working a mine, that is material; other facts might exist which are also material-such as the particular manner in which the irrigation is carried on or proposed, or how the mining is to be cione in a particular place where water is needed for that pur- 
Chapter
VIII. VIII. land or of the mines themselves might also be material and what proportion of the water each owner should be entitled to; also the extent of the population living in the surrounding country, and whether each orwner of land or mines could be, in fact, furnished with the necessary water in any other way than by the condemuation in his own behalf, and not by a company, for his use and that of others.

Irrigation ditchesUtah.
"We are, however, as we have said, disposed to agree with the Utah court with regard to the validity of the State statute which provides, under the circumstances stated in the Act, for the condemnation of the land of one individual for the purpose of allowing another individual to obtain water from a stream in which he has an interest, to irrigate his land, which otherwise would remain absolutely valueless. But we do not desire to be understood by this decision as approving of the broad proposition that private property may be taken in all cases where the taking may promote the public interest and tend to develop the natural resources of the State. We simply say that in this particular case, and upon the facts stated in the findings of the court, and having reference to the conditions already stated, we are of opinion that the use is a public one, although the taking of the right of way is for the purpose simply of thereby obtaining the water for an individual, where it is absolntely necessary to enable him to make any use whatever of his land, and which will be valuable and fertile only if water can be obtained. . . . 
"The rights of a riparian owner in and to the use of the water flowing by his land are not the same in the arid and mountainous States of the West that they are in the States of the East. . . This court

must recognize the differences of climate and soil, which render necessary these different laws in the States so situated.", 1

But whatever the view as to the test of a public use, the courts are united on the proposition that the power of eminent domain does not justify a Acts which amount to confiscation not for public
purpose. taking for private purposes merely, as when property is transferred from one person to another, or to several persons for their peculiar benefit and advantage, even though compensation is provided for. ${ }^{2}$ Nor does it justify a taking for subsidiary enterprises connected with but not necessary for an admitted public purpose. ${ }^{3}$ In the last case, the question is the connection between the subsidiary and the main object to be attained, and the decisions are frequently at variance. "Spur tracks," from railroads to business establishments, for instance, are sometimes held to be essential to the railroad's business and so to warrant the exercise of eminent domain, ${ }^{4}$ sometimes to be unnecessary and a taking of

1 Clark $v$. Nash, 198 U. S. 361.

2 Missouri Pac. R. Co. v. Nebraska, 164 U. S. 403 (grain elevator of private individuals); Evergreen Cemetery Assoc. $v$. Beecher, 53 Coun. 551; Talbot $v$. Hudson, 16 Gray (Mass.) 417; Chicago, etc., R. Co. $v$. State, 50 Neb. 399 (private grain elevator).

3 New York, etc., R. Co. v. Kip, 46 N. Y. 546. 7 Am. Rep. 385 (car factories and houses for employees).

"The need of the land sought in aid of collateral enterprises, remotely connected with the running or operating of the [rail] road, will not justify an assertion of the right of eminent domain." Matter of Rochester, etc., 110 N. Y. 119.

${ }^{4}$ See Chicago, etc. R. Co. $v$. Morehouse, 112 Wis. 1, 88 Am. St. 
Chanter property therefor a taking without due process of VIII. law..$^{5}$

State may use expro. priated property for incidental profit.

Incidental private benefit not fatal.
While the raising of revenue is not a public purpose which will justify the taking of private property by the State, yet when property has been acquired by the State for a legitimate public purpose, and the works constructed for the end in view are incidentally capable of valuable uses and may be made a source of revenue, their employment for this object is not a subject of complaint. ${ }^{6}$ Thus where, in improving the navigability of a stream, it was necessary to construct a dam and a canal to avoid a rapids in the stream, the surplus water power may be rented by the State, and a riparian proprietor, though cut off from the use of the power, has not been deprived of his property. But the erection of the dam must have been bona fide and to improve navigation, not a colorable device for creating a water power. ${ }^{\top}$

While the State can not by eminent domain further purely private objects which tend merely to the enrichment of private individuals, the fact that a legitimate public object tends incidentally to benefit

Rep. 918,56 L. R. A. 240 , where many cases so holding are collected and discussed in the opinion.

5 Teidenfeld $r$. Sugar Run R. Co., 48 Fed. Rep. 615; Garbutt Lumber Co. $v$. Georgia, etc., R. Co., 111 Ga. 714; Chicago, ete., R. Co. $\imath$. Wiltse, 116 Ill. 449; Matter of Niagara Falls, etc., R. Co., 108 N. Y. 375; Natter of Rochester, etc., 110 N. Y. 119 ; State $v$. Hazelton, etc., R. Co., 40 Ohio St. 504; Apex Tramp Co. v. Garbade. 32 Oregon 582.62 L. R. A. 513: Pittsburg, etc., R. Co. v. Benwood Iron Works, 31 W. Va. 710, 2 L. R. A. 680.

${ }^{6}$ Fox $v$. Cincinnati, 104 U. S. 783; Buckingham $v$. Smith, 10 Ohio 296 .

7 Kaukauna Water-Power Co. $v$. Green Bay, ete., Canal Co., 142 U. S. 254. 
private interests does not deprive it of its public character. This is clearly shown in cases when the Chapter VIII. power is conferred on corporations such as railroads and the like, and their right to appropriate profits is to be regarded only as a compensation in return for the public duties they are selected to perform. ${ }^{8}$

That the eminent domain may be exercised for local purposes is not disputed. It may, as has been Local public advantage suffiseen, be employed for municipal purposes, such as the provision of water or gas for cities. These facilities are open to every citizen who brings himself within certain conditions, and this is all that is required to give a public character to the use. Thus, it has been said that "it is not essential that the entire community or even any considerable portion thereof should directly enjoy or participate in an improvement in order to constitute a public use." ${ }^{9}$ And, again, the public use "may be for the inhabitants of a small or restricted locality; but the use and benefit must be in common, not to particular individuals or estates." 1 Nor need the public have a general use of the property; its use is ordinarily limited by the objects to be attained by the grant, and in other respects the authority over the property of the persons on whom the eminent domain is conferred may be exclusive. ${ }^{2}$

8 Stockton, etc., R. Co. $v$. Stockton, 41 Cal. 147; Swan $v$. Williams, 2 Mich. 427; Matter of Townsend, 39 N. Y. 171.

9 Matter of New York, 135 N. Y. 253, 260; Fallbrook Irrigation Dist. $v$. Bradley, 164 U. S. 112, 161. See also O'Reiley $v$. Kankakee Valley Draining Co., 32 Ind. 169; Talbot $v$. Husdon, 16 Gray (Mass.) 417 ; Bloomfield, ete., Natural Gas Light Co. $v$. Richardson, 63 Barb. (N. Y.) 437 .

1 Coster $v$. Tide Water Co., 18 N. J. Eq. 54, 68.

2 Matter of New York, 135 N. Y. 253. See also Williams $v$. Parker, 188 U. S. 491. 
Chapter

VIII.

Different meanings of "necessity."
"Intrinsic" and "circumstantial" necessity.

THE NECESSITY OF TAKING OR APPROPRIATION.

Necessity may be used in respect to eminent domain in at least two different senses. It may refer to the relation between the well being of society as a whole and the particular object for which the eminent domain is employed. In this sense, it is used by Chancellor Kent in the case of Gardner v. Newburgh:" "Grotius, Puffendorf and Bynkershoeck, when speaking of the eminent domain of the sovereign, admit that private property may be taken for public uses, when public necessity or utility require it."

Necessity in this sense exists whenever the use is public, and resolves itself into the question of public benefit or utility. As we have seen, the question belongs to the legislature, although, as in the case of the exercise of any other limited power, the legislature may exceed the authority committed to it, and its determination, therefore, may, so to say, be vetoed by the courts in the application of constitutional principles. But we may speak of necessity not as warranting the employment of eminent domain in general, that is, the appropriation of any property, but as justifying the appropriation of the particular property of a certain individual and the extent to which it shall be taken. Before this problem of "circumstantial necessity" can arise, "intrinsic necessity," the public character of the use, must have already been decided in the affirmative. ${ }^{4}$

In some cases, the questions of intrinsic neces32 Johns. Ch. (N. Y.) 162.

4 These expressions are adopted from Randolph on Eminent Domain, $\$ 334$. 
sity and circumstantial necessity may be sharply distinguished, while in other cases they shade into one another or are lost in the question of the public character of the use. For that public character depends largely upon the facts and circumstances surrounding the particular case and the subject-matter with regard to which the eminent domain is to be exercised; ${ }^{5}$ and this is true whether the criterion of eminent domain is regarded as public benefit or public control. If the theory that State control is essential be adopted, the want of the necessity for employing eminent domain is all that prevents such a business as that of a hotel or theatre from using the power of eminent domain ${ }^{6}$ while, if the presence of important public benefit is enough, the necessity of condemning property in order to effectuate the particular purpose or policy is to be regarded.7 Upon the theory of public benefits, also, the magnitude of the interests involved in the particular community is always considered as an important element, ${ }^{8}$ and this is nothing more than necessity under another aspect.

Circumstantial necessity is usually said to be entirely a political and legislative question. "The general principle is now well settled," it has been Circumnecessity not purely legislative. observed by a court of high authority, "that when

5 Fallbrook Irrigation Dist. $v$. Bradley, 164 U. S. 112, 159, 160 ; Talbot $v$. Hudson, 16 Gray (Mass.) 417, 423; Dayton Gold, etc., Min. Co. $v$. Seawell, $11 \mathrm{Nev}$ 394, 410.

6 See Dayton Gold, etc., Min. Co. $r$. Seawell, 11 Nev. 394, 410.

7 See Ryerson $v$. Brown, 35 Mich. 333, 339, 340.

8 Irrigation Dist. $v$. Williams, 76 Cal. 360, 369, 370 (irrigation in California); Hagar $v$. Yolo County, $47 \mathrm{Cal} .222$ (drainage); Battle, etc.. R. Co. $r$. Montana Union R. Co., 16 Mont. 504 (mining in Montana). See also supra, p. 266. 


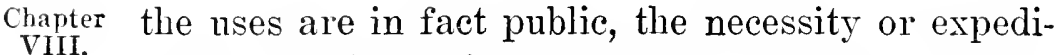
VIII. ency of taking private property for such uses by the exercise of the power of eminent domain, the instrumentalities to be used, and the extent to which such right shall be delegated are questions appertaining to the political and legislative branches of the government."'9 It will be observed that this statement groups several questions as equally for the legislature. That of instrumentalities or machinery to be used in administering eminent domain is for the legislature exclusively, subject to special constitutional provisions and to the general requirement of notice and hearing. The extent to which the power is delegated is also a purely political question, subject to the limitations implied in the separation of the departments of government under our constitutional system. But the existence of circumstantial necessity in a given case brings up other questions which can not be disposed of so easily. The legislature may itself decide both the questions of intrinsic and circumstantial necessity, that is, it may determine that a certain public use justifies the employment of eminent domain and may designate the particular property to be taken; or, instead of determining the necessity of taking specific property directly, it may delegate the power of making the determination. This delegation may include the whole duty of deciding the necessity and extent of the taking, or the legislature may prescribe the extent of the property to be taken and the estate therein which is to be appropriated, and delegate

8 Matter of Niagara Falls, etc., R. Co., 108 N. Y. 375, 383. See also State $v$. Rapp, 39 Minn. 65. 
merely the power of deciding whether the public use requires the taking of particular property to the pre-

scribed extent. When the legislature determines the entire question of circumstantial necessity, or when it takes upon itself to mark out the extent of property to be condemned, if the authorities to whom the power of decision is delegated conclude that there is need of condemnation, the true principle would seem to be not, as usually stated, that the decision is absolute and final, ${ }^{1}$ but that the courts will not interfere with the decision of the legislature unless its powers have been exercised arbitrarily and the taking is clearly out of all proportion to, and is manifestly unnecessary for, the end in view.

In such a case, the taking can not in any just sense be said to be for a public purpose, and, giving all respect to the legislative determination, property obviously not necessary for the object involved is, so far as its owner is concerned, merely confiscated. Yet we find the absolute nature of the legislative decision broadly stated by the Supreme Court of the United States in recent cases. "By granting," says the court, "a right of way four hundred feet in width, Congress must be understood to have conclu-

1 Mississippi, etc., Boom Co. v. Patterson, 98 U. S. 403, 406 ; Shoemaker $v$. U. S., 147 U. S. 282 ; Backus $v$. Fort St. Union Depot Co., 169 U. S. 567 ; Moore $v$. Sanford, 151 Mass. 285; Lynch $v$. Forbes, 161 Mass. 302 ; Fairchild $v$. St. Paul, 46 Minn. 540; Matter of Niagara Falls, etc, R. Co., 108 N. Y. 375, 383; Bridal Veil Lumbering Co. $v$. Johnson, 30 Oregon 205; Ryan $v$. Louisville, etc., Terminal Co., 102 Tenn. 111 .

In almost all these cases, the rule is merely stated in the course of argument, and is not applied, or the case is distinguished.

It has been held otherwise when the Constitution anthorizes taking private property "when necessity requires it." The question of necessity is then judicial. Stearns $v$. Barre, $73 \mathrm{Vt} .28 \mathrm{l}$.

Legislative determin. ation of circumstantial necessity may involve confiscation. 

Chapter sively determined that a strip of that width was
VIII.

necessary for a public work of such importance.", 2 Some adaptation of the extent of the property whose condemnation was authorized to the end to be obtained might be found in such a right of way for a great transcontinental railroad, and this would dispose of the question under any view. For, so long as any adjustment of the condemnation authorized to the public purpose proposed can be discerned, the legislative decision is, upon every principle of constitutional law, final here as elsewhere. ${ }^{3}$ When and to the extent that the question of circumstantial necessity is delegated, the existence of the necessity is jurisdictional and like other questions of jurisdiction it is a judicial question which the courts must pass upon. ${ }^{4}$ Aspects of circumstantial necessity which have thus been held to be for the court under general laws delegating the power of eminent domain are: Whether to a grant of eminent domain it is necessary to condemn lands already condemned and make another grant; ${ }^{5}$ whether a subsidiary object is a

2 Northern Pac. R. Co. $v$. Smith, 171 U. S. 261, 275; Northern Pac. R. Co. $v$. Townsend, 190 U. S. $267,272$.

3 Sce Lewis, Em. Dom., §393; Atlantic, etc., R. Co. v. Penny, 119 Ga. 479 .

A statute authorizing the taking of an entire lot through which a street was laid out has been held unconstitutional as taking private property unnecessary for public use. Matter of Albany St., 11 Wend. (N. Y.) 149, 25 Am. Dec. 618.

It would hardly be contended that a statute authorizing the condemnation of a strip of teritory a mile wide for the use of a railroad, would foreclose all inquiry as to the necessity of such a taking.

4 O'Hare $v$. Chicago, ete., R. Co., 139 111. 151; Fruyer $r$. Davenport, ete., R. Co., 196 Ill, 370, 377; Erie R. Cn. $\iota$. Steward, 170 N. Y. 172; Hightand Boy Gold Min. Co. r. Strickley. (C. C. A.) 116 Ferl. Rep. 852. See Lewis. Em. Dom., 393; and infra, p. 296, where the exceptional doctrine in some States is noted.

- Spring Valley Water Works $v$. San Mateo Water Works, 64 Cal. 
necessity for effecting a given public purpose, as a given "spur line" of railway to the objects of the incorporation of the road; ${ }^{6}$ or whether a particular statute justifies a certain act of expropriation, under the rule that a grant of eminent domain must be so construed as to be limited to the necessity of the case. $^{7}$ The general rule ordinarily stated seems to be a survival from times when the power of eminent domain had not been subjected to the analysis which has resulted from the multitude of decisions at the present day, and when the courts were inclined to concede uncontrolled authority on many questions to the legislature.

The extent of public necessity, whether absolute or relative merels, is a subject of difference of opinOnly reasonable necessity ion. It has been said in cases where the necessity was under consideration as an element in the public character of the use, ${ }^{8}$ as well as in cases where the question was the right of one corporation to condemn the property of another, ${ }^{9}$ that the object to be accomplished must be one which is absolutely essential and is otherwise impracticable. But such a rule obviously shears the legislature of all discretion and is not a fitting criterion. Much more reasonable is the doctrine thus laid down in an Alabama case, where the condemnation of the property of one railroad by another was involved: "It would be difficult to lay down any specific rule, as to the meas123 ; Milwaukee, etc., R. Co., $v$. Faribault, 23 Minn. 167; Butte, etc., R. Co. v. Montana Union, ete., R. Co., 16 Mont. 504.

6 See supra, p. 269.

7 Creston Waterworks Co. v. McGrath, 89 Iowa 502; Fairchild $v$. St. Paul, 46 Minn. 540, 543.

8 Ryerson $v$. Brown, 35 Mich. 333, 335.

9 Scranton Gas, etc., Co. $v$. Northern Coal, etc., Co., 192 Pa. St. 80. 

Chapter ure of the necessity, of sufficient scope to include all
VIII.

cases. It may be observed generally that necessary in this connection does not mean an absolute or indispensable necessity, but reasonably requisite and proper for the accomplishment of the end in view, under the particular circumstances of the case." 1

\section{COMPENSATION.}

\section{Necessity for Compensation.}

Compensation an equitable and moral right.
In stating the conditions for the exercise of eminent domain, Grotius says that, if it can be done, compensation should be made from the common treasury of the State, to him who has lost his property. $^{2}$ Thus the moral duty of compensation, based on a "clear principle of natural equity," ${ }_{3}$ is recognized, and a legal sanction was given this principle by special provisions in the United States Constitution and in the constitutions of almost all the States. ${ }^{4}$ These provisions for compensation form

1 Mobile, etc., R. Co. $v$. Alabama Midland R. Co., 87 Ala. 501.

To the same effect. see Butte, ete., R. Co. $r$. Montana, etc., Union R. Co., 16 Mont. 504.

That the property be reasonably necessary to the public use is all that should be required by the courts when the legislature has submitted to them the question of neeessity. Tracy $v$. Elizabethtown. ete., R. Co., 80 Ky. 259, 266.

2 "Requiritur . . . deinde, ut, si fieri potest, compensatio fiat ei qui suum amisit. ex communi." De Jure Belli et l'acis, lib. ii, e. 14, see. 7. Various passages from the writings of Grotius (A. D. 1625), Pufendorf (A. D. 1672), Heineccius (A. D. 1730), Brnkershoek (A. D. 1737), and Vattel (A. D. 1758) on the subject of eminent domain are collected in Thayer's Cas. on Const. Law, pp. 946. 951,982 , note.

3 Monongahela Nav. Co. $v$. U. S., 148 U. S. 312 ; Gardner $v$. Newburgh, 2 Johns. Ch. (N. Y.) 162.

4 Const. U. S.. Amend. V; 9 Fed. Stat. Annot. 305; and see the several State constitutions, and $10 \mathrm{Am}$. and Eng. Eneye. of Law (2d ed.) 1050,1152 . 
no part of the porrer of eminent domain itself, which exists in the State independent of constitutional recognition. They are a mere limitation upon the use of the power, constituting a condition upon which it may be exercised. ${ }^{5}$

The right to compensation was felt, therefore, to require for its practical enforcement direct constitutional recognition. The older constitutions Right directly rec. ognized in constitu. tions. provided for compensation when property was "taken" "for public use, while more recent instruments specify "taken or damaged." " In very many jurisdictions, as we shall see, judicial construction of the term "taken" has brought about somewhat similar results in the absence of any addition to the constitutional clause. ${ }^{8}$

But the requirement of compensation may exist in the absence of a constitutional clause dealing Right pro. tected by specifically with eminent domain. The obligation to compensate the owner whose property is taken by authority of the State for public needs arises from the guaranties of the right to property contained in our bills of rights, and specifically from the provision that private property shall not be taken without due process of law. This was intimated at an early period in State courts. In North Carolina, where the constitution contains no speeific provision for compensation, Chief Justice Ruffin, in 1837, speaking for the Supreme Court, said in

5 U. S. $v$. Jones, 109 U. S. 513. But see Sinnickson $v$. Johnson, 17 N. J. L. 129, quoted in Monongahela Nar. Co. $v$. U. S., 148 U. S. 312 .

6 U. S. Const., Amendment V; 9 Fed. Stat. Annot. $30 \tilde{5}$.

7 Beginning with Illinois in 1870. See Chicago $v$. Taylor, 125 U. S. 161 .

8 See infra, p. 295. 
Chapter reference to the guaranty of "the law of the land:" vIII. "Under the guaranty of this article, it has been held, and in our opinion properly held, that private property is protected from the arbitrary power of transferring it from one person to another. We doubt not that it is also protected from the power of despotic resumption, upon a legislative declaration of forfeiture, or merely to deprive the owner of it, or to enrich the treasury, unless as a pecuniary contribution by way of tax. . . . Though not so obvious, it may also be true that the clause under consideration is restrictive of the right of the public to the use of private property, and impliedly forbids it, without compensation. But it is a point on which the court is not disposed, nor at liberty, to give a positive opinion on this occasion.", 9 The principle has been explicitly adopted by the Supreme Conrt of the United States in construing the Fourteenth Amendment to the Federal Constitution. In Chicago, etc., R. Co. v. Chicago," the court said: "Due protection of the rights of property has been regarded as a rital principle of republican institutions. 'Next in degree to the right of personal liberty,' Mr. Broom, in his work on Constitutional Law, says, "is that of enjoying private property without undue interference or molestation.' 2 The requirement that the property shall not be taken for public use without just compensation is but 'an affirmance of a great doctrine established by the common law for the protection of private property. It is founded in natural

9 Raleigh, etc., R. Co. $r$. Daris. 2 Dev. \& B. L. (19 N. Car.) 451. And see Iohnston r. Rankin, 70 N. Car. 550.

1166 U. S. 226.

2 Broom's Const. Law, 228. 
equity, and is laid down by jurists as a principle of universal law. Indeed, in a free government, almost all other rights would become worthless if the government possessed an uncontrollable power over the private fortune of every citizen.' 3

"But if, as this court has adjudged, a legislative enactment assuming arbitrarily to take the property of one individual and give it to another individual, would not be due process of law, as enjoined by the Fourteentl Amendment, it must be that the recuirement of due process of law in that amendment is applicable to the direct appropriation by the State to public use and without compensation of the private property of the citizen. The legislature may prescribe a form of procedure to be observed in the taking of private property for public use, but it is not due process of law if provision be not made for compensation. Notice to the owner to appear in some judicial tribunal and show cause why his property shall not be taken for public use without compensation would be a mockery of justice. Due process of law, as applied to judicial proceedings instituted for the taking of private property for public use means, therefore, such process as recognizes the right of the owner to be compensated if his property be wrested from him and transferred to the public. The mere form of the proceeding instituted against the owner, even if he be admitted to defend, can not

3 Citing 2 Story, Const., sec. 1790; 1 Bl. Com. 138, 139; Cooley, Const. Limit. 559; People v. Platt, 17 Johns. (N. Y.) 195, 215; Bradshaw $r$. Rogers, 20 Johns. (N. Y.) 103, 106; Petition of Mt. Washington Road Co., 35 N. H. 134, 142; Parham v. Justices, 9 Ga. 341, 348; Ex p. Martin, 13 Ark. 199, 206 et seq.; Johnston $v$. Rankin, 70 N. Car. $550,555$. 
Chapter convert the process used into due process of law if VIII.

the necessary result be to deprive him of his property without compensation.", ${ }_{4}$

Substantial denial of compensa. tion by States re. viewable.

The Federal Supreme Court may always examine proceedings had in a State court under State authority for the appropriation of private property to public purposes, so far as to inquire whether that court prescribed any rule of law in absolute disregard of the owner's right to just compensation. The restriction "in absolute disregard of the right to just compensation" is necessary, said the court, "because we do not wish to be understood as holding that every order or ruling of the State court in a case like this may be reviewed here, notwithstanding our jurisdiction, for some purposes, is beyond question. Many matters may occur in the progress of such cases that do not necessarily involve, in any substantial sense, the federal right alleged to have been denied; and in respect of such matters, that which is done or omitted to be done by the State court may constitute only error in the administration of the law under which the proceedings were instituted." ${ }_{5}$

Congress may legis. late against laches.
When an act of Congress has admitted a liability on the part of the government to pay for property taken for public use, and pointed out a method for

4 See also Long Island Water Supply Co. v. Brooklyn, 166 U. S. 655: Tindal r. Wesley, 167 U. S. 204; Norwood v. Baker, 172 U. S. 269): San Diego Land Co. v. National City, 174 U. S. 739 : Madisonville Traetion Co. v. St. Bernard Min. Co., 196 U. S. 252.

In Yeser $r$. Washington Harbor Line Com'rs, 146 U. S. 646. the court declared that the provision for eompensation in the Fifth Amendment was "to he read with the Fourteenth Amendment, prohibiting the States from depriving any person of property without due process of law."

5 Chicagn, etr., R. Co. r. Chieago, 166 U. S. 226 ; Backus $r$. Fort Street Union Depot Co., 169 U. S. 567. 
determining the compensation due, a repeal of the statute after thirteen years, with a saving as to proChapter VIII. ceedings already begun, is a legitimate exercise of authority. "Congress was not obliged to keep the Act of 1875 in operation forever ; and reasonable opportunity having been afforded to the plaintiffs in error to obtain compensation for the damages sustained by the construction of the improvement, we think they must be deemed to have waived their rights to them.", 6

\section{Property for Which Compensation Must Be Provided.}

The power of eminent domain embraces all "property." Property is nomen generalissimum and extends to every species of valuable right and Compensation coex tensive property. interest, and includes real and personal property, easements, franchises, and incorporeal hereditaments. ${ }^{i}$ The right to compensation is coextensive with the right of property, wherever a right of property exists, in the language of the Fourteenth Amendment, in any "person."

When a property right exists in or has been once legally acquired by the State, or its agents, the use of

Property held by the State or its agencies.

6 Kalkauna Water Power Co. $v$. Green Bay, etc., Canal Co., 142 U. S. 254. The real point decided seems only to be that, if the repeal of the Act of Congress left the property owner the right to assert his rights by a common-law action, he certainly after the long lapse of time and acquiescence had no right to resort to self nelp.

i Boston, etc., R. Co. $v$. Salem, etc., R. Co., 2 Gray (Mass.) 1. That money may be seized under the power of eminent domain has been denied, Burnett $v$. Sacramento, 12 Cal. 76 ; and affirmed Hammett $r$. Philadelphia, 65 Pa. St. 152, sometimes with the limitation that it can only be done by the State itself in time of war. Cary Library $r$. Bliss, 151 Mass. 364; People $r$. Brooklyn, 4 N. Y. 419. 
Chapter such right by the State does not demand any compenVIII.

State prop. erty and eminent domain; State and municipality.

sation to the former owner. Thus, when the State acquires or in virtue of its sovereignty possesses an easement or servitude in property, the use of the property for any purpose within the scope of the easement acquired gives no right to compensation to the general owner, ${ }^{8}$ but an additional or totally different servitude can not be placed upon the property without compensation. ${ }^{9}$ Corporeal property which the State, by the delegation of the eminent domain, has allowed private persons or corporations to acquire for some public purpose is so far private property in the hand of such persons or corporations that it can not be used for other public purposes unless it is again condemned and compensation paid for it. ${ }^{1}$

Like principles regulate the property of the States with relation to the paramount power of eminent domain in the federal government, and the property of municipalities with regard to the State. The federal government, acting in pursuance of powers expressly or impliedly rested in it by the Constitution, may acquire property of the States by condemnation subject to the right of compensation. ${ }^{2}$ But property held by the States in trust for purposes the control of which is specifically rested in the general govermment may be used by the United

8 People $v$. Kerr, 27 N. Y. 188.

9 Story $r$. New York El. R. Co., 90 N. Y. 122.

What amounts to an additional servitude, and what rights the State or the public has acquired in given property, depend on construction, and the decisions vary widely.

1 Testern Union Tel. Co. $v$. Pennsylvania R. Co., 195 U. S. 540 , applying the doctrine stated to a railroad right of way and distinguishing it from a mere easement.

2 See St. Louis $r$. Western Union Tel. Co., 148 U. S. 92. 
States for those purposes without making compensation. If the State holds lands under navigable water, it is in trust for the public uses of navigation and commerce, and such lands may be appropriated by the United States for a bridge to be used as a post road without making any compensation to the State, ${ }^{3}$ and this although such lands have passed into the hands of a private person by grant from the State. The property of municipal corporations, if held in trust for the public, may be taken by the legislature mithout additional compensation, but the property of such corporations held for their own corporate purposes can not be taken without compensation. ${ }^{5}$

The determination of what water is navigable, the title to lands thereunder, and the extent of Riparian rights and public
ownership. the riparian owner's rights in the water and to the banks are matters of local sorereignty, the regulation of which belongs exclusively to the States; and whether in a given case the curtailment of the enjorment of the stream by the riparian owner amounts to a taking of property requiring compensation, depends on how far the law of the State recognizes the enjoyment as private property. ${ }^{6}$ Where

3 Stockton $v$. Baltimore, etc., R. Co., 32 Fed. Rep. 9. See also Luxton $r$. North River Bridge Co., 153 U. S. 52.5. The whole question of the title to sueh lands is exhanstivels considered by the United States Supreme Court, speaking per Gras, J., in Shively $v$. Bowlbr, 152 U. S. 1.

4 Hawkins Point Light-House Case, 39 Fed. Rep. 77.

5 Clinton $v$. Cedar Rapids, etc. R. Co., 24 Iowa 455; Mount Hope Cemetery $r$. Boston, 158 Mass. 509.

6 Barney $r$. Keokuk. 94 L. S. 324; St. Louis $v$. Myers, 113 U. S. 566 ; Packer $r$. Bird, 137 C. S. 661: St. Louis $r$. Rutz. 138 U.S. 226; Hardin $v$. Jordan, 140 U. S. 371; Kaukauna Water-Power Co. $v$. Green Bay, etc., Canal Co., 142 L. S. 254. 
Chapter the State does recognize riparian rights on such

VIII. streams as private property provision for compensation must be made when riparian rights are taken for a public purpose. ${ }^{7}$ On the other hand, if lands under navigable water and the right to the accustomed flow of the stream are regarded as the property of the State or subject to its control, a loss suffered by a lower riparian owner in consequence of the use of the water at a point higher on the stream for municipal water supply under legislative anthority, is not a deprivation of property without due process of law, though the lower riparian owner receives no compensation.s In Louisiana lands abutting on rivers and bayous are, in accordance with a doctrine existing in the territory of Lonisiana before its acquisition by the United States, subject to a servitude in favor of the public, whereby such portions thereof as are necessary for the purpose of making and repairing public levees may be taken, in pursuance of law, without compensation. Lands therefore taken by the State for these purposes without compensation are taken in accordance with due process of lam.9

Tust com. pensation a judicial question.

The right to "just compensation" being given by the Constitution, the question of what amounts to an adequate return for property taken is a judicial one, and the legislature has no right to lay down an arbitrary rule that the tribunals appointed to assess values shall not take into account certain definite

7 Kaukauna Water-Power Co. $v$. Green Bay, etc. Canal Co., 142 U. S. 254 .

8 St. Anthony Falls Water Power Co. $v$. St. Paul Water Com'rs, I68 U. S. 360 .

${ }^{9}$ Eldridge $r$. Trezevant, 160 U. S. 452. 
elements in the value of the property taken. Thus, when the national government, by virtue of its authority over commerce, undertook to improve a navigable stream and to that end condemned a lock erected therein under a franchise from the State government by a State corporation, Congress had no right to provide that "in estimating the sum to be paid by the United States, the franchise of said corporation to collect tolls should not be considered or estimated." The franchise to collect tolls was a vested right of property and a necessary element in estimating the value of the property taken. The court said: "But, like the other powers granted to Congress by the Constitution, the power to regulate commerce is subject to all the limitations imposed by such instrument; and among them is that of the Fifth Amendment, we have heretofore quoted. Congress has supreme control over the regulation of commerce, but if, in exercising that supreme control. it deems it necessary to take private property, then it must proceed subject to the limitations imposed by the Fifth Amendment, and can take only on payment of just compensation. . . . If a man's house must be taken, that must be paid for ; and if the property is held and improved under a franchise from the State, with power to take tolls, that franchise must be paid for, because it is a substantial element in the value of the property taken. So, coming to the case before us, while the power of Congress to take this property is unquestionable, yet the power to take is subject to the constitutional limitation of just compensation."' 1 But it appears that by an express

1 Monongahela Nav. Co. $v$. U. S., 148 U. S. 312. 

Chapter reservation in the charter creating the franchise, the
VIII.

Effect of act limiting expenditure. franchise may be subsequently destroyed by the government without creating any liability to make compensation therefor. ${ }^{2}$

It can not be claimed that the legislature values land arbitrarily because it limits the aggregate amount to be expended for a certain public purpose. In a case where such a claim was made, the court said: "The validity of the law is further challenged because the aggregate amount to be expended in the purchase of land for the park is limited to the amount of $\$ 1,200,000$. It is said that this is equivalent to condemning the lands and fixing their value by arbitrary enactment. But a glance at the act shows that the property holders are not affected by the limitation. The value of the lands is to be agreed upon, or, in the absence of agreement, is to be found by appraisers to be appointed by the court. The intention expressed by Congress not to go beyond a certain aggregate expenditure can not be deemed a direction to the appraisers to keep within any given limit in valuing any particular piece of property. It is not unusual for Congress, in making appropriations for the erection of public buildings, including the purchase of sites, to name a sum berond which expenditure shall not be made, but nobody ever thought that such a limitation had anything to do with what the owners of property should have a right to receive in case proceedings to condemn had to be resorted to."' 3

2 Bridge Co. r. U. S.. 105 U. S. 470, as explained in Monongahela Nar. Co. $r$. C. S., 149 [T. S. 312.

3 Shoemaker $r$. I. S.. 147 U. S. 282.

Perhaps a different question might arise if the appropriation had 
Amount of Compensation and Provision for

\section{Payment.}

The just compensation required by the Constitution to be made to the owner is to be neasured by the loss caused to him by the appropriation. He is enwner en. titied to value of property titled to receive the value of which he has been deprived, and no more. To award him less would be unjust to him; to award him more would be unjust to the public. ${ }^{4}$ The rarious rules adopted in State courts for determining the value of the property taken and the consequent right to compensation are mainly matter of local law. ${ }^{5}$

The general rule for estimating values is thus stated by the United States Supreme Court: "Upon the question litigated in the court below, the compensation which the owner of the land condemned was entitled to receive, and the principle upon which the compensation should be estimated, there is less difficulty. In determining the value of land appropriated for public purposes, the same considerations are to be regarded as in a sale of property between private parties. The inquiry in such cases must be, what is the property worth in the market, viewed not merely with reference to the uses to which it is at the time applied, but with reference to the uses to which it is plainly adapted; that is to say, what is it worth from its availability for valuable uses? Property is not to be deemed worthless because the

been already exhausted. U. S. $v$. Gettysburg Electric R. Co., 160 U. S. 668 .

4 Bauman $r$. Ross, 167 U. S. 54 S.

5 See Meyer $r$. Richmond, 172 U. S. 82. 

Chapter owner allows it to go to waste, or to be regarded as
viII. valueless because he is unable to put it to any use. Others may be able to use it and make it subserve the necessities or conveniences of life. Its capability of being made thus available gives it a market value which can be readily estimated. So many and varied are the circumstances to be taken into account in determining the value of property condemned for public purposes, that it is perhaps impossible to formulate a rule to govern its appraisement in all cases. Exceptional circumstances will modify the most carefully guarded rule; but, as a general thing, we should say that the compensation to the owner is to be estimated by reference to the uses for which the property is suitable, having regard to the existing business or wants of the community, or such as may be reasonably expected in the immediate future.", 6

Taking part of tract or one of two tracts.

In determining a case which arose in the District of Columbia, and whose constitutional aspects were, therefore, governed by the Fifth Amendment, it was held that when only a part of a tract of land is taken for a public purpose, the value of that part is not the sole measure of the compensation or damages to be paid the owner; but the incidental injury or benefit to the part not taken is also to be considered. $^{7}$ But there can be no recovery for consequen-

B Mississippi, etc., Boom Co. $v$. Patterson, 98 U. S. 403 . See also New York El. R. Co. $v$. Fifth Nat. Bank, 135 U. S. 432; Monongahela Nav. Co. $v$. U. S., 148 U. S. 312 ; Backus $v$. Fort St. Union Depot Co., 169 U. S. 567.

7 Bauman $v$. Ross, 167 U. S. 548. See also as to diminishing damages by assessments for benefits, Shoemaker $v$. U. S., 147 U. S. 302. 
tial damages to one of two distinct and independent tracts, by reason of the condemnation of the other, although the two belong to a single owner. ${ }^{8}$

When adequate compensation is provided, it is no denial of due process of law in the case of property riglits taken by a city for publie purposes that the compensation must be established against the eity which meanwhile is in the enjogment of the rights withont having instituted any condemnation proceedings and so is not bound by a technical estoppel by judgment. This point was ruled in a case where the height of buildings, either built or to be built, about a publie square was limited by a statute, which provided that any person sustaining damage might recover such damage "in the manner preseribed by law for obtaining payment for damages sustained by any person whose land is taken in the laying out of a highway.", 9

In the absence of specific provision there is nothing that requires compensation to be made in advance of the taking or appropriation, ${ }^{1}$ and consequently a previous payment or tender is not essential to due process of law, provided adequate provision for compensation is made. ${ }^{2}$

WHAT AMOUNTS TO A TAKING OF PROPERTY.

According to the broad and equitable doctrine of modern cases, it is not necessary to constitute a

Compensation for limiting use of property.

8 Sharp $v$. U. S., 191 U. S. 341.

$\theta$ Williams v. Parker, 188 U. S. 491.

1 Cherokee Nation $v$. Sonthern Kansas R. Co., 135 U. S. 641 ; Sweet $v$. Rechel, 159 U. S. 402 ; Adirondack R. Co. v. New York, 176 U. S. 335.

2 Backus v. Fort St. Union Depot Co., 169 U. S. 567 ; Williams $v$. Parker, 188 U. S. 491.

Depriva-
tion of use is "taking." 
Chapter "taking" of property for public purposes that the VIII. actual occupancy or possession of the property should be assumed and its title acquired. A physical interference with property which substantially abridges the owner's right to use and enjoy it and to exclude others from its use takes his property to just the extent that he is deprived of its enjoyment. ${ }^{3} \mathrm{~A}$ serious interruption to the common and necessary use of property has been said to be equivalent to taking it within the constitutional provision, and it is not necessary that the land be absolutely taken. ${ }^{4}$

Physical invasion necessary.

This principle has been confined, however, to cases when the interference is accompanied with a physical invasion of property and practical ouster of possession, as happens when lands are flooded by the construction of public works. "Where the government, by the construction of a dam, or other public works, so floods lands belonging to an individual as to substantially destroy their value, there is," said the United States Supreme Court in a recent case, "a taking within the scope of the Fifth Amendment. While the government does not directly proceed to appropriate the title, yet it takes away the use and value; when that is done it is of little consequence in whom the fee may be vested." ${ }_{5}$

Purely consequential damages do not constitute taking.
When there is no physical invasion, no ouster of possession, and the property owner suffers loss merely because of the construction or operation of public works on abutting or neighboring property, it is held in a large number of cases that there is no

3 Eaton $v$. Boston, etc., R. Co., 51 N. H. 504.

4 Pumpelly $v$. Green Bay, etc., Canal Co., 13 Wall. (U. S.) 166, citing Angell on Watercourses, $\$ 465 a$.

5 U. S. $v$. Lynch, 188 U. S. $445,470$. 
taking of the property, the loss or damage is consequential merely, and the maxim dammum absque injuria has place. This doctrine is applied to improvements in highways by the government or local authorities. "Persons appointed or authorized by law to make or improve a highway are not answerable for consequential damages, if they act within their jurisdiction and with care and skill." "' It has been so held when the owner was temporarily excluded from his water front by the construction of a tumnel, ${ }^{7}$ or temporarily interrupted in the enjoyment of a mine by an order for its inspection; ${ }^{8}$ where the access to land abutting on a navigable river was destroyed by the construction, under authority of an Act of Congress, of a pier on the submerged lands in front of the property ${ }^{9}{ }^{9}$ where, by the construction of a dike by the United States in the improvement of a narigable stream, the riparian owner was deprived through the greater part of the season of access to his landing and his lands in consequence much diminished in valne; ${ }^{1}$ where damage to land was produced by flooding as a result of revetments constructed by the United States along a river bank to prevent erosion; ' where expense was caused to a landowner by having to

6 Northern Transp. Co. $v$. Chicago, 99 U. S. 635.

7 Northern Transp. Co. v. Chicago, 99 U. S. 635.

8 Montana Co. v. St. Louis Min., ete., Co., 152 U. S. 160.

- Scranton $v$. Wheeler, 17? U. S. 141. See also Manigault $v$. Springs, 199 U. S. 473 , in which the same ruling was made when the erection of a dam under the authority of a State across a navigable stream was claimed as an injury to an owner's rights of navigation and of access to lands above the dam.

1 Gibson $v$. U. S., 166 U. S. 269.

2 Bedford $v$. U. S., 192 U. S. 217. 
Chapter raise embankments around his land in consequence VIII.

Proceeding which

leaves property rights as before no taking. of the building of a dam across a neighboring stream. ${ }^{3}$

There is no taking of property when the proceedings, instituted by the State and claimed to constitute a taking, leave the rights of the property owner the same as they were before. So, when the owner of a wharf extending into navigable water sought to prohibit the State harbor commissioners from establishing harbor lines, which should embrace lands reserved by the State, so as to include his wharf, it was held that the proceeding would not deprive him of property without due process of law and that prohibition would not lie. "The design," said the court, "of the State law is to prohibit the encroachment by private individuals and corporations on navigable waters, and to secure a uniform water front; and it does not appear from relator's application that the defendants have threatened in any manner to disturb him in his possession, nor that that which is proposed to be done tends to produce that effect. Whatever his rights, they remained the same after as before, and the proceedings, as the Supreme Court said, could not operate to constitute a clond upon them from the standpoint of relator himself, for, if nothing further could lawfully be done in the absence of legislation for his protection, that was apparent. The consequences which he deprecated were too remote to form the basis of decision. Whaterer private rights or property he has .. . we do not see that he would be deprived

3 Manigault $v$. Springs, 199 U. S. 473 ; Mills $v$. U. S., 46 Fed. Rep. 738. 
of any of them by the action he has sought to prohibit." ${ }_{4}$

Injuries which under a constitutional provision against taking without compensation would be merely consequential, have been held to require compensation when the constitution read "taken or damaged;" "5 and this right to damages for "injury" may be acquired under an act of the legislature, though the constitution reads "taken" merely. ${ }^{\text {" }}$ So, it has been held that change in the constitutional provision from a requirement of compensation for property "taken" to a like requirement for property "taken or damaged," although it creates a prospective liability for consequential damages which did not before exist, is not unconstitutional as against previous grantees of the State so far as further condemnation by them is concerned. ${ }^{7}$

Due process of law is not denied by the holding of the highest court of a State that its constitution makes no provision for the recovery of consequential damage to property. ${ }^{8}$ In so holding in a case which Denial of right to consequen tial dam. age, not deprivation of due came before the Federal Supreme Court on error to the Supreme Court of Pennsylvania, it was said: "We are not authorized to inquire into the grounds and reasons upon which the Supreme Court of Penn-

4 Yesler $v$. Washington Harbor Line Com'rs, 146 U. S. 646.

5 Chicago $r$. Taylor, $125 \mathrm{C}$. S. 161 . The facts in this case were similar to those in Northern Transp. Co. $\iota$. Chicago, 99 U. S. 635, but the earlier case was decided under the lllinois constitution of 1848. which specificd only "taken," while the later case was governed by the constitution of 18i0. To the same effect is Hot Springs R. Co. $v$. Williamson, 136 U. S. 129.

${ }^{6}$ U.S. $v$. Alexander, 148 U. S. 187; U. S. $v$. Truesdell, 148 U. S. 196; O'Connor $v$. Pittsburgh, $18 \mathrm{~Pa}$. St. 187.

i Pennsylvania R. Co. $v$. Miller, 132 U. S. 75.

8 Meyer $v$. Richmond, 172 U. S. 82. 
Chapter sylvania proceeded in its construction of the statutes

VIII. and constitution of that State, and, if this record presented no other question except errors alleged to have been committed by that court in its construction of its domestic laws, we should be obliged to hold, as has been often held in like cases, that we have no jurisdiction to review the judgment of the State court, and we should have to dismiss this writ of error for that reason. But we are urged to sustain and exercise our jurisdiction in this case, because it is said that the plaintiff's property was taken without 'due process of law,' and becanse the plaintiff was denied 'the equal protection of the laws,' and these propositions are said to present federal questions arising under the Fourteenth Amendment of the Constitution of the United States, to which our jurisdiction extends. It is sufficient for us in the present case to say that, even if the plaintiff could be regarded as having been deprived of her property, the proceedings that so resulted were in 'due process of law.' The plaintiff below had the benefit of a full and fair trial in the several courts of her own State, whose jurisdiction was invoked by herself. In those courts, her rights were measured, not by laws made to affect her individually, but by general provisions of law applicable to all those in like condition." 9

NOTICE AND HEARING.

Necessity; power of legislature; effect of delegation. deciding on the public eharacter of the use, the expediency of employing eminent domain and the extent to which it shall be employed is, 
as has been seen, for the legislature, unless the constitution provides otherwise, with a supervisory right in the courts to see that the legislature does not exceed its constitutional functions. With regard to these questions, action by the legislature, unless wholly arbitrary and unreasonable, is, in itself, due process of law, and, where the legislature chooses to art, the owner of property condemned can not complain of the want of a hearing on these matters. ${ }^{1}$ But the legislature may choose to delegate the decision of some of these questions to tribumals, and when the matter is so delegated it becomes julicial and due process of law is not satisfied but by notice and a hearing. ${ }^{2}$

The doctrine in Massachusetts is exceptional. The courts of that State hold that the question is alMassachusetts docways a legislative one, and the final decision rests, even when the power has been delegated, "with the body or individuals to whom the State has delegated the authority to take.", 3 It is not a question upon which the property owner can demand a hearing except to the extent that the legislature has granted him the right to be heard. ${ }^{4}$

Usually, however, it is held that an agency rested with the power of eminent domain must. upon a proper issue, establish the fact of the neProvisions
for procur. ing hearing on necessity. cessity of the particular taking to the satisfaction

1 People $v$. Smith, 21 N. Y. 595 ; People $v$. Adirondack R. Co., 160 N. Y. 225.

2 See supra. p. 273. Compre supra, pp. 236, 248.

3 Lrnch $r$. Forbes, 161 Mass. 302.

4 Holt $x$. Somerville, 127 Mass. 408 : Lrinch $v$. Forbes, 161 Mass. 302, 42 Am. St. Rep. 402: Old Colony R. Co., Petitioner, 163 Mass. 356 ; Burnett $v$. Boston, 173 Mass. 173. 

Chapter of either the court ${ }^{5}$ or the jury ${ }^{6}$ or a statutory
vill.

tribunal, ${ }^{7}$ as required by the local laws. But agencies to which the power of eminent domain is delegated are vested with a large discretion to determine the amount of property necessary for the public use, a discretion always subordinate, however, to the right of the courts to prevent an abuse of the power. ${ }^{8}$ Consequently in some States such an agency need only show that it is lawfully in possession of the power of eminent domain and that the particular property whose condemnation is sought is necessary for the construction of the appropriate works, which have been located thereon in the proper manner." In other States the question of necessity can not be raised in the condemnation proceedings, but the property owner is still not without remedy against an abuse of discretion on the part of those to whom the power of eminent domain is delegated; he may have the necessity determined

5 O'Hare 2 . Chicago, etc., R. Co., 139 Ill. 151, 158, 161; Traç $v$. Elizahethtown, etc., R. Co., 80 Ky. 259; Matter of St. Paul, etc.. R. Co. 34 Minn. 227; Matter of New York Cent. R. Co., 66 N. Y. 407: Erie R. Co. $v$. Steward, 170 N. Y. 172, 178; Wisconsin Cent. R. Co. $v$. Cornell L'niversity. 52 Wis. 537; Wisconsin Cent. R. Co. $v$. Kneale, 79 Wis. 89; Sonth Carolina R. Co. v. Blake, 9 Rich. (S. Car.) 228; Baltimore, etr., R. Co, r. Pittsburg, etc., R. Co., 17 W. Va. S12.

6. Mlatter of Powers, 29 Mich. 504 (the Michigan constitution requiring the submission of the necessity to a jury).

7 Sand Creck Lateral Irrigation Co. $v$. Davis, 17 Colo. 326.

8 Atlantir, etc.. R. Co. r. Penny, 119 Ga. 479; Schuster $r$. Sanitary Dist., $17 \%$ IIl. 626.

a San Francisen, cte. R. Co. $r$. Leviston, 134 Cal. 412. 415 : Pasadena $r$. Stimson, 91 Cal. 2:38; O'Ilare $r$. Chicago, ete., R. Co.. 139 IIl. 151 .

In Michigan under the constitutional provision the showing of necessity is not satisfied by such proof. Matter of Powers, 29 Mich. 504 . 
on application to a court of equity for an injunc- Chapter tion. ${ }^{1}$

The question of compensation is in its nature a judicial question, which involves directly the propHearing as to compensation. erty rights of private individuals, and can be decided only after notice and a hearing before some impartial tribunal. ${ }^{2}$ The nature of the tribunal is for the legislature to determine. "All that is essential is that in some appropriate way, before some properly constituted tribunal, inquiry shall be made as to the amount of compensation, and, when this has been provided, there is that due process of law which is required by the Federal Constitution.", 3 This duty may be devolved upon the same body who determine the necessity of the taking or upon a separate body. ${ }^{4}$ Again, the duty of determining the amount of damage to the property owner may or may not be united with that of determining special benefits received by the property under laws which require such benefits to be deducted from the damage. 5

1 Atlantic, etc., R. Co. v. Penny, 119 Ga. 479.

2 People $v$. Adirondack R. Co., 160 N. Y. 225, affirmed 176 U. S. 335 .

3 Backus $v$. Fort St. Union Depot Co., 169 U. S. 567. And see Pearson $v$. Yewdall, 95 U. S. 296; Adirondack R. Co. $v$. New York, 176 U. S. 335 .

When inquiry has been legally made by the properly constituted tribnnal (which in this case consisted of commissioners) there is no need of provision for appeal: their determination may be final. Long Island Water Supply Co. $v$. Brooklyn, 166 U. S. 694.

4 Backus $r$. Fort St. Union Depot Co., 169 U. S. 567.

5 Bauman $v$. Ross, 167 U. S. 548 . 


\section{CHAPTER IX.}

\section{THE POLICE POIVER.}

\section{CHARACTERISTICS AND LIMITATIONS.}

Chapter IX.

TH

HE police power has been defined by Chief Justice Shaw in the celebrated case of Com. $v$. Alger," as " the power vested in the legislature by the Coustitution, to make, ordain, and establish all manner of wholesome and reasonable laws, statutes, and ordinances, either with penalties or without, not repugnant to the Constitution, as they shall judge to be for the good and welfare of the commonwealth and of the subjects of the same." In Barbier $v$. Connolly, 2 the object of the police power is stated to be "to prescribe regulations to promote the health, peace, morals, education, and good order of the people, and to legislate so as to increase the industries of the State, develop its resources, and add to its realth and prosperity.', The sphere of the police porrer is thus stated in Lawton $v$. Stecle: ${ }^{3}$ "It is miversally conceded to include everything essential to the public safety, health, and morals, and to justify the destruction or abatement, by summary proceedings, of whatever may be regarded as a public nuisance. Under this power it has been held that the State may order the destruction of a house fall-

17 Cush. (Mass.) 53. And see Manigault v. Springs, 199 U. S. 473.

2113 U. S. 31.

3 152 U. S. 133. 
ing to decay or otherwise endangering the lives of passers-by; the demolition of such as are in the path Chapter

IX. of a conflagration; the slaughter of diseased cattle; the destruction of decayed $\mathrm{ol}^{\circ}$ unwholesome food; the prohibition of wooden buildings in cities; the regulation of railways and other means of public conveyance, and of interments in burial grounds; the restriction of objectionable trades to certain localities; the compulsory vaccination of children; the confinement of the insane or those afflicted with contagious diseases; the restraint of ragrants, beggars, and habitual drunkards; the suppression of obscene publications and houses of ill fame; and the prohibition of gambling houses and places where intoxicating liquors are sold. Beyond this, however, the State may interfere wherever the public interests demand it, and in this particular a large discretion is necessarily vested in the legislature to determine, not only what the interests of the publio require, but what measures are necessary for the protection of such interests."

In this wide sense the police porver is understood to embrace not only the preservation of the order, peace, health, morals, and safety of the community, but also all legislation looking to the well being of society in its economic and intellectual aspects. ${ }^{*}$ It is sometimes restricted to the first branch of activities merely, namely, the maintenance of morals, health and safety. As so limited it occupies a definite field comparable with the powers of eminent domain and taxation, and is so essential to the very being of the State, that it can not be curtailed by

4 See Manigault $v$. Springs, 199 U. S. 473. 

Chapter contract on the part of the State. ${ }^{5}$ In its wider
IX. meaning it loses definiteness. It embraces a vast mass of miscellaneous legislation. It may or may not be subject to the contract clause of the Federal Constitution. It is nothing more nor less than a name for the residual powers of sovereignty after shearing off the powers of taxation and the eminent domain. In the License Cases, ${ }^{6}$ Chief Justice Taney aslied the question, "What are the police powers of a state?" and answered it as follows: "They are nothing more or less than the powers of govermment inherent in every sovereignty to the extent of its dominions. And whether a state passes a quarantine law, or a law to punish offenses, or to establish courts of justice, or requiring certain instruments to be recorded, or to regulate commerce within its own limits, in every case it exercises the same power; that is to say, the power of sovereignty, the power to govern men and things within the limits of its dominion.', Some authors have pointed out the desirability of separating the police power in its narrower sense from the general residual legislative power which goes under that name, but the courts use the term in its widest meaning, and in many instances it might be difficult and embarrassing to say on which side of the line dividing the pure police powers from general legislative powers a given case should fall. Many instances of the application of the legislative power as applied to procedure, evidence, remedies and the like have already been considered in other connections. ${ }^{7}$

5 see infra, p. 304.

6 5 How. (U. S.) $504,583$.

7 See especially Chapter IV, p. 138, and section on Procedure, p. 159. 
The legislature may, if it see fit, delegate the power to pass local laws or ordinances to municipal corporations, which are but subdivisions of the State. ${ }^{\mathrm{s}}$ Consequently, under the general police power, the Chapter IX. to municipalities. legislature may delegate to a municipality the authority to pass ordinances for the preservation of the health or the promotion of the comfort, convenience, good order and general welfare of its citizens, provided always that they are not in conflict with constitutional provisions. ${ }^{9}$

The legislature may likewise charge public officials with the duty of carrying into effect a scheme of police regulation devised by it, and the duties of Adminis tive officials with judicial duties. such officials may be made merely administrative, ${ }^{1}$ or judicial or quasi-judicial without violating the constitutional provision for due process, if, on questions of fact involving private rights, notice and hearing is provided. ${ }^{2}$

A characteristic of the action of the police and the legislative power is that it does not require the taking of private property for public use, in a conDoes not requite "taking" of property. stitutional sense, and does not, therefore, demand as a condition of its rightful exercise that compensation be made. This matter is considered in detail elsewhere. ${ }^{3}$

Police legislation on the part of the State may be invalid because it trenches on the sphere of the na-

8 Fischer $v$. St. Louis, 194 U. S. 361, 370. See supra, p. 212.

9 California Reduction Co. $v$. Sanitary Reduction Works, 199 U. S. 306 ; State v. Summerfield, 107 N. Car. 895; State v. Tenant, 110 N. Car. 609.

1 Reagan $v$. Farmers' L. \& T. Co., 154 U. S. 362.

2 Reetz $v$. Michigan, 188 U. S. 505 . See also infra, p. 370.

3 See supra, p. 203. 
Chapter tional government under the Federal Constitution.
IX.

Regulation of commerce as affecting States' po. lice powers

Not extraterritorial.

Obligation of contracts and the States' police power.
Laws which, enacted under the plea of the police power, are in fact a regulation of interstate commerce are void. ${ }^{5}$ But a statute is not a regulation of commerce because it may incidentally or indirectly affect commerce. ${ }^{6} \quad$ While State laws yield to acts of Congress passed in execution of powers conferred by the Constitution, the mere grant to Congress of the power to regulate commerce with foreign nations and among the States does not of itself and without legislation by Congress impair the authority of the States to establish reasonable police regulations. ${ }^{7}$

Again, police legislation which purports to deal with subjects beyond the territorial jurisdiction is opposed to the conception of due process of law and void.s

While it is settled that the State can not divest itself by contract of the police power in its restricted sense, so as to deprive itself of the capacity to legislate in the interests of the lives, health, or morals of its citizens, ${ }^{2}$ many regulations controlling business and economic conditions in the interests of the gen-

4. Jacobson $v$. Massachusetts, 197 U. S. 11, 25.

5 Hamihal, etc., R. Co. $r$. Husen, 95 U. S. 465 ; Norgan's Steamship Co. $r$. Lonisiana, 118 U. S. 455, 464; Schollenberger $v$. Pennsylvania, $171 \mathrm{C}$. S. 1 .

a Mimsouri, etc., R. Co. $v$. Haber, 169 U. S. 618; Reid $v$. Colorado, 187 U.S. 137.

7 New York, ete., R. Co. $v$. New York, 165 U. S. 628.

8 Allgeyer $r$. Louisiana, 165 U. S. 578. See infra, p. 351 et seq.

a Boston Beer Co. $v$. Massachusetts, 97 U. S. 25; Stone $v$. Mississippi, 101 U. S. 814; Butehers' Union Slaughter-House, etc.. Co. $t$. Crescent City Live Stock Landing, ete, Co., 111 U. S. 74t; New Orleans Gas Co. $v$. Louisiana Light Co., 115 U. S. 650; Wabash R. Co. $v$. Defiance, 167 U. S. 88; Chicago, Burlington, etc. R. Co. $r$. Nebraska, 170 U. S. 57 ; Manigault v. Springs, 199 U. S. 473. 
eral welfare can not be enforced against a contract existing between the State and persons or corporaChapter tions whose affairs are the subject of regulation. ${ }^{1}$ Thus the State's right to regulate the charges by railroads and other public service corporations may be surrendered to such a company by the stipulations of its charter or other legislation, amounting to a contract. ${ }^{2}$

It has been repeatedly declared by the Supreme Court of the United States that the limitations on State action contained in the Fourteenth Amendment were not designed to limit or interfere with the exercise of the police power on the part of the States. ${ }^{3}$ This declaration only means that the sphere of the legitimate police power is the same under the amendment as without it. ${ }^{4}$ What is the legitimate sphere of the police power is under that amendment a question for the final determination of the Federal Supreme Court, and to be tested by the body of doctrines which have grown up in its decisions, in the interpretation of the National Constitution.

1 New Orleans Gas Co. v. Louisiana Light Co., 115 U. S. 650; Railroad Commission Cases, 116 U. S. 307, 325.

2 Georgia R., etc., Co. $v$. Smith, 128 U. S. 174,179 ; Reagan $v$. Farmers' L. \& T. Co., 154 U. S. 362, 393; Knoxville Water Co. $v$. Knoxville, 189 U. S. 434.

3 Barbier $v$. Comolly, 113 U. S. 31 ; Jones $v$. Brim, 165 U. S. 180, 182; L'Hote $v$. New Orleans, 177 U. S. 587 ; Cunnius $v$. Reading School Dist., 198 U. S. 469.

4 "The States possess, because they have never surrendered, the power - and therefore municipal bodies, under legislative sanction, may exercise the power - to prescribe such regulations as may be reasonable, necessary, and appropriate for the protection of the public health and comfort." California Reduction Co. v. Sanitary Reduction Works, 199 U. S. 306. 
Chapter

IX.

Due process requires reasonable. ness.

Primarily for legisla. ture, ulti. mately for court.

\section{ITS EXERCISE MUST BE REASONABLE.}

A general limitation on the exercise of the police power is found in the idea of reasonableness; that is, to be valid a statute must be reasonable and enacted in good faith; ${ }^{5}$ for every merely arbitrary and capricions fiat of the legislature is out of place in "a government of lars and not of men," and is irreconcilable with the conception of due process of law. ${ }^{6}$

As the reasonableness of legislation is a matter pre-eminently for the consideration of the law-making branch of the government, the court will not examine the question de nor.o and substitute its judgment for that of the legislature, but will pronounce a law void only when it is merely arbitrary or not enacted in good faith." "No court," it was remarked in a recent case, "would declare a usury law unconstitutional, even if every member of it believed that Jeremy Bentham had said the last word on that sub-

5 Plessy r. Ferguson, 163 L. S. 550.

6 See summ. pp. 51, 61, 142.

7 Yick Wo $r$. Hopkins, 118 U. S. 356 ; Powell $v$. Penusylvania, 127 U. S. 677, 684; Morgan's Steamship Co. $v$. Lonisiana, 118 U. S. 455 , 459: Powell $r$. Penncylvania, 127 U. S. 677, 684; L'Hote $v$. New Orleans. 177 C. S. 587; Jacobson $r$. Massachusetts, 197 U. S. 11, 30, 31: Cunnius $r$. Rearling Sehonl Dist., 19S U. S. 469; Com. $v$. Pear. 183 Mass. 242, 247; Holden $v$. Hardy, 169 U. S. 366; Lake Shore, ete., R. Co. $r$. Ohio, 173 U. S. 285, 301 ; Health Dept. $v$. Trinity Chureh, 145 N. Y. $32,42$.

Whether the applieation of a police regulation, reasonable in itself, is in the circumstances of an individual case reasonable or arbitrary, is a question of fact, and the defense of unreasonableness cannot be asserted in the United States Supreme Court. When the trial court has determined after hearing that the requirement of the improvement is reasonable in the circumstances, and their finding has been affirmed in the highest State court, the question is one of fact which has been conclusively settled. Minneapolis, etc., R. Co. $v$. Minnesota, 193 U. S. 53. 
ject, and had shown for all time that such laws did more larm than good. The Sunday laws, no doubt, would be sustained by a bench of judges, even if every one of them thought it superstitious to make any day holy. Or, to take cases where opinion has moved in the opposite direction, wagers may be declared illegal without the aid of statute, or lotteries forbidden by express enactment, although at an earlier day they were thought pardonable at least. The case would not be decided differently if lotteries had been lawful when the Fourteenth Amendment became law, as indeed they were in some civilized states." 1 Ultimately, then, reasonableness must be passed upon by the courts, in the exercise of their proper function of keeping the legislature within constitutional bounds, and reasonableness may in this sense, and in this sense only, be called a judicial question.

Varying aspects of the principle may be stated. A law or ordinance not enacted in good faith for the promotion of the public good but passed from the Tests of tional police legislation. sinister motive of annoying or oppressing a particular person or class is invalid as offending the fundamental principle of the generality of the laws. ${ }^{2}$ If the legislature in passing a law exereises the right of classification over persons or things, the classification must be founded on a natural basis, on differences not arbitrary merely, but such as in the nature of things furnish a reasonable ground for separate laws and regulations. ${ }^{3}$ The police power can not be 1 Otis $v$. Parker, 187 U. S. 606, 609.

2 Yick Wo $v$. Hopkins, 118 U. S. 356 ; Dobbins $v$. Los Angeles, 195 U. S. 223 .

3 Gulf, etc., R. Co. $v$. Ellis, 165 U. S. 150 ; State $v$. Loomis, 115 Mo. $307,314$. 
Chapter interposed to support statutes which have no posIX.

General and local police regulation.

sible tendency to protect the community or promote the public welfare, but which, having no substantial relation to the public welfare, arbitrarily deprive the owner of liberty or property. ${ }^{4}$ It has been said that if police regulations passed by the State in the interest of public health, morals or safety, "amount to a denial to persons within its jurisdiction of the equal protection of the laws, they must be deemed unconstitutional and void.",5 But this is only saying in other words that a statute which arbitrarily selects certain members of the community for regulation is not a valid exercise of the police power.

The test of reasonableness is applicable alike to the statutes of the legislature passed in the exercise of the police power and to the acts of local municipal legislative bodies acting under powers delegated by the legislature. ${ }^{6}$ The English courts have from time immemorial applied the test to municipal legislation, ${ }^{\top}$ and our courts assume a much more untrammelled attitude in examining the reasonableness of

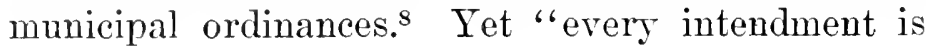

4 Mugler $v$. Kansas, 123 U. S. 623, 661, 669; Lawton $v$. Steele. 152 U. S. 133; Holden $v$. Hardy, 169 U. S. 366, 398; California Reduction Co. $v$. Sanitary Reduction Works, 199 U. S. 306; Matter of Jacobs, 98 N. Y. 98, 50 Am. Rep. 636; Colon $v$. Lisk, 153 N. Y. 185.

5 Connolly $x$. Union Sewer Pipe Co., 184 U. S. 540.

e Plessy r. Ferguson, 163 U. S. 550.

7 See supra, p. 25.

8 "While the courts." says Professor Freund, "profess to regard the State legislature as a co-ordinate power, they frankly treat the municipal authorities as subordinate," and judge each ordinance or regulation on its own merits. Frennd, Police Power, § 142 . In examining municipal legislation there is the question, not only of the hamony of the legislation with the constitution, which must arise equally as to acts of the legislatore, but there is the additional 
to be made in favor of the lawfulness of the exercise of municipal power making regulations to promote the public health and safety, and it is not the province of courts, except in clear cases, to interfere with the exercise of the power reposed by law in municipal corporations for the protection of local rights and the health and welfare of the people in the community.", 9

Police Power or Eminent Domain as Dependent on Reasonableness.

When legislation has the effect of prohibiting a use which is incidental to property generally, or provides for the destruction of property in particular conditions as constituting a nuisance, ${ }^{1}$ it has been said that its validity as police regulation, requiring no compensation, depends on its extent, or on the reasonableness of the provision in question; that when a statute oversteps this line of reasonableness it becomes an exercise of the eminent domain and compensation is necessary, so that, in such a case, if no provision is made for compensation, the act is invalid. In Massachusetts, it has been held that an act forbidding the erection of fences unnecessarily exceeding six feet in height from motives of malevolence and to annoy one's neighbors was a valid regulation of the use of property rights not amounting to a taking of property under the law of eminent domain. The court said: "Some small limitations of question whether the ordinance is in harmony with the general laws of the State.

9 Dobbins $v$. Los Angeles, 195 U. S. 223, 235; California Reduction Co. $v$. Sanitary Reduction Works, 199 U. S. 306.

1 See infra, p. 337. 
Chapter previously existing rights incident to property may
IX.

be imposed for the sake of preventing a manifest evil; larger ones could not be except by tne exercise of the right of eminent domain."'2 When legislation providing for the killing of diseased animals was in question, it was declared: "We can not admit that the legislature has an unlimited right to destroy property without compensation, on the ground that destruction is not an appropriation to public use; . . . when a healthy horse is killed by a public officer, acting under a general statute, for fear that it should spread disease, the horse certainly would seem to be taken for public use, as truly as if it were seized to drag an artillery wagon. The public equally appropriate it, whatever they do with it afterwards." 3 In accordance with these principles a statute has been held void which declared particular encroachments on the merely private rights of others a muisance punishable with forfeiture of the property employed in the encroachment, without regard either to the extent of the trespass, or the intentional wrongdoing or innocence of the owner, or the value of the property to be forfeited. ${ }^{4}$

Use of property for adver. tising.
Overstepping the bounds of reasonable regulation and amounting to a taking of property without compensation has been held to be a statute or ordinance prohibiting the use of private property for advertising purposes. The purpose of such a regulation is only the asthetic enjoyment of members of the

2 Ridcout $v$. Knox, 148 Mass. 368, 372, 373, per Holmes, .T.

3 Miler $r$. liorton, 152 Mass. 540. See also Jawton $r$. Steele, 152 U. S. 133. But apparently no such limitation was thought of in Mugler $v$. Kansas, 123 U. S. 623, and per Field, J., dissenting, 678.

4 Colon v. Lisk. 153 N. Y. 195. 
public, and it is unreasonable in view of the end to be

attained to deprive persons of a recognized and valuable use of property without compensation. Of the use of property for adrertising, the Massachusetts court observed: "This has come to be an ordinary and remumerative use of lands near largely traveled streets, parkways, public parks, railroads, and other places frequented in numbers by the public. It is as natural a use of such lands as is the use of store fronts and show windows for display of goods kept for sale, or for other modes of adrertising. It resembles the placing of adrertising pages on each side of the literary portion of a periodical or the placing in street cars or railway stations of advertisements disconnected with the business of transportation. All these at present are usual, common, and profitable uses of property, of which every one sees daily numerous instances." 5 But when the end is adequate, particular classes of signs may be prohibited without compensation, as, for instance, immoral advertisements, or signs which are a menace to public safety. ${ }^{6}$

\section{Classification.}

Classification is controlled both by the clause of the Fourteenth Amendment forbidding the denial of due process of law and that requiring the equal protection of the laws. Perhaps the same effects might have been attained by the due process clause alone and it will not be possible to separate the cases un-

5 Com. $v$. Boston Advertising Co., (Mass. 1905) 74 N. E. Rep. 601. To the same effect is People $v$. Greene, 85 N. Y. App. Div. 400.

6 People $r$. Greene, 85 N. Y. App. Div. 400, distinguishing Rochester $v$. West, 164 N. Y. 510. 

Chapter der the two clauses with rigid distinctness. As has
IX.

Subjects regulation cannot. that others are not vegulated.

Specially dangerous employments.

been seen, both clauses are satisfied when a law is founded on some natural basis of classification and all persons within its scope are treated alike under similar circumstances, ${ }^{7}$ and this is but an application of the wider principle of reasonableness.

When regulations are imposed upon one trade or business on valid grounds, it is not a subject of complaint that other kinds of business are not subjected to like regulation. "The specific regulations for one kind of business, which may be necessary for the protection of the public, can never be the just ground of complaint because like restrictions are not imposed upon other business of a different kind. The discriminations which are open to objection are those where persons engaged in the same business are subiected to different restrictions, or are held entitled to different privileges under the same conditions. It is only then that the discrimination can be said to impair that equal right which all can claim in the enforcement of the laws." 8

Employments involving special dangers either to those engaged in them or to the public may be made the subject of legislation under the police power, and the nature of the employment justifies the exercise of the legislative powers and prevents the act being a denial of due process of law. Upon this ground, statutes abolishing the fellow-servant rule as applied to the employees of railroad corporations have been sustained. ${ }^{\circ}$ The danger to cattle straying on rail-

7 See supra, p. 58.

8 Soon Hing $v$. Crowley, 113 U. S. 703. See also Missouri, etc., R. Co. $v$. May, 194 U. S. 267 ; Ohio v. Dollison, 194 U. S. 445.

${ }^{9}$ Missouri Pac. R. Co. v. Mackey, 127 U. S. 206 ; Chicago, etc., 
roads justifies a law requiring railroad companies to fence their rights of way and providing for punitive damages when cattle are killed in the absence of fences." "The statutes of nearly every State of the Union," said the Federal Supreme Court, "provide for the increase of damages where the injury complained of results from the neglect of duties imposed for the better security of life and property. . . . And experience favors this legislation as the most efficient mode of preventing, with the least inconvenience, the commission of injuries." 2

The pursuit of harmless employments in a manner which may endanger the property of others may be prohibited. Thus a police regulation prohibiting Harmiess employ. ments pur. sued in dangerous washing and ironing in public laundries in prescribed limits within a city during certain hours of the night has been upheld on the ground of the danger of fire were the laundry business allowed under the prohibited conditions. ${ }^{3}$

The tendencies of two similar employments may afford a sufficient ground of discrimination. In a case wherein a specific tax laid by the State of GeorSimilar em. ployments discriminated by gia on the occupation of hiring persons to labor outside the State was resisted on the ground that it constituted an invalid discrimination against the oceupation involved, because no tax was laid on hiring to labor within the State, the Federal Supreme Court sustained the tax. The Supreme Court of R. Co. v. Pontius, 157 U. S. 209 ; Tullis $v$. Lake Erie, etc., R. Co., 175 U. S. 348 ; Minnesota Iron Co. v. Kline, 199 U. S. 593.

1 Missouri Pac. R. Co. $v$. Humes, 115 U. S. 512 ; Minneapolis, etc., R. Co. $v$. Beckwith, 129 U. S. 26.

2 Missouri Pac. R. Co. $v$. Humes, 115 U. S. 512.

3 Barbier $v$. Connolly, 113 U. 8.27 ; Soon Hing $v$. Crowley, 113 U. S. 703 . 
Chapter Georgia upheld the law because, first, it did not ap-
Ix. pear that employing laborers for work in the State was a business followed by any one, and, second, because the State could properly discriminate between occupations of a similar nature but a dissimilar tendency, between those which tended to induce the laboring population to leave the State, and those which tended to induce that population to remain. After noticing this holding, the Supreme Court of the United States said: "We are umable to say that such a discrimination, if it existed, did not rest on reasonable grounds, and was not within the discretion of the State legislature." 4

BUSINESS AFFECTED WITH A PUBLIC INTEREST.

Business whose man. agement affects the public.
One large field of legislative activity which is placed under the head of the police power is the regulation of business or property affected with a public interest. The doctrine was authoritatively declared in Munn v. Illinois, ${ }^{5}$ in 1876, being there developed from principles stated in the treatise $D e$ Portibus Maris by Lord Hale, who declared that when "wharves, cranes and other conveniences are affected with a public interest, they cease to be juris privati only," and ought to be under public regulation; "as if a man set out a street in a new building on his own land, it is no longer bare private interest, but is affected with a public interest." " ${ }^{\circ}$ The Federal Supreme Court states the doctrine thus: "Property does become clothed with a public interest when

4 Williams $r$. Fears, 179 U. S. 270.

594 U. S. 113.

6 Hale, De Portibus llaris, part ii. c. fo (Hargrave's Law Tracts, p. 77 ) ; Bolt $v$. Stennett, 8 T. R. 606 ; Allnutt $v$. Inglis. I2 Eist 527. 
used in a manner to make it of public consequence and affect the community at large. When, therefore, one devotes his property to a use in which the public has an interest, he, in effect, grants to the public an interest in that use and must submit to be controlled by the public for the common good, to the extent of the interest he has thus created." The same idea has been stated by Mr. Justice Bradley $^{8}$ as follows: "Then an employment or business . • . becomes a practical monopoly, to which the citizen is compelled to resort, and by means of which a tribute can be exacted from the community, it is subject to regulation by the legislative power." The principle of virtual monopoly which seems to give a reasonable foundation for the doctrine appears to have been abandoned by the United States Supreme Court in later cases. ${ }^{9}$

The most familiar instances of the regulation of business affected with a public interest are found

Instances
of busines offusines with public

7 Munn $v$. Illinois, 94 U. S. 113, 126; Budd $v$. New York, 143 interest.

U. S. 517 ; Brass $v$. Stoeser, 153 U. S. 391 ; Cotting $v$. Kansas City Stock Yards Co., 183 U. S. 79, 84.

The doctrine of Munn $v$. Illinois has been sharply criticised on the ground that the doctrine of Lord Chief Justice Hale was misconceived; that in all the instances cited by Lord Hale, the public or the crown had an actual proprietary interest in the property "affected with a public interest." See note to the Munn Case, 16 Am. Law Reg. N. S. 539, valuable as a contemporary analysis of the authorities on which the decision is founded; State $v$. Associated Press, 159 Mo. 410 ; Cooley, Const. Limit., 6th ed., 734 et seq.; The Power of the State to Regulate Prices and Charges, by G. A. Finkelnburg. 32 Am. L. Rev. 501.

8 Dissenting opinion in Sinking Fund Cases. 99 U. S. 700, 747, quoted in the opinion of the court in Budd $v$. New York, 143 U. S. 517,537 .

9 See Brass $v$. Stoeser, 153 U. S. 391, 403, and dissenting opinion of Brewer, Field, Jackson, and White, JJ., at p. 409. Compare, however, 32 Am. Law Rev. 511. 
Chapter in the regulation of common carriers and railroads, ${ }_{1}^{1}$ innkeepers, wharfingers, ferrymen, millers, and warehousemen, ${ }^{2}$ but the principle is a general one.

1 In Gladson $v$. Minnesota, 166 U. S. 427, a State statute requiring all regular passenger trains, operated wholly within the State, to stop at all county seats through which the road passed and where it had a station, was held to be valid. The court said: "A railroad corporation, created by a State, is for all purposes of local government a domestic corporation, and its railroad within the State is a matter of domestic concern. . . . It [the State] may prescribe the location and plan of construction of the road, the rate of speed at which the trains shall run, and the places at which they shall stop, and may make any other reasonable regulations for their management, in order to secure the objects of the incorporation, and the safety, good order, convenience, and comfort of the passengers and of the public. All such regulations are strictly within the police power of the State."

2 Grain elevators: Munn $v$. Illinois, 94 U. S. 113, 131, 132; Budd $v$. New York, 143 U. S. 517, 536. Grist-mills: Burlington $v$. Beasley, 94 U. S. 310 ; State $v$. Edwards, 86 Me. 105, 25 L. R. A. 505. Bakers: Mobile $v$. Yuille, 3 Ala. 137 (ordinance regulating weight, quality, and price of bread sustained).

Many of the older examples enumerated in Munn's Case are founded ultimately on mediæval legislative precedents adopted under conditions and cconomical ideas foreign to modern times. In the Middle Ages, before the law of supply and demand was understood, it was assumed that there was for every commodity a just natural price, and that this price might be found and established by the state. Freund, Pol. Power, 374, citing, inter alia, Cunningham, Growth of Eng. Com., vol. 2, p. 232. Consequently, the English governmental anthorities, national and local, undertook to regulate the prices, not only of labor, but of a variety of commodities. In the same way, elaborate lists of prices and wages were established by legislation in some of the American colonies. Finkelnburg, Pouer of States to Regulate Prices and Charges, 32 Am. L. Rev. 502, 503. In short, what would now be called the police power of the state had an indefinitely widler range in early times, and its application to state regulation of prices and wages was unhampered by notions of equality of rights or due process. Again, in colonial times, when the country was thinly settled, some employments, as that of a miller, may have partaken to an extent quite impossible at this day of the character of a virtual monopoly. In West $v$. Rawson, 40 W. Va. 480, the statute regulating the business and charges of milling had been brought forward in the statute books from the year 
It extends to the business of grain elevators ${ }^{3}$ companies supplying water and gas; ${ }^{4}$ stockyard comChapter panies; ${ }^{5}$ telegraph and telephone companies; ${ }^{6}$ and has been held to inelude the owners of places of public amusement, ${ }^{7}$ hackmen, ${ }^{8}$ and the business of furnishing market quotations. ${ }^{9}$ Business purely private, not affected with a public interest, is not subject to public regulation. Under this class have been placed the dispensing of drinks from a sodawater fountain ${ }^{1}$ and, in Missouri, the business of a news agency in supplying news items. ${ }^{2}$

A test of inclusion, but not of exclusion, has been

1748 , and it was enforced without any question as to its constitutionality.

3 Brass v. Stoeser, 153 U. S. 391, and cases cited in last note.

4 Spring Valley Water Works $v$. Schottler, 110 U. S. 347; San Diego Land Co. $v$. National City, 174 U. S. 739 ; Mobile $v$. Bienville Water Supply Co., 130 Ala. 379; Indiana Natural, etc., Gas Co. v. State, 158 Ind. 516; Charleston Natural Gas Co. v. Lowe, $52 \mathrm{~W}$. Va. 662 .

5 Cotting $v$. Kansas City Stock Yards Co., 183 U. S. 79.

6 New York $v$. Squire, 145 U. S. 175, affirming 107 N. Y. 593; Central Union Telephone Co. $v$. State, 118 Ind. 194, 10 Am. St. Rep. 114 ; Chesapeake, etc., Telephone Co. $v$. Baltimore, etc., Tel. Co., 66 Md. 399, 59 Am. Rep. 167; Godwin v. Carolina Telephone, etc., Co., 136 N. Car. 258; Gardner $v$. Providence Telephone Co., 23 R. I. 262; Commercial Union Tel. Co. $v$. New England Telephone, etc., Co., 61 Vt. 241.

7 Greenberg $v$. Western Turf Assoc., 140 Cal. 357 ; Cecil $v$. Green, 161 Ill. 265; People v. King, 110 N. Y. 418, 1 L. R. A. 293. See also Civil Rights Cases, 109 U. S. 3, per Harlan, J., dissenting, at p. 42.

s Lindsay $v$. Anniston, 104 Ala. 261.

9 New York, etc., Grain, etc., Exch. $v$. Board of Trade, $127 \mathrm{Ill}$. 153.

1 Cecil $v$. Green, 161 Ill. 265.

2 State $v$. Associated Press, 159 Mo. 410.

A different conclusion was reached in Inter-Ocean Pub. Co. $v$. Associated Press, 184 Ill. 438, and the business of the Associated Press was held to be "affected with a public interest." 
Chapter found in the fact that the business sought to be regu-

IX.

Work

which the

State might perform.

lated is one which is confessedly of a public character, that is, which is a proper work for the State itself, and that the State has authorized in its prosecution the employment of some of the powers of overeignty, as of the power of eminent domain. ${ }^{3}$ This is not, however, a test of exclusion, because many businesses have been held affected with a public purpose, which may properly be carried on by private individuals, and which are conducted without the aid of the State's supreme power. ${ }^{4}$

\section{REGULATION OF RATES.}

Restraints on legisla. tive power to regulate.

From the principles already stated it follows that the rate of the charges of all business affected with a public interest is subject to regulation by the legislature. When the question was first presented in 1876 to the United States Supreme Court in Munn v. Illinois, ${ }^{5}$ and the so-ealled Granger Cases, ${ }^{6}$ the right of the State legislature to regulate rates was declared to be complete, the question of reasonableness was pronounced to be a legislative one, and it was said that "for protection against abuses by legislatures the people must resort to the polls, not to the courts." 7 The doctrine thus announced, how-

3 Cotting $v$. Kansas City Stock Yards Co., 183 U. S. 79 ; Fallsburg Power, etc., Co. v. Alexander, 101 Va. 98, 109.

4 Cotting $v$. Kansas City Stock Yards Co., 183 U. S. 79.

594 U. S. 113.

${ }^{6}$ Chicago, etc., R. Co. $v$. Iowa, 94 U. S. 155; Peik $v$. Chicago, etc., R. Co., 94 U. S. 164; Chicago, ete., R. Co. v. Ackley, 94 U. S. 179 ; Winona, etc., R. Co. $r$. Blake, 94 U. S. 180 ; Stone $r$. Wisconsin, 94 U. S. 181. For the name, see 94 U. S. 183.

7 Munn $v$. Illinois, 94 C. S. 113, 133, 134. Soe also Peik $v$. Chicago, etc., R. Co., 94 U. S. 164, 178. 
ever, has undergone progressive modification in later decisions. In the Railroad Commission Cases, ${ }^{\mathrm{s}}$ Chapter IX. which came before the court in 1886, the court in a dictum declared there were limitations on the State's authority. "This power to regulate," it was said, "is not a power to destroy, and limitation is not the equivalent of confiscation. Under pretense of regulating fares and freights, the State cannot require a railroad corporation to carry persons or property without reward; neither can it do that which in law amounts to a taking of private property for public use without just compensation, or without due process of law." 9 The prescribing of future rates is a legislative act, while the inquiry whether existing rates are reasonable is a judicial act. ${ }^{9}$

When the rates were established not by the legis-

lature directly, but by an administrative board cretive power. ated by the legislature, the court said: "The question of the reasonableness of a rate of charge for transportation by a railroad company, involving as it does the element of reasonableness both as regards the company and as regards the public, is eminently a question for judicial investigation, requiring due process of law for its determination."'] This requires in such cases hearing and notice, but

8116 U. S. 307.

9116 U. S. 331. See also Dow $v$. Beidelman, 125 U. S. 680, 688; Georgia R., etc., Co. $v$. Smith, 128 U. S. 179 ; Louisville, etc., R. Co. $v$. Kentucky, 183 U. S. 503, 510.

$9^{*}$ Interstate Commerce Com. $v$. Cincinnati, etc., R. Co., 167 U. S. 479,499 .

1 Chicago, etc., R. Co. v. Minnesota, 134 U. S. 418, 458; Louisville, etc., R. Co. $v$. Kentucky, 183 U. S. 503, 510, where a ruling requiring the same rates for long and for short hauls was sustained. 
Chapter when the legislature acts directly in establishing

IX.

Even when the legislature acts directly, the courts have power to set aside unreasonable rates. "The legislature," the Federal Supreme Court has said, "has power to fix rates, and the extent of judicial interference is protection against unreasonable rates." 3 In a case involving the validity of water rates fixed by local authorities, the same principles were laid down, and the court added: "Judicial interference should never occur unless the case presents, clearly and beyond all doubt, such a flagrant attack on the rights of property under the guise of regulation as to compel the court to say that the rates prescribed will necessarily have the effect to deny just compensation for private property taken for public use." "4 In Smyth $v$. Ames, ${ }^{5}$ decided in 1898 , the court, after a full examination of authorities, sums up its conclusion on this point as follows: "While rates for the transportation of persons and property within the limits of a State are primarily for its determination, the question whether they are so unreasonably low as to deprive the carrier of its property without such compensation as the constitution secures, and, therefore, without due process

2 Budd $r$. New York, 143 U. S. 517, affirming 117 N. Y. 1.

3 Chicago, etc., R. Co. $r$. Wellman, 143 U. S. 339; Reagan $v$. Farmers' L. \& T. Co., 154 U. S. 362 ; St. Louis, etc., R. Co. $r$. Gill. 156 U. S. 649, 657; Covington, etc., Turnpike Road Co. $v$. Sandford. 364 U. S. 578, 592; Interstate Commerce Commission $v$. Cincinnati. ete. R. Co., 167 U. S. 479, 499; Lake Shore, etc., R. Co. $r$. Smith. 173 U. S. 687.

4 San Diego Land Co. $v$. National City, 174 U. S. 739. 754. See also Stanislaus County $r$. San Joaquin, etc., Canal, etc., Co.. 192 U. S. 201 .

5169 U. S. 466. 
of law, cannot be so conclusively determined by the legislature of the State, or by regulations adopted under its authority, that the matter may not become the subject of judicial inquiry."

The question of the reasonableness of the rate is an equitable question depending on a consideration of all the circumstances of the particular case, and requiring the weighing of the various interests involved; on the one hand, the interests of the owners of the property, including those who have acquired rights therein as bondholders; on the other, the interests of the public. What the property owners are entitled to ask is a fair return upon the value of that which is employed for the public convenience; what the public is entitled to demand is that no more be exacted from it than the services rendered are reasonably worth. ${ }^{6}$

In a case involving the validity of rates prescribed for a turnpike company, the court said: "Each case must depend upon its special facts; and when a court, without assuming itself to prescribe rates, is required to determine whether the rates prescribed by the legislature for a corporation controlling a public highway are, as an entirety, so unjust as to destroy the value of its property for all the purposes for which it was acquired, its duty is to take into consideration the interests both of the public and of the owner of the property, together with all other circumstances that are fairly to be considered in determining whether the legislature has, under the guise of regulating rates, exceeded its constitutional authority, and practically deprived the owner of

${ }^{6}$ Smyth $v$. Ames, 169 U. S. 466, 547. 
Chapter property without due process of law." 7 It was held in this case that an allegation in an answer to a bill for an injunction, that under the rates established the income of the company would be so reduced that it could not maintain its road, meet its ordinary expenses, and earn any dividends for stockholders, made, in connection with facts stated, a prima facie case of their invalidity. ${ }^{\mathrm{s}}$

Effect of rate on entire line, not on parts, considered.

Mortgage bondholders.

Value of property the basis of calculation.
When a railroad company has been formed by the consolidation of several pre-existing separate lines, the reasonableness of the rate established for the consolidated company is to be tested by the effect of the rate on the entire line of railway as consolidated and not by its effect on the road belonging to one of the pre-existing companies only. "The company cannot claim the right to earn a net profit from every mile, section, or other part into which the road might be divided, nor attack as unjust a regulation which fixed a rate at which some such part would be unremunerative.", 9

The interest of mortgage bondholders is an element to be considered, and if, under the schedule of rates fixed, interest on the mortgage debt cannot be paid, the enforcement of the schedule ordinarily means confiscation. ${ }^{1}$

The basis of any calculation of reasonable rates is held to be the present value of the property em-

7 Covington, etc., Turnpike Road Co. v. Sandford, 164 U. S. 578, 597. See also Ames $v$. Union Pac. R. Co., $6+$ Fed. Rep. 165, 178.

8 See also Smyth $v$. Ames, 169 U. S. 466 , when proof of facts showing rates so low that ordinary expenses could not be met was held to avoid the rates.

9 St. Louis, ete., R. Co. $r$. Gill, 156 U. S. 649, 657.

1 Chicago, etc., R. Co. v. Dey, 35 Fed. Rep. 866, 879, 880. 
ployed in the public service, and any rate which fails to give "a fair return" on this value deprives Chapter IX. the owner of property without compensation." But it has been said that there may be cases where the original cost of construction evidenced by outstanding bonds, rather than the real value of the property, should be taken into account, so as not to cast the entire burden of depreciation on those who have invested their money in railroads.

In order to ascertain the value of the property employed in the public service, "the original cost of construction, the amount expended in permanent improvements, the amount and market value of its bonds and stock, the present as compared with the original cost of construction, the probable earning capacity of the property under particular rates prescribed by statute, and the sum required to meet operating expenses, are all matter's for consideration,

2 Smyth $v$. Ames, 169 U. S. 466; San Diego Land Co. $v$. National City, 174 U. S. 739 ; Cotting v. Kansas City Stock Yards Co., 183 U. S., 79, 91; San Diego Land, ete., Co. v. Jasper, 189 U. S., 439, 442 , where it was held, however, that when a water supply plant has been built for a large area, and the rates fixed with reference to its capacity, the company cannot complain that the rates do not give a reasonable return, if it has not as yet the customers contemplated.

Judge Noyes, approaching the question of rates at once as a railroad president and a lawyer, concludes that "charging according to the value of the service is the only feasible method of making rates." American Railroad Rates, 236. Valure of service (to the shipper) is opposed to cost of service. Reasonableness is always a matter of comparison, and "when rates do not exceed the charges made by other railroads similarly situated they are prima facie reasonable." Ib. 63. There is no such thing as a rate reasonable per se (ib. 61), and "rates, like taxes, are based upon ability to pay." Ib. 53. See also infra, p. 327 , and note 4.

3 Ames $v$. Union Pac. R. Co., 64 Fed. Rep. 165, 177, 178, per Brewer, Cir. Justice. 
Chapter and are to be given such weight as may be just and IX.

right in each case." This enumeration of the elements of value is not exclusive, and "there may be other matters to be regarded." 4

Considera.

The consideration to be accorded these elements ed to differ. ent elements varies. may vary. The interest of the public as well as the property owners being a consideration, the public is not to be burdened with increased rates necessary to meet a bond issue in excess of fair value, or a fictitious capitalization, ${ }^{5}$ or reckless operating expenses. "There may be circumstances,"' it has been said, "that mould justify such a tariff [as fails to produce any profit]; there may have been extravagance and a needless expenditure of money; there may be waste in the management of the road; enormous salaries, unjust discrimination as between individual shippers, resulting in general loss. The construction mar have been at a time when material and labor were at the highest price, so that the actual cost far exceeds the present value; the road may have been unwisely built, in localities where there is not sufficient business to sustain a road. Doubtless, too, there are many other matters affecting the rights of the community in which the road is built, as well as the rights of those who have built the road." ${ }^{6}$ "Fair re- A "fair return" on the value of property invested cannot, therefore, be set at a certain per cent on the capital. ${ }^{7}$

4 Smyth $v$. Ames, 169 U. S. 466. See also San Diego Land Co. $v$. National City, 174 U. S. $739,757$.

5 Smyth $r$. Ames, 169 U. S. 466, 544; San Diego Land Co. $r$. National City, 174 U. S. 739, 757, 758 .

- Reagan $x$. Farmer's L. \& T., etc., Co., 154 U. S. $362,412$.

- Covington, ete., Turnpike Road Co. $v$. Sandford, 164 U. S. 578, 
On the other hand, the rule once laid down that Chaptcr "when the proposed rates will give some compensaIX. tion, however small, to the owners of the railroad property, the courts have no power to interfere,"s has yielded with the advance of opinion that reasonableness is an equitable question in all the circumstances of the case. ${ }^{9}$

In Cotting v. Kansas City Stock Yards Co., ${ }^{1}$ Mr. Reasonable rates as de. Justice Bremer, writing the opinion of tlle court, nature of but speaking on this point only for himself and two other judges, suggested a distinction in the consid erations which make a rate reasonable according as the property owner is intentionally acting in the performance of State functions and with the aid of State franchises, such as eminent domain, or as without any intent to perform a public service he las placed his property in such a position that the public has an interest in its use.

In the first case, the property owner distinctly undertakes to do the work of the State, and it may be said that by his action he voluntarily accepts all the conditions of public service which would attach were perform. 597, 598; San Diego Land Co. v. National City, 174 U. S. 739, 756; Chicago, etc., R. Co. $v$. Der, 35 Fed. Rep. $866,878$.

8 Chicago, etc., R. Co. $v$. Dey, 35 Fed. Rep. 866 , 879, per Brewer, J. See Dow $v$. Beidelman, 125 U. S. 680 , where rates giving a return of one and a half per cent on the original cost of the road and only a little more than two per cent on the amount of the bonded debt were sustained.

In Cotting $v$. Kansas City Stock Yards Co., 183 U. S. 79, 91, it is said: "It [the court] has not held affirmatively that the legislature may enforce rates which stop only this side of confiscation and leave the property in the hands and under the care of the owners without any remuneration for its use."

a Southern Pac. R. Co. v. Board of Railroad Com'rs, 78 Fed. Rep. 261, per McKenna, J.

1183 U. S. 79. 
Chapter the State itself performing the service. "He ex-

IX. presses his willinguess to do the work of the State, aware that the State in the discharge of its public duties is not guided solely by a question of profit. It may rightfully determine that the particular service is of such importance to the public that it may be conducted at a pecuniary loss, having in view a larger general interest. At any rate, it does not perform its services with the single idea of profit. Its thought is the general public welfare. If, in such a case, an individual is willing to undertake the work of the State, may it not be urged that he in a measure subjects himself to the same rules of action, and that if the body which expresses the judgment of the State believes that the particular service should be rendered without profit, he is not at liberty to complain?". 2

Where business is in the nature of a private en. terprise.

In the several cases where a private business becomes subject to government control, solely because it is held to be affected with a public interest, the position of the owner is different. He is not performing the work of the State, nor can he avail himself of the power of the State. "His business in all matters of purchase and sale is subject to the ordinary conditions of the market and the freedom of contract. He can force no one to sell to him; he cannot prescribe the price he shall pay. He must deal in the market as others deal, buying only when he can buy and at the price at which the owner is willing to sell; and selling only when he can find a purchaser and at the price which the latter is willing to pay. If, under such circumstances, he is bound

2183 U. S. 93. 
by all the conditions of ordinary mercantile transactions, lae may justly claim some of the privileges which attach to those engaged in such transactions." ${ }^{3}$ In this case, his rates are not to be measured by the aggregate amount of his profits, determined by the volume of the business, but by the question whether any particular charge to an individual dealing with him is, considering the services rendered, an unreasonable exaction. "He has a right to do business. He has a right to charge for each separate service that which is a reasonable compensation therefor, and the legislature may not deny him such reasonable compensation; and may not interfere simply because out of the multitude of his transactions, the amount of his profits is large." 4 In determining what charge is reasonable by the intrinsic value of the services rendered, the customary charge for similar services, as determined by ordinary natural conditions, is obviously of great importance. ${ }^{5}$

A statute which, purporting to regulate rates, in Arbitrary discrimina. effect gives to a class arbitrarily selected, as, for tion. instance, purchasers of one-thousand-mile tickets, rights denied to the public generally, is a taking of property without due process of law. ${ }^{6}$

3183 U. S. $94,95$.

4 Cotting $r$. Kansas City Stock Yards Co., 183 U. S. 95. See also Parkersburg, etc., Transp. Co. v. Parkersburg, 107 U. S. 691, 699.

"The principle must be, when reasonableness comes in question, not what profit it may be reasonable for a company to make, but what it is reasonable to charge to the person who is charged." Canada Soithern R. Co. $v$. International Bridge Co., 8 App. Cas. 723, 731, per Earl of Selborne, L. C.

5183 C. S. $97,98$.

6 Lake Shore, etc., R. Co. v. Smith, 173 U. S. 684. 
Chapter

IX.

DEPRIVATION OF PROPERTY.

\section{Private Rights Must Be Involved.}

In arguing that a person has been deprived of life, liberty, or property without due process of law by the exercise on the part of the State of its police power or its general legislative power, it must necessarily be shown first that the State's action interfered with some individual private right. Thus, when the complaint is that the legislature has deprived a person of a right of property, the argument must fail if it is shown that no property

State may iegislate freely where no vesterl. rights in volved.
Reducing interest on judgments. right is involved in the case. ${ }^{7}$ A statute of California provided for the salaries of the police officers of San Francisco, and created a fund for pensioning policemen by providing that the city should retain two dollars a month out of each officer's salary, as fixed in accordance with the provisions of the law. Several years later the act was repealed. It was held that a policeman who had "contributed" to the fund had no rested rights therein and that the repealing act was not a taking of property without due process. Looking behind the terms of the statute to its substance, it was apparent that the two dollars set apart each month for each officer was not a part of his pay, since it was never in his control, but merely an amount contributed by the State to create the fund. ${ }^{\mathrm{s}}$

When the State exercises its legislative powers by enacting a reduced rate of interest on judgments,

7 New Orleans $v$. New Orleans Water Works Co., 142 U. S. 79, 88.

\& Pennie $r$. Reis, 132 U. S. 464. 
no right of a judgment creditor is infringed by the prospective application of the statute to a judgment previously recovered, because the judgment creditor never had a vested right of property in interest not yet accrued, and the question how much interest shall be allowed is entirely within the discretion of the legislature. ${ }^{9}$

When legislative regulations are concerned with the preservation of property title to which is in the Regulating State property. people of a State as a whole, there is no deprivation of property without due process of law. The right of a municipality acting under authority from the State to forbid public speaking where it had previonsly been allowed in a public park within the municipality has been upheld on this ground. "For the legislature absolutely or conditionally to forbid public speaking in a highway or public park is no more an infringement of the rights of a member of the public than for the owner of a private house to forbid it in his house. When no proprietary

9 Morley $v$. Lake Shore, etc., R. Co., 146 U. S. 162.

The court in this case after remarking that "if the plaintiff has actually received on account of his judgment all that he is entitled to receive, he can not be said to have been deprived of his property," proceeds to observe that "the adjudication of the plaintiff's claims by the courts of his own. State must be admitted to be due process of law." The last remark would seem to be too sweeping and liable to misconstruction. Due process does indeed exist, because in such a case the legislative action in the bona fide exercise of its discretion is due process; but a State court's adjudication on the constitutionality of a State statute is not due process, and if it were no case could ever reach the Federal supreme Court under the due process clause of the Fourteenth Amendment. The question really involved, namely, whether there is a vested right in future interest at the legal rate on a judgment, has been decided differently in some State courts. See the dissenting opinion of Judge Harlan in the case cited. 
Chapter right interferes the legislature may end the right

IX. of the public to enter upon the public place by putting an end to the dedication to public uses. So it may take the lesser step of limiting the public use to certain purposes." 1

Game. The title to game, animals ferae naturae, is in the State until reduced to possession by an individual, ${ }^{2}$ and due process of law is not denied by statutes regulating the times and conditions of taling game. ${ }^{3}$

Reclaimed animals; dogs.

Natural gas; petroleum.
Animals ferae naturae may, by being reclaimed from their wild state, become the subject of a qualified property, which subsists so long as its subject is within the control of its possessor. Assimilated to animals of this class are dogs, which "stand, as it were, between animals ferae naturae, in which, until killed or subdued, there is no property, and domestic animals, in which the right of property is perfect and complete." The right of property in dogs is enjoyed subject to such regulation as the State may see fit to impose, and a law giving the right of recovery for their destruction only when the owner has complied with the dog taxing or licensing statutes does not deprive the owner of property without due process of law. ${ }^{4}$

In some States, deposits of natural gas and petroleum are by the State law, which in this matter is controlling, ${ }^{5}$ treated as analogous to animals ferae

1 Com. $r$. Davis, 162 Mass. 510, quoted in Davis $r$. Massachusetts, 167 U. S. 43, where the Massachusetts case was affirmed.

2 Geer $r$. Connecticut. 161 U. S. 519.

3 Lawton $v$. Steele, 152 U. S. 133; Daniels $v$. Homer, $139 \mathrm{~N}$. Car. 219.

4 Sentell $r$. New Orleans, ete., R. Co., 166 U. S. 705.

- The right of the surface owner to reduce to possession natural gas and oil is an incident of his ownership of the land, and regula- 
naturae, that is, title is in the State until they are reduced to possession, when they become private property. Consequently, in such a State, a statute requiring the owner's of the soil to stop up gas and oil wells thereon when they are abandoned and making it unlawful for any one to allow the escape of natural gas or oil into the open air was held to be a regulation by the State of its own property in the interest of all the people and not a taking of private property. ${ }^{6}$ In giving its decision, the court said: "As to gas and oil the surface proprietors within the gas field all have the right to reduce to possession the gas and oil beneath. They could not be absolutely deprived of this right which belongs to them without a taking of private property. But there is a coequal right in them all to take from a common source of supply the tro substances which in the nature of things are united, though separate. It follows from the essence of their right and from the situation of the things as to which it can be exerted, that the use by one of his power to seek to convert a part of the common fund to actual possession may result in an undue proportion being attributed to one of the possessors of the right to the detriment of the others, or by waste by one or more to the annihilation of the rights of the remainder. Hence it is that the legislative power, from the peculiar nature of the right and the objects upon which it is to be exerted, can be manifested for the purpose of protecting all the collective owners, by

tion of this right is but a regulation of real property governed by the lex rei sitae. Ohio Oil Co. $r$. Indiana, 17 L. S. 190.

6 Ohio Oil Co. $v$. Indiana, 17 U. S. 190. 
Chapter securing a just distribution, to arise from the en-

IX. joyment, by them, of their privilege to reduce to possession, and to reach the like end by preventing waste."

Corpora. tions; reserving power to repeal charter.

Foreign corporations.

Property of school districts.

The reserved power of repeal of the charter of a water company may prevent the question of the deprivation of property without due process of law arising on an act empowering the municipality to erect its own water works. ${ }^{7}$ And the expiration of the contract of a water works company with a village to supply it with water leaves the village free to construct its own water works, and its consent to the incorporation of the company under a franchise not exclusire will not work an estoppel or render its act a deprivation of property without due process of law.s

Restraints on the right to contract placed on foreign corporations by the laws under which they accept the State's permission to do business therein are valid because, such corporations having no right to contract except as given to them by the State, no right of theirs can be said to be denied or infringed. ${ }^{9}$

The subdivision of a State into subordinate territorial units for the various purposes of govermment is at all times a matter entirely in the discretion of the State, and such subdivisions acquire as against the State no private rights in property vested in them for public purposes. Consequently a law cre-

7 Newburpport Water Co. $v$. Newburyport, 193 U. S. 57 .

8 Skaneateles Waterworks Co. $v$. Skaneateles, 184 U. S. 354.

- Waters-Pierce Oil Co. $v$. Texas, 177 U. S. 28; John Hancock Mut. L. Ins Co. $r$. Warren, 181 U. S. 73: Fidelity Mut. L. Ins. Assoc. $v$. Mettler, 185 U. S. 308 . As to the protection extended to foreign corporations generally, supra, p. 100. 

ating a new school district and giving to it the prop- Chapter erty within its limits which had belonged to the districts from which it was created is not a taking of property without due process of law. ${ }^{1}$

It would seem clear that no individual could have a right of property in the future use for private Rights in flags and
emblems. purposes of the national flag or of State seals or emblems, and that the use of these things was, therefore, in the absolute control of the legislature, whose enactments on the subject, howerer unwise, could not be declared void by the courts. This view is supported by recent decisions in some states, ${ }^{2}$ while a contrary view has been entertained by the courts of Illinois, and a statute forbidding the use of the national flag for advertising purposes held to be void as an unwarranted interference with individual liberty. 3 The New York court has held such a law invalid in so far as it operated retrospectively upon articles already made, being as to them a deprivation of property without due process of law. ${ }^{4}$

\section{Professions and Offices as Property.}

The selection to a public office confers on the individual selected no right of property in the office, 5 of property nor is his right thereto a right arising from any contract between himself and the sovereign." "The

1 Atty.-Gen. v. Lowrev, 199 U. S. 233.

2 Com. $v$. R. I. Sherman Mfg. Co., (Mass. 1905) 75 N. E. Rep. 71 ; Halter $v$. State, (Neb. 1905) 105 S. W. Rep. 298.

3 Ruhstrat $v$. People, 185 Ill. 133.

4 People $v$. Van De Carr, 178 N. Y. 425.

5 Tavlor $v$. Beckham, 178 U. S. 548; Atty.-Gen. $v$. Jochim, 99 Mich. 358, 41 Am. St. Rep. 606; Mial v. Ellington, 134 N. Car. 131.

6 Dartmouth College $v$. Woodward, 4 Wheat. (U.S.) 518 ; Butler $v$. Pennsylvania, 10 How. (U. S.) 402, 416; Newton v. Mahoning County, 100 U. S. 548 ; Crenshaw $v$. U. S., 134 U. S. 99. 
Chapter decisions are numerous," said the Supreme Court, IX. "to the effect that public offices are mere agencies or trusts, and not property as such. Nor are the salary and emoluments property, secured by contract, but compensation for services actually rendered. Nor does the fact that the constitution [of the State] may forbid the legislature from abolishing a public office or diminishing the salary thereof during the term of the incumbent change its character or make it property." 7 In an earlier case, the same court had said: "The selection of officers who are nothing more than agents for the effectuating of such public purposes is a matter of public convenience or necessity, and so, too, are the periods for the appointment of such agents; but neither the one nor the other of these arrangements can constitute any obligation to continue such agents, or to re-appoint them, after the measures which brought them into being shall have been found useless, shall have been fulfilled, or shall have been abrogated as even detrimental to the well-being of the public. The promised compensation for services actually performed and accepted during the continuance of the particular agency, may undoubtedly be claimed both upon principles of compact and of equity; but to insist beyond this on the perpetuation of a public policy either useless or detrimental, and upon a reward for acts neither desired nor performed, would appear to be reconcilable with neither common justice nor common sense." 8

7 Taylor $v$. Beckham, 178 U. S. 548, 577.

8 Butler $v$. Pennsylvania, 10 How. (U. S.) 402. 
Proceeding upon such reasoning, a contest about the right to public office has been held to involve no federal question within the due process clause of the United States Constitution, which would justify the interference of the United States Supreme Court with the determination of the proper State authorities. ${ }^{9}$

The case is different with the right to pursue a private profession, calling, or business, such as that of a clergyman, ${ }^{1}$ lawyer, ${ }^{2}$ or physician. ${ }^{3}$ This is Private profession

Chapter IX.

Right to State office does not involve due process un. der Four teenth Amend. ment. or calling.

9 Taylor $r$. Beckham, $17 \mathrm{~S}$ U. S. 548, was the first case in which this point was directly determined, and a writ of error to the Supreme Court of a State dismissed. In Wilson $v$. North Carolina, 169 U. S. 586, the writ was also dismissed, but not squarely on the ground that no federal question could be involved. The court said: "Lpon the case made by the plaintiff in error, the federal questior which he attempts to raise is so unfounded in substance that w are justified in saying that it does not really exist." Boyd $v$. Nebraska, 143 U. S. 155, was entertained because it presented the rights of a citizen of the United States. The writs in two earlier cases, involving the right to public office, Kennard $v$. Louisiana, 92 $\mathrm{U}$. S. 480, and Foster $v$. Kansas, 112 U. S. 201, were entertained, the decisions of the State court in each case being affirmed on the ground that due process was present. These cases are distinguished in Taylor $v$. Beckham, 178 U. S. 548, on the ground that "the constitutionality of the statute under which the disputed title to office was tried was drawn in question." See the dissenting opinions of Brewer, Brown and Harlan, JJ., in the case last cited. In his opinion, Mr. Justice Brewer said: "I am clear, as a matter of principle, that an office to which a salary is attached is, as between two contestants for such office, to be considered a matter of property. I agree fully with those decisions which are referred to and which hold that as between the State and the office holder there is no contract right either to the term of office or to the amount of salary, and that the legislature may if not restrained by constitutional provisions abolish the office or reduce the salary. . . . While not concurring in the order of dismissal, I am of opinion that the judgment of the Court of Appeals of Kentucky should be affirmed."

1 Cummings $v$. Missouri, 4 Wall. (U. S.) 277.

2 Ex p. Garland, 4 Wall. (U. S.) 333.

3 Dent $v$. West Virginia, 129 U. S. 114. 
Clapter property, of which a person may not be deprived

IX.

except with due process of law. But this does not prevent the State from regulating such callings in the interest of the public welfare. ${ }^{4}$

\section{Limiting the Enjoyment of Property.}

Loss of

value to property by prohibition of business.

Requiring disposition of garbage in a way to deprive its owner.
A valid regulation by the legislature in the interest of public health, morals or safety, although it may greatly lessen or destroy the value of property embarked in some business regulated or prohibited, is not a taking of property for public purposes, which requires compensation to its owner. It is one of the implied conditions on which all private property is held and an implied risk to which all business ventures are subject, that the State may in the exercise of the police power require the discontinuance of the traffic or manufacture to which the property is deroted. The inconvenience and loss which individuals suffer in consequence does not violate any fundamental right or require any compensation. $^{5}$

The disposal of garbage in cities is a matter within the control of the police power acting for the preservation of the public health, and the fact that the garbage or refuse may have elements of value does not render an ordinance providing for its transportation in a given manner and its destruction and

4 Sce Reetz $r$. Michigan, 188 U. S. 505 , and infra, p. 346.

5 Boston Beer Co. $v$. Massachusetts, 97 U. S. 32; Northwestern Fertilizer Co, $v$. Hrde Park, 97 U. S. 659; Stone $v$. Mississippi. 101 U. S. 814; liugler $v$. Kansas, 123 U. S. 623. Compare the suggestive essay of Mr. Brooks Adams on Law under Inequality. He find: in instances such as these but an illustration of practical confiscation exerted by a sentiment which has become dominant against obnoxious property rights. Centralization and the $\mathrm{Law}$, p. 108. 
cremation a taking of property without due process of law. The property rights of individuals in the Chapter noxious materials must be subordinated to the general good. ${ }^{6}$

\section{Confiscation of Property.}

The legislature may go further and provide for the confiscation and destruction of property in certain circumstances, as a penalty attached to its misuse in designated ways. ${ }^{\top}$ Legislation forfeiting gaming instruments, ${ }^{8}$ articles used in connection with the illegal sale of liquors and the liquors themselves, ${ }^{9}$ property seized for the violation of the revenue laws, ${ }^{1}$ vessels violating the regulation of the right to fish, ${ }^{2}$ and a host of similar laws illustrate the proposition.

Property may be made subject to a lien for penalties arising from its misuse, or the wrong-doing of its owner, without violating the due process clause of Confiscation as penalty. the Constitution, and it matters not that the penalty is given to a common informer. A law of Ohio made a judgment for money lost at play a lien on the real and personal property of the judgment debtor and a lien likewise on the building where the money was lost, if the building was used for gaming with the owner's knowledge, and in the event that the loser

6 California Reduction Co. $v$. Sanitary Reduction Works, 199 U. S. 306 ; Gardner $v$. Michigan, 199 U. S. 325.

; See Fisher $v$. MeGirr. 1 Gray (Mass.) 1, quoted supra, p. 204.

8 Ridgeway $v$. West. 60 Ind. 37I: Com. $v$. Gaming Implements, 119 Mass. 332: Hastings $v$. Haug. S5 Mich, si.

9 Mugler $r$. Kansas, 123 U. S. 623; Kidd $r$. Pearson, 128 U. S. I.

1 See the title Revenue Laws, 24 Am. and Eng. Encyce of Lav (2d ed.) 930 . 1002 .

2 The Alexander, 60 Fed. Rep. 914; McCandlish $r$. Com., 76 Va.

Misuse of
property may render it liable for conse. quences. 

Chanter did not bring suit within six months after the loss,
IX. gave the right of recovery to any person suing for the same. Under this statute, the loser's wife, after recovering judgment against the winners, brought an action to make the judgment a lien on the building wherein the money was lost. The Supreme Court of the United States upheld the validity of the statute as against the objection that it constitutes a denial of due process of law. ${ }^{3}$

\section{Consequential Damage from Police Regulation.}

Losses in value which are consequential merely.
The same principles apply when the police regulation of some rocation depreciates the value of property in no way connected with the calling regulated. Such loss is simply consequential, dammum absque injuria. The city of New Orleans in the exercise of its power to regulate prostitution in the interest of public morals and decency, passed an ordinance remoring from a designated street of the city the protection of an inhibition previously existing against any public prostitute occupying a room, living or sleeping therein. Property owners within the specified limits attacked the ordinance on the ground that it deprived them of property without due process of law, but the Federal Supreme Court held that the ordinance was valid. After stating cases, like those referred to above, where injury resulting directly from the exercise of the legislature's police porrer was held to give the property owner no right of complaint against the State, it was said: "If under such circumstances the individual has no cause of action, a fortiori must the

3 Marvin $v$. Trout, 199 U. S. 212. 
same be true when the injuries are not direct but Chapter consequential, when his property is not directly $1 \mathrm{x}$. touched by the legislative action but is affected in only an ineidental and consequential ray. Here the ordinance in no manner touched the property of the plaintiffs. It subjected that property to no burden, it cast no duty or restraint upon it, and only in an indirect way can it be said that its pecuniary value was affected by this ordinance. Tho can say in advance that in proximity to their property any houses of the character indicated will be established, or that any persons of loose character will find near by a home? They may go to the other end of the named district." 4

\section{Imposition of Expense Connected with Police Regulation.}

When certain acts or precautions are demanded in the interest of the public health or safety, the expenses ineident thereto may be required, without a deprivation of due process of law, to be borne by the owners of the property or business out of which the necessity for the acts or precautions arises. Quarantine regulations being adopted for the protection of the public against the spread of disease, the requirement that the vessel examined shall pay for the examination is a part of all systems of quarantine; ${ }^{5}$ and householders in a city may be required to bear the expense of the transportation of garbage to the place provided for its cremation. ${ }^{6}$

4 L'Hote $r$. New Orleans, 177 U. S. 587.

5 Morgan's Steamship Co. $v$. Louisiana Board of Health, $118 \mathrm{U}$. S. 466 . S. 306 .

6. California Reduction Co. $v$. Sanitary Reduction Works, 199 U.

Expense of regulation for health 
Chapter

IX.

Further illustrations.

Expenses for improved facilities to be borne by quasi-public corporations.
The expense of a compulsory examination of railroad engineers, to ascertain whether they are free from color blindness, has been held to be properly chargeable against the railroad companies. ${ }^{7}$ So the expenses of a railroad commission may be charged against the railroad corporations $;^{8}$ of mining inspectors, against the owners of mines; ${ }^{9}$ of sanitary improvements, against the owners of the tenement houses in which the improvements are required $;^{1}$ of constructing and maintaining such safeguards as are required to protect the public safety in connection with the operation of railroads, against the railroad companies. ${ }^{2}$

Such exactions may be made of corporations conducting business charged with a public interest, although the requirement is merely for the convenience of the public. Railroads may be required to make specific improvements at their own cost. ${ }^{3}$ The imposition of tolls by a State statute upon those using an improred interior waterway in order to reimburse the State for the expense of improvements is not a deprivation of property without due process

7 Nashrille, etc. R. Co. v. Alabama, 128 U. S. 96.

8 Charlotte, etc., R. Co. $v$. Gibbes, 142 U. S. 386 ; New York $v$. Squire, 145 U. S. 175.

๑ Consolidated Coal Co. $v$. Illinois, 185 U. S. 203, 207.

1 Ilealth Dept. $v$. Trinity Church, 145 N. Y. 32.

2 New York, etc., R. Co. $v$. Bristol, 151 U. S. 556 (elininating grade crossings): Chicago, etc., R. Co. $v$. Nebraskia, 170 U. S. 57 (maintenance of riaduet).

3 Take Shore, etc., R. Co. $v$. Ohio, 173 U. S. 28.5 (enforeement of statute requiring railroads to stop trains in citins of a certain size); Wisconsin, pte., R. Co. $r$. Jacobson. 179 U. S. 287 (enforcement of track conncetions between railroads upheld): State $r$. Minnesota, ete, R. Co., 76 Minn. 469. 479 (requirement of station held unreasonable): People $v$. Boston, etc., li. Co., 70 N. Y. 569 (required to build a bridge). 
of law. The making of such improvements lies in the discretion of the State, and to meet the cost involved Chapter IX. it rests with the State either to levy a tax or lay tolls on the use of the improved stream. Such tolls are merely equivalents for benefits conferred." A gas company furnishing gas to a city under an exclusive contract may be required, upon improvements in the drainage system of the city, to pay the cost of shifting its pipes and mains rendered necessary by such improvements, and the requirement of payment in no way affects the obligation of the contract between the city and the company. ${ }^{5}$

It has been said that the expense imposed must be a reasonable, proper and fair exaction when conLimitation to extent. of imposisidered with reference to the object to be attained and the surrounding facts. In a case inrolving the legality of imposing the costs of sanitary improvements in a tenement house upon its owner, the cost, it was declared, must "not exceed what may be termed one of the conditions upon which individual property is held." One of the conditions is that the property must not improperly cause harm to the public, and the legislature may therefore require such expenditure on the part of the owner as will guard "the health and safety of the occupants and of the public through them.", 6

4 Huse $v$. Glover, 119 U. S. 543; Sands $v$. Manistee River Imp. Co., 123 U. S. 288.

5 New Orleans Gas Light Co. v. Drainage Commission, $197 \mathrm{U} . \mathrm{S}$. 453.

6 Health Dept. $v$. Trinity Church, 145 N. Y. 32, 42. 
Chapter

IX.

Creation of liabilities connected with certain uses of property.

Illustrations from railroads.

Further illustrations.
Creation of Liabilities Connected with Enjoyment of Property or Occupation.

The doctrine which makes every one responsible for the use of his own in such a way as not to injure others, lies at the basis of laws which cast peculiar responsibilities upon the owners of property devoted to enterprises which, though lawful or even necessary, are especially liable to cause damage to others, or upon the owners of property who allow it to be devoted to unlawful occupations.

Illustrations are laws requiring railroad companies to fence their rights of way and making them responsible for all damages sustained in consequence of a failure to do so $;^{7}$ liable absolutely for fires caused by locomotives $;^{8}$ answerable in a penal action to contiguous landowners for allowing Johnson grass to mature on the right of way; $;$ statutes extending the liability of a common carrier of goods to carriers of passengers $;^{1}$ or depriving railroads, when sued by an employee for injuries, of the defense that the injuries were due to the negligence of a fellow servant. ${ }^{2}$

Persons driving cattle along highwars may be made absolutely liable for injuries caused to the highways. ${ }^{3}$ I number of enactments make the owner's of property answerable for damages result-

7 Missouri Pac. R. Co. $v$. IIumes, 115 U. S. 512 ; Minneapolis, ete, R. Co.r. Emmons, 149 L. S. 364. See supra, p. 313.

s. St. Louis, etc.. R. Co. $r$. Mathews. 165 U. S. 1. See supra, p. 186.

- Missouri, ete. R. Co. $v$. May, 194 U. S. 267.

1 Chicago, etc.. R. Co. $r$. Zernecke, 183 U. S. 582.

2 Missouri Pac. R. Co. $r$. Mackey, 127 U. S. 205. See supra, p. 313 .

3 Jones $v$. Brim, 165 U. S. 180. See supra, p. 186. 
ing from its use for unlawful purposes, as gambling ; ${ }^{+}$or for its misuse in pursuits, such as the sale of intoxicating liquor's, which are carefully regulated in behalf of the public welfare.

The exercise of the police power in the creation of such liabilities is subject to the usual limitation of reasonableness, and classification based on real distinctions.

\section{DEPRIVATION OF LIBERTY.}

The liberty which is secured by the Constitution is not unrestricted license to act according to one's own will. It is only freedom from restraint upon Liberty ac. cording to law; com vaccinaconditions essential to the enjoyment of the same right by others, and is subject to regulation by the State in the exercise of its police power. ${ }^{6}$ The observance of all such measures and precautions as the State deems vital for the protection of public health, safety, morals or welfare may be enforced upon all citizens and residents without regard to their own private views of the wisdom or beneficial effect of the measures adopted. Compulsory vaccination prescribed by the State or its proper authorities may be enforced against all members of the community. It is matter of common knowledge that vaccination is considered by high medical authority as an effective prevention of the spread of smallpox, and the court would be usurping legislative functions if it undertook to determine against

4 Marrin $v$. Trout, 199 L. S. 212. See supra, p. 337.

5 Bertholf $v$. O'Reilly, 74 N. Y. 509, upholding the constitutionality of a provision in a civil damage act, making the owner of the premises whereon liquor was sold liable for the consequences of intoxication produced there.

6 Crowley $v$. Christensen, 137 U. S. 86. 
Chapter its efficiency and so to pronounce that there was no

IX. connection between a legitimate object of the police power, the prevention of infectious diseases, and the means adopted, vaccination. ${ }^{7}$ As the State may interfere directly with freedom, it can not be a valid objection to legislation that incidentally and remotely liberty is affected by it.s

Restraint on lunatics and incompetents.

The State as parens patriae may extend its care over and protect the interests of incompetents, such as insane or weak-minded persons and children. The liberty of these classes with respect to their persons and their property rights may be regulated for the welfare of the individuals themselves and for the protection of the community at large. In the exercise of this power the State may provide for the involuntary confinement of the insane until the restoration of their reason, and this whether the insane person is dangerous and criminal or entirely harmless. ${ }^{1}$ The same principles sanction statutes which provide for the confinement of young criminals in "homes of correction" or "reformatories," in which "education for good is made a condition of their restraint;" 2 statutes allowing indeterminate

7 Jacobson $v$. Massachusetts, 197 U. S. 11, affirming 183 Mass. 242 ; Morris $v$. Columbus, 102 Ga. 792 ; State $v$. Hay, 126 N. Car. 999.

Compulsory vaccination regulations established by boards of health or health officers have been held to be under the circumstances of the case unreasonable and an unwarranted interference with the liberty of the eitizen. Potts $v$. Breen, $167 \mathrm{Ill} .67,59 \mathrm{Am}$. St. Rep. 263; Matter of Smith, 146 N. Y. 68, 48 Am. St. Rep. 769; State $v$. Burdge, 95 Wis. 390.

8 Williams $v$. Fears, 179 U. S. 270.

1 Simon v. Craft, I82 U. S. 436, affirming I18 Ala. 625; Underwood $r$. People, 32 Nich. 1; In re Boyett, 136 N. Car. 415.

2 Milwaukee Industrial Sehool r. Milwaukee County, 40 Wis. 328. And see the title Houses of Rofune and Correction, $15 \mathrm{Am}$. and Eng. Ereyc. of Law (2d ed.) 777. 
sentences, ${ }^{3}$ and other statutes varying the degree of restraint with the purpose of adapting punishment to the good of particular classes."

\section{Freedom of Contract and Business.}

Although freedom and the liberty to contract are fundamental rights within the guaranties of the Constitution, they may be limited by the state in the exercise of the police power in the interest of public safety, health, or morals, or, under certain conditions, in the exercise of the legislative power merely.

Regulated for Public Morals, Health, or Safety.

Liberty does not include the right to carry on a business injurious to the public health or morals, and occuor the right to enter into immoral contracts. ${ }^{5}$ To determine what contracts or what occupations are injurious to public health or morals rests in the legislature exercising the police power, and the courts cannot interfere with its decision, "unless, looking through mere forms and at the substance of the matter, they can say that the statute enacted professedly to protect the public morals [or health] has no real or substantial relation to that object, but is a clear, unmistakable infringement of rights secured by the fundamental law.", 6

3 Murphy $v$. Com., 172 Mass. 264. And see the same case, Murphy $v$. Massachusetts, 177 U. S. 155.

4 See the titles Reprieve, Pardon and Amnesty, 24 Am. and Eng. Encyc. of Law (2d ed.) 547; Sentence and Punishment, 25 id. 289.

5 Soon Hing $v$. Crowley, 113 U. S. 703.

6 Booth $v$. Illinois, 184 U. S. 425, 429. 
Chapter

IS.

Illustrations.
Regulations for the public health and safety.
The practice of prostitution, ${ }^{7}$ and the manufacture of, or traffic in, intoxicating liquors may be prohibited or regulated by the State. ${ }^{8}$ Gaming and gambling contracts and the business of lotteries may be prohibited. ${ }^{9}$ Dealing in options and futures and the sale of stocks on margins are legitimate subjects of police legislation." "A calling may not in itself be immoral, and yet the tendency of what is generally or ordinarily or often done in pursuing that calling may be torards that which is admittedly immoral or pernicious. . . . It must be assumed that the legislature was of opinion that an effectual mode to suppress gambling grain contracts was to declare illegal all options to sell or buy at a future time. The court is unable to say that the means employed were not appropriate to the end sought to be attained and which it was competent for the State to accomplish.", 2 The police power extends to make punishable a visit to "any barred or barricaded house or room" wherein gambling instruments are exhibited, and one convicted of the offense is not deprived of his liberty without due process of law, because his visit was made innocently.3."

In providing for the safety and health of the public, the business of dealing in dangerous substances,

i Lilote $r$. New Orleans. 17T U. S. 587.

* Nugler $r$. Kancas, 123 U. S. 623; Kidd $v$. Pearson, $128 \mathrm{U}$. S. 16; Fopriano r. Speed, 199 U. S. 501.

9 Stone $r$. Missisippi, 101 U. S. 914; Lottery Case, 188 U. S. 321 ; th $\sin r$. Wittman, 198 U. S. 500, 506.

1 Otis $r$. Parker, 187 U. S. 606.

2 Booth $r$. Iltinois, 184 U. S. 425, 429, 430. And see Otis $r$. Parker. 187 C. S. 606.

3 Ah Sin $r$. Wittman, 198 U. S. 500. 
such as explosives, ${ }^{4}$ and the conduct of unsanitary and offensive trades, the regulation of the sale of Chapter IX. articles such as milk, whose purity affects the public, ${ }^{\circ}$ may be regulated. Laws providing for the examination and licensing of phrsicians before State medical boards, ${ }^{i}$ and quarantine laws ${ }^{\curvearrowright}$ have been held a proper exercise of the State's power to protect public health and safety.

The hours of labor in dangerous employments may be limited. ${ }^{9}$ The legislative action may extend no further than the limitation of rorking hours for certain classes, as women and children, to whom prolonged emplorment at labor otherwise harmless is considered especially dangerous. ${ }^{1}$ And the State may absolutely interdict certain emplorments to children although their parents approve of such emplorments for them. ${ }^{2}$

The prevention of fraud is a valid ground for legislative action as to contracts, and for the sup-

4 Patterson $v$. Kentucky, 97 U. S. 501.

5 Slaughter-House Cases, 16 Wall. (U. S.) 36; Butcher's Union Slaughter-House, etc., Co. $v$. Crescent City Live-Stock Landing, etc., Co., 111 U. S. 746.

The keeping of markets may be regulated, and private markets may be prohibited within a certain distance of public markets. Natal $v$. Louisiana, 139 U. S. 621.

e New York $r$. Van De Carr, 199 U. S. 552.

7 Dent $r$. West Virginia, 129 U. S. 114: Hawker $v$. New York, 170 U. S. 189 ; Reetz $r$. Michigan, 188 U. S. 505.

8 Morgan's Steamship Co. $v$. Louisiara, 118 U. S. 455.

Under the circumstances of the cases quarantine regulations have been held an unreasonable interference with liberty. Hurst $r$. Warner, 102 Mich. 238; Kosciusko $v$. Slomberg, 68 Miss. 449 ; Wilson $v$. Alabama G. S. R. Co., 77 Miss. 714 ; Matter of Smith, 146 N. Y. 68.

9 Holden $v$. Hardy, 169 U. S. 366.

1 Com. $r$. Hamilton Mfg. Co., 120 Mass. 383.

2 People $r$. Ewer, 141 N. Y. 129. 


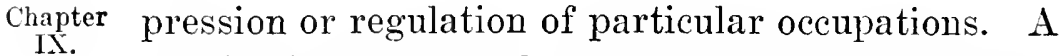
striking instance are the statutes of frauds which for the prevention "of frauds and perjuries"' regulate the forms which certain contracts shall take. Statutes regulating the time and method of disposing of a staple agricultural product of the State, from its nature peculiarly exposed to theft, have been upheld as within the police power. ${ }^{3}$

Oleomargarine.

An illustration of the application and limitation of this principle as applied to particular occupations is found in statutes prohibiting or regulating the manufacture and sale of oleomargarine. It has been held by the Supreme Court of the United States that the State might absolutely prohibit the manufacture and sale of oleomargarine, and the person whose liberty was thus curtailed was not deprived of liberty within the Fourteenth Amendment. The court based its ruling on the fact that there was no evidence in the record to show that oleomargarine was not often composed of ingredients deleterious to health, and it could not assume, in default of evidence of the fact, that all oleomargarine was harmless, because of testimony that that manufactured by the defendant was so; that it could not say that there was no relation between the prohibitions of the act and the public health and the prevention of fraud, which were the specific grounds of the legislation. Fraud in the sale, that is, an effort to palm off on the public the manufactured article for natural butter, could not well be alleged in this case because the article

3 Davis $v$. State, 68 Ala. 58; State $v$. Moore, 104 N. Car. 714. These statutes prohibited moving seed cotton at night, or its sale in small quantities under certain restrictions. 

was labeled and sold as "oleomargarine." 4 Many Chapter State courts have held that, since oleomargarine is a nutritious and harmless substance used as food, the State cannot without infringing upon liberty prohibit its manufacture and sale; ${ }^{5}$ but it may prevent its manufacture and sale with an intermixture of coloring matter making it liable to be mistaken for butter, for the police power extends to prevent frauds and deceptions, and it is no defense that the substituted article is a healthful article of food. ${ }^{6}$ The later cases in the Federal Supreme Court have rested on this last proposition only, and it has been held beyond the power of the State to exclude oleomargarine entirely on the ground that it might be so adulterated as to be harmful, s since oleomargarine as such las become a recognized article of interstate commerce. ${ }^{9}$

\section{Business Affected with Public Interest.}

The purely legislative powers, when the public health, safety, or morals are not concerned, may be employed in making regulations based on a proper classification for a business affected with a public interest, if regard be had to the sacredness of vested rights and to the obligations of contracts already entered into by the State. ${ }^{1}$ A statute requiring

Railroad companies.

4 Powell r. Pennsylvania, 127 U. S. 67s.

5 People $r$. Marx, 99 N. I. 377.

6 McAllister $v$. State, $72 \mathrm{Md}$. 390; State $v$. Addington, $77 \mathrm{Mo}$. 110; State $r$. Marshall, 64 N. H. 549: Waterbury $v$. Newton, 50 N. J. L. 534; People $x$. Arensberg, 105 N. Y. 123.

7 Plumley $v$. Massachusetts, 155 U. S. 461; Capitol City Dairy Co. $r$. Ohio, 183 U. S. 238.

8 Schollenberger $v$. Pennsylvania, 171 U. S. 1.

9 In re Kollock, 165 U. S. 536 ; McCray $r$. L. S.. 195 U. S. 27.

1 St. Louis, etc., R. Co. $v$. Paul, 173 U. S. 404. 
Chapter

IX.
Unjust discrimination against quasi-public corpora. tions. railroad companies to pay employees discharged with or withont cause, at the time of the discharge, with. out any deduction and providing a penalty in case of failure to do so, was sustained against the objection that it was a denial of due process of law. The act was found to be purely prospective, not to interfere with existing contracts or vested rights, and not to destroy, or "sensibly encroach upon," the right to contract. It was a proper regulation "promoting the public interest in the protection of employees." 2

A quasi-public corporation, though its business is undoubtedly affected with a public interest, can not be singled out for regulation in regard to a duty, such as the payment of debts, which rests in no special sense on corporations, but is equally obligatory on all debtors. A statute penalizing the non-performance by railroad companies alone of such a duty is invalid, the penalty not being inflicted on any comprehensible ground, such as the protection of laborers, the prevention of trifling litigation, or in consideration of special corporate privileges. $^{3}$ On the other hand, a statute allowing to

In Gundling $v$. Chicago, 177 U. S. 188, it is said: "Regulations respecting the pursuit of a lawful trade or business are of very frequent necurrence in the varions cities of the country, and what such regulations shall be and to what particular trade, business or oecupation they shall apply are questions for the State to determine, and their determination comes within the proper exercise of the police power by the State, and unless the regulations are so utterly unreasonable and extravagant in their nature and purpose that the property and personal rights of the citizen are unnceessarily, and in a manner wholly arbitrary, interfered with or destroyed without due process of law, they do not extend beyond the power of the State to pass, and they form no subjeet for federal interference."

2 St. Louis, etc., R. Co. $v$. Paul, 173 U. S. 404.

3 Gulf, etc.. R. Co. $r$. Ellis, 165 U. S. 150, holding void a Texas statute requiring railroads to pay an attorney's fee of ten dollars in 

the plaintiff a reasonable attorney's fee in suits Chapter against railroad companies for damages by fire caused by the operation of railroads has been held, in view of the peculiar danger of fire from such sources, to be valid and based on elassification, not on arbitrary selection. ${ }^{*}$

The business of conducting elevators and warehouses on railroad rights of way may be subjected Grain ele. vators and wareto conditions not provided for the same business in other locations. ${ }^{5}$

The business of insurance is subject to State Insurance. regulation, and such regulation if fonnded on reasonable classification is valid. Liabilities not shared by all insurance companies may be imposed on life insurance companies, ${ }^{6}$ or fire insurance companies, ${ }^{7}$ and the court cannot pronounce the statutes roid for arbitrary selection. The legislature may insert certain statutory terms in insurance policies and mullify any stipulation in the policy to the contrary.

A State statute which, under the guise of controlling foreign insurance companies doing business in No power to regulate contracts State. the State, operates as interpreted by the State Supreme Court to prevent a citizen of the State from arailing himself in an effective way of a contract of insurance made beyond the State in a comcase certain specified small claims against the companies were not settled in thirty days. The statute was declared not to be based on classification but on "arbitrary selection." The reasoning of the case on the points of the text is not bound up with the conclusion on the arbitrary nature of the selection or classification. Three justices dissented.

4 Atchison, etc., R. Co. $v$. Matthews, 174 U. S. 96.

5 W. W. Cargill Co. v. Minnesota, 180 U. S. 452.

6 Carroll $r$. Greenwich Ins. Co., 199 U. S. 401.

i Fidelity Mut. L. Ins. Assoc. $x$. Mettler, 185 U. S. 308, 325.

8 See Equitable L. Assur. Soc. $v$. Clements, 140 U. S. 226. 
Chapter pany not doing business in the State, is an unconstitutional interference with freedom of contract. The court said: ${ }^{9}$ "When we speak of the liberty to contract for insurance or to do an act to effectuate such a contract already existing, we refer to and have in mind the facts of this case, where the contract was made outside the State, and as such was a valid and proper contract. The act done within the limits of the State, under the circumstances of this case and for the purpose therein mentioned, we hold a proper act, - one which the defendants were at liberty to perform, and which the State legislature had no right to prevent, at least with reference to the Federal Constitution. To deprive the citizen of such a right as herein described without due process of law is illegal. Such a statute as this in question is not due process of law, because it prohibits an act which, under the Federal Constitution, the defendants had a right to perform. . . . In the privilege of pursuing an ordinary calling or trade, and of acquiring, holding, and selling property, must be embraced the right to make all proper contracts in relation thereto; and although it may be conceded that this right to contract in relation to persons or property or to do business within the jurisdiction of the State may be regulated, and sometimes prohibited, when the contracts or business conflict with the policy of the State as contained in its statutes, yet the power does not and can not extend to prohibiting a ritizen from making contracts of the nature involved in this case outside of the limits and

• Allgeyer $r$ Louisiana, 165 U. S. 578. 
jurisdiction of the State, and which are also to be Chapter performed outside of such jurisdiction."

Regulation in the Interest of Certain Classes - to Prevent Oppression.

The State may legislate to protect certain classes against themselves, so to say, and such legislation Regulation to prevent has been held valid if not objectionable for other reasons, as for unjust discrimination, although it interfered with freedom of contract. Usury laws may be based on this principle, because the lender and the borrower of money do not occupy toward each other the same relation of equality that parties occupy in contracting with regard to the loan or sale of other kinds of property, and the borrower's necessities deprive him of freedom of contracting and place him at the mercy of the lender. ${ }^{1}$

Sailors form a class whose freedom and right to Sailors. contract have at all times and among all nations been subject to peculiar restraints. Deserting sailors may be summarily arrested and punished criminally for what in ordinary cases of employment would be only a breach of contract. ${ }^{2}$ As their liberty is curtailed by law and custom, so their rights may be by law protected, and statutes framed for their protection have been declared no violation of the right to contract, although making it a misdemeanor for the employer to pay wages in advance and providing that advance payment shall not ab-

1 Frorer $v$. People, 141 Ill. 171.

2 Robertson $v$. Baldwin, 165 U. S. 275, 282. 
Chapter solve from payment after the wages have been
IX. earned. ${ }^{3}$

The so-called Truck Acts or Store-order Acts illustrate the same principle. As was said by Byles, J., in an English case under the Truck Act (1 \& 2 Wm. IV, c. 37): "The Truck Act, when passed, was a practical deduction from a principle, still more general, pervading more or less all systems of law founded on experience; that is to say, that where two classes of persons are dealing together, and one class is, generally speaking, weaker than the other, and liable to oppression either from natural or incidental causes, the law should, as far as possible, redress the inequality, by protecting the weak against the strong. On this principle rests the protection thrown around infants and persons of unsound or weak minds, [and] the protection afforded even by the common law to the victims of fraud. ${ }^{4}$ A statute requiring, under certain conditions, the redemption in money at par of orders payable in goods and produce, issued to laborers by employer's, has been sustained in the United States Supreme Court. The Tennessee court, in a passage approved in the federal court, said: "The legislature evidently deemed the laborer at some disadvantage under existing laws and customs and by this act undertook to ameliorate his condition in some measure by enabling him or his bona fide transferee, at his election and at a proper time, to demand and receive his unpaid wages in money rather than in something less valuable. Its tendency,

3 Patterson r. The Eudora, 190 U. S. 169.

4 Archer v. James, 2 B. \& S. 82, 110 E. C. L. 82. 
though slight it may be, is to place the employer and employee upon equal ground in the matter of wages, and, so far as calculated to accomplish that end, it deserves commendation. Being general in its operation and enforceable by ordinary suit, and being unimpeached and unimpeachable upon other constitutional grounds, the act is entitled to full recognition as the "law of the land' and 'due process of law' as to the matter's embraced." 5

Acts for the protection of employees generally or of employees in particnlar pursuits and industries to protect employees have, on the other hand, frequently been held by held void.

State courts an unconstitutional restraint on the right to make contracts and do business. So, with statutes forbidding contracts of employment payable otherwise than in money to be made by corporations or persons engaged in manufacturing or mining; ${ }^{6}$ a statute compelling manufacturing, mining, and other enumerated corporations to pay employees at stated intervals and forbidding assignments to the employer of future wages ${ }^{7}$ forbidding corporations or persons engaged in mining or manufacturing to maintain stores for the purpose of furnishing their employees with supplies, clothing, provisions, etc. ${ }^{8}$ forbidding those engaged in weaving to withhold from the wages of or to fine an employee because of imperfections in his work ${ }^{9}$ requiring coal

5 Knoxvlle Iron Co. $v$. Harbison, 183 U. S. 13, affirming 103 Tenn. 421.

6 State $v$. Loomis, 115 Mo. 307 ; Godcharles $v$. Wigeman, 113 Pa. St. 431 ; State $v$. Goodwill, 33 W. Va. 179 ; State $v$. Fire Creek Coal, etc., Co., 33 W. Va. 188.

7 Braceville Coal Co. v. People, 147 Ill. 66.

8 Frorer $v$. People, 141 Ill. 171.

- Com. $v$. Perry, 155 Mass. 117. 
Chapter miners to be paid by the weight of coal mined and providing for the method of weighing. ${ }^{1}$ These cases emphasize the sacredness of the right to contract, but almost all place the ruling on the ground that the legislature discriminates arbitrarily among industries. When this feature was lacking, similar statutes have been sustained.2

Purely private voca. tion not subject to regulation.
A purely private vocation or calling which has no connection with the public health or well-being, which is lawful and is not attended with any peculiar dangers, can not be subjected to special regulation impairing the freedom of contract, even though the legislation is ostensibly for the protection of public health. ${ }^{3}$ Thus a law restricting the employment of bakers to sixty hours a week has been held by the United States Supreme Court an arbitrary interference with freedom of contract, ${ }^{4}$ and statutes regulating the trade of horseshoeing; have been pronounced in the State courts besond the legislative power and an infringement on personal liberty and freedom of contract. ${ }^{5}$

1 Hillett $v$. People, 117 Ill. 294; Ramsey $v$. People, 142 Ill. 380 .

2 Hancock $r$. Yalen, 121 Ind. 366; State $r$. Peel Splint Coal Co.. 36 W. Va. 802. See also Avent-Beattyville Coal Co. $v$. Com., 96 K. 218 ,

Such legislation directed against corporations only has been sustained, when the power to amend their charters was reserved by the State. Lepp r. St. Louis, etc. R. Co.. 5s Ark. 407; Shafier $r$. Union Min. Co., 55 Md. 74; State $v$. Brown, etc.. Mfg. Co., 18 R. 1. 18 .

3 Lochner $v$. New York, 198 U. S. 45: Matter of Jaenbs, 98 N. Y. 98. And see sumra. the eases referring to oleomargarine, p. 349.

4 Jochner $v$. New York, 198 U. S. 45.

s Bessette $v$. People, 193 I1l. 334: Penple $v$. Beattie, 96 N. Y. App. Div. 383; Matter of Aubrey, 36 Wash. 308. 
Regulation in the Interest of Economic Prosperity

IX. and General Welfare.

Freedom of contract may be regulated in the exer- $\begin{gathered}\text { Economic } \\ \text { legislation. }\end{gathered}$ cise of the legislative power in the interests of the general welfare of society. Sunday laws have been sustained as not an arbitrary interference with business or liberty. Public health and well-being demand periodical cessation from labor, and it rests with the legislature to prescribe the frequency of rest and the day to be observed. ${ }^{6}$

Monopolies and combinations tending to control prices and suppress competition are almost universally believed to be detrimental to society, and Trusts, monopolies, and combina lars passed to suppress this evil, although interfering to some extent with freedom to contract, are valid. In a recent case wherein a State anti-trust law was attacked as interfering with liberty to contract, the court said: "There are some things which counsel easily demonstrate. They easily demonstrate that some combination of 'capital, skill or acts' is necessary to any business development, and that the result nust inevitably be a cessation of competition. But this does not prove that all combinations are inviolable or that no restriction upon competition can be forbidden. . . . It is certainly the conception of a large body of public opinion that the control of prices through combinations tends to restraint of trade and to monopoly, and is evil. The foundations of the belief, we are not called upon to discuss, nor does om purpose re-

6 Hennington $v$. Georgia, 163 U. S. 299 ; Petit $v$. Minnesota, 177 U. S. 164 . 
Chapter quire us to distinguish between the kinds of com-

binations or the degrees of monopoly. It is enough to say that the idea of monopoly is not now confined to a grant of privileges. It is understood to include a 'condition produced by the acts of mere individuals.' Its dominant thought now is, to quote another, 'the notion of exclusiveness or unity;' in other words, the suppression of competition by the unification of interest or management, or it may be through agreement and concert of action. And the purpose is so definitely the control of prices that monopoly has been defined to be 'unified tactics with regard to prices.' It is the power to control prices which makes the inducement of combinations and their profit. It is such power that makes it the concern of the law to prolibit or limit them. And this concern and the policy based upon it has not only expression in the Texas statutes; it has expression in the statutes of other States and in a well-known national enactment. According to them competition, not combination, should be the law of trade. If there is evil in this it is accepted as less than that which may result from the unification of interest, and the power such unification gives. And that legislatures may so ordain this court has decided." $\tau$

In another case, even more recent, the court de-

7 National Cotton Oil Co. $r$. Texas, 197 U. S. 115 . See also Aikens $r$. Wisconsin, 195 C. S. 194: Smiley $r$. Kansas, 196 U. S. 447.

As sustaining such legistation by Congress, see Jorthem Securities Co. r. U. S., 193 U. S. ]97; Swift $r$. U. S., 196 U. S. 375 , and the cases aited in these opinions.

The liberty to contract does not include the liberty to make contracts whin interfere with interstate commerce. Addystone Pipe, ete., Co. v. U. S., 175 L. S. $211,229$. 
clared: "Many State laws which limit the freedom of contract have been sustained by this court, and Chapter therefore an objection to this law on the general ground that it limits that freedom can not be upheld. There is no greater sanctity in the right to combine than in the right to make other contracts. Indeed, Mr. Dicey, in his recent work on Law and Public Opinion in England during the Nineteenth Century, indicates that it is out of the very right to make what contracts one chooses, so strenuously advocated by Bentham, that combinations have arisen which restrict the very freedom that Bentham sought to attain, and which even might menace the authority of the State. . . . Again, if an evil is specially experienced in a particular branch of business, the Constitution embodies no prohibition of laws confined to the evil, or doctrinaire requirement that they should be couched in all-embracing terms. It does not forbid the cautious advance, step by step, and the distrust of generalities, which sometimes have been the reakness, but often the strength, of English legislation." s

Legislation may create, upon equitable principles, Mechanics' liens in favor of those who work on property without infringing on the due process clause of the Constitution. Mechanies' lien laws rest on the natural equity that the payment for benefits accruing to property should be made a charge on that property. ${ }^{9}$ Provisions in such statutes extending the lien to sub-contractors, material-men, and laborers, who have no direct contract with the property owner,

8 Carroll $v$. Greenwich Ins. Co., 199 U. S. 401.

9 Provident Sav. Inst. $v$. Jersey City, 113 U. S. 506. 
Chapter have been the most frequent objects of attack. IX.

Where the sub-contractor's or laborer's lien was enforceable against the property directly, and not worked out through, and as subordinate to, the claim of the principal contractor, the provision has occasionally been held not to be due process of law, on the ground that it was an arbitrary interference witl freedom of contract, ${ }^{1}$ or that it deprived the owner of his property without his consent, and without allowing him a hearing. ${ }^{2}$ But sub-contractor's liens have generally been sustained against such objections; at least, when the rights of the property owner are guarded by provisions confining his liability, in the absence of fraud, to the amount due the original contractor, and the statute defines his rights so that he may protect himself from the danger of double parment. ${ }^{3}$

Ohio me.

A statute of Ohio giving sub-contractors, mateupheld. rialmen, etc., liens, upon filing notes within four months after the work done or materials furnished, for the artual value thereof, which, however, except in case of frand can not in the aggregate exceed the original contract price, was held valid by the United States Supreme Court, against the objection that it was an arbitrary interference with freedom of con-

${ }^{1}$ Palmer $r$. Tingle. 55 Ohin St. 423, disapproved in Great Southern Fire Proof Hotel Co. $v$. Tones, 193 U. S. 532, 30 C. C. A. 108. 8e Fed. Rep. 371.

2 Meper $r$. Tierlandi, 39 Minn. 438; John Spry Lumber Co $v$. Sault Sav. Bank, ste., Co., 77 Mich. 199.

3 See, among numerous authorities, Jones $r$. Great Southern Fire Proof Hotel Co., 58 C. S. App. 397. 86 Fed. Rep. 371, collecting and reviewing many eases: Smith $r$. Newhaur. 144 Ind. 95; Smalley $v$. Gearing, 121 Mich. 190; Henny, etc. Co. $v$. Evans, 97 Mo. 47 ; Title Guarantee, ete., Co. $x$. Wrenn, 35 Oregon 62. 
tract. The court adopted the conclusions of the Circuit Court of Appeals on this point, which were thus Chapter IX. summed up: "That the restraints put upon the owner by the provisions in faror of sub-contractors and those who furnished materials to be used by the contractor in execution of his contract with the owner were neither arbitrary nor oppressive; that such provisions were no more onerous than required by the necessity of protecting those who actually do the work or furnish the material by which the orner is benefited; and that, as the legislation in question was sanctioned by the dictates of natural justice, and, as must be conclusively presumed, was known to the owner when he contracted for the building of his house, its requirements could only be aroided by pointing out some specific part of the organic law which has been violated by its enactment.", 4

A statute forbidding the assignment of certain claims by citizens against citizens for the purpose of Assigning claims citizens. suit in another State has been upheld in a State court. ${ }^{5}$

All the cases noticed above, and their number might be increased indefinitely from the State reports, involve a conflict of interest, as viewed by Ouestions of rublic policy; ne. cessity of the legislative mind, between the relfare of the State as a whole and the untrammeled liberty of certain classes of the community. The question of the policy of the State in dealing with such conflicts is an exceedingly difficult one and requires the ap.

4 Great Southern Fire Proof Hotel Co. $v$. Jones, 193 U. S. 532, 549, approving 58 U. S. App. 397, 86 Fed. Rep. 371.

5 Sweeny $v$. Hunter, 145 Pa. St. 363. See also supra, p. 105. 
Chapter plication of broad principles of public policy and IX. economic theory to practical legislation. These principles are not yet so firmly settled that our courts may mark exactly the point at which State interference should in all cases cease and the freedom of the individual have unrestricted sway. The rapid development of modern industries bringing into play new forms of power from wealth and combination, and the increasing complexity of civilization have already rendered necessary restrictive legislation which would have seemed intolerable to a generation nurtured in the legislative theories of Bentham. Enlightened public opinion, as reflected by our legislatures and courts, has receded from the strict doctrine of laissez faire, and we can not say that a further abandonment of that position may not be adrisable. It is of the utmost importance, then, not to give to the broad and simple phrases employed by the Constitution in the enumeration of fundamental rights, so rigid an interpretation as will hamper the legislature in fashioning remedies for apparent evils and abuses. Or in the auxiety to preserve individual liberty in theory, the courts may sanction a state of practical oppression. In discussing the attitude of the United States Supreme Comrt toward State legislation, that court has said: "While the courts must exercise a judgment of their orn, it by no means is true that every law is void which may seem to the judges who pass upon it excessive, monited to its ostensible end, or based upon conceptions of morality with which ther disagree. Considerable latitude must be allowed for differences of view, as well as for possible peculiar 
conditions which this court can know but imperfectly, if at all. Otherwise, a constitution, instead of embodying only relatively fundamental rules of right, as generally understood by all English-speaking communities, would become the partisan of a particular set of ethical or economical opinions, which by no means are held semper ubique et $a b$ omnibus." 6

\section{Exaction of Licenses.}

Police regulation may take the form of licenses exacted as a condition precedent to entering into Regulation
of business by means
of licenses. any business. When the issuance of the license is dependent upon the payment of a license fee, the transaction approaches very close to an exercise of the power of taxation by the imposition of occupation taxes. A license fee may partake of both character's, so that its validity does not depend alone on the adjustment between the amount of the exaction and the expense of, or necessity for, police regulation. A municipal license tax of one hundred dollars upon the business of selling cigarettes has been held both within the police and the taxing power. "So long as the State law anthorizes both regulation and taxation it is enough, and the enforcement of the ordinance violates no provision of the Federal Constitution." 7

The distinction between a police license and an oceupation tax has been thus stated in a case wherein an exaction was held to belong to the latter class: "It is an occupation tax, for which the li-

6 Otis $v$. Parker, 187 U. S. 608.

7 Gundling $v$. Chicagn, 177 U. S. 183. See also Hodge $v$. Muscatine County, 196 U. S. 276. 
Chapter cense is merely a receipt, and not an authority, except $\mathrm{IX}$. in that sense, because it is laid and collected as revenue, and not merely as incident to the general police power of the State; which, under certain circumstances and conditions, regulates certain employments with a view to the public health, comfort and convenience. In the latter class of cases, the exactions may be either fees or fines, as they are proportioned to the expense of regulation, or laid as a burden upon and a discouragement to the business, and not taxes which are levied for the purpose of raising public revenue by means of a contribution either from the person or the property or the occupation of all citizens in like circumstances.", $\mathrm{s}$

License no waiver of further regulation.

Issuance by local board exercising reasonable discretion.
The right acquired by a license to pursue any rocation is almars subject to the exercise of the police porrer. Thus a license to follow the occupation of a druggist does not give the licensee a right to use spirituous liquors in the compounding of his drugs on the prescriptions of physicians, if the State requires, in regulating the sale of such liquors, that the druggist must have another license to engage in the sale from the board of county commissioners. ${ }^{9}$

Authority to grant licenses to vend commodities, whose purity is a proper subject of police regulation, may be rested in a local board acting in the honest exercise of a reasonable discretion, and when it is so rested one who is punished for failure to secure a license can not complain of a deprivation

8 Royall r. Virginia, 116 U. S. 572.

- Gray $r$. Connecticut, 159 U. S. 77. 
of due process of law within the Fourteenth Amendment. ${ }^{1}$

Police regulations may frequently be made universal, with the power committed to some board or officer to grant a dispensation from the observance of the regulation, or a license to do the act generally prohibited. The denial of the license in a particular case is not a depriration of due process of law under the Federal Constitution, even though the power is rested in a single indiridual. ${ }^{2}$ Some State courts have, however, taken a contrary view and held it to be contrary to the spirit of American institutions to vest such dispensing porrer in the hands of a single individual. ${ }^{3}$

COMMITTING LEGISLATIVE OR JUDICIAL FUNCTIONS TO EXECUTIVE.

The legislature may embody in an enactment a complete rule or standard of conduct with regard Direct
action or legislature. to the matter dealt with which leares open only the judicial question of the application of the law to the circumstances of the individual case. Thus in re-

$1 \mathrm{New}$ York $v$. Van De Carr, 199 U. S. 552, affirming $175 \mathrm{~N}$. Y. 440 .

2 Com. $v$. Daris, 162 Mass. 510, affirmed 167 U. S. 43; Wilson $v$. Eureka Citr. 173 U. S. 32 ; Fiseher $v$. St. Loulis, 194 U. S. 381, affirming 167 Mo. 654; Matter of Flaherty. 105 Cal. 558. And see Louisville, ete. R. Co. $r$. Kentuckr, 183 U. S. 503.

${ }^{3}$ Cases to this effect from Illinois. Chicago $r$. Trotter. $136 \mathrm{Ill}$. 430 ; Kansas, Anderson $r$. Wellington. 40 Kan. 173; Maryland, Baltimore $r$. Radecke, 49 Md. 217; Michigan. Matter of Frazee, 63 Mich. 396; Rhode Island, State $x$. Fiske, 9 R. I. 94; South Dakota, Sioux Falls $r$. Kirby, 6 S. Dak. 62, are cited in Wilson $v$. Eureka City, 173 U. S. 32, and Fischer $r$. St. Louis, 194 U. S. 361.

In California, Ex p. Sing Lee, 96 Cal. 354, and Missouri, St. Louis $v$. Russell, 116 Mo. 248, it is held that the power to grant dispensations cannot be rested in adjoining lot owners. 
Chapter gard to property, the legislature may prospectiveiy - IX. prohibit particular uses thereof, or enact that its existence under certain conditions is a menace to the rights of society. In other words, the existence or mlawful use of designated classes of property may be declared a nuisance. To the establishment of such a rule neither notice nor an opportunity to be heard on the part of the persons whose property is affected is essential. A direct exercise by the legislature of the police power is in accordance with immemorial governmental usage and constitutes in itself due process of law. ${ }^{4}$

Working out of gen. eral plan intrusted trative officials.
But the subject matter mas be such that only a general scheme of policy can with advantage be laid down by the legislature, and the working out in detail of the policy indicated may be left to the discretion of administrative or executive officials. Sometimes the discretionary duties so intrusted to administrative officials are under the terms of the statute to be performed without granting a hearing to those whose interests are affected. In such cases attacks have been made on the laws as unconstitutional delegations of power to the executive. Where the statute has indicated with all practical definiteness a general scheme of policy and a standard to be followed, leaving for the executive only details which it could not in the nature of things decide, such legislation has uniformly been upheld by the Federal Supreme Court.

In upholding the validity of tolls fixed for the use

4 Chicago, ete., R. Co. $v$. Nebraska, 170 U. S. 57 ; Mugler $v$. Kansas, 123 U. S. 623, 670, 672; State $v$. Griffin, 69 N. H. 1; Newark, etc., Horse Car R. Co. r. Hunt, 50 N. J. L. 308, 312; Health Dept. v. Trinity Church, 145 N. Y. 32. 
of an improved stream by a board appointed by the State for that purpose, the court said: "The legislature, acting upon information received, may prescribe at once the tolls to be charged; but, ordinaChapter IX. rily, it leaves their amount to be fixed by officer's or boards appointed for that purpose, who may previously inspect the works, and ascertain the probable anount of business which will be transacted by means of them, and thus be more likely to adjust wisely the rates of toll in conformity with that business. This subject, like a multitude of other matters, can be better regulated by them than by the legislature. In the administration of government, matter's of detail are usually placed under the direction of officials. The execution of general directions of the law is left, in a great degree, to their judgment and fidelity. Any other course rould be attended with infinite embarrassment. . . . No notice can be given to parties who may have occasion to use the stream, to attend before the board and present their views upon the tolls to be charged. Such parties can not be known in advance. The occasion for using the improved stream may arise at any time in the year; perhaps after the tolls have been established. The whole subject is one of administrative regulation, in which a certain amount of discretionary authority is necessarily confided to officers intrusted with its execution. Should there be any gross injustice in the rate of tolls fixed, it would not, in our system of government, remain long uncorrected."' 5 In a late case it was said: "While it is undoubtedly true that legislative power

- Sands v. Manistee River Imp. Co., 123 U. S. 288. 
Chapter can not be delegated to the courts or to the execuIX. tive, there are some exceptions to the rule. . . . In enacting a law with regard to the inspection of mines, we see no objection, in case the legislature find it impracticable to classify the mines for the purposes of inspection, to commit that power to a body of experts who are not only experienced in the operation of mines, but are acquainted with the details necessary to be known to make a reasonable classification, although it may affect the amount of fees to be paid by the mine owners." ${ }^{6}$ In this case by the statute the inspectors might regulate the charge for inspection, which might vary from six dollars to ten dollars, according to the class of the mine as determined by them, and they might determine the number of inspections "necessary and proper " during the year, a minimum of four being" required. It was contended that the discretion thus delegated to the inspectors violated the due process clanse of the Constitution, but the court held otherwise. While admitting that there might be much force in the suggestion, if the discretion was unlimited and if the fees were retained by the inspector, ret, as he received a fixed salary and paid orer the fees to the State, and as actually less than the four required inspections had been made in the average on the defendant's thirty-one mines, and there was no complaint of an abuse of the discretion, the statute was mpheld. Further

Classes of cases wherein the legislative department has committed to the executive the determination of questions of fact, involving to some extent

a Consolidated Coal Co. $v$. Illinois, 185 U. S. 203. 

judicial powers, and has even made the executive Chapter determination final, when within the authority conferred and free from frand or abuse, are found in the findings of the land department upon questions of fact; ${ }^{7}$ and in the decision by heads of departments of matters committed to them requiring the exercise of judgment and discretion, whether the decision involves questions of law or fact. ${ }^{\text {. }}$

Thus the rulings of the postmaster general as to the mailable character of matter offered to the mails ${ }^{9}$ and the right of the per'son addressed to rePostmasterrulings on questions ceive mail ${ }^{1}$ do not work a denial of due process of law, since if he exceeds his authority his action is reviewable in the courts.

An Act of Congress expressed the purpose to ex- Inspection clude from the country the lowest grades of tea, and left to the secretary of the treasury and a board of tea experts the duty of determining in detail uniform standards of teas with regard to purity, quality, and fitness for consumption. The standards so established were held to be legal and their determination not to involve a delegation of legislative power. The court said: "Congress legislated on the subject as far as was reasonably practicable, and from the necessities of the case was compelled to leave to executive officials the duty of bringing about the result pointed out by the statute. To

7 Burfenning $v$. Chicago, etc., R. Co., 163 U. S. 321, 323; Gardner $v$. Bonestell, 180 U. S. 362; Bates, etc., Co. $v$. Payne, 194 U. S. $106,108$.

8 Decatur $v$. Paulding, 14 Pet. (U. S.) 497; U. S. $v$. Hitchcock, 190 U. S. 324 ; Bates, etc.. Co. $r$. Payne, 194 U. S. 106, 108, 109.

9 Bates, etc., Co, $r$. Payne, 194 U. S. 106.

1 Public Clearing House $v$. Coyne, 194 U. S. 497. 
Chapter deny the power of Congress to delegate such a duty
IX.

Kentucky long and short haul enactment. would in effect amount but to declaring that the plenary power vested in Congress to regulate foreign commerce could not be efficaciously exerted." 2

The ruling of a State railroad commission made in accordance with law on the application of a carrier, denying to the carrier an exemption from the provisions of a "long and short haul" enactment, after an investigation of all the facts, may a fortiori be made final as to questions of fact. The commission under the State constitution was a regular constitutional tribunal or court emporrered to investigate judicial questions submitted within its jurisdiction, and "finality is a characteristic of the judgments of all tribunals, unless the laws provide for a review." 2 *

It has been held by a Federal Circuit Court that a statute committing both legislative and judicial duties to the same body was unconstitutional as denying to the persons subject to its rulings due process of law under the Fourteenth Amendment. ${ }^{3}$ But it seems difficult to reconcile this holding with later decisions of the T'nited States Supreme Court. ${ }^{*}$

\section{NOTICE AND HEARING.}

Application of legislative rule generally requires hearing.
When a regular rule or standard for the regulation of conduct or property has been framed, the application of the regulation to the circumstances of the individual involves a judicial question requiring the presence of that notice and hearing which in

2 Buttfield $r$. Stranahan, 192 U. S. $470,496$.

2* Lonisville, etc., R. Co. $r$. Kentucky, 183 U. S. 503, 515.

3 Western Union Tel. Co. $v$. Myatt, 98 Fed. Rep. 335, and see supra, p. 164.

$3^{*}$ See the cases just discussed and supra, p. 71 . 
such circumstances is necessary to constitute due Chapter process of law.

Due Process Does Not Require Jury, and May Be Executive.

Due process in this connection under the Federal Constitution does not require a jury trial. The Hearing dispensed with of jurisdiction of courts of equity to abate nuisances is of ancient origin and such an abatement satisfies the constitutional requirement. ${ }^{4}$ Nor under that constitution is a judicial proceeding necessary, ${ }^{5}$ however essential it may be under State constitutions. There are cases in the Federal Supreme Cour' which hold that hearing and notice is not always requisite even here. This is obviously the case where in view of the subject dealt with, the general rule framed must be of so uncertain a kind as to leave much to the discretion of administrative officers in applying it to particular cases. Such was the case stated above where inspector's were to inspect mines as often as was "necessary and proper," a minimum number of inspections being provided for. ${ }^{6}$ But the same court has gone further and sanctioned, in the case upholding the law

4 Mugler $v$. Kansas, 123 U. S. 672, 673.

Expressions of some State courts indicate that under the Stato constitution a jury trial is essential to due process. Dunn $v$. Burleigh, 62 Me. 24 ; Sterling $v$. Littlefield, 97 Me. 479.

5 Simon $v$. Craft, 182 U. S. 436 ; Reetz $v$. Michigan, $188 \mathrm{U} . \mathrm{S}$. 505, 507. See also supra, pl. 80, 163.

Due process is present when a statute, valid in substance, is administered by a competent tribunal in the established method, the defendant being present. New York, etc., R. Co. $v$. New York, 165 U. S. 628 .

6 See supra, p. 368. 
Chapter for tea inspection, an inspection admittedly without IX. any provision for a hearing, whereby tea was graded below the standard required for entrance, and, as a result, was ordered deported. The proceedings were held to work no denial of due process of law. The court said: "The provisions in respect to - . the examination of samples by government experts was for the purpose of determining whether the conditions existed which conferred the right to import, and they, therefore, in no just sense concerned a taking of property. This latter question was intended by Congress to be finally settled, not by a judicial proceeding, but by the action of the agents of the government, upon whom power on the subject was conferred." '7

Necessity. may modify require. ment of notice and hearing.
Necessity, not to dispense with altogether, but to postpone hearing, may exist in the case of the de-

i Buttfield $v$. Stranahan, 192 U. S. 470, 497. The opinion on this point is not entirely clear. If it is meant to hold that Congress in its plenary power over imports may, on the ground that no rights of property attach until the goods are imported, exclude them without a hearing, it goes further than the two most analogous lines of cases. These are those which concern the exclusion of aliens and the appraisal of the value of imports. But each of these classes of ases proceeds ostensibly on the theory that provision is made for a reasonable bearing in accordance with the equitable principle of due process of law. See supra, pp. 190, 242.

As the determination of the quality of the teas is the point upon which hearing was claimed, and the act carefully guards the interests of the importers in the selection of the samples for examination, and, in the event that the importer is dissatisfied with the examination, provision is made for re-examination before a board composed of three ceneral appraisers, whose conclusion should be "after due examination," it might well have been held that due process was providerl by the law. What was "dne examination" by the re-examining board, would, of course, have heen letermined with regard to the eximencies of the government; lut it might have been held to include some restricted right of hearing, as in the case of the appraisal of the value of imports. 
struction of houses in the path of a conflagration or of infected articles or animals. Delay, before the destruction of the property condemned, for the purpose of giving notice, and it may be to ascertain who are the parties whose interests will be affected, and further delay for such hearing as the parties may think necessary for the protection of their interests, might defeat all beneficial results from the contemplated action. ${ }^{8}$ Haring regard to the necessities of this class of cases then, and adjusting the requirements of notice and hearing to it, it is held that local authorities may, when the necessities of the case justify this action, proceed to condemn property and destroy it as a nuisance in advance of notice or a hearing. But the property owner has a right to have a judicial determination of the validity of the regulation and the existence of the nuisance upon a review of the matter in the courts. The $e x$ parte determination of the local authorities can not be made conclusive. ${ }^{9}$

When authority is given to municipal legislative boards or local officials to regulate the use of property and to abate as nuisances infractions of their Exercise of authority depends on tional fact. regulations, they are, according to most authorities, said to be vested with a quasi-judicial or judicial authority, the valid exercise of which depends as a jurisdictional fact on the actual existence of the nuisance. Their authority is to declare a nuisance where the facts warrant it, and not to determine that the lawful possession of inoffensive property is a

8 Salem $v$. Eastern R. Co., 98 Mass. 431, 96 Am. Dec. 650; People v. Board of Health, 140 N. Y. 1, 37 Am. St. Rep. 522.

9 Stone $v$. Heath, 179 Mass. 385; Daniels $v$. Homer, 139 N. Car. 219 ; and citations to last note supra. 
Chapter nuisance. This leaves open a judicial inquiry to which hearing is a necessary requisite. ${ }^{1}$ In abating a nuisance under such an order, local boards or officers act at their peril, and if it is proved that they have overstepped the bounds of reasonable police action, the order will be no protection to them. When they are in doubt whether the order is within their authority, they may always have the matter determined in advance by the courts in a proceeding to restrain or abate the nuisance. ${ }^{2}$ But they need not do so, and the exigencies of the situation may justify immediate action.

1 Pearson $v$. Zehr, 138 Ill. 48; Loesch $v$. Koehler, 144 Ind. 278; Miller $v$. Horton, 152 Mass. 540; Hutton $v$. Camden, 39 N. J. L. 122; Underwood $v$. Green, 42 N. Y. 140; People $v$. Board of Health, 140 N. Y. 1 ; Dillon, Munic. Corp., 4th ed. $\S 374$. See also Yates $v$. Milwaukee, 10 Wall. (U. S.) 497.

Perhaps the matter might be stated in this way:

The legislative powers of municipalities are such only as are expressly conferred by the legislature, and a condition of their valid exercise is that ordinances passed must be in harmony with the general law of the State. This question of the conformity of the ordinance with the general law raises a judicial question, for the determination of which, notice and hearing are necessary. But this should not imply that notice and hearing are necessary of the action of the munieipal authorities in considering and framing the general regulation; for if they act within their delegated legislative power, their action is legislative and is due process without notice. Chicago, etc., R. Co. $v$. Nebraska, 170 U. S. 57 ; People $v$. Board of Health, 140 N. Y. 1. When the local legislative body act in the case of the property of a particular individual and declare it to be a nuisance, it seems that they are in so doing still exercising legislative powers, although the rule they frame is confined to a single individual, and the property owner can not complain of want of prior notice and an opportunity to oppose the action taken. But he still has a right in the courts to test the legality of the action.

2 In People $r$. Board of Health, 140 N. Y. 1, it is said: "The nuisance actually existing, and the jurisdiction having been regularly exercised, the order or ordinance has all the operation and effect provided in the act, and the persons who abate the nuisance have the protection which they would not have as private persons 


\section{Right to Destroy Before IIearing Limited by Necessity.}

The right to destroy property in advance of a hearing is limited to cases of necessity. The necesexists. sity is apparent where the property in its existing condition constitutes a continuing menace to the health or property of the community, as in the instances just mentioned, of infected clothing, diseased animals, or houses in the path of a conflagration. But necessity has been held to arise in other cases, thougl a necessity which sprung from different consideration and rested on different grounds. Thus the effective administration of a penal statute has been held to justify summary confiscation of property of small value, while it was clearly intimated that such considerations would not justify destruction in advance of hearing in the case of valuable property. ${ }^{3}$ But it is to be observed that its trifling amount is dealt with, not as putting the property beyond constitutional protection, but as a consideration which the legislature might properly have in mind in providing for the enforcement of

abating, not a private nuisance especially injurious to them, but a public nuisance injurious to the general public. It may be said that if the determination of a board of health as to a nuisance be not final and conclusive, then the members of the board, and all persons acting under their authority in abating the alleged nuisance, act at their peril; and so they do, and no other view of the law would give adequate protection to private rights. They should not destroy property as a nuisance unless they know it to be such, and if there be doubt whether it be a nuisance or not, the board should proceed by action to restrain or abate the nuisance, and thus have the protection of a judgment for what it may do."

3 Lawton $v$. Steele, 152 U. S. 133, affirming 119 N. Y. 226; Bit- 
Chapter the act. The object to be attained, and the effectiveness of the means adopted (although this may depend on the value of the property confiscated) are the real considerations, and not the value of the property as a matter in itself.

Destroying fish nets in advance of
hearing.

The Federal Supreme Court, in sustaining an act allowing the destruction of fish nets by a game warden, said: "The value of the nets in question was but fifteen dollars apiece. The cost of condemning one (and the use of one is as illegal as the use of a dozen) by judicial proceedings would largely exceed the value of the net, and doubtless the State rould, in many cases, be deterred from executing the lam by the expense. They could only be remored from the water with difficulty and were liable to injury in the process of removal. The object of the law is, undoubtedly, a beneficent one, and the State ought not to be hampered in its enforcement by the application of constitutional prorisions which are intended for the protection of substantial rights of property. It is evident that the efficacy of this statute would be very seriously impaired by requiring every net illegally used to be carefully taken from the water, carried before a court or magistrate, notice of the seizure to be given by publication, and regular judicial proceedings to be instituted for its condemnation." It may be added that the amount at risk in such a case being trifling could not be supposed to act as a deterrent on the offender, while in the case of property of considerable value, the confiscation in itself rould be tenhaus $v$. Johnston, 92 Wis. 588; Daniels $v$. Homer, 139 N. Car. 219. 
the thing dreaded and the necessity for summary measures, existing in the actual case to give effectiveness to the law, would not arise. ${ }^{4}$

Some of the State courts have held, however, that Chapter IX. a right to destroy property on the ground of nuisance does not exist until some sort of judicial determination, though property may be seized and held till judicial proceedings can be instituted to try the right to have it forfeited. ${ }^{5}$ These holdings are rested on the ground that forfeiture is necessarily a penal provision and can be inflicted only after hearing. Such laws are upheld, howerer, on the ground, not of the abrogation of notice, but that necessity requires its postponement. The necessity must exist and its existence is to be determined in view of all the facts. No sufficient necessity has been held to exist for the slaughter without prior notice or hearing of neglected or abandoned animals, and a statute empowering certain officials to proceed in this way has been held uneonstitutional. ${ }^{6}$ Nor is the seizure and sale of ships in the absence

4 Lawton $v$. Steele, 152 U. S. 133, 141. This decision has been condemned by some authorities. Thus Professor Freund declares that the right to forfeit property "is not an exercise of the police power, but of the judicial power," and requires judicial proceedings, with notice in personam or in rem. And he remarks on the argument that the small value of the property justified the forfeiture that "the trifling value of the property taken and the disproportionate cost of condemnation proceedings is an inadmissible argument when constitutional rights are involved." Freund, Police Power, 525 et seq.

5 Dunn $v$. Burleigh, 62 Me. 24; King $v$. Hayes, 80 Me. 206; Edson $v$. Crangle, 62 Ohio St. 49 (a case essentially similar to Lawton $v$. Steele, $152 \mathrm{U}$. S. 133, which the court did not follow, although it was fully argued before them).

${ }^{6}$ Loesch $v$. Koehler, 144 Ind. 278. 
Chapter of prior notice and hearing a reasonable exercise of police power. ${ }^{7}$

The legislature acting directly may establish by rates. general laws a scale of rates, provided they are reasonable, for the use of businesses affected with a public interest, ${ }^{s}$ but where the establishment of rates is delegated to administrative officials (such as a State railroad commission not "clothed with judicial functions or possessing the machinery of a court of justice"') the question of reasonableness is a judicial one, and any rates established, however reasonable they may be, are void in the absence of notice and hearing. ${ }^{9}$ There notice and hearing is required, a general statute or constitutional provision, as in the case of general taxes, fixing the time of the meeting of administrative or local officers to pass upon the question of rates, is sufficient notice. ${ }^{1}$

¿ Colon $r$. T.isk, 153 X. Y. 183.

s liukd $r$. New York. 143 C. S. 517, affirming 117 N. Y. 1, 5 L. R. A. 366 . The reasonableness of the rates so established may be questioned in an action brought against the company to recover a penalty for violating them. St. Lonis, ete., R. Co. $\iota$. Gill, $156 \mathrm{U}$. S. 649 .

9 Chicago, ete. R. Co. $r$. Minnesota, 134 U. S. 418, reversing 33 Minn. 2ul. Ser San Diewo Water Co. $v$. San Diego, 118 Cal. 556, 38 L. R. A. 460.

i San Diego Land Co. $v$. National City, 174 U. S. 739, 752. 


\section{TABLE OF CASES CITED.}

A.

PAGE

Abbott $v$. Tacoma Bank of Commerce, 175 C. S. $409 \ldots \ldots \ldots \ldots 161$ Adams $v$. New York, 192 U. S. $585 \ldots \ldots \ldots 34,58,64,180,181,188$ Adans $v$. Shelbyville, 154 U. S. $473 \ldots \ldots \ldots \ldots \ldots \ldots \ldots 251$

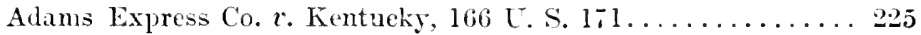
Adams Express Co. v. Ohio State Auditor, 165 U. S. 194, 166 U.

S. $185 \ldots \ldots \ldots \ldots \ldots \ldots \ldots \ldots \ldots \ldots \ldots \ldots \ldots \ldots \ldots \ldots \ldots \ldots \ldots \ldots \ldots \ldots \ldots \ldots \ldots . .225$

Addystone Pipe, etc., Co. $x$. U. S., 175 U. S. $211,229 . \ldots \ldots \ldots 358$ Adirondack R. Co. $v$. New York. 176 U. S. 335........ 291, 299

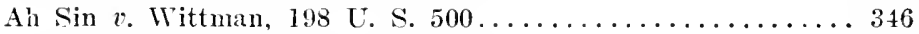

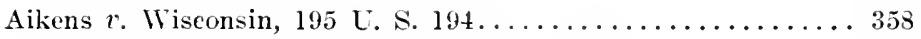
Albany st.. Matter of, 11 Wend. (N. Y.) $149 \ldots \ldots \ldots \ldots \ldots 276$ Alexander, 'The, 60 Fed. Rep. $914 \ldots \ldots \ldots \ldots \ldots \ldots \ldots \ldots \ldots \ldots$ Allen $v$. Armstrong, 16 Iowa $513 \ldots \ldots \ldots \ldots \ldots \ldots \ldots \ldots \ldots \ldots$ Allen $r$. Georgia, 166 U. S. $138 \ldots \ldots \ldots \ldots \ldots \ldots \ldots, 167,168$ Allen $v$. Pullman's Palace Car Co., 191 U. S. $171 \ldots \ldots \ldots \ldots 217$ Allentown $v$. Henry, 73 Pa. St. $404 \ldots \ldots \ldots \ldots \ldots \ldots \ldots \ldots 212$ Allgeyer $v$. Louisiana, $165 \mathrm{U}$. S. $578 \ldots \ldots \ldots \ldots \ldots 140,304,352$

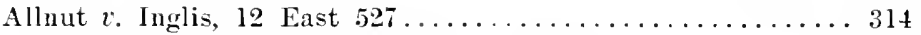
American Express Co. v. Indiana, 165 U. S. $255 \ldots \ldots \ldots \ldots \ldots \ldots .225$ Ameriean Pub. Co. $v$. Fisher, 166 U. S. $464 \ldots \ldots \ldots \ldots \ldots 163,200$ Ameriean Refrigerator Transit Co. $r$. Hall, 174 U. S. 70...220, 225 Ames $r$. Union Pae. R. Co., 64 Fed. Rep. 165.......... 322, 323 Anderson $v$. Kerns Drainage Co., 14 Ind. $199 \ldots \ldots \ldots \ldots \ldots \ldots .259$

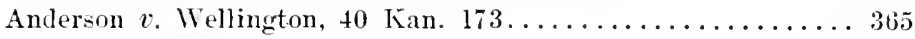
Andrews $r$. Andrews, 188 U. S. $14 \ldots \ldots \ldots \ldots \ldots \ldots$. 122,124

Andrews $v$. Swartz, 156 U. S. $272 \ldots \ldots \ldots \ldots \ldots \ldots \ldots \ldots$ Ann, The. 5 Hnghes (U. S.) $292 \ldots \ldots \ldots \ldots \ldots \ldots \ldots \ldots \ldots \ldots 11$ Antoni $v$. Greenhow, 107 U. S. $769 \ldots \ldots \ldots \ldots \ldots \ldots \ldots \ldots \ldots$ Apex Transp. Co. $v$. Garbade, 32 Oregon $582 \ldots \ldots \ldots \ldots \ldots \ldots 270$ Areher $v$. Jimmes, 2 B. \& S. 82,110 E. C. L. $82 \ldots \ldots \ldots \ldots \ldots . .354$ Ark Foo $v$. U. S., 128 Fed. Rep. $697 \ldots \ldots \ldots \ldots \ldots \ldots \ldots \ldots \ldots$ Armstrong $v$. U. S., 182 U. S. $243 \ldots \ldots \ldots \ldots \ldots \ldots \ldots \ldots \ldots 197$ Arndt $v$. Griggs, 134 U. S. $316 \ldots \ldots \ldots \ldots \ldots \ldots \ldots \ldots \ldots, 239$ Arnold $v$. Covington, etc., Bridge Co., 1 Duval (Ky.) 372 . . . 25s Arrowsmith $v$. Harmoning, 118 U. S. $194 \ldots \ldots \ldots \ldots \ldots \ldots . \ldots 1$ Ashford $v$. Thornton, 1 B. \& Ald. $405 \ldots \ldots \ldots \ldots \ldots \ldots \ldots \ldots 25$ 
PAGE

Assessors v. Comptoir d'Escompte, 191 U. S. 381.......120, 222 Atchison, etc., R. Co. 2 . Natthews, 174 U. S. $96 \ldots \ldots \ldots \ldots .351$ Atherton $v$. Atherton, 181 U. S. $155 . \ldots .92,122,123,125,127,129$ Atlantic, te., R. Co. $v$. l'emny, 119 Ga. $479 \ldots \ldots \ldots .276,298,299$ Atlantic, etc., 'Tel. Co. v. l'hiladelphia, 190 U. S. $160 \ldots \ldots \ldots 217$ Atty-Gen. v. Jochim, 99 Mieh. $358 \ldots \ldots \ldots \ldots \ldots \ldots \ldots \ldots \ldots$ Atty-cien. v. lowrey, 199 [.. S. 233.............213, 333 Attg-tien. $r$. Willianss, 174 Mass. $476 \ldots \ldots \ldots \ldots \ldots \ldots \ldots \ldots 2$

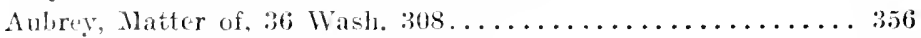
Auditur $v$. Railroad Co., 4 Kan. $500 \ldots \ldots \ldots \ldots \ldots \ldots \ldots \ldots 164$ Aufromalt $r$ lledlen, 137 [. \$. $310 \ldots \ldots \ldots \ldots \ldots \ldots \ldots \ldots 242$ Augusta liank $r$. Earle, 13 let. (U. S.) $519 \ldots \ldots \ldots \ldots \ldots \ldots 101$ Avent-ieatlyville conl ('o., $96 \mathrm{Ky} .218 \ldots \ldots \ldots \ldots \ldots \ldots \ldots \ldots 356$ Avery $r$. Vermont Electric $C^{\circ} 0 ., 75$ Vt. $235 \ldots \ldots \ldots \ldots \ldots \ldots . \ldots 264$

B.

Lackus $r$. Furt St. Union Depot Co., 169 U. S. $557 \ldots \ldots \ldots \ldots$ $\ldots \ldots \ldots \ldots \ldots \ldots \ldots \ldots \ldots \ldots \ldots \ldots \ldots, 160,275,282,290,291,299$

Bacon $v$. llooker, 17 Mass. 335................. 120

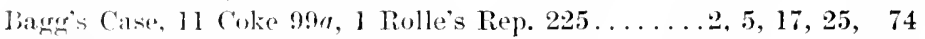
balley r. Jhiladelphia, ete., R. Co., 4 Harr. (Del.) $389 \ldots \ldots \ldots 143$ biker $x$. Norworl, it foel. Rep. $997 \ldots \ldots \ldots \ldots \ldots \ldots \ldots . . \ldots 249$

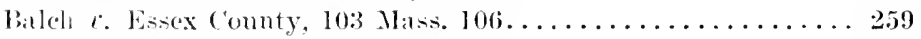
Baldwin $r$. 1late. 1 Wall. (L. S.) $223 \ldots \ldots \ldots \ldots \ldots \ldots \ldots 130,132$ Baltimore $r$. Raderke, 49 Ml. $217 \ldots \ldots \ldots \ldots \ldots \ldots \ldots \ldots \ldots . \ldots \ldots 5$ Baltimore, etc.. R. Co. r. IJarris, 12 Wall. (U. S.) (65....102, 105 Baltimore, ete., R. Co. $r$. Nebut, 10 How. (U. S.) $395 \ldots \ldots \ldots 155$ Baltimore, ete., R. Co. v. Pitslurgh, ete., R. Co., 17 W. Va. 812.298 lialtimore Traction Co. $v$. lielt R. Co., 151 U. S. $138 \ldots \ldots \ldots .38$ baunhaugh $r$. bambaugh, 11 S. \& R. (Pa.) $191 \ldots \ldots \ldots \ldots \ldots 158$

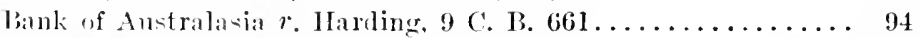
Barber $v$. Barlier, 21 llow. (L. S.) $582 \ldots \ldots \ldots \ldots \ldots 122,123,126$ liarbice r. ('omolly, 113 U. .. $27 \ldots \ldots \ldots \ldots \ldots \ldots \ldots 300,305,313$

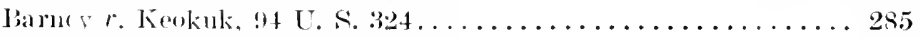

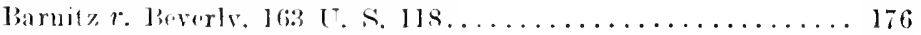
larrett $r$ liarrett, 120 X. ('ar. $127 \ldots \ldots \ldots \ldots \ldots \ldots \ldots \ldots \ldots 158$

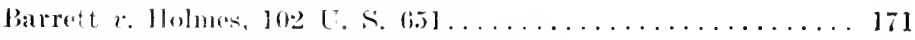

Barron $r$. Baltimore, 7 Pet. (IT. S.) $243 \ldots \ldots \ldots \ldots \ldots \ldots \ldots \ldots$ Barrow Steamship Co. $v$ Kane. 170 U. S. 100.....95, 102, 105, 189 Barton $r$. Norris, 15 ()hio $40 . \ldots \ldots \ldots \ldots \ldots \ldots \ldots \ldots \ldots . \ldots \ldots$ Bilss $r$. Romoke Nav.. ete. ('o.. 111 N. Car. $439 \ldots \ldots \ldots \ldots \ldots 157$ Bates, ete. Co. r. layne. 194 U. S. $106 \ldots \ldots \ldots \ldots \ldots \ldots \ldots \ldots . \ldots 363$ Battle, ete., R. Co. v. Montana Union R. Co., 16 Mont. 504... . . 273 Bauman $v$. Ross, 167 U. S. 548........247, 248, 289, 290, 299 
PAGE

Beall $v$. New Mexico, 16 Wall. (U. S.) $535 \ldots \ldots \ldots \ldots \ldots \ldots$

Bedford $v$. U. S., 192 U. S. $217 \ldots \ldots \ldots \ldots \ldots \ldots \ldots \ldots \ldots \ldots$

Bcekman v. Saratoga, ete., R. Co., 3 Paige Ch. (N. X.) $45 \ldots 254,257$

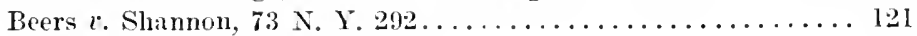

Bell $v$. Bell, 181 U. S. $175 \ldots \ldots \ldots \ldots \ldots \ldots \ldots \ldots \ldots \ldots$ 1.2

Bellingham Bay, etc., R. Co. $v$. New Whateom, 172 U. S. 318.

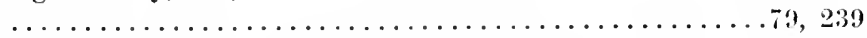

Bell's Gap R. Co. v. Pennsylvania, 134 U. S. 232. . .60, 211, 237, 239

Bergemann $v$. Baeker, 157 U. S. 655..............40, 168

Bertholf $r$. O'Reilly, 74 N. Y. $509 \ldots \ldots \ldots \ldots \ldots \ldots \ldots \ldots, 343$

Bessette $r$. People, 193 Ill. $334 \ldots \ldots \ldots \ldots \ldots \ldots \ldots \ldots \ldots \ldots . \ldots \ldots$

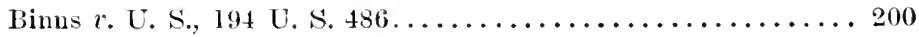

Bittenhaus $v$. Johnston, 92 Wis. $585 \ldots \ldots \ldots \ldots \ldots \ldots \ldots \ldots 376$

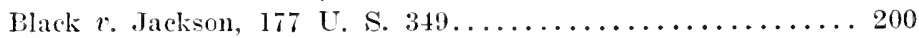

Black $v$. Zacharie, 3 How. (U. S.) $514 \ldots \ldots \ldots \ldots \ldots \ldots \ldots 18$

Blackstone $v$. Niller, 185 C. S. $189 \ldots \ldots \ldots \ldots \ldots 19,120,222,223$

Blake $v$. MeClung, 172 U. S. $239 \ldots \ldots \ldots \ldots \ldots \ldots 9,101,102,190$

Bloodgood $v$. Mohawk, ete., R. Co., 18 Wend. (N. Y.) $9 \ldots \ldots \ldots 263$

Bloomfield, ete., Natural Gas Light Co. $v$. Richardson, 63 Barb.

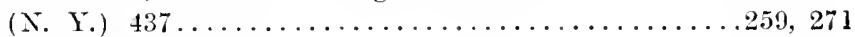

Board of Health $r$. Van Hoesen, s7 Mich. 533........262, 265

Board of Public Works $v$. Columbia College, 17 Wall. (U. S.)

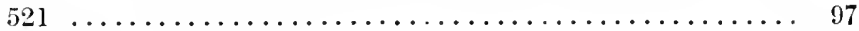

Boggs $r$. Com., to Va. $989 \ldots \ldots \ldots \ldots \ldots \ldots \ldots \ldots \ldots \ldots \ldots$, 85

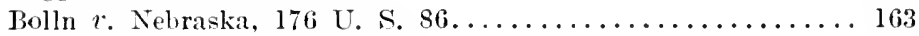

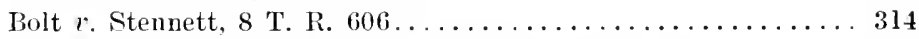

Bonaker $r$. Evans, 16 Q. B. 162, 71 E. C. L. $162 \ldots \ldots \ldots \ldots \ldots$, 75

Bonaparte $r$. Camden, etc., R. Co., Baldw. (U. S.) 205...... 257

Bonham's Case, 8 Coke 115, 118a...........26, 29, 58

Bonnemort $r$. Gill, 167 Mass. $338 \ldots \ldots \ldots \ldots \ldots \ldots \ldots \ldots \ldots$

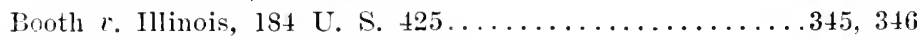

Bonth $r$. Woodburs, 32 Conn. 128...............232

Boston Beer Co. $v$. Massaehusetts, 97 U. S. $26 \ldots \ldots \ldots \ldots . \ldots 304,336$

Boston. etc., R. Co. $v$. Salem, cte., R. Co., 2 Gray (Mass.) 1... 283

Boswell r. Otis, 9 How. (U. S.) $336 \ldots \ldots \ldots \ldots \ldots \ldots s 7,89,112$

Bottoms $v$. Brewer, 58 Ala. $288 \ldots \ldots \ldots \ldots \ldots \ldots \ldots \ldots \ldots . \ldots \ldots 4$

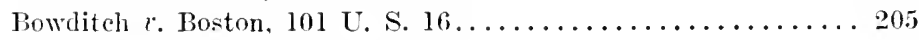

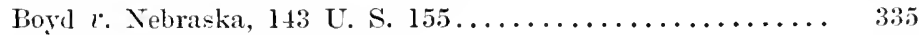

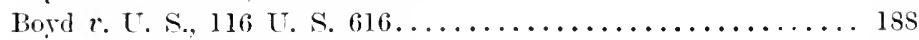

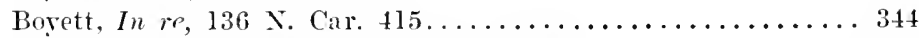

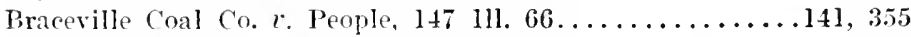

Bradley, E.x p., 7 Wall. (U. S.) $523 \ldots \ldots \ldots \ldots \ldots \ldots \ldots \ldots 171$

Bradley $r$. Fallbrook Irrigation Dist., 68 Fed. Rep. 948. . . . . 243

Bradley $r$. Fisher, 13 WaIl. (U. S.) $335 \ldots \ldots \ldots \ldots \ldots \ldots 17$

Bradley $v$. Lighteap, $195 \mathrm{U}$. S. $1 \ldots \ldots \ldots \ldots \ldots \ldots \ldots \ldots \ldots$ 
Bradshaw $v$. Rogers, 20 Johns. (N. Y.) $103 \ldots \ldots \ldots \ldots \ldots \ldots 28$ Bradstreet $v$. Neptune Ins. Co., 3 Sumn. (U. S.) 600...76, 85, 111

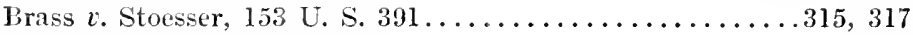

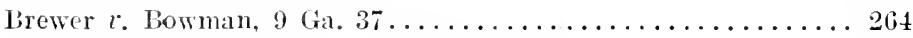
Brewster v. J. J. Rogers Co., 169 N. Y. 73............ 258 Bridal Veil Lumbering Co. $v$. Johnson, 30 Oregon $205 \ldots \ldots \ldots 275$ Bridge Co. $v$. U. S.. 105 U. S. $470 \ldots \ldots \ldots \ldots \ldots \ldots \ldots \ldots$ ass Trinton $x$ Seevers, 12 Iowa $389 \ldots \ldots \ldots \ldots \ldots \ldots \ldots \ldots \ldots \ldots$ Bristol v. Washington County, 177 U. S. $133 \ldots \ldots \ldots \ldots \ldots .222$ British Cast Plate Manufacturers $v$. Meredith, 4 T. R. 794... 205 Pronsm $r$ Kinzie, 1 How. (U. S.) $311 \ldots \ldots \ldots \ldots \ldots \ldots 175,176$ Brooklyn City R. Co. $r$. Tax Com'rs, 199 U. S. $48 \ldots \ldots \ldots .227,246$ Brooks $v$. Dun, 51 Fed. Rep. $158 \ldots \ldots \ldots \ldots \ldots \ldots \ldots \ldots \ldots . \ldots \ldots$ Brown $t$. Houston, 114 U. S. $622 \ldots \ldots \ldots \ldots \ldots \ldots \ldots \ldots \ldots . \ldots 220$

Prown $r$. Lee Com'rs, 50 Miss. $468 \ldots \ldots \ldots \ldots \ldots \ldots \ldots \ldots \ldots 56$ brown r. Narpland. 12 Wheat. (U. S.) $419 \ldots \ldots \ldots \ldots \ldots \ldots 20$

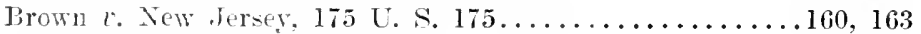
Brown $x$. Smart. 69 Md. 331, 145 U. S. 454...........131, 133

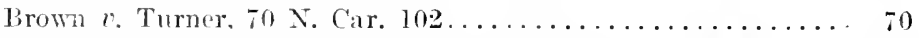
Brunswick Gin light Co. r. United Gas, etc., Co., 85 Me. 532 . . 259 Buckingham $r$. Smith, 10 Ohio $296 \ldots \ldots \ldots \ldots \ldots \ldots \ldots . \ldots \ldots$ Burd r. New Tork. 1t3 C. S. 517.........315, 316, 320, 378

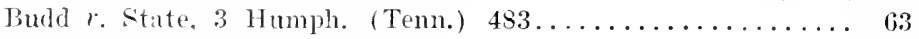
Burden $r$ Stein, 27 Ala. $104 \ldots \ldots \ldots \ldots \ldots \ldots \ldots \ldots \ldots \ldots \ldots \ldots$ Burfeming $r$. Clicago, etc., R. Co., 163 U. S. $321 \ldots . . \ldots \ldots . .369$ Burlington $r$. Bealsley, L. S. $310 \ldots \ldots \ldots \ldots \ldots \ldots \ldots \ldots \ldots \ldots$

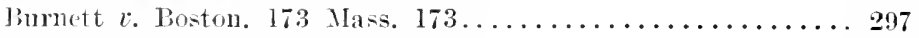
Burnett $r$. Sacramento, 1. Cal. $76 \ldots \ldots \ldots \ldots \ldots \ldots \ldots \ldots 283$ Burr, Ex p.. Wheat. (L.S.) 529, 2 Cranch (C. C.) $379 \ldots \ldots \ldots 171$ Butcher's Union, etc. Co. r. Crescent City Live Stock Landing, etc., Co., 111 [. S. $746 \ldots \ldots \ldots \ldots \ldots \ldots \ldots \ldots 135.304,347$ Entler r. Penusylrania, 10 Irow. (U. S.) $402 \ldots \ldots \ldots$. . . 2. 333, 334 livtte. ete., R. Co. r. Montana Union, etc., R. Co., 16 Mont. 504. .

$277,27 \mathrm{~s}$

Buttfield $v$. Stranahan, 192 U. S. $470 \ldots \ldots \ldots \ldots \ldots 496,370,372$

\section{C.}

Cady $r$. Associatel Colonies, 119 Fed. Rep. 420........101, 103 Calder $r$ Bnll, 3 Dall. (U. S.) $386 \ldots \ldots \ldots \ldots \ldots 143,145,146,147$ Caldwell v. Texas, 137 U. S. $692 \ldots \ldots \ldots .38,52,80,163,167,168$ California Reduction Co. $\iota$. Sanitary Reduction Works, 199 U. S. $306 \ldots \ldots \ldots \ldots \ldots \ldots \ldots \ldots 2,303,305,308,309,337,339$

Callan $r$ Wilson, 127 T. S. $540 \ldots \ldots \ldots \ldots \ldots \ldots \ldots \ldots \ldots$ Callanan $r$. Hurley, 93 U. S. $357 \ldots \ldots \ldots \ldots \ldots \ldots \ldots \ldots \ldots$ 
PAGE

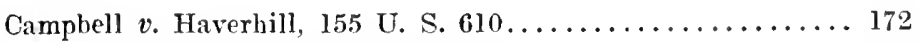

Campbell v. Holt, 115 U. S. $620 \ldots \ldots \ldots \ldots \ldots \ldots \ldots \ldots \ldots \ldots \ldots$

Canada Southern R. Co. $v$. International Bridge Co., 8 App. Cas.

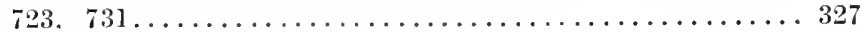

Capel r. Child, 2 Cromp. \& J. 558................ 75

Capital City Dairy Co. v. Ohio, 183 U. S. $238 \ldots \ldots \ldots \ldots \ldots \ldots 349$

Capital Traction Co. v. Hof, $17 \pm$ T. S. $1 \ldots \ldots \ldots \ldots \ldots \ldots 200$

Carroll $v$. Greenwich Ins. Co., 199 U. S. 401...........351, 359

Carstairs $v$. Cochran, 193 U. S. $10 \ldots \ldots \ldots \ldots \ldots \ldots \ldots \ldots \ldots$

Cary Library $v$. Bliss, 151 Mass. $364 \ldots \ldots \ldots \ldots \ldots \ldots \ldots \ldots 283$

Cass Farm Co. $v$. Detroit, 181 U. S. $396 \ldots \ldots \ldots \ldots \ldots 251,252$

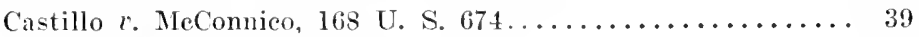

Castrique r. Imrie, L. R. 4 H. L. $414 \ldots \ldots \ldots \ldots \ldots \ldots \ldots \ldots \ldots 9$

Cecil $v$. Green, 161 Ill. 265.................... 317

Central Bridge Corp. v. Lowell, 4 Gray (Mass.) $482 \ldots . . \ldots .255$

Central Land Co. $r$. Laidles, 150 U. S. $103 \ldots \ldots \ldots \ldots \ldots \ldots 40$

Central Union Telephone Co. $v$. State, 118 lnd. 194........ 317

Chadwick $v$. Kelley, 187 U. S. $540 \ldots \ldots \ldots \ldots \ldots \ldots \ldots \ldots 247$

Chae Chan Ping $v$. U. S., 130 U. S. $581 \ldots \ldots \ldots \ldots \ldots \ldots \ldots 190$

Chappell $\imath$. U. S., 160 U. S. $499 \ldots \ldots \ldots \ldots \ldots \ldots \ldots \ldots \ldots . \ldots 257$

Charles River Bridge $v$. Warren Bridge, 11 Pet. (U. S.) $420 \ldots 151$

Charleston Natural Gas Co. v. Lowe, 52 W. Va. 662....... 317

Charlotte, ete., R. Co. v. Gibbes, 142 U. S. $586 \ldots \ldots \ldots \ldots \ldots . \ldots 340$

Cheely $v$. Clayton, 110 U. S. $701 \ldots \ldots \ldots \ldots \ldots \ldots \ldots \ldots$

Cheever $r$. Wilson, 9 Wall. (U. S.) $108 \ldots \ldots \ldots \ldots \ldots \ldots 123,126$

Cherokee Nation $v$. Southern Kansas R. Co., 135 U. S. 641...

Chesapeake, etc., Canal Co. v. Ǩes, 3 Cranch (C. C.) $599 \ldots . . . .257$

Chesapeake, etc., Telephone Co. $v$. Baltimore, etc., Tel. Co., 66

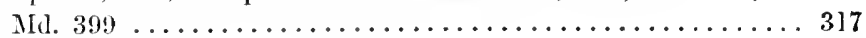

Chestnut $v$. Shane, 16 Ohio $599 \ldots \ldots \ldots \ldots \ldots \ldots \ldots \ldots \ldots$

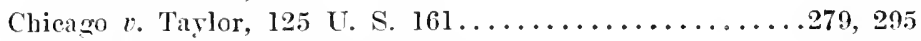

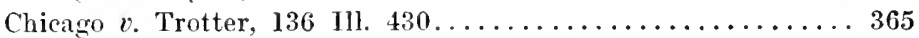

Chicago, etc., R. Co. $v$. Ackley, 94 U. S. $179 \ldots \ldots \ldots \ldots \ldots . \ldots 318$

Chicago, ete., R. Co. $v$. Chicago, 166 U. S. $226 \ldots \ldots \ldots \ldots \ldots$

. 1, 26, 28, 30, 33, 58, 68, 280, 282

Chicago, etc., R. Co. $v$. Dey, 35 Fed. Rep. $866,879 \ldots \ldots \ldots 322,325$

Chicago, ete., R. Co. $v$. Iowa, 94 U. S. $155 \ldots \ldots \ldots \ldots \ldots 6318$

Chicago, ete., R. Co. $v$. Minnesota, 134 U. S. 418....182, 319, 378

Chieago, etc., R. Co. v. Morehouse, 112 Wis. 1......256, 263, 269

Chicago, ete., R. Co. v. Nebraska, 170 U. S. $57 \ldots 304,340,366,374$

Chicago, ete., R. Co. v. Pontius, 157 U. S. $209 \ldots \ldots \ldots \ldots \ldots 313$

Chicago, ete., R. Co. $v$. State, 50 Neb. $399 \ldots \ldots \ldots \ldots \ldots \ldots . \ldots 269$

Chicago, etc., R. Co. $v$. Sturm, 174 U. S. $710 \ldots \ldots \ldots \ldots \ldots 121$

Chicago, etc., R. Co. $v$. Wellman, 143 U. S. $339 \ldots \ldots \ldots \ldots$ 
Chicago, etc., R. Co. $v$. Wilson, 17 Ill. $123 \ldots \ldots \ldots \ldots \ldots \ldots 258$

Chicago, etc., R. Co. $v$. Wiltse, 116 Ill. $449 \ldots \ldots \ldots \ldots \ldots \ldots 270$

Chicago, etc., R. Co. $v$. Zernecke, 183 U. S. $582 \ldots \ldots \ldots \ldots \ldots 342$

Chicago L. Ins. Co. v. Needles, 113 U. S. $574 \ldots \ldots \ldots \ldots \ldots \ldots 151$

Chicago Theological Seminary $v$. Illinois, 188 U. S. 662..... 227

China Mut. Ins. Co. $v$. Force, 142 N. Y. $95 \ldots \ldots \ldots \ldots \ldots \ldots$ \$5

Chin Bak Kan $v$. U. S., 186 U. S. $193 \ldots \ldots \ldots \ldots \ldots \ldots \ldots \ldots \ldots$

Church $v$. Kelsey, 121 U. S. $282 \ldots \ldots \ldots \ldots \ldots \ldots \ldots \ldots 162,164$

Church of Jesus Christ v. U. S., 136 U. S. $1 \ldots \ldots \ldots 1,98,199,200$

Citizens' Sav. etc., Assoc. v. Topeka, 20 Wall. (U. S.) 655. .228, 230

Civil Rights Cases, 109 U. S. $3 \ldots \ldots \ldots \ldots \ldots \ldots \ldots \ldots 43,44,317$

Clark $r$. Nash, 198 U. S. $361 \ldots \ldots \ldots \ldots \ldots \ldots \ldots \ldots \ldots . \ldots 269$

Cleveland, etc., R. Co. $r$. Backus, 154 U. S. $439 \ldots \ldots \ldots \ldots .224$

Cleveland, ete., R. Co. v. People, 212 Ill. $638 \ldots \ldots \ldots \ldots \ldots \ldots$ il

Cline, Matter of, 1 Ben. (U. S.) $338 \ldots \ldots \ldots \ldots \ldots \ldots \ldots \ldots . \ldots 185$

Clinton $r$. Cedar Rapids, ete, R. Co., 24 Iowa $455 \ldots \ldots \ldots \ldots 285$

Coddington $v$. Coddington, 20 N. J. Eq. $263 \ldots \ldots \ldots \ldots \ldots \ldots 125$

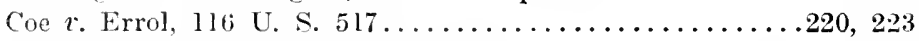

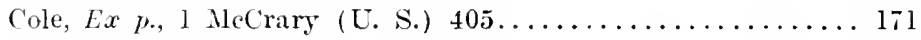

Cole $\because$. Cumningham, 133 L. S. $107 \ldots \ldots \ldots 87,106,107,131,133$

Cole $r$. La Grange, 113 U. S. $1 \ldots \ldots \ldots \ldots \ldots \ldots \ldots \ldots \ldots 228$

Collector $r$. Day, 11 Wall. (U. S.) $113 \ldots \ldots \ldots \ldots \ldots \ldots \ldots 217$

Colon $r$ Link, 15.3 N. Y. $188 \ldots \ldots \ldots \ldots \ldots \ldots \ldots \ldots$. . . 310, 378

Columbia Jiank $x$ Okely, \& Wheat. (U. S.) $235 \ldots \ldots \ldots \ldots \ldots 51$

Columbia Bottom Levee Co. $v$. Neier, 39 Mo. $53 \ldots \ldots \ldots \ldots \ldots .259$

Commercial Cnion Tel. Co. $r$. New England Telephone, etc., Co.,

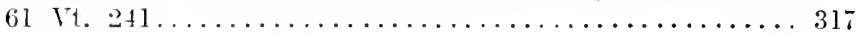

Com. $r$. Alger, 7 Cush. (Mass.) $53 \ldots \ldots \ldots \ldots \ldots \ldots \ldots \ldots 204,300$

Com. r. Boston Advertising Co., 74 N. E. Rep. 601....... 311

Com. r. Dann, 2 Met. (Mass.) $329 \ldots \ldots \ldots \ldots \ldots \ldots \ldots \ldots \ldots . \ldots \ldots$

Com. r. Davis, 162 Mass. $510 \ldots \ldots \ldots \ldots \ldots \ldots \ldots \ldots \ldots 330,365$

Com. $r$. Gaming Implements, 119 Mass. $332 \ldots \ldots \ldots \ldots \ldots \ldots . \ldots 337$

Com. $r$. Hamilton Mlfg. Co., 120 Mass. $383 \ldots \ldots \ldots \ldots \ldots \ldots . \ldots 34$

Com. r. Highway Com'rs. 6 Pick. (Mass.) $508 \ldots \ldots \ldots \ldots \ldots \ldots 160$

Com. $r$. Nareon, 101 Mass. $1 \ldots \ldots \ldots \ldots \ldots \ldots \ldots \ldots \ldots \ldots \ldots 135$

Com. r. Pear, 183 Mass. 242................. 306

Com. $r$. Perry, 15j Mass. $117 \ldots \ldots \ldots \ldots \ldots \ldots \ldots \ldots \ldots \ldots . \ldots \ldots$

Com. r. R. I. Sherman Mfr. Co.. 75 N. E. Rep. $71 \ldots \ldots \ldots \ldots 33$

Com. 1 . Tilhetts, 157 Mass. $519 \ldots \ldots \ldots \ldots \ldots \ldots \ldots \ldots \ldots . \ldots 188$

Com. $r$. Williams, G Gray (Mass.) $1 \ldots \ldots \ldots \ldots \ldots \ldots \ldots 180,181$

Com. $x$. Wyman, 12 Cumlı. (Mass.) $237 \ldots \ldots \ldots \ldots \ldots \ldots \ldots 147$

Conley $r$. Wathiown Alkali Works, 100 C. S. $406 \ldots \ldots \ldots \ldots .103$

Connectient Mut. 1. Ins. Con. r. Cushman, Jos UT. S. G4....... 175

Connetient Wut. L. Ins. Co. r. Spratley, 172 U. S. 602 . . . . 103

Connolly r. Cnion sewer l'ipe Co.. 184 U. S. $540 \ldots \ldots \ldots \ldots . .308$ 
Consolidatcd Coal Co. $v$. lllinois, 185 U. S. $203 \ldots \ldots \ldots \ldots . \ldots 40,36 \mathrm{~S}$ Converse, In re, 137 U. S. $624 \ldots \ldots \ldots \ldots \ldots \ldots \ldots \ldots \ldots 40,80$ Cook $v$. Moliat, 5 How. (U. S.) $310 \ldots \ldots \ldots \ldots \ldots \ldots \ldots \ldots$ Cooper $v$. Reyuolds, 10 Wall. (U.S.) $30 \mathrm{~s} \ldots \ldots .85,89,10 \mathrm{~s}, 1 \mathrm{il}, 112$ Copin $r$. Adamson, L. R. 9 Rach. $345 \ldots \ldots \ldots \ldots \ldots \ldots \ldots \ldots 9$ Coquitlam, Steamer, $v$. U. S., 163 U. S. $346 \ldots \ldots \ldots \ldots \ldots \ldots . \ldots 00$ Corry $v$. Baltimore, 96 MA. 321,196 C. S. $466 \ldots \ldots \ldots \ldots \ldots 99,120$ Coster $v$. Tide Water Co., 18 N. J. Eq. 54, 518........259, 271 Cotting $v$. Kansas City Stock Yards Co., 183 U. S. $79 \ldots \ldots \ldots$. . . $\ldots \ldots \ldots \ldots \ldots \ldots \ldots \ldots \ldots \ldots \ldots \ldots \ldots \ldots \ldots \ldots \ldots \ldots \ldots, 318,323,325,327$

Colton $v$. Mississippi, ete., Boom Co., 22 Minn. $372 \ldots \ldots \ldots \ldots 258$

Couch $v$. Jeffries, 4 Burr. $2460 \ldots \ldots \ldots \ldots \ldots \ldots \ldots \ldots \ldots \ldots$. . . . . . . . . .

County Seat of Linn County, 15 Kan. 500............ 183

Covington, etc., Turnpike Road Co. $\imath$. Sandford, 164 U. S. 578. .189, 320, 822,324

Covington Stock-Yards Co. $r$ Keith, 139 U. S. 128........ 258

Cowles $v$. Mercer County, 7 Wall. (U. S.) $118 \ldots \ldots \ldots \ldots \ldots \ldots 95$

Craemer $v$. Washington, 168 T. S. $124 \ldots \ldots \ldots \ldots \ldots \ldots \ldots$

Crain $v$. U. S., 162 U. S. $625 \ldots \ldots \ldots \ldots \ldots \ldots \ldots \ldots \ldots \ldots \ldots 165$

Crane $v$. McGinnis, 1 Gill \& J. (Md.) $476 \ldots \ldots \ldots \ldots \ldots \ldots \ldots 9$

Crapo v. Kelly, 16 Wall. (U. S.) $610 \ldots \ldots \ldots \ldots \ldots \ldots \ldots \ldots 131$

Creston Waterworks Co. v. McGrith, 89 Iowa $502 \ldots \ldots \ldots \ldots \ldots 277$

Cross $v$. North Carolina, 132 U. S. $131 \ldots \ldots \ldots \ldots \ldots \ldots \ldots 135,168$

Crowley v. Christensen, 137 U. S. $86 \ldots \ldots \ldots \ldots \ldots \ldots 201,243$

Croxall $v$. Shererd, 5 Wall. (U. S.) $26 \mathrm{~s} \ldots \ldots \ldots \ldots \ldots \ldots \ldots 157$

Cuddy, Petitioner. 131 U. S. $280 \ldots \ldots \ldots \ldots \ldots \ldots \ldots \ldots \ldots 170$

Cummings $v$. Missouri, 4 Wall. (U. S.) $277 \ldots 64,67,139,147,335$ Cunningham $v$. Butler, 142 Mass. $47 \ldots \ldots \ldots \ldots \ldots \ldots \ldots \ldots 107$

Cunnius $v$. Reading School Dist., 198 U. S. $458 \ldots \ldots \ldots \ldots \ldots$ $.88,117,118,305,306$

D.

Daniels $v$. Homer, 139 N. Car. $219 \ldots \ldots \ldots \ldots \ldots \ldots 330,373,376$

D'Arey $v$. Ketchum, 11 How. (T. S.) $165 \ldots \ldots \ldots \ldots 75,89,9 \mathrm{I}, 97$

Dartmouth College $v$. Woodward, 4 Wheat. (U. S.) $518 \ldots .$.

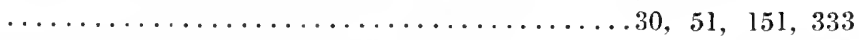

Dash $v$. Van Kleeck, 7 .Jolns. (N. Y.) $\$ 77 \ldots \ldots \ldots \ldots \ldots 146,154$

Davidson $v$. New Orleans, 96 U. S. $97 \ldots \ldots \ldots \ldots \ldots \ldots \ldots$ $\ldots \ldots \ldots \ldots \ldots \ldots \ldots \ldots \ldots \ldots \ldots \ldots, 29,30,37,56,59,68,80,240$

Davies Henderson Lumber Co. $v$. Gottschalk, 81 Cal. 641..... 178

Davis $v$. Burke, 179 U. S. $404 \ldots \ldots \ldots \ldots \ldots \ldots \ldots \ldots \ldots \ldots \ldots$

Davis $v$. Gray, 16 Wall. (U. S.) $203 \ldots \ldots \ldots \ldots \ldots \ldots \ldots \ldots 151$

Davis $v$. Massachnsetts, 167 U. S. $43 \ldots \ldots \ldots \ldots \ldots \ldots \ldots \ldots . \ldots \ldots$

Davis $v$. Mills, 194 U. S. $451 \ldots \ldots \ldots \ldots \ldots \ldots \ldots 171,172,173$ 
Davis $v$. State, 68 Ala. $58 \ldots \ldots \ldots \ldots \ldots \ldots \ldots \ldots \ldots \ldots, 348$

Davis $v$. Texas, 139 U. S. $651 \ldots \ldots \ldots \ldots \ldots \ldots \ldots \ldots \ldots$

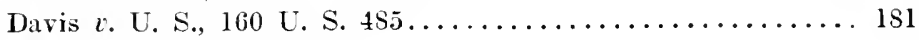

Dily $v$. Savadge, Hob. $s 7 \ldots \ldots \ldots \ldots \ldots \ldots \ldots \ldots \ldots \ldots \ldots \ldots . \ldots \ldots$

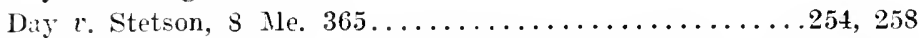

Dayton Gold, etc., Mlin. Co. 2 . Seawell, 11 Nev. 394...263, 264, 273

Deansville Cemetery Assoc., Matter of, 66 N. Y. 569....263, 265

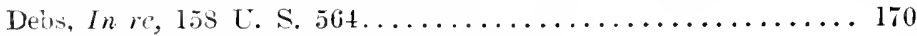

Decatur $v$. Paulding, 14 Pet. (U. S.) $497 \ldots \ldots \ldots \ldots \ldots \ldots \ldots 369$

Dehon $v$. Foster, 4 Allen (Mass.) $545 \ldots \ldots \ldots \ldots \ldots \ldots \ldots \ldots 107$

De La Montanya $v$. De La Nontanya, 112 Cal. 115........92, 129

Delaware, ete. li. Co. $r$. Pennsylyania, 198 U. S. $341 \ldots 218,221,224$

Delaware Railroad Tax, is Wall. (U. S.) $206 \ldots \ldots \ldots \ldots \ldots .224$

De Lima $v$. Bidwell, $18 \geq$ U. S. $1 \ldots \ldots \ldots \ldots \ldots \ldots \ldots \ldots \ldots \ldots 7$

De Mill $v$, Lockwooi, 3 Blatchf. (U. S.) $63 \ldots \ldots \ldots \ldots \ldots \ldots 157$

Den $r$. Van Piper, 16 N. J. L. $7 \ldots \ldots \ldots \ldots \ldots \ldots \ldots \ldots \ldots \ldots$

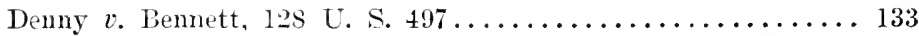

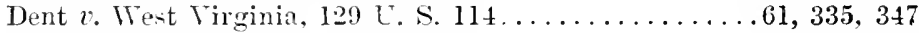

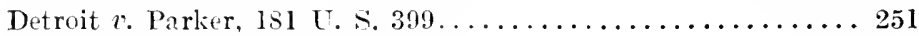

Dewey $v$. Des Moines, 173 U. S. 193..........112, 218, 240

Dewey $v$. Kimball, s9 Minn. $454 \ldots \ldots \ldots \ldots \ldots \ldots \ldots \ldots \ldots \ldots 117$

Diamond Match Co. $r$. Ontonaron, $18 s$ U. S. $82 \ldots \ldots \ldots \ldots \ldots 221$

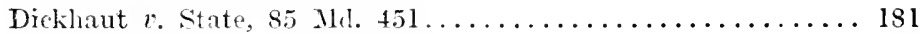

Dillon $v$. Heller, 39 Kan. $599 \ldots \ldots \ldots \ldots \ldots \ldots \ldots \ldots \ldots \ldots . \ldots \ldots$

Dingley $r$ Boston, 100 Mass. $544 \ldots \ldots \ldots \ldots \ldots \ldots \ldots \ldots 206,259$

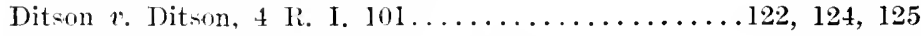

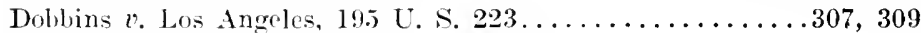

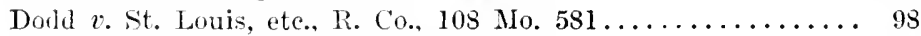

Doe $v$. Buford, l Dana (Ky.) $510 \ldots \ldots \ldots \ldots \ldots \ldots \ldots \ldots \ldots 64$

Dollar Sav. Bank $v$. U. S., 19 Wall. (U. S.) $240 \ldots \ldots \ldots \ldots .237$

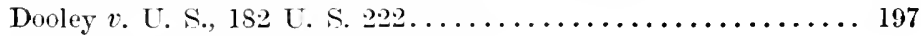

Dorgan $v$. Boston, 12 Allen (Mlass.) 223............. 213

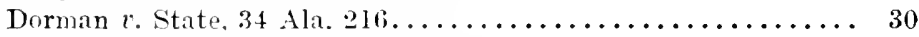

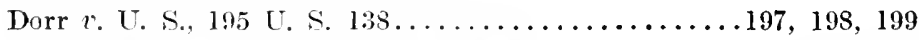

Doughty $v$. Doughty. 2s X. J. Eq. $586 \ldots \ldots \ldots \ldots \ldots \ldots \ldots \ldots 129$

Dow $r$. Beidelman, 125 U. S. $680 \ldots \ldots \ldots \ldots \ldots \ldots \ldots 63,319,325$

Downes $r$. Bidwell, 182 U. S. 244............197, 198, 199, 200

Dred seott $r$. Simiford, 19 How. (U. S.) $614 \ldots \ldots \ldots \ldots \ldots \ldots 199$

Dreper $v$. lllinois. 187 U. S. $71 \ldots \ldots \ldots \ldots \ldots \ldots \ldots 33,58,72,164$

Lronberger $r$. Reed, 11 Ind. $420 \ldots \ldots \ldots \ldots \ldots \ldots \ldots \ldots \ldots 257$

Duncan $v$. Missouri, 152 U. S. $377 \ldots \ldots \ldots \ldots 61,62,147,164,169$

Dunham $v$. Dunham, 62 Ill. $604 \ldots \ldots \ldots \ldots \ldots \ldots \ldots \ldots \ldots, 125$

Dunn $v$. Beaman, 126 N. Car. $766 \ldots \ldots \ldots \ldots \ldots \ldots \ldots \ldots \ldots$

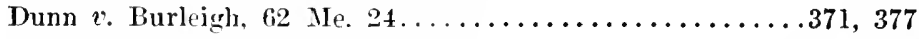

Durkce $v$. Janesville, 28 Wis. $464 \ldots \ldots \ldots \ldots \ldots \ldots \ldots \ldots$ 23, 24 
E.

PAGE

Eakin $v$. Raub, 12 S. \& R. (1'a.) $330 \ldots \ldots \ldots \ldots \ldots \ldots \ldots \ldots$

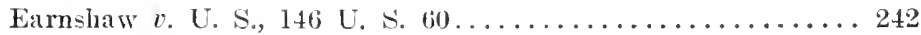

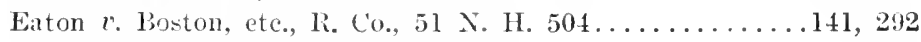

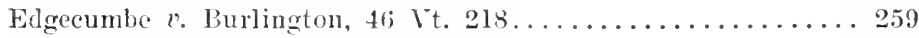

Edson $v$. Crangle, (62 ohio st. $49 \ldots \ldots \ldots \ldots \ldots \ldots \ldots \ldots \ldots \ldots 77$

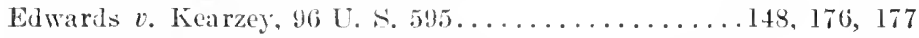

Eiwards $v$. Stonington Cemetery Assoc., 20 Coun. 466...... 259

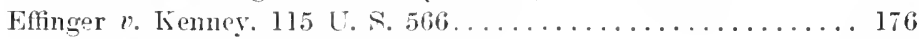

Eidman v. Nartinez, $184 \mathrm{U} . \mathrm{s} .578 \ldots \ldots \ldots \ldots \ldots \ldots \ldots \ldots 22$

Eilenbecker $v$. District Ct., 134 U. S. $31 \ldots \ldots \ldots \ldots \ldots \ldots 4,170$

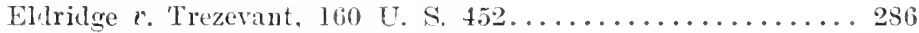

Ellis $r$. M'Henry, L. R. 6 C. P. $234 \ldots \ldots \ldots \ldots \ldots \ldots \ldots \ldots \ldots$

Elmore $x$. Drainage Conl'rs, 135 111. 269.............. 259

Equitable L. Assur. Soe. $r$. Clements, 140 U. S. $226 \ldots . . \ldots . .351$

Erie R. Co. $r$. Pennsylvania, 21 Wall. (U.S.) $492 \ldots \ldots \ldots \ldots .224$

Erie R. Co. $v$. Steward, 170 N. Y. $172 \ldots \ldots \ldots \ldots \ldots 276,298$

Everrreen Cenctery Assoc. $v$. Beecher, 53 Conn. 551....259, 265, 269

Excise Com'rs $v$. Merchant, 103 N. Y. 143........... 181

F.

Fairchild $r$. St. Paul, 46 Minn. $540 \ldots \ldots \ldots \ldots \ldots \ldots . \ldots 275,277$

Fallbrook Irrigation Dist. $v$. Bradley, $164 \mathrm{U}$. S. $112,163 \ldots \ldots$

$19,33,37,213,228,229,230,242,245,247,248,259,266,271,273$

Fallsburg Power, etc., Co. $v$. Alexander, 101 Va. $98 . . . \ldots \ldots$

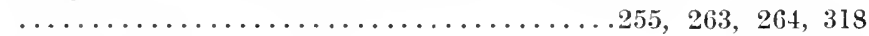

Fargo $v$. Hart, 193 U. S. $490 \ldots \ldots \ldots \ldots \ldots \ldots \ldots \ldots \ldots 24,225$

Farrell $r$. West Chicago Park Com'rs, 181 U. S. 401......... 251

Farrington $i$. Tennessee, 95 U. S. $679 \ldots \ldots \ldots \ldots \ldots \ldots \ldots 26$

Felix $v$. Wallace County, 62 Kan. $832 \ldots \ldots \ldots \ldots \ldots \ldots \ldots . \ldots . \ldots 182$

Felt v. Felt, 59 N. J. Eq. $607 \ldots \ldots \ldots \ldots \ldots \ldots \ldots \ldots \ldots \ldots 124,126$

Fidelity Mnt. L. Ins. Assoc. v. Mettler, 185 U. S. 308. . 185, 332, 351

Fielden $v$. Illinois, 143 U. S. $452 \ldots \ldots \ldots \ldots \ldots \ldots \ldots \ldots \ldots$

Fischer $r$. St. Louis, 194 U. S. $361 \ldots \ldots \ldots \ldots \ldots \ldots \ldots 303,365$

Fisher $v$. MeGirr, 1 Gray (Miss.) $1 \ldots \ldots \ldots \ldots \ldots \ldots \ldots$. 337

Fitzgerald, etc., Constr. Co. l'. Fitzgerald, 137 U. S. $98 \ldots . . .103$

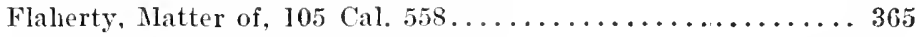

Fletcher $v$. Peck, 6 Cranch (U. S.) $87 \ldots \ldots \ldots \ldots \ldots \ldots 147,151$

Florida Cent., etc., R. Co. v. Reynolds, 183 U. S. $471 \ldots \ldots \ldots 210$

Fok Yung Yo $v$. U. S., I85 U. S. $296 \ldots \ldots \ldots \ldots \ldots \ldots \ldots . \ldots \ldots$

Fong Yue Ting $v$. U. S., 149 U. S. $711 \ldots \ldots \ldots \ldots \ldots \ldots 180,191$

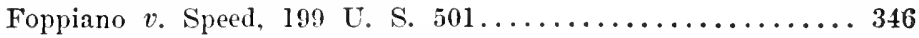

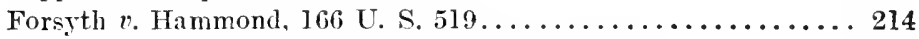

Fort Leavenworth R. Co. v. Lowe, 114 U. S. $525 \ldots \ldots \ldots \ldots \ldots 257$ 
PAGE

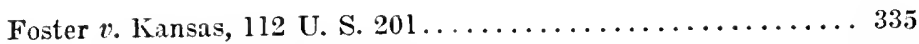

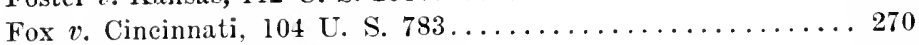

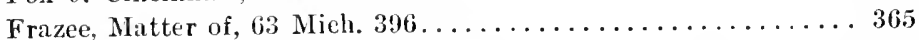

Freeland $r$. Willians, $13 \mathrm{~L}$ U. S. $405 \ldots \ldots \ldots \ldots \ldots \ldots \ldots, 162$

Freeman $r$ Alderson. 119 U. S. $185 \ldots \ldots \ldots \ldots .89,108,112,113$

French $r$. Barber Asphalt Paving Co., 181 U. S. $324 \ldots \ldots \ldots$

$.35,37,247,248,251,252$

French $v$. Taylor, 199 U. S. $274 \ldots \ldots \ldots \ldots \ldots \ldots \ldots \ldots \ldots, 240$

Frorer $v$. People, 141 Ill. $171 \ldots \ldots \ldots \ldots \ldots \ldots \ldots \ldots \ldots 353.355$

G.

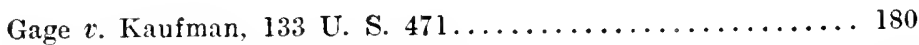

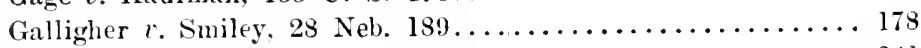

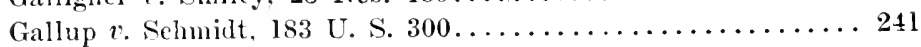

Galpin $v$. Page, 18 Wall. (U. S.) $350 \ldots \ldots \ldots \ldots \ldots \ldots \ldots .66,87$

Garbutt Lumber Co. ". Georgia, etc., R. Co., 111 Ga. 714.... 270

Gardner $\bullet$. Bonestell. 180 U. S. $362 \ldots \ldots \ldots \ldots \ldots \ldots \ldots \ldots \ldots \ldots$

Garlner $r$. Mlichigan, 199 U. S. $325 \ldots \ldots \ldots \ldots \ldots \ldots \ldots \ldots 337$

Gardner $\%$. Newburgh, 2 Johns. Ch. (N. Y.) 162 . .253, 259, 272, 278

Gardner $r$. Providence Telephone Co., 23 R. I. $262 \ldots \ldots \ldots \ldots 317$

Garland, Ex p., + Wall. (L. S.) $333 \ldots \ldots \ldots \ldots \ldots \ldots \ldots \ldots 14,335$

Gaylord $\imath$. Sanitary Dist., 204 Ill. $576 \ldots \ldots \ldots \ldots \ldots \ldots \ldots . \ldots 264$

Gee Fook sing $r$. U. s.. 7 U. S. App. $27 \ldots \ldots \ldots \ldots \ldots \ldots \ldots 194$

Geer $r$. Connetient, 161 C. S. $519 \ldots \ldots \ldots \ldots \ldots \ldots \ldots 181,330$

Geer $v$. Mathieson Alkali Works, 190 U. S. $428 \ldots \ldots \ldots \ldots \ldots 103$

Geilinger $v$. Philippi, 133 U. S. $246 \ldots \ldots \ldots \ldots \ldots \ldots \ldots \ldots \ldots 131$

Georgia, R., «tc.. Co. r. Smith, 128 U. S. $174 \ldots \ldots \ldots \ldots \ldots 305,319$

Gibbs $v$. Ja sociêté Induntrielle, ete., 25 Q. 13. D. $399 \ldots \ldots \ldots \ldots 132$

Gibson $v$. U. ... 166 U. S. $269 \ldots \ldots \ldots \ldots \ldots \ldots \ldots \ldots \ldots \ldots$

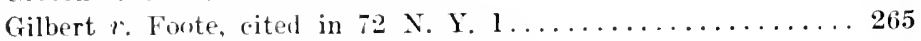

Gilehrist $r$. Schmidling, 12 Kan. $203 \ldots \ldots \ldots \ldots \ldots \ldots \ldots 24$

Gilman $v$. Lockwood, + Wall. (U. S.) $409 \ldots \ldots \ldots \ldots \ldots \ldots \ldots 133$

Gilmore $r$. Hentig, 33 Kan. 15t..............238, 241

Gilmore $r$. Shuter, I Vent. 330, 2 Show. I6, 2 Lev. 227, 2 Mod.

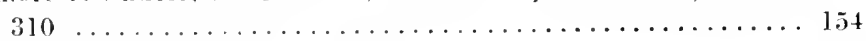

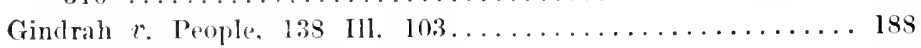

Giozza. v. Tiernan, 148 U. S. 657..............61, 210

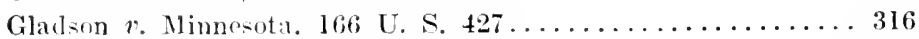

Glidden $v$. Harrington, 189 U. S. 255........... 80, 238, 240

Globe, The, 2 Platchf. (I. S.) $427 \ldots \ldots \ldots \ldots \ldots \ldots \ldots \ldots \ldots$. . . . . .

Gloncester Ferry Co. $r$. Pennsylvania, 114 U. S. $196 \ldots \ldots \ldots 218$

Godeharles $r$. Wigeman, 113 Pa. St. $431 \ldots \ldots \ldots \ldots \ldots \ldots \ldots . \ldots . \ldots 35$

Godwin $r$. Carolina Telephone, etc., Co., 136 N. Car. 258.... 317

Goetze $v$. U. S., 182 U. S. $221 \ldots \ldots \ldots \ldots \ldots \ldots \ldots \ldots \ldots \ldots$ 
PAGE

Goldey $v$. Morning News, 156 U. S. 518......92, 93, 95, 97, 103

Gonzales $v$. Williams, 192 C. S. $1 \ldots \ldots \ldots \ldots \ldots \ldots \ldots \ldots \ldots$

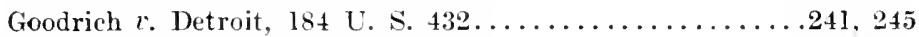

Goshen $v$. Richmond, 4 Allen (Mass.) $458 \ldots \ldots \ldots \ldots \ldots \ldots \ldots$

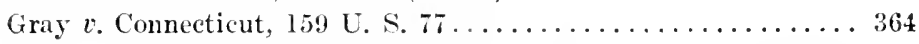

Great Southeru Fire Proof Hotel Co. v. Jones, 193 U. S. $532 \ldots$.

$.360,361$

Great Western Tel. Co. $\iota$. Purdy, 162 U. S. $329 \ldots \ldots \ldots \ldots \ldots 171$

Green $v$. Van Buskirk, 5 Wall. (U. S.) $307 \ldots \ldots \ldots \ldots \ldots \ldots 119$

Green Bay, ete., Canal Co. $r$. Patten Paper Co., 172 U. S. 58... 37

Greenberg $v$. Western Turf Assoc., 140 Cal. $357 \ldots \ldots \ldots \ldots \ldots 317$

Greene $v$. Briggs, 1 Curt. (U. S.) $311 \ldots \ldots \ldots \ldots \ldots \ldots \ldots \ldots 16$

Greer $x$. Blanchar, 40 Cal. $194 \ldots \ldots \ldots \ldots \ldots \ldots \ldots \ldots \ldots \ldots$

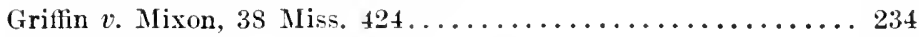

Grignon $v$. Astor, 2 How. (U. S.) $319 \ldots \ldots \ldots \ldots \ldots \ldots \ldots$

Grinder $v$. Nelson, 9 Gill (Md.) $299 \ldots \ldots \ldots \ldots \ldots \ldots \ldots \ldots 143$

Grover, etc., Sewing Mach. Co. $v$. Radeliffe, 137 U. S. 297.....

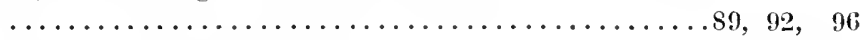

Gulf, etc., R. Co. v. Ellis, 165 U. S. $150 \ldots \ldots \ldots \ldots \ldots \ldots 307,350$

Gundling $r$. Chicago, 177 U. S. $183 \ldots \ldots \ldots \ldots \ldots \ldots \ldots 350,363$

Gunn $r$. Barry, 15 Wall. (U. S.) $622 \ldots \ldots \ldots \ldots \ldots \ldots \ldots \ldots \ldots$

Guyer $v$. Davenport, etc., R. Co., 196 Ill. $370 \ldots \ldots \ldots \ldots \ldots 276$

H.

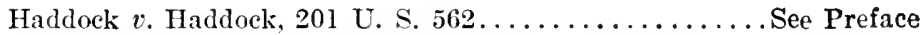
Hagar $v$. Reelamation Dist. No. 108, 111 U. S. $701 \ldots \ldots \ldots$

$\ldots \ldots \ldots \ldots \ldots \ldots \ldots 3,57,80,192,209,213,236,238,241$

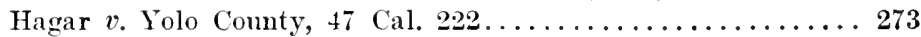

Hall $v$. Lamning. 91 U. S. $160 \ldots \ldots \ldots \ldots \ldots \ldots \ldots \ldots \ldots \ldots$

Hallinger $v$. Davis, 146 U. S. $314 \ldots \ldots \ldots \ldots \ldots \ldots \ldots, 81,163$

Halter $v$. State, (Neb. 1905 ) 105 S. W. Rep. $298 \ldots \ldots \ldots \ldots \ldots 33$

Hamilton $v$. Brown, 161 C. S. $256 \ldots \ldots \ldots \ldots \ldots \ldots \ldots \ldots \ldots \ldots \ldots$

Hammett $v$. Philadelphia, 65 Pa. St. $152 \ldots \ldots \ldots \ldots \ldots \ldots \ldots 283$

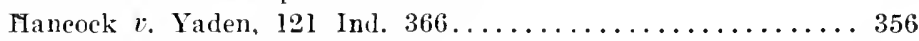

Hanks $v$. State. 13 Tex. App. 289................. 135

Hanley $v$. Donohue, 116 U. S. $1 \ldots \ldots \ldots \ldots \ldots \ldots \ldots . \ldots \ldots, 97$

Hannibal, ete., R. Co. $v$. Husen, 95 U. S. $465 \ldots \ldots \ldots \ldots \ldots . \ldots 304$

Hanover Nat. Bank $v$. Mopses, 186 U. S. $181 \ldots \ldots \ldots \ldots \ldots 130,131$

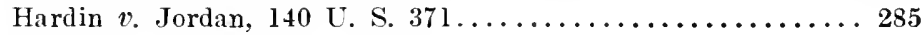

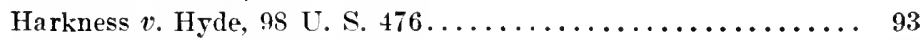

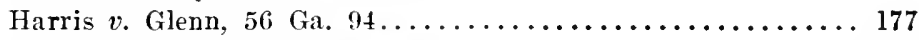

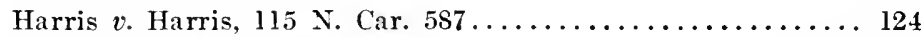

Hart $v$. Sanson, 110 U. S. $151 \ldots \ldots \ldots \ldots \ldots \ldots \ldots \ldots . \ldots, 91,114$

Hartung $v$. People, 22 N. Y. $95 \ldots \ldots \ldots \ldots \ldots \ldots \ldots \ldots \ldots \ldots \ldots$ 
PACE

Harvey $v$. Thomas, 10 Watts (Pa.) $63 \ldots \ldots \ldots \ldots \ldots \ldots \ldots$

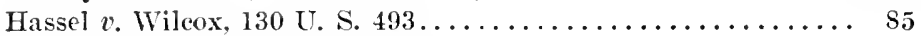

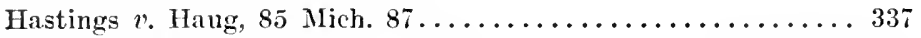

Hawa.ii $v$. Mankichi, 190 U. S. $197 \ldots \ldots \ldots \ldots \ldots \ldots 198,199,200$

Hawker $v$. New York, 170 U. S. $189 \ldots \ldots \ldots \ldots \ldots \ldots \ldots \ldots 184,347$

Hawkins Point Light-House Case, 39 Fed. Rep. 77......... 285

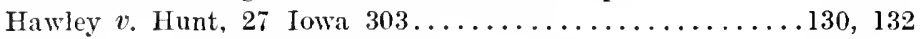

Hayden $v$. Androscoggin Mills, 1 Fed. Rep. $93 \ldots \ldots \ldots \ldots \ldots 105$

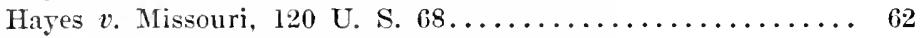

Hazen $v$. Essex County, 12 Cush. (Mass.) $477 \ldots \ldots \ldots \ldots \ldots .256$

Head v. Amoskeag Mfg. Co., 113 U. S. 9.......264, 265, 266

Healey Lumber Co. $v$. Morris, 33 Wash. $490 \ldots \ldots \ldots \ldots 256,263,264$

Health Dept. $v$. Trinity Chureh, 145 N. Y. 32.

$.203,204,306,340,341,366$

Heffner $v$. Cass County, 193 Ill. $439 \ldots \ldots \ldots \ldots \ldots \ldots \ldots . \ldots 259$

Heine $v$ Levee Com'rs, 19 Wall. (U. S.) $655 \ldots \ldots \ldots \ldots \ldots \ldots .209$

Henderson Bridge Co. $v$. Henderson, 173 U. S. $592 \ldots \ldots \ldots 214,232$

Henderson Bridge Co. $v$. Kentucky, 166 U. S. 150......... 219

Henkel $v$. Detroit, 49 Mieh. $249 \ldots \ldots \ldots \ldots \ldots \ldots \ldots \ldots \ldots . \ldots 259$

Henly Lumber Co. $v$. Morris, 33 Wash. $490 \ldots \ldots \ldots \ldots \ldots \ldots .258$

Hennington $v$. Georgia, 163 U. S. $299 \ldots \ldots \ldots \ldots \ldots \ldots \ldots \ldots \ldots$

Henny, etc., Co. $v$ Erans, 97 Mo. $47 \ldots \ldots \ldots \ldots \ldots \ldots \ldots \ldots$

Hess $v$. Werts, 4 S. \& R. (Pa.) $361 \ldots \ldots \ldots \ldots \ldots \ldots \ldots \ldots \ldots 157$

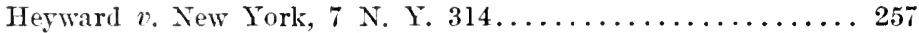

Hibben $v$. Smith, 191 U. S. $310 \ldots \ldots \ldots .35,37,58,72,73,81,242$

Highland Boy Gold Mining Co. v. Striekley, 116 Fed. Rep. S52. . 276

Hilton $v$ Merritt, 110 U. S. $97 \ldots \ldots \ldots \ldots \ldots \ldots \ldots \ldots \ldots$

Hodge $v$. Muscatine County, 196 U. S. 276.....235, 236, 241, 363

Hodgson $v$. Vermont, 168 U. S. $272 \ldots \ldots \ldots \ldots \ldots \ldots \ldots \ldots \ldots$

Hoeft $v$. Supreme Lodge, ete., 113 Cal. $91 \ldots \ldots \ldots \ldots \ldots \ldots 156$

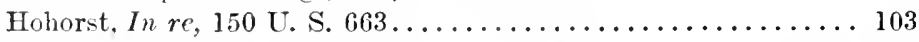

Hoke $v$. Jienderson, 4 Der. L. (I5 N. Car.) $1 \ldots \ldots \ldots . . .630,6 \mathrm{~s}$

Holbrook $v$. Finney, 4 Mass. $568 \ldots \ldots \ldots \ldots \ldots \ldots \ldots \ldots \ldots . \ldots \ldots$

Folden $r$. Hardy, 169 U. S. $366 \ldots . .22,39,40,56,306,308,347$

Holden $v$. Minnesota, 137 U. S. $495 \ldots \ldots \ldots \ldots \ldots \ldots \ldots \ldots . . .169$

Holtr River Coal Co. $v$. Howell, 36 T. Va. $459 \ldots \ldots \ldots \ldots \ldots .234$

Holmes $r$ Hunt 122 Mass. $505 \ldots \ldots \ldots \ldots \ldots \ldots \ldots \ldots \ldots \ldots$ l 80

Holt $x$. Somerville, 127 Mass. 408............... 297

Home Ins. Co. $v$. Morse, 20 Wall. (U. S.) $445 \ldots \ldots \ldots \ldots \ldots . . \ldots 5$

IIcme Ins. Co. $r$. New York, 134 U. S. $594 \ldots \ldots \ldots \ldots \ldots \ldots \ldots . . \ldots 10$

Hnoker $v$. Los Angeles, 189 U. S. $314 \ldots \ldots \ldots \ldots \ldots \ldots \ldots 76,160$

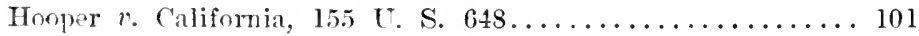

Hopkins $v$. Orr, 124 U. S. $510 \ldots \ldots \ldots \ldots \ldots \ldots \ldots \ldots \ldots . \ldots . \ldots 9 . \ldots$

Hopt $n$. Utah, 110 U. S. $574 \ldots \ldots \ldots \ldots \ldots \ldots \ldots$ 147, 148, 160, 166

Hovey $v$. Elliot, 167 U. S. $409 \ldots \ldots \ldots \ldots 3,27,51,76,85,171$ 


\section{PAGE}

Howard $v$. Fleming, 191 U. S. $126 \ldots \ldots \ldots \ldots \ldots \ldots \ldots \ldots$

Howard $v$. Moot, 64 N. Y. 268................. 182

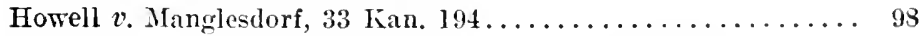

Huling $v$. Kaw Valley R., etc., Co., 130 U. S. $559 \ldots \ldots \ldots \ldots 114$

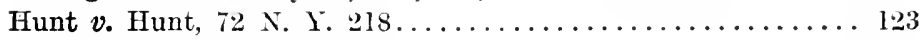

Huntington $v$. Attrill, 146 U. S. $657 \ldots \ldots \ldots \ldots \ldots \ldots \ldots \ldots$

Hurst $v$. Warner, 102 Mich. 238............... 347

Hurtado $v$. California, 110 U. S. $516 \ldots \ldots \ldots \ldots \ldots \ldots \ldots$ $\ldots \ldots \ldots \ldots \ldots \ldots 2,5,28,31,32,34,51,54,56.57,59,163$

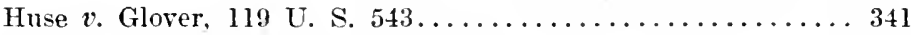

Hutton $v$. Camden, 39 N. J. L. $122 \ldots \ldots \ldots \ldots \ldots \ldots \ldots \ldots \ldots$

Hyde Park $v$. Oakwoods Cemetery Assoc., 119 Ill. $141 \ldots \ldots \ldots .254$

I.

Illinois Cent. R. Co. $v$. Decatur, 147 U. S. $190 \ldots \ldots \ldots 2$

Indiana Natural, ete., Gas Co. v. State, 158 lnd. $516 \ldots \ldots \ldots 317$

Inter-Ocean Pub. Co. v. Assceiated Press, 184 Ill. $43 \mathrm{~s} \ldots \ldots \ldots . .317$

Interstate Commerce Commission $v$. Brimson. 154 U. S. $447 \ldots 170$

Interstate Commerce Commission $r$. Cincinnati, etc., R. Co., 167

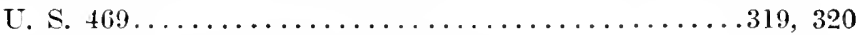

Iowa Cent. R. Co. $v$. Iowa, 160 U. S. $399 \ldots \ldots \ldots . \ldots 38,39,40,41$

Irrigation Dist. $v$. Williams, 76 Cal. $360 \ldots \ldots \ldots \ldots \ldots 273$

\section{J.}

Jackson $r$. Trood, 2 Cow. (X. Y.) $819 \ldots \ldots \ldots \ldots \ldots \ldots \ldots \ldots 18$

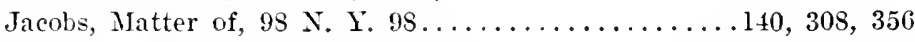

Jacobson $\iota$. Massachusetts, 197 L. S. 11......140,304, 306, 344

James 2 . Bowman, 190 U. S. $127 \ldots \ldots \ldots \ldots \ldots \ldots \ldots \ldots \ldots 43$

James Clark Distilling Co. $v$. Cumberland, 95 MI. $474 \ldots \ldots .99$

Japanese Immigrant C'ase. 189 U. S. $86 \ldots \ldots \ldots \ldots \ldots 190,191,193$

John Hancock Mut. L. Ins. Co. v. Warren, 1s1 U. S. 73.... 185, 332

Johnson $v$. Chicago, ete., Elerator Co., 119 U. S. $39 s \ldots . \ldots . .96$

Johnson $r$. Clayton County, 61 lowa $\$ 9 . \ldots \ldots \ldots \ldots \ldots \ldots \ldots . \ldots \ldots$

Johnson $r$. Powers, 139 U. S. $159 \ldots \ldots \ldots \ldots \ldots \ldots \ldots \ldots \ldots 112$

John Spry Lumber Co. $v$. Sault Sar. Bank. etc., Co., 77 Mich.

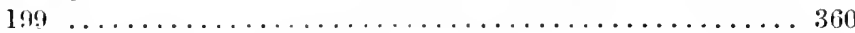

Johnston $r$. Rankin, 70 N. Car. $550 \ldots \ldots \ldots \ldots \ldots \ldots \ldots 280,281$

Jones $r$. Brim, 165 U. S. $180 \ldots \ldots \ldots \ldots \ldots \ldots 62.187 .305 .342$

Jones $v$. Great Southern Fire Proof Hotel Co., 58 U. S. App.

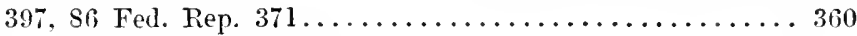

Jones $r$. Jones, $10 \mathrm{~s}$ N. Y. $415 \ldots \ldots \ldots \ldots \ldots \ldots \ldots \ldots \ldots \ldots 124$

Journeny $r$ Gibson. 56 Pa. St. $57 \ldots \ldots \ldots \ldots \ldots \ldots \ldots \ldots \ldots$ 
K.

PAGE

Kauffman $v$. Wooters, 138 U. S. $285 \ldots \ldots \ldots \ldots \ldots \ldots \ldots \ldots$

Kaukauna Water Power Co. v. Green Bay, etc., Canal Co., 142

U. S. $254 \ldots \ldots \ldots \ldots \ldots \ldots \ldots \ldots \ldots .23,270,283,285,286$

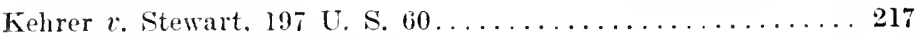

Kelley $v$. Rhoads, 188 U. S. 1................. 221

Kelly $x$. Pittshurgh, 104 U. S. $78 \ldots \ldots \ldots \ldots \ldots \ldots, 214,228,233$

Kemmler, In re, 136 C. S. $436 \ldots \ldots \ldots \ldots \ldots \ldots \ldots 33,35,36,169$

Kemper-Thomas Paper Co. v. Slyer, 108 Tenn. $450 \ldots \ldots \ldots .92,115$

Kendall $v$. Kingston, 5 Mass. $52+\ldots \ldots \ldots \ldots \ldots \ldots \ldots \ldots \ldots$

Kennard $r$ loniniana, 92 U. $\$ .4 \$ 0 \ldots \ldots \ldots \ldots \ldots \ldots \ldots \ldots \ldots$

Kent $r$ Gray, 53 ×. H. $576 \ldots \ldots \ldots \ldots \ldots \ldots \ldots \ldots \ldots \ldots \ldots$

Kentucky $x$. Dennion, $2+$ How. (U. S.) $66 \ldots \ldots \ldots \ldots \ldots \ldots 137$

Kentucky Railyoad Tax Cares, 115 U. S. $321 \ldots \ldots \ldots \ldots \ldots$

$\ldots \ldots \ldots \ldots \ldots \ldots \ldots \ldots \ldots \ldots \ldots 2,84,210,215,238,241,245$

Ker r. Hllinois, 119 C. S. $430 \ldots \ldots \ldots \ldots \ldots \ldots \ldots \ldots \ldots \ldots \ldots$

Kever $r$ Rice. 47 Md. $203 \ldots \ldots \ldots \ldots \ldots \ldots \ldots \ldots \ldots \ldots \ldots$

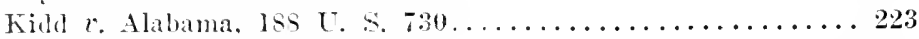

Kidl r. Pearon, 12s L. \&. $1 \ldots \ldots \ldots \ldots \ldots \ldots \ldots \ldots \ldots 337,346$

Kibmom $r$ Thompon, 103 U. S. $168 \ldots \ldots \ldots \ldots \ldots \ldots \ldots \ldots \ldots 69$

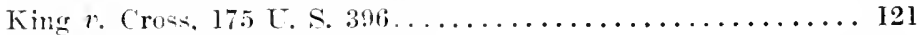

King $r$. Hayes. so Me. $206 \ldots \ldots \ldots \ldots \ldots \ldots \ldots \ldots \ldots \ldots \ldots \ldots$

King $r$ Mullins, 17$\}$ L. \&. $404 \ldots \ldots \ldots \ldots \ldots \ldots \ldots \ldots 37,233,235$

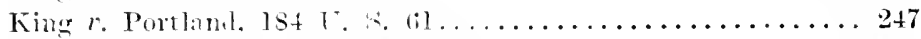

Kiugman. Putioner. 15.3 sian. $506 \ldots \ldots \ldots \ldots \ldots \ldots \ldots \ldots .259$

Kingman $r$ Pauliom. 120 Ind. $507 \ldots \ldots \ldots \ldots \ldots \ldots \ldots \ldots . \ldots \ldots$

Kingsland $r$. New York, 110 x. Y. 569............ 258

Kinney, Ex p., 3 Hughes (U. s.) $9 \ldots \ldots \ldots \ldots \ldots \ldots \ldots \ldots \ldots 136$

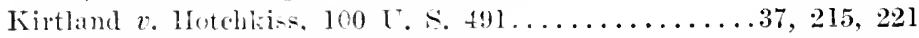

Knowiton $r$. Nonre, 17s L. S. $41 \ldots \ldots \ldots \ldots \ldots \ldots \ldots 208,222,223$

Finoxville Iron ('o. r. Harbiom, 1s3 L. S. $13 \ldots \ldots \ldots \ldots \ldots \ldots 35$

Kunxille Witu (i) $r$. Inoxville, 189 U. S. $434 \ldots \ldots \ldots \ldots 305$

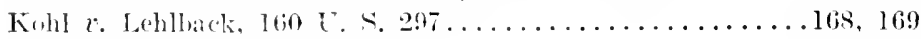

Kohl $r$. U. S., 91 U. .. $316 \ldots \ldots \ldots \ldots \ldots \ldots \ldots \ldots \ldots .253,257$

Follock, In re, 165 Ч. .. $536 \ldots \ldots \ldots \ldots \ldots \ldots \ldots \ldots \ldots \ldots \ldots$

Kosciusko $r$. Slombere, is Mi-s. $449 \ldots \ldots \ldots \ldots \ldots \ldots \ldots \ldots 347$

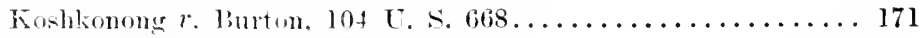

Kring $v$ Missomi, 107 I. S. $221 \ldots \ldots \ldots \ldots \ldots \ldots \ldots \ldots 147,159$

Krug, In re, 79 Fed. Rep. $308 \ldots \ldots \ldots \ldots \ldots \ldots \ldots \ldots \ldots \ldots \ldots$

L.

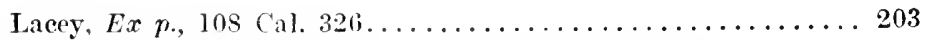

Lafayette Ius. (o. $r$. French, 18 How. (U. S.) $404 \ldots \ldots \ldots \ldots$

$.75,91,101,102,103$

Lake Shore, etc., R. Co. $v$. Ohio, 173 U. S. $285 \ldots \ldots \ldots \ldots 306,340$ 
PAGE

Lake Shore, ete., R. Co. $v$. Smith, 173 U. S. $684 \ldots \ldots .189,320,327$

Lambert $v$. Barrett, 157 U. S. 697,159 U. S. $660 \ldots \ldots \ldots \ldots \ldots 169$

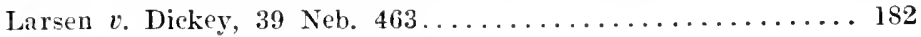

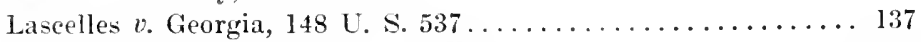

Lau Ow Bew $r$. U. S., 144 U. S. $47 \ldots \ldots \ldots \ldots \ldots \ldots \ldots \ldots$

Lavin $v$. Emigrant 1ndustrial Sav. Bank, 18 Blatehf. (U. S.) 1..

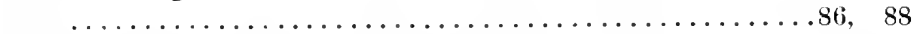

Lawler $v$. Baring Boom Co., 56 Me. $443 \ldots \ldots \ldots \ldots \ldots \ldots \ldots 5$

Lawton $v$. Steele, 152 U. S. $133 \ldots \ldots 300,308,310,330,375,377$

League $v$. Texas, 184 U. S. $156 \ldots \ldots \ldots \ldots \ldots 155,15 \overrightarrow{7}, 160.234$

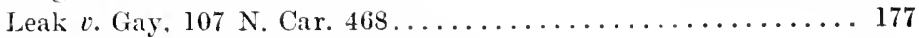

Leeds $r$. Richmond. 102 lnd. $372 \ldots \ldots \ldots \ldots \ldots \ldots \ldots \ldots . \ldots \ldots 9$

Lee Gon Yung $v$. U. S., 185 U. S. $306 \ldots \ldots \ldots \ldots \ldots \ldots \ldots \ldots 19 \ldots \ldots$

Leep $v$. St. Louis, etc., R. Co., 58 Ark. $407 \ldots \ldots \ldots \ldots \ldots \ldots 6$

Leeper $r$. Texas, 139 U. S. $462 \ldots \ldots \ldots \ldots \ldots \ldots \ldots \ldots 61,80,168$

Legal Tender Cases, ]2 Wall. (U. S.) $457 \ldots \ldots \ldots \ldots \ldots \ldots 142,153$

Lehigh Water Co. v. Easton, 121 U. S. $385 \ldots \ldots \ldots \ldots \ldots \ldots 4152$

Leigh $v$. Green, 193 U. S. $79 \ldots \ldots \ldots \ldots \ldots 111,117,233,240,241$

Leloup $v$. Port of Mobile, 127 U. S. $640 \ldots \ldots \ldots \ldots \ldots \ldots 217$

Lem Moon Sing $l$. U. S., 159 U. S. $539 \ldots \ldots \ldots \ldots \ldots \ldots \ldots 2,194$

Lent $v$. Tillson, 140 U. S. $316 \ldots \ldots \ldots \ldots \ldots \ldots \ldots \ldots, 239,241$

Le Roy $v$. Champion, 1 Sid. 14, 2 Sid. $97 \ldots \ldots \ldots \ldots \ldots \ldots 75$

Levasser $r$. Washburn, 11 Gratt. (Va.) $572 \ldots \ldots \ldots \ldots \ldots \ldots 234$

Lew is $v$. U. S., 146 U. S. $372 \ldots \ldots \ldots \ldots \ldots \ldots \ldots \ldots \ldots, 165$

L'Hote $r$. New Orleans, 177 U. S. 587.........305, 306, 339, 346

License Cases, 5 How. (U. S.) $504 \ldots \ldots \ldots \ldots \ldots \ldots \ldots \ldots \ldots . \ldots \ldots 2$

Lieberman $r$. Van De Carr, 199 U. S. $552 \ldots \ldots \ldots \ldots \ldots \ldots \ldots 73$

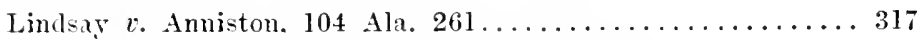

Little Rock, etc., R. Co. $v$. Payne, 33 Ark. $816 \ldots \ldots \ldots \ldots \ldots 185$

Lochner $r$. New York, 198 U. S. $45 \ldots \ldots \ldots \ldots \ldots \ldots \ldots \ldots 3,356$

Loeseh $v$. Koehler, 144 Ind. $278 \ldots \ldots \ldots \ldots \ldots \ldots \ldots \ldots 37,377$

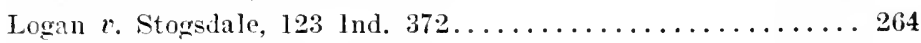

Logan $v$. U. S.. 144 U. S. $263 \ldots \ldots \ldots \ldots \ldots \ldots \ldots \ldots 42,43,45$

Lombarl $v$. West Chicago Park Com'rs, 181 U. S. $33 \ldots \ldots \ldots .254$

London's Case, s Coke $125 a \ldots \ldots \ldots \ldots \ldots \ldots \ldots \ldots \ldots \ldots . \ldots \ldots$

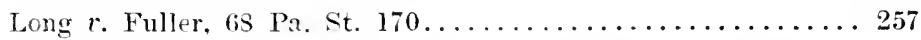

Long Island Water Supply Co. v. Brooklyn, 166 U. S. 685...

$.81,259,282,299$

Look Ting Sing, In re, 10 Sawy. (U. S.) $353 \ldots \ldots \ldots \ldots \ldots \ldots 195$

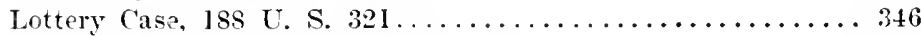

Longhborough $v$. Blake, 5 Wheat. (U. S.) $317 \ldots \ldots \ldots \ldots \ldots 200$

Lonisiana $v$. New Orleans, 109 U. S. $285 \ldots \ldots \ldots \ldots \ldots \ldots 150,212$

Lovisville, ete.. Ferry Co. $v$. Kentucky, 188 U. S. 385. . . 122, 218. 219

Lonicrille, ete., R. Co. $v$. Barber Asphalt Pav. Co., 197 U. S.

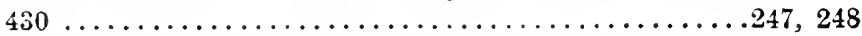


PAGE

Louisville, etc., R. Co. $v$. Kentucky, 183 U. S. $503 \ldots \ldots .319,365,370$ Louisville, etc., R. Co. $v$. Sehmidt, 177 U. S. $230 \ldots 39,77,92,160,161$ Lowe $r$. Kansas, 163 U. S. $81 \ldots \ldots \ldots \ldots \ldots 54,62,160,179,180$ Lowell $v$. Boston, 111 Mass. $454 \ldots \ldots \ldots \ldots \ldots \ldots 28,229,265$ Luxton $v$. North River Bridge Co., 153 U. S. $525 \ldots \ldots \ldots \ldots \ldots 285$ Lynch $r$. Forbes, 161 Mass. $302 \ldots \ldots \ldots \ldots \ldots \ldots \ldots 259,275,297$

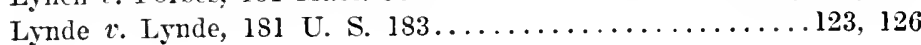

M.

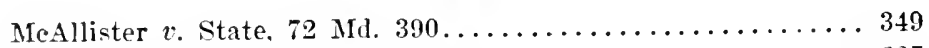

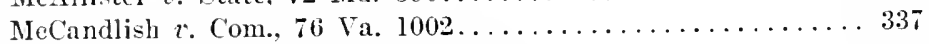

NeClure $v$. Maitland, 24 W. Va. $561 \ldots \ldots \ldots \ldots \ldots \ldots \ldots \ldots 234$

MeCracken $v$. Havward, 2 How. (U. S.) $608 \ldots \ldots \ldots \ldots \ldots 150,176$

MeCray $v$. U. S., 195 U. S. $27 \ldots \ldots \ldots \ldots \ldots \ldots \ldots \ldots \ldots 208,217$

MeCreery $v$. Daris, 44 s. Car. $195 \ldots \ldots \ldots \ldots \ldots \ldots \ldots \ldots \ldots . \ldots \ldots$

McCulloch $r$. Maryland, 4 Wheat. (U. S.) $316 \ldots \ldots \ldots \ldots 208,217$

McEldowney $r$. Wyatt, $44 \mathrm{~W}$. Va. $711 \ldots \ldots \ldots \ldots \ldots \ldots \ldots . \ldots \ldots$

MeFadden $r$. Evans-Snider-liuel Co., 185 C. S. $505 \ldots \ldots \ldots \ldots .158$

MeGahey $v$. Virginia, 135 U. S. $662 \ldots \ldots \ldots \ldots \ldots \ldots \ldots \ldots 2,175$

MeKane r. Durston. 153 U. S. $684 \ldots \ldots \ldots \ldots \ldots \ldots \ldots \ldots 1,169$

Me.jillen $v$. Anderson, 95 U. S. 37........ 80, 178, 234, 241

MeNeeley, Ex p., 36 W. Va. $84 \ldots \ldots \ldots \ldots \ldots \ldots \ldots \ldots \ldots \ldots 136$

Me Nitt $x$. Turner, 16 Vall. (U.S.) $366 \ldots \ldots \ldots \ldots \ldots \ldots \ldots \ldots . \$ \ldots 9$

McNults $r$. California, 149 U. S. $648 \ldots \ldots \ldots \ldots \ldots \ldots \ldots \ldots$ Madisonville Traction Co. $r$. St. Bernard Min. Co., 196 U. S.

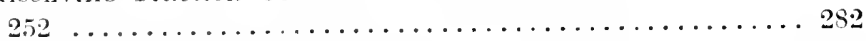

Magoun $r$. Illinnis Trust. ete. Bank, 170 U. S. $283 \ldots \ldots \ldots \ldots .22$

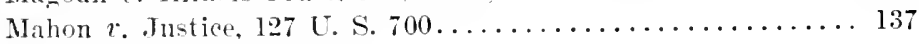

Maier, Ex p., 103 Cal. $476 \ldots \ldots \ldots \ldots \ldots \ldots \ldots \ldots \ldots \ldots \ldots 181$

Main $v$. Neswer, 17 Oregon $78 \ldots \ldots \ldots \ldots \ldots \ldots \ldots \ldots \ldots, 132$

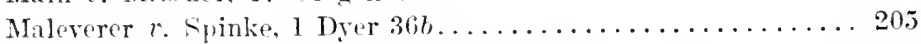

Mallett $x$. North Carolina. 1sl U. S. $589 \ldots \ldots \ldots \ldots \ldots \ldots \ldots 147$

Manigault r. Springs. 1!99 C. S. 473. . 259, 293, 294, 300. 301, 304

Manning, In rr. 139 T. S. $5016 \ldots \ldots \ldots \ldots \ldots \ldots \ldots \ldots \ldots$ les

Manning $r$ spurek. 199 111. $450 \ldots \ldots \ldots \ldots \ldots \ldots \ldots \ldots \ldots \ldots$

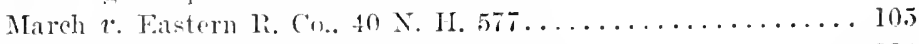

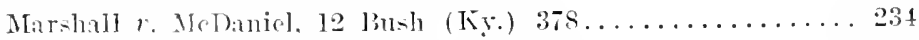

Martin, E.r p.. 13 Ark. $399 \ldots \ldots \ldots \ldots \ldots \ldots \ldots \ldots \ldots \ldots \ldots$

Nitin $r$. Thltimnre, ete. R. Co., 15] U. S. $686 \ldots \ldots \ldots \ldots \ldots$. 45

Martindale $r$. Mrore. 3 liackf. (Ind.) $282 \ldots \ldots \ldots \ldots \ldots \ldots .143$

Marrin $\imath$. Tront, 199 U. S. 212.............162, 338. 343

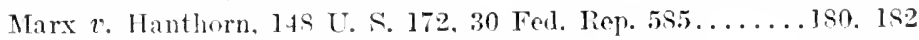

Marr, The. ( Cranch (U. S.) 144............... 111

Marge $r$. Paltimore. ete. R. Co.. 127 U. S. $117 \ldots \ldots \ldots \ldots \ldots .225$ 


\section{PAGE}

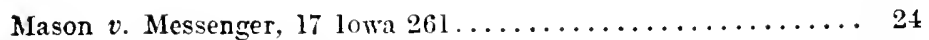

Massachusetts $v$. Western Union Tel. Co., 141 U. S. $40 \ldots \ldots 224$

Massie $v$. Watts, 6 Cranch (U. S.) 148............ 106

Mattingly $v$. District of Columbia, 97 U. S. $687 \ldots \ldots \ldots \ldots \ldots 247$

Maxwell $v$. Dow, 176 U. S. $581 \ldots \ldots \ldots \ldots .5,22,32,34,59,163$

Maxwell $v$. Goetschius, 40 N. J. L. $391 \ldots \ldots \ldots \ldots \ldots \ldots \ldots 23$

Maynard $v$. Hill, 125 U. S. $210 \ldots \ldots \ldots \ldots \ldots \ldots \ldots \ldots \ldots \ldots 124$

Medley, Petitioner, 134 U. S. $160 \ldots \ldots \ldots \ldots \ldots \ldots \ldots \ldots \ldots 147$

Merchant $v$. Pennsylvania R. Co., 153 U. S. $380 \ldots \ldots \ldots \ldots \ldots 296$

Merchants', ttc., Bank $v$. Pennsylvania, 167 U. S. 461 ......237, 239

Merchants' Nat. Bank $v$. U. S., 101 U. S. $1 . \ldots \ldots \ldots \ldots . \ldots . . .208$

Meriwether $v$. Garrett, I02 U. S. $472 \ldots \ldots \ldots \ldots \ldots \ldots 209,212$

Metropolitan St. R. Co. v. Tax Com'rs, 199 U. S. $1 \ldots .212,227,228$

Mexican Cent. R. Co. v. Pinkney, 149 U. S. $194 \ldots \ldots \ldots \ldots \ldots . . \ldots 3,103$

Merer $v$. Berlandi, 39 Minn. $438 \ldots \ldots \ldots \ldots \ldots \ldots \ldots \ldots \ldots . \ldots \ldots 6$

Neyer $r$. Richmond, 172 U. S. $82 \ldots \ldots \ldots \ldots \ldots \ldots \ldots \ldots 289,295$

Mial $r$. Ellington, 134 N. Car. $131 \ldots \ldots \ldots \ldots \ldots \ldots \ldots \ldots \ldots$

Michigan Ins. Co. $v$. Eldred, 130 U. S. $693 \ldots \ldots \ldots \ldots \ldots \ldots 171$

Middlebrooks $v$. Springfield F. Ins. Co., 14 Conn. $301 \ldots \ldots \ldots \ldots 101$

Miller $r$ Dennett, 6 N. H. $109 \ldots \ldots \ldots \ldots \ldots \ldots \ldots \ldots \ldots \ldots \ldots$

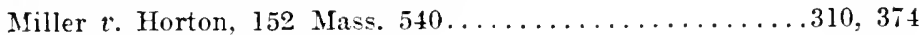

Miller $r$. Miller, 16 Mass. $59 \ldots \ldots \ldots \ldots \ldots \ldots \ldots \ldots \ldots \ldots \ldots$. . . . .

Miller $\because$ Texas, 153 U. S. $535 \ldots \ldots \ldots \ldots \ldots \ldots \ldots \ldots \ldots \ldots 10 \ldots$

Millett $v$. People, 117 11l. 294................61, 356

Mills $v$. U. S., 46 Fed. Rep. $738 \ldots \ldots \ldots \ldots \ldots \ldots \ldots \ldots \ldots . \ldots \ldots$

Milwaukee, etc., R. Co. $v$. Faribault, 23 Minn. $167 \ldots \ldots \ldots \ldots .27 i$

Milwaukee Industrial School $v$. Milwaukee County. 40 Wis. 328. 344

Minneapolis, etc., R. Co. v. Beckwith, 129 C. S. $26 \ldots \ldots \ldots .313$

Minneapolis, etc., R. Co. $v$. Emmons, 149 U. S. $364 \ldots \ldots \ldots \ldots 342$

Minneapolis, etc., R. Co. $v$. Minnesota, 193 U. S. $53 \ldots \ldots \ldots .306$

Minnesota Iron Co. $v$. Kline, 199 U. S. $593 \ldots \ldots \ldots \ldots \ldots \ldots 313$

Mississippi, etc., Boom Co. $r$. Patterson, 99 U. S. $403 \ldots \ldots .275,290$

Missouri $v$. Lewis, 101 U. S. $22 \ldots \ldots \ldots \ldots \ldots \ldots \ldots \ldots \ldots \ldots$

Missouri. etc. R. Co. $r$. Haber, 169 U. S. $618 \ldots \ldots \ldots \ldots \ldots \ldots 304$

Missouri. etc., R. Co. $\imath$. Mar, 194 U. S. $267 \ldots \ldots \ldots \ldots \ldots 312,342$

Missouri, etc., R. Co. $v$. Simonson, 64 Kan. 802.......182. 185

Missouri Pac. R. Co. $r$. Humes, 115 U. S. $512 \ldots \ldots . .37 .313,342$

Nissouri Pac. R. Co. $v$. Macker, 127 U. S. $205 \ldots \ldots \ldots .312,342$

Missomi Pac. R. Co. $v$. Nebraska. 164 U. S. 493. . . .68, 255. 269

Mitchell $r$. Clark. 110 U. S. $633 \ldots \ldots \ldots \ldots \ldots \ldots \ldots \ldots \ldots 153$

Mrobile $r$. Pienville Water Supply Co., 130 Ala. $89 . \ldots \ldots \ldots \ldots 317$

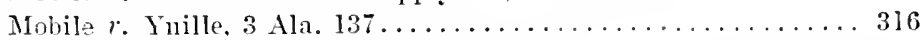

Mobile County $v$. Kimball. 102 L. S. 691..........202. 215, 231

Mobile. etc.. R. Co. $r$. Alabama Midland R. Co., 87 Ala. $501 \ldots$. 278

Mohr $v$. Manierre. 101 U. S. $417 \ldots \ldots \ldots \ldots \ldots \ldots \ldots \ldots . \ldots$ 
Monongahela Nav. Co. $v$. U. S., 148 U. S. 312. .278, 279, 287, 288, 290 Montana Co. $r$. St. Louis Min., etc., Co., 152 U. S. 160....... 293 Moore $v$. Huntington, 17 Wall. (U. S.) $417 \ldots \ldots \ldots \ldots \ldots \ldots 96$

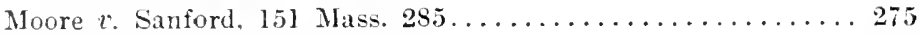
Moore $v$. State, 43 X. J. I. $203 \ldots \ldots \ldots \ldots \ldots \ldots .58,143,144.149$

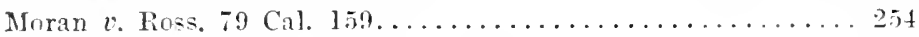

Moredock $r$. Kirhy, 118 Fed. Rep. 182............. 97 Morford $v$. Lnger. 8 lowa $\$ 2 \ldots \ldots \ldots \ldots \ldots \ldots \ldots \ldots \ldots \ldots \ldots \ldots . \ldots \ldots$ Morran's Steamship Co. 1. Louisiana Board of Health, 1]S C.S.

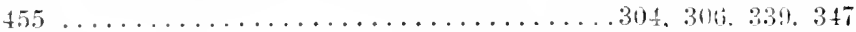
Murley $r$. Lake shore, ete., R. Co., 146 U. S. 162........150, 329 Morris $r$ Columbus, 102 dia. $702 \ldots \ldots \ldots \ldots \ldots \ldots \ldots \ldots \ldots \ldots$ Mound City Land, ete. Co. r. Millen, 170 Mo. 240. . . . . . 259, 265 Niount Hope Cemetery $r$. Boston, 6 is Mass. 509.......... 285

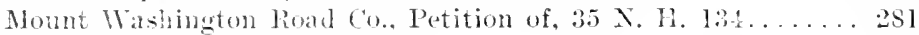

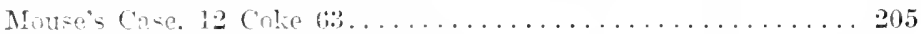

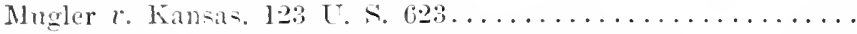
. ist, 181, 204, 308, 310, 336, 337, 346, 366, 371

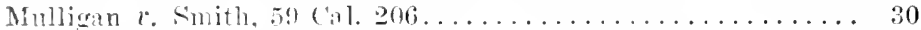

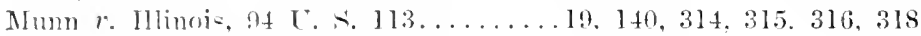

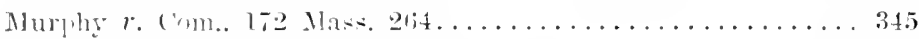

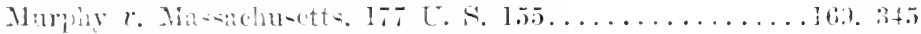

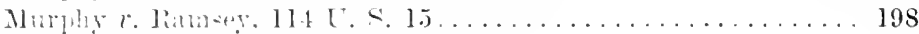

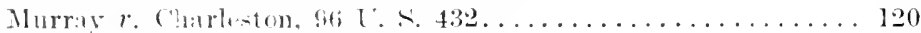
Muray $r$. Hobulen Land, ete., Co., 18 Ifow. (U. S.) 272..... $.16,26,52,53,72,162,233$

N.

Nashville, rite., R. Co. r. Alabama, 128 U. S. $96 \ldots \ldots \ldots \ldots \ldots 340$

Natal $r$. Lnuisiana, 139 C. S. $621 \ldots \ldots \ldots \ldots \ldots \ldots \ldots \ldots . \ldots \ldots$

National rotton Oil Co. r. Texas, 197 I. . . 115........37, 40, 358

Nationd Exel. Wank r. Wilcy, 195 C. S. $257 \ldots \ldots \ldots \ldots .85,96$

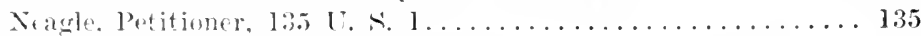

Newark, ete. Horse (ar R. Co. r. Hunt, 50 N. J. 1. $812 \ldots . .366$

Newhuryport Water ('o. r. Newburyport, 193 U. . .57. . . . 332

New England Mnt. L. Ins. ('o. r. Woolworth, 111 U. S. 146... 105

New Jersey r. Wilson. 7 ('ranch (L. S.) $164 \ldots \ldots \ldots \ldots \ldots$........ 15]

New Urleans r. Clark, 95 (T. S. 644.............. 159

Now Orleans r. Houston, 11! U. S. $265 \ldots \ldots \ldots \ldots \ldots \ldots \ldots .224$

New Orleans $r$. New Orleans Water Works Co., 142 T. S. 79. 328

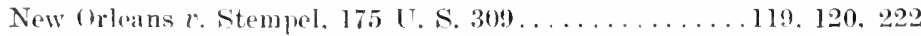

New Orleans ("ity, ate., R. Co. r. New Orleans, 143 1. S. 192. . 226

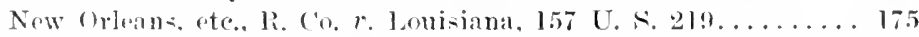

New Orleans Gas Co. r. Luiniana light ('o., 115 C. S. 650. 304,305 


\section{PAGE}

New Orleans Gas Light Co. v. Drainage Commission, 197 U. S.

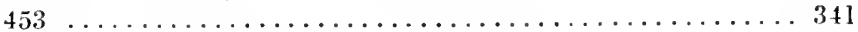

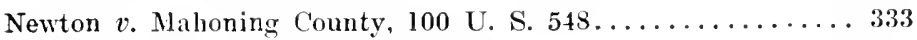

New York, Matter of, 135 N. Y. $253 \ldots \ldots \ldots \ldots \ldots \ldots \ldots 258,271$

New York $v$. Squire, 145 U. S. $175 \ldots \ldots \ldots \ldots \ldots \ldots \ldots 317,340$

New York $v$. Van De Carr, 18 S. S. 552............ 347,365

New York Cent. R. Co., Matter of, 66 N. Y. $407 \ldots \ldots \ldots \ldots .298$

New York El. R. Co. $v$. Fifth Nat. Bank, 135 U. S. 432 . . . . . 290

New York, etc., Grain, etc., Exch. $v$. Board of Trade, 127 11l. 153. 317

New York, ete., R. Co. $r$. Pristol. 151 U. S. $556 \ldots \ldots \ldots .37,340$

New York, etc., R. Co. $r$. Kip, 46 N. Y. $546 \ldots \ldots \ldots \ldots 258,269$

New York, etc., R. Co. $v$. New York, 165 U. S. $628 \ldots . . . \ldots .371$

New York L. Ins. Co. $v$. Cravens, 178 U. S. $399 \ldots \ldots \ldots \ldots \ldots .185$

Niagara Falls, ete., R. Co., In re, 108 N. Y. 375.... 257, 270, 275

vishimura Ekiu $v$. U. S., 142 U. S. $659 \ldots \ldots \ldots \ldots \ldots \ldots \ldots \ldots$

Nobles $v$. Georgia, 168 U. S. $405 \ldots \ldots \ldots \ldots \ldots \ldots \ldots \ldots \ldots 16$

Normal School Dist. $v$. Blodgett, 155 Ill. $441 \ldots \ldots \ldots \ldots \ldots \ldots, 16$

Norman $v$. Heist, 5 W. \& S. (Pa.) $171 \ldots \ldots \ldots \ldots \ldots \ldots \ldots 68$

North Dakota $v$. Nelson County, 1 N. Dak. 83............ 230

Northern Indiana R. Co. v. Michigan Cent. R. Co., 15 How. (U.

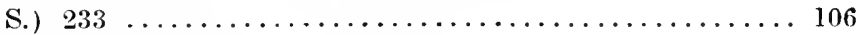

Northern Pac. R. Co. $v$. Ely, 197 U. S. $1 \ldots \ldots \ldots \ldots \ldots \ldots 173$

Northern Pac. R. Co. v. Smith, 171 U. S. $261,275 \ldots \ldots \ldots \ldots 276$

Northern Pac. R. Co. $v$. Townsend, 190 U. S. 297, 272..... 276

Northern Securities Co. v. U. S., 193 U. S. $197 \ldots \ldots \ldots \ldots \ldots 35$

Northern Transp. Co. $v$. Chieago, 99 U. S. $635 \ldots \ldots \ldots \ldots 293,295$

Northwestern Fertilizer Co. v. Hyde Park, 97 U. S. $659 . . . \ldots .336$

Norwood $r$. Baker, 172 U. S. 269.........33, 202, 213, 249, 282

O.

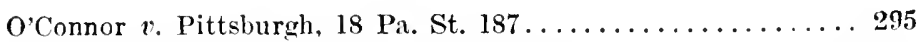

Ogden $r$. Saunders, 12 Wheat. (U. S.) $213 \ldots \ldots \ldots \ldots \ldots \ldots 176$

O'Hare $v$. Chieago, ete., R. Co., 139 111. 151........276, 298

Ohio $v$. Dollison. 194 U. S. $445 \ldots \ldots \ldots \ldots \ldots \ldots \ldots \ldots \ldots, 312$

Onio Oil Co. $v$. Indiana, 177 U. S. $190 \ldots \ldots \ldots \ldots \ldots \ldots \ldots \ldots 331$

OH Colony R. Co., Petitioner, 163 Mass. $356 \ldots \ldots \ldots \ldots \ldots \ldots 297$

Old Dominion Steamship Co. $r$. Virginia, 198 U. S. $305 \ldots \ldots \ldots 119$

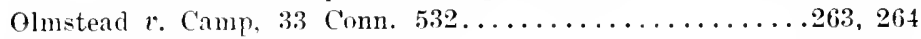

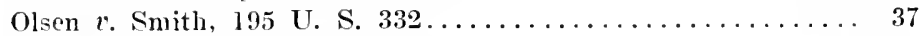

O'Neil $r$. Vermont, 144 L. S. $323 \ldots \ldots \ldots \ldots \ldots \ldots \ldots \ldots 18,34,168$

O'Reiley $r$. Kankakce Valley Drainage Co., 32 Ind. 169...... 27l

Orient Ins. Co. v. Daggs, 172 U. S. 557.......56, 101, 102, 185

Orignt $r$. Hedden. 155 U. S. $228 \ldots \ldots \ldots \ldots \ldots \ldots \ldots \ldots \ldots \ldots 242$

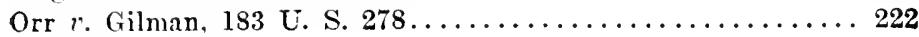


PAGE

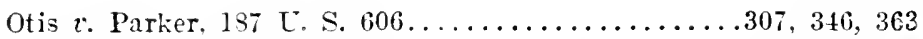
Ouseley $v$. Lehigh Valley Trust, ete., Co., 84 Fed. Rep. 602. . . 94

P.

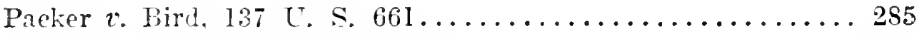

Palmer $r$. MeMahon, 133 C. S. 660.........80, 209, 237, 241

Palmer $x$. Tingle. 5j ohis St. $423 \ldots \ldots \ldots \ldots \ldots \ldots \ldots \ldots \ldots$

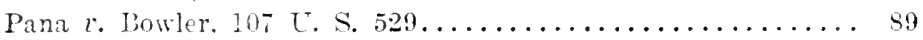

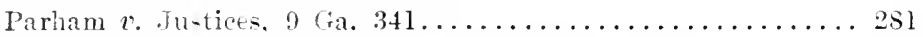

Parish r. East Cosst Celar Co., 133 X. Car. $473 \ldots . . \ldots \ldots \ldots 234$

Parker-bure. etc., Transp. Co. $\imath$. Parkersburg, 107 U. S. 691 ... 327

Parsons $v$. Distriet of Columbia. 170 U. S. $45 \ldots \ldots \ldots \ldots \ldots 248$

Pasadena r. Stim-on. 91 Cal. $233 \ldots \ldots \ldots \ldots \ldots \ldots \ldots \ldots \ldots . \ldots 29$

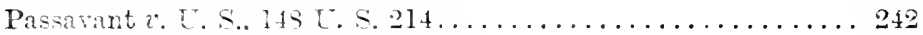

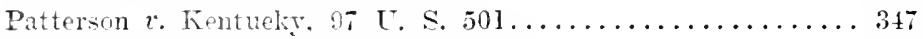

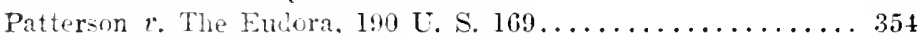

Paul $v$. Virminia, s Wall. (L. S.) $168 \ldots \ldots \ldots \ldots \ldots \ldots \ldots \ldots 101$

Panlsen $v$. Purtland. 149 C. S. $30 \ldots \ldots \ldots \ldots$. . 238, 239, 241, 248

Paulson v. Portland, 16 Oregon $450 \ldots \ldots \ldots \ldots \ldots \ldots \ldots \ldots . \ldots 3$

Pearsall $r$ Great Northern R. Co., 161 U. S. 673.......... 143

Pearion $r$. Yewdall, 95 L. S. $296 \ldots \ldots \ldots \ldots \ldots \ldots \ldots \ldots$

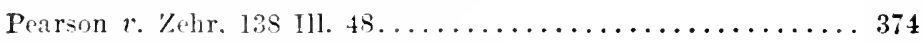

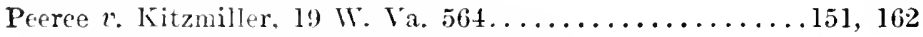

Peik $v$. Chieago, cte., F. Co., 94 U. S. $164 \ldots \ldots \ldots \ldots \ldots \ldots \ldots 318$

Pembina Consol. Silver Min., ete., Co. $v$. Pennsylvania, 125 U. S.

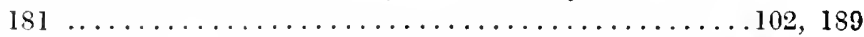

Penn 2 . Baltimore, 1 Ves. 444, 2 White \& T. Lead. Cas. (4th Am.

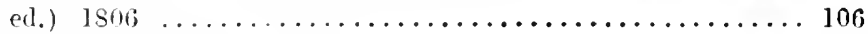

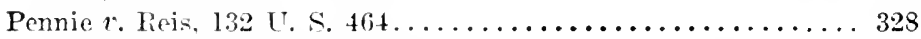

Pennoyer r. Neff, 95 U. S. $714 \ldots \ldots \ldots \ldots \ldots \ldots \ldots \ldots \ldots \ldots$ .52, 59, 59, 85, 89, 40, 91, 94, 95, 100, 106, 109, 112, 122

Pennstrania R. Co. r. Miller, 132 U. S. $75 \ldots \ldots \ldots \ldots \ldots \ldots \ldots .295$

Perple r. Aliromlack R. ('o., l60 N. Y. $225 \ldots \ldots \ldots \ldots \ldots .297,299$

Periple $r$. Armulere. 10.5 N. Y. $123 \ldots \ldots \ldots \ldots \ldots \ldots \ldots \ldots \ldots$

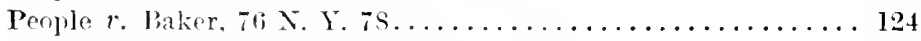

People $r$. lieattie, gf N. Y. App. Div. $383 \ldots \ldots \ldots \ldots \ldots \ldots \ldots 356$

People $r$. Boarl of Health. 140 N. Y. 1.............373. 374

Penple v. Postrin, ete. R. Co., 70 N. Y. 569.......... 340

Pesple $r$. Brorklyn. 4 N. Y. 419...........209, 213, 283

People $v$. Purke, l] Wend. (N. Y.) $129 \ldots \ldots \ldots \ldots \ldots \ldots \ldots \ldots 136$

People $v$. Cannon, 139 N. Y. 32................ 181

People v. Ewer. 141 N. Y. $129 \ldots \ldots \ldots \ldots \ldots \ldots \ldots \ldots \ldots \ldots 347$

People 2 . Greene, s.j X. Y. App. Div. $400 \ldots \ldots \ldots \ldots \ldots \ldots \ldots 311$

People $v$. Hayes, 140 N. Y. $484 \ldots \ldots \ldots \ldots \ldots \ldots \ldots \ldots \ldots \ldots$ 
PAGE

People $v$. Hurlbut, 24 Mich. $63 \ldots \ldots \ldots \ldots \ldots \ldots \ldots \ldots \ldots \ldots 71$

People $\imath$. Kerr, 27 N. Y. $188 \ldots \ldots \ldots \ldots \ldots \ldots \ldots \ldots \ldots . \ldots \ldots 4$

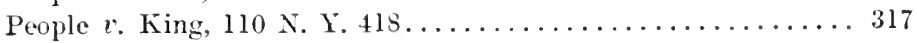

People $v$. Marx, 99 N. Y. 377................. 140,349

People $\imath$. Merrill, 2 Park. Crim. (N. Y.) $590 \ldots \ldots \ldots \ldots \ldots \ldots 136$

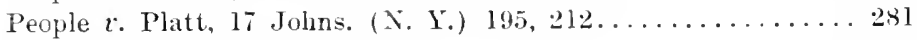

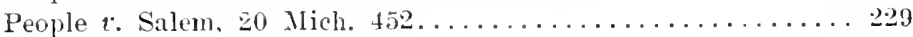

People $r$. Simon, 176 111. $165 \ldots \ldots \ldots \ldots \ldots \ldots \ldots \ldots \ldots \ldots \ldots \ldots$

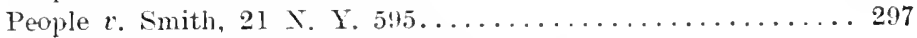

People $r$. Township Board, 20 Mich. 452........... 257

People $r$. Turner, 11 . X. Y. 227................. 182

People $r$. Van De Carr, 178 N. Y. $425 \ldots \ldots \ldots \ldots \ldots \ldots \ldots \ldots 33$

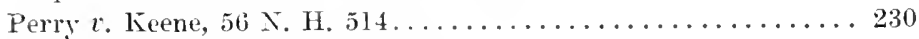

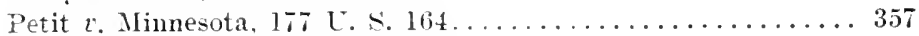

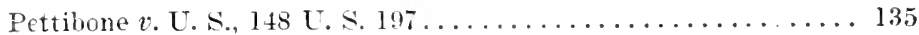

Phelps $v$. MeDonald, 99 U. s. $298 \ldots \ldots \ldots \ldots \ldots \ldots \ldots \ldots \ldots$

Pliladelphia, ete., R. Co. $v$. Maryland, $10 \mathrm{How}$ ( $\mathrm{C}^{\dagger}$. S.) $376 \ldots 226$

Philadelphia F. Assoc. $x$. New York, 119 L. S. $110 \ldots \ldots \ldots \ldots 189$

Picquet $v$. Swan, 5 Mason (U. S.) $35 \ldots \ldots \ldots \ldots \ldots \ldots 75.87,89$

Pillow $v$. Roberts, 13 How. (U. S.) $472 \ldots \ldots \ldots \ldots \ldots \ldots \ldots \ldots$

Piqua Branch of State Bank $v$. Knoop, 16 How. (L. S.) $369 \ldots 226$

Pittsburg, etc., R. Co. $v$. Benwood Iron Works, 31 W. Va. $710 \ldots 270$

Pittsburgh $v$. Scott, 1 Pa. St. $309 \ldots \ldots \ldots \ldots \ldots \ldots \ldots \ldots \ldots 258$

Pittsburgh, etc., Coal Co. $v$. Bates, 156 U. S. $577 \ldots \ldots \ldots \ldots 220$

Pittsburgh, etc., R. Co. $v$. Backus, 154 U. S. $421 \ldots \ldots \ldots \ldots$

$63,81,211,224,225,237,239$

Pittsburgh, etc., R. Co. $v$. Board of Public Works, 172 U. S. 45 . . 241

Plessy $v$. Ferguson, 163 U. S. $550 \ldots \ldots \ldots \ldots \ldots \ldots \ldots \ldots$. 306,308

Plumley $v$. Massachusetts, 155 U. S. $461 \ldots \ldots \ldots \ldots \ldots \ldots \ldots 349$

Pollock $v$. Farmers' Loan, etc., Co., 157 U. S. $429 \ldots \ldots \ldots \ldots$. . 217

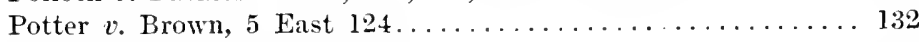

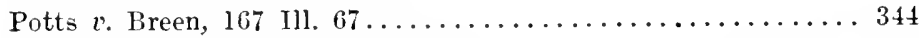

Powell $v$. Pennsylvania, 127 U. S. $677 \ldots \ldots \ldots \ldots \ldots 140,306,349$

Powers, Matter of, 29 Mich. $504 \ldots \ldots \ldots \ldots \ldots \ldots \ldots \ldots \ldots \ldots . \ldots \ldots$

Powers $r$. Chesapeake, etc., R. Co., 169 U. S. $98 \ldots \ldots \ldots \ldots . . .65$

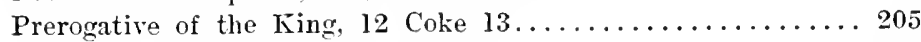

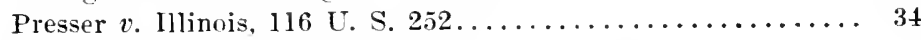

Protector 2 . Colchester, Style $447 \ldots \ldots \ldots \ldots \ldots \ldots \ldots \ldots \ldots 75$

Providence Bank $v$. Billings, 4 Pet. (U. S.) $514 \ldots \ldots \ldots \ldots \ldots 226$

Provident Sav. Inst. $v$. Jersey City, 113 U. S. 506. .152, 176, 249, 359

Public Clearing House $v$. Coyne, 194 U. S. $497 \ldots \ldots \ldots \ldots . . . .40,369$

Pullman's Palace Car Co. $v$. Pennsylvania, 141 U. S. $18 \ldots \ldots \ldots$ $.119,120,217,218,224,225$

Pumpelly v. Green Bay, etc., Canal Co., 13 Wall. (U. S.) $166 \ldots 292$ 
R.

PAGE

Railroad Commission Cases, 116 U. S. $307 \ldots \ldots \ldots \ldots \ldots . \ldots 5,319$

Raleigh $r$. Pearce, 110 N. Car. $32 \ldots \ldots \ldots \ldots \ldots \ldots \ldots \ldots . \ldots 213$

Raleigh, ete., R. Co. l. Davis, 2 Der. \& B. L. 19 ( N. Car.) 451 . . 290

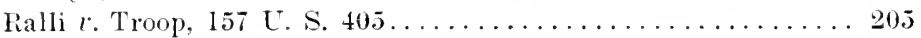

lialya Market Co. $v$. Armour, 102 Fed. Rep. $530 \ldots \ldots \ldots \ldots \ldots 100$

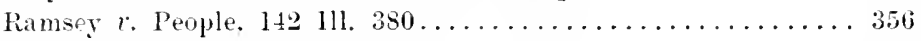

Randall $r$. Kreiger. 23 Wall. (U. S.) $137 \ldots \ldots \ldots \ldots \ldots \ldots .157,155$

Passmussen $t$. U. S., 197 U. S. $516 \ldots \ldots \ldots \ldots \ldots \ldots 197,198,200$

Raverty $t$. Fridge, 3 MeLean (U. S.) $230 \ldots \ldots \ldots \ldots \ldots \ldots \ldots 158$

Reagan $r$. Farmers' L. \& T. Co., 154 U. S. 362 . . . 393, 305, 320, 324

Receiver of State Bank 1 . Plainfield First Nat. Bank, 34 N. J. Eq.

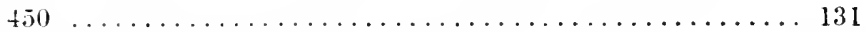

Red River Valley Nat. Bank v. Craig, 181 U. S. $543 \ldots \ldots \ldots \ldots 175$

Rees $r$. Watertown. 1!) Wall. (C. S.) $107 \ldots \ldots \ldots \ldots \ldots \ldots$. . 212

Reetz $v$. Michigan, 188 C. S. $505 \ldots \ldots \ldots \ldots \ldots \ldots \ldots \ldots \ldots$

.52, $73,80,81,84,163,303,334,347,371$

Reit r. Coloritlo, 187 [. S. 137.................. 304

Reinach $v$. Atlantic, ete. R. Co., 58 Fed. Rep. $43 \ldots \ldots \ldots \ldots \ldots$. . 89

Renaud $r$. Abbott. 116 U. S. $277 \ldots \ldots \ldots \ldots \ldots \ldots \ldots \ldots \ldots$

Re-publica $r$. Sparhask, I Dall. (Pa.) $3.5 \ldots \ldots \ldots \ldots \ldots \ldots \ldots .20 .5$

Rex $r$. Combridge University, 1 Stra. $5.58 \ldots \ldots \ldots \ldots \ldots \ldots \ldots$,

Rex $r$ Oxf.ril, Palmer $453 \ldots \ldots \ldots \ldots \ldots \ldots \ldots \ldots \ldots \ldots \ldots$

Fhole lstand Suburben R. Co.. In re, 22 R. I. $455 \ldots \ldots \ldots \ldots .255$

Rich $r$. Flanders. 39 X. H. $304 \ldots \ldots \ldots \ldots \ldots \ldots \ldots \ldots \ldots \ldots 180$

Richmond, ete., R. Co. r. Richmond, 96 U. S. 521 ...... 151, 203

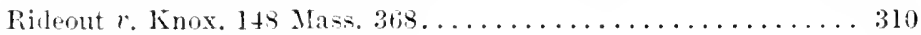

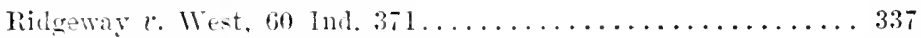

Rigrina. Ex p., 13t Fexl. Rep. $404 \ldots \ldots \ldots \ldots \ldots \ldots \ldots 36,45,46$

Rigrins r. T. S.. 199 L. S. $547 \ldots \ldots \ldots \ldots \ldots \ldots \ldots \ldots \ldots \ldots 47$

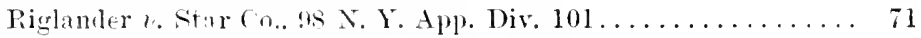

Rimey $x$ limer 127 I. Y. $408 \ldots \ldots \ldots \ldots \ldots \ldots \ldots \ldots \ldots$

Poad in Plumcreek Tp.. In re. 110 Pa. St. $544 \ldots \ldots \ldots \ldots \ldots .264$

liohards $r$ lamb. 127 U. S. $58 \ldots \ldots \ldots \ldots \ldots \ldots \ldots \ldots \ldots 161$

Robertion, In re, ]56 I. S. $183 \ldots \ldots \ldots \ldots \ldots \ldots \ldots \ldots \ldots \ldots . \ldots \ldots$

Robertson 1. Baldwin. 16.5 U. S. $275 \ldots \ldots \ldots \ldots \ldots \ldots \ldots \ldots \ldots 35$

Rochester r. West. lit X. Y. 510................ 311

Rochester. ete. 1i. Co.. Matter of, 110 X. Y. 119......269. 270

Roderigas 1. Fast River Sar. Inst., 63 N. Y. 460.76 N. Y. 316. 83

Bugers r. Peck. 199 T. S. 105. . . . . . . . . . . . . . . 164. 169

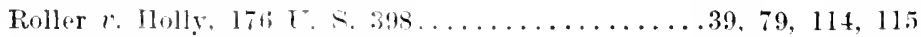

Rolph r. Faren. 7 X. Dak. 640.................. 202

Rione $r$. llunely, 4 (ranch (I'. S.) $241 \ldots \ldots \ldots \ldots \ldots \ldots \ldots$ \&Q

Rousillon $r$. Rousilion. It (h. D. $370 \ldots \ldots \ldots \ldots \ldots \ldots \ldots$ 


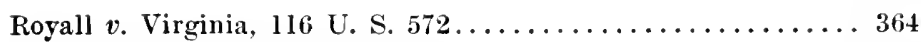

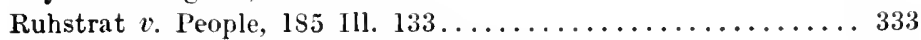

Russell $v$. New York, 2 Den. (N. Y.) $461 \ldots \ldots \ldots \ldots \ldots \ldots \ldots$

Ryan $v$. Louisville, etc. Terminal Co., 102 Tenn. 111....... 275

Ryers, Matter of, 72 N. Y. $1 \ldots \ldots \ldots \ldots \ldots \ldots \ldots \ldots \ldots 259,265$

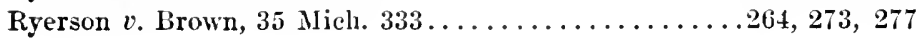

S.

St. Anthony Falls Water Power Co. v. St. Paul Water Com'rs,

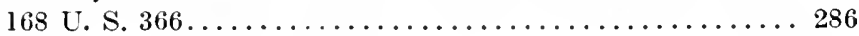

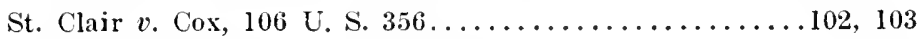

St. Joseph Tp. $v$. Rogers, 16 Wall. (U. S.) $644 \ldots \ldots \ldots \ldots \ldots .158$

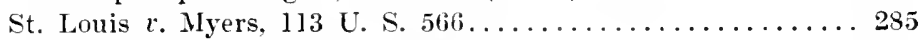

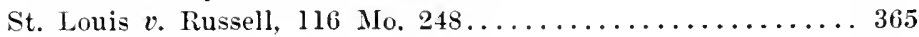

St. Louis $v$. Rutz, 138 U. S. $226 \ldots \ldots \ldots \ldots \ldots \ldots \ldots \ldots \ldots 285$

St. Louis $v$. Western Union Tel. Co., 148 U. S. 92......... 284

St. Louis, cte., R. Co. $v$. Gill, 156 U. S. $649 \ldots \ldots \ldots 320,322,378$

St. Louis, ete., R. Co. $v$. Matthews, 165 U. S. $1 \ldots \ldots \ldots 186,342$

St. Louis, etc., R. Co. $v$. Paul, 173 U. S. $404 \ldots \ldots \ldots \ldots . \ldots 349,350$

St. Paul, etc., R. Co., Matter of, 34 Minn. $227 \ldots \ldots \ldots \ldots \ldots 298$

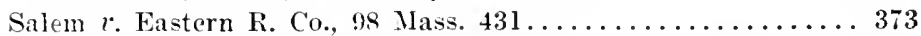

Sand Creek Lateral Irrigation Co. $r$. Davis, 17 Colo. 326..... 298

San Diego Land, etc., Co. $v$. Jasper, 189 U. S. $439 \ldots \ldots \ldots \ldots \ldots 323$

San Diego Land, etc., Co. $v$. National City, 174 U. S. $739 \ldots \ldots$ $.33,282,317,320,323,324,325,378$

San Diego Water Co. $r$. San Diego, 118 Cal. 556......... 378

Sanda $r$. Manistee River Imp. Co., 123 U. S. 2Ss........341, 367

San Francisco, etc., R. Co. v. Leviston, 134 Cal. 412....... 298

San Mateo County $r$. Southern Pac. R. Co., 116 U. S. $138 \ldots \ldots 22$

Santa Clara County $\ell$. Southern Pac. R. Co., 18 Fed. Rep. 385. 21

Santa Clara County r. Southern Pac. R. Co.. 118 C. S. $394 \ldots . .189$

Saranac Land, ete., Co. $v$. Comptroller, 17 U. S. $318 \ldots . \ldots \ldots 182$

Satterlee $v$. Mathewson, 2 Pet. (U. S.) $390 \ldots \ldots \ldots 149,151,152$

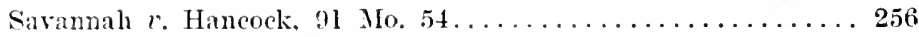

Saronnah, ete., R. Co. $r$. Savannal, 198 U. S. $392 \ldots \ldots \ldots \ldots 212$

Savin. Petiticner, 131 U. S. $267 \ldots \ldots \ldots \ldots \ldots \ldots \ldots \ldots, 170$

Savines, etc. Soc. $r$. Multnomah County. 169 U. S. $421 \ldots \ldots .220$

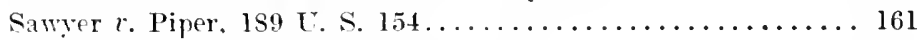

Schauble $r$. Schulz, 137 Fed. Rep. $389 \ldots \ldots \ldots \ldots \ldots \ldots \ldots \ldots$. 172

Schollenberger. $E_{x} p_{.,} 96$ U. S. $369 \ldots \ldots \ldots \ldots \ldots \ldots \ldots \ldots 102,105$

Schollenberger $r$. Pennsylvania. 171 U. S. $1 \ldots \ldots \ldots \ldots \ldots 304,349$

Schuster $r$. Sanitary Dist., 177 11l. $626 \ldots \ldots \ldots \ldots \ldots \ldots \ldots . \ldots \ldots$

Schwab $r$. Berggren, 143 U. S. $442 \ldots \ldots \ldots \ldots \ldots \ldots \ldots \ldots \ldots$

Scott $x$. MeNeal. 154 U. S. $34 \ldots \ldots \ldots \ldots \ldots \ldots 28,39,51,52,88$ 
PAGE

Scott $v$. Toledo, 36 Fed. Rep. $385 \ldots \ldots \ldots \ldots \ldots \ldots \ldots \ldots \ldots 2$

Scottish Union. etc., Ins. Co. $v$. Bowland, 196 U. S. $611 \ldots \ldots .233$

Scranton $v$. Wheeler, 179 U. S. $1+1 \ldots \ldots \ldots \ldots \ldots \ldots \ldots \ldots . \ldots 29$

Scranton Gas, ete., Co. $v$. Northern Coal, etc., Co., 192 Pa. St.

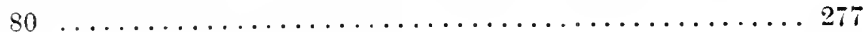

Seribner $v$. Fisher. 2 Gray (Mass.) $43 \ldots \ldots \ldots \ldots \ldots \ldots \ldots \ldots \ldots 2$

Scudder $v$. Trenton Delaware Falls Co., 1 N. J. Eq. 694....... 264

Searl $v$. School Dist. No. 2, 133 C. S. $553 \ldots \ldots \ldots \ldots \ldots \ldots \ldots . \ldots \ldots 3$

Sears $r$. Cottrell, 5 Mich. $251 \ldots \ldots \ldots \ldots \ldots \ldots \ldots \ldots \ldots \ldots \ldots$

Seattle $v$. Kelleher, 195 U. S. $351 \ldots \ldots \ldots \ldots \ldots \ldots \ldots \ldots 247$

Secombe, Ex p., 19 How. (C. S.) $9 \ldots \ldots \ldots \ldots \ldots \ldots \ldots \ldots 171$

Secombe $r$. Milwaukee. etc., F. Co., 23 Wall. (C. S.) 10S. .254, 257

Security Trust Co. $r$. Dorld, 173 U. S. $628 \ldots \ldots \ldots \ldots \ldots \ldots \ldots 131$

Sentell $r$. New Orleans, etc., R. Co., 166 U. S. 705......... 330

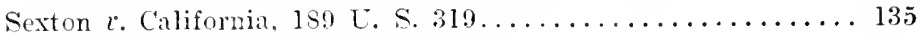

Shaffer $x$. Lnion Min. Co.. 55 MI]. $74 \ldots \ldots \ldots \ldots \ldots \ldots \ldots \ldots 6$

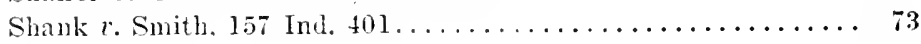

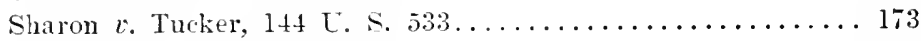

Sharp $v$. U. S., 191 U. S. $3+1 \ldots \ldots \ldots \ldots \ldots \ldots \ldots \ldots \ldots \ldots . \ldots \ldots$

Shawhan $r$. Wherritt, 7 How. (L. S.) $613 \ldots \ldots \ldots \ldots \ldots \ldots \ldots 131$

Shepard $x$ librron, 194 L. S. $553 \ldots \ldots \ldots \ldots \ldots \ldots \ldots \ldots \ldots .252$

Shively r. Bowlby, 152 L. S. 1................ 285

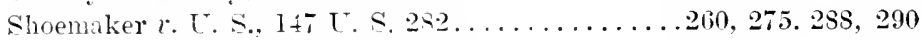

Shumate $x$. ITeman. 181 [. \&. $402 \ldots \ldots \ldots \ldots \ldots \ldots \ldots \ldots \ldots 251$

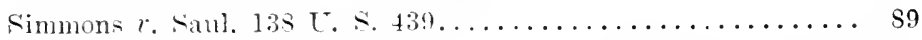

Simon $r$ Craft, 182 [. S. $431, \ldots \ldots \ldots \ldots 39,76,77,160,344,371$

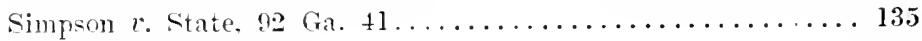

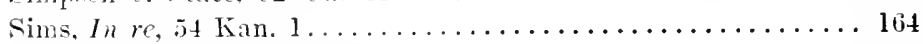

Sing Lee, E.r p., 96 Cal. $354 \ldots \ldots \ldots \ldots \ldots \ldots \ldots \ldots \ldots \ldots \ldots 6$

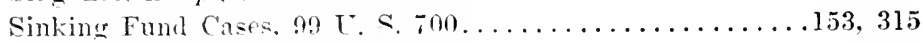

Simnickson $x$. Johnson, 17 X. J. L. $129 \ldots \ldots \ldots \ldots \ldots \ldots \ldots \ldots 279$

Sioux Falls $r$. Kiely, os. Dak. $62 \ldots \ldots \ldots \ldots \ldots \ldots \ldots \ldots \ldots \ldots$

Skameateles Waterworks Co. r. Skaneateles, 184 U. S. $354 . \ldots 332$

Slaighter-Jouse Cases. 16 Wall. (L.S.) $36.20,22,36,135,141,347$

Smalley $x$. Gearing, 121 Mich. $190 \ldots \ldots \ldots \ldots \ldots \ldots \ldots \ldots \ldots$

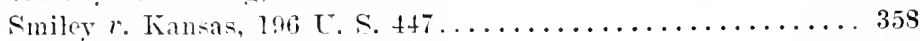

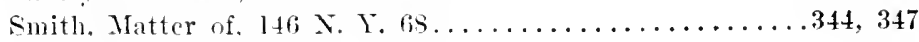

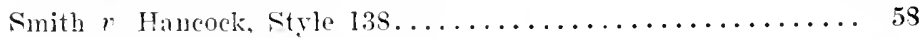

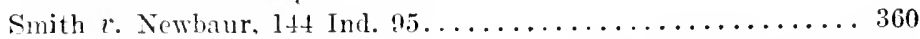

Simyth $x$. Ames, 169 C. S. $466 \ldots \ldots \ldots \ldots \ldots 189,320,321,322,323,324$

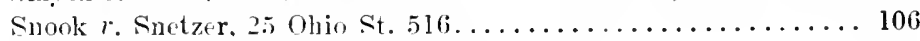

Sinciety, etc., $r$. Wheeler, 2 Gall. (U. S.) $105 \ldots \ldots \ldots \ldots \ldots \ldots 146$

Soon Hing $v$. Crowley, 113 T. S. 703............312, 313, 345

South Carolina $r$ U. S., 199 U. S. $437 \ldots \ldots \ldots \ldots \ldots \ldots \ldots 223$

South Carolina R. Co. $r$. Blake, 9 Rich. L. (S. Car.) $228 \ldots \ldots .298$ 
Southern 1llinois, etc., Bridge Co. $v$. Stone, 174 Mo. 1....... 258

Southern Pac. R. Co. v. Board of Railroad Com'rs, 78 Fed. Rep.

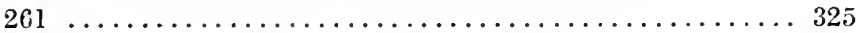

Southern Pac. R. Co. v. Denton, 146 U. S. $202 \ldots \ldots \ldots \ldots \ldots . . \ldots 3$ Spencer $v$. Merchant, 125 L. S. $345 \ldots \ldots \ldots \ldots \ldots \ldots 213,241,248$ Spies $v$. lllinois, 123 U.S. $131,166 \ldots \ldots \ldots \ldots \ldots \ldots \ldots \ldots, 34$ Springer $v$. U. S., 102 U. S. $586 \ldots \ldots \ldots \ldots \ldots \ldots \ldots \ldots \ldots \ldots \ldots$ Spring Valley Water Works $v$. San Mateo Water Works, 64 Cal.

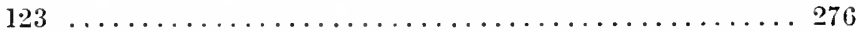

Spring Valley Water Works $v$. Sehottler, 110 U. S. 347..73, 241, 317 Springville $v$. Thomas, 166 U. S. $707 \ldots \ldots \ldots \ldots \ldots \ldots \ldots \ldots$

Stanislaus County $r$. San Joaquin, etc., Canal, etc., Co., 192 U. S.

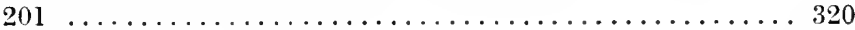

State $v$. Addington, 77 Mo. $110 \ldots \ldots \ldots \ldots \ldots \ldots \ldots \ldots \ldots \ldots$

State $v$. Associated Press, 159 Mo. $410 \ldots \ldots \ldots \ldots \ldots \ldots 315,317$

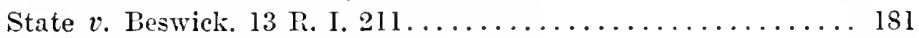

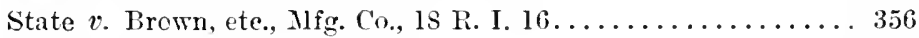

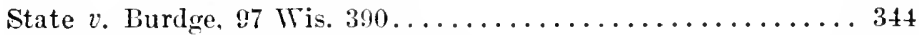

State $v$. Caldwell, 115 N. Car. $794 \ldots \ldots \ldots \ldots \ldots \ldots \ldots 135,136$

State $v$. Campbell, 64 N. H. $402 \ldots \ldots \ldots \ldots \ldots \ldots \ldots \ldots \ldots . \ldots \ldots$

State $v$. Central New Jersey Telephone Co., 53 N. J. L. $341 \ldots .257$

State $r$. Cutshall, 110 N. Car. $552 \ldots \ldots \ldots \ldots \ldots \ldots \ldots \ldots \ldots$

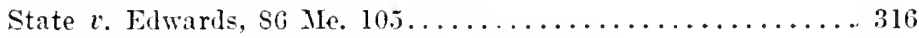

State $v$. Fire Creek Coal, ete., Co., 33 W. Va. $188 \ldots \ldots \ldots \ldots 355$

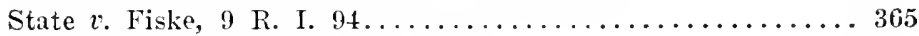

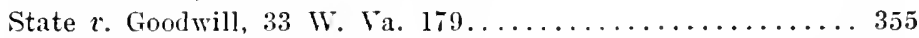

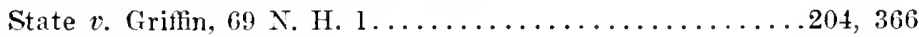

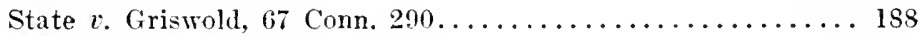

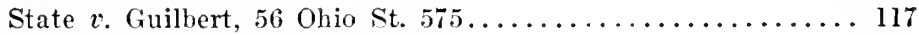

State $v$. Hay, 126 N. Car. $999 \ldots \ldots \ldots \ldots \ldots \ldots \ldots \ldots \ldots \ldots \ldots$

State $v$. Hazelton, etc., R. Co., 40 Ohio St. $504 \ldots \ldots \ldots \ldots \ldots 270$

State $v$. Height, 117 Iowa $650 \ldots \ldots \ldots \ldots \ldots \ldots \ldots \ldots \ldots \ldots \ldots \ldots$

State $v$. Higgins, 13 R. I. $330 \ldots \ldots \ldots \ldots \ldots \ldots \ldots \ldots \ldots \ldots \ldots$

State $v$. Julow, 129 Mo. $163 \ldots \ldots \ldots \ldots \ldots \ldots \ldots \ldots \ldots \ldots \ldots \ldots$

State $v$. Kartz, 13 R. I. $528 \ldots \ldots \ldots \ldots \ldots \ldots \ldots \ldots \ldots \ldots \ldots \ldots$

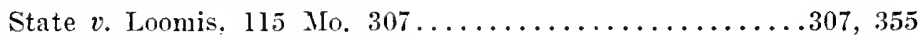

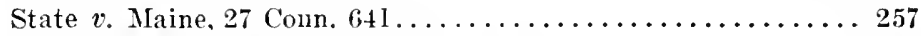

State $v$. Marshall, 64 N. H. $549 \ldots \ldots \ldots \ldots \ldots \ldots \ldots \ldots \ldots . \ldots 349$

State $v$. Minnesota, etc., R. Co., 76 Minn. 469, 479....... 340

State $v$. Moore, 104 X. Car. $714 \ldots \ldots \ldots \ldots \ldots \ldots \ldots \ldots \ldots, 348$

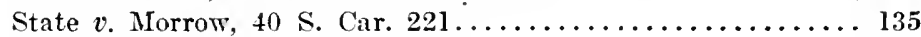

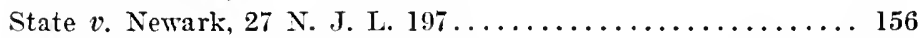

State $v$. Newark, 37 N. J. L. $415 \ldots \ldots \ldots \ldots \ldots \ldots 202,213,249$

State $v$. O'Connor, 3 Kan. App. $594 \ldots \ldots \ldots \ldots \ldots \ldots \ldots \ldots 188$

State $v$. Peel Splint Coal Co., 36 W. Va. $802 \ldots \ldots \ldots \ldots \ldots . \ldots 36$ 
PAGE

State $v$. Polk County, 87 Minn. $325 \ldots \ldots \ldots \ldots \ldots \ldots \ldots \ldots 259$

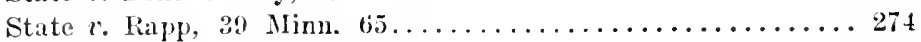

State $r$. Stewart, 74 Wis. $620 \ldots \ldots \ldots \ldots \ldots \ldots \ldots \ldots \ldots \ldots 259$

State $v$. Summerfield, 107 N. Car. $895 \ldots \ldots \ldots \ldots \ldots \ldots \ldots \ldots \ldots 3$

State $i$. Tenant, 110 X. Car. 609................. 303

State $v$. Thomas, 47 Conn. $546 \ldots \ldots \ldots \ldots \ldots \ldots \ldots \ldots \ldots \ldots$

State Railroad Tax Cases, 92 U. S. 575. 63, 84, 120, 209. 210, 215, 224

State Tax on Foreign Held Bonds, 15 Wall. (U. S.) $300 \ldots 119,209$

Stearns $r$. Barre, 73 Vt. $281 \ldots \ldots \ldots \ldots \ldots \ldots \ldots \ldots \ldots 259,275$

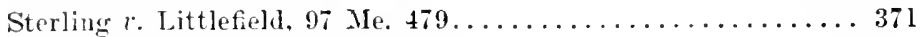

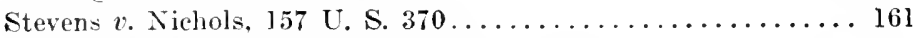

Stockton 1 . Baltimore, ete., R. Co., 32 Fell. Rep. 19.....254, 285

Stockton $r$. Central R. Co., 50 N. J. Eq. 52........... 259

Stockton, etc., R. Co. v. Stockton, 41 Cal. $147 \ldots \ldots \ldots \ldots \ldots \ldots 27$

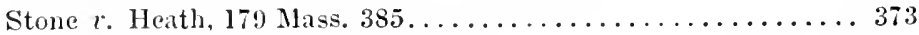

Stone $r$. Mississippi, 101 U. S. $814 \ldots \ldots \ldots \ldots \ldots \ldots 304,336,346$

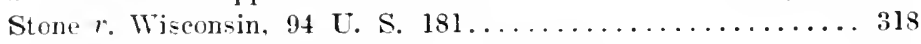

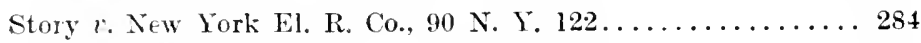

Stoullinger $v$. Newark, 28 N. J. Eq. $187 \ldots \ldots \ldots \ldots \ldots \ldots \ldots . \ldots 259$

Strain 2 Chicago Portrait Co., 126 Fed. Rep. $831 \ldots \ldots \ldots \ldots \ldots 104$

Stratton $v$. Morris, 89 Tenn. $497 \ldots \ldots \ldots \ldots \ldots \ldots \ldots \ldots . \ldots \ldots$

Streitwolf $r$. Streitwolf, 181 U. S. $179 \ldots \ldots \ldots \ldots \ldots \ldots \ldots \ldots 22$

Strole $r$. Washer, 17 Oregon $53 \ldots \ldots \ldots \ldots \ldots \ldots \ldots \ldots \ldots \ldots . \ldots \ldots$

Stuart r. Palmer, $7 t$ N. Y. $183 \ldots \ldots \ldots \ldots \ldots \ldots \ldots \ldots \ldots$ s2

Sturges r. Crowninshield, 4 Wheat. (U. S.) $122 \ldots \ldots 133,150,176$

Suger $r$. Thornton, 132 U. S. $524 \ldots \ldots \ldots \ldots \ldots \ldots \ldots \ldots . \ldots 2,100$

Sully $r$. American Nat. Bank, 179 U. S. $289 \ldots \ldots \ldots \ldots \ldots \ldots 190$

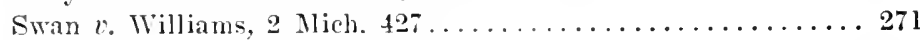

Sweny r. 1lunter, 145 1'a. St. $363 \ldots \ldots \ldots \ldots \ldots \ldots \ldots \ldots \ldots \ldots \ldots$

Sweet $r$. Rechel. 159 U. S. $380 \ldots \ldots \ldots \ldots \ldots \ldots 205,206,259,291$

Swift $v$. U. S., 196 U. S. $375 \ldots \ldots \ldots \ldots \ldots \ldots \ldots \ldots \ldots \ldots \ldots$

T.

Tabor r. Warl. 83 N. Car. 291 ................. 160

Talbot r. IJudson, 16 Gray (Mass.) 417......263, 269, 271, 273

Talton $v$. Mayes, 163 U. S. $376 \ldots \ldots \ldots \ldots \ldots \ldots \ldots \ldots \ldots$

Tappan r. Mierchants' Nat. Bank, 19 Wall. (U. S.) 490...119, 120

Tay $r$. Haw ]

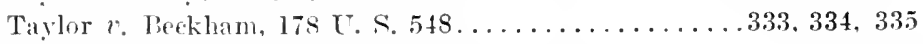

Taylor $r$. Columbian $[n s$. (n.. 14 Allen (Mass.) $353 \ldots \ldots \ldots \ldots 133$

Taylor $r$. Porter \& 1 ill (N. Y.) $140 \ldots \ldots \ldots \ldots \ldots \ldots, 264$

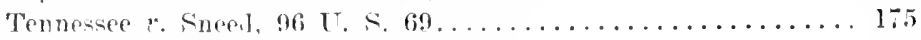

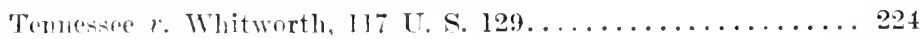

Terry, lix $\%$, 128 U. S. $299 \ldots \ldots \ldots \ldots \ldots \ldots \ldots \ldots \ldots \ldots \ldots$ 
Terry $\because$ Anderson, 95 U. S. $628 \ldots \ldots \ldots \ldots \ldots \ldots \ldots \ldots 17173$

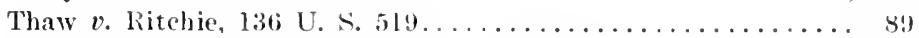

Thomson $t$. Lee County, 3 Wall. (L. S.) $327 \ldots \ldots \ldots \ldots \ldots \ldots 158$

Thompson i. Missouri, $17 !$ U. ... $3 \$ 0 \ldots \ldots \ldots \ldots \ldots \ldots \ldots 147$

Thompson $v$. Perrine. 103 U. S. $806 \ldots \ldots \ldots \ldots \ldots \ldots \ldots \ldots$

Thompson $r$ Ctah, 170 U. ... $343 \ldots \ldots \ldots \ldots \ldots \ldots \ldots, 147,200$

Thompson $r$. Whitman. Is Wall. (L. \$.) $457 \ldots \ldots \ldots \ldots \ldots .87$

Thorington $r$. Montgomery, 14t T. s. $490 \ldots \ldots \ldots \ldots \ldots \ldots$. 161

Thormann $r$. Frame, 176 U. \$. $350 \ldots \ldots \ldots \ldots \ldots \ldots \ldots . . \ldots 7$

Thorpe $v$. Rutland, cte., R. C'o., 27 Vt. $140 \ldots \ldots \ldots \ldots \ldots \ldots 2113$

Tide Water Co. $v$. Coster, 18 N. J. Eq. $518 \ldots \ldots \ldots \ldots \ldots \ldots \ldots . . .249$

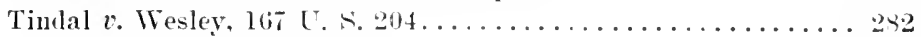

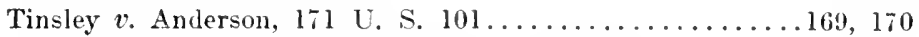

Title Guarantee, etc., Co. r. Wren, 35 Oregon $62 \ldots \ldots \ldots \ldots \ldots 360$

Tivan, In re, 5 B. \& S. 679,117 E. C. L. $679 \ldots \ldots \ldots \ldots \ldots \ldots 134$

Toltec Ranch Co. $v$. Cook, 191 U. S. $532 \ldots \ldots \ldots \ldots \ldots \ldots \ldots$

Tonawanda $v$ Lyon, 181 U. S. $389 \ldots \ldots \ldots \ldots \ldots \ldots \ldots 251,252$

Townsend, Matter of, 39 N. Y. $171 \ldots \ldots \ldots \ldots \ldots \ldots \ldots \ldots 27$

Townsend $v$. Jemison, 9 How. (U. S.) $407 \ldots \ldots \ldots \ldots \ldots 171,173$

Tracy $v$. Elizabethtown, ete., R. Co., $80 \mathrm{Ky}$. 259, 266.....278, 298

Trenton, etc., Turnpike Co. $r$. American, etc., News Co., 43

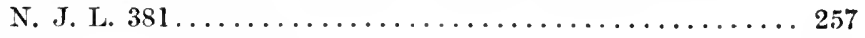

Trono $v$. U. S., 199 U. S. $521 \ldots \ldots \ldots \ldots \ldots \ldots \ldots \ldots \ldots \ldots \ldots$

Tullis v. Lake Erie, etc., R. Co., 175 U. S. $348 \ldots \ldots \ldots \ldots \ldots . .313$

Turlock Irrigation Dist. $v$. Williams, 76 Cal. $360 \ldots \ldots \ldots \ldots .266$

Turner $v$. New York, 168 C. S. 90.............. 172. 182

Turpin $v$. Lemon, 187 U. S. $57 \ldots \ldots \ldots \ldots \ldots \ldots$ 180, 182, 238, 239

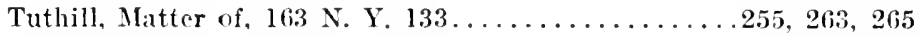

Tuttle $r$. Noore, 3 Indian Ter. $712 \ldots \ldots \ldots \ldots \ldots \ldots \ldots \ldots 256.263$

Twenty-third St. R. Co. $v$. Tax Com'rs, 199 U. S. $53 \ldots \ldots \ldots .227$

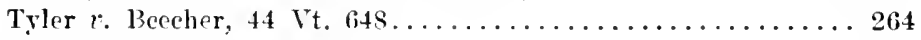

Tyler $v$. Judges, 175 Mass. $71 \ldots \ldots \ldots \ldots \ldots \ldots \ldots \ldots \ldots 113,117$

Tyler $v$. Pcople, 8 Mich. $820 \ldots \ldots \ldots \ldots \ldots \ldots \ldots \ldots \ldots \ldots$

U.

Underwod $r$. Pailey. 59 N. H. $480 \ldots \ldots \ldots \ldots \ldots \ldots \ldots \ldots \ldots 264$

Underwood $r$. Green, 42 N. Y. $140 \ldots \ldots \ldots \ldots \ldots \ldots \ldots \ldots \ldots$

Underwood $r$. People. 32 Mich. $1 \ldots \ldots \ldots \ldots \ldots \ldots \ldots \ldots \ldots 44$

Union Ref:igerator Transit Co. $r$. Kentucky, 199 U. S. 194...

U. S. $v$. Alexander, 148 U. S. $187 \ldots \ldots \ldots \ldots \ldots \ldots \ldots \ldots . \ldots 295$

U. S. $v$. Baltimore, etc., R. Co., 17 Will. (U. S.) $322 \ldots \ldots \ldots 217$

U. S. $v$. Clintock, 5 Wheat. (U. S.) $144 \ldots \ldots \ldots \ldots \ldots \ldots \ldots 134$

U. S. $v$. Cruikshank, 1 Woods (U. S.) 308,92 U. S. 542 .... 


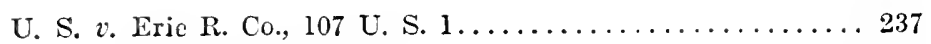

U. S. $v$. Furlong, 5 Wheat. (U. S.) $184 \ldots \ldots \ldots \ldots \ldots \ldots \ldots 134$

U. S. $v$. Gettysburg Electric R. Co., 160 U. S. $668 \ldots .253,261,289$

U. S. $v$. Great Falls Mfg. Co., 112 U. S. $645 \ldots \ldots \ldots \ldots \ldots \ldots 259$

U. S. $v$. Hall, 2 Wash. (U. S.) $366 \ldots \ldots \ldots \ldots \ldots \ldots \ldots \ldots 147$

U. S. $v$. Harris, 106 U. S. $629 \ldots \ldots \ldots \ldots \ldots \ldots \ldots \ldots 43,44,46$

U. S. $v$. Hitchcock, 190 U. S. $324 \ldots \ldots \ldots \ldots \ldots \ldots \ldots \ldots \ldots$

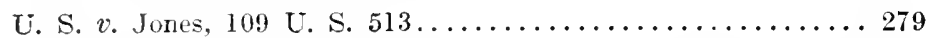

U. S. v. Ju Toy, 198 U. S. $253 \ldots \ldots \ldots \ldots 190,191,193,194,197$

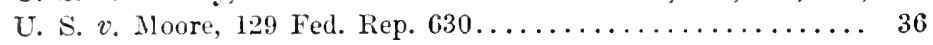

U. S. $v$. New Orleans, 98 U. S. $381 \ldots \ldots \ldots \ldots \ldots \ldots \ldots \ldots 212$

U. S. $v$. Perkins, 163 U. S. $625 \ldots \ldots \ldots \ldots \ldots \ldots \ldots \ldots \ldots 22$

U. S. $v$. Philadelphia, etc., R. Co., 123 U. S. $113 \ldots \ldots \ldots \ldots \ldots 237$

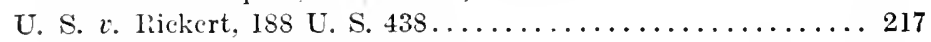

U. S. $v$. Sing Tuck, 194 U. S. $161 \ldots \ldots \ldots \ldots \ldots \ldots 191,196,197$

U. S. $r$. Smith, 5 Wheat. (U. S.) $153 \ldots \ldots \ldots \ldots \ldots \ldots \ldots \ldots$ 134

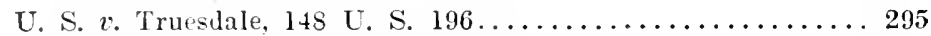

U. S. $r$. Lnion Pac. R. Co., 160 U. S. $1 \ldots \ldots \ldots \ldots \ldots \ldots \ldots 153$

U. S. $v$. Ward, Woolw. (U. S.) $17 \ldots \ldots \ldots \ldots \ldots \ldots \ldots \ldots \ldots 134$

U. S. $v$. Williams, 194 U. S. $279 \ldots \ldots \ldots \ldots \ldots \ldots \ldots \ldots 190,193$

U. S. $v$. Wung Kim Ark, I69 U. S. $649 \ldots \ldots \ldots \ldots \ldots 192,195,196$

U. S. $v$. Yamasaka, I00 Fed. Rep. $404 \ldots \ldots \ldots \ldots \ldots \ldots \ldots$

Vallée $v$. Dumergue. 4 Exch. $290 \ldots \ldots \ldots \ldots \ldots \ldots \ldots \ldots \ldots .94$

Van Brocklin $v$. Tennessee, 117 U. S. $151 \ldots \ldots \ldots \ldots \ldots \ldots . \ldots 217$

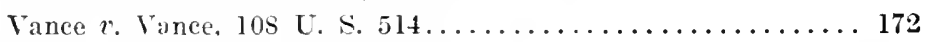

Vanzant $r$. Waddel. 2 Yerg. (Tenn.) $260 \ldots \ldots \ldots \ldots \ldots \ldots \ldots 6$

Varner $v$. Martin, 21 W. Va. $534 \ldots \ldots \ldots \ldots \ldots \ldots \ldots . \ldots 256,264$

Veazie Bank r. Fenno, 8 Wall. (U. S.) $533 \ldots \ldots \ldots \ldots \ldots \ldots 208$

Vicksburg, cte., R. Co. r. Dennis, 116 U. S. $665 \ldots \ldots \ldots \ldots \ldots .226$

Virginia, $\operatorname{Er} p ., 100$ l. S. $339 \ldots \ldots \ldots \ldots \ldots \ldots \ldots \ldots \ldots, 43$

Virginia $v$. lives, 100 L. S. $313 \ldots \ldots \ldots \ldots \ldots \ldots \ldots \ldots \ldots \ldots 43$

Voght $r$. State, 124 Ind. $358 \ldots \ldots \ldots \ldots \ldots \ldots \ldots \ldots \ldots \ldots 18,182$

Voint $r$. Detroit. Ist C. S. $115 \ldots \ldots \ldots \ldots \ldots \ldots \ldots \ldots 241,245$

Von Hoffman $x$. Quincy, 4 Wall. (U. S.) $535 \ldots \ldots \ldots \ldots \ldots 152,175$

IV.

W. W. Cargill Co. $x$. Minnesota, 180 U. S. $452 \ldots \ldots \ldots \ldots \ldots 35$

Wabash R. Co. $r$. Defiance, 167 U. S. $88 \ldots \ldots \ldots \ldots \ldots \ldots \ldots . \ldots . \ldots 304$

Wabash Western R. Co. $x$. Brow, I64 U. S. $271 \ldots \ldots \ldots \ldots \ldots 103$

Waite, Matter of, 99 N. Y. $433 \ldots \ldots \ldots \ldots \ldots \ldots \ldots \ldots \ldots \ldots 131$

Waite $v$. Santa Cruz, 184 U. S. $302 \ldots \ldots \ldots \ldots \ldots \ldots \ldots \ldots \ldots . \ldots \ldots$ 
PAGE

Walker $r$. Saurinet, 92 C. S. $90 \ldots \ldots \ldots \ldots \ldots \ldots \ldots \ldots \ldots$ Wall. Ex p.. 107 U. S. $265 \ldots \ldots \ldots \ldots \ldots \ldots 51,52,53,54.59,171$ Wallace $x$. Wallace, 62 X. J. Eq. $509 \ldots \ldots \ldots \ldots \ldots \ldots \ldots 122,125$

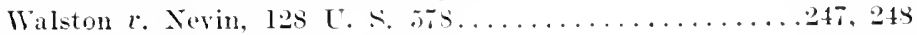
Wantlan $x$. White, 1! Ind. $470 \ldots \ldots \ldots \ldots \ldots \ldots \ldots \ldots \ldots .155$ Ward $v$. Miaryland, 12 Wall. (L. S.) $418 \ldots \ldots \ldots \ldots \ldots \ldots \ldots 217$ Warren Mf.g. Co. $r$. Etna lus. Co. 2 Paine (L. S.) $50 \mathrm{l} \ldots \ldots \ldots$. I 54 Waterbury $l$. Newton, 50 ‥ J. L. $534 \ldots \ldots \ldots \ldots \ldots \ldots \ldots 349$ Waters-Pieree Oil ('o. $r$. Texas. 17 L. S. 2s........... 332 Watson $r$. Mercer, 8 Pet. (C. S.) $110 \ldots \ldots \ldots \ldots \ldots \ldots 151$, 155 Warman $r$. Southard, 10 Wheat. (L.S.) $1 \ldots \ldots \ldots \ldots \ldots 69,70$ Webb $r$. Den, 17 1low. (U. S.) $576 \ldots \ldots \ldots \ldots \ldots \ldots \ldots \ldots 180$ Webster $r$. Fargo, 9 N. Dak. 208, 181 U. S. 394........202, 251 Webster $r$. Reid, 11 How. (L. S.) $437 \ldots \ldots \ldots \ldots \ldots \ldots \ldots \ldots . . \ldots 9$ Weed $t$. Binghamton, 26 Mise. (X. Y.) $208 \ldots \ldots \ldots \ldots \ldots \ldots 144$ Weidenfeld $r$ Sugar Run R. Co., 45 Fed. Rep. 6I5......... 270

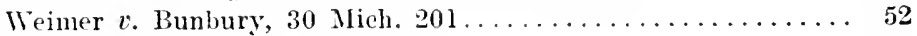
Wells $v$. Savannah, 181 U. S. $531 \ldots \ldots \ldots \ldots \ldots \ldots \ldots \ldots \ldots 226$

Welton $x$. Missouri, 91 U. S. $275 \ldots \ldots \ldots \ldots \ldots \ldots \ldots \ldots \ldots 220$

West $v$. Louisiana, 194 U. S. $258 \ldots \ldots \ldots \ldots \ldots \ldots \ldots \ldots 160,161$

Western Union Tel, Co. $r$. Attr.-Gen., 125 U. S. $530 \ldots . \ldots \ldots .224$ Western Union Tel. Co. $r$. Missouri. 190 L. S. 412.....225, 246 Western Union Tel. Co. $v$. Myatt. 98 Fed. Rep. 335......164, 370 Western Union Tel. Co. $v$. Pennsylyania R. Co., 195 U. S. $540 .$.

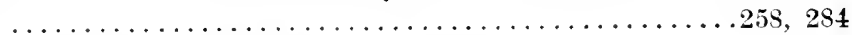

Western Union Tel. Co. $v$. Taggart, 163 U. S. 1......224, 225

Weston $r$. Charleston, 2 Pet. (U. S.) $466 \ldots \ldots \ldots \ldots \ldots \ldots 217$

West River Bridge Co. $v$. Dix, 6 How. (U. S.) $507 \ldots \ldots \ldots \ldots 254$

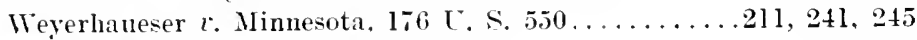

Wheeler $x$. Jackson, 137 U. S. $245 \ldots \ldots \ldots \ldots \ldots \ldots \ldots \ldots \ldots$

Wight $r$. Davilson. 181 U. S. $371 \ldots \ldots \ldots \ldots \ldots \ldots \ldots \ldots 251,252$

Wild $r$. Serpell, 10 Gratt. (Ta.) $405 \ldots \ldots \ldots \ldots \ldots \ldots \ldots \ldots . \ldots 234$

Wilkins $r$. Ellett, 9 Wall. (U. S.) $740 \ldots \ldots \ldots \ldots \ldots \ldots \ldots 121$

Williams $r$. Eggleston, 170 U. S. $304 \ldots \ldots \ldots \ldots \ldots \ldots \ldots 213$

Williams $r$. Fears, 179 C. S. $270 \ldots \ldots \ldots \ldots \ldots \ldots \ldots \ldots 314.344$

Williams $v$. Parker, 18s L. S. $491 \ldots \ldots \ldots \ldots \ldots \ldots 262,271,291$

Williams $r$. School Dist. No. 6, 33 Vt. $271 \ldots \ldots \ldots \ldots \ldots \ldots \ldots .257$

Willyard $v$. Hamilton, 7 Ohio (pt. 2) $111 \ldots \ldots \ldots \ldots \ldots \ldots \ldots 257$

Wilson $r$. Alabama G. S. R. Co., 77 Miss. $714 \ldots \ldots \ldots \ldots \ldots 347$

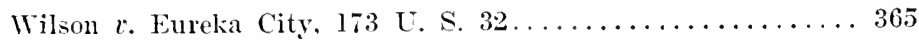

Wilson $v$. Harrey, 24 N. H. $34 t \ldots \ldots \ldots \ldots \ldots \ldots \ldots \ldots \ldots \ldots 172$

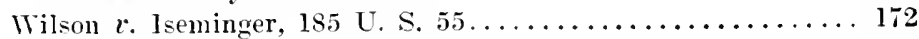

Wilson $v$. Joseph, 107 Ind. $490 \ldots \ldots \ldots \ldots \ldots \ldots \ldots \ldots \ldots \ldots$

Wilson $v$. Lanbert, 168 U. S. $611 \ldots \ldots \ldots \ldots \ldots \ldots \ldots 230,232$

Wilson $r$. North Carolina, 169 X. Car. 586.......162, 167, 335 
Wilson $v$. Seligman, 144 U. S. $41 \ldots \ldots \ldots \ldots \ldots \ldots \ldots$. 98

Wilson $v$. Standefer, 184 U. S. $399 \ldots \ldots \ldots \ldots \ldots \ldots \ldots \ldots 7,227$

Wilson Packing Co. v. Huntern, S Biss. (U. S.) $429 \ldots \ldots \ldots \ldots 105$

Windsor $r$.11 Veigh, 93 C. S. $274 \ldots \ldots \ldots \ldots \ldots \ldots \ldots 76,85,109$

Winona, etc., Land Co. $r$. Winnesota, 159 U. S. 526. . .211, 238, 241

Winona, ete. R. Co. r. Blake, 94 U. S. $180 \ldots \ldots \ldots \ldots \ldots \ldots . \ldots 318$

Winston $r$. Winston, 189 C. S. $507 \ldots \ldots \ldots \ldots \ldots \ldots \ldots \ldots \ldots$

Wisconsin $r$. Pelican Ins. Co., 127 C. S. $205 \ldots \ldots \ldots \ldots \ldots$, 136

Wisconsin Cent. R. Co. $r$. Kneale. 70 Wis. $89 \ldots \ldots \ldots \ldots \ldots 298$

Wisconsin Cent. R. Co. r. Price County 133 L. S. $496 \ldots \ldots 217$

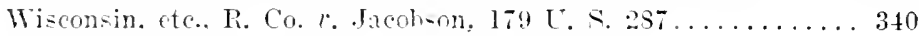

Wise $x$. Withers. 3 Cranch (L. S.) $331 \ldots \ldots \ldots \ldots \ldots \ldots$ ss

Wong Kim Ark, In re. 71 Fet. Rep. $382 \ldots \ldots \ldots \ldots \ldots \ldots . . . .195$

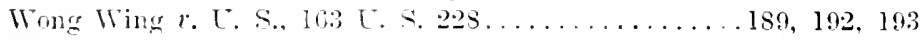

Woodruff $r$. Taylor. 00 Vt. $65 \ldots \ldots \ldots \ldots \ldots \ldots \ldots \ldots \ldots \ldots . \ldots . \ldots \ldots$

Wormley $r$. District of Columbia. 181 L. S. 402......... 251

Wurts $e$. Iloagland, 114 L. S. 606, $014 \ldots \ldots \ldots \ldots \ldots \ldots 265,266$

Wyllie. In re. 2 Hughes (L. S.) $449 \ldots \ldots \ldots \ldots \ldots \ldots \ldots \ldots \ldots 153$

Wyman $r$. Halstead. 109 L. S. $656 \ldots \ldots \ldots \ldots \ldots \ldots \ldots \ldots$. 121

Wynehamer $r$. People, 13 N. Y. $378 \ldots \ldots \ldots \ldots \ldots \ldots \ldots, 141$

\section{Y.}

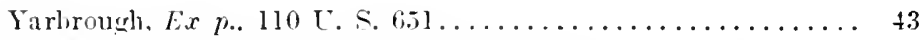

Yates $r$. Nilwankee. 10 Wall. (C. S.) $497 \ldots \ldots \ldots \ldots \ldots \ldots \ldots 37$

Sesler $v$. Washington Harbor Line Com'rs, 146 U. S. 646.....

$61,282,295$

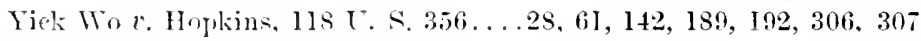

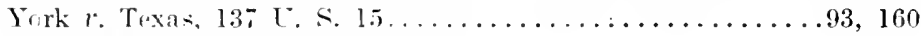

Young. Nlatter of, 123 ऽ. Car. $358 \ldots \ldots \ldots \ldots \ldots \ldots \ldots \ldots$

Z.

Zeigler $r$. South. etc., Alabama R. Co., 58 Ala. $594 \ldots \ldots \ldots 68,185$

Zimmerman $t$. Franke, 34 Kan. $650 \ldots \ldots \ldots \ldots \ldots \ldots \ldots \ldots \ldots \ldots \ldots$ 


\section{INDEX.}

Acknowledgments -

PAGE

Acts curing defective.

158 note

\section{Administration -}

Grant of letters treated as in rem............117, 118

lssuance of letters on absentee's estate as absentee....... 88

Issuance of letters on estate of absentee as decedent...... 88

Settlement of special administrator without giving hond... 161

Situs of dehts for....................... 121

\section{Administrative officers -}

See Separatiox of Gonernaental Powers.

Action of limited by due process............... $\mathbf{\Omega}$

Charged with carrying out details of police regulation.... 303

Judicial duties intrusted to............72, 245, 366

May administer laws excluding alicns............ 190

May determine qualification of physician.......... 163

May determine question of sanity.............. 163

May determine whether applicant for admission an alion... 194

Notice and hearing required when rates fixed by ........ 319

Proceedings before as due process of law...72, 163, 190, 233, 366

Statutes making decisions by heads of departments final... 369

\section{Administrator -}

See Administration.

\section{Advertising -}

Use of property for

\section{Esthetic considerations -}

Whether justify employment of eminent domain....... 261

Whether justify police power................ 310

\section{Agent -}

To receive service for foreign corporation.........101, 103

To receive service for individual .............. 93

\section{Alaska -}

Entitled to all constitutional guaranties........... 200

Alien -

Administrative officer may determine when person entering country is citizen or .................. 195

Cannot claim judicial process before entry.......... 190

$$
\text { [4०9] }
$$


Alien - Continued. PAGE

Congress may regulate admission of $\ldots \ldots \ldots \ldots \ldots \ldots \ldots 190$

Effect of departure from country............... 193

Entitled to due process.............................. 190

Exelusion of, by administrative efficials due process...... 191

Exelusion of, held not reviewable................ 191

Rightfully admitted are protected as are citizens....... 191

Lnlawful entry confers no rights.............. 192

Unlawful entry not punishable infamously.......... 193

\section{Almshouses -}

Aequisition of property for, a public purpose........ 257

Amendments to Constitution of United States -

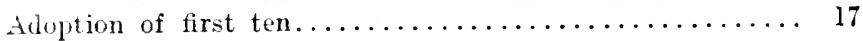

liesulting from Civil War.................. 19

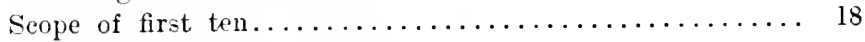

Whether first eight extend to inhabitants of acquired ter-

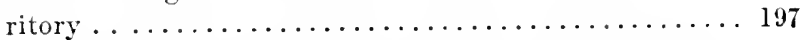

Whether rights enumerated in first cight essential for due

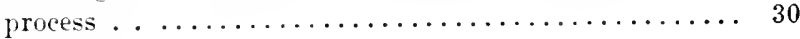

\section{Amendments to pleading -}

Right to amend denied.................... 161

\section{Amusement -}

Regulation of places of public................ 317

\section{Animals -}

See Cattle; Dogs.

Property in animals fere natura $\ldots \ldots \ldots \ldots \ldots \ldots \ldots \ldots 330$

Property in reclaimed animals................. 330

Whether killing diseased is a taking of property........ 310

\section{Appeal -}

Dismissed for prison breach.................. 168

Not essential to due process..............81, 169, 211

Provi-ion for, a local question................ 81

\section{Appearance -}

Sirecial appearance...................... 93

Efrect of state statute regulating, in federal courts..93 note Statute reculating effect of ............... 93

Voluntary gives juri-diction................ 93

Voluntary valielates dirorce..................... 126

\section{Apportionment of taxes -}

See Taxatros.

\section{Appraisement -}

Of imports 
Aequisition of property for, a public purpose......... 257

\section{Arsenals -}

Acquisition of property for, a public purpose......... 257

Jurisdiction of Enited States over lanils reserved for ...... 134

Within states entitled to all constitutional gudrantics....200

Arundel, Earl of -

Attainder

Assessment -

See Reassessment; Special Assessmexts.

Of railroads by board of equalization..........83, 84

Proper classification for in taxation.............. 63

\section{Assignment -}

Statute forbidding, to nonresidents............ 361

\section{Assignment for benefit of creditors -}

Valid where made, valid everywhere.

131 note

\section{Attachment -}

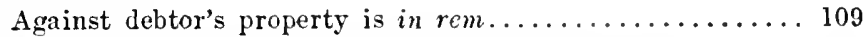

No personal judgment in without personal service........ 112

Right may be taken away if legal remedy remains.... 175 note

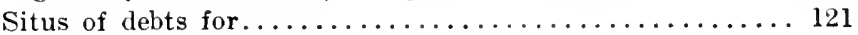

When in rem or in personam................ 111

\section{Attainder, bills of -}

As violating vested rights................ 146

History ........................... 65

Prohibited by Constitution................ 67

\section{Atterbury, Bishop -}

Bill of pains and penalties against............ 67

\section{Attorney at law -}

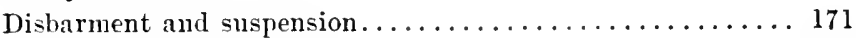

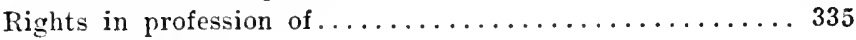

\section{Attorneys' fees -}

Exacted of railroads as penalty for non-settlement of

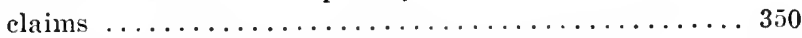

Railroads required to pay, in suits for damage by fire.... 351

Validity of judgment confessed for in sister state...... 96

\section{Anstin -}

On vested rights............ 142 note, 144 note, 156 note

\section{Bakers -}

Business of affected with public interest............. note

Statute limiting hours of emplorment........... 356

\section{Banking associations -}

Statute repealing statute aroiding notes of $\ldots \ldots \ldots \ldots 156$ note 
Baxkrupt and insolvent laws - PAGE

In England discharge under, valid everywhere.......132 note

Judgments under both in rem and in personam ........ 130

Judgment under in personam as discharge........... 131

Judgment under $i n$ rem as to status of debtor........... 131

Power of state to pass................... 132

Retrospective state insolvency laws............. 176

\section{Beanty -}

Education of taste for as ground for taking property....261, 310

\section{Bills of attainder -}

See Atrainder, Bills of.

\section{Bills of pains and penalties -}

See Attaixder, Bills of.

Defined

\section{Blackstone -}

On ex post facto laws...................... note

Blood-feud .85 note

Bonds -

Issuance in excess of value as affecting rates......... 324

Situs of foreign held for taxation............... 119

\section{Booms -}

Acquicition of property for, a public purpose..........258

\section{Bridge -}

Aequisition of property for, a public purpose......... 257

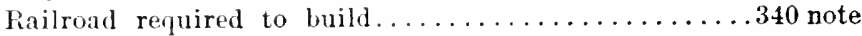

Taxation of, by municipality................ 214

Taxation of, situated between states...........219 note

\section{Business affected with public interest -}

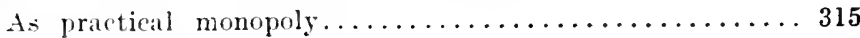

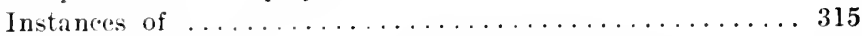

Regulation in exereise of purely legislative powers...... 349

Sir Mathew Hale on.......................... 314

Subject to police regulation.................. 314

\section{Canals -}

Acquisition of property for, a public purpose..........257

\section{Caroline, Queen -}

lill of pains and penalties against............. 67

\section{Carriers, common -}

See Common Carrier.

\section{Carriers of passengers -}

Made liable as insurers...................... 342 
Liability of owners for injury to highway........186, 342

Straying on railroads protected................... 312

\section{Cemeteries -}

Acquisition of property for, a public purpose........259, 264

\section{Chattels -}

See Personal Property.

\section{Children -}

Euployments prohibited to ................ 347

Imprisonment of, in homes and reformatories......... 344

Rights of regulated in their own interests........... 344

\section{Citizen -}

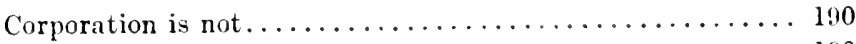

Rights of. and rights of alien ................ 190

Right of, to resort to federal courts............. 95

\section{Civil cases -}

Right to jury trial in .................. 162

\section{Civil damage acts -}

Coustitutionality of $\ldots \ldots \ldots \ldots \ldots \ldots \ldots \ldots \ldots \ldots \ldots \ldots \ldots$ note

\section{Classification -}

Must be based on real difference.............. 63

Not prohibited by due process.............6. 63

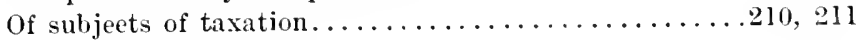

Under the police power.................... 311

\section{Clergyman -}

Rights in profession of $\ldots \ldots \ldots \ldots \ldots \ldots \ldots \ldots \ldots \ldots \ldots \ldots$

\section{Cloud on title -}

See Titue.

\section{Color blindness -}

Railroads to bear expense of examination of engineers for. . 340

\section{Combinations in restraint of trade -}

See Moxomolies and Combinitioxs.

\section{Comity -}

See Foneigr Corporations.

As applied to judgment in bankruptey............ 131

Situs of debts dependent on................ 1 21

\section{Commerce -}

See Jxterstate Commere.

Regulation of belongs to national government......... 304

United States may condemn land for purposes of ........ 285 
Common carrier -

See Railroads.

Business of affected with publie interest............ 316

Statute making earrier of passengers an insurer.

\section{Compensation -}

See Emincht Domalx; Paramount Rights of State;

Police Power.

\section{Condemnation -}

See Eminext Domain.

Conarmatio cartarum

Confiscatory legislation -

See Attalyoer, Bills of; Ex Post Facto Laws; For. FEITLRE.

In eivil cases, violates due proeess.............68

Opposed to due proeess.................... 64

\section{Conflict of laws -}

See Sirts.

\section{Congress -}

Legislative powers under Fourteenth Amendment.......42-47

\section{Consequential damage -}

Denial of right to. no denial of due process.......... 295

Destruction of aecess to land, as................ 293

\section{Constitution of United States -}

Whether it follows the tlag ...................

Construction and interpretation -

By state courts-

Errors and irrecularities in construetion......... 40

Of meaning of state eonstitution and statutes final. .37, 38

On matters of procedure usually a local question...37, 40

On presence of due process, reviewable.......... 37

Existing laws a part of contract............. 152

Grant of eminent domain limited to necessity of ease..... 27:

Provision for "hearing" eonstrued............... 242

Retrosuective ennstruction avoided............. 154

\section{Constractive service -}

See Process, Service of.

\section{Contempt -}

Totice and hearing essential in indirect............ 170

Notice and hearing not essential in direet............ 169

Power of courts to mish................... 169

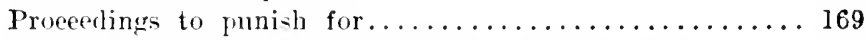

Striking out defendant's answer as punishment for...... 170

Summary process against................. 170 
Contingency -

Distinguished from vested right.............. 157

\section{Contracts -}

See Impairment of Orligation of Coxtracts.

State may not regulate extraterritorial contracts........ 351

Cooley, Judge Thomas M:-

On vested rights........................ 143

\section{Corporations -}

See Foreign Corporations; Master axd Servant;

Process, Service of; Rimlrodos.

Are not eitizens....................... 190

Are persons under the Fourtentl Amendment.......... 189

Enforcement from quasi-public, of duty common to all

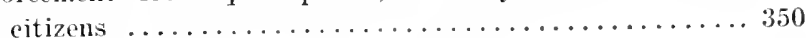

Grants to, protected by Feleral Constitution.......... 151

Reservation of right to repeal elarter............ 332

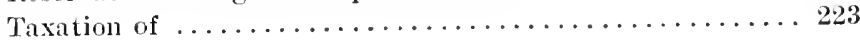

\section{Costs -}

Confession of judgment for, on judgment-note......... 96

Imposed as penalty for malicious prosecution.......... 179

lmposed for nompayment of taxes............... 233

Imposed on railroads as penalty for fire........... 351

\section{Council -}

See Iing's Courcil.

\section{County seats -}

Passenger trains required to stop at............. 316 note

\section{Court houses -}

Acquisition of property for, a public purpose......... 257

\section{Courts -}

See Tribunal.

\section{Crimes and penalties -}

See l'rocentre.

Criminal laws not extraterritorial. . . . . . . . . 133

Seeming exceptions to rule -

Exelusive jurisdiction reserved to United States.. 134

Extraterritorial crime in fraud of state laws.... 136

Extraterritorial erime offense against sovereignty of

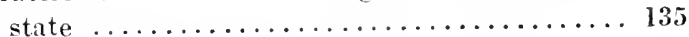

Extraterritorial crime taking effect in state.... 135

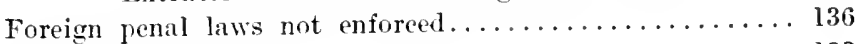

Jurisdiction as to..................... 133

Right of person aceused of felony to be present at trial $\ldots \ldots \ldots \ldots \ldots \ldots \ldots \ldots \ldots \ldots \ldots \ldots . \ldots \ldots, 165,167$

Right to jury trial in criminal cases............ 163 
Cromwell - $\quad$ PAGE

Attainted after death ...................66 note

\section{Curative acts -}

Cannot affect vested rights of third parties........... 158

Validity of $\ldots \ldots \ldots \ldots \ldots \ldots \ldots \ldots \ldots \ldots \ldots \ldots \ldots \ldots \ldots \ldots \ldots \ldots$

\section{Custom honses -}

Acquisition of property for, a public purpose........257

Dam -

Maintenance of as nuisance................ 23

Damage -

Requirement of compensation when property "damaged".. 295

Dangerous employments -

See Police Power.

\section{Dangerous substances -}

Traffic in regulated.............................. 346

Debt -

See Situ's.

Situs of special and simple distinguished.......... 121

Declaration of Independence -

Enumeration of inalienable rights in............. 13s

Deeds -

Presumption from ..................

Defamation -

In pleadings held privileged................. 161

Defense -

light to present not denied where none is asserted..... 161

Departments of government -

Sie Separation of Governmental Powers.

Deposition -

Of absent witness held admissible.............. 161

Depots -

See RaILroans.

Acquisition of property for, a public purpose......... 258

Despencers -

Attainiler of

Dictinsou -

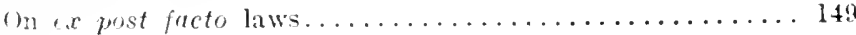

Dike -

Acquicition of property for, a public purpose......... 259

consenpential damage from construction of .......... 293

\section{Discretion -}

Excreise of by administrative oflicials........... 
Se'e ClaAssification.

Distributive justice

51 note

District of Columbia -

Entitled to all onstitutional guaranties............ 200

\section{Ditch -}

Over another's lind to obtain water, whether public purpose. 266

\section{Divorce decrees -}

Domieil of parties determines jurisdiction.......... 122

In state of fraludulent domicil.............. 122

In state where both parties domiciled........122, 126

In state where neither party domiciled.......... 122

In state where one party domiciled.......... 123, 127

Results of Atherton $v$. Atherton............. 129

Results of Haddock $v$. Haddock.............. iv

Validity of decree on constructive service as against

nonresident ...................127-130

Whether in rem or in personam.............. 122

Dogs -

Property rights in........................ 330

\section{Domicil -}

See Divorce Decrees.

When wife may acquire separate.............. 123

\section{Dower -}

Expectancy of not rested................ 158

\section{Drainage -}

Acquisition of property in cities for, a public purpose.... 259

As involving eminent domain and police power........ 205

Constitutionality of acts condemning property for....... 265

\section{Druggists -}

Double license required from, for sale of spirit.

\section{Due process of law -}

See Equality and Generality of Laws; Jurisdiction; Law of the Land; Persons Protected by Due Process: States; Livited States.

Absorbs other conceptions.................16, 49

Analogous phrases in eily writs............... note

Becomes fumlamental part of American constitutional

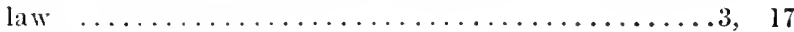

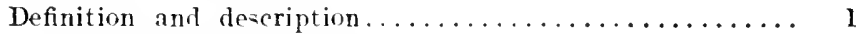

By Sir Edward Coke................. 15

Emphasizing absence of arbitrary caprice........ 51

Emphasizing necessity of jurisdiction......... 52 
Due process of law - Continued.

PAGE

Definition and description - Continued.

Emphasizing necessity of orderly procedure....... 51

In Parliamentary debates................ 15

Webster's definition ...................49-51

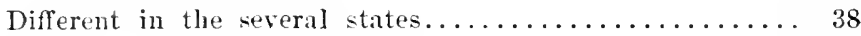

Earliest uses of phrases............... note, 65

Elements and requisites -

Appeal not essential to................. sl

Compensation for property condemned essential..... 279

Depend on subject-matter involved........... 59

Exclude arbitrary exercise of power............61

Judge acting in bis own case...........

Judicial process not essential............. 52

Jury trial is not essential.........53, 162, 233, 371

Equivalent phrases in state constitutions........... 23

Identity of under fifth and Fourteenth Amendments as-

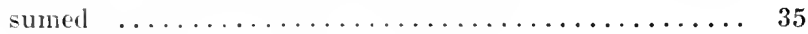

In Fifth Amendment of Federal Constitution......... 17

In Fifth and Fourteenth Amendments compared.......31, 32

In fourtecnth century statutes................

In various legal systems........................... 2

Presence of, presents federal question under Fourteenth

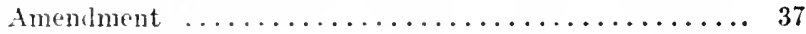

Seope of glaranty -

In America restricts all departments of government ................... 26

In England municipalities restricted by ........ 25

In England Parliment not restricted by........ 25

In England restricts king and executive........20-24

Tests of presence -

By gradual process of inclusion and exclusion..... 56

Conformity to establislitel usages............53-56

Too narrow as test....................... 54

Conformity with fumdamental principles........56-60

\section{Easements -}

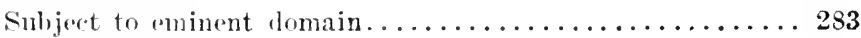

Elevators, grain -

See Graix Elevators

\section{Emblems -}

Regulation of use of state emblems.............. 333

\section{Eminent domain -}

See Necessity; Paramount Rights of State; TakING OF P'ROPERTY.

A sovereign power............................ 25 
Eminent domain-Continued.

Compensition -

1 prineiple of natural equity.............. 278

Can be elaimed only when property rights infringed $\ldots \ldots \ldots \ldots \ldots \ldots \ldots \ldots \ldots \ldots \ldots \ldots \ldots$

Constitutional recognition of necessity for........ 279

Denial of right to comsequential damages, no denial of. . 295

Ellect of appropriating limited amount for.........

Elements to lo enminered in estimating.......... 2sa

for subjecting tondemued property to adelitional

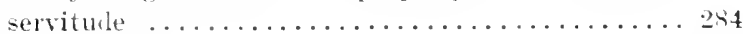

History of requirement of . . . . . . . . .

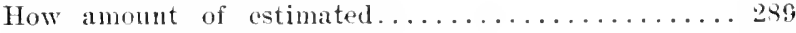

Just compensation a judicial question...........2st

Need not precede taking....................

Required by due process of law..........202, 279

Requirement for when lands "damaged". . . . . . . . 95

Requirement for when lands "taken"......... 295

Right of state to, where its pronerty is taken...... 284

Right to may be lost by laches.............. 282

Substantial denial by state courts raises federal ques-

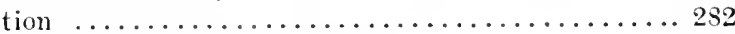

Where one of two tracts is taken............ 290

Where part only of tract is taken............ 290

Where the use of property is limited.......... 291

Condemuation and voluntary sale contrasted.......202 note

Exercisable by legislature................... 254

Grant of, no estoppel to new grant.............. 254

Notice and hearing -

Decision on compensation requires............ 299

Doctrine in Massachusetts as to............. 297

Right to, where legislative decision delegated...... 297

Right to, where legislature decides directly........ 297

Of states and of United States................ 253

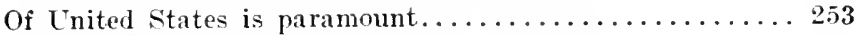

Proceeding for, against nonresident is in rem......... 113

Property subject to -

Federal govermment may condemn state's property. .283, 284

Franehise to collect tolls................ 287

Lands held by state in trust for national purposes.. 284

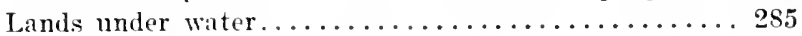

Things already condemned............... 284

What may be taken................... 283

Public purposes -

Courts may supervise legislative decision of question.. 256

Criterion stated ..................... 262 
Eminent domain - Continued.

Public purposes - Continued.

Determined primarily by legislature........... 255

Enterprises subsidiary to main purpose......... 269

Held equivalent to "public benefit"...........263

Held to require state ownership and control.......263

Incidental benefit for state does not affect....... 270

Incidental private benefit does not affect........ 270

Local conditions influence............... 266

May be local merely.................. 27 I

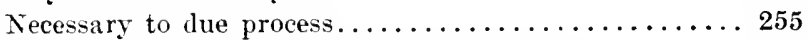

Taking for purposes purely private forbidden....... 269

Various purposes enumerated............. 257

Whether purposes purely æsthetic justify condemna-

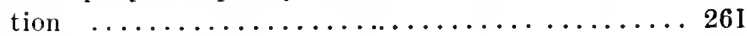

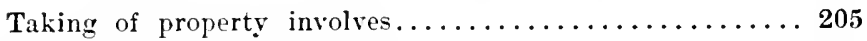

Term derived from Grotius................ 253

Value of rights involved may deternine between police

power and ............................. 206

\section{Engineers -}

Expense for physical examination of, imposed on railroads. 340

\section{Entry of judgment -}

See Jingments.

\section{Equality and generality of laws -}

See Classification; Confiscatory legislation.

Essential to due process.................60-64

Exclusive or sepatrate emoluments prohibited......... 62

\section{Equality of taxes -}

Under Fourteenth Amendment...............210

\section{Equal protection of laws -}

Spe Eqcality axd Gexerality of laws.

Guaranteed by Fourteenth Amendment...........62, 311

\section{Equity -}

Abatement of nuisance in, is due process.......... $37 \mathrm{I}$

May eontrol extraterritorial property and rights....... 105

\section{Escape -}

Of prisoner ground for dismissal of appeal.......... 168

\section{Escheat -}

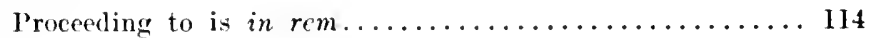

\section{Estoppel -}

Presumption made conclusive on principle of......... 184 
See Presumptions.

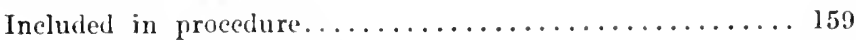

No vested right in rules of . . . . . . . . . . . . 160

Rules and effects of, legislative power over.......... 180

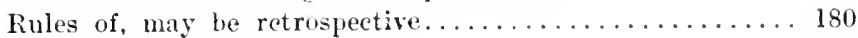

Che of, illegally obtained................ 187

\section{Execution -}

See Exemptions from Exection.

Laws extending time of $\ldots \ldots \ldots \ldots \ldots \ldots \ldots \ldots \ldots \ldots \ldots$

Laws limiting right to sell under.............. 176

Personal not issued in suit merely in rem........... 112

\section{Executive -}

See Administrative Officers; Separation of GoverNmental Powers.

\section{Executors and administrators -}

See Administration.

\section{Exemptions from execution -}

Laws creating and modifying............... 176

\section{Exemptions from taration -}

Held contractual in nature.................226

Legislature may create...................210

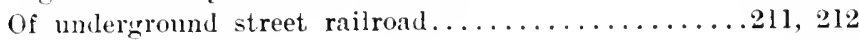

Strictly construed $\ldots \ldots \ldots \ldots \ldots \ldots \ldots \ldots \ldots \ldots \ldots$

\section{Expectancies -}

Distinguished from vested rights............. 157

\section{Expenses -}

Caused by public works held consequential.......... 293

\section{Explosives -}

Traffic in, regulated..................... 347

Ex post facto laws -

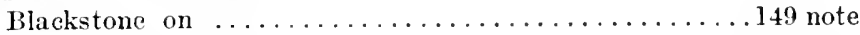

Declared not confined to crimes only.......149 note, 152 note

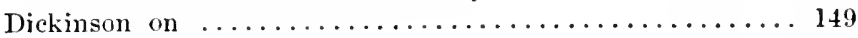

Prohibited by constitution.................. 67

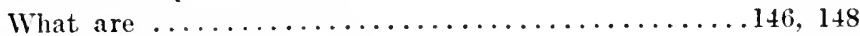

Laws affecting procedure only as............. 147

Laws mitigating erime or punishment as........ 147

Laws remitting separable portion of punishment as... 147

\section{Express companies -}

Mileage as basis of taxation of ............... 225

\section{Extradition -}

International and interstate.............136, 137 
Farriers - $\quad$ PAGE

Statute regulating trade of $\ldots \ldots \ldots \ldots \ldots \ldots \ldots \ldots \ldots . \ldots \ldots 6$

Fearne -

On vested rights........................ 143

Federal bill of rights -

First eight amendments to Federal Constitution known as. . 30

Fee tail -

Expectancy of heir not vested............... 157

Statute changing to fee simple............... note

Fellow servants -

Railroads deprived of benefit of fellow-servant rule...312, 342

Fences, spite -

Whether regulation is a taking of property......... 309

Fenwick, Sir J. -

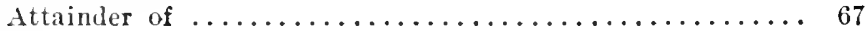

Ferry -

Acquisition of property for, a public purpose......... 258

As a business affected with public interest.......... 316

Taxation of franchise for, between states........... 218

Fictitions capitalization -

As atrecting rates............................... 324

Fifth Amendment -

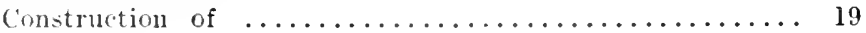

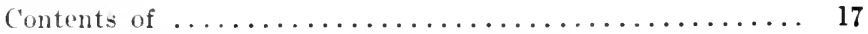

Due process under, contrasted with that under Fourtcentl

Amendment ......................... 32

Proviles for due process.................. 17

Right of person aceused of felony to be present at trial under ...................... 165-167

Fires -

('aused hy railroads, costs as penalty in suits for........ 351

Statute rembling ralilroals' liability for......... 185,342

Fish nets -

b)etruction of, by same warden in advance of hearing... 376

Fitzgerald. Lord Edward -

Attrintarl aiter leath..................66 note

Five Knights -

Caso of $\ldots \ldots \ldots \ldots \ldots \ldots \ldots \ldots \ldots \ldots \ldots \ldots \ldots \ldots \ldots \ldots, 14$

Flag -

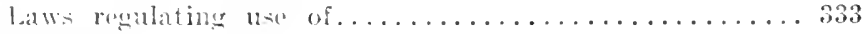

Flooding -

Consequential damage from flooding............. 293 
Proceeding to foreclose mortgage is in rem.......... 109

\section{Foreign corporations -}

Discrimination against, not denial of due process....... 189

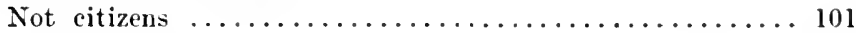

Rights dependent on comity............... 101

Service on agent of, valid without statute-

In local federal courts.................. 105

In state courts .......................... 104

State may annex conditions to recognizing........97, 100

State regulation of, infringes no constitutional right..... 332

Statute requiring assent to specified form of service...... 100

Grounds of construction of such statute......... 101

Limitations on constitutionality of .......... 102

Must be doing business in state........... 102

Must not impair right to resort to feleral court.. 102

Must not include federal corporations........ 102

Persons served must represent corporation...... 103

Who is proper agent to receive service........ 103

Validating service on public oflicer in default of desig-

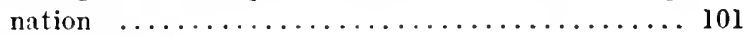

Validating service on resident officer or agent...... 101

\section{Forfeiture -}

Of property for nonpayment of taxes........... 234

Proceeding for, against property of rebels.........110

\section{Forts -}

Acquisition of property for, a public purpose........257

Within states entitled to all constitutional guaranties.... 200

\section{Fourteenth Amendment -}

See Equal Protection of Laws.

Adoption of $\ldots \ldots \ldots \ldots \ldots \ldots \ldots \ldots \ldots \ldots \ldots \ldots \ldots \ldots$

All classes within protection of . . . . . . . . . 20-22

Application of, to state legislation under police power.... 305

Contents of the first section of ................ 20

Equal taxation under...................... 11

Relation of the rights guaranteed by first eight amendments to due process under............30,33, 34

Restrains state action through its agents.......... 27

Retrospective application of ............... 22

\section{Franchise -}

Corporate, taxation of $\ldots \ldots \ldots \ldots \ldots \ldots \ldots \ldots \ldots \ldots .224$

Corporate, within contract clause of Federal Constitution.. 151

New York law taxing.................... 227

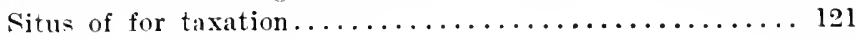

Subject to eminent domain...........283 note, 287 
Prevention of, as ground of police regulation...

\section{Freedom of contract -}

Illegal and forbidden contracts, does not include right to

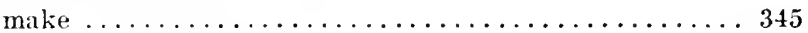

Included in "liberty" and "property".........140, 141

In purely private vocation not generally subject to restraint. 356

Not infringed by mechanies' lien laws............. 359

Not infringed by statute prohibiting assignment of claim to nonresident ......................... 361

Public policy may determine whether it is abridged..... 361

Regulation of. in business affected with public interest... 349

Regulation of. in interest of general welfare......... 357

Reurulation of in int re-t of morals. healtlu, or safety..... 345

Reculation of. to prevent oppression............ 353

States have no pwer to regulate extraterritorial contracts.. 351

\section{Full faith and credit clause-}

Appliation of to per-mal judgment of sister states..... 90

As applied to ciecrees of divoree.............. 122

Not applicalle to judgmont without jurisdiction........ 86

\section{Futures -}

1) ling in regulated....................... 346

\section{Gambling -}

An Mitcres: Optioxs.

Noney font at, male lien on property............ 337

Prompetions in connection with laws against........ isl

Property owner liable for injuries from, on premises..... 343

\section{Gambling instruments -}

Forfeiture of ....................... 337

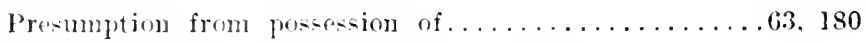

Yisit to birricaded hom where exhibiter.......... 346

\section{Game -}

Title to ............................... 330

\section{Game laws -}

Presmptions in connection with.............181 note

\section{Garbage -}

Disposal of in cities regulated................ 336

Expence incident to transportation imposed on owners.... 339

\section{Garnishment -}

\section{Gas -}

Sere Attacinmext.

Aequizition of property for supply of, a public purpose... 260

Companies to supply as affected with public interest..... 317 
Gas - Continued.

PAGE

Cost of shifting gas main imposed on company furnishing

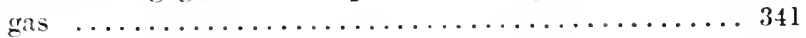

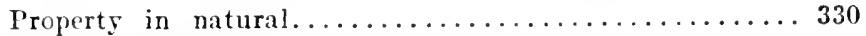

\section{Gettysburg, battle of -}

Acquisition of property to mark site, a public purpose.... 260

\section{Grade crossing -}

Railroad repuired to eliminate.............. 340 notc

\section{Grain elevators -}

Business of affected with public interest........316 note, 317

On railroad rights of way..................... 351

\section{Grand jury -}

Indictment by, in federal eourt, guaranteed by constitution.. 163

Indictment by, in state courts, matter of local law....... 163

\section{Grist mills -}

Business of, affected with public interest........... 316 note

\section{Grotins -}

U'ses term eminent domain.................. 253

\section{Gnardian's bond -}

Sale without

\section{Habeas corpus -}

Dismissal of writ by appellate court........... 168

Not available as writ of error............... 169

\section{Hackmen -}

Business of as affected with public interest.......... 317

Hale, Sir Matthew -

On business affected with public interest............ 314

\section{Harbor lines -}

Establishing, not a taking.................... 394

\section{Hawaii -}

Entitled to all constitutional guaranties........... 200

\section{Hearing -}

See Notice and Hearing.

Appeal or review not essential to........... $1,169,211$

Before executive officer sufhicient.............. 8

By administrative officials enforced by mandamus o: injunction $\ldots \ldots \ldots \ldots \ldots \ldots \ldots \ldots \ldots \ldots \ldots \ldots \ldots$

Essential in proceeding in $r \mathrm{~cm} . \ldots \ldots \ldots \ldots \ldots \ldots \ldots .100$

Implied in public sitting after notice...........83, 84

State statute providing for construed........... 242

Striking out anwwer held denial of ............

Innecessary after plea of guilty............... 80

Waiver of right to by failure to claim........... 73 
Heir -

Expectancy of not vested.................. 157

\section{High ways -}

Acquisition of property for, a public purpose......... 257

Liability of owners of cattle for injuries to......186, 342

\section{Homestead -}

Retrospective laws increasing, held void.......... 177

Retrospective laws reducing, whether valid........ 177

\section{Horseshoeing -}

Statute regulating trade of $\ldots \ldots \ldots \ldots \ldots \ldots \ldots \ldots \ldots \ldots$

\section{Immigration laws -}

See Aliex.

\section{Impairment of obligation of contracts -}

See Obligation of Contracts.

And the police power of the state................. 304

Constitutional clause against -

Applies to contraets exeeuted and executory........ 151

Applies to contracts of the state............. 15l

Applies to grants to eorporations............. 151

Federal government not bound by ..........152-153

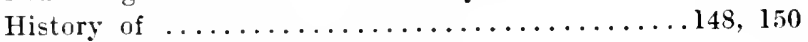

Not violated by antecedent laws............ 152

Protects only vested rights arising out of contract.. 151

Protects true contraets.................. 150

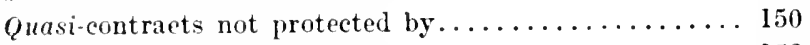

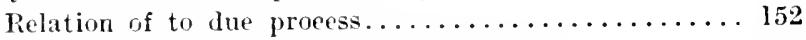

Retrospeetive legislation not forbidden by ....... 153

States bound by ....................... 152

\section{Imports -}

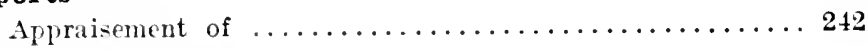

\section{Inalienable rights -}

Ser Rights Protected by Due Process.

Alienable by due process.................. 142

Enumerated in beelaration of Independence......... 138

\section{Incorporeal hereditaments -}

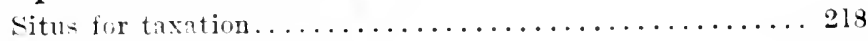

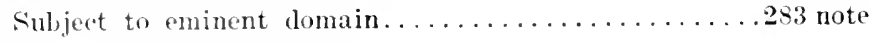

\section{Indeterminate sentences -}

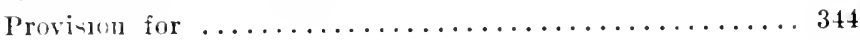

\section{Indictment -}

She Grixp Jerr.

Exi-tence of defeets in, for state courts.......... 168

Sufficieney of, for state courts............. 168 
Indictment - Continued. PAGE

Whether acts indictable for state courts.......... lib

Whether defects in indictment waived, for state courts.... 168

Infant -

Oath of on enlistment made conclusive on question of age.. 185

Sale of infant's land by guardian............. 40

Informer -

Right to recover money lost in play given to........ 337

Inheritance taxes -

See Succession Taxws.

\section{Injunction -}

Against enforcment of judgment in tort........... 161

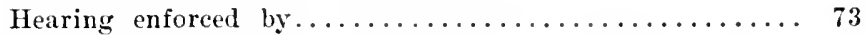

Right to, to stay taxes made dependent on giving security. . 178

\section{Innkeeper -}

Business of, affected with public interest.......... 316

\section{Insane persons -}

See Lunatics.

\section{Insolvent laws -}

See Bankrupt and Ixsolvent Laws.

\section{Insurance -}

Regulation of, by states................. 351

\section{Interest -}

As penalty for nonpayment of taxes.............234

Future, on judgments not vested............. 328

\section{International law -}

See Law of Nature.

Requires notice and hearing............... 75

\section{Interstate commerce -}

Regulation vested in national govermment........217, 304

\section{Intoxicating liquors -}

Articles used in connection with illegal traffic forfeited... 327 Double license required from druggists for sale of ...... 364 Laws forfeiting as penalty for illegal traftic........... 33: Manufacture and traffic in, regulated............. 346 Presumptions in connection with trafle in.......... ISl note Property owners liable for unlawful sale on premises.... 343

\section{Irrigation -}

Aequisition of property for, a public parpon.......... 259

Constitutionality of acts allowing condemnation for..... 266

\section{Irrigation district -}

Formation of, notice and hearing.............. 243 
Johnson grass - PAGE

Railroads liable for allowing to mature........... 342

\section{Joint debtor acts -}

Validity of judgment under...........97 note, 100 note

\section{Joint tenants -}

Expectancy of survivorship not vested........... 157

\section{Judgment note -}

Validity of judgment confessed on, in sister state...... 96

\section{Judgments -}

See Full faitil axd Credit Clause; Jurisdiction; Proceenixgs in Rem; Process, Service of.

Collateral attack-

Crrors of court, not ground for............ 89

Want of jurisdiction or jurisdictional facts, ground for $\ldots \ldots \ldots \ldots \ldots \ldots \ldots \ldots \ldots \ldots \ldots \ldots \ldots, 88$

Domestic -

Due process required in, under Fourteenth Amenlment.. 91

Status dependent on local law before Fourteenth

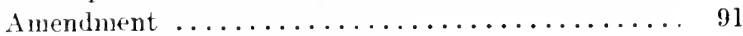

Future interest on, subject to change............ 328

In presonem -

Acrainst nomresidents by prior consent.......... 93

Peronal service or voluntary appearance essential... 89

Status in sister states................. 90

Status of in state of rendition............. 90

In $\mathrm{rem}$ -

Acts equivalent to seizure sufficient........... 107

In $\mathrm{rrm}$ and quasi in $\mathrm{rem} \ldots \ldots \ldots \ldots \ldots \ldots \ldots \ldots \ldots . \ldots \ldots \ldots$

Personal notice not essential. .............. 109

Presence and seizure of res essential.......107, 109

Seizure gives jurisliction subject to due process..... 109

Seizure no warrant for personal judgment........ 111

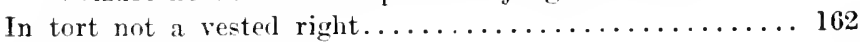

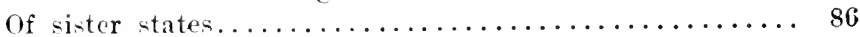

Rule to show cause against, is due process......... 77

Statute allowing entry of against nonresident on five days' notice ......................... 79

\section{Jndicial powers -}

See Aiministrative Officers; Separation of Governmental Powers.

Devolved on administrative officials............ 163

Involved in administrative action under police power..... 368 
See Separation of Governiental Powers.

Action of, limited by due process............. 27

Judicium parium $\ldots \ldots \ldots \ldots \ldots \ldots \ldots \ldots \ldots \ldots \ldots 16,24,25$

And jury trial.................... note

\section{Jurisdiction -}

See Appearance; Bankrupt and Ixsolvent Laws; Crimes and Penalties; Divorce Decrees; Judgments; Process, Service of.

Collateral attack -

Julgment arbitrarily transferring property subject to.. 171

Consent or notice essential to acquisition of ......... 85

Essential to due process.................. 85

Existence of nuisance a jurisdictional fact......... 373

Extent of -

Acquired by consent................... 87

Equitable over extraterritorial property......... 105

Over persons and things in territory.........87, 90

Primitive law required consent to ............ 85 note

\section{Jury -}

Impaneling in federal courts.............. 54 note

\section{Jury trial -}

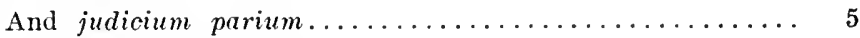

By jury with alien member................ 168

Erroneous denial of ..................... 41

Not essential to due process...........53, 162, 233, 371

Right to depends on state laws............... 162

Jus gentium -

See Law of Nature.

\section{Justice -}

Definition of in Justinian's Institutes.........2,51 note

Distribute justice...............2 note, 51 note

\section{Kent, Chancellor -}

On vested rights.......................... 143

King can do no wrong.

24 note

\section{King, Rufus -}

Proposes clause protecting contracts in federal convention.. 148

\section{King's council -}

Early history of, and Parliament............. 7

\section{Labor -}

Hours of, regulated..................... 347

\section{Land Department -}

Finding of fact by officials of, final. 
Landings - $\quad$ PAGE

Acquisition of property for, a public purpose......... 258

Landowner -

Statute requiring to clean streams.............. 70

Laundries -

Washing and ironing $i n$, regulated................. 313

Law -

Its progressive nature illustrated.............54-55

Law of God -

See Law of Nature.

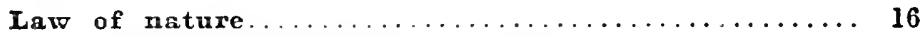

Due jrocess essential to.................. 73

Use interchangeable with jus gentium or law of God...... 2

Law of the land -

Equivalent to due process of law..............10, 16

Lawyer -

Rights in profession of $\ldots \ldots \ldots \ldots \ldots \ldots \ldots \ldots \ldots \ldots \ldots$

Legislature -

See Eminent Domain; Police Power; Procedure; Taxation.

Action of, linited by due process............... 28

May not exercise judicial power............... 64

Paramount powers of state reside primarily in....... 201

Statute assigning judicial powers to............. 71

\section{Levees -}

Acquisition of property for, a public purpose......... 259

In Louisiana ownership subject to easement for........286

\section{Levy of taxes -}

Is legislative function. .................... 209

\section{Libel -}

See Defamation.

Libel in admiralty -

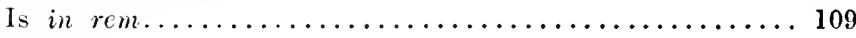

\section{Liberty -}

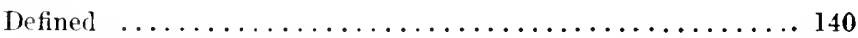

Historical content of term....................... note

Includes right to freedom of contract............. 140

Includes right to pursue lawful calling............ 140

May be lawfully curtailed.................140 note

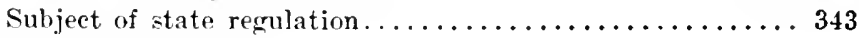

\section{Liberty of subject -}

Debates in Parliament on..................... 14 
As police regulation distinguished from tax .......... 363

Constitutes no waiver of further regulation......... 36.4

lmposed as tax or as police regulation............ 363

Permits for acts generilly forbidden............. 365

Who has authority to grant....................... 364

\section{Lien -}

See Mechaxics' Lien.

On property for nompayment of occupation tax....... 235

On preperty for penalties for unlawful use........... 337

Proceeding to enforce equitable lien is in rem.......... 115

\section{Life -}

Right to, defined...................... 139

Life, liberty, and property, rights of -

See Rights Protected by Due Process.

\section{Lighthouses -}

Acquisition of property for, a public purpose......... 257

\section{Limitation of actions -}

Bar in case of debt and by adverse possession distinguished.. 173

Governed by lex fori......................... 171

Retrospective statute of, constitutional............ 171

Rights under statutes not vested............... 171

Subject to change by legislature.............. 172

Whether complete statutory bar gives vested right....... 173

\section{Liquor laws -}

See Intoxicating Lrquons.

\section{Local assessments -}

See Special Assessments.

\section{Long and short haul -}

Clause in state statute as to............. 319 note, 370

\section{Lonisiana -}

Fiparian rights in subject to easement for levees........286

\section{Lnnatics -}

Involuntary confinement of, held valid............ 344

Presence at inquisition not essential............. 77

Question of Iunacy determined by administrative officials.. 163

Rights of, regulated in their own interests........... 344

\section{Iynching -}

Of prisoner in federal custody as denial of due process . . .44 note

Of prisoner in state custody as denial of due process. . . 44-48 
Chapter 59 of, 17 John 1215 -

Contents of, and aduitional provisions in reissues..... 5

In fouteenth century statutes...............

Numbering of, in reissues of charter...........4 note

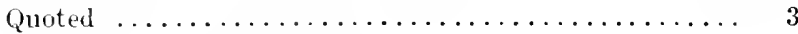

Traditional interpretation of $\ldots \ldots \ldots \ldots \ldots \ldots \ldots \ldots 6,8$

True meaning of $\ldots \ldots \ldots \ldots \ldots \ldots \ldots \ldots \ldots \ldots \ldots, 5$

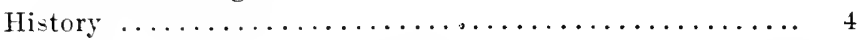

Rights of property enumerated in ............138 note

\section{Malicious prosecution -}

Statutes allowing jury to find prosecution malicious...... 179

statutes allowing jury to fix prosecutor with costs...... 179

\section{Mandamus -}

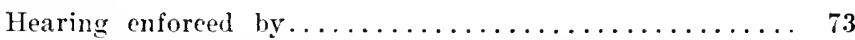

Right may be taken away if legal remedy remains.....175 note

\section{Market quotations -}

Business of furnishing as affected with public interest.... 317

\section{Markets -}

Acquisition of property for public, a public purpose...... 259

Keeping of, regulated.................... note

\section{Marriage -}

As contract and as status................. 123

\section{Martial law -}

Deelared to violate law of the land in Petition of Right....

\section{Master and servant -}

See Railroads.

Fellow-servant rule abolished as to railroads.........312, 342

Statute compelling corporations to pay servants at stated

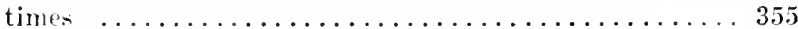

Statute forlidding certain eorporations to fine servants... 355

Statute forbilding eertain corporations to withlold wages. 355

Statute forbidling corporations to maintain stores for em-

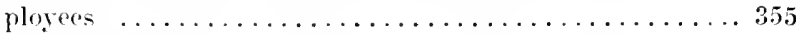

Statute forbidding corporations to reeeive asignments of future wages . . . . . . . . . . . . . . . . . . 355

Statute forbidling payment by corporations except $i_{1}$

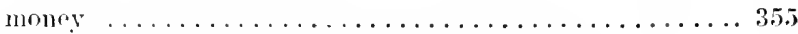

Statute limiting lour of employment of lakers........ 356

Statute proteeting employees held uneonstitutional as re-

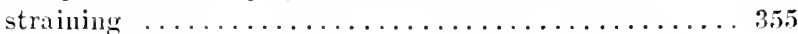

Statute requiring miners to be paid by weight of coal..... 356 


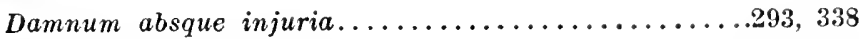

King can do no wrong..................24 note

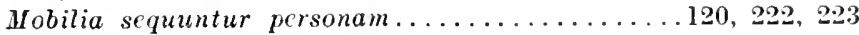

Salus populi est suprema lex...............203, 205

Sic utere tuo ut alicnum non locdas............... 203

Suum euique tribuere................ note, 51 note

\section{Mechanics' lien -}

Not an interference with freedom of contract......... 359

Remedy on, changed.................... 175 note

\section{Medicine -}

See Physicran.

\section{Mileage -}

As basis of taxation.

\section{Military authority -}

Acts committed under................... 162

\section{Milk -}

Traffic in, regulated.................... 347

\section{Mills -}

Business of conducting, as affected with public interest... 316

Whether construction of, under mill acts, a public purpose. 264

\section{Mines -}

Administrative officials to classify for inspection....... 368

Expense of inspection imposed on owners............ 340

Inspection of, by administrative officials........... 371

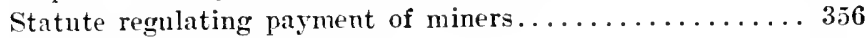

Temporary interruption in use of .................... 293

\section{Ministerial officials -}

See Administratrve Offrcers.

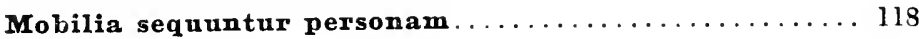

líaxim a fiction...................... 120

\section{Money -}

Whether subject to eminent domain...........283 note

\section{Monition -}

In proceeding in rem....................... 110

\section{Monopolies and combinations -}

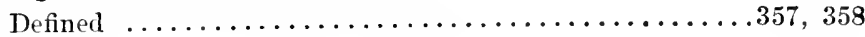

Regulation of, under police power............. 357

\section{Montesguieu -}

Theory of separation of governmental powers due to....69 note 
Mortgages -

PAGE

See Foreclosure.

Situs of ............................. note

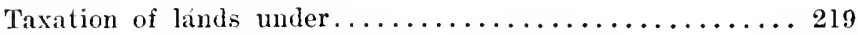

Taxation of, where mortgagee is non resident........ 220

\section{Mortimer, Earl of -}

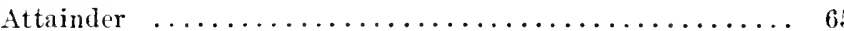

\section{Municipal corporations -}

Constitutional provisions read into grant of power to.... 82

Exercise of police power by ................ 303

Exercise of powers limitel by due process........... 60

Existence of misance a juridictional fact.......... 373

Imposing cost of shifting gas main on company furnishing

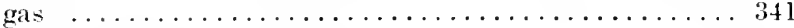

In England restrained by due process............

Lecrislature may deprive of taxing power.......... 212

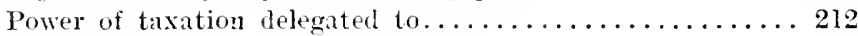

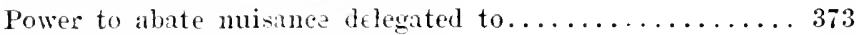

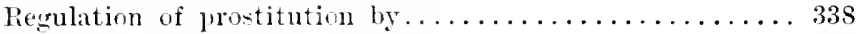

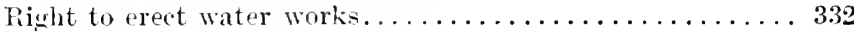

Taxation of property annexed to .............. 213

\section{Natural gas -}

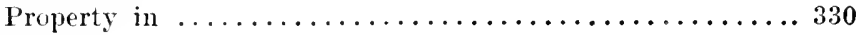

\section{Natnral jnstice -}

See Law of Nature.

\section{Natural price -}

Mediæval theory of ......................

\section{Navigable waters -}

Extent of riparian rights in, depends on local law....... 285

\section{Navigation -}

United States may take lands for purposes of........ 283

\section{Navy yards -}

Acquisition of property for, a public purpose......... 257

\section{Necessity -}

In eminent domain -

Circumstantial, how far legislative or political question.. 273

Courts may review legislative decision.......... 276

Decision of eircumstantial necessity may involve con-

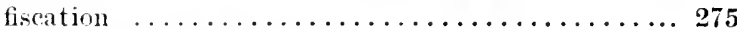

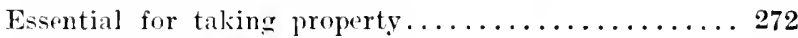

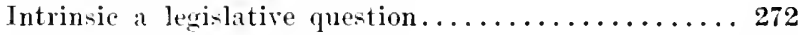

Intrinsic and circumstantial............... 272 
Necessity - Continued.

In eminent domain - Contimued.

Legislative delegation of power to decide.........274

Legislature acting directly may decide finally...... 274

Only reasonable, not absolute, is essential.......... 277

\section{Negligence -}

Of duties imposed for public protection punished........ 313

Statutes creating presumption of $\ldots \ldots \ldots \ldots \ldots \ldots \ldots \ldots, 187$

\section{Negro race -}

Rights under the Constitution............20, 21, 22

\section{News agency -}

As affected with public interest................ 317

\section{Nolle prosequi -}

Entry of on certain counts................ 168

Northwest Territory, ordinance for government of ...23 note

Provision in, protecting contracts............. 148

Who author of clause protecting contracts in........148 note

\section{Notice -}

See Notice and Hearing.

Legislature may prescribe length of ............ 77

Must be rasonable.................... 77

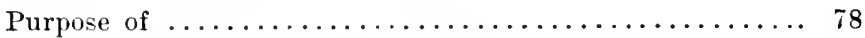

Reasonableness of, a federal question............. 39

Statute requiring five days for nonresidents......... 79

Time and place of .................... 78

\section{Notice and hearing -}

See Administrative Officers; Eminent Domain; Jurisdiction; Police Power; Taxation.

Dispensed with in certain cases................... 371

Essential to due process or law of land.......73, 74, 76, 82

Extent of in cases of aliens...................... 191

In proceedings for contempt............... 169, 170

Must be adapted to the case................ 238

Must be required, not matter of grace........... 82

Personal presence not generally essential to.......... 77

Postponed in cases of necessity............... 372

Provision for may be express or implied........... 82

Required by common law................. 75

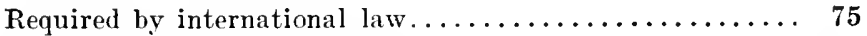

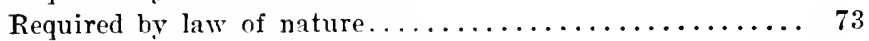

What is essential to constitute.............. 76 
Nuisance -

Acquisition of property for abatement of, a public' purpose. 259

Existence of, is jurisdictional. when abated by local au-

thorities ................................. 373

Property destroyed as, in advance of notice and hearing.... 373

\section{Obligation of contracts -}

See lipairment of Obligation of Contracts.

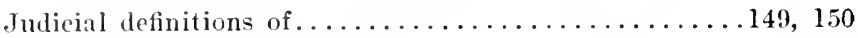

Phrase found in Roman law................. 149

Plirase in Constitution attributed to Wilson......... 149

Taxation of foreign-held bonds held impairment of ....119, 120

\section{Occupation tax -}

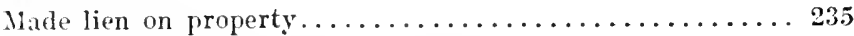

On hiring persons to labor outside the state.......... 313

Office -

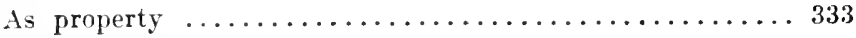

Oleomargarine -

Statutes prohibiting and regulating traffic in......... 348

Operating expenses -

Rieckless, as affecting rates................. 324

\section{Opportunity to defend -}

See Totice and Hearing.

\section{Options -}

Dealing in regulated..................... 346

\section{Ordinance -}

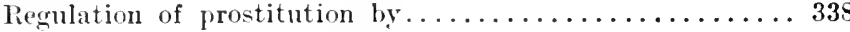

Taxing, provision for notice in ................ 82

\section{Paramount rights of state -}

Must be exercised in accorlance with due process....... 206

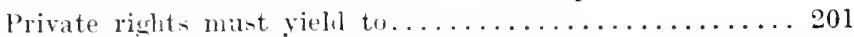

Taxation, eminent domain and police power contrasted.... 201

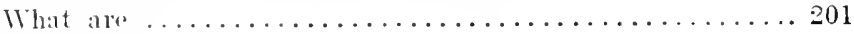

Pa:k -

Acruicition of property for, a public purpose........260, 288

liecrilation of right to speak in................ 329

\section{Parliament -}

Omnipotence of ................26 note, 29

Partition -

Proresling for is in rm................. 109,113

Partnerstin -

Sep Process, Service of. 
Pension - PAGE

Statute ereating fund for pensioning policemen........ 328

Per legem terra -

See Law of the LAND.

Per legem terre.................6 note, 15, 25

Permits -

See Licesise.

Perpetuitics and monopolies prohibited.

Personal property -

See Situs.

Whether proceeding in rem binds title to........... 115

Persons protected by due process -

See Corporations.

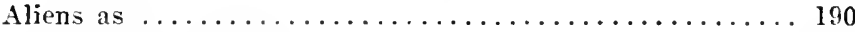

Due process a right of all................ 189

Inhabitants of acquired territory ............. 197

Petition of Right $\ldots \ldots \ldots \ldots \ldots \ldots \ldots \ldots \ldots \ldots \ldots \ldots \ldots \ldots$

\section{Petroleum -}

Property in .............................. 330

\section{Physician -}

Examination and license of, regulated........... 347

Power of state medical board over qualifications of ..... 163

Rights in profession of ..................... 335

Statutory presumption as to charaeter of, applied retrospectively $\ldots \ldots \ldots \ldots \ldots \ldots \ldots \ldots \ldots \ldots \ldots \ldots \ldots \ldots \ldots \ldots$

Pier -

Consequential damage from building.

\section{Pleading -}

See Amendments to Pleading; Supplementary PleadINGS.

Included in procedure.

\section{Policemen -}

Statute reserving part of salary for pensions.

\section{Police power -}

See Business Affecten with Public Interest; Freedom of Contract ; License; Regulation of Rates; Takixg of Property.

Administrative officers to earry out scheme of regulation

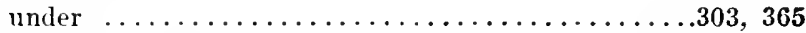

Classification under ...................... 311

Business properly regulated though other not...... 312

Harmless occupations pursued in a dangerous manner. . 313 
Police power - Continued.

Classification under - Continued.

Similar employments distinguished by tendencies.... 313

Specially dangerous employments regulated....... 312

Compensation not required................203, 303

Defined and described..............201 note, 300

Contrasted with other paramount powers of state... 203

Strict, distinguished from legislative power........ 301

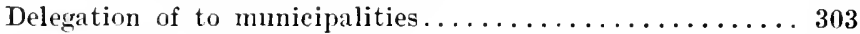

Deprivation of liberty under................ 343

Freedom of contract and of business regulated...... 345

In interest of public morals, health, and safety....300, 345

In interest of public welfare............

In order to prevent fraud............... 347

In order to prevent oppression............ 353

Deprivation of property under................... 328

Confiscation or distinction of property as penalty.... 337

Consequential damages from police regulation....... 338

Enjoyment of property limited............ 336

Imposition of expenses incident to police regulation. . . 339

New duties and liabilities created........... 342

Private rights must be involved............. 328

Profession or office as property............ 333

Direct legislative act under, is due process......... 366

Legislature exercises .................. 300

Not extraterritorial ..................... 304

Notice and hearing -

Application of police regulation to circumstances gen-

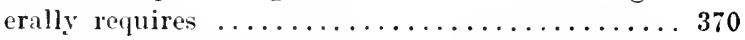

Dispensed witl when necessary under statuie devolving

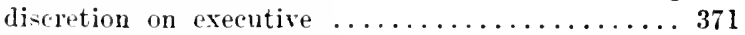

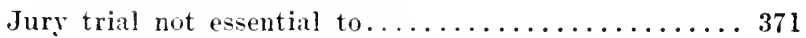

Legislature nay act directly without.......... 319

Postponed in cases of necessity.............. 372

Right to destroy before hearing limited to cases of necessity ................. 375

Value of property destroyed as affecting necessity. . 375

Right to destroy before hearing not admitted in some states ..................... 377

Reasonableness of exercise -

An essential of police regulation............ 306

As determining between police power and eminent domain ...................206, 309

Primarily for legislature, ultimately for court...... 306

Required both in general and local regulation...... 308

Tests of, stated ........................ 307 
Police power-Continued.

PAGE

Separation of govermmental powers -

Carrying out police regulation permitted to executive. 365

Judicial duties required of administrative officials.... 366

Whether a delegation of legislative duties..... 366

Matters of detail delegated to administrative offieials.. 366

State legislation under -

Fourteenth Amendment ................ 305

Must not trench on federal powers.......... 303

Obligation of contraets................. 304

Regulation of commerce................ 304

Whether action under is taking of property..........204

Policy slips -

Possession by officer of $\ldots \ldots \ldots \ldots \ldots \ldots \ldots \ldots \ldots \ldots$

Porto Rico -

Status of inhabitants of ....................... 192 note

\section{Possession -}

Presumptions from $\ldots \ldots \ldots \ldots \ldots \ldots \ldots \ldots \ldots \ldots$

\section{Possibility -}

Distinguished from vested right............. 157

\section{Postal laws -}

Ruling of postmaster-general on addressee's right to mail matter ........................ 369

Ruling of postmaster-general on mailable matter....... 369

\section{Post offices -}

Acquisition of property for, a public purpose......... 257

\section{Practice -}

Included in procedure................... 159

\section{Prerogative of king -}

To imprison by special mandate.............11, 13

Challenged by Parliament as contrary to due process.. 12

To imprison on writs quibusdam certis de causis........ 11

\section{Fresumptions -}

Legislature may ereate prima facic............... 180

Must be naturally connected with facts........... 181

None of denial of fundamental rights........... 160

of negligence from certain aets...........185, 187

On questions of contract state may create conclusive..... 184

Whetlier legislature may create conclusive......... 181

\section{Private international law -}

See Situs.

\section{Private roads -}

Whether construction of, a public purpose..........264 
Privilege - $\quad$ PAGE

Defamatory statements in pleadings held privileged

\section{Probate -}

Proceedings for, held in $r e m \ldots \ldots \ldots \ldots \ldots \ldots \ldots \ldots$

\section{Procedure -}

Defined $\ldots \ldots \ldots \ldots \ldots \ldots \ldots \ldots \ldots \ldots \ldots \ldots \ldots \ldots$

Inclules pleading, practice, and evidence........ 159

In criminal cases $\ldots \ldots \ldots \ldots \ldots \ldots \ldots \ldots \ldots \ldots \ldots \ldots \ldots$

Entry of plea involves due process........... 165

Instances where due process not involved........ 168

Jurisdictional questions involve due process....... 165

Presence in appellate court not essential........ 166

Right of accused to be present............165

Whetler presence essential under Fourteenth Amend-

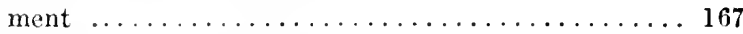

Laws affecting heirs ex post facto............. 147

No presumption of denial of rights............. 160

No vested rights in $\ldots \ldots \ldots \ldots \ldots \ldots \ldots \ldots \ldots \ldots \ldots \ldots$

Within control of state................. 160

\section{Proceedings in rem -}

All proceedings either in rem or in personam........ 112 Conception extended to proceedings not begun by seizure.

History of, against inanimate objects..........113 note Number of persons affected suggested as test......... 117 Political necessity as determining whether proceeding is... 116 Strictly in rem are against property itself.......... 108

\section{Process, service of -}

See foreign Corporations.

Agreement that nonresident stockholder bound by, on corpo-

ration $\ldots \ldots \ldots \ldots \ldots \ldots \ldots \ldots \ldots \ldots \ldots \ldots .97-99$

Constructive -

As validating suit determining title.......... 115

On foreign corporations................ 97

Effect of nomresident's prior consent to -

As estopping denial of state court's jurisdiction..... 95

Doctrine under Federal Constitution............ 94

General doctrine of international law.........93, 94

What amounts to consent................94 note

Nonresident designating agent to receive........... 93

On partnership, effect on nonresident partner.......99, 100 Personal -

Essential to judgment in personam...........89, 92

Outside of state gives no jurisdiction......... 89 
As property $\ldots \ldots \ldots \ldots \ldots \ldots \ldots \ldots \ldots \ldots \ldots \ldots \ldots \ldots \ldots$

\section{Property -}

Arbitrary transfer from one to another not dine process... 170

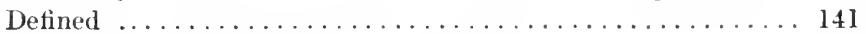

Includes right to freedom of contract.............141

Includes right to labor. ................. 141

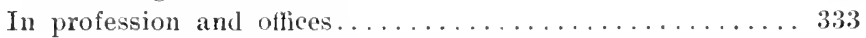

Is nomen generalissimum.................... 283

Laws limiting enjovment of ................. 336

Of states subject to legislative regulation. . . . . . . . . 329

Owners of, liable for injuries from gambling on........ 343

Private rights subordinate to state welfare......... 337

Right of, distinguished from thing possessed......... 141

Right of, protected by due process.............. 155

Subject to lien for penalties for unlawful use......... 337

U'se of, for advertising. ................ 310

Within right of enrinent domain............... 283

\section{Prostitution -}

Regulation of $\ldots \ldots \ldots \ldots \ldots \ldots \ldots \ldots \ldots \ldots \ldots \ldots \ldots \ldots \ldots \ldots \ldots \ldots$

\section{Public amusement -}

Regulation of places of .................. 317

\section{Publication -}

In proceeding in rem.................... 110

\section{Public interest, business affected with -}

See Business Affected with Public Interest.

\section{Public morals, health, and safety -}

Regulation must bear real relation to............ 345

\section{Public office -}

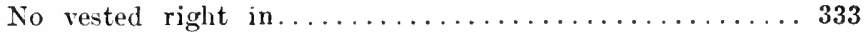

State decision of right to state office raises no federal ques-

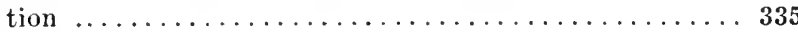

\section{Public policy -}

May determine whether freedom of contract abridged.... 361

\section{Public proclamation -}

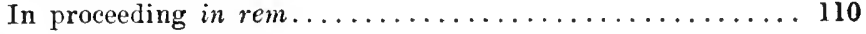

\section{Pablic purpose -}

See Taxation.

In taxation and eminent domain distinguished........ 228

Prof. J. B. Thayer on legislative power to determine... .256 note 
Quarantine - PAaE

Expense inciaent to, imposed on ships........... 339

state regulation of $\ldots \ldots \ldots \ldots \ldots \ldots \ldots \ldots \ldots \ldots \ldots \ldots \ldots$

\section{Railroad commission -}

Expenses of, imposed on railroal............. 340

Ruling of state, held fintl. . . . . . . . . . . . 370

\section{Railroads -}

See Assessuent; Common Carrier; Regulation of Rates; Street Rallways.

Acquisition of property for, a public purpose......... 257

Business of, affected with public interest.......... 316

Classified for assessment in taxation............ 63

Deprived of benefit of fellow-servant rule......... 342

Expense of safeguards for, imposed on .......... 340

Liability for allowing Johnson grass to mature........ 342

Mileage as basis of taxation...............224

Must bear expenses of physical examination of engineers... 340

Passenger trains required to stop at county seats......316 note

Reasonableness of rates, determined by effect on whole line. 322

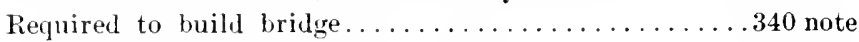

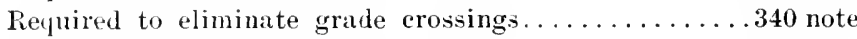

Required to erect $\operatorname{lepots} . \ldots \ldots \ldots \ldots \ldots \ldots \ldots \ldots \ldots \ldots 340$ note

Required to fence right of way................ 342

Required to maintain viaduct.................. 340 note

Required to make improvements at their own cost. . . . . 340

Required to pay employees on discharge........... 350

Required to stop trains in cities.............. 340 note

Statutes penalizing failure to settle small claims....... 350

Steam locomotives in streets prohibited...........203 note

Train connections between, enforced............340 note

\section{Rates -}

Regulation of, see Regulation of Rates.

\section{Real property -}

Proceeding to quiet title is in rem............114, 115

\section{Reassessment -}

Sufficiency of notice of $\ldots \ldots \ldots \ldots \ldots \ldots \ldots \ldots \ldots \ldots 77,78$

Redemption from execution -

See Execctiox.

\section{Reformatories -}

Imprisonment of young criminals in........... 344

\section{Refrigerator cars -}

Average number in state as basis of taxation......... 225 
Registration - PAGE

presumptions ftom, of deeds.............. 180

\section{Regulation of rates -}

By court of visitation........................ 164

Courts may set aside unreasonable rates........... 320

Does not inclurle power to eonfiscate............... 319

Legislative power to regulate.................... 318

Reasonableness of rites -

Arbitrary discrimination prohibited.......... 327

As affected by nature of business............ 325

As to existing rates, a legislative question........ 319

Elements of reasonableness................;

Elements to be eonsidered in estimating valuc....... 323

Fair return as test................... 324

Interest of mortgage bondholders to be considered.... 322

Interest of publie to be considered. . . . . . . . 324

Judicial question when delegated by legisiation...... 319

Of railroad determined by effect on entire line...... 322

Sufficiency of allegation to raise question......... 32.2

Value of property employed to be considered....... 3.2

Where business is in the nature of private enterprise. 326

Where business is one which state might perform.... 325

What amounts to notice and hearing in proceedings for... 378

\section{Remedies -}

Given by statute as against prior rights not rested...... 161

May be changed if effective remedy left........... 174

No rested right in particular remedies............. 160

Power of legislature over................... 174

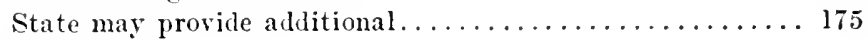

\section{Repair shops -}

Acquisition of property for, a public purpose..........258

\section{Retrospective laws -}

See Vested Rignts.

Imposing penalties for nonpayment of taxes.........234

Not favored ........................ 153-155

\section{Reversion -}

Possibility of reversion not vested............. 157

\section{Revetments -}

Consequential damage from construction of ......... 293

\section{Review -}

See Appeal; Notice and Hearing.

\section{Right of action -}

Attaching conditions to $\ldots \ldots \ldots \ldots \ldots \ldots \ldots \ldots \ldots \ldots \ldots$

Statutory regulation of existing.............. 178 


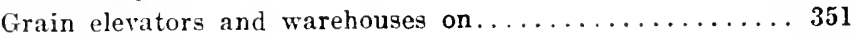

Railroads required to fence................. 342

\section{Rights -}

See Ixaliexable Rigitss; Vested Rights; Pabayount Rigitss of State.

Fundamental, what are................153, 155

Rights of wan -

Conservation of courts in declaring............. 57

Rights protected by due process -

See Vestei Rigits.

Life, liherty, and property. ............... 138

Classified as natural and inalienable......... 138

Enumeration representative only............. 139

Recognized. not conferred by constitution.......... 138

Subject to paramount state authority.......... 141

\section{Riparian owner -}

Dim a violation of rights of $\ldots \ldots \ldots \ldots \ldots \ldots \ldots \ldots, 23$

\section{Riparian rights -}

See Navigable Waters.

\section{Rale to show cause -}

Why judgment not paid is due process........... 77

\section{Sallors -}

Rights of, subject to state regulation.

\section{Sale under execntion -}

See Executiox.

\section{Salisbary, Conntess of -}

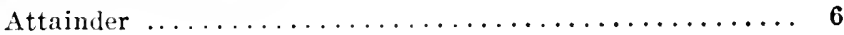

\section{Sanity -}

See Lunatics.

\section{School districts -}

Property rights of $\ldots \ldots \ldots \ldots \ldots \ldots \ldots \ldots \ldots \ldots \ldots . \ldots 32$

Schools, public -

Acquisition of property for, a public purpose.........257

\section{Seal -}

Regulation of use of state seal.

\section{Seneca -}

Lines from, embody principle of due process.......... 2

\section{Sentence -}

Before de facto judge. 
Sentence, execntion of - PAGE

Appellate court fixing time of ...........166, 169 note

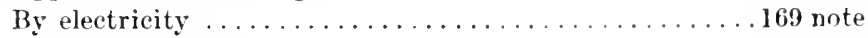

Depends on local law..................... 169

Governor fixing time of ................. 169 note

Separation of governmental powers...........68-73

Courts reluctunt to avoid statutes for failure in ....... 70

Derived from Montesquieu. ................69 note

Ditliculty of demarkation................. 69

Judieial and legislative functions committed to same body. . 370

Judicial functions exereised by exeentive ondials.......7l-73

Question gen rally of locil liw ............... 71

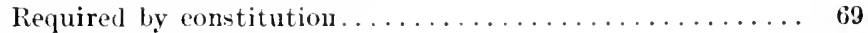

Theory of, criticised .................69 note

\section{Service of process -}

See Process, Service of.

\section{Servitudes -}

Additional in property condemned.............. 284

\section{Seymour, Lord Admiral -}

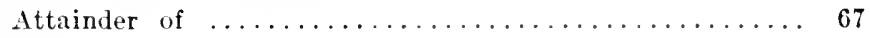

\section{Ships -}

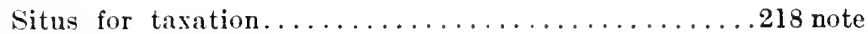

\section{Sister state judgments - \\ See Judgments.}

\section{Situs -}

For taxation -

Of eorporate stock................. 120

Of debts . . . . . . . .

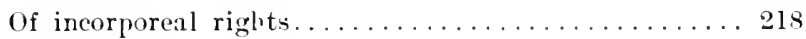

Of intangible personal property............ 119

Of intangible property.................2.

Of real property and tangible personal property..... 218

Of tangible personal property movel from state to

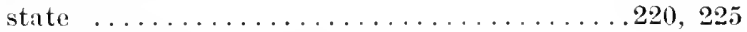

Of intangible personal property.............. 119

of intangible personal property for various purposes.... 121

Of personal property................... 118

\section{slander -}

See Defamation.

\section{Sleeping-car companies -}

Mileage as basis of taxation................ 225

\section{Soda-water fountain -}

Dispensing drinks from, as affected with public interest... 317 
Special administrator - PAGE Settlement with regular representative without giving bond. 161

\section{8pecial assersments -}

According to benefits...................247 note

Poundaries of taxing district, question for legislature.... 247

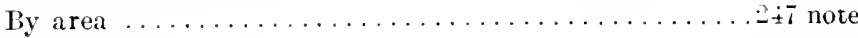

Py front-foot rnie.................... 47 note

By value of property.................... note

Legislative delegation of power to impose...........248

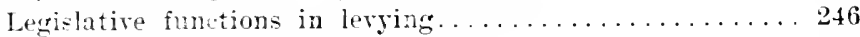

Lery of, depends on taxing power............. 212

Mamner of a plyortionment. for legislature.......... 247

Necessity of hearing by local authorities............. 248

Necessity of question for legrislature............ 247

Notice of, by implication in ordinance............. 82

lower of leginlature to fix absolute rule of apportionment.. 248

\section{Epecial mandate -}

See Prerogative of Kixg.

\section{Spur tracks -}

Question of necessity of ................ 277

Whether construction of, public purpose...........269

Star chamber -

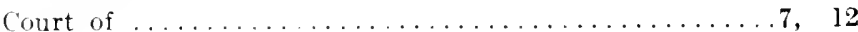

\section{Strites -}

Contracts lir, within contract clause of constitution...... 151

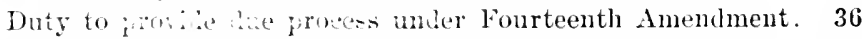

Wow far nat buald gormment concerned with due process by. 35

Subdivision of, into territorial units............. 332

Station, railroad -

See Derots; Pailroads.

\section{Statrs -}

light of state to determine, of citizen.........122, 127

\section{Statute of frands -}

As police regulation................... 348

Statute of limitation -

See Limitation of Actions.

\section{Staj law: -}

Validity of

\section{Stock -}

Situs of, see Sitrs.

Taxation of corporate.

\section{Stockholders -}

See l'rucess. Service of. 
Acquisition of property for, a public purpose.........258

As affected with public interest................ 317

\section{Store-order acts -}

Constitutionality of

\section{Strearns -}

Statute requiring landowner to clean............ 70

\section{Street railways -}

Discrimination in taxing ................ 211, 212

New York law taxing franchises of ............. 227

Snbmission of case -

Motion to set aside denied................... 16]

Succession -

See Administration.

Heir's right of, not rested................ 157

\section{Snccession taxes -}

Operates on devolution, not on property........... 222

\section{Summary proceedings -}

See Contempt Taxation.

\section{Sunday laws -}

Constitutionality of $\ldots \ldots \ldots \ldots \ldots \ldots \ldots \ldots \ldots \ldots \ldots$

\section{Supplementary pleadings -}

Right to file denied...................... 161

\section{Suretyship -}

Julgment against principal enforceable against surety... 96

\section{Survivorship -}

See Joint Tenants.

\section{Taking of property -}

Any deprivation of use is ................. 292

Both eminent domain and police power may be involved... 205

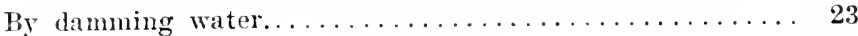

Extent of limitation of use determines whether there is . . . 309

Injury purely consequential is not............. 292

May be taken for certain uses only, leaving ownership other-

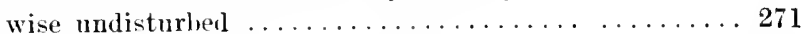

Necessary destruction not a taking.............. 205

Penal consequences for unlawful use not a taking........204

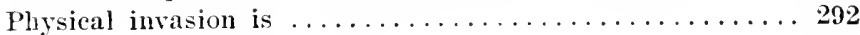

Police power does not require................ 303

Proceeding not affecting owner's right is not......... 294

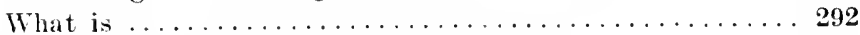

Whether destruction of property a taking.......... 310 
Taking of property - Continued.

Whether regulation of spite fences is............. 309

Whole lot where right of way sufficient.........276 note

\section{Taxation -}

See Exemptions from Taxation; Occupation Tax; Special Assessuents; Situs.

\section{Assessment -}

Discrimination in provision for review......... 211

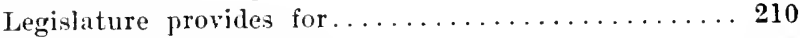

Mileage rule as basis for . . . . . . . 224

Petitioner for tax estopped to question.......... 252

Review of proceedings not essential........... 211

Collection of taxes, legislature provides for.......... 210

Delegation of power of -

Not to private corporations............... 212

To municipal corporations................ 212

Different jurisdictions may tax same property.........223

Discrimination in levying....................... 15

Equality of, not guaranteed by Fourteenth Amendment... . 211

Equating taxes to benefits. . . . . . . . . . 202, 2l4 note

Includes power of apportionment.............. 209

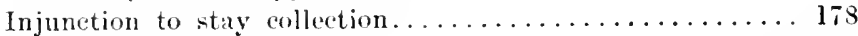

Involves nower to destroy. . . . . . . . . . . . . 208 noth

Legislature nay classify subject-matter of ......... 210

Limitation of power of -

By due process...................... 215

Must be for public purposes.............. 217

Only persons or things in jurisdiction may be taxed... 217

State may not tax interstate commerce......... 217

State or nation may not tax ageneies of other...... 217

Notice and hearing -

Assessment by executive oficial requires.......... 837

By hoard of equalization sufficient............ 241

By executive and judicial officers............ 236

Escentials of . ..................... 24

Implicution of from provision for "suit" . . . . . 25

In statutes imposing general taxes. . . . . . . . . 238

In statutes imposing sperial taxes. . . . . . . . 238

Not required where legislature acts directly........ 235

(1) appeal from assessment sufficient........... 24l

On legility of tax includes assessment.......... 245

l'resenes of property owner not essential......... 24l

Refuired when legislature lelegates decision to others. 236

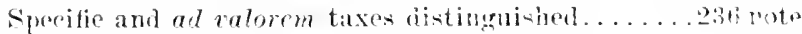

Statute levying tax may provide notice.......... $\mathbf{2 3 7}$ 
Taxation - Continucd. PAGE

Power of, legislative, not judieial. . . . . . . . . . . 209

Proceeding for, against nonresident is in rem......... 114

Public purpose of -

A question of general jurisprudence........... 230

Courts may supervise legislative deeision.........229

Essential for taxation. ................ 228

Legislature decides what is.............. 229

With reference to loral or general taxes.........231

Security against abuse of power of ............ 208

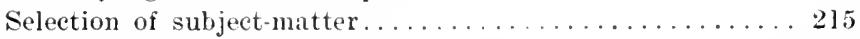

Subject-matters to which power extends........... 209

Summary procedings for collection are due process. . 232, 234

Taxing distriets, determination of, matter of state law... 213

Taxpayer receives value in protection............202

Valuation of property for -

Elements of value of corporate...........224

Left to taxing officers............... 246

May not inelude chattels beyond state.......... 221

Of property lying in different jurisdietion.........223

Property outside state must be excluded..........224

\section{Tax deeds -}

Presumptions from $\ldots \ldots \ldots \ldots \ldots \ldots \ldots \ldots \ldots \ldots, 182$

Tea, inspection of -

By administrative officials is due process........... 369,372

\section{Telegraph -}

See Regulation of Rates.

Acquisition of property for, a public purpose........ 257

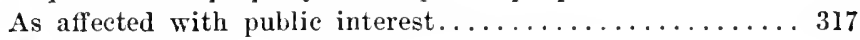

Mileage as basis of taxation................ 225

Telephone -

Acquisition of property for, a public purpose........ 257

As affeeted with public interest................ 317

\section{Tenement houses -}

Expense of improvements imposed on owners......... 340

\section{Territory -}

Ineorporated in United States............... 197

Merely annexed..................... 198

What is, entitled to all eonstitutional guaranties........ 199

\section{Territory acquired by Spanish war -}

Status of inhabitants.................. 197 note

\section{Thayer, Prof. J. B. -}

On judieial and legislative functions in exercising para. mount powers of government............. 256 
PAGE

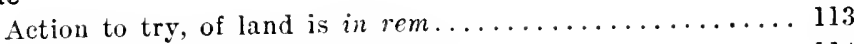

Proceeding to quiet, is in rem............... 114

Tolls -

Imposed for use of improved waterway........... 340

Torrens Act -

Constitutionality of

Tort -

Judgment in, not a vested right.............. 162

Trades -

Unsanitary and offensive trades regulated.

Trial -

See Notice and Hearixg; Hearing; Procedure; TriBUNAL.

Before de facto judge.................. 168

\section{Tribunal -}

Character of, usually matter of local law.........162-164

\section{Truck Acts -}

Constitutionality of $\ldots \ldots \ldots \ldots \ldots \ldots \ldots \ldots \ldots \ldots \ldots \ldots$

\section{Trusts -}

See Monopolies and Combinations.

\section{Turnpikes -}

Acquisition of property for, a public purpose........ 257

Rates prescribed for....................... 321

\section{United States -}

Supervisory power of, as to due process under Fourteentl

Amendment ..................... 36

\section{Vaccination -}

State may prescrihe compulsory.............. 343

\section{Vested rights -}

Ser crrative acts; Impairment of Obligation of Contracts.

Affected ly retrospective laws................ 145

As limiting scope of legrislative power ............ 328

Austin on ..................142 note, 144 note, 1510

Laws impairing, not farored................ 153

Maxims of Roman law condemning impairment of . . . . . 15:?

Mere expectancy, possibility, or contingency is not...... 1.57

None in procedure...................... 160

Protection of, by conctitutional clanses -

By clause forbidding bills of attainder . . . . . . 146

By clause forbilling ex post facto laws.... .... 146

By clause forbidling impairing obligation of contracts. 148

By guaranty of due process............... 153 
Vested rights - Continued.

PAGE

Statute of descent and distrilutions confers no.......15i note

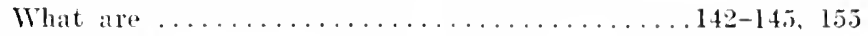

When arising from contract protected by contract clause in constitution ....................... 151

\section{Viaduct -}

Railroad required to maintain.................. 340 note

\section{Waiver -}

Of objection to juror als alien............... 188

Of right to hearing........................ 73

Whether defects in indictment waived, question for state courts ......................... 168

\section{Warehousemen -}

Business of, affected with public interest.......... 310

\section{Warehonses -}

On railroad rights of way................. 351

\section{Water -}

Companies to supply, as affected with public interest.... 317

\section{Water front -}

Temporary exclusion from, held consequential........ 293

\section{Water rates -}

Fixed by local authorities................ 320

\section{Water rents -}

Additional remedy to enforce, provided

Water supply company -

Regulation of rates of .................... 323 note

\section{water supply for cities -}

Acquisition of property for, a public purpose......... 259

\section{Waterways -}

Administrative officials to fix tolls for ........... 366

Improvements in, defrayed by tolls............ 310

\section{Waterworks -}

Municipality empowered to erect............. 332

\section{Webster, Dantel -}

Definition of due process.................49-51

\section{Wharfingers -}

Business of, affected with public interest.......... 316

\section{Wharves -}

Acquisition of property for, a public purpose.

\section{wills -}

See Probate.

Writ quibusdam certis de cansis -

See Prerogative of King. 




\section{UNIVERSITY OF CALIFORNIA LIBRARY}

Los Angeles

This book is DUE on the last date stamped below. 
UC SOUTHERN REGIONAL LIBRARY FACILITY

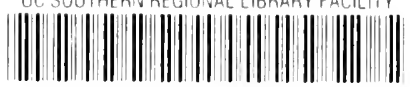
AA 000814407 
(1)

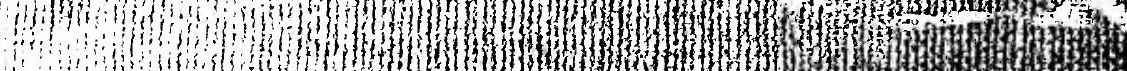

(fris

(1)

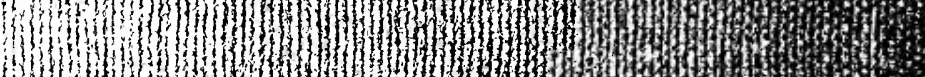

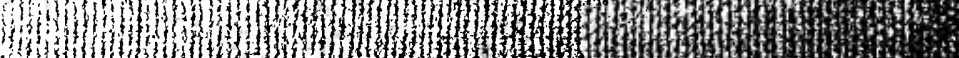

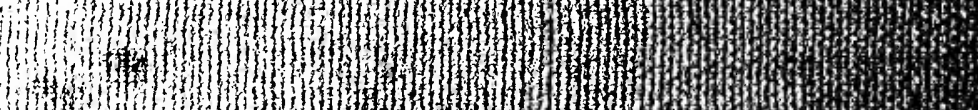

(1) (1) (1) (a) 1. 1 . (1) 1 Non

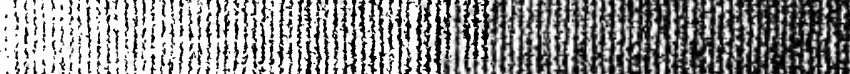

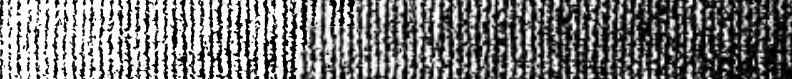

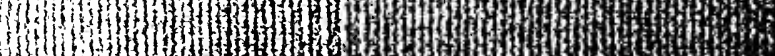
(1)
ing if

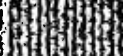
作

ifing

1)

If

(1)

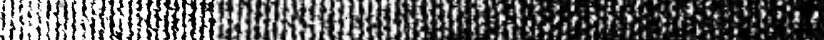

(1)

(1)

(1)

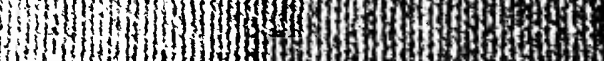

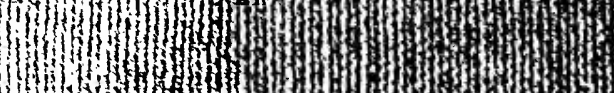

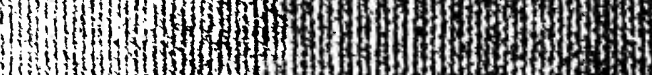

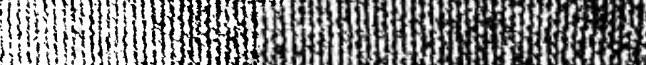
istis. (i) (1)

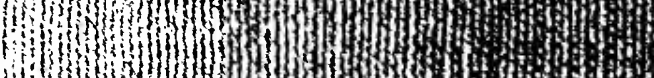

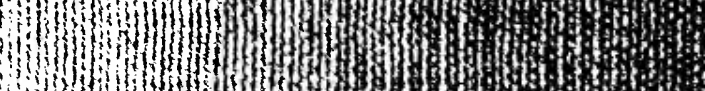
in

Nol

(1) 